Rozwój terytorialny

w świetle dorobku

ekonomii

instytucjonalnej

Przestrzeń - bliskość - instytucje 
盗 
Ekonomia

\section{Rozwój terytorialny}

w świetle dorobku

ekonomii

instytucjonalnej

Przestrzeń - bliskość - instytucje

Mariusz E. Sokołowicz 
Mariusz E. Sokołowicz - Uniwersytet Łódzki, Wydział Ekonomiczno-Socjologiczny

Katedra Gospodarki Regionalnej i Środowiska, 90-214 Łódź, ul. Rewolucji 1905 r. nr 39

\author{
RECENZENT \\ Wanda M. Gaczek \\ REDAKTOR WYDAWNICTWA U \\ Katarzyna Gorzkowska \\ SKŁAD I ŁAMANIE \\ Munda-Maciej Torz \\ PROJEKT OKŁADKI \\ Stämpfli Polska Sp. z o.o. \\ Zdjęcie wykorzystane na okładce: ( Shutterstock.com
}

Publikacja finansowana ze środków Ministerstwa Nauki i Szkolnictwa Wyższego w ramach grantu „Współfinansowanie projektu międzynarodowego Funkcjonowanie lokalnych systemów produkcyjnych w warunkach kryzysu gospodarczego (analiza porównawcza i benchmarking w wybranych krajach UE oraz krajach trzecich)". Nr umowy: 2529/7.PR/2012/2

(c) Copyright by Uniwersytet Łódzki, Łódź 2015

Wydane przez Wydawnictwo Uniwersytetu Łódzkiego

Wydanie I. W.06928.15.0.M

Ark. wyd. 16,8; ark. druk. 17,625

ISBN 978-83-7969-785-4

e-ISBN 978-83-7969-786-1

Wydawnictwo Uniwersytetu Łódzkiego

90-131 Łódź, ul. Lindleya 8

www.wydawnictwo.uni.lodz.pl

e-mail: ksiegarnia@uni.lodz.pl

tel. (42) 6655863 


\section{Spis treści}

Wstęp

Rozdział I

Przestrzeń w analizach ekonomicznych - ewolucja teorii i nurtów badawczych

1. Mechanizmy koncentracji działalności gospodarczej w świetle klasycznych teorii gospodarki przestrzennej

1.1. Modele renty gruntowej

1.2. Modele lokalizacji przedsiębiorstw

1.3. Modele kształtowania się hierarchii przestrzennej i układów osadniczych

2. Konwergencja a polaryzacja regionalna - siły kształtujące strukturę przestrzenną gospodarki

3. Korzyści aglomeracji i ich ewolucja

4. Terytorialny paradygmat rozwoju - współczesne podejście do analiz przestrzennych

Rozdział II

Ekonomia instytucjonalna - podstawowe pojęcia i geneza

1. Miejsce instytucjonalizmu w naukach ekonomicznych 69

2. Pojęcie i typy instytucji

3. Początki orientacji instytucjonalnej w naukach ekonomicznych - „stara” ekonomia instytucjonalna 
Rozdział III

Współczesne nurty ekonomii instytucjonalnej

1. Nowa ekonomia instytucjonalna jako próba operacjonalizacji instytu-

cji w ekonomii

1.1. Teoria praw własności

1.2. Teoria kosztów transakcyjnych i teoria agencji

1.3. Teoria wyboru publicznego

2. Koncepcje pokrewne i powiązane z ekonomią instytucjonalną

2.1. Francuska ekonomia konwencji

2.2. Ekonomia ewolucyjna

2.3. Zasobowa szkoła myślenia strategicznego

Rozdziat IV

Nurty ekonomii instytucjonalnej w procesach rozwoju terytorialnego - perspektywa badawcza

1. Instytucjonalizm w wyjaśnianiu procesów rozwoju terytorialnego - próby konceptualizacji

2. Możliwości zastosowań ekonomii instytucjonalnej w badaniach rozwoju terytorialnego

3. Ujęcie instytucjonalne w dotychczasowych badaniach nad rozwojem terytorialnym

Podsumowanie. Dylematy wokół instytucjonalnych analiz rozwoju terytorialnego

Bibliografia

Summary 


\section{Wstęp}

http://dx.doi.org/10.18778/8088-785-4

Wobec zmieniających się uwarunkowań procesów gospodarczych rola i pozycja miast oraz regionów wciąż pozostaje niezwykle istotna. W warunkach rosnącego umiędzynarodowienia przepływów czynników produkcji, towarów i informacji, a także niezwykle dynamicznego postępu technicznego w rozwoju technologii komunikowania się paradoksalnie wzrasta rola lokalnego i regionalnego poziomu gospodarowania. Ujawnia się ona przede wszystkim we wzrastającej roli bliskości w budowaniu przewagi konkurencyjnej we współczesnej gospodarce. Fenomeny Doliny Krzemowej, a wcześniej tzw. Trzeciej Italii, Badenii-Wirtembergii, rozwój klastrów przemysłowych oraz koncentracja ludności i działalności gospodarczej przede wszystkim w zurbanizowanych obszarach metropolii światowych stanowią najbardziej znamienne przykłady na poparcie tej tezy. Innymi słowy, w warunkach rosnącej mobilności kapitału, ludności, towarów i informacji pewne czynniki odpowiedzialne za rozwój gospodarczy wciąż pozostają „zlokalizowane”, choć ich charakter bywa trudno uchwytny z punktu widzenia badań naukowych. Zjawisko to coraz częściej określa się mianem „terytorialnego” charakteru rozwoju.

Opisywane procesy stanowią przedmiot badań wielu dyscyplin naukowych, m.in. geografii, socjologii, urbanistyki, jednak zainteresowanie nimi można zaobserwować przede wszystkim w naukach ekonomicznych. Z ekonomicznego punktu widzenia pierwszoplanowym zagadnieniem pozostaje pytanie o kluczowe czynniki odpowiedzialne za koncentrację procesów rozwojowych. Odpowiedzi udzielane przez ekonomistów różnią się w zależności od nurtów badawczych, choć należy podkreślić, że typowa dla większości nurtów ekonomicznych tendencja do modelowania - a zatem upraszczania sposobu wyjaśniania rzeczywistości - skutkuje pozostawaniem tej problematyki poza głównym nurtem rozważań. 
Modele wykorzystywane na potrzeby badań ekonomicznych cechuje wysoka użyteczność w odniesieniu do wyjaśniania tzw. klasycznych (pierwotnych) przyczyn koncentracji działalności ludzkiej w przestrzeni - obejmują one analizy kosztów czynników produkcji, dostępności siły roboczej, odległości od źródeł surowców i rynków zbytu. Najtrudniejsze w operacjonalizacji pozostają natomiast czynniki miękkie, takie jak przestrzenna koncentracja wiedzy niekodyfikowanej jako źródła innowacyjności, kreatywność, zróżnicowana przestrzennie skłonność do przedsiębiorczości czy sprawność otoczenia instytucjonalnego dla prowadzenia działalności gospodarczej oraz organizowania życia społeczności miejskich i regionalnych. Wciąż zatem pożądane jest poszukiwanie teorii, metod i technik, które rozszerzą możliwości prowadzenia badań w tym zakresie.

$\mathrm{W}$ ostatnich latach daje się zaobserwować rosnące zainteresowanie ekonomistów instytucjonalnymi czynnikami rozwoju, które istotnych podstaw procesów ekonomicznych upatrują zarówno $\mathrm{w}$ instytucjach formalnych (np. stabilność rządów, efektywność systemów prawnych, sprawność działania przedsiębiorstw i organizacji sektora publicznego), jak i pozaformalnych (czynniki kulturowe, poziom zaufania, sposób zorganizowania społeczności i społeczeństw). Determinanty te stają się przedmiotem rosnącej uwagi ze strony tzw. ekonomii instytucjonalnej, która - pomimo długiej historii - w zasadzie znajduje się poza głównym prądem dociekań ekonomistów.

Ekonomia instytucjonalna pozostaje przy tym silnie zróżnicowaną dziedziną wiedzy, składającą się z wielu nurtów, odmiennych w swych fundamentalnych założeniach. Bogactwo to pozostaje $\mathrm{z}$ jednej strony wyzwaniem, $z$ drugiej strony jednak otwiera szerokie pole dla wykorzystania dorobku instytucjonalizmu w badaniu złożonych procesów gospodarczych. Ponieważ kompleksowość tych procesów stanowi istotne zagadnienie również w studiach lokalnych i regionalnych, instytucjonalizm wydaje się obiecującym narzędziem również i dla tej dziedziny wiedzy.

Konieczność wzbogacenia rozważań na temat rozwoju lokalnego i regionalnego (coraz częściej nazywanego rozwojem terytorialnym) wynika także ze specyfiki tego poziomu funkcjonowania gospodarek i społeczeństw. Przykładowo, o ile relacje między poszczególnymi osobami czy w ramach związków rodzinnych mają charakter pozaformalny, zaś poziomy narodowy i ponadnarodowy procesów społeczno-gospodarczych ciążą w kierunku formalnego wymiaru instytucji, o tyle poziomy lokalny i regionalny (terytorialny) cechuje pośredniość tego rodzaju relacji. Wydaje się, że w obliczu zakładanego przez coraz większą liczbę ekonomistów istotnego znaczenia terytorialnych uwarunkowań procesów rozwojowych (których charakter, podobnie jak charakter samych instytucji, pozostaje trudno mierzalny), instytucjonalizm może stanowić 
dobrą podstawę teoretyczną dla badania terytorialnie zakorzenionych, instytucjonalnych uwarunkowań rozwoju.

W nawiązaniu do powyższych rozważań zaproponowano trzy cele główne niniejszej pracy. Pierwszym z nich jest wzmocnienie podbudowy teoretycznej w obszarze badań nad procesami rozwoju terytorialnego - poprzez uporządkowanie, klasyfikację i szczegółową charakterystykę dorobku ekonomii instytucjonalnej. Za cel drugi przyjęto wskazanie możliwości operacjonalizacji badań miękkich czynników lokalizacji działalności gospodarczej i gospodarstw domowych oraz rozwoju terytorialnego poprzez wykorzystanie koncepcji ekonomii instytucjonalnej. Natomiast trzeci cel stanowi wypracowanie rekomendacji dla polityki rozwoju terytorialnego, poprzez uwzględnienie dorobku intelektualnego instytucjonalizmu.

Realizacja założonych celów wymaga odpowiedzi na następujące pytania badawcze:

1. Czy procesy rozwoju terytorialnego mogą być analizowane z wykorzystaniem aparatu ekonomii instytucjonalnej?

2. Czy można pogodzić ze sobą różne nurty ekonomii instytucjonalnej, odwołując się do nich w analizach poświęconych rozwojowi terytorialnemu?

3. Czy wykorzystanie aparatu ekonomii instytucjonalnej można operacjonalizować na gruncie badań nad procesami rozwoju terytorialnego?

4. W jaki sposób dorobek instytucjonalizmu może przyczynić się (w swym wymiarze normatywnym) do podniesienia skuteczności realizacji celów i zadań formułowanych w politykach i strategiach rozwojowych?

Monografia ma charakter teoretyczny i porządkujący. Jej zadaniem jest charakterystyka poszczególnych nurtów ekonomii instytucjonalnej dla wyeksponowania ich specyfiki i różnic w zakresie podstaw metodologicznych. Ma to na celu identyfikację przydatności poszczególnych nurtów instytucjonalizmu w rozwoju badań nad procesami rozwoju terytorialnego. Efekt podjętych rozważań stanowi wypracowanie tez będących punktem wyjścia dla rozwoju prac empirycznych, zmierzających do „operacjonalizacji” instytucji w badaniach procesów rozwoju terytorialnego. Obecnie trudno bowiem znaleźć w literaturze przedmiotu takie opracowania, które w istotnym stopniu porządkują pod tym kątem różnorodne podejścia instytucjonalne. Można wręcz zaryzykować stwierdzenie, że w przypadku badań nad rozwojem terytorialnym są one w gruncie rzeczy mało rozpoznane, a zadaniem niniejszej dysertacji jest przyczynienie się do zmiany tego stanu rzeczy.

Opracowanie składa się z czterech rozdziałów, z których trzy pierwsze zawierają rozważania o charakterze teoretycznym, natomiast ostatni 
stanowi próbę ich konceptualizacji na potrzeby badań procesów rozwoju terytorialnego oraz zawiera przegląd badań podejmowanych w tej dziedzinie. Rozdział pierwszy to przypomnienie dorobku prac ekonomistów i geografów ekonomicznych, uwzględniających w swych rozważaniach czynnik przestrzenny. Tym samym służy on prezentacji ewolucji podejścia do procesów koncentracji działalności gospodarczej oraz ludności w przestrzeni, począwszy od klasycznych teorii gospodarki przestrzennej aż do prac współczesnych. W rozdziale dokonano też prezentacji ewolucji pojęcia korzyści aglomeracji i zaprezentowano rozważania na temat tzw. terytorialnego charakteru rozwoju. W obydwu podejściach podjęto przy tym próbę opisania ich stosunku do instytucjonalnych uwarunkowań procesów rozwojowych.

Rozdział drugi i trzeci prezentują dorobek teoretyczny związany z ekonomią instytucjonalną. Na wstępie wskazano miejsce instytucjonalizmu i samych instytucji w naukach ekonomicznych, zaprezentowano przegląd definicji instytucji, ich klasyfikacje oraz przybliżono historię rozwoju ekonomii instytucjonalnej. W dalszej kolejności (rozdział trzeci) zaprezentowano współczesne nurty ekonomi instytucjonalnej. Skoncentrowano się przy tym na charakterystyce poszczególnych nurtów tzw. nowej ekonomii instytucjonalnej, która stanowi manifestację obserwowanego dziś renesansu instytucjonalizmu w ekonomii. Następnie ujęto dorobek tej dziedziny wiedzy poza ekonomią głównego nurtu. Poddano charakterystyce koncepcje i nurty teoretyczne nie klasyfikowane wprost jako nurty ekonomii instytucjonalnej, jednak silnie z nimi powiązane. Szczególną uwagę poświęcono przy tym dorobkowi francuskich ekonomistów (ekonomia konwencji, ekonomika bliskości), ewolucjonistów ekonomicznych i przedstawicieli tzw. szkoły zasobowej.

Rozprawę zamyka rozdział, w którym podjęto próbę nakreślenia perspektywy badawczej na styku dotychczasowych prac nad procesami rozwoju lokalnego i regionalnego oraz ekonomii instytucjonalnej. Zaprezentowano w tym celu próby konceptualizacji instytucjonalizmu na potrzeby tego rodzaju badań, a także - poprzez bezpośrednie odwołania do zaprezentowanych w poprzednich rozdziałach nurtów ekonomii instytucjonalnej - możliwości operacjonalizacji ich założeń w badaniach nad procesami rozwoju terytorialnego. W rozdziale uwzględniono ponadto przegląd dotychczasowych prac odwołujących się do zmiennych instytucjonalnych na poziomie lokalnym i regionalnym. Należy podkreślić, że ze względu na przyczynkarski charakter tych badań omawiana część pracy ma charakter uzupełniający. Całość rozważań zamyka prezentacja dylematów metodologicznych dotyczących analiz instytucjonalnych na poziomie lokalnym i regionalnym, ujętych w pięć tez podsumowujących rozważania i zakończonych rekomendacjami dla dalszych badań. 
$\mathrm{W}$ opracowaniu wykorzystano różnorodne metody badawcze. Z uwagi na teoretyczno-metodologiczny charakter pracy, dominującymi narzędziami były analiza treści oraz metoda opisowa. Dodatkowo przydatne okazały się analiza porównawcza i analiza historyczna, wsparta w przypadku odwołań do danych empirycznych metodą prezentacji tzw. stylizowanych faktów. Natomiast w ostatnim rozdziale wykorzystano metody statystyki opisowej.

Opracowania i materiały, które posłużyły do napisania rozprawy, obejmują głównie monografie i artykuły naukowe, zarówno o charakterze teoretycznym, jak i empirycznym. Dorobek będący przedmiotem przeglądu można przy tym podzielić na dwie grupy. Pierwszą z nich stanowią prace ekonomistów i geografów ekonomicznych poświęcone zagadnieniom lokalizacji działalności gospodarczej w przestrzeni, kluczowym teoriom wyjaśniającym procesy rozwoju lokalnego i regionalnego, pojęciu oraz istocie korzyści aglomeracji, jak też najnowsze opracowania dotyczące roli przestrzeni w procesach gospodarczych i tzw. terytorialnego charakteru rozwoju. Drugą grupę stanowią prace przedstawicieli różnych nurtów ekonomii instytucjonalnej oraz nurtów bliskich lub pokrewnych instytucjonalizmowi.

W dysertacji wykorzystano ponadto opracowania o charakterze empirycznym - raporty i artykuły naukowe ukazujące wyniki badań poświęconych zarówno ekonomii instytucjonalnej, jak i procesom rozwoju terytorialnego. Posłużyły one z jednej strony przybliżeniu dorobku w analizowanej dziedzinie, $\mathrm{z}$ drugiej zaś - były przedmiotem oceny pod kątem ich przydatności w badaniach nad procesami rozwoju terytorialnego.

Praca nie stanowi wyczerpującego studium z punktu widzenia przeglądu nurtów tworzących szeroko rozumiany instytucjonalizm. Znajdują się w niej odniesienia przede wszystkim do tych teorii i koncepcji, które mają ścisły związek z dorobkiem nauk ekonomicznych i które mogą być wykorzystywane przede wszystkim przez ekonomistów oraz geografów ekonomicznych. Tym samym w pracy nie podjęto opisu takich nurtów instytucjonalizmu, które w swojej istocie bliższe są naturze nauk politycznych i socjologii. Świadomie pominięto m.in. (nie umniejszając ich wartości) bogate (i często bezpośrednio związane $\mathrm{z}$ instytucjonalizmem) podejście marksistowskie, które współcześnie wydaje się bliższe socjologii niż ekonomii oraz napotyka na istotne trudności w potencjalnej operacjonalizacji. Nie odwoływano się również do nurtów bliskich socjologii przestrzeni czy socjologii miasta, takich jak teoria strukturacji, nurt kulturalistyczny, orientacja ekologiczna, koncepcja społecznego wytwarzania przestrzeni, czy też do ujęcia neomarksistowskiego w badaniach miejskich.

$\mathrm{Z}$ uwagi na teoretyczny charakter rozprawy mniejszy nacisk położono na wyniki prac empirycznych. Wykorzystywane dane statystyczne i rezultaty badań (z których część dotyczy badań prowadzonych przez autora), czy wreszcie prezentacja wybranych stylizowanych faktów, stanowią 
jedynie tło dla zobrazowania możliwości wykorzystania dorobku teoretycznego ekonomii instytucjonalnej w odniesieniu do analiz procesów rozwoju terytorialnego. Możliwości prowadzenia badań empirycznych nad procesami rozwoju terytorialnego $\mathrm{z}$ wykorzystaniem dorobku ekonomii instytucjonalnej zostały zatem wstępnie zasygnalizowane i mogą stanowić punkt wyjścia dla dalszych zastosowań w dziedzinie wiedzy będącej przedmiotem opracowania.

Adresatami książki są przede wszystkim przedstawiciele nauk ekonomicznych, geograficznych, nauk o zarządzaniu oraz socjologowie zajmujący się poszukiwaniem instytucjonalnych czynników odpowiedzialnych za rozwój społeczno-gospodarczy na poziomie lokalnym i regionalnym. Ponadto praca może okazać się przydatna dla specjalistów takich dziedzin, jak gospodarka przestrzenna, ekonomia miejska i regionalna oraz dla menadżerów zatrudnionych $\mathrm{w}$ samorządzie terytorialnym, przede wszystkim z uwagi na szeroki opis kluczowych nurtów teoretycznych rozwijanych w ramach ekonomii instytucjonalnej. Niektóre tezy i rekomendacje mogą wreszcie stać się przedmiotem zainteresowania praktyków zaangażowanych w pracę lub działalność społeczną w samorządach lokalnych i regionalnych, a także w organizacjach szczebla krajowego, powołanych $\mathrm{w}$ celu realizowania polityki przestrzennej.

Do powstania niniejszej publikacji przyczyniło się wiele osób, którym pragnę podziękować. W pierwszej kolejności wyrażam wdzięczność pracownikom Katedry Gospodarki Regionalnej i Środowiska Uniwersytetu Łódzkiego za inspirującą i przyjazną atmosferę oraz kulturę pracy w zespole od lat kierowanym przez Panią prof. Aleksandrę Jewtuchowicz. Umożliwiło mi to poznanie specyfiki działalności badawczej oraz satysfakcjonujące prowadzenie badań. Szczególne wyrazy uznania kieruję do Pani prof. Aleksandry Nowakowskiej, która zachęciła mnie do podjęcia pracy na uczelni oraz wielokrotnie inspirowała do działań $\mathrm{w}$ dziedzinie szeroko rozumianej gospodarki przestrzennej, pomagając przy tym w trafnym wyborze obszarów zainteresowań badawczych. Nie bez znaczenia pozostaje również wsparcie i inspiracja ze strony Pana dra Zbigniewa Przygodzkiego, który w toku codziennej współpracy potrafił udowodnić, że praca naukowa może być nowoczesna, profesjonalna i nie oderwana od rzeczywistości społeczno-gospodarczej. Wreszcie pragnę podziękować Pani prof. Wandzie M. Gaczek z Katedry Ekonomii Przestrzennej i Środowiskowej Uniwersytetu Ekonomicznego w Poznaniu, której wkład w postaci recenzji niniejszej monografii okazał się kluczowy dla jej ostatecznego kształtu. 


\section{Rozdział I \\ Przestrzeń w analizach \\ ekonomicznych - ewolucja \\ teorii i nurtów badawczych}

\section{Mechanizmy koncentracji działalności gospodarczej w świetle klasycznych teorii gospodarki przestrzennej}

Rozważania poświęcone przestrzennym aspektom funkcjonowania przedsiębiorstw i gospodarstw domowych są obecne w pracach ekonomistów od wielu lat. Prace te, umownie nazywane współcześnie klasycznymi teoriami gospodarki przestrzennej, można podzielić na trzy zasadnicze grupy ${ }^{1}$ :

1) teorie nawiązujące do koncepcji renty gruntowej, poszukujące przyczyn zróżnicowania wartości ziemi jako czynnika produkcji (D. Ricardo, J. H. von Thünen, E. M. Hoover),

1 Prace te mają bogatą tradycję i w niniejszym opracowaniu zostały przedstawione $w$ formie syntetycznego przeglądu, stanowiącego punkt wyjścia do dalszych rozważań. Bogaty opis klasycznych teorii gospodarki przestrzennej dostępny jest w licznych źródłach. Wśród polskich opracowań na ten temat wymienić należy przede wszystkim następujące pozycje: E. M. Hoover, Lokalizacja działalności gospodarczej, PWN, Warszawa 1962; W. Isard, Metody analizy regionalnej. Wprowadzenie do nauki o regionach, PWN, Warszawa 1965; B. Malisz, Zarys teorii ksztattowania układów osadniczych, Arkady, Warszawa 1966; B. Gruchman, Czynniki aglomeracji i deglomeracji przemysłu w gospodarce socjalistycznej (na przykładzie Polski), PWN, Warszawa 1967; A. Klasik, Optymalna struktura przestrzenna a rozwój regionalny, PWE, Warszawa 1974; K. Secomski, Teoria rozwoju regionalnego i planowania, PWE, Warszawa 1987; K. Kuciński, Podstawy teorii rozwoju ekonomicznego, PWN, Warszawa 1990; A. Fajferek, Region ekonomiczny i metody analizy regionalnej, PWE, Warszawa 1996; Z. Szymla, Determinanty rozwoju regionalnego, Zakład Narodowy im. Ossolińskich, Wrocław 2000; J. J. Parysek, Podstawy gospodarki lokalnej, Wyd. Uniwersytetu A. Mickiewicza w Poznaniu, Poznań 2001; R. Domański, Gospodarka przestrzenna, PWN, Warszawa 2002. 
2) teorie lokalizacji przedsiębiorstw, wyjaśniające źródła i klasyfikujące tzw. czynniki lokalizacji działalności gospodarczej (W. Launhardt, A. Weber, A. Predöhl, T. Palander),

3) teorie wyjaśniające mechanizmy kształtowania się układów osadniczych (W. Christaller, A. Lösch, G. K. Zipf, W. Isard).

Rozwój powyższych koncepcji miał charakter kumulatywny i został zapoczątkowany badaniami nad przyczynami różnic $\mathrm{w}$ wartości ziemi jako czynnika produkcji oraz różnic $\mathrm{w}$ sposobie jej zagospodarowania już w latach 20. XIX w. Z czasem w ekonomii zaczęto podejmować badania nad czynnikami lokalizacji przedsiębiorstw, by wreszcie podjąć próby poszukiwania ekonomicznych przyczyn przestrzennego zróżnicowania całych układów osadniczych.

\subsection{Modele renty gruntowej}

Pierwszym ważnym dziełem poświęconym zagadnieniu lokalizacji działalności gospodarczej, w którym doszukiwano się korzyści ekonomicznych płynących z przestrzennej koncentracji tej działalności, było opracowanie niemieckiego ekonomisty Johanna H. von Thünena ${ }^{2}$. Tytuł jego pracy (Izolowane państwo) stanowi doskonałe odzwierciedlenie prostoty tego modelu, w którym rozpatruje się sytuację zmiany wartości gruntów użytkowanych rolniczo w zależności od odległości od hipotetycznego miasta, zlokalizowanego w odseparowanym od innych i samowystarczalnym obszarze. Model ten, opracowany w odniesieniu do gospodarki, która nie weszła jeszcze na ścieżkę gwałtownego uprzemysłowienia, wyjaśniał „naturalne” (rynkowe) mechanizmy prowadzące do opłacalności specjalizowania się poszczególnych obszarów użytkowanych rolniczo, w zależności od odległości od miasta jako rynku zbytu towarów rolnych, które oferuje największe korzyści wynikające z jednoczesnej bliskości dostawców i odbiorców, dzięki czemu wartość znajdujących się na nim terenów pozostaje najwyższa.

W opisywanym modelu przyjmuje się szereg upraszczających założeń. Zakłada on m.in. jednakową urodzajność gleby w każdym punkcie analizowanego obszaru, występowanie tylko jednego, izolowanego od innych ośrodka konsumpcji, przyjmuje kalkulację kosztów transportu jako liniową funkcję odległości i masy ładunku oraz jednolite ceny sprzedaży dla wszystkich produktów danego rodzaju (charakterystyczne dla modelu konkurencji doskonałej) $)^{3}$.

2 Pierwsze wydanie: J. von Thünen, Der isolierte Staat in Beziehung auf Landwirtschaft und Nationalekonomie, Perthes, Hamburg 1826.

3 R. Domański, Gospodarka..., s. 40. 
Celem analizy von Thünena było wspomniane już poszukiwanie racjonalnego ekonomicznie układu stref rolniczych wokół miasta będącego rynkiem zbytu, gdzie wyznacznikiem racjonalności jest maksymalizacja renty rozumianej jako różnica między przychodami ze sprzedaży płodów rolnych a kosztami ich transportu ${ }^{4}$. Analiza doprowadziła do wniosku, że na kształtowanie się struktury osadniczej danego obszaru wpływają dwa kluczowe czynniki, tj. odległość od pojedynczego rynku zbytu oraz koszty transportu. W sytuacji jednolitych kosztów transportu w każdym kierunku oraz jednolitej urodzajności gleby wyraźnie dostrzegalna jest koncentracja określonych typów wytwórczości w jego poszczególnych częściach, które w warunkach braku zróżnicowania terenu przyjmują kształt okręgów (rys. 1).



Rys. 1. Gradienty renty dla czterech typów działalności rolniczej wokół miasta będącego rynkiem zbytu

Źródło: M. E. Edwards, Regional and Urban Economics and Economic Development, Auerbach Publicatons, Taylor and Francis Group, Boca Raton-New York 2007, s. 259.

4 Ibidem. 
Koncepcja Thünena odnosi się do rozważań nad rentą gruntową, czyli wynagrodzeniem ziemi jako czynnika produkcji o stałej podaży, wprowadzonym do teorii ekonomii przez Davida Ricardo na przełomie XVIII i XIX w. ${ }^{5}$ Innymi słowy, wielkość poszczególnych okręgów oraz ich odległość od modelowego miasta zależy od wysokości renty gruntowej, którą różnicuje z jednej strony dochód z ziemi, a z drugiej - koszty transportu. W konsekwencji najbliżej rynku zbytu lokalizują się te typy działalności gospodarczej, które gwarantują przychody pozwalające na poniesienie najwyższych kosztów użytkowania ziemi jako czynnika produkcji.

Model Thünena, pomimo swojej prostoty, znajduje zastosowanie do wyjaśnienia głównych przyczyn kształtowania się wartości nie tylko w sektorze rolnictwa, lecz także w odniesieniu do miejsc koncentracji gospodarstw domowych, przedsiębiorstw, rynków zbytu, itd. na terenach zurbanizowanych. O ile jednak J. H. von Thünen uzależnił wysokość renty od urodzajności gleby i odległości do rynków zbytu, o tyle w przypadku renty budowlanej w mieście miejsce rynku zbytu towarów rolnych zajmuje centrum miasta, natomiast odległość od rynku zbytu zastępowana jest przez dostępność do zasobów oraz walory popytu ${ }^{6}$.

W konsekwencji, koncentryczne kręgi reprezentujące wykorzystywanie gruntów na różne rodzaje produkcji rolnej zostają zastąpione przez odpowiednie rodzaje działalności pozarolniczej, tj. usługi, handel i produkcję przemysłową. Różnicowanie wartości ziemi w przestrzeni w warunkach gospodarki rynkowej polega - z jednej strony - na tym, że najwyższą wartość reprezentują tereny w centrum, ponieważ charakteryzują się najwyższymi korzyściami wynikającymi z przestrzennej koncentracji działalności gospodarczej i ludności, natomiast - z drugiej strony - jest ono konsekwencją realizowanych funkcji. W efekcie tereny bardziej wartościowe są zagospodarowane przez funkcje potrafiące je najefektywniej wykorzystać.

Przykładowo, usługi wyższego rzędu osiągają wysokie przychody na małej powierzchni, a ponadto takie czynniki, jak bliskość (bezpośrednie relacje) czy prestiż wynikający z lokalizacji, powodują, że usługi te są w stanie zaakceptować wysokie stawki czynszów. Natomiast w przypadku przemysłu przestrzenna dostępność nie jest już tak istotna, a zatem ten rodzaj działalności gospodarczej preferuje tereny tańsze, dostępne

5 Podstawowa różnica pomiędzy podażą ziemi a podażą innych czynników produkcji polega na tym, że jest ona stała. Innymi słowy, podaż ziemi jest doskonale nieelastyczna, a w interpretacji graficznej krzywa podaży jest linią pionową (R. Milewski, E. Kwiatkowski, Podstawy ekonomii, PWN, Warszawa 2007, s. 190-191). 
dla komunikacji i większe obszarowo ${ }^{7}$. W interpretacji graficznej krzywa renty dla przedsiębiorstwa produkcyjnego (będąca krzywą obojętności wynikającą z alternatywy decyzji dotyczącej kosztu dzierżawy terenu i kosztów transportu będących funkcją odległości) będzie cechowała się mniejszym nachyleniem względem początku układu współrzędnych oraz mniejszą odległością od osi OX (wykres 1).

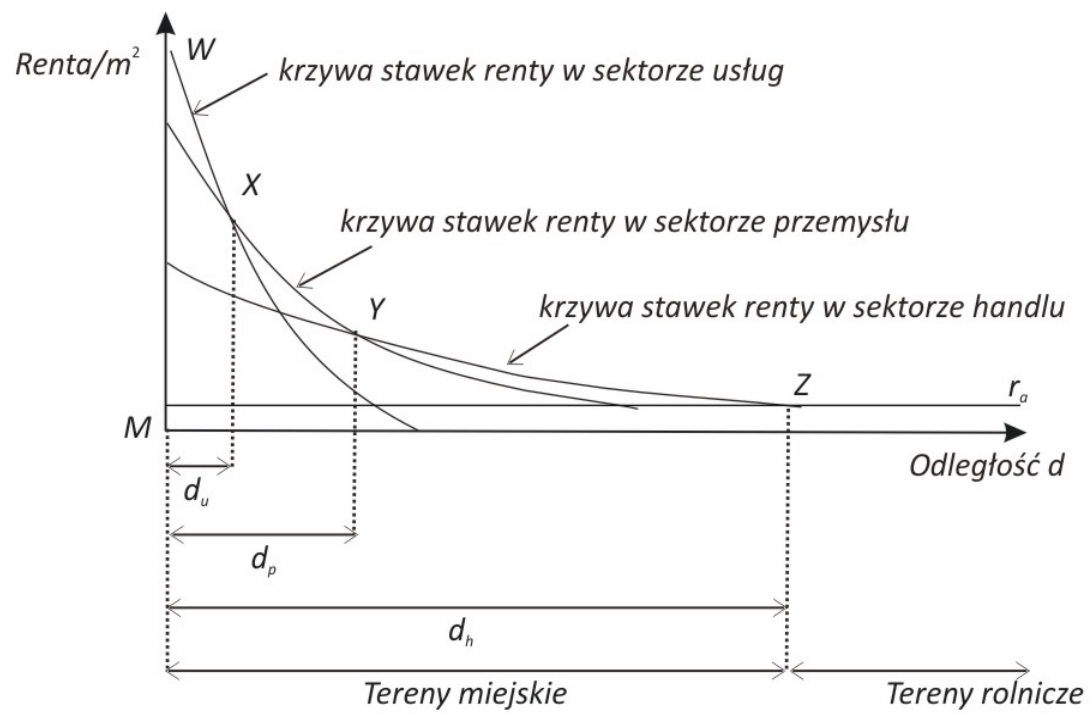

Wykres 1. Alokacja funkcji w przestrzeni miejskiej według sektorów Źródło: Ph. McCann, Urban and Regional Economics, Oxford University Press, Oxford 2001, s. 105.

Podobny mechanizm różnicujący wartość terenów w zależności od odległości od największej koncentracji korzyści ekonomicznych występuje $\mathrm{w}$ sektorze gospodarstw domowych, zaspokajających potrzeby mieszkaniowe. Gospodarstwa domowe w poszukiwaniu optymalnej lokalizacji dążą do maksymalizacji użyteczności, uwzględniając odległość oraz koszt zajęcia działki, rozważając je z punktu widzenia swoich preferencji. Preferencje te, podobnie jak wielkość dochodów przeznaczanych na transport, różnią się w zależności od statusu społeczno-ekonomicznego mieszkańców. Ludność o niskich dochodach preferuje przestrzenną

7 W. M. Gaczek, Zarządzanie w gospodarce przestrzennej, Branta, Bydgoszcz-Poznań 2003, s. 52-54. 
dostępność i oszczędność kosztów transportu. Akceptuje mniejsze powierzchnie mieszkalne oraz różne niekorzyści mieszkania w centrum ${ }^{8}$. Tym samym krzywa stawek renty tego typu gospodarstw domowych, $c e-$ teris paribus, spada gwałtownie wraz z oddalaniem się od centrum miasta. Natomiast im wyższy status ekonomiczny mieszańców, tym mniejszy popyt na powierzchnie mieszkalne w centrum i większa gotowość do pokonywania oporu przestrzeni (wykres 2).

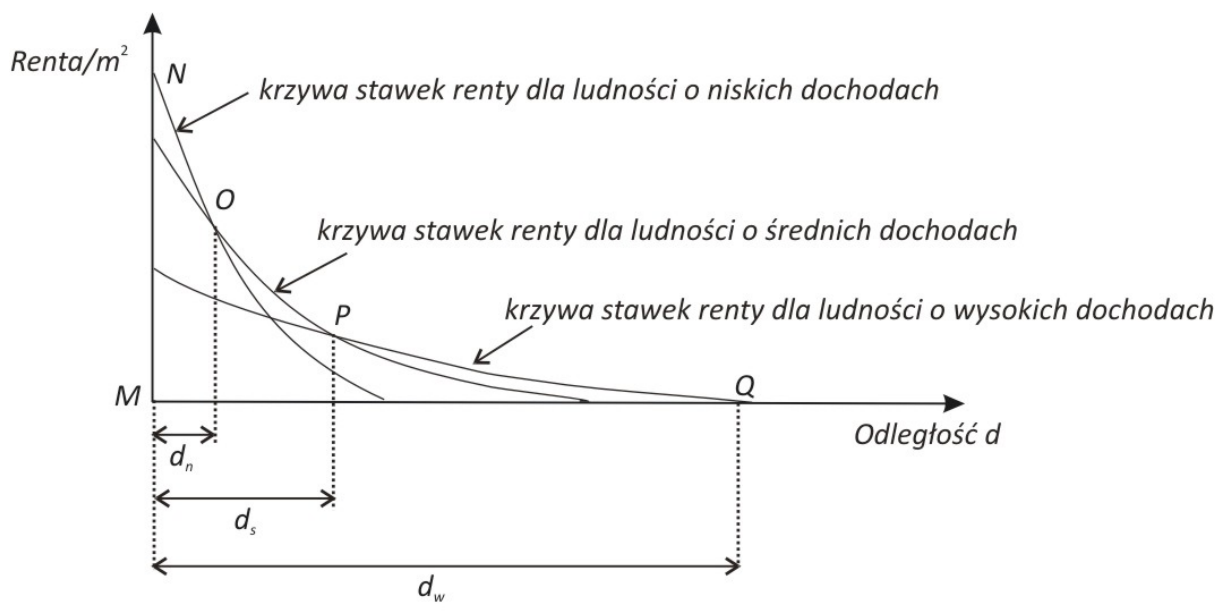

Wykres 2. Alokacja funkcji mieszkaniowych w mieście według dochodów Źródło: jak do wykresu 1, s. 110.

W warunkach coraz bardziej skomplikowanej rzeczywistości społeczno-gospodarczej występuje szereg "zakłóceń" tradycyjnego modelu renty. Obok dość oczywistych czynników różnicujących przestrzeń, takich jak zróżnicowanie terenu, można wskazać następujące przyczyny opisanej wyżej sytuacji?:

1. Użytkownicy przestrzeni rzadko kierują się tymi samymi celami. Na skutek przemian społecznych zwiększa się zarówno różnorodność użytkowników, jak i prawdopodobieństwo występowania konfliktów w sposobach użytkowania przestrzeni miasta.

2. Dostęp do informacji na rynku nieruchomości miejskich jest daleki od doskonałości. Ponadto użytkownicy przestrzeni miasta

8 Ibidem, s. 56.

9 C. J. Webster, L. W. C. Lai, Property Rights, Planning and Markets. Managing Spontaneous Cities, Edward Elgar, Cheltenham-Northampton 2003, s. 82. 
dysponują różną siłą przetargową na tych rynkach, co utrudnia osiąganie na nich równowagi.

3. Oprócz kosztów pokonywania odległości występuje wiele innych kosztów funkcjonowania na miejskich rynkach nieruchomości (tzw. kosztów transakcyjnych). Są to przede wszystkim koszty:

- wynikające ze zwiększania liczby różnych typów praw do nieruchomości (prawo własności, współwłasność, najem, użytkowanie, wierzytelności hipoteczne, zobowiązania wobec ubezpieczycieli itp.),

- poszukiwania korzystnych lokalizacji (dla różnych typów lokalizacji występują różne koszty ich użytkowania),

- tzw. koszty utopione ${ }^{10}$ w sytuacji chęci zmiany lokalizacji.

4. W konsekwencji występowania powyższych trzech czynników pojawia się konieczność korygowania mechanizmów rynkowych w postaci polityki przestrzennej i systemu planowania przestrzennego (zoning), które również przyczyniają się do zmian warunków brzegowych powodujących nieregularności w stosunku do tradycyjnego modelu renty ${ }^{11}$.

\subsection{Modele lokalizacji przedsiębiorstw}

Kolejną koncepcją opisującą mechanizm przestrzennej koncentracji działalności gospodarczej jest model optymalnej lokalizacji pojedynczego przedsiębiorstwa przemysłowego opracowany przez Alfreda Webera ${ }^{12}$. Warto wspomnieć, że A. Weber wprowadził do rozważań na temat przestrzeni pojęcie czynników lokalizacji, wiążąc je ze ściśle określoną korzyścią występującą wówczas, gdy działalność gospodarcza jest zlokalizowana w określonym punkcie lub obszarze. Przez korzyść należy rozumieć oszczędności w kosztach produkcji. Ich osiągnięcie łączy się z tym, że „produkcja okre-

10 Poniesione koszty, których nie można w większości przypadków odzyskać (por. J. Sutton, Sunk Costs and Market Structure, MIT Press, Cambridge 1991).

11 Przykładem działania polityki przestrzennej wpływającej w istotnym stopniu na kształtowanie przestrzeni w sposób odmienny od mechanizmów wolnorynkowych są mniej lub bardziej udane próby wprowadzania w życie koncepcji tzw. miast idealnych (np. model T. Fritscha, miast-ogrodów E. Howarda, model Ch. E. Le Corbusiera, miasto przemysłowe Toniego Garniera oraz założenia Karty Ateńskiej itp.). Warto jednak mieć na uwadze, że odstępstwa od tradycyjnego modelu renty występują w sytuacji wielu innych, również drobnych decyzji, zapadających w obszarze polityki przestrzennej. Przykłady tych odstępstw opisuje bardzo obszernie Ph. McCann (Ph. McCann, Urban and Regional Economics, Oxford University Press, Oxford 2001, rozdziały 3 i 7).

12 A. Weber, Über den Standort der Industrie. Reine Theorie des Standorts, J. C. B. Mohr, Tübingen 1909. 
ślonego wyrobu w danym punkcie lub obszarze odbywa się przy mniejszym nakładzie kosztów niż w każdym innym punkcie lub obszarze"13.

Pierwotny model lokalizacji przedsiębiorstwa przemysłowego zakładał m.in. szereg uproszczeń, takich jak: jednorodność wytwarzanego produktu, doskonała dostępność informacji o lokalizacji miejsc konsumpcji i źródeł surowców, jednolite koszty transportu za jednostkę towaru czy stałe techniczne współczynniki produkcji.

Eksperyment Webera, zakładający występowanie dwóch źródeł pozyskiwania surowców oraz jednego miejsca konsumpcji, pozwolił na wyznaczenie jednego punktu stanowiącego optymalne miejsce lokalizacji produkcji1 ${ }^{14}$. Lokalizacja ta zapewnia minimalizację całkowitych kosztów transportu zarówno surowców z miejsca ich pozyskiwania, jak i produktów gotowych do miejsca ich zbytu. Bardzo istotnym wkładem teorii lokalizacji Webera w ekonomiczną analizę przestrzenną jest jednak przede wszystkim zwrócenie uwagi na fakt, iż kolejnym obok kosztów transportu oraz odległości czynnikiem lokalizacji jest przestrzenne zróżnicowanie kosztów pracy.

Z kolei poszukiwanie przyczyn tego, że nie pokrywają się ze sobą punkt optymalnej lokalizacji przedsiębiorstwa przemysłowego bez uwzględnienia kosztów pracy oraz punkt, w którym występują najniższe koszty pracy, doprowadziło do odkrycia, iż przyczyną takiego stanu rzeczy jest bliskość na danym obszarze innych przedsiębiorstw przemysłowych. Innymi słowy, bliskość przestrzenna została uznana za kolejny istotny czynnik lokalizacji. A. Weber podkreślił tym samym, że gdy koncentracja produkcji w danym miejscu przynosi większe korzyści poszczególnym przedsiębiorstwom niż ich lokalizacja w punktach zapewniających minimalne koszty transportu, opłacalna jest aglomeracja przemysłu ${ }^{15}$. Wątek ten został później rozwinięty przez naśladowców koncepcji Webera w formie pojęcia tzw. korzyści aglomeracji.

Kontynuatorami koncepcji Webera byli m.in. ekonomista niemiecki Andreas Predöhl ${ }^{16}$ oraz ekonomista szwedzki Told Palander ${ }^{17}$. Pierwszy z nich

13 W. Budner, Lokalizacja przedsiębiorstw. Aspekty ekonomiczno-przestrzenne i środowiskowe, Wyd. Akademii Ekonomicznej w Poznaniu, Poznań 2003, s. 57

14 Należy podkreślić, że takie ujęcie zagadnienia lokalizacji pojedynczego przedsiębiorstwa przemysłowego w zasadzie jako pierwszy zaproponował Wilhelm Launhardt, a brat Maxa Webera był w zasadzie kontynuatorem tej myśli (W. Launhardt, Die Bestimmung des Zweckmäßigsten Standortes einer gewerblichen Anlage, „Zeitschrift des Vereins Deutschen Ingenieure" 1882, vol. XXVI; [cyt. za:] J. Brdulak, Lokalne uwarunkowania kulturowe lokalizacji przedsiębiorstw, [w:] K. Kuciński (red.), Glokalizacja, Difin, Warszawa 2011, s. 58.

15 I. Fierla, Lokalizacja przemysłu, PWE, Warszawa 1987, s. 168.

16 A. Predöhl, Das Standortsproblem in der Wirtschaftstheorie, „Weltwirtschaftliches Archiv" 1925, vol. 21.

17 T. Palander, Beitrdge zur Standortstheorie, Almqvist and Wiksells, Uppsala 1935. 
jest autorem zasady tzw. substytucji przestrzennej, traktując zagadnienie lokalizacji działalności gospodarczej jako problem dotyczący racjonalności wyboru $^{18}$. A. Predöhl wskazał, że zmiany w lokalizacji przedsiębiorstw wynikają z substytucji czynników produkcji. Czynniki zlokalizowane w różnych miejscach charakteryzują się odmiennymi właściwościami i cenami, co wyraża się możliwością zróżnicowania ich proporcji przy takiej samej produkcji. Analizując koszty alternatywnych kombinacji czynników w zależności od lokalizacji, można zatem wyznaczyć miejsca o takim samym koszcie produkcji, pomimo niejednakowego zaangażowania czynników produkcji. Są to miejsca reprezentujące ten sam poziom atrakcyjności dla przedsiębiorstwa $\mathrm{z}$ punktu widzenia jego lokalizacji. W ten sposób ustala się równowaga przestrzenna. Koncepcja substytucji przestrzennej stanowi tym samym pomost między ekonomiczną teorią równowagi a wcześniejszymi teoriami lokalizacyjnymi J. H. Thünena i A. Webera ${ }^{19}$.

T. Palander z kolei zwrócił uwagę na to, aby analizie ekonomicznej związanej z lokalizacją działalności przemysłowej poddawać obszar, a nie pojedynczy punkt $\mathrm{w}$ przestrzeni. Zauważył, iż lokalizacja przedsiębiorstw jest zależna od stref, na których działają przedsiębiorstwa (od rynku zbytu, surowców itp.).

Lokalizacja określa przestrzenną rozciągłość obszarów rynkowych, a wielkość obszarów rynkowych z kolei jest współwyznacznikiem optymalnej lokalizacji przedsiębiorstw. Pomiędzy wielkością sprzedaży, cenami, kształtem i rozmiarem obszarów rynkowych istnieje wzajemna współzależność. Analiza obszarów rynkowych winna więc być powiązana z teorią lokalizacji ${ }^{20}$.

\subsection{Modele ksztattowania się hierarchii przestrzennej i układów osadniczych}

Analiza potencjału obszarów rynkowych w odniesieniu do kształtowania się całego układu osadniczego została rozwinięta przez Waltera Christallera $^{21}$. Autor koncepcji ośrodków centralnych udowodnił, że o randze każdego miasta w strukturze osadniczej regionów i krajów decyduje przestrzenny zasięg sprzedaży oferowanych $\mathrm{w}$ nim towarów i usług,

18 Z. Przygodzki, A. Nowakowska, J. Chądzyński, Region i jego rozwój w warunkach globalizacji, Wyd. CeDeWu, Warszawa 2007, s. 48-49.

19 R. Domański, Gospodarka..., s. 44.

20 Z. Przygodzki, A. Nowakowska, J. Chądzyński, Region i jego rozwój..., s. 48.

21 W. Christaller, Die Zentralen Orte in Süddeutschland. Eine ökonomisch-geographische Untersuchung über die Gesetzmässigkeit der Vorbereitung und Entwicklung der Siedlungen mit städtischen Funktionen, Fischer, Jena 1933. 
wyznaczony przez maksymalną odległość, jaką rozproszona ludność gotowa jest pokonać, aby nabyć oferowane $\mathrm{w}$ nim dobra i usługi ${ }^{22}$. Odległość ta rośnie przy tym wraz z zakresem funkcji pełnionych przez dany ośrodek w przestrzeni. Dlatego, aby wyjaśnić zróżnicowanie występujące wśród jednostek centralnych, W. Christaller dokonał rozróżnienia funkcji centralnych na wyższego i niższego $\mathrm{rzędu}^{23}$. Odległość postrzegana była przez autora w sensie ekonomicznym, jako funkcja czasu i kosztów transportu, natomiast ranga ośrodka centralnego stanowiła wypadkową liczby jego ludności, rozległości obsługiwanego obszaru oraz zamożności jego mieszkańców. Innymi słowy, o oferowanym „asortymencie” różnorodnych korzyści w poszczególnych ośrodkach systemu osadniczego decydują takie czynniki, jak liczba przedsiębiorstw i gospodarstw domowych oraz wydajność pracy i kapitału, będące w znacznej mierze wypadkowymi ich koncentracji przestrzennej.

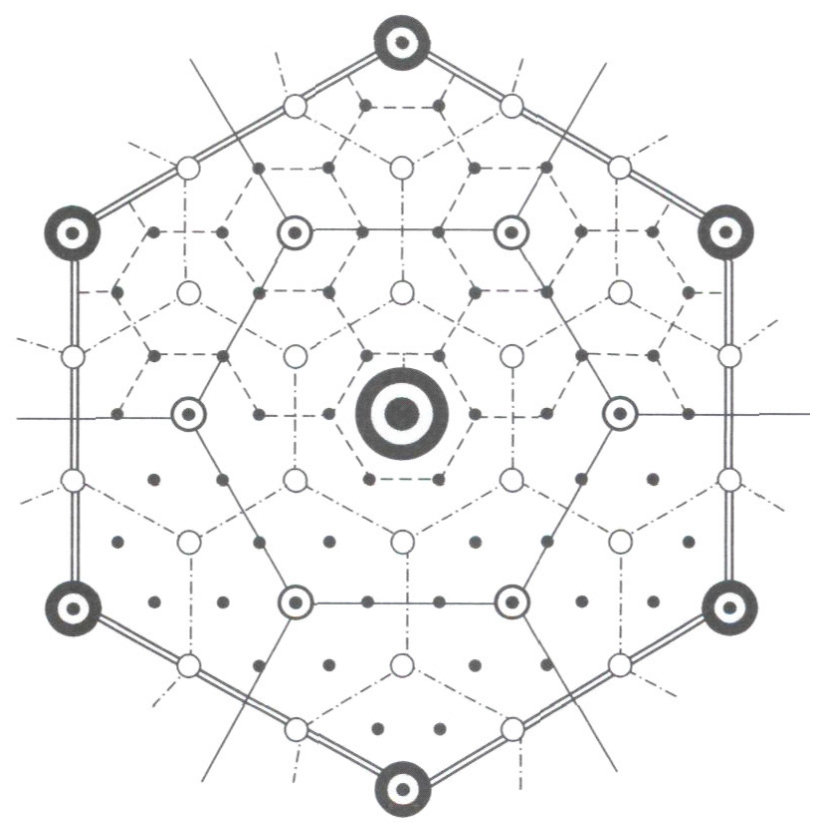

Rys. 2. Kształt systemu osadniczego w systemie ośrodków centralnych W. Christallera Źródło: W. Christaller, Ośrodki centralne w Południowych Niemczech, „Przegląd Zagranicznej Literatury Geograficznej" 1963, z. 1, s. 66.

22 R. Domański, Gospodarka..., s. 45.

23 Z. Przygodzki, A. Nowakowska, J. Chądzyński, Region i jego rozwój..., s. 49. 
W. Christaller przyjął szereg założeń upraszczających, tj. występowanie przestrzeni niezróżnicowanej z punktu widzenia ukształtowania powierzchni, relatywnie równomierne rozmieszczenie w niej ludności, brak różnic $\mathrm{w}$ sile nabywczej i preferencjach konsumentów, istnienie mechanizmu konkurencji doskonałej oraz jednolite koszty transportu w każdym kierunku. Pozwoliło to na graficzne wyznaczenie struktury systemu osadniczego pozostającego $\mathrm{w}$ równowadze przestrzennej (rys. 2). Układ ten pozwala domniemywać, że w warunkach zbliżonych do konkurencji doskonałej i relatywnie równomiernie rozwiniętej infrastruktury komunikacyjnej (wpływającej na koszty transportu) układy osadnicze wykazują "naturalną" tendencję do kształtowania się w nich stosunkowo niewielkiej liczby położonych w jednakowej od siebie odległości ośrodków centralnych oraz znacznie większej liczby ośrodków niższego rzędu.

Teoria ośrodków centralnych w dużej mierze sprawdza się w odniesieniu do „starych” układów osadniczych (np. w Europie Zachodniej), których geneza sięga czasów feudalnych. Czasy po „rewolucji przemysłowej” zniekształciły jednak ten model poprzez rosnące znaczenie takich czynników, jak nieregularne występowanie surowców, korzyści aglomeracji, duże przestrzenie państw (np. Kanada czy Australia) czy wreszcie procesy metropolizacji ${ }^{24}$. Warto jednak zauważyć, iż teoria ta wciąż znajduje zastosowanie przy wyznaczaniu lokalizacji obiektów działalności handlowej w dużych miastach ${ }^{25}$.

Pierwsza ogólna teoria gospodarki przestrzennej jest dziełem Augusta Löscha ${ }^{26}$. Podstawą jego rozważań był obszar (a nie punkt) charakteryzujący się następującymi cechami: jednorodnością pod względem rozmieszczenia ludności rolniczej, istnieniem sieci transportowej zbudowanej zgodnie z ideą minimalizacji kosztów transportu, występowaniem korzyści aglomeracji i korzyści skali produkcji, istnieniem kosztów związanych $\mathrm{z}$ transportem produktów, stosowaniem systemu cen loco magazyn wytwórcy, brakiem zróżnicowania gustów i preferencji ludności, elastycznością popytu, dążeniem przedsiębiorców do maksymalizacji zysku oraz taką organizacją systemu, która minimalizuje całkowite koszty transportu ${ }^{27}$.

24 Por. J. Słodczyk, Przestrzeń miasta i jej przeobrażenia, „Studia i Monografie Uniwersytetu Opolskiego" nr 298, Opole 2003, s. 81.

25 Por. International Council of Shopping Centers, Certified Shopping Center Manager (CSM) Handbook, New York 2001, s. 108-109.

26 A. Lösch, Die räumliche Ordnung der Wirtschaft. Eine Untersuchung über Standort, Wirtschaftsgebiete und internationalem Handel, Fischer, Jena 1940; A. Lösch, The Economics of Location, Yale University Press, New Haven 1954.

27 R. Domański, Gospodarka..., s. 47. 
W modelu A. Löscha przyjmuje się, że w procesie produkcji pojawiają się korzyści skali, umożliwiające zwiększanie zysku z jednostki produkcji. Jednakże sprzedaż powiększonej produkcji pociąga za sobą rosnące koszty transportu. W konsekwencji przestrzenny układ produkcji będzie rezultatem wzajemnego, jednoczesnego oddziaływania korzyści skali i aglomeracji oraz kosztów transportu. W odniesieniu do decyzji przedsiębiorstw, w warunkach doskonałej konkurencji dążą one do lokalizowania się możliwie blisko chłonnego rynku zbytu. Zatem do rozważań lokalizacyjnych wprowadzony został czynnik popytu, systematyzujący analizę rynku według klasycznej krzywej popytu wyznaczonej przez cenę dóbr zaproponowanych na rynku i ich ilość. Pomimo indywidualnych decyzji działalność przedsiębiorstw na rynku pozostaje współzależna - ich liczba będzie wzrastać tak długo, aż znikną zyski nadzwyczajne, wtedy przestrzeń stanie się obojętna (neutralna) dla przedsiębiorcy ${ }^{28}$. Model regionu ekonomicznego opisanego przez A. Löscha powinien mieć kształt obszaru heksagonalnego (w czym widać nawiązanie do prac W. Christallera). Stanowi on jedną z pierwszych koncepcji regionów modelowych, wyodrębnionych na użytek ekonomiki regionalnej ${ }^{29}$.

W oparciu o dotychczasowy dorobek teorię lokalizacji zaproponował także amerykański ekonomista Walter Isard, którego uznaje się za inicjatora wielodyscyplinarnej dziedziny wiedzy z pogranicza ekonomii i geografii, zwanej regionalistyką (regional science) ${ }^{30}$. Rozwój tej gałęzi wiedzy przyczynił się przy tym do ponownego zbliżenia się tych dwóch nauk, z których pierwsza w coraz większej mierze korzystała ze sformalizowanych modeli matematycznych i ekonometrycznych, lecz kosztem tego

28 Z. Przygodzki, A. Nowakowska, J. Chądzyński, Region i jego rozwój..., s. 51.

29 A. Lösch, Gospodarka przestrzenna - teoria lokalizacji, PWE, Warszawa 1961, s. 17.

30 Warto dodać, że istotnym wkładem Waltera Isarda było trwałe zakorzenienie regionalistyki w strukturze nauk społeczno-ekonomicznych poprzez jego silną instytucjonalizację oraz wkład w rozwój kadry naukowej dla tej dziedziny wiedzy. Dzięki jego inicjatywom w roku 1954 w Stanach Zjednoczonych powstało stowarzyszenie regionalistów pod nazwą Regional Science Association, które w ciągu kolejnych kilkunastu lat uległo bardzo dynamicznemu umiędzynarodowieniu. Istnienie tej organizacji przyczynito się do rozwoju wielu poczytnych czasopism naukowych, m.in. „Papers in Regional Science”, ,Journal of Regional Science”, „The Annals of Regional Science” oraz „Regional Science and Urban Economics”. Sam „ojciec” regionalistyki podkreślał przy tym, że jej główną siłą pozostaje różnorodność, choć ta prowadzi siłą rzeczy do trudności w uznaniu regional science za ugruntowaną dyscyplinę naukową. Regionalistom nie chodzi jednak przede wszystkim o sztywność wygodnych, ale często rozbieżnych z rzeczywistością konwencji, charakterystycznych dla ugruntowanych gałęzi nauki. Podejście to świadczy niewątpliwie o sukcesie zrzeszającej ich organizacji - Regional Science Association (D. Boyce, A Short History of the Field of Regional Science, „Papers in Regional Science” 2004, vol. 83, s. 46). 
zmierzała coraz bardziej w kierunku aprzestrzennych i niedynamicznych analiz ekonomicznych, podczas gdy geografia społeczno-ekonomiczna skłaniała się ku opisowemu i kartograficznemu ujmowaniu badanych zjawisk $^{31}$. Według W. Isarda, regional science

zajmuje się badaniem człowieka i wzajemnego oddziaływania zachodzącego między nim a środowiskiem przyrodniczym [...], kładzie szczególny nacisk na analizę położenia, na aspekt przestrzenny (badanych zjawisk), biorąc w pełni pod uwagę całość zmienności powierzchni Ziemi, jej wyposażenie w bogactwa naturalne. [...] podobnie jak ekonomia, a w mniejszym zakresie także socjologia, kładzie szczególny nacisk na metodologię ${ }^{32}$.

Tym samym, za najistotniejszy dorobek tej gałęzi wiedzy uznaje się to, że w obszarze opisanych powyżej analiz, posiadających przede wszystkim wymiar czysto teoretyczny, wypracowała ona bogatą i rzetelną metodykę badań, wykorzystując ją do empirycznej weryfikacji postawionych wcześniej hipotez. W. Isard stosował $\mathrm{w}$ analizie regionalnej m.in. metody programowania liniowego, metody nakładów-wyników (input-output), modele ciążenia, mnożnik handlu międzyregionalnego oraz analizę powiązań między regionalnymi i narodowymi cyklami gospodarczymi. Co więcej, dążył on do urealnienia budowanych modeli, dopuszczając m.in. istnienie nierówności w występowaniu zasobów surowcowych, pracy i kapitału, nierównomierne i nieciągłe rozmieszczenie ludności oraz inne lokalne różnice ${ }^{33}$. Model równowagi ogólnej zaproponowany przez W. Isarda łączy zatem określenie optymalnej lokalizacji przedsiębiorstwa w przestrzeni z optymalną kombinacją nakładów czynników produkcji. Został on urealniony poprzez uwzględnienie konieczności ponoszenia nakładów transportowych, a także uwzględnienie mobilności czynników produkcji w przestrzeni (ruchliwości czynników), co wpływa na ich unikalność, niepowtarzalność, a w konsekwencji cenę $e^{34}$.

31 Geografowie niekiedy „zarzucają” ekonomistom, że metodyka analiz ekonomicznych, podejmujących próby włączenia w swe analizy przestrzeni, nawet współcześnie w mało twórczy sposób wykorzystuje pojęcia znane już w latach 60. i 70. XX w. „Narzędzia matematyczne, na których opierają się modele nowej geografii ekonomicznej, mogą stawać się coraz bardziej wyrafinowane, a i tak większość geografów będzie postrzegała ich wyniki jako nieszczególnie odkrywcze, a zastosowania empiryczne jako trywialne" (R. Martin, The New "Geographical Turn" in Economics: Some Critical Reflections, „Cambridge Journal of Economics” 1999, no. 23, s. 67; [cyt. za:] A. Cieślik, Geografia inwestycji zagranicznych, Wyd. Uniwersytetu Warszawskiego, Warszawa 2005, s. 136).

32 W. Isard, Metody analizy regionalnej..., s. 10.

33 Z. Przygodzki, A. Nowakowska, J. Chądzyński, Region i jego rozwój..., s. 52.

34 Szerzej: W. Budner, Lokalizacja przedsiębiorstw..., s. 64-66 
Próbę uniwersalnego uogólnienia opisu procesów prowadzących do kształtowania struktury przestrzennej gospodarki na skutek wzajemnego oddziaływania korzyści i niekorzyści aglomeracji zaproponował George Kingsley Zipf w formie reguły wielkości-kolejności (rank-size rule $)^{35}$. Ujawnia ona powszechną prawidłowość, że na wielu obszarach występuje niewiele miast dużych, zaś dużo ośrodków małych. Reguła ta pozwala określić teoretyczną strukturę systemu osadniczego za pomocą wzoru:

$$
L_{j}=L_{1} \times j^{a}(a<0)
$$

gdzie:

$L_{1}$ - liczba mieszkańców największego miasta w strukturze osadniczej,

$a$ - wykładnik kontrastu danego systemu osadniczego,

$j$ - ranga miasta w strukturze osadniczej.

W sytuacji, gdy parametr a ma wartość -1 , system osadniczy osiąga stan równowagi, gdy $|a|>1$, występuje nadmiar koncentracji ludności w dużych miastach, natomiast gdy $|a|<1$ ludność koncentruje się w malych miastach ${ }^{36}$.

Warto podkreślić, że rozważania Zipfa odnoszą się przy tym do wielu prawidłowości i zachowań ludzkich, wykraczając poza domenę gospodarki przestrzennej czy geografii osadnictwa. Dotyczą one bowiem i takich obserwacji, jak np. częstotliwość pojawiania się pewnych słów w książce (G. K. Zipf był lingwistą) $)^{37}$.

Rozwój analiz poświęconych zagadnieniu koncentracji działalności gospodarczej w przestrzeni odbywał się równolegle dzięki dynamicznemu postępowi w obszarze tzw. regional science oraz w geografii ekonomicznej, dla odróżnienia nazywanej analizą przestrzenną (spatial analysis). Ta ostatnia, choć bardziej zróżnicowana metodologicznie, $\mathrm{w}$ równym stopniu rozwijała badania empiryczne służące weryfikacji teorii i hipotez zbudowanych na bazie klasycznych teorii lokalizacji. W jej ramach badano czynniki lokalizacji przemysłu, strukturę wykorzystania gruntów, procesy urbanizacji i kształtowanie się hierarchii osadniczej miast, jak również wpływ sieci transportowych na efektyw-

35 G. K. Zipf, The Psychobiology of Language, Routledge, London 1936; idem, Human Behavior and the Principle of Last Effort, Addison-Wesley, Cambridge 1949.

36 Zob. np. I. Jażdżewska, Sieć i system osadniczy miast, [w:] S. Liszewski (red.), Geografia urbanistyczna, Wyd. Uniwersytetu Łódzkiego, Łódź 2008, s. 332.

37 K. Gawlikowska-Hueckel, Innowacje a rozwój regionów w Unii Europejskiej. Europa dwóch prędkości?, [w:] A. Jewtuchowicz (red.), Region w gospodarce opartej na wiedzy, Wyd. Uniwersytetu Łódzkiego, Łódź 2007, s. 121. 
ność i dynamikę wymiany handlowej oraz dynamikę mobilności społecznej w przestrzeni ${ }^{38}$.

Zarówno spatial analysis, jak i regional science od samego początku tworzyły jednak wspólną całość intelektualną ${ }^{39}$. Oba nurty w równym stopniu czerpały z dorobku W. Christallera, E. M. Hoovera ${ }^{40}$, A. Löscha, T. Palandera, J. H. von Thünena, A. Webera, jak również z późniejszych opracowań ekonomistów francuskich zajmujących się procesami nierówności przestrzennych rozwoju (F. Perroux ${ }^{41}$, J. Boudeville ${ }^{42}$, C. Pon$\left.\operatorname{sard}^{43}\right)$.

\section{Konwergencja a polaryzacja regionalna - siły kształtujące strukturę przestrzenną gospodarki}

Pierwsze teorie lokalizacji działalności gospodarczej oraz kształtowania się układów osadniczych, za podstawowe przyczyny umiejscowienia działalności gospodarczej w przestrzeni uznawały czynniki określające dostęp do surowców, wpływające na minimalizację kosztów transportu oraz niektóre z nich, np. koszty pracy. Dodatkowo podkreślały fakt, że obszary, gdzie z powodu dogodnych warunków naturalnych i transportowych została zlokalizowana produkcja, rozwijają się szczególnie dynamicznie, dyskontując przewagi zdobyte w przeszłości. Na ich obszarze powstają często wielkie aglomeracje, które - ze względu na koncentrację produkcji i ludności - stanowią centra wzrostu, zdolne do aktywizowania działalności całego otoczenia. Firmy funkcjonujące w takich centrach uzyskują korzyści zewnętrzne, których źródłem jest ich bliskie położenie.

38 A. Scott, Economic Geography: The Great Half Century, [w:] G. L. Clark, M. P. Feldman, M. S. Gertler (eds.), Oxford Handbook of Economic Geography, Oxford University Press, Oxford 2000, s. 21.

39 Ibidem, s. 22.

40 E. M. Hoover, Location Theory and the Shoe and Leather Industries, Harvard University Press, Cambridge 1937.

41 F. Perroux, Les espaces économiques, „Économie Appliquée” 1950, vol. 3, s. 225244; idem, La notion de pôle de croissance, „Économie Appliquée” 1955, vol. 8, s. 307-314.

42 J. R. Boudeville, Les espaces économiques, Presses Universitaires de France, Paris 1961.

43 C. Ponsard, Économie et éspace, Sedes, Paris 1955. 
Nasilanie się tego rodzaju zjawisk i ich obserwacja ukierunkowały dalszy rozwój teorii lokalizacji ${ }^{44}$.

Od czasu opracowania ogólnej teorii gospodarki przestrzennej przez A. Löscha ekonomiści coraz częściej podejmowali próby zmierzenia się z problemem dotyczącym tego, jak dwie przeciwstawne siły - sprzyjające koncentracji (korzyści aglomeracji) oraz przyczyniające się do dekoncentracji procesów gospodarczych (koszty transportu i niekorzyści aglomeracji) - prowadzą do kształtowania się porządku ekonomicznego w przestrzeni. Zrodziło to obszerną gałąź rozważań teoretycznych na temat dylematu „konwergencja $v s$. dywergencja przestrzenna”.

Praktyka gospodarcza i liczne badania na ten temat wskazywały, że w zależności od szeregu uwarunkowań może dochodzić zarówno do zjawiska polaryzacji, jak i konwergencji. Przyglądając się współczesnym procesom rozwoju społeczno-gospodarczego w warunkach globalizującej się gospodarki, można dostrzec zjawisko ich przestrzennej koncentracji. Badacze procesów globalizacji zgadzają się co do faktu, iż większość światowych zasobów czynników produkcji skupiona jest $\mathrm{w}$ niewielkiej grupie „krajów Triady”45, którą tworzy ok. 20 państw i zamieszkuje ok. $16 \%$ ludności świata ${ }^{46}$. Na fakt ten wskazuje też W. Anioł pisząc, iż „globalizacja w gruncie rzeczy nie jest globalna”, gdyż dotyczy przede wszystkim krajów Triady oraz że „nie jest wszechogarniająca”, ponieważ np. w dużo większym stopniu dotyczy sfery ekonomicznej niż kulturowej, natomiast w samej sferze ekonomicznej bardziej globalne są rynki finansowe niż rynki pracy itd. ${ }^{47}$ Faktem jest, iż największą wartość produktu krajowego brutto wytwarzają obecnie kraje najwyżej rozwinięte, których ludność stanowi jedynie ok. 1/5 populacji świata. Pozostałą cześć mieszkańców Ziemi stanowią natomiast obywatele państw skupiających jedynie ok. 20\% światowego bogactwa. Należy przy tym mieć na uwadze, iż na przestrzeni lat dysproporcje rozwojowe między krajami rozwiniętymi a rozwijającymi się ulegają pogłębieniu. Przykładowo, w latach

44 K. Gawlikowska-Hueckel, Procesy rozwoju regionalnego w Unii Europejskiej. Konwergencja czy polaryzacja?, Wyd. Uniwersytetu Gdańskiego, Gdańsk 2003, s. 16.

45 Termin „kraje Triady” stanowi konsekwencję występowania trzech głównych obszarów gospodarczych świata, charakteryzujących się największą intensywnością i dynamiką procesów rozwoju społeczno-gospodarczego. Są to odpowiednio: obszar Ameryki Północnej ze stanowiącą siłę napędową jego rozwoju gospodarką Stanów Zjednoczonych, kraje Unii Europejskiej (w tym przede wszystkim tzw. „stare” kraje Unii, czyli najbardziej rozwinięty gospodarczo obszar Europy Zachodniej) oraz kraje Azji Wschodniej i Południowo-Wschodniej z gospodarką Japonii na czele.

46 A. Zorska, Ku globalizacji?, PWN, Warszawa 1998, s. 29.

47 W. Anioł, Paradoksy globalizacji, Instytut Polityki Społecznej Uniwersytetu Warszawskiego, Warszawa 2002, s. 34-38. 
1989-1999 udział handlu w krajach bogatych wzrósł z 28 do 37\% wartości światowego produktu krajowego, podczas gdy w krajach biednych jedynie $z 7,2$ do $7,8 \%{ }^{48}$.

Z drugiej strony, w wyniku badań podejmowanych w zakresie zróżnicowań międzyregionalnych w Europie podkreślono, że w długim okresie można zaobserwować postępującą konwergencję produktywności i dochodów na poziomie państw narodowych. Jednocześnie obserwacje tych wskaźników na poziomie regionalnym ukazały postępujące zróżnicowania między nimi ${ }^{49}$.

Zagadnienia koncentracji i rozprzestrzeniania się procesów rozwoju od lat stanowią ważny problem dla teorii rozwoju lokalnego i regionalnego. Dokonany przez wielu autorów ${ }^{50}$ przegląd tych teorii wskazuje, iż jedne stanowią próbę wyjaśnienia przyczyn polaryzacji rozwoju w układzie przestrzennym, podczas gdy w innych poddaje się analizie czynniki sprzyjające jego konwergencji. Odniesienie założeń teorii rozwoju regionalnego do praktyki gospodarczej sugeruje przy tym, że w rzeczywistości w różnych przestrzeniach występować mogą oba te procesy ${ }^{51}$.

Wyróżnić można dwa zasadnicze modele rozwoju przestrzennego. Pierwszy z nich opiera się na założeniu, że dywergencja jest zjawiskiem naturalnym i z ekonomicznego punktu widzenia korzystnym. Prowadzi ona do powstawania tzw. biegunów wzrostu. Autorem tego pojęcia (pôle

48 The World Bank, World Development Indicators 2001, Washington D.C. 2001, cyt. za: S. Chakravorty, Urban Development in the Global Periphery: The Consequences of Economic and Ideological Globalization, „The Annals of Regional Science” 2003, no. 37, s. 359.

49 A. Cappelen, J. Fagerberg, B. Verspagen, Lack of Regional Convergence, [w:] J. Fagerberg, P. Guerrieri, B. Verspagen (eds.), The Economic Challenge for Europe: Adapting to Innovation-based Growth, Edward Elgar, Aldershot 1999; cyt. za: Cities and Regions in the New Learning Economy, OECD 2001, s. 21; zob. także: K. Gawlikowska-Hueckel, Konwergencja regionalna w Unii Europejskiej, „Gospodarka Narodowa” 2002, nr 10, s. 110-113.

$50 \mathrm{~W}$ polskiej literaturze przegląd teorii rozwoju regionalnego można spotkać m.in. w pracach: E. Nowińska-Łaźniewska, Relacje przestrzenne w Polsce w okresie transformacji w świetle teorii rozwoju regionalnego, „Prace Habilitacyjne Akademii Ekonomicznej w Poznaniu" nr 13, Poznań 2004; K. Gawlikowska-Hueckel, Procesy rozwoju regionalnego...; T. G. Grosse, Przegląd koncepcji teoretycznych rozwoju regionalnego, „Studia Regionalne i Lokalne” 2002, nr 1 (8), s. 25-48; H. Godlewska, Lokalizacja działalności gospodarczej, Wyższa Szkoła Handlu i Finansów Międzynarodowych, Warszawa 2001; R. Domański, Gospodarka przestrzenna. Podstawy teoretyczne, PWN, Warszawa 2006; J. Chądzyński, A. Nowakowska, Z. Przygodzki, Region i jego rozwój...

51 M. E. Sokołowicz, W kierunku nowej polityki regionalnej? Rozważania nad przyszłym ksztattem polityki regionalnej w Polsce, [w:] Polityka spójności. Ocena i wyzwania, Ministerstwo Rozwoju Regionalnego, Warszawa 2008, s. 12. 
de croissance $^{52}$ ) jest ekonomista François Perroux, który wskazywał, iż siły rynkowe nie gwarantują równomiernego wzrostu, gdyż działalność ludzka (a działalność gospodarcza w szczególności) wykazuje tendencję do koncentracji ${ }^{53}$. Teoria biegunów wzrostu w ujęciu Perroux nie odnosiła się jednak wprost do wymiaru przestrzennego. Ekonomista ten dokonał rozróżnienia między tzw. przestrzenią geonomiczną i ekonomiczną, przy czym pierwszy z tych terminów utożsamia $\mathrm{z}$ tzw. przestrzenią „banalną”, definiowaną przez geonomiczne relacje między punktami, liniami i rozmiara$\mathrm{mi}$, natomiast drugą proponuje definiować przez pryzmat różnorodnych powiązań gospodarczych (zob. też podrozdział $4 \mathrm{w}$ niniejszym rozdziale) ${ }^{54}$.

W abstrakcyjnym definiowaniu przestrzeni ekonomicznej F. Perroux za biegun wzrostu uznawał nie jednostkę terytorialną, ale np. duże przedsiębiorstwo, kompleks przemysłowy, grupę przedsiębiorstw lub gałąź przemysłu określaną jako „przemysł wiodący”, tj. taki, który w określonym momencie cechuje wyższa od przeciętnej $\mathrm{w}$ całej gospodarce stopa wzrostu, co pozwala wcześniej podejmować w nich produkcję na wielką skalę i wcześniej następuje w nich koncentracja kapitału. Poprzez powiązania $z$ innymi gałęziami gospodarki bieguny wzrostu stają się siłą napędową jej rozwoju.

Wymiar przestrzenny koncepcji biegunów wzrostu nadał J. R. Boudeville ${ }^{55}$, opierając się na badaniach przemysłu stalowego w Minas Gerais w Brazylii. Tym samym Boudeville wskazał, że pomimo tego, co podkreśla F. Perroux (prezentujący podejście sektorowe), istnieją bieguny wzrostu posiadające wymiar ściśle przestrzenny. Zaakcentował zatem, iż polaryzacja sektorowa prowadzi jednocześnie do polaryzacji regionalnej, a proces polaryzacji gospodarki może mieć również wymiar międzysektorowy ${ }^{56}$.

Teoria polaryzacji gospodarczej (jest to pojęcie zamienne w stosunku do teorii biegunów wzrostu) akcentuje zatem endemiczność zjawiska polegającego na niezrównoważonym charakterze wzrostu i rozwoju gospodarczego. Według F. Perroux „wzrost nie uwidacznia się wszędzie jednocześnie; przejawia się on ze zmienną intensywnością w postaci bie-

52 F. Perroux, La notion...

53 Szerzej: M. E. Edwards, Regional and Urban Economics and Economic Development. Theory and Methods, Auerbach Publications, Taylor and Francis Group, New York 2007, s. 269.

54 F. Perroux, Economic Space: Theory and Applications, „Quarterly Journal of Economics" 1950, vol. 64 (1), s. 92 . Szerzej w rozdziale IV niniejszej książki.

55 J. R. Boudeville, Aménagement du territoire et polarisation, Th. Génin, Librairies techniques, Paris 1972.

56 Zob. też: J. Grzeszczak, Bieguny wzrostu a formy przestrzeni spolaryzowanej, Instytut Geografii i Przestrzennego Zagospodarowania PAN, Wyd. Continuo, Wrocław 1999. 
gunów wzrostu; rozchodzi się różnymi kanałami i ze zmiennymi skutkami końcowymi dla całości gospodarki”"57.

Ważny wkład w rozwinięcie teorii polaryzacji mieli także ekonomiści Gunnar Myrdal ${ }^{58}$ i Albert O. Hirschman ${ }^{59}$. Pierwszy z nich jest twórcą zasady tzw. okrężnej i kumulatywnej przyczynowości, zgodnie z którą oddziaływanie czynnika będącego przyczyną danego zjawiska spowoduje skutek, który będzie jednocześnie przyczyną wzmocnienia pierwotnego charakteru oddziaływania tego czynnika. Tym samym, w wyniku sprzężeń zwrotnych, następuje wzmocnienie intensywności wzajemnych wpływów oraz uruchomienie kumulatywnego procesu zmian ${ }^{60}$. W pierwszej fazie prowadzi to do efektu wysysania kapitału, ludności i innych zasobów do najbardziej dynamicznie rozwijających się obszarów (przede wszystkim wielkich aglomeracji miejskich) (backwash effects). Jednak po pewnym czasie niekorzyści aglomeracji w tych obszarach powodują przesunięcia zasobów do regionów słabiej rozwiniętych ${ }^{61}$. Zaczynają działać tzw. efekty rozprzestrzeniania (spread effects). Potwierdzają to obserwacje zmniejszających się nierówności regionalnych w krajach wysoko rozwiniętych, mające miejsce $\mathrm{w}$ drugiej połowie XX w. ${ }^{62}$ Można zatem zgodzić się z sugestią, iż „postęp spójności ma miejsce wówczas, gdy efekty dyfuzji i rozprzestrzeniania dominują nad skutkami wiru (zasysania)" ${ }^{63}$. Zgodnie z prognozami Myrdala siła efektów rozprzestrzeniania jest w praktyce gospodarczej zbyt słaba i - przy braku interwencji sektora publicznego w procesy rozwoju przestrzennego - wzrost jednych regionów prowadzi do hamowania wzrostu w innych obszarach, co pogłębia procesy przestrzennej dywergencji ${ }^{64}$.

57 A. Jewtuchowicz, Bieguny wzrostu, [w:] K. B. Matusiak (red.), Innowacje i transfer technologii. Słownik pojęć, Polska Agencja Rozwoju Przedsiębiorczości, Warszawa 2008, s. 31.

58 G. Myrdal, Economic Theory and Underdeveloped Regions, Gerald Duckworth, London 1957.

59 A. O. Hirschman, Investment Policies and Dualism in Underdeveloped Countries, „American Economic Review” 1957, vol. 47, no. 5, s. 550-570.

60 A. Jewtuchowicz, Bieguny wzrostu..., s. 31.

61 Dla wyjaśniania tego procesu regionaliści posługują się często modelem grawitacji i potencjału, znanym z fizyki newtonowskiej, gdzie im większy potencjał danego ośrodka (w tym przypadku aglomeracji), tym większa siła przyciągania jeszcze większej liczby czynników produkcji, malejąca oczywiście wraz z odległością. Pierwsze badania empiryczne na ten temat (w sektorze handle detalicznego) zrealizowat J. Reilly (J. Reilly, The Law of Retail Gravitation, W. Reilly Editions, New York 1931).

62 R. Domański, Geografia ekonomiczna. Ujęcie dynamiczne, PWN, Warszawa 2004, s. 135-136.

63 K. Gawlikowska-Hueckel, Procesy rozwoju regionalnego..., s. 113.

64 K. Gawlikowska-Hueckel, Konwergencja regionalna..., s. 22. 
Albert Hirschman, podejmując próbę łączenia koncepcji polaryzacji sektorowej z regionalną, analizował podział świata na rozwiniętą uprzemysłowioną Północ i słabo rozwinięte rolnicze Południe ${ }^{65}$. W początkowej fazie rozwoju inwestycje dokonywane są w sektory szybko rozwijające się na Północy, a działalność gospodarcza lokalizowana jest w ośrodkach centralnych - dających największe korzyści zewnętrzne ${ }^{66}$. A. Hirschman, w przeciwieństwie do G. Myrdala, prezentuje pozytywne podejście do koncepcji polaryzacji, zakładając, iż w wyniku wzrostu popytu na import w regionach rozwiniętych lub dyfuzji kapitału (poszukującego wyższych stóp zwrotu) i technologii do regionów słabiej rozwiniętych, efekty przesączania (trickle down) zaczną z czasem dominować nad efektami zasysania. Wskazuje przy tym, że niezrównoważony wzrost jest nie tyle zjawiskiem towarzyszącym rozwojowi, ile jego warunkiem ${ }^{67}$.

Jedną z najbardziej znanych współcześnie koncepcji nawiązujących do zjawiska nierówności przestrzennych jest model rdzenia i peryferii (core and peripheries) Johna R. Friedmanna, zgodnie z którym świat to zorganizowany system, składający się z subsystemów centralnych i subsystemów peryferyjnych $^{68}$. Działalność wytwórcza i usługowa najbardziej konkurencyjnych przedsiębiorstw jest lokowana w najsilniej rozwiniętych regionach, głównie dużych ośrodkach metropolitalnych ${ }^{69}$. Te centra gospodarcze dominują nad

65 A. O. Hirschman, Investment policies..., s. 555.

66 Ibidem, s. 557-562.

67 A. Jewtuchowicz, Bieguny wzrostu..., s. 31.

68 Ściślej rzecz ujmując, J. R. Friedman wskazywał na cztery stadia rozwoju regionalnego, z których centrum i peryferie stanowią dwa skrajne bieguny. Obszary centralne w myśl tej koncepcji to miejsca koncentracji najbardziej dynamicznie rozwijających się aktywności gospodarczych (przede wszystkim trzeciego sektora), a także politycznych, społecznych i kulturalnych, podczas gdy regiony peryferyjne (zwykle rolnicze) dotknięte są ryzykiem daleko idącej marginalizacji, czego wyrazem może być upadająca gospodarka i depopulacja. Pomiędzy tymi biegunami znajdują się obszary transformacji gospodarczej z perspektywą rozwojową (upward transitional regions), w których obserwuje się przechodzenie od gospodarki rolniczej do przemysłowej, a następnie opartej na usługach oraz regiony graniczne $i /$ lub bogate w zasoby naturalne (z reguły słabo zaludnione), czerpiące ewentualnie korzyści z rozwoju przemysłu wydobywczego bądź przygranicznego położenia (J. R. Friedman, A General Theory of Polarized Development, University of California, School of Architecture and Urban Planning, Los Angeles 1969). Powiązanie dynamiki rozwoju ze stadiami rozwoju gospodarki pozwoliło też na podział regionów na: charakterystyczne dla gospodarki preindustrialnej, charakterystyczne dla gospodarki transformującej się, charakterystyczne dla gospodarki przemysłowej oraz charakterystyczne dla gospodarki poprzemystowej (J. R. Friedman, Regional Development Policy: A Case Study of Venezuela, MIT Press, Cambridge 1966).

69 Metropolizacja jest pojęciem oznaczającym pełnienie przez pewne obszary kierowniczych funkcji w zarządzaniu gospodarką w skali przynajmniej krajowej. Innymi 
swoimi peryferiami, których rozwój pozostaje silnie uzależniony od obszarów centralnych ${ }^{70}$. Rozwój w tej koncepcji został zdefiniowany jako

nieciągły, skumulowany proces, którego sekwencje pojawiają się na skutek innowacji, w wyniku których powstają bieguny wzrostu, a w końcu rozległy system innowacji. Procesy te zachodzą w przestrzeni, są bowiem zależne od ludzkich działań i społecznych interakcji, a te uwidaczniają się właśnie w przestrzeni ${ }^{71}$.

słowy, proces ten prowadzi do budowania silnych powiązań danego ośrodka zurbanizowanego $z$ innymi światowymi metropoliami, uznawanymi za węzły w sieci globalnych przepływów kapitału, towarów, osób i informacji (por. S. Sassen, Cities in a World Economy, Columbia University Press, New York 2003; S. Sassen, Globalizacja. Eseje o nowej mobilności ludzi i pieniędzy, Wyd. Uniwersytetu Jagiellońskiego, Kraków 2007). Ponadto, metropolizacja oznacza pewnego rodzaju odstępstwo od zasady hierarchicznej organizacji przestrzeni (por. teoria ośrodków centralnych W. Christallera), polegające na osłabieniu relacji między miastem metropolitalnym i otaczającym je regionem. Skutkiem tego współczesna globalna przestrzeń powiązań ekonomicznych nabiera kształtu określanego przez P. Veltza mianem „gospodarki archipelagowej" (l'économie d'archipel) (P. Veltz, Mondialisation, villes et territoires: une économie d'archipel, Presses Universitaires de France, Paris 1996). W kontekście zjawiska metropolizacji należy mieć na uwadze, iż stanowi ono istotną konsekwencję procesów globalizacji. Największe metropolie jako światowe obszary rdzeniowe (bieguny wzrostu) stanowią platformę dla globalnych przepływów kapitałowych. Choć w warunkach gospodarki globalnej obniżające się koszty transportu, pojawiające się nowe metody organizacji produkcji oraz rozwój technologii informacyjnych sprzyjają nieograniczonym przepływom kapitałowym, kapitał mimo wszystko dąży do koncentracji w tych miejscach przestrzeni, które oferują najlepszą ku temu infrastrukturę techniczną, instytucjonalną i społeczną, wynikające z niej korzyści aglomeracji oraz duże i elastyczne rynki pracy (N. Brenner, Globalization as Reterritorialisation: The Re-scaling of Urban Governance in the European Union, „Urban Studies" 1999, vol. 36, no. 3, s. 437). Warto też podkreślić, że obserwowana współcześnie hipermobilność kapitału (dostrzegalna głównie w sektorze finansów oraz w aktywności korporacji transnarodowych) - ponieważ wymaga ogromnych zdolności kooperacyjnych i koordynacyjnych - pozostaje wrażliwa na zjawisko występowania korzyści aglomeracji, przede wszystkim w obszarze dostępności wykwalifikowanej siły roboczej oraz bliskości przedsiębiorstw oferujących usługi dla biznesu (S. Sassen, Globalizacja. Eseje o nowej mobilności..., s. 190-191). Innymi słowy, poszukiwanie bliskości do podmiotów sprzyjających ograniczaniu tzw. kosztów transakcyjnych (sektora transakcyjnego) pozostaje znaczącą siłą sprawczą formowania się lub wzmacniania istniejących metropolii - biegunów wzrostu w gospodarce globalnej.

70 T. G. Grosse, Przegląd koncepcji..., s. 29, [za:] E. E. Malizia, E. J. Feser, Understanding Local Economic Development, Center for Urban Policy Research, Rutgers, New York 1999, s. 109-117.

71 K. von Stackelberg, U. Hahne, Teorie rozwoju regionalnego, [w:] S. Golinowska (red.), Rozwój ekonomiczny regionów. Rynek pracy. Procesy migracyjne. Polska, Czechy, Niemcy, Raport IPiSS, z. 16, Warszawa 1998, s. 82, [cyt. za:] Z. Przygodzki, A. Nowakowska, J. Chądzyński, Region i jego rozwój..., s. 62-63. 
Hierarchiczna zależność „centrum-peryferie” może stanowić źródło konfliktów, jednak J. Friedmann wskazuje, że to właśnie w interesie centrum jest, aby peryferie skutecznie adoptowały innowacje, ponieważ $\mathrm{w}$ ten sposób jest ono wspomagane dzięki przekazaniu niektórych kompetencji peryferyjnym centrom subsydiarnym. Skutkiem mogą być efekty synergiczne, przyspieszające rozwój zarówno ośrodków centralnych, jak i peryferii. Co istotne, Friedman w swych rozważaniach nawiązywał silnie do dorobku poprzedników, wprowadzając jednak do nich nowy element, a mianowicie silnie eksponowane kryteria pozaekonomiczne (socjologiczne, polityczne, psychologiczne) decydujące o koncentracji, zbliżając się tym samym do akcentowania czynników o charakterze instytucjonalnym jako warunkujących kształtowanie się układu osadniczego.

Powyższe rozważania teoretyczne, poświęcone wzajemnym relacjom między polaryzacją przestrzenną (jako efektem działania korzyści aglomeracji) a konwergencją (wynikającą ze zjawiska niekorzyści aglomeracji oraz częściowo oddziaływania polityki państwa), znajdują swoje odzwierciedlenie w dyskusji na temat polityki rozwoju przestrzennego ${ }^{72}$. Najważniejszą rekomendacją dla polityki regionalnej eksponującej zalety polaryzacji, zaproponowaną przez F. Perroux już w latach 60. XX w., jest wzmacnianie dotychczasowych lub tworzenie nowych biegunów wzrostu ${ }^{73}$. Ponadto należy

72 Por. M. E. Sokołowicz, W kierunku nowej polityki..., s. 7-22; idem, Zintegrowane podejście do rozwoju. Polityka spójności a polityki wspierania konkurencyjności i innowacyjności Unii Europejskiej, [w:] T. G. Grosse, A. Galek, Zintegrowane podejście do rozwoju - rola polityki spójności, Ministerstwo Rozwoju Regionalnego, Warszawa 2008, s. 47-72.

73 Należy jednak mieć na uwadze, że wspieranie biegunów wzrostu nie zawsze przynosi pożądane efekty. Potwierdzity to $\mathrm{m}$.in. badania prowadzone w południowych regionach Włoch (tzw. Mezzogiorno), które wskazały, że aktywne wspieranie w nich wybranych sektorów gospodarki nie doprowadziło do przenoszenia się „impulsów” do innych jej obszarów. Powstawały tzw. „katedry na pustyni” (J. G. Lambooy, Globalization, Regional Context and Governance: A Relational Perspective, [w:] H. Bünz, A. Kukliński, Globalization, Experiences and Prospects, Wyd. Rewasz, Warszawa 2001, s. 301-302). Najbardziej skuteczne inicjatywy to takie, które wspierają realizację inicjatyw oddolnych, już istniejących, jednak wymagających wsparcia w początkowych fazach rozwoju (M. E. Edwards, Regional and Urban Economics..., s. 330). Ponadto, wspieranie biegunów wzrostu ma nie tylko swój wymiar przestrzenny, lecz także sektorowy. Zakłada się, iż największe rezultaty przynosi zaangażowanie się sektora publicznego w rozwój infrastruktury komunikacyjnej, edukację oraz wsparcie sektorów zaawansowanych technologii. W pewnych regionach skuteczne jest również inwestowanie w bazę turystyczną, rekreacyjną i wypoczynkową (M. E. Edwards, Regional and Urban Economics..., s. 330-338). Najbardziej wątpliwą skuteczność oddziaływania wykazują natomiast wyrównawcze transfery miedzyregionalne oraz subsydiowanie ze środków publicznych działalności przedsiębiorstw (z wyjątkiem subsydiowania działalno- 
rozwijać sieć komunikacyjną między dominującymi obszarami wzrostu (biegunami wzrostu), aby przyspieszać proces rozprzestrzeniania się wzrostu gospodarczego ${ }^{74}$. Jak dostrzegła K. Gawlikowska-Hueckel, zwolennicy tego nurtu argumentują, iż realizacja strategii wspierania regionów najbardziej konkurencyjnych nie skazuje regionów mniej rozwiniętych na trwałą marginalizację. Wiadomo, że po pewnym czasie ośrodki nowoczesne, bardzo dobrze rozwinięte, staną się „lokomotywami” wzrostu i „pociągną" obszary o niższym poziomie rozwoju ${ }^{75}$.

U podstaw powyższego założenia leży hipoteza „odwróconego U”76, sformułowana przez J. G. Willimasona, zgodnie z którą w początkowym okresie rozwoju danego kraju (kiedy poziom rozwoju gospodarczego mierzony PKB per capita jest relatywnie niski) luka między regionami biednymi i bogatymi powiększa się. Stanowi to skutek faktu, że w tym okresie powiązania międzyregionalne, przepływ czynników produkcji i polityka regionalna działają selektywnie w kierunku wspierania ośrodków i centrów dobrze rozwiniętych. Jednak gdy osiągnięty zostanie wyższy poziom dochodu narodowego, następuje wzrost regionów słabiej rozwiniętych ${ }^{77}$. W myśl tego założenia najlepszym rozwiązaniem, gdy kraj znajduje się na relatywnie niskim poziomie rozwoju gospodarczego, pozostaje wspieranie kilku biegunów wzrostu (polityka koncentracji wysiłków na ograniczonej liczbie celów). Będzie to prowadziło do szybszej stopy wzrostu, której ceną jest większa jego dywergencja.

Drugi nurt rozważań na temat polityki regionalnej zakłada natomiast, że dywergencja (polaryzacja regionalna) w negatywnym stopniu oddziałuje przede wszystkim na sferę społeczną. Prowadzi ona m.in. do wzrostu bezrobocia w regionach słabiej rozwiniętych. Pojawia się problem biedy, kryzysu przemysłów tradycyjnych itp. W wymiarze całego kontynentu (np. UE) podnosi się też argumenty, że różnice te są konsekwencją uwarunkowań historycznych, które defaworyzowały pewne kraje. To podejście prowadzi do następujących założeń polityki przestrzennej:

- dążenie do restrukturyzacji przemysłów tradycyjnych,

- inwestowanie w infrastrukturę intraregionalną w regionach słabiej rozwiniętych,

- realizacja programów rewitalizacji,

ści innowacyjnej - zob. też: P. Gajewski, Ekonomiczne aspekty polityki regionalnej, „Gospodarka Narodowa” 2007, nr 1-2, s. 77-78).

74 E. E. Malizia, E. J. Feser, Understanding Local Economic Development..., s. 104-106.

75 K. Gawlikowska-Hueckel, Innowacje a rozwój regionów..., s. 136.

76 J. G. Williamson, Regional Inequality and the Process of International Development: A Description of Patterns, „Economic Development and Cultural Change” 1965, vol. 13, no. 4, s. 10.

77 Za: K. Gawlikowska-Hueckel, Innowacje a rozwój regionów..., s. 136. 
- realizacja programów społecznych (walka z biedą, programy edukacyjne, kształcenie ustawicznie itp.),

- programy ochrony środowiska naturalnego itp.

Coraz częściej wskazuje się jednak na nieskuteczność polityki spójności, polegającej na wyrównywaniu różnic między regionami „za wszelką cenę". Jednym $\mathrm{z}$ istotnych argumentów przeciwko polityce wyrównawczej jest teza, iż podstawę procesu konwergencji dochodowej stworzyła przede wszystkim stabilność makroekonomiczna i właściwe funkcjonowanie rynków dóbr, kapitału i pracy, a nie redystrybucja dochodów z regionów lepiej do słabiej rozwiniętych ${ }^{78}$.

Należy dostrzec, że obydwa przeciwstawne modele rozwoju mają swoje dobre i złe strony. W praktyce wspieranie biegunów wzrostu (polityka sprzyjająca polaryzacji) może prowadzić do niższych jednostkowych kosztów produkcji, specjalizacji funkcjonalnej wspieranych regionów, niższych kosztów wprowadzania innowacji, a zatem w ostatecznym rozrachunku do szybszego tempa wzrostu gospodarczego i większej konkurencyjności. $\mathrm{Z}$ kolei nadmierna polaryzacja przestrzenna sprzyja inflacji, negatywnym skutkom społecznym (np. problemy strukturalne $\mathrm{w}$ regionach słabiej rozwiniętych), pogarszającej się jakości życia w największych aglomeracjach miejskich (tab. 1). Wydaje się, że rozwiązaniem optymalnym jest kombinacja obydwu podejść. Należy jednak odpowiedzieć na pytanie o proporcje w zakresie stosowania w praktyce rozwiązań modelowych ${ }^{79}$.

Z punktu widzenia wkładu w uwzględnienie przestrzeni w formalnych modelach ekonomicznych za najbardziej wpływowe w ostatnich latach uznaje się prace Paula Krugmana - laureata Nagrody Banku Szwecji im. Alfreda Nobla w dziedzinie ekonomii z 2008 r. Jego publikacje z początku lat 90 . XX w. są uznawane za umowny początek nurtu badawczego zwanego Nową Geografią Ekonomiczną (NGE) ${ }^{80}$. Choć sam autor New Economic Geography przyznaje, że nurt ten dotyka zagadnień, które dla analiz przestrzennych nie są nowe ${ }^{81}$, ujęcie ich $\mathrm{w}$ formalne ramy uważa się za znaczący wkład w ekonomiczną analizę przestrzenną.

78 J. Bradley, The Impact of Community Support Frameworks on Objective 1 Countries: Greece, Ireland, Portugal and Spain 1989-2006, Economic and Social Research Institute, Dublin 2000, [za:] K. Gawlikowska-Hueckel, Innowacje a rozwój regionów..., s. 136.

79 Zob. też: M. E. Sokołowicz, Territorial Context in the Research on the EU Cohesion. One-speed or Multi-speed Europe?, [w:] T. Markowski, M. Turała (eds.), Territorial Cohesion Policy in Poland - Issues in Impact Assessment, „Studia Regionalia” 2012, vol. 33, s. 9-28.

80 P. Krugman, Geography and Trade, MIT Press, Cambridge 1991; idem, Increasing Returns and Economic Geography, „Journal of Political Economy” 1991, 99 (3), s. 483-499.

81 P. Krugman, Where in the World is the 'New Economic Geography'?, [w:] G. L. Clark, M. P. Feldman, M. S. Gertler (eds.), Oxford Handbook..., s. 50. 
Tabela 1. Korzyści i niekorzyści płynące z polaryzacji przestrzennej

\begin{tabular}{|c|c|}
\hline Korzyści polaryzacji & Niekorzyści polaryzacji \\
\hline $\begin{array}{l}\text { - } \text { koncentracja działalności gospodarczej } \\
\text { prowadzi do niższych jednostkowych } \\
\text { kosztów transportu, niższych kosztów } \\
\text { wprowadzania innowacji, specjalizacji } \\
\text { produkcji, łatwości znalezienia kontra- } \\
\text { hentów oraz odpowiednich pracowników, } \\
\text { - wzrost płac w regionie, } \\
\text { - wraz z rozwojem biegunów wzrostu przy- } \\
\text { ciąganych jest więcej przedsiębiorstw } \\
\text { (co oznacza większą konkurencję, co } \\
\text { w powiązaniu ze wzrostem płac stano- } \\
\text { wi bodziec do relokowania działalności } \\
\text { w inne miejsce); zatem impulsy do kon- } \\
\text { wergencji są impulsami w pewnym sensie } \\
\text { endogenicznymi (niezależnymi od działań } \\
\text { sektora publicznego). }\end{array}$ & $\begin{array}{l}\text { - } \text { koncentracja przedsiębiorstw i pracowni- } \\
\text { ków prowadzi do inflacji (np. wzrostu cen } \\
\text { nieruchomości); impulsy inflacyjne prze- } \\
\text { noszą się przy tym z czasem do regionów } \\
\text { słabiej rozwiniętych, } \\
\text { - } \text { deprecjacja kapitału ludzkiego (bezro- } \\
\text { bocie, bieda, przestępczość) powoduje } \\
\text { wzrost kosztów społecznych ponoszo- } \\
\text { nych przez sektor publiczny, } \\
\text { - bezrobocie strukturalne w regionach sła- } \\
\text { biej rozwiniętych, } \\
\text { - } \text { niekorzyści aglomeracji (niedostatecz- } \\
\text { nie rozwinięta infrastruktura, negatywny } \\
\text { wpływ na środowisko, pogarszający się } \\
\text { standard życia). }\end{array}$ \\
\hline
\end{tabular}

Źródło: opracowanie własne na podstawie: P. Gajewski, Ekonomiczne aspekty polityki regionalnej, „Gospodarka Narodowa” 2007, nr 1-2, s. 61-67.

Głównym celem wspomnianej gałęzi ekonomii pozostaje poszukiwanie równowagi ogólnej w decyzjach lokalizacyjnych przedsiębiorstw oraz gospodarstw domowych poprzez jednoczesną analizę sił dośrodkowych i odśrodkowych, wpływających na te decyzje. Konstrukcja teoretyczna NGE bazuje przy tym na następujących założeniach:

1. Podstawową strukturą rynkową jest konkurencja monopolistyczna - w pewnym uproszczeniu można powiedzieć, że chodzi o sytuację, w której każda firma ma „monopol” na swój produkt, a produkty innych firm są dla niego niedoskonałymi substytutami. Zaakceptowanie takiej struktury pozwala na uwzględnienie w procesach gospodarczych zjawiska rosnących stóp zwrotu.

2. Analiza kosztów transportu odbywa się zgodnie z założeniami tzw. modelu "góry lodowej” - pozwala to na niedodawanie do modelu kolejnej zmiennej, tj. transportu jako gałęzi gospodarki. Koszty transportu ujmowane są bowiem pośrednio w ten sposób, że wraz z odległością „topnieje” ilość przewożonych towarów.

3. Występowanie dynamiki - decyzje lokalizacyjne są zmienne i zależne od sytuacji. Innymi słowy, historia determinuje procesy gospodarcze. 
4. Skomplikowanie modelu (bazującego na modelu konkurencji monopolistycznej Dixita-Stiglitza ${ }^{82}$ ) jest możliwe dzięki wykorzystaniu zaawansowanych komputerowych technik obliczeniowych ${ }^{83}$.

Paul Krugman podjął próbę analizy nie tyle przyczyn koncentracji działalności gospodarczej konkretnych gałęzi przemysłu, ile stworzenia uniwersalnej koncepcji ekonomicznej odnoszącej się do fenomenu przestrzennej koncentracji gospodarstw domowych przedsiębiorstw w ogó$1 e^{84}$. Wartością modelu jest również to, że koncentruje się na pieniężnych efektach zewnętrznych, nie rozważając efektów o charakterze technologicznym (por. podrozdział 3). Dzięki temu analiza pozostaje konkretna i uwiarygodniona matematycznie. Dzieje się to oczywiście kosztem daleko idącego uproszczenia modelu, co częściowo jest rekompensowane przez możliwości stawiania ugruntowanych tez ${ }^{85}$.

W ogólnym zarysie model P. Krugmana zakłada, iż przy jednakowych innych warunkach, na skutek działania wzrastających przychodów oraz w sytuacji występowania istotnych kosztów transportu, producenci (poprzez powiązania wstecz i w przód) lokalizują się blisko siebie (dochodzi do aglomeracji). $Z$ drugiej strony, przy jednoczesnej niemobilności niektórych zasobów (gruntów oraz częściowo także pracy), koszty transportu działają jak siła odśrodkowa - przeciwdziałająca procesom aglomeracji ${ }^{86}$. Napięcie między tymi dwiema siłami (gdzie nawet drobna zmiana parametrów analizowanego przez P. Krugmana modelu może decydować - zamiennie w różnym czasie - o przewadze sił aglomeracyjnych bądź sił dośrodkowych) kształtuje ewolucję przestrzennej struktury gospodarki. Tym samym struktura ta nie powinna być analizowana jako układ statystyczny, lecz podlegający daleko idącym dynamicznym zmianom ${ }^{87}$.

82 A. K. Dixit, J. E. Stiglitz, Monopolistic Competition and Optimum Product Diversity, „American Economic Review” 1997, vol. 3, s. 297-308.

83 Założenia te wyrażone są w żargonie NGE sloganem: Dixit-Stiglitz, Icebergs, Evolution and the Computer, za: M. Fujita, P. Krugman, T. Venables, The Spatial Economy, MIT Press, Cambridge 1999.

84 P. Krugman, Increasing returns..., s. 485.

85 Na obecnym etapie rozwoju w Nowej Geografii Ekonomicznej analizuje się wprost tylko jedno z trzech marshallowskich źródeł korzyści aglomeracji (tj. powiązania wstecz i wprzód, nie zajmując się bujnymi rynkami pracy oraz zjawiskiem spill-over informacji). P. Krugman traktuje to z jednej strony jako słabość, ale z drugiej - wyzwanie rozwojowe tej dziedziny nauk ekonomicznych (P. Krugman, Where in the World..., s. 59).

86 R. Domański, Nowa geografia ekonomiczna według Paula Krugmana, [w:] W. M. Gaczek, Prace z gospodarki przestrzennej, „Zeszyty Naukowe Uniwersytetu Ekonomicznego w Poznaniu" 2010, nr 161, s. 43.

87 Zob. też: R. Domański, Ewolucyjna gospodarka przestrzenna, Wyd. Uniwersytetu Ekonomicznego w Poznaniu, Poznań 2012, s. 87. 
Innymi słowy, wśród głównych przyczyn formowania się aglomeracji należy wskazaćc8:

1) występowanie zjawiska wzrastających przychodów wraz ze skalą działalności gospodarczej,

2) występowanie zjawiska efektów zewnętrznych,

3) występowanie zjawiska konkurencji niedoskonałej, mającej związek z niemobilnością niektórych zasobów.

Napięcie między dwiema wskazanymi wyżej, przeciwstawnymi siłami kształtuje ewolucję struktury przestrzennej gospodarki. Autor Nowej Geografii Ekonomicznej zwraca przy tym uwagę, że gdyby popyt na towary przemysłowe pochodził jedynie z sektora rolniczego, wówczas system osadniczy każdego kraju przypominałby te opisywane przez A. Löscha i W. Christallera. W rzeczywistości jednak powiązania między różnorodnymi gałęziami gospodarki są bardziej skomplikowane (popyt na towary przemysłowe zgłaszany jest także przez sam przemysł) ${ }^{89}$. W efekcie w gospodarce zaczyna działać omawiany przez G. Myrdala mechanizm kumulatywnej przyczynowości, za którym stoją korzyści aglomeracji. Istota „obliczeń” w ramach NGE sprowadza się zatem do konstatacji, że nawet bardzo małe wahania wartości zmiennych objaśniających (koszty transportu, korzyści skali, udział zasobów mobilnych w gospodarce) mogą doprowadzić do działania zarówno sił dośrodkowych (core), jak i odśrodkowych (periphery) ${ }^{90}$.

Model P. Krugmana (wykres 3) uwzględnia zarówno podstawowy podział gospodarki na przemysł i rolnictwo, jak i spontaniczne pojawianie się hierarchii miast. Opisuje zatem prawa uniwersalne i dzięki temu może służyć do analizy różnych zagadnień za pomocą tych samych zestawów równań. Co istotne, eksperymenty prowadzone przy użyciu tego modelu wykazały, iż gospodarka ma więcej niż jeden punkt równowagi - potwierdza to systematyczną tendencję do formowania się wielu aglomeracji (ośrodków centralnych), które jednak są rozmieszczone $\mathrm{w}$ przestrzeni niemal równomiernie, tworząc mimo wszystko strukturę podobną do christallerowskiego systemu ośrodków centralnych. Podstawowy model NGE ujawnia przy tym proces samowzmacniania począt-

88 M. Fujita, J. F. Thisse, Economics of Agglomeration. Cities, Industrial Location, and Regional Growth, Cambridge University Press, Cambridge 2002, s. 5-15.

89 Obserwacja ta tłumaczy w znacznym stopniu różnice między systemem osadniczym państw europejskich a systemami osadniczymi innych części świata (np. Stanów Zjednoczonych czy Ameryki Południowej). W tych pierwszych bowiem systemy osadnicze zdążyły ukształtować sie jeszcze przed okresem rewolucji przemysłowej, czyli w okresie daleko idącej dominacji rolnictwa (por. J. Stodczyk, Przestrzeń miasta..., s. 81).

90 P. Krugman, Increasing returns..., s. 486. 
kowych korzyści aglomeracji. W przykładzie na wykresie 3 lokalizacja nr 11, którą cechuje największy udział pracowników, ma zdolność przyciągania dalszych pracowników i ostatecznie przejmuje połowę ogółu zatrudnienia w danym układzie osadniczym. Druga koncentracja pojawia się w lokalizacji nr 6, jednak - choć początkowo miała ona dość duże zasoby pracy - była mniejsza od innych, np. od lokalizacji nr 10. Ponieważ jednak lokalizacja nr 10 leżała zbyt blisko lokalizacji nr 11, na skutek działania zjawiska tzw. cienia aglomeracyjnego (działały efekty wysysania) jej pozycja w całym układzie osadniczym uległa w czasie znacznemu osłabieniu.

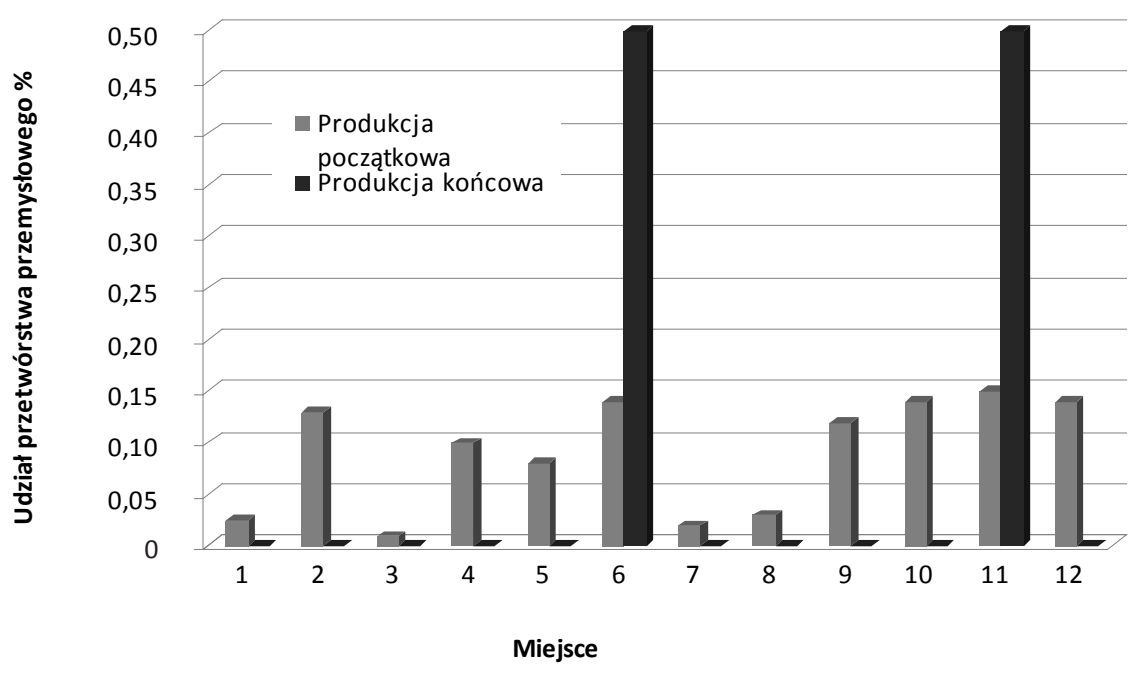

Wykres 3. Kształtowanie się hierarchii osadniczej na skutek działania sił odśrodkowych i dośrodkowych w modelu Paula Krugmana

Źródto: P. R. Krugman, Development, Geography and Economic Theory, MIT Press, Cambridge 1998, s. 107.

Największą zaletą powyższego modelu jest niewątpliwie jego uniwersalizm. Warto jednak podkreślić, iż ujawnia on jedynie ogólną tendencję. Wskazuje kierunek dążenia gospodarki do osiągnięcia przestrzennej równowagi, nie uwzględniając charakterystyk dróg dochodzenia do niej. Nie bierze pod uwagę choćby tego, skąd biorą się korzyści aglomeracji, w tym nie dotyka zagadnienia czynników społecznych, politycznych czy kulturowych (instytucjonalnych), faworyzujących jedne i defaworyzujących inne miejsca. Modelom Nowej Geografii Ekonomicznej zarzuca się tym samym, iż nie posiadają konkretnego kontekstu geo- 
graficznego czy historycznego i nie potrafią odpowiedzieć na pytanie, w których regionach w przyszłości będzie miała miejsce koncentracja i dlaczego właśnie tam.

Z powyższych względów Nowa Geografia Ekonomiczna przeciwstawiana bywa innej myśli amerykańskiej podejmującej próby wyjaśniania współczesnych przyczyn koncentracji działalności gospodarczej, zwanej koncepcją Nowych Przestrzeni Przemysłowych (New Industrial Spaces), reprezentowanej przede wszystkim przez A. Scotta i M. Storpera. Jest ona oparta na koncepcji tzw. elastycznej specjalizacji ${ }^{91}$. W przeciwieństwie do NGE podejście to zakłada, że koncentracji nie powodują te same czynniki, co w XIX w., a przede wszystkim nie mają one tendencji do nadmiernego uniwersalizmu $\mathrm{w}$ wyjaśnianiu mechanizmów koncentracji działalności regionalnej oraz konkurencyjności regionalnej. Współcześnie korzyści skali zastępuje zatem elastyczna specjalizacja, oparta w zaczym stopniu na sieciowych relacjach współpracy między przedsiębiorstwami (także konkurującymi ze sobą), zaś koncentrację przestrzenną powodują koszty koordynacji tej współpracy, rosnące wraz z odległością ${ }^{92}$. W tym kontekście Nowa Geografia Przemysłowa pozostaje nurtem badawczym na pograniczu ekonomiki przemysłu i geografii. Zajmuje się przede wszystkim problemem zakorzenienia $\mathrm{w}$ przestrzennej organizacji produkcji, które $\mathrm{w}$ istotnym stopniu zależy od układu instytucjonalnego (tab. 2).

Ważnym zagadnieniem poruszanym we współczesnych koncepcjach teoretycznych dotyczących przestrzennych aspektów rozwoju gospodarczego pozostaje stosunek do wpływu procesów globalizacji na formowanie się hierarchii przestrzennej regionów i ośrodków miejskich. W tym kontekście prezentowane są dwa przeciwstawne scenariusze przyszłości regionów. Pierwszy z nich wskazuje na duże prawdopodobieństwo ich malejącego znaczenia we współczesnej gospodarce. Tak zwany „koniec geografii" ${ }^{\prime \prime 3}$ ma być przy tym konsekwencją przejmowania działających w nich, najbardziej dynamicznych małych i średnich przedsiębiorstw przez duże międzynarodowe korporacje. Inną przyczyną takiego scenariusza może być fakt, że najlepiej rozwijające się przedsiębiorstwa w regionie przejmą kontrolę nad innymi firmami. Tym samym partnerskie relacje współpracy zostaną zastąpione układami hierarchicznymi, zakłócającymi z definicji możliwości dalszego rozwoju w oparciu o współpracę ${ }^{94}$.

91 A. Scott, New Industrial Spaces: Flexible Production Organization and Regional Development in North America and Western Europe, Pion, London 1998.

92 Zob. też: A. Cieślik, Geografia inwestycji..., s. 145.

93 R. O'Brien, Global Financial Integration: The End of Geography, Pinter, London 1992.

94 Por. B. Harrison, The Italian Industrial Districts and the Crisis of the Cooperative Form: Part I-II, „European Planning Studies” 1994, no. 2 (1-2), s. 3-22; 159-174. 
Tabela 2. Różnice między Nową Geografią Ekonomiczną a Nową Geografią Przemysłową

\begin{tabular}{|c|c|c|}
\hline & Nowa Geografia Ekonomiczna & Nowa Geografia Przemysłowa \\
\hline $\begin{array}{l}\text { Formy koncen- } \\
\text { tracji działalności } \\
\text { gospodarczej }\end{array}$ & $\begin{array}{l}\text { lokalne skupiska działalności go- } \\
\text { spodarczej związane z kosztami } \\
\text { transportu; układ centrum-pery- } \\
\text { ferie; kluczową rolę odgrywają pie- } \\
\text { niężne efekty zewnętrzne }\end{array}$ & $\begin{array}{l}\text { dzielnice przemysłowe: tradycyjne, } \\
\text { wysokich technologii, centra finan- } \\
\text { sowe związane z pionową dezinte- } \\
\text { gracją procesu produkcji i koszta- } \\
\text { mi transakcyjnymi; kluczową rolę } \\
\text { odgrywają technologiczne efekty } \\
\text { zewnętrzne }\end{array}$ \\
\hline $\begin{array}{l}\text { Struktura rynku } \\
\text { i konkurencja }\end{array}$ & $\begin{array}{l}\text { niedoskonała: monopolistyczna } \\
\text { i oligopolistyczna, korzyści skali } \\
\text { (economies of scale) }\end{array}$ & $\begin{array}{l}\text { „prawie doskonata”: elastyczna } \\
\text { specjalizacja, korzyści zakresu } \\
\text { (economies of scope) }\end{array}$ \\
\hline $\begin{array}{l}\text { Efekty } \\
\text { zewnętrzne: } \\
\text { - pieniężne }\end{array}$ & $\begin{array}{l}\text { traktowane jako endogeniczne, } \\
\text { regionalna specjalizacja i koncen- } \\
\text { tracja produkcji na dużą skalę, } \\
\text { prowadząca do powstania układu } \\
\text { centrum-peryferie przez interak- } \\
\text { cje korzyści skali, popytu na dobra } \\
\text { zróżnicowane i kosztów transportu }\end{array}$ & $\begin{array}{l}\text { traktowane jako egzogeniczne, ale } \\
\text { uznawane za mało istotne w po- } \\
\text { równaniu z uwarunkowaniami wol- } \\
\text { norynkowymi }\end{array}$ \\
\hline - technologiczne & $\begin{array}{l}\text { nietypowe, ale uznawane za ważne } \\
\text { w pewnych gałęziach, w większo- } \\
\text { ści przypadków uznawane za trud- } \\
\text { ne do modelowania i traktowane } \\
\text { jako egzogeniczne }\end{array}$ & $\begin{array}{l}\text { traktowane jako egzogeniczne, } \\
\text { uznawane za nietypowe, ale ich } \\
\text { obecność sprawia, że firmy doko- } \\
\text { nują decentralizacji działalności } \\
\text { i przyjmują elastyczne formy orga- } \\
\text { nizacyjne }\end{array}$ \\
\hline $\begin{array}{l}\text { Charakterystyki } \\
\text { społeczne i kul- } \\
\text { turowe }\end{array}$ & $\begin{array}{l}\text { uznawane za trudne do sformalizo- } \\
\text { wania i zakładane a priori, najchęt- } \\
\text { niej „pozostawiane socjologom” }\end{array}$ & $\begin{array}{l}\text { uznawane za kluczowe dla zro- } \\
\text { zumienia zjawiska koncentracji, } \\
\text { główną rolę odgrywają warunki } \\
\text { wstępne niezbędne do ulokowania } \\
\text { działalności gospodarczej }\end{array}$ \\
\hline
\end{tabular}

Źródto: A. Cieślik, Geografia inwestycji zagranicznych, Wyd. Uniwersytetu Warszawskiego, Warszawa 2005, s. 145.

W drugim scenariuszu obszary koncentracji przedsiębiorstw i gospodarstw domowych nie tylko nie będą zanikały, lecz z powodzeniem będą potrafiły włączyć się w globalny system produkcji, jako swoiste „węzły” globalnych sieci' ${ }^{95}$. Współcześnie najlepiej rozwijające się regiony nie są

95 A. Amin, N. Thrift, Neo-Marshallian Nodes in Global Networks, „International Journal of Urban and Regional Research" 1992, no. 16 (4), s. 571-587. 
bowiem statycznym modelem organizacji produkcji. Przeciwnie, rozwój i zmiana powinny być traktowane jako naturalny element rozwoju regionalnego ${ }^{96}$. Nie ulega wątpliwości, iż strategiczne znaczenie dla przyszłości regionów ma obecnie przede wszystkim ich wewnętrzna zdolność do kreowania innowacji i ciągłego uczenia się ${ }^{97}$.

Ten „paradoks lokalizacji” skłania do poszukiwania lokalnych i regionalnych czynników konkurencyjności w gospodarce globalnej. Czynniki te oparte są przy tym na specyficznych dla danego układu terytorialnego uwarunkowaniach, niejednokrotnie zakorzenionych w lokalnej kulturze, regułach, konwencjach, przyzwyczajeniach, a także w poziomie zaufania, skłonności do współpracy czy wreszcie tradycjach przemysłowych. $\mathrm{W}$ pierwotnych rozważaniach poświęconych zagadnieniu koncentracji procesów gospodarczych w przestrzeni traktowane one były jako jedno - zazwyczaj nigdy dogłębnie nie analizowane - źródło korzyści aglomeracji. Współcześnie jednak powyższe czynniki mogą być rozważane bardziej szczegółowo, w znacznej mierze dzięki rozwojowi płodnego nurtu analiz ekonomicznych - tzw. ekonomii instytucjonalnej.

\section{Korzyści aglomeracji i ich ewolucja}

Opisane dotychczas nurty teoretyczne uwzględniające przestrzeń w procesach gospodarczych w większości przypadków zakładają występowanie zjawiska odpowiedzialnego za ekonomiczne przyczyny koncentracji przedsiębiorstw i gospodarstw domowych. Zjawisko to nosi nazwę korzyści aglomeracji i definiowane jest jako forma korzyści zewnętrznych ${ }^{98}$ wy-

96 B. Asheim, Industrial Districts as Learning Regions. A Condition for Prosperity?, „Studies in Technology, Innovation and Economic Policy" 1995, s. 1.

97 Por. m.in.: B. Asheim, Industrial Districts, Inter-Firm Cooperation and Endogenous Technological Development. The Experience of Developed Countries, [w:] UNCTAD, Technological Dynamism in Industrial Districts: An Alternative Approach to Industrialization in Developing Countries?, New York-Geneva 1994, s. 91-142; G. Benko, A. Lipietz, Les regions qui gagnent, Presses Universitaires de France, Paris 1992; R. Florida, Toward the Learning Region, „Futures” 1995, vol. 27, no. 5, s. 527-536.

98 Efekty zewnętrzne definiuje się jako skutki działań pojedynczych podmiotów, które wpływają na poziom użyteczności pozostałych jednostek gospodarujących, niemających bezpośredniego wpływu na siłę i kierunek tych oddziaływań. Ponieważ efekty zewnętrzne nie są uwzględnianie w rachunku kosztów pojedynczego podmiotu, a oddziałują na rachunek ekonomiczny pozostałych, ich występowanie powoduje brak możliwości osiągnięcia optimum w sensie Pareto (A. Jewtucho- 
nikających ze skupienia na małym obszarze ludności, zabudowy, produkcji, usług, działalności handlowej itd. W ujęciu mikroekonomicznym korzyści aglomeracji są zatem czynnikiem wpływającym na poziom użyteczności przedsiębiorstw i gospodarstw domowych, choć podmioty te - jako odbiorcy efektów zewnętrznych - nie mają wpływu na ich siłę. W ujęciu graficznym, w odniesieniu do pojedynczego przedsiębiorstwa w sytuacji braku występowania tego rodzaju efektów, optymalna wielkość produkcji kształtowałaby się na przecięciu krzywych krańcowych zysków oraz krańcowych kosztów działalności gospodarczej (por. $Q_{1}$ na wykresie 4). Jednak jeśli na działalność przedsiębiorstwa $A$ wpływa działalność innego podmiotu gospodarczego, może to prowadzić do obniżenia poziomu kosztów krańcowych (np. gdy przestrzenna koncentracja przedsiębiorstw w jednym sektorze gospodarki spowoduje powstawanie większej liczby poddostawców, ci ostatni na skutek zwiększonej konkurencji obniżą ceny na oferowane przez siebie produkty). Tym samym dzięki występowaniu korzyści zewnętrznych przedsiębiorstwo $A$ może zaoferować konsumentom $Q_{2}-Q_{1}$ więcej dóbr po cenach niższych o $P_{1}-P_{2}$ (por. wykres 4$)^{99}$.

Tak rozumiane pojęcie korzyści zewnętrznych zostało wprowadzone do ekonomii przez A. Marshalla w pracy pt. Zasady ekonomiki, w rozdziałach poświęconych teorii przedsiębiorstwa. Analizując zagadnienia koncentracji przemysłu i możliwości obniżki jednostkowych kosztów produkcji, wyróżnił on dwa rodzaje korzyści wynikające ze zwiększania skali produkcji, tj. korzyści wewnętrzne (internal economies), które zależą od środków, jakimi rozporządzają poszczególne indywidualne przedsiębiorstwa, od ich organizacji i sprawności ich kierownictwa oraz korzyści zewnętrzne (external economies), będące wynikiem ogólnego rozwoju gospodarczego ${ }^{100}$. Z czasem wprowadzono podział na tzw. pie-

wicz, Efekty zewnętrzne w procesach urbanizacji i uprzemysłowienia, Wyd. Uniwersytetu Łódzkiego, Łódź 1987, s. 33). Teza ta jest spójna z wykorzystywaną na gruncie teorii gier koncepcją tzw. równowagi Johna F. Nasha, zgodnie z którą system może osiągnąć równowagę, której stan nie musi pokrywać się ze stanem optimum społecznego w sensie Pareto (por. „dylemat więźnia”, gdzie żaden aktor działający indywidualnie nie jest w stanie poprawić swojej sytuacji i wygaszane są wszelkie bodźce do zmiany). Sposobem na uniknięcie tej sytuacji może być ingerencja ze strony sektora publicznego, będąca formą internalizacji efektów zewnętrznych (por. A. C. Pigou, The Economics of Welfare, Macmillan, London 1920), lub też przyjęcie przez „graczy”, tj. podmioty ekonomiczne, strategii kooperacyjnych w miejsce konkurencji (por. R. Coase, The Problem of Social Cost, „The Journal of Law and Economics" 1960, vol. III (October), s. 1-44).

99 A. Jewtuchowicz, Efekty zewnętrzne..., s. 69.

100 A. Marshall, Zasady ekonomiki, Wyd. M. Arota, Warszawa 1925, s. 256-259 (oryg.: A. Marshall, Principles of Economics, Macmillan, London 1920); cyt. za: A. Jewtuchowicz, Efekty zewnętrzne..., s. 18. 


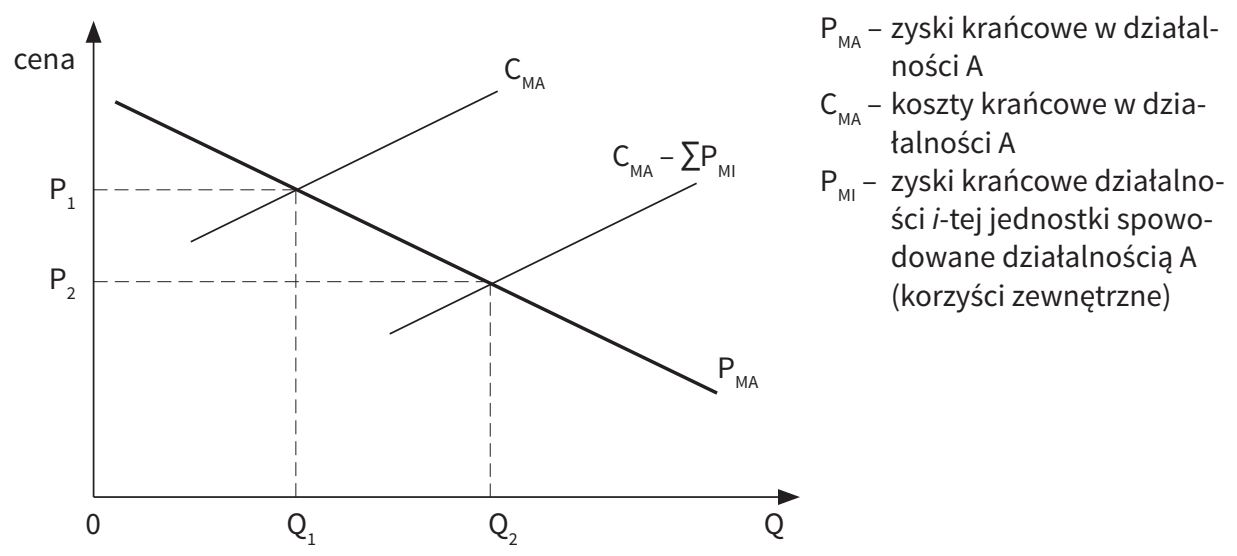

Wykres 4. Optymalna wielkość produkcji w warunkach występowania korzyści zewnętrznych Źródło: A. Jewtuchowicz, Efekty zewnętrzne w procesach urbanizacji i uprzemysłowienia, Wyd. Uniwersytetu Łódzkiego, Łódź 1987, s. 68.

niężne oraz technologiczne efekty zewnętrzne ${ }^{101}$. Efekty zewnętrzne pieniężne polegają na uzależnieniu zysków jednych przedsiębiorstw od rozmiarów wytworzonej produkcji oraz nakładów poniesionych przez inne podmioty gospodarcze. Działają one bezpośrednio poprzez rynek, za pośrednictwem mechanizmu cen ${ }^{102}$. Natomiast efekty technologiczne (spillovers) polegają na tym, że działalność przedsiębiorców wiążąca się z ich produkcją wpływa bezpośrednio na warunki działania innych jednostek, tzn. efekty zewnętrzne wystąpią wtedy, gdy produkcja jednego przedsiębiorstwa będzie zależała (obok czynników wewnętrznych) również od produkcji innych przedsiębiorstw. Zależności te występują poza mechanizmem rynkowym i jako takie są trudno mierzalne za pomocą klasycznych metod ekonomicznych ${ }^{103}$. Jak zauważył R. Domański, technologiczne efekty zewnętrzne są przy tym często „czarną skrzynką”, w której mieści się ważna rola złożonych instytucji nierynkowych, których znaczenie jest silnie akcentowane przez geografów ekonomicznych i analityków przestrzennych ${ }^{104}$.

101 J. Viner, Cost Curves and Supply Curves, „Readings in Price Theory” 1931, s. 198231, cyt. za: A. Jewtuchowicz, Efekty zewnętrzne..., s. 21.

102 T. Scitovsky, Two Concepts of External Economies, „Journal of Political Economy" 1954, no. 2, s. 443-451, cyt. za: A. Jewtuchowicz, Efekty zewnętrzne..., s. 41; A. Cieślik, Geografia inwestycji..., s. 118.

103 M. E. Sokołowicz, Region wobec procesów globalizacji - terytorializacja przedsiębiorstw międzynarodowych (na przykładzie regionu tódzkiego), Wyd. Uniwersytetu Łódzkiego, Łódź 2008, s. 33.

104 R. Domański, Ewolucyjna gospodarka..., s. 44. 
W literaturze przedmiotu można spotkać również podział na efekty zewnętrzne publiczne i prywatne ${ }^{105}$. Jeśli współzależność ekonomiczna wpływa na niewiele podmiotów, wówczas pojawiający się efekt zewnętrzny ma charakter prywatny. Gdy wpływa ona na znaczną liczbę osób, wówczas efekt zewnętrzny jest publiczny i jako taki posiada cechy dóbr publicznych, co uzasadnia wówczas rozwój sektora publicznego w gospodarce ${ }^{106}$.

Jednym z głównych źródeł korzyści zewnętrznych pozostaje koncentracja przedsiębiorstw i gospodarstw domowych na relatywnie niewielkiej przestrzeni. Prowadzi ona do sytuacji, w której jej użytkownicy uzyskują dostęp do różnorodnych pożytków, np. obniżenia jednostkowych kosztów produkcji, powiększenia rynku zbytu, możliwości funkcjonowania na lepiej rozwiniętym rynku pracy, zapewnienia różnorodności wyborów konsumenckich czy też korzystania z dobrodziejstw korzyści skali w użytkowaniu infrastruktury przez relatywnie dużą liczbę użytkowników. W ujęciu makroekonomicznym korzyści aglomeracji stanowią zatem najbardziej fundamentalną formę wyjaśniania przyczyn koncentracji działalności gospodarczej w przestrzeni. Ekonomiczną przyczyną istnienia dużych skupisk ludności i działalności gospodarczej jest niewątpliwie to, że działalność w nich zapewnia większą produktywność i rosnące zyski ${ }^{107}$.

Wśród przyczyn koncentracji działalności gospodarczej można wyróżniać te, którą pozostają egzogeniczne w stosunku do przestrzeni oraz te o charakterze endogenicznym (por. rys. 3), przy czym miano korzyści aglomeracji należy przypisać drugiemu $\mathrm{z}$ wymienionych typów. Źródła korzyści o charakterze egzogenicznym nie odwołują się bowiem do kategorii efektów zewnętrznych, lecz do aspektów związanych z lokalizacją w przestrzeni, wpływającą na minimalizację kosztów transportu, bliskością surowców naturalnych itp., czyli do czynników lokalizacji analizowanych w ramach klasycznych teorii lokalizacyjnych - na ogół z perspektywy pojedynczego przedsiębiorstwa lub pojedynczego gospodarstwa domowego (por. podrozdziały 1.1 i 1.2). W literaturze przedmiotu źródła korzyści o charakterze endogenicznym zwykło się dzielić na wynikające ze specjalizacji gospodarczej oraz te, które wynikają $\mathrm{z}$ różnorodności struktury gospodarczej. Pierwsze z nich zostały nazwa-

105 R. Cooter, Th. Ulen, Ekonomiczna analiza prawa, C.H. Beck, Warszawa 2009, S. 208.

106 Szerzej na temat podziału na dobra publiczne i prywatne w podrozdziale 1.1 rozdziału III.

107 R. Lucas, Making a Miracle, „Econometrica” 1993, no. 61, s. 251-272, [cyt. za:] M. P. Feldman, Location and Innovation: The New Economic Geography of Innovation, Spillover, and Agglomeration, [w:] G. L. Clark, M. P. Feldman, M. S. Gertler (eds.), Oxford Handbook..., s. 384. 
ne korzyściami aglomeracji Marshalla-Arrowa-Romera (M-A-R) ${ }^{108}$ lub po prostu efektami typu marshallowskiego, natomiast drugi typ nazwano efektami typu J. Jacobs ${ }^{109}$.

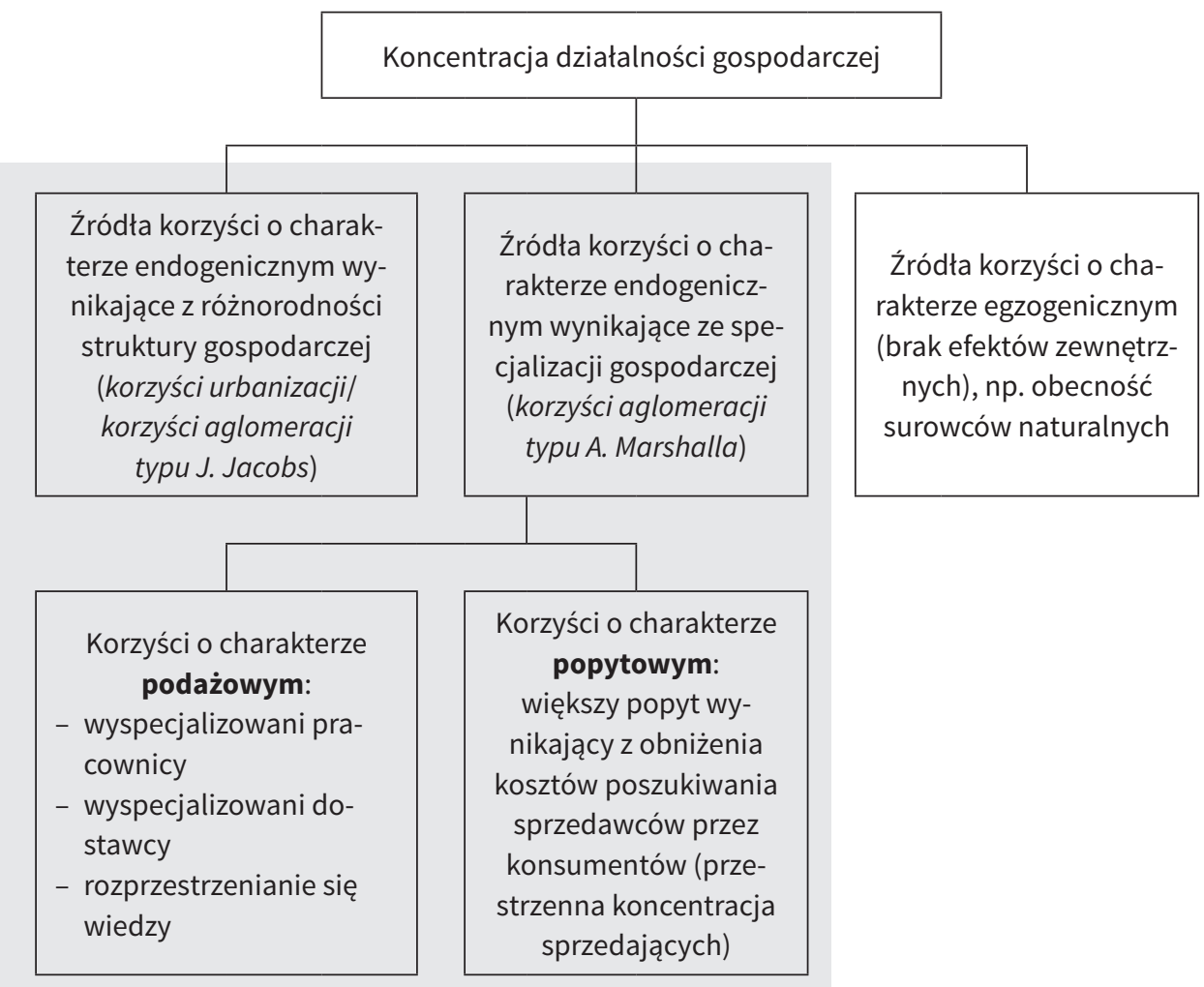

KORZYŚCI AGLOMERACJI

Rys. 3. Klasyfikacja przyczyn koncentracji działalności gospodarczej - korzyści aglomeracji Źródło: opracowanie na podstawie B. T. McCann, T. B. Folta, Location Matters: Where We Have Been and Where We Might Go in Agglomeration Research, „Journal of Management” 2008, vol. 34, no. 3, June, s. 534.

108 E. Glaeser et al., Growth in Cities, „Journal of Political Economy” 1992, no. 100, s. 1126-1152; G. van der Panne, Agglomeration externalities: Marshall versus Jacobs, „Journal of Evolutionary Economics” 2004, vol. 14, s. 594-595.

109 Jane Jacobs była pierwszym badaczem, która zwróciła uwagę na fakt, że typowe dla wielkich miast zróżnicowanie struktury społecznej (i gospodarczej) stanowi ich niepowtarzalną wartość (J. Jacobs, The Economy of Cities, Random House, New York 1969). 
W odniesieniu do pierwszego typu korzyści najczęściej wymienianymi ich źródłami są ${ }^{110}$ :

1) bogaty rynek pracy, będący efektem specjalizacji gospodarczej danego obszaru,

2) łatwość znalezienia firmy produkującej określone dobro lub świadczącej określoną usługę w ramach powiązań kooperacyjnych wstecz i wprzód, jak również relatywnie niskie ceny tych dóbr i usług, będące konsekwencją dużej liczby tych firm (non-traded local inputs)

3) zjawisko szybkiego i efektywnego rozprzestrzeniania się informacji i tzw. wiedzy ukrytej (spillovers), nazwane przez A. Marshalla „atmosferą przemysłową”, prowadzące do większej innowacyjności.

Wielkość i jakość rynku pracy mają znaczenie zarówno dla przedsiębiorstw poszukujących wykwalifikowanych pracowników, jak i dla samych pracujących. Firmy poszukujące na rynku pracy wysoko wykwalifikowanych pracowników, stojące jednocześnie przed koniecznością ciągłego dostosowywania oferty do potrzeb klientów, rozglądają się za elastycznymi rynkami pracy, na których znalezienie odpowiedniej kadry jest szybkie i nie wiąże się z nadmiernymi kosztami. Rynki pracy o takich charakterystykach znajdują się najczęściej na terenie dużych aglomeracji miejskich. Z drugiej strony, najbardziej obecnie poszukiwani na rynkach pracy wysoko wykwalifikowani pracownicy należą $\mathrm{z}$ reguły do grup osób, które w rozwój własnej wiedzy i umiejętności inwestują duże środki materialne. Poszukiwanie miejsca zatrudnienia w aglomeracjach stwarzających większe szanse na znalezienie satysfakcjonującej pracy pozwala im szybciej zdyskontować posiadany kapitał intelektualny.

Gęsta koncentracja wielu dostawców i odbiorców na danej przestrzeni prowadzi do sytuacji, w której niepewność kompensowana jest przez różnorodność partnerów, zapewniając szybki dostęp do pożądanych zasobów. Stąd coraz bardziej powszechne zjawisko wzrastającego znaczenia kontaktów face-to-face, jako drogi ku redukcji niepewności i budowania wzajemnego zaufania między potencjalnymi partnerami w ciągle zmieniającym się otoczeniu. W konsekwencji łatwość znalezienia partnerów gospodarczych ma istotne znaczenie zarówno w wymiarze pieniężnym (niższe ceny na skutek konkurencji), jak i technologicznym. Nawet w sytuacji gwałtownego rozwoju technologii transportowych i komunikacyjnych, prowadzących do istotnego spadku kosztów zawierania potencjalnych transakcji na odległość, bezpośrednie kontak- 
ty w celu zawierania umów i porozumień między przedsiębiorstwami wciąż pozostają istotnym elementem decydującym o redukcji kosztów transakcyjnych ${ }^{111}$.

Wreszcie, przestrzenna bliskość dużej liczby podmiotów, powiązanych gęstą siecią wzajemnych relacji, kształtuje warunki niezbędne dla szybkiej i częstej wymiany informacji. Wyspecjalizowane gospodarki regionalne są miejscem intensywnego rozprzestrzeniania wiedzy, wspomagającego procesy innowacyjne i generującego wzrost w długim okresie. Firmy wiążą się zarówno w formalne, jak i nieformalne organizacje współpracy, które wspomagają procesy wzajemnych interakcji, przyczyniają się do budowania atmosfery wzajemnego zaufania, a w efekcie - osiągania wspólnych celów ekonomicznych ${ }^{112}$.

Obok korzyści o charakterze podażowym ważnym elementem marshallowskich korzyści aglomeracji pozostaje ponadto zbiór korzyści o charakterze popytowym. Koncentracja przedsiębiorstw i gospodarstw domowych w przestrzeni generuje bowiem większy popyt, wynikający nie tylko z większej dostępności kupujących (korzyść dla sprzedających), lecz także z obniżenia kosztów poszukiwania sprzedawców przez konsumentów (korzyść dla kupujących). O tym elemencie korzyści zewnętrznych pisał już A. Marshall, natomiast z czasem zwrócono uwagę na to, że popytowe korzyści aglomeracji będą szczególnie dostrzegalne w tych sektorach gospodarki, w których istotne znaczenie ma bezpośrednie zapoznanie się z cechami produktu ${ }^{113}$ oraz tam, gdzie występuje ich duża różnorodnośćc ${ }^{114}$. Po stronie popytowej działa również mechanizm użyteczności typu CES (constant elasticity of substitution $)^{115}$. Stwierdzenie, że korzyści aglomeracji po stronie

111 Ten aspekt korzyści aglomeracyjnych odnosi się do zagadnienia kosztów transakcyjnych, szczegółowo analizowanych w podrozdziale 1.2 rozdziału III, jako element tzw. ekonomii instytucjonalnej.

112 Por. B. T. Asheim, Industrial Districts: the Contributions of Marshall and Beyond, [w:] G. L. Clark, M. P. Feldman, M. S. Gertler (eds.), Oxford Handbook... oraz: G. Becattini, The Marshallian Industrial District as a Socio-Economic Notion, [w:] F. Pyke, G. Becattini, W. Sengenberger (eds.), Industrial Districts and Inter-firm Cooperation in Italy, International Institute of Labor Studies, Geneva 1990, s. 37-51, cyt. za: A. Scott, M. Storper, Regions, Globalization, Development, „Regional Studies" 2003, vol. 37 (6-7), s. 579-593.

113 K. Stahl, Differentiated Products, Consumer Search, and Locational Oligopoly, „Journal of Industrial Economics” 1982, vol. 31 (1/2), s. 97-113

114 J. H. Fischer, J. E. Harrington Jr., Product Variety and Firm Agglomeration, „RAND Journal of Economics" 1996, vol. 27 (2), s. 281-309.

115 Zróżnicowanie produktów lub nakładów powoduje działanie sił prowadzących do koncentracji produkcji, bowiem im więcej odmian danego dobra, tym wyższa jego użyteczność (A. Cieślik, Geografia inwestycji..., s. 124). 
popytowej prowadzą do obniżania kosztów transakcyjnych związanych z poszukiwaniami kupujących i sprzedających jest jednak przedmiotem relatywnie małego zainteresowania ekonomistów. Wynika to przede wszystkim z ograniczeń metodologicznych, bowiem analizy ograniczają się zwykle do modeli dwóch przedsiębiorstw, funkcjonujących na rynkach liniowych (w sensie przestrzennym) ${ }^{116}$, przy założeniu równomiernego rozmieszczenia kupujących i braku badań potrzeb rynkowych ex ante ${ }^{117}$.

Korzyści aglomeracji typu J. Jacobs, w przeciwieństwie do typu poprzedniego, koncentrują się na pozytywnych aspektach związanych z różnorodnością struktury gospodarczej. Korzyści te są wówczas zewnętrzne w stosunku do sektora gospodarki, natomiast endogeniczne w stosunku do analizowanego układu przestrzennego (miasta, zespołu miast, regionu itd.). Pojawiają się wówczas, gdy jeden typ działalności gospodarczej przyczynia się do zwiększenia krańcowej produktywności innych typów takiej działalności dzięki ich bliskiej wzajemnej lokalizacji (cross-product increasing returns). Warto też wskazać, iż ten typ korzyści aglomeracji, oprócz zmniejszania „kosztów poszukiwania” (np. dostawców, odbiorców, dóbr poszukiwanych przez konsumentów), stwarza możliwości stykania się z sytuacjami, które mogą być źródłem lub inspiracją dla innowacji. Wskazują na to badania podejmujące próbę powiązania klasyfikacji korzyści aglomeracji z cyklem życia produktów i sektorów gospodarki. Wyraźnie dostrzega się przy tym następującą tendencję: podczas gdy efekty zewnętrzne M-A-R wzrastają wraz z kolejnymi fazami dojrzałości przemysłu, korzyści typu Jacobs są dodatnie w młodych gałęziach przemysłu, a w sektorach bardziej dojrzałych obserwuje się ich spadek czy wręcz wartości ujemne. Młode gałęzie gospodarki wykazują tym samym tendencję do lokalizowania się w miejscach o dużej różnorodności, oferujących środowiska sprzyjające innowacyjności i kreatywności za cenę ich wysokich kosztów, natomiast gałęzie dojrzałe preferują lokalizacje tańsze, reprezentujące wysokie korzyści specjalizacji i relatywnie duże rynki zbytu (por. tab. 3) ${ }^{118}$.

116 Por. model długiej ulicy Harolda Hotellinga (H. Hotelling, Stability in Competition, „Economic Journal” 1929, vol. 39 (153), s. 41-57).

117 B. T. McCann, T. B. Folta, Location Matters: Where We Have Been and Where We Might Go in Agglomeration Research, „Journal of Management” 2008, vol. 34, no. 3 (June), s. 538.

118 Zob. F. Neffke et al., The Dynamics of Agglomeration Externalities Along the Life Cycle of Industries, „Regional Studies” 2011, vol. 45, no. 1, s. 49-65. 
Tabela 3. Typy korzyści aglomeracji a dynamika cyklu życia produktów i sektorów

\begin{tabular}{|c|c|c|c|c|c|}
\hline \multirow{2}{*}{\multicolumn{3}{|c|}{ Korzyści }} & \multicolumn{3}{|c|}{ Cykl życia sektora } \\
\hline & & & Młody & $\rightarrow$ & Dojrzały \\
\hline \multirow{3}{*}{ 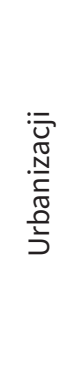 } & $\begin{array}{l}\text { Koszty } \\
\text { czynników } \\
\text { produkcji }\end{array}$ & $\begin{array}{l}\text { Wysokie ceny ziemi } \\
\text { Wysokie płace } \\
\text { Kongestia }\end{array}$ & $\begin{array}{l}0 \\
0 \\
0\end{array}$ & & $\begin{array}{l}- \\
- \\
-\end{array}$ \\
\hline & Wiedza & $\begin{array}{l}\text { Wykwalifikowana siła robocza } \\
\text { Infrastruktura wiedzy }\end{array}$ & + & & $\begin{array}{l}0 \\
+\end{array}$ \\
\hline & $\begin{array}{l}\text { Sytuacja } \\
\text { na rynku }\end{array}$ & $\begin{array}{l}\text { Dostęp do dużych rynków zbytu } \\
\text { Dostęp do wymagających rynków zbytu }\end{array}$ & $\begin{array}{l}0 \\
+\end{array}$ & & $\begin{array}{l}+ \\
0\end{array}$ \\
\hline \multirow{3}{*}{ 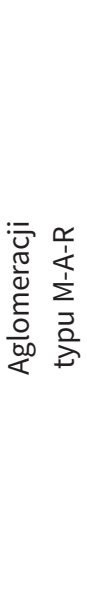 } & $\begin{array}{l}\text { Koszty } \\
\text { czynników } \\
\text { produkcji }\end{array}$ & $\begin{array}{l}\text { Niskie koszty dopasowania na rynku pracy } \\
\text { Niskie koszty utrzymywania zapasów } \\
\text { Niskie koszty transportu w łańcuchu wartości } \\
\text { dodanej }\end{array}$ & $\begin{array}{l}0 \\
0 \\
0\end{array}$ & & $\begin{array}{l}+ \\
+ \\
+\end{array}$ \\
\hline & Wiedza & $\begin{array}{l}\text { Wyspecjalizowana siła robocza } \\
\text { Łatwość rozprzestrzeniania się wiedzy } \\
\text { w sektorze } \\
\text { Łatwość podjęcia wspólnych działań na rzecz } \\
\text { innowacji w przypadku współpracy w ramach } \\
\text { łańcucha wartości dodanej }\end{array}$ & $\begin{array}{l}0 \\
+ \\
0\end{array}$ & & $\begin{array}{l}+ \\
+ \\
+\end{array}$ \\
\hline & $\begin{array}{l}\text { Sytuacja } \\
\text { na rynku }\end{array}$ & $\begin{array}{l}\text { Łatwy dostęp do wyspecjalizowanych dostaw- } \\
\text { ców i odbiorców }\end{array}$ & 0 & & + \\
\hline \multirow{3}{*}{  } & $\begin{array}{l}\text { Koszty } \\
\text { czynników } \\
\text { produkcji }\end{array}$ & $\begin{array}{l}\text { Duża różnorodność produktów i usług } \\
\text { Unikanie zbyt wąskiego spojrzenia }\end{array}$ & + & & $\begin{array}{l}0 \\
-\end{array}$ \\
\hline & Wiedza & $\begin{array}{l}\text { Łatwość rozprzestrzeniania się wiedzy między } \\
\text { sektorami }\end{array}$ & + & & 0 \\
\hline & $\begin{array}{l}\text { Sytuacja } \\
\text { na rynku }\end{array}$ & $\begin{array}{l}\text { Zmniejszona zmienność warunków po stronie } \\
\text { popytu i podaży }\end{array}$ & + & & 0 \\
\hline
\end{tabular}

„+" - spodziewany efekt pozytywny

"0" - zmiana nie jest spodziewana/korzyści i niekorzyści bilansują się

„-" - spodziewany efekt negatywny

Źródło: F. Neffke et al., The Dynamics of Agglomeration Externalities Along the Life Cycle of Industries, „Regional Studies” 2011, vol. 45, no. 1, s. 54. 
W klasyfikacji korzyści aglomeracji warto wskazać jeszcze na jeden z ich typów, zwany za E. Hooverem ${ }^{119}$ korzyściami urbanizacji. Odnoszą się one do korzyści płynącej z samego faktu rozwoju miast i przekładają się na wzrost użyteczności ich użytkowników na skutek korzyści skali. W tym kontekście korzyści urbanizacji należy uznać za kategorię najszerszą w stosunku do dwóch poprzednich, przekładającą się m.in. na ${ }^{120}$ : udogodnienia transportowe, a tym samym redukcję kosztów transportu (obszary zurbanizowane jako węzły komunikacyjne), istnienie bujnych i zróżnicowanych rynków pracy, stanowiących korzyść zarówno dla pracodawców, jak i pracowników, korzyści skali w użytkowaniu infrastruktury technicznej i społecznej, a co za tym idzie - malejące koszty krańcowe i opłaty za jej użytkowanie, rozbudowanie otoczenie instytucjonalne (uczelnie, ośrodki badawcze, ośrodki finansujące itp.) oraz szybciej rozprzestrzeniającą się wiedzę, sprzyjającą wyższemu poziomowi innowacyjności i kreatywności.

Należy podkreślić, że podobnie jak w pojedynczym przedsiębiorstwie, korzyści skali produkcji po osiągnięciu pewnego poziomu rozwoju mogą przeistoczyć się w niekorzyści skali. Ponadto, w różnych lokalizacjach korzyści lokalizacji mogą zacząć przyjmować ujemne wartości krańcowe, prowadząc w efekcie do niekorzyści aglomeracji netto. Do niekorzyści aglomeracji zalicza się: wzrost cen terenów budowlanych (na skutek wzrostu dochodów i wzrastającego popytu na nieruchomości), obniżenie się rentowności przedsiębiorstw na skutek wzrostu płac, zatłoczenie transportu (kongestię), obniżanie się poziomu usług publicznych, pogarszanie się jakości środowiska czy np. wzrost skali patologii społecznych.

W konsekwencji, o ile w początkowym okresie rozwoju miasta lub regionu obserwuje się wzrost liczby jego mieszkańców i użytkowników na skutek zwiększonej wydajności pracy oraz poziomu krańcowej użyteczności gospodarstw domowych, o tyle po przekroczeniu pewnego poziomu może dojść do zjawiska odwrotnego (wykres 5). Można tym samym postawić tezę, iż decyzję o lokalizacji w obrębie aglomeracji lub poza nią przedsiębiorstwo lub gospodarstwo domowe podejmuje w oparciu o analizę ogólnego bilansu korzyści i niekorzyści aglomeracji ${ }^{121}$.

119 E. M. Hoover, Lokalizacja działalności...

120 M. E. Edwards, Regional and Urban Economics..., s. 121-123; R. Domański, Gospodarka..., s. 32-33.

121 H. Knödler, U. Alberthauser, Glocalisation, Foreign Direct Investment and Regional Development Perspectives: Empirical Results for West German Regions, HWWA Discusion Paper no. 117, Hamburg 2001, s. 14; http://econstor.eu/bitstream/ 10419/19434/1/117.pdf (dostęp: 28.08.2013). 


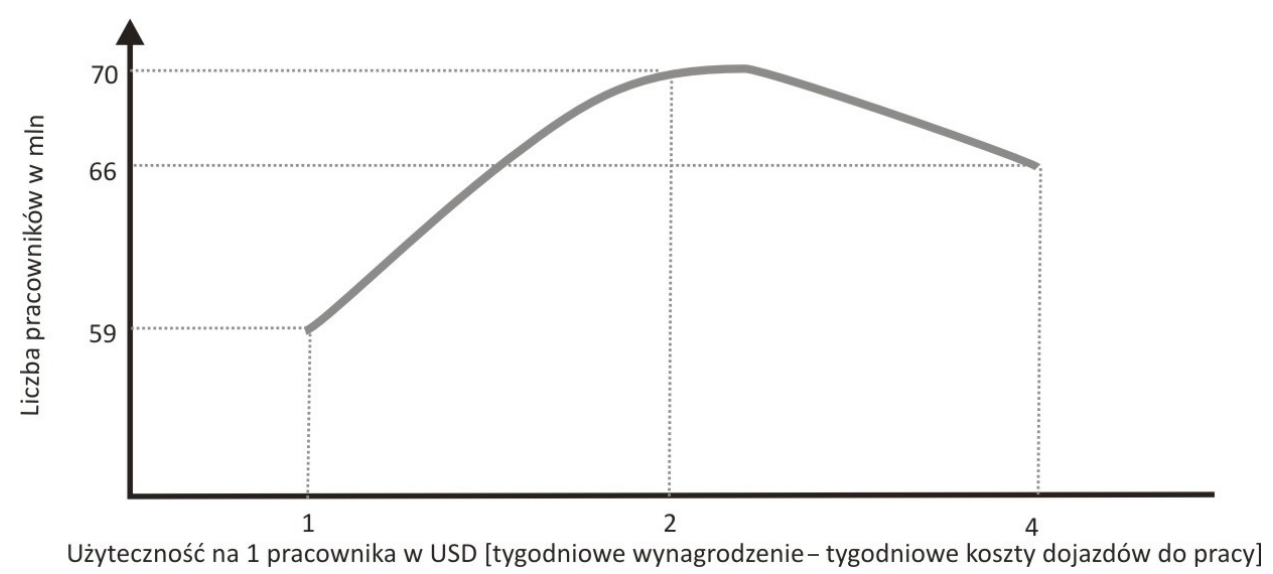

Wykres 5. Relacje pomiędzy poziomem użyteczności a wielkością hipotetycznej aglomeracji miejskiej (wartości wskazane na osi OX i OY są wartościami hipotetycznymi)

Źródto: A. O’Sullivan, Urban Economics, McGraw Hill-Irwin, New York 2007, s. 57.

Warto nadmienić, że w odniesieniu do zjawiska korzyści i niekorzyści aglomeracji istotne znaczenie odgrywa postęp technologiczny ( $\mathrm{w}$ transporcie, budownictwie, technikach komunikacji) oraz innowacje społeczne. Powoduje on bowiem, że w miarę upływu czasu oddala się punkt, po przekroczeniu którego odczuwalne są niekorzyści aglomeracji (np. rozwój motoryzacji albo sprawnie funkcjonującego systemu aglomeracyjnego transportu zbiorowego umożliwia lokalizację w dalszej odległości od centrum).

Zagadnienie korzyści aglomeracji jest na tyle złożone, że współcześnie często akcentuje się trudności w jego pomiarze, w szczególności w odniesieniu do tzw. spillovers i innych pozapieniężnych efektów zewnętrznych. Większość badań empirycznych prowadzonych $\mathrm{w}$ ramach ekonomiki miast i regionów (urban and regional economics) potwierdza działanie mechanizmu oddziaływania korzyści aglomeracji przede wszystkim typu M-A-R, poprzez odkrywanie pozytywnej korelacji między koncentracją przedsiębiorstw z tych samych i pokrewnych sektorów gospodarki z takimi wskaźnikami, jak wydajność pracy, liczba nowo powstających firm czy wzrost zatrudnienia w sektorze ${ }^{122}$.

Wraz z rozwojem społeczno-gospodarczym samo identyfikowanie koncentracji działalności ludzkiej w przestrzeni (aglomeracja) może stanowić co najwyżej pierwszy etap we współczesnych analizach przestrzennych. Zwrócili na to uwagę G. Colletis i B. Pecqueur, wyróżniając trzy etapy rozwoju terytorialnego: aglomerację (skupienie), specjaliza-

122 Por. A. O’Sullivan, Urban Economics, McGraw Hill-Irwin, New York 2007, s. 46-47. 
cję i specyficzność ${ }^{123}$. Proces tworzenia skupisk (aglomeracja) polega na koncentracji w danej przestrzeni geograficznej różnorodnych rodzajów działalności. Na tym etapie rozwoju dostrzega się przewagę pieniężnych korzyści aglomeracji, relatywnie łatwo mierzalnych. Proces tworzenia się specjalizacji opiera się na istnieniu na danym terytorium zorganizowanej struktury gospodarczej, w której przeważa jeden rodzaj działalności przemysłowej lub jeden produkt. W tej fazie rozwoju większego znaczenia nabierają efekty zewnętrzne, technologiczne. Efekty te wyrażają się w istnieniu centrów kształcenia związanych ze specjalizacją terytorium, centrów technicznych oraz innych instytucji i podmiotów zapewniających pomoc technologiczną, tworzących wspólne strategie eksportu itp. ${ }^{124}$

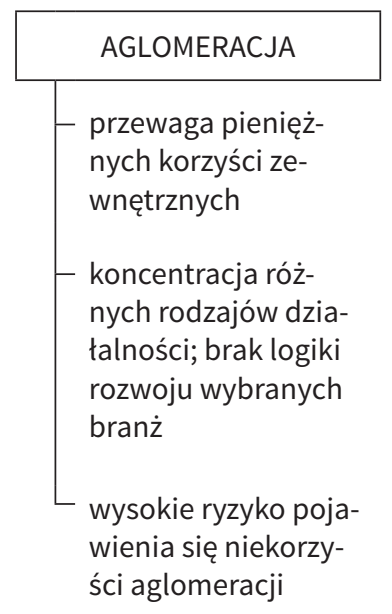

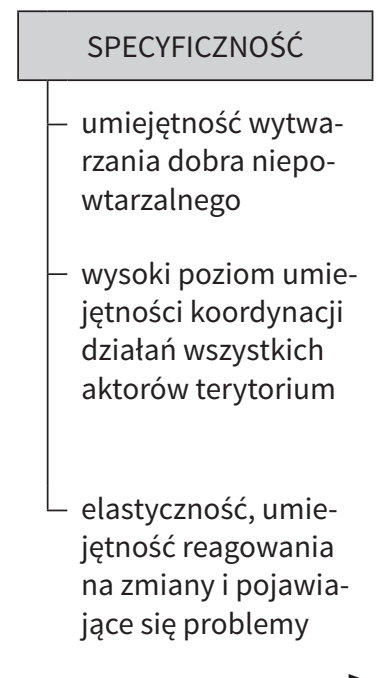

niskie ZNACZENIE CZYNNIKÓW O CHARAKTERZE INSTYTUCJONALNYM w tym instytucji nieformalnych wysokie

Rys. 4. Etapy rozwoju terytorialnego - ewolucja koncepcji korzyści aglomeracji

Źródło: opracowanie własne na podstawie: A. Jewtuchowicz, Terytorium i współczesne dylematy jego rozwoju, Wyd. Uniwersytetu Łódzkiego, Łódź 2005, s. 130-134.

123 G. Colletis et al., Construction territoriale et dynamiques économiques, „Sciences de la Société" 1999, nr 48; B. Pecqueur, Le développement local; pour une économie des territories, deuxième edition revue et augmentée, Syros, Paris 2000, [cyt. za:] A. Jewtuchowicz, Terytorium i współczesne dylematy jego rozwoju, Wyd. Uniwersytetu Łódzkiego, Łódź 2005, s. 130-134.

124 A. Jewtuchowicz, Budowa konkurencyjności regionów. Rozważania na temat dynamiki rozwoju terytorialnego, [w:] R. Brol (red.), Gospodarka lokalna i regionalna w teorii i praktyce, „Prace Naukowe Akademii Ekonomicznej we Wrocławiu” nr 1023, Wroctaw 2004, s. 351. 
Co istotne, o ile w fazie aglomeracji przeważają indywidualne interesy poszczególnych aktorów, o tyle $\mathrm{w}$ fazie specjalizacji rodzą się "procesy koordynacji między aktorami ekonomicznymi, które przyczyniają się do tworzenia pewnego rodzaju »dobra publicznego«, wiążącego strategie każdego z podmiotów" 125 . W etapie specjalizacji zaczyna być więc dostrzegalna przewaga czynników o charakterze instytucjonalnym nad efektami zewnętrznymi o charakterze pieniężnym.

Najbardziej zaawansowany etap koncentracji działalności gospodarczej i rozwoju terytorialnego to etap specyficzności terytorialnej, oznaczającej możliwość wytwarzania dobra niepowtarzalnego, bez konkurencji, nieodłącznie związanego z określonym procesem produkcji i z konkretnym terytorium. Umiejętność ta stanowi efekt koordynacji wewnątrz terytorium, angażującej wszystkich aktorów lokalnych (przedsiębiorstwa, władze oraz inne instytucje) $)^{126}$.

Powyższe ujęcie stanowi próbę wyeksponowania swoistej ewolucji koncepcji korzyści aglomeracji - początkowo koncentrującej się na mierzalnych efektach koncentracji ludności i działalności gospodarczej, z czasem eksponującej również korzyści o charakterze jakościowym (rys. 4). Szczególnie płodny kierunek badań nad aglomeracjami w tym właśnie duchu zainicjował w latach 80. XX w. Ph. Aydalot. Zapoczątkował on powstanie międzynarodowej grupy badawczej, mającej na celu określenie warunków powstania $\mathrm{w}$ aglomeracjach tzw. środowisk innowacyjnych ${ }^{127}$. Jak pisze B. Gruchman, prowadzona pod jego kierownictwem grupa GREMI odwoływała się przy tym do dorobku trzech dziedzin, tj. teorii ekonomicznej dotyczącej działań wspólnych, socjologii w zakresie koncepcji kapitału społecznego oraz do osiągnięć ekonomii instytucjonalnej i reguł postępowania (formalnych i nieformalnych) ${ }^{128}$. Preferowała w związku z tym analizy dynamiczne w miejsce statycznych i zwróciła uwagę, że o istocie korzyści aglomeracji w coraz bardziej złożonych i ukierunkowanych na innowacyjność systemach gospodarczych decydują takie czynniki, jak wzajemne zaufanie, poczucie spójności i przynależności, otwarcie na współpracę i synergię oraz wkład indywidualny i zespoło-

125 A. Jewtuchowicz, Budowa konkurencyjności..., s. 352.

126 Ibidem, s. 353.

127 Groupe de Recherche Européen sur les Milieux Innovateurs (GREMI) - międzynarodowa grupa badawcza zajmująca się od wielu lat zagadnieniami rozwoju regionów, przede wszystkim w kontekście tworzenia się i funkcjonowania tzw. środowisk innowacyjnych. Jej członkowie rekrutowali się z ośrodków badawczych Francji, Belgii, Szwajcarii, Włoch, Hiszpanii, Wielkiej Brytanii, USA, Niemiec i Polski.

128 B. Gruchman, Od aglomeracji do klastrów przemysłowych i środowisk innowacyjnych, [w:] M. Klamut (red.), Polityka ekonomiczna. Wspótczesne wyzwania, Wyd. Naukowe PWN, Warszawa 2007, s. 208. 
wy na rzecz dobrej reputacji danego ośrodka. Wszystko to przyczynia się do umocnienia zdolności środowiska w zakresie generowania innowacji oraz otwartości milieu na impulsy innowacyjne z zewnątrz ${ }^{129}$. Innymi słowy, koncepcja korzyści aglomeracji wyraźnie ewoluowała w kierunku instytucjonalnych nurtów analiz ekonomicznych, w tym przede wszystkim ekonomiki bliskości (economics of proximity) ${ }^{130}$.

Rozważania nad zagadnieniem korzyści aglomeracji, a także ich rolą w koncentracji działalności gospodarczej i ludności warto uzupełnić o spostrzeżenie, że zjawisko to stanowi fundament powstawania miast i aglomeracji miejskich, pozostając podstawowym sposobem wyjaśniania procesów formowania się różnych tzw. terytorialnych form organizacji produkcji. W pierwszym ujęciu miasto jawi się jako miejsce uprzywilejowane i nieuniknione dla powstania i lokalizacji niektórych rodzajów działalności gospodarczej, tym samym przyczyniając się do stymulowania rozwoju endogenicznego ${ }^{131}$. W tym kontekście F. Corolleur i współpracownicy wskazują na szereg funkcji, jakie pełnią miasta i obszary zurbanizowane, odgrywając rolę katalizatorów rozwoju społeczno-gospodarczego ${ }^{132}$. Po pierwsze, stanowią one swojego rodzaju instytucjonalne systemy różnorodnych graczy, powiązanych formalnymi i nieformalnymi zasadami zachowań. Miasta jako źródła instytucji prowadzą tym samym do obiektywizacji zachowań, sprzyjając przekształcaniu się okazjonalnych działań w kierunku działań trwałych, przewidywalnych, opartych na społecznym podziale pracy. Po drugie, miasta jako obszary koncentracji przedsiębiorstw i gospodarstw domowych wspierają tzw. zakotwiczenie środowiska materialnego. Jako „obiekty materialne”, na skutek koncentracji zabudowy i infrastruktury na relatywnie małym obszarze ułatwiają osiągnięcie korzyści skali w ich użytkowaniu oraz odtwarzaniu.

Rozwój otoczenia materialnego wiąże się również z trzecią funkcją miast, jaką jest funkcja symboliczna.

Od zamku, poprzez uniwersytet, do opery pewne budynki są emanacją władzy, kultury i wiedzy oraz związanych z tymi obszarami grup społecznych.

129 R. Camagni, Conclusion et regard sur l'avenir, [w:] R. Camagni, D. Maillat, Milieux inovateurs. Théorie et politiques, Economica, Paris 2006, [cyt. za:] B. Gruchman, Od aglomeracji do klastrów przemysłowych..., s. 208.

130 Szerzej na temat ekonomiki bliskości w podrozdziale 2.4 rozdziału III.

131 D. Maillat, Interactions between Urban Systems and Localized Productive Systems: An Approach to Endogenous Regional Development in Terms of Innovative Milieu, „European Planning Studies” 1998, vol. 6 (2), s. 117-130.

132 F. Corolleur et al., Villes et innovation: le cas de trots villes de Suisse occidentale, Neuchatel: IRER, Working Paper 1996, no. 9601, [cyt. za:] D. Maillat, Interactions between Urban Systems..., s. 117-130. 
Wymiar symboliczny odgrywa szczególnie ważną rolę w powstawaniu nowych typów działalności, a zwłaszcza ich uznania społecznego i instytucjonalnego. Kształtuje on wizerunek miast i wspomaga ich reputację ${ }^{133}$.

Czwartą funkcją miast pozostaje oferowana przez nie różnorodność środków produkcji. Dostępność odmiennych typów działalności gospodarczych - w tym takich, które wiążą się z innowacyjnością i kreatywnością (komunikacja, projektowanie i moda, marketing, reklama, obsługa finansowa, kultura, administracja, nauka i oświata) - jest przez autorów interpretowana właśnie w kategoriach korzyści aglomeracji. Uznając je za korzyści zewnętrzne, D. Maillat podkreśla, iż wynikają one z przestrzennej bliskości, różnorodności oraz dostępności, zapewnianej przez rozwój infrastruktury miejskiej.

W odniesieniu do terytorialnych form organizacji produkcji jako emanacji działania mechanizmu korzyści aglomeracji należy wskazać na ich korzenie, analizowane w pracach A. Marshalla, który wprowadził pojęcie tzw. dystryktu przemysłowego jako sposobu na wyjaśnienie rosnącej wydajności pracy, powodowanej bliskością przedsiębiorstw. Dzięki połączeniu gospodarczych, społecznych i kulturowych zasobów danego terytorium w obrębie dystryktu pojawia się dodatkowy czynnik rozwoju o znaczeniu równorzędnym w stosunku do tradycyjnych czynników produkcji. Koncentracja przedsiębiorstw nie jest już od tego momentu postrzegana jedynie jako grupa oddzielnych podmiotów gospodarczych zlokalizowanych w określonym obszarze, lecz jako sieć oparta na wzajemnych relacjach i zaufaniu, gdzie zewnętrzne efekty współpracy pozostają wyraźnie widoczne.

Koncepcja dystryktów przemysłowych stała się podstawą prac nad wieloma innymi formami organizacji produkcji w przestrzeni ${ }^{134}$. Wśród nich można wskazać koncepcje neomarshalowskich dystryktów przemysłowych (znanych też jako włoskie dystrykty przemysłowe) ${ }^{135}$, nowych przestrzeni produkcyjnych (new industrial spaces) ${ }^{136}$ czy koncepcje lokalnych systemów produkcyjnych ${ }^{137}$. Do innych, pochodnych koncepcji

133 D. Maillat, Interactions between Urban Systems..., s. 117-130.

134 Szeroki przegląd terytorialnych form organizacji produkcji, który wykracza poza ramy niniejszej pracy, dostępny jest m.in. w następujących opracowaniach: Z. Przygodzki, A. Nowakowska, J. Chądzyński, Region i jego rozwój..., rozdział IV; S. Cruz, A. Teixeira, A New Look into the Evolution of Clusters Literature. A Bibliometric Exercise, Working Papers 2007, issue 164 (December); http://wps.fep.up. pt/wps/wp257.pdf (dostęp: 20.07.2012).

135 G. Becattini, The Marshallian Industrial District...

136 A. Scott, New Industrial Spaces...

137 C. Courlet, Les systèmes productifs locaux: de la definition au modele, [w:] Reseaux d'entreprises et territories. Regards sur les systemes productifs locaux, DATAR, La documentation Francaise, Paris 2001. 
należą: środowiska innowacyjne (milieux innovateurs ${ }^{138}$ ), regionalne systemy innowacji ${ }^{139}$, koncepcja regionów uczących się ${ }^{140}$ czy wreszcie teoria klastrów, upowszechniona przez M. Portera ${ }^{141}$, choć znajdująca też wielu krytyków ${ }^{142}$.

A. Jewtuchowicz wyróżnia pięć znaczących terytorialnych form organizacji produkcji, pisząc, iż wraz z rozwojem badań w wielu krajach i przez różne grupy badawcze zjawisko to dopiero zaczyna być systematyzowane i porządkowane, pojawiają się też próby podejścia syntetycznego. Ogólnie można wymienić kilka kategorii prac, w których zarysowują się wyraźnie pewne „szkoły”. Można je zgrupować wokół trzech pojęć: dystryktu przemysłowego, technopolu (dystryktu technologicznego) i lokalnych (terytorialnych) systemów produkcyjnych. Obok tych trzech podstawowych kategorii na uwagę zasługują jeszcze dwie koncepcje: skupisk przemysłowych (clusters) i przedsiębiorczości rozproszonej (lentreprisation diffuse $)^{143}$. Ostatnia $\mathrm{z}$ wymienionych form charakteryzuje sytuację $\mathrm{w}$ transformujących się krajach postsocjalistycznych, będącą wynikiem rozpadu gospodarki zintegrowanej pionowo i pojawienia się w jej miejsce, w wyniku procesów „rojenia się" (ang. spinoff, fr. essaimage), dużej liczby małych i średnich przedsiębiorstw ${ }^{144}$.

We współczesnej literaturze przedmiotu nie brakuje jednak krytyki pod adresem terytorialnych form organizacji produkcji. Najogólniej rzecz ujmując, wynika ona $\mathrm{z}$ dwóch przesłanek. Pierwsza odnosi się do obserwacji, że pomimo podobieństwa semantycznego sposobów definiowania terytorialnych form organizacji produkcji (np. każdy z nich bez-

138 Ph. Aydalot, Trajectoires technologiques et milieux l'innovation, [w:] idem (ed.), Milieux innovateurs en Europe, GREMI, Paris 1986; R. Camagni, D. Maillat, Milieux innovateurs. Theorie et politiques, Economica, Paris 2006.

139 H.-J. Braczyk, Ph. Cooke, M. Heidenreich, Regional Innovation Systems. The Role of Governance in a Globalized World, UCL Press, London 1998.

140 B. Asheim, Industrial Districts as Learning Regions...; R. Florida, Toward the Learning...

141 M. E. Porter, Clusters and the New Economic Competition, „Harvard Business Review" 1998, (November-December), s. 78; M. E. Porter, The Competitive Advantage of Nations, The Free Press, New York 1990.

142 E. J. Feser, Old and New Theories of Industry Clusters, [w:] M. Steiner (ed.), Clusters and Regional Specialisation, Pion Ltd., London 1998; A. Hamdouch, Innovation Networks and Clusters: A Critical Review of the Recent Literature, Proceedings of the 19 ${ }^{\text {th }}$ EAEPE Conference: „Economic Growth, Development and Institutions”, Porto 2007; http://www.fep.up.pt/conferencias/eaepe2007/Papers\%20and\%20 abstracts_CD/Hamdouch.pdf (dostęp: 20.07.2012); R. Martin, P. Sunley, Deconstructing Clusters: Chaotic Concept or Political Panacea?, „Journal of Economic Geography” 2003, vol. 3 (1), s. 5-35.

143 A. Jewtuchowicz, Terytorium i wspótczesne dylematy..., s. 73-94.

144 Ibidem, s. 75, [za:] C. Courlet, Les systèmes productifs locaux..., s. 41. 
pośrednio lub pośrednio odnosi się do pojęcia korzyści aglomeracji), pozostają one koncepcyjnie wieloznaczne. Wieloznaczność ta dotyczy przy tym zarówno podstawowych pojęć, jak i skali analizy (tj. w jakiej skali geograficznej należy interpretować bliskość przestrzenną) $)^{145}$. Ta koncepcyjna wieloznaczność ogranicza tym samym możliwości budowania jednorodnej i spójnej wewnętrznie teorii w zakresie terytorialnych form organizacji produkcji ${ }^{146}$.

Natomiast druga przesłanka dotyczy trudności w operacjonalizacji, a w konsekwencji - w prowadzeniu badań nad samymi korzyściami aglomeracji oraz funkcjonowaniem terytorialnych form organizacji produkcji. W konsekwencji, w pierwszym przypadku podejmuje się głównie badania nad procesami tzw. konwergencji i polaryzacji regionalnej, natomiast $\mathrm{w}$ drugim przypadku badania sprowadzają się przede wszystkim do prowadzenia pogłębionych studiów przypadków i analiz porównawczych. O ile pierwsze ujęcie zbliża badania nad korzyściami aglomeracji do analiz makroekonomicznych, o tyle drugie $\mathrm{z}$ nich stwarza pole dla stosowania na szerszą skalę analizy wykorzystującej dorobek ekonomii instytucjonalnej.

\section{Terytorialny paradygmat rozwoju - wspótczesne podejście do analiz przestrzennych}

Kluczowym punktem wyjścia dla poszukiwania zbieżności między ekonomią instytucjonalną a zagadnieniami rozwoju lokalnego i regionalnego staje się obecnie koncepcja „terytorialnego charakteru rozwoju”, silnie upowszechniania zarówno wśród naukowców, jak i praktyków w zakresie gospodarki przestrzennej. Współczesne analizy przestrzenne koncentrują się bowiem coraz częściej wokół pojęcia „terytorium”, którego istota sprowadza się do połączenia wymiaru związanego z przestrzenią fizyczną - z wymiarami poznawczym i społecznym. Ostatnie dwa wymiary obejmują przy tym stosunek mieszkańców do zamieszkiwanego przez nich

145 Por. T. G Bunnell, N. M. Coe, Spaces and Scales of Innovation, „Progress in Human Geography” 2001, no. 25 (4), s. 569-589.

146 F. Moulaert, F. Sekia, Territorial Innovation Models: A Critical Survey, „Regional Studies" 2003, vol. 37, no. 3, s. 289-302. Zob. też: M. E. Sokołowicz, Territorial context... 
obszaru, a także relacje między mieszkańcami składające się na tzw. specyficzność miejsca.

Wśród ekonomistów, którzy jako pierwsi silnie akcentowali złożoność zagadnienia przestrzeni oraz konieczność porzucenia jej „uproszczonej” interpretacji, znalazł się w latach 60. XX w. François Perroux, proponując rozróżnienie między tzw. przestrzenią geonomiczną i ekonomiczną (tab. 4). Przestrzeń geonomiczna, zwana przez autora banalną (l'espace banal), interpretowana jest $\mathrm{w}$ kategoriach dostępności siły roboczej i środków materialnych, a zatem klasycznie pojmowanych czynników lokalizacji ${ }^{147}$. Jako taka ma wymiar bardziej techniczny niż ekonomiczny.

Tymczasem drugi typ przestrzeni - przestrzeń ekonomiczna - powinien być interpretowany $\mathrm{w}$ trzech ujęciach: poprzez plany i zachowania strategiczne podmiotów gospodarczych, jako obszar oddziaływania sił dośrodkowych i odśrodkowych oraz jako homogeniczny agregat, dający się interpretować w kategoriach abstrakcyjnych modeli ekonomicznych. $\mathrm{W}$ ujęciu pierwszym przestrzeń ekonomiczna wiąże się z takimi aspektami, jak: 1) planowanie relacji z dostawcami i odbiorcami; 2) analizowanie wartości wyrażonych w pieniądzu (sygnałów rynkowych), w celu dostosowywania się do zmiennych warunków otoczenia; 3) dostosowywanie się do zmian w zachowaniach innych podmiotów gospodarczych.

Przestrzeń (ekonomiczna) definiowana jako obszar oddziaływania sił składa się z centrów (biegunów wzrostu), z których emanują jednocześnie siły dośrodkowe i odśrodkowe (por. podrozdział 1.2). W takich kategoriach może być analizowane nawet pojedyncze przedsiębiorstwo, ponieważ z jednej strony stanowi ono podmiot, który przyciąga ludzi i obiekty do konkretnej przestrzeni $\mathrm{w}$ jej wymiarze geonomicznym, z drugiej zaś - może je też odpychać (np. czyniąc daną przestrzeń nieatrakcyjną turystycznie). Wzajemne ścieranie się sił dośrodkowych i odśrodkowych pozostaje $\mathrm{w}$ centrum zainteresowania analiz regionalnych, choć napotyka na problemy analityczne (lub wręcz niemożność) $\mathrm{w}$ analizowaniu przestrzeni w wymiarze geonomicznym. Wreszcie, przestrzeń ekonomiczna definiowana jako homogeniczny agregat interpretowana jest $\mathrm{w}$ ujęciu relatywnym, ponieważ każdy podmiot ekonomiczny (przedsiębiorstwo, grupa przedsiębiorstw, region) może zostać wyodrębniony z otoczenia w kategoriach warunków produkcji, sprzedaży, kosztów itd. ${ }^{148}$

147 I. Couzon, "Les espaces économiques » de Francois Perroux (1950). Organisation de l'espace et aménagement du territoire dans l'économie et la géographie françaises au milieu du XXème siècle, „Revue d'Histoire des Sciences Humaines” 2003, nr 9, s. 90.

148 F. Perroux, Economic space..., s. 95-96. 
Tabela 4. Zestawienie typów przestrzeni w ujęciu François Perroux

\begin{tabular}{|c|c|c|c|c|}
\hline \multirow{2}{*}{ Przestrzeń } & \multirow{2}{*}{ Relacje } & \multicolumn{2}{|c|}{ Jednostki analizy } & \multirow{2}{*}{$\begin{array}{l}\text { Loka- } \\
\text { lizacja }\end{array}$} \\
\hline & & proste & złożone & \\
\hline $\begin{array}{l}\text { I. Przestrzeń } \\
\text { geonomiczna } \\
\left(\mathrm{E}_{0}\right)\end{array}$ & $\begin{array}{l}\text { Relacje geonomiczne między: } \\
\text { punktami } \\
\text { - liniami } \\
- \text { powierzchniami } \\
- \text { rozmiarami }\end{array}$ & $\begin{array}{l}\text { ludzie } \\
\text { rzeczy }\end{array}$ & $\begin{array}{l}\text { grupy ludzi } \\
\text { grupy rze- } \\
\text { czy }\end{array}$ & 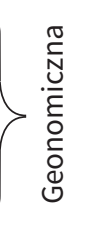 \\
\hline $\begin{array}{l}\text { II. Przestrzeń } \\
\text { ekonomiczna } \\
\left(E_{a}\right)\end{array}$ & Relacje ekonomiczne & $\begin{array}{l}\text { Mikrojed- } \\
\text { nostki pro- } \\
\text { dukcji }\end{array}$ & $\begin{array}{l}\text { Makrojed- } \\
\text { nostki pro- } \\
\text { dukcji }\end{array}$ & \\
\hline $\begin{array}{l}\text { 1. Definiowana } \\
\text { przez plan } \\
\left(\mathrm{E}_{\mathrm{a} 1}\right)\end{array}$ & $\begin{array}{l}\text { Relacje definiujące plan } \\
\text { jednostki } \\
\text { Relacje definiujące plany } \\
\text { innych jednostek w tym } \\
\text { samym zbiorze }\end{array}$ & $\begin{array}{l}\text { Mikroilości } \\
\text { Ceny mikro- } \\
\text { ilości } \\
\text { Mikrojed- } \\
\text { nostki kon- } \\
\text { sumpcji }\end{array}$ & $\begin{array}{l}\text { Makroilości } \\
\text { Ceny ma- } \\
\text { kroilości }\end{array}$ & \\
\hline $\begin{array}{l}\text { 2. Definiowana } \\
\text { jako obszar od- } \\
\text { dziatywania sit } \\
\left(E_{\mathrm{a} 2}\right)\end{array}$ & $\begin{array}{l}\text { Siły oddziaływania } \\
\text { jednostki } \\
\text { Siły działające na } \\
\text { jednostkę }\end{array}$ & & & 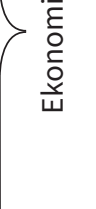 \\
\hline $\begin{array}{l}\text { 3. Definiowana } \\
\text { jako homogenicz- } \\
\text { ny agregat } \\
\left(\mathrm{E}_{\mathrm{a} 3}\right)\end{array}$ & $\left\{\begin{array}{l}\text { Relacje jednorodności, } \\
\text { relatywne w stosunku } \\
\text { do jednostek i relacji } \\
\text { między jednostkami }\end{array}\right.$ & & & \\
\hline
\end{tabular}

Każdy zbiór relacji oznaczony symbolami $\mathrm{E}_{\mathrm{a} 1}, \mathrm{E}_{\mathrm{a} 2}$ i $\mathrm{E}_{\mathrm{a} 3}$ może być uznany za przestrzeń abstrakcyj$n q$. Koncepcja ta, wykorzystywana przez francuskiego matematyka Frécheta, może być uszczegółowiona poprzez odwołanie się do natury przestrzeni abstrakcyjnych wykorzystywanych w procesach matematyzacji (np. przestrzeń wektorowa, topograficzna itp.). Można podejrzewać - choć pewność da się uzyskać tylko w wyniku przeprowadzenia dowodów matematycznych że $\mathrm{E}_{\mathrm{a} 1}, \mathrm{E}_{\mathrm{a} 2} \mathrm{i}_{\mathrm{a} 3}$ przedstawiają istotne i różnorodne trudności w trakcie prób matematycznej formalizacji każdego typu relacji zachodzących wewnątrz nich i między nimi.

Źródło: F. Perroux, Economic Space: Theory and Applications, „Quarterly Journal of Economics" 1950, vol. 64 (1), s. 93. 
Przykładowo, region interpretowany w kategoriach przestrzeni ekonomicznej to „zespół przylegających do siebie obszarów posiadających - pod względem pewnych kryteriów - możliwie wiele cech wspólnych i wykazujących możliwie wiele różnic w stosunku do obszarów otaczających” ${ }^{149}$ lub „wydzielony na podstawie wyraźnie określonych cech obszar, charakteryzujący się swoistymi formami zagospodarowania"150. Podobnie postrzegają region inni badacze, np. A. Fajferek, dla którego region ekonomiczny to „terytorialny kompleks produkcyjno-usługowy, wyróżniający się od otaczających obszarów swoistymi formami zagospodarowania"151.

Na gruncie geografii społecznej zagadnienie przestrzeni poruszał także Yi-Fu Tuan, wprowadzając rozróżnienie na „przestrzeń” i „miejsce”. Podczas gdy „przestrzeń" traktowana jest jak pusta karta, to „miejsce” stanowi centrum pewnych ustalonych wartości. Tym samym „przestrzeń w sensie semiotycznym jest bardziej abstrakcyjna niż miejsce. To, co na początku jest przestrzenią, staje się jednak miejscem w miarę poznawania i nadawaniu mu wartości" ${ }^{152}$.

Złożoność pojęć przestrzeni i miejsca akcentował Edward W. Soja, wskazując na konieczność analizowania zagadnień przestrzennych przez pryzmat trzech ujęć:

1) kontroli nad dystrybucją, alokacją i strukturą własności rzadkich zasobów, wśród których za najistotniejsze uznawał m.in. ziemię jako czynnik produkcji,

2) utrzymania porządku i wykonywania władzy na danym terytorium, wyłaniających się w toku trajektorii jego rozwoju,

3) legitymizacji władzy w celu integracji społecznej ${ }^{153}$.

W konsekwencji powyższych rozważań coraz częściej proponowano konceptualne rozróżnienie między pojęciami: „ziemi” jako czynnika produkcji, „przestrzeni”, „miejsca” i „terytorium”. Ziemia jako czynnik produkcji powinna być zgodnie z powyższą klasyfikacją interpretowana w kategoriach rzadkiego zasobu, o który konkurują różni aktorzy ekonomiczni. Alokacja i dystrybucja tego zasobu następuje w wyniku ustanowienia określonego systemu politycznego i ekonomicznego, definiującego obowiązującą strukturę praw własności. Natomiast przestrzeń

149 K. Kuciński, Podstawy teorii..., s. 17.

150 Z. Szymla, Determinanty rozwoju..., s. 10.

151 A. Fajferek, Region ekonomiczny..., s. 9.

152 Yi-Fu Tuan, Przestrzeń i miejsce, Państwowy Instytut Wydawniczy, Warszawa 1987, [cyt. za:] A. Majer, Socjologia i przestrzeń miejska, PWN, Warszawa 2010, s. 63.

153 E. W. Soja, The Political Organization of Space, Association of American Geographers, Commission on College Geography Resource Paper 8, Washington D.C. 1971, s. 7. 
wiąże się ze strukturą władzy, mającej zdolność do utrzymywania w niej porządku i ustanowienia określonego systemu administracyjnego do zachowania nad nią zwierzchnictwa. Wreszcie terytorium stanowi z jednej strony połączenie powyższych pojęć, jednak z drugiej - pozostaje czymś więcej. Powinno być definiowane poprzez tzw. „terytorialność”, rozumianą jako określony stosunek do ziemi i przestrzeni ${ }^{154}$. Należy podkreślić, iż „terytorium”, oprócz współzależności z takimi pojęciami, jak „ziemia”, „przestrzeń”, „teren”, „obszar” czy „miejsce”, proponuje się rozpatrywać w kontekście specyficzności zachodzących na nim relacji społecznych (specyficzność jako cecha terytorium) ${ }^{155}$.

W takim ujęciu terytorium pozostaje przede wszystkim źródłem zasobów, aktywnym aktorem procesów społeczno-gospodarczych, a także źródłem zmian pozwalających dostosowywać się do zmiennej rzeczywistości. Pojęcie to przestaje być zatem utożsamiane jedynie z przestrzenią fizyczną, traktowaną w tradycyjnych teoriach lokalizacji gospodarczej w kategoriach kosztów ziemi, kapitału, siły roboczej czy transportu. Terytorium

jest to obszar, w którym dochodzi do spotkania relacji rynkowych i społecznych form regulacji; obszar, który determinuje różne formy organizacji produkcji i zdolności innowacyjne (zarówno w odniesieniu do produktów, jak i procesów), prowadzące do dywersyfikacji produkcji oferowanej na rynku nie tylko w oparciu o relatywne koszty czynników ${ }^{156}$.

W konsekwencji istota terytorium wyraża się w stosunkach społecznych, w relacjach między zbiorowością ludzi a obszarem przez nią zamieszkiwanym, w przynależności do tego obszaru, który określają takie pojęcia, jak tożsamość, przywłaszczenie przestrzeni, „zakorzenienie” w określonym miejscu ${ }^{157}$. M. Le Berre określa terytorium jako część powierzchni ziemi „przystosowaną" przez grupę społeczną w celu zapew-

154 S. Elden, Land, Terrain, Territory, „Progress in Human Geography” 2010, vol. 34 (6), s. 804. Należy jednak zwrócić uwagę na trudność w bardziej precyzyjnym wskazaniu powyższych różnic, spowodowaną ograniczonymi możliwościami przetłumaczenia z oryginału pojęć: land (ziemia), terrain (teren, przestrzeń) oraz territory (terytorium).

155 S. Elden, Land, Terrain..., s. 807.

156 G. Garfoli, Economic Development. Organisation of Production and Territory, „Revue d'Économie Industrielle” 1993, nr 64, [cyt. za:] I. Pietrzyk, Polityka regionalna Unii Europejskiej i regiony w państwach członkowskich, PWN, Warszawa 2001, s. 34.

157 A. Bailly, Territoires et territorialités, [w:] J.-P. Auray et al., Encyclopédie d'economie spatiale: concepts, comportements, organisations, Economica, Paris 1994, s. 274-279. 
nienia reprodukcji i zabezpieczenia swoich życiowych potrzeb ${ }^{158}$. Jest ono zatem „stworzone” przez określoną społecznośććc ${ }^{159}$ i - jak twierdzi C. Lacour - łączy przeszłość mieszkańców, ich teraźniejszość i ich przyszłe wizje ${ }^{160}$.

A. Jewtuchowicz ujmuje terytorium jako „konstrukcję historyczną, która na drodze specyficznego rozwoju została wyposażona we własny potencjał techniczny i ludzki”'161. Potencjał ten wykształcił się w danym miejscu w wyniku długiej ewolucji, przez co uległ silnemu „zakorzenieniu”. Takie rozumienie „terytorium” pozwala dostrzec, że czynnikiem spajającym pozostaje nie tyle bliskość $\mathrm{w}$ wymiarze fizycznym, ile bliskość wynikająca $z$ budowania różnorodnych relacji o charakterze rynkowym i pozarynkowym, a to $z$ kolei otwiera pole dla eksponowania w nich czynnika instytucjonalnego.

Należy zatem podkreślić, iż zarówno rozważania teoretyczne, jak i badania nad "terytorialnością" procesów rozwojowych nie stanowią nowego zagadnienia. Analizy w tym duchu podejmowane są bowiem na gruncie nauk geograficznych od połowy XIX w., a na gruncie socjologii przestrzeni co najmniej od lat 30 . XX w. Jednak z uwagi na trudności w operacjonalizacji tego zagadnienia, zwiększającej prawdopodobieństwo uwiarygodnienia stawianych tez, opartych na materiale empirycznym, pozostawały one poza głównym nurtem rozważań podejmowanych na gruncie nauk ekonomicznych ${ }^{162}$.

W ostatnich latach - na skutek niedoskonałości zbyt upraszczającego rzeczywistość modelowania zjawisk ekonomicznych oraz wzrastającego poziomu złożoności struktur społeczno-gospodarczych - obserwuje się zmianę podejścia także wśród ekonomistów. Wśród dynamicznie rozwijających się gałęzi tej dziedziny wiedzy na uwagę zasługuje w tym kontekście zwłaszcza ekonomia instytucjonalna, ukazująca wiele nowych kierunków badań nad zagadnieniami rozwoju lokalnego i regionalnego.

158 M. Le Berre, Territoires, [w:] A. Bailly, R. Ferras, D. Pumain (eds.), Encyclopedie de géographie, Paris 1992, s. 622.

159 I. Pietrzyk, Globalizacja, integracja europejska a rozwój regionalny, [w:] A. Jewtuchowicz (red.), Wiedza, innowacyjność, przedsiębiorczość a rozwój regionów, Wyd. Uniwersytetu Łódzkiego, Łódź 2004, s. 12-13.

160 C. Lacour, La tectonique des territoires: d'une métaphore à une théoretisation, [w:] B. Pecqueur (ed.), Dynamiques territoriales et mutations économiques, L'Harmattan, Paris 1996, s. 36-38.

161 A. Jewtuchowicz, Terytorium i współczesne dylematy..., s. 65.

162 Szerzej w: M. E. Sokołowicz, Zagadnienie bliskości w badaniach nad rozwojem terytorialnym. Podejście instytucjonalne, [w:] A. Nowakowska (red.), Zrozumieć terytorium. Idea i praktyka, Wyd. Uniwersytetu Łódzkiego, Łódź 2013, s. 59-92. 
Zmiana paradygmatu rozwoju lokalnego i regionalnego w kierunku jego „uterytorialnienia” skutkuje ponadto przeobrażeniami $\mathrm{w}$ domenie polityki rozwoju lokalnego i regionalnego. We wcześniejszych jej etapach stosowano ten sam model polityki regionalnej, nieuwzględniający specyficznych uwarunkowań terytorialnych ${ }^{163}$. Wynikało to z przekonania, iż dające sie replikować w różnych lokalizacjach odgórne narzędzia w zakresie rozwoju infrastruktury, edukacji czy polityki przemysłowej wystarczą dla wspierania wzrostu gospodarczego oraz eliminowania dysproporcji rozwojowych i nie muszą uwzględniać lokalnego kontekstu instytucjonalnego ${ }^{164}$. Podejście to było tym samym zdominowane przez stosowanie bezpośrednich instrumentów oddziaływania ze strony sektora publicznego, miało charakter sektorowy (osobno traktowano kwestie rozwoju gospodarczego, mieszkalnictwa, zdrowia, edukacji, transportu, rolnictwa, turystyki itd.) oraz abstrahowało od wzajemnych istniejących i potencjalnych interakcji między tymi sektorami. Pozostawało zatem - zdaniem Patsy Healey - w znacznym miejscu „ślepe na miejsce” 165 .

Współcześnie polityka przestrzenna pozostaje pod coraz silniejszym wpływem nauk regionalnych (czerpiących silnie $z$ ekonomii instytucjonalnej i ewolucyjnej), a także nauk $\mathrm{z}$ obszaru ochrony środowiska, kładących nacisk na podejście zintegrowane, tj. traktujące układ człowiek-gospodarka-środowisko jako system wzajemnych powiązań i geografii kultury, która poświęca wiele uwagi zagadnieniom jakości życia w przestrzeni. Kombinacja powyższych podjeść i wykorzystanie w praktyce ich dorobku intelektualnego doprowadziło do rosnącej świadomości wartości miejsca i terytorium w planowaniu przestrzennym jako dobra per $s e^{166}$.

Wyrazem eksponowania konieczności stosowania terytorialnego podejścia do polityki rozwoju jest powszechność odwołań w literaturze przedmiotu do raportu F. Barci z roku $2009^{167}$, a w ostatnich latach również upowszechnienie tego podejścia na gruncie północnoamerykańskim ${ }^{168}$. Ponadto, wśród ekonomistów zajmujących się zagadnieniami rozwoju lo-

163 A. Rodríguez-Pose, Do Institutions Matter for Regional Development?, Working Papers Series in Economics and Social Sciences, Sciencias Sociales IMDEA 2010, no. 2, s. 4-5.

164 Por. A. Pike, A. Rodríguez-Pose, J. Tomaney, Local and Regional Development, Routledge, London-New York 2006.

165 P. Healey, Institutionalist Analysis, Communicative Planning and Shaping Places, „Journal of Planning Education and Research” 1999, no. 19, s. 111-121.

166 Ibidem, s. 120.

167 F. Barca, An Agenda for a Reformed Cohesion Policy. A Place-based Approach to Meeting European Union Challenges and Expectations (Barca Report), April 2009.

168 White House, Developing effective place-based policies for the FY 2012 Budget, 2010; http://www.whitehouse.gov/sites/default/files/omb/assets/memoranda_2010/m10-21.pdf (dostęp: 16.09.2014). 
kalnego i regionalnego, obok tak powszechnych pojęć jak „kapitał ludzki” czy „kapitał społeczny”, zaczęło upowszechniać się pojęcie „kapitału terytorialnego". Neologizm ten zyskuje popularność w dyskursie na temat roli regionów w rozwoju społeczno-gospodarczym oraz w polityce regionalnej. Traktowanie terytorialnych zasobów specyficznych (czyli takich, których wygenerowanie lub odtworzenie $w$ innym miejscu jest niemożliwe lub pociąga ze sobą koszty niewspółmierne w stosunku do korzyści) jako kapitału (czyli jednego z podstawowych czynników produkcji) oznacza, że stanowi on dla regionu zasób, który może być wykorzystany w celach gospodarczych i przynosić wartość dodaną, jak również może być przedmiotem inwestowania (akumulacji). Kapitał terytorialny to typ kapitału o charakterze niematerialnym, którego cechą charakterystyczną pozostaje przywiązanie do danego terytorium (uterytorialnienie), chociaż efekty wykorzystania kapitału terytorialnego w postaci towarów, usług, rozwiązań technologicznych, marek lokalnych i regionalnych itp. mogą być przedmiotem transferu w skali ponadregionalnej i międzynarodowej).

Równie silnie terytorialny charakter rozwoju akcentowany jest przez przedstawicieli ekonomiki bliskości (por. podrozdział $2.4 \mathrm{w}$ rozdziale III). Podstawowy podział na bliskość „geograficzną” i „organizacyjną”, upowszechniony przez A. Torre oraz A. Ralleta w roku $2005^{169}$, został z czasem uzupełniony o tezę, że wymiar polityczny i instytucjonalny odgrywają na tyle istotną rolę w procesach społeczno-gospodarczych, iż konieczne jest wprowadzenie kategorii trzeciej, tj. bliskości „instytucjonalnej”. Definiuje się ją jako przywiązanie aktorów do danej przestrzeni na podstawie zestawu współdzielonych zasad, reprezentacji czy wzorców myślowych ${ }^{170}$. Przedstawiciele tej szkoły zakładają przy tym, iż wymiar polityczny, istotne znaczenie praw i zasad rządzących relacjami społecznymi oraz ekonomicznymi są wystarczające dla uzasadnienia wprowadzenia instytucjonalnego wymiaru bliskości ${ }^{171}$.

Przegląd teorii i nurtów badawczych uwzględniających przestrzeń $\mathrm{w}$ analizach ekonomicznych pozwala zaobserwować ich ewolucję. Jednym $\mathrm{z}$ przejawów rozwoju myśli ekonomicznej $\mathrm{w}$ tym aspekcie jest wzrastająca liczba uwzględnianych czynników, które mogą potencjalnie wiązać się z instytucjonalnym nurtem badawczym w ekonomii. W przypadku klasycznych teorii lokalizacji przedsiębiorstw związki te pozo-

169 A. Rallet, A. Torre, Proximity and Localization, „Regional Studies” 2005, vol. 39, no. 1.

170 T. Kirat, Y. Lung, Innovation and Proximity: Territories as Loci of Collective Learning Processes, „European Urban and Regional Studies” 1999, vol. 6 (1), s. 27-39.

171 A. Torre, F. Wallet, The Role of Proximity Relations in Regional and Territorial Development Processes, Proceedings of the 54 ${ }^{\text {th }}$ ERSA Congress, 26-29 September, Saint-Petersburg 2014, s. 13. 
stają nieznaczne, jednak w odniesieniu do modeli renty gruntowej oraz modeli kształtowania się hierarchii osadniczej można już identyfikować zagadnienia, które współcześnie da się opisać językiem wybranych nurtów ekonomii instytucjonalnej. W pierwszym przypadku może to wynikać z faktu uświadamiania sobie przez kolejnych badaczy czynników - innych niż odległość i wydajność ziemi - różnicujących rentę gruntową w przestrzeni fizycznej. W drugim przypadku uwarunkowania instytucjonalne kształtowania się hierarchii osadniczej są identyfikowane przez powiązanie siły oddziaływania ośrodków centralnych $\mathrm{z}$ ich pozycją w strukturze administracyjnej, będącej pochodną zjawiska koncentracji lub dekoncentracji tej funkcji w wybranych obszarach.

$\mathrm{W}$ przypadku teorii służących wyjaśnianiu procesów konwergencji i polaryzacji przestrzennej można doszukiwać się powiązań z instytucjonalizmem w tym, że ich autorzy niejednokrotnie wskazują na pozaekonomiczne (np. historyczne, kulturowe) przyczyny zróżnicowań regionalnych. Ponadto związek $\mathrm{z}$ instytucjonalnym nurtem badawczym w ekonomii może dotyczyć dyskusji na temat polityki rozwoju przestrzennego, szczególnie w kontekście stawianego coraz częściej pytania o jej skuteczność wobec „naturalnej” rynkowej skłonności do polaryzacji przestrzennej.

Najwięcej powiązań $\mathrm{z}$ instytucjonalnymi uwarunkowaniami procesów gospodarczych można doszukiwać się $\mathrm{w}$ rozważaniach na temat korzyści aglomeracji oraz rozważaniach o terytorialnym charakterze rozwoju społeczno-gospodarczego. W pierwszym przypadku przejawia się to w podziale na technologiczne i pieniężne efekty zewnętrzne, $w$ sygnalizowaniu publicznego charakteru pewnych typów efektów aglomeracji oraz w identyfikacji endogenicznych źródeł korzyści aglomeracji, szczególnie poprzez odwoływanie się do relacji między bliskością przestrzenną a budowaniem sieci relacji gospodarczych. Ewolucja spojrzenia na tak rozumiane korzyści aglomeracji doprowadziła ekonomistów do wyłonienia się tzw. terytorialnego paradygmatu rozwoju, w ramach którego pojęcie „przestrzeń” nie jest jednoznaczne i gdzie kontynuacja badań bez uwzględnienia czynników instytucjonalnych wydaje się niemożliwa. 



\section{Rozdział II}

\section{Ekonomia instytucjonalna \\ - podstawowe pojęcia i geneza}

\section{Miejsce instytucjonalizmu w naukach ekonomicznych}

W naukach ekonomicznych instytucjonalizm, a w szczególności ekonomia instytucjonalna, coraz częściej postrzegane są jako jedne $\mathrm{z}$ najbardziej płodnych nurtów teoretycznych, rozwijających się w oparciu o założenie, iż specyficzne uwarunkowania społeczne, relacyjne i kulturowe pozostają w znacznym stopniu odpowiedzialne za różnice $\mathrm{w}$ funkcjonowaniu takich podmiotów, jak przedsiębiorstwa, kraje czy regiony. Różnice te ujawniają się przy tym pomimo podobnego poziomu wyposażenia $\mathrm{w}$ tradycyjnie rozumiane czynniki produkcji. Tym samym instytucjonalizm może skutecznie przyczynić się do wyjaśnienia nie tylko podstawowych przyczyn dysproporcji przestrzennych w rozwoju gospodarczym, lecz także charakteru procesów, które stoją za tymi różnicami ${ }^{1}$.

Na poziomie państwa narodowego i gospodarek narodowych koncepcja, zgodnie z którą istnienie różnorodnych systemów instytucjonalnych doprowadziło do wyłonienia się odmiennych modeli gospodarki, nie jest nowa. Do pozaekonomicznych przyczyn zróżnicowań gospodarczych odwoływał się już m.in. John Maynard Keynes, który stwierdził, że stopa procentowa jest zjawiskiem $\mathrm{w}$ dużym stopniu psychologicznym² ${ }^{2}$.

1 W tym miejscu należy przede wszystkim wspomnieć pierwsze prace w ramach geografii ekonomicznej, odwołujące się do ekonomii instytucjonalnej: A. Amin, N. Thrift (eds.), Globalization, Institutions and Regional Development in Europe, Oxford University Press, Oxford 1994; Ph. Cooke, K. Morgan, The Associational Economy: Firms, Regions, and Innovation, Oxford University Press, Oxford 1998; M. Storper, The Regional World: Territorial Development in a Global Economy, Guilford Press, London 1997.

2 J. M. Keynes, Ogólna teoria zatrudnienia, procentu i pieniq̨dza, PWN, Warszawa 2003, s. 180. 
W czasach współczesnych ten aspekt procesów gospodarczych eksponuje się coraz powszechniej. Przykładowo, Bruno Amable dla pokazania różnic instytucjonalnych w sposobie zorganizowania gospodarek narodowych wyróżnił pięć modeli kapitalizmu: 1) anglosaski - rynkowy (Wielka Brytania, USA, Australia, Nowa Zelandia, Irlandia); 2) socjaldemokratyczny (Szwecja, Norwegia, Dania); 3) kontynentalny - europejski (Francja, Niemcy, Holandia, Austria); 4. śródziemnomorski oraz 5) azjatycki (Japonia, Korea) ${ }^{3}$. Idea ta rozwijana jest również bardzo szeroko na gruncie analiz instytucjonalnych podejmowanych przez tzw. francuską szkołę regulacji ${ }^{4}$.

Innym wybitnym przedstawicielem ekonomicznej analizy instytucjonalnej jest japoński ekonomista Masahiko Aoki, który zaproponował siedem modeli funkcjonowania gospodarek. W propozycji M. Aoki znalazły się modele: amerykański, niemiecki i japoński, a także bardziej szczegółowe modele instytucjonalne: model Leona Walrasa, model Olivera Harta i Johna Moore’a, czy wreszcie zyskujący na znaczeniu model globalny ${ }^{5}$.

Oryginalne typologie tzw. narodowych kultur ekonomicznych wskazali ponadto Richard Gesteland, Geert Hofstede i Lawrence Harrison. Pierwszy autor, analizując takie elementy „kultury gospodarczej”, jak stosunek do oszczędzania, zaciągania kredytu, zaufanie, stosunek do pracy, własności oraz powszechność poglądów egalitarnych i elitarnych, zaproponował osiem możliwych konfiguracji instytucjonalnych w gospodarce ${ }^{6}$.

Z kolei G. Hofstede dokonał analizy kulturowych (a zatem częściowo też instytucjonalnych) uwarunkowań procesów gospodarczych na podstawie pięciu przeciwstawianych sobie kluczowych wymiarów i norm, tj. mały - duży dystans władzy, indywidualizm - kolektywizm, męskość - kobiecość, niska - wysoka skłonność do unikania niepewności, orientacja krótkoterminowa - długoterminowa ${ }^{7}$. L. Harrison natomiast, podobnie jak poprzednicy, analizując takie czynniki, jak orientacja cza-

3 B. Amable, The Diversity of Modern Capitalism, Oxford University Press, Oxford 2003, s. 13-15.

4 B. Chavance, L'économie institutionelle, Editions La Découverte, Paris 2007, s. 80-86.

5 M. Aoki, Toward a Comparative Institutional Analysis, MIT Press, Cambridge 2000, [cyt. za:] B. Chavance, L'économie..., s. 76-77.

6 Kultury protransakcyjne, propartnerskie, nieceremonialne, ceremonialne, monochromiczne, polichromiczne, ekspresyjne oraz kultury powściągliwe (R. Gesteland, Różnice kulturowe a zachowania w biznesie, PWN, Warszawa 2000, s. 5-7, 131-133).

7 G. Hofstede, Kultury i organizacje. Zaprogramowanie umysłu, PWE, Warszawa 2000. 
sowa, praca, oszczędność, role przypisywane edukacji, poczucie wspólnoty, moralność czy sekularyzm, przeciwstawił kultury postępowe zachowawczym ${ }^{8}$.

Znaczenie czynników kulturowych w sposobie tworzenia bogactwa narodów zostało silnie wyartykułowane w głośnej pracy Charlesa Hampdena-Turnera i Alfonsa Trompenaarsa, w której na zagadnienie to spojrzano przez pryzmat analizy wpływu różnic międzykulturowych na style działań menadżerów korporacyjnych ${ }^{9}$. Autorzy wyróżnili w swej pracy siedem tytułowych kultur, stawiając tezę, iż zróżnicowane stylów działania i organizacji systemów gospodarczych (analizowanych pod kątem siedmiu przeciwstawianych sobie par składających się na przekonania i systemy wartości ${ }^{10}$ ) w istotnym stopniu pozostaje konsekwencją czynników kulturowych i instytucjonalnych.

Istotne znaczenie uwarunkowań instytucjonalnych w procesach gospodarczych (choć w przeważającej części przypadków ujmowane implicite) wskazywane było jednak w literaturze znacznie wcześniej. Dokonując w Wielkiej transformacji ${ }^{11}$ analizy ewolucji kapitalizmu od czasów Kongresu Wiedeńskiego do wybuchu I wojny światowej, węgierski intelektualista K. Polanyi już w latach 40. XX w. stwierdzil, że rynek oraz społeczeństwo, w którym ten rynek funkcjonuje, są ze sobą powiązane. Dlatego kapitalizm w szczególny sposób potrzebuje instytucji społecznych ${ }^{12}$. Na podobne kwestie zwracał uwagę również jeden z najważniejszych w XX w.

8 L. Harrison, S. Huntington (red.), Kultura ma znaczenie, Zysk i S-ka, Warszawa 2003, s. 105-113. Syntetyczny przegląd zaprezentowanych klasyfikacji w polskiej literaturze dostępny jest w opracowaniu K. Kostro, Zagadnienia kulturowe w ekonomii, „Gospodarka Narodowa” 2009, nr 3, s. 27-59.

9 Ch. Hampden-Turner, A. Trompenaars, Siedem kultur kapitalizmu: USA, Japonia, Niemcy, Francja, Wielka Brytania, Szwecja, Holandia, Oficyna Ekonomiczna, Warszawa 2006.

10 1) Uniwersalizm vs. partykularyzm w zakresie ustanawiania regut; 2) analiza vs. synteza w zakresie sposobu postrzegania rzeczywistości; 3) indywidualizm vs. kolektywizm w zakresie systemów zarządzania; 4) wewnątrzsterowność vs. zewnątrzsterowność w zakresie poczucia wpływu na wywoływanie zmian w otoczeniu; 5) sekwencyjność vs. synchroniczność w zakresie zarządzania czasem; 6) osiąganie statusu vs. przypisywanie statusu w zakresie sposobów wybierania liderów; 7) równość vs. hierarchia w zakresie sposobu funkcjonowania organizacji.

11 K. Polanyi, The Great Transformation. The Political and Economic Origins of Time, Rinehart and Company, New York 1944; wyd. polskie: K. Polanyi, Wielka transformacja, PWN, Warszawa 2010. Znamienne jest dla popularności nurtów instytucjonalnych w Polsce, że pierwsze polskie wydanie tej książki ukazało się w Polsce ponad 60 lat od wydania oryginatu.

12 R. Patel, Wartość niczego. Jak przeksztatcić społeczeństwo rynkowe i na nowo zbudować demokrację, Wyd. Muza, Warszawa 2010, s. 24. 
specjalistów ds. zarządzania Peter Drucker, pisząc, iż centrum problemów społecznych i ekonomicznych współczesnego świata stanowią nie technologie, informacje czy wydajność, lecz właśnie instytucje ${ }^{13}$. Innych przykładów na to, że kultura może kształtować sposób akumulacji i dystrybucji zasobów w gospodarce, dostarcza szeroki nurt badań znanych jako ekonomia eksperymentalna ${ }^{14}$. Za pomocą eksperymentów podejmuje się tam próbę analizy, jak wzajemne oczekiwania podmiotów podejmujących decyzje ekonomiczne (interpretowane zazwyczaj w kategoriach teorii gier) i poziom zaufania między nimi wpływa na ich zachowania gospodarcze ${ }^{15}$.

Co ciekawe, głosy na temat złożoności oraz trudności w mierzeniu wielu istotnych aspektów procesów wzrostu i rozwoju gospodarczego (oraz ich zróżnicowania przestrzennego) ujawniają się także w dyskusji nad produktem krajowym (narodowym) brutto (PKB) jako miernikiem rozwoju. Szeroka argumentacja na ten temat została ujęta w 2011 r. w raporcie Komisji ds. Pomiaru Rozwoju Ekonomicznego, której pracom przewodzili J. Stiglitz, A. Sen oraz J.-P. Fitoussi. Komisję powołał w roku 2008 ówczesny prezydent Francji N. Sarkozy jako odpowiedź na nieadekwatność wielu powszechnie używanych mierników gospodarczych. W raporcie końcowym zaproponowano bardziej wszechstronny sposób pomiaru poziomu rozwoju, odwołujący się nie tylko do mierzenia wzrostu produkcji, lecz będący próbą uchwycenia wielu innych aspektów dobrobytu czy tzw. „dobrostanu”16.

Autorzy raportu podkreślili przy tym, że PKB nie jest miernikiem, który należy zastąpić ${ }^{17}$, natomiast wskazali na wiele innych możliwych

13 P. F. Drucker, Management Challenges for the $21^{\text {st }}$ Century, Butterworth-Heineman, Oxford-New York-Tokyo 2002, s. 39-40.

14 Godny przywołania jest m.in. eksperyment, polegający na porównaniu zachowania indiańskich chłopców z plemienia Lakota oraz białych chłopców z północnoamerykańskich rodzin. Polegał on na rozdaniu w obydwu grupach każdemu dziecku dwóch lizaków. W obydwu grupach pierwszy lizak został od razu zjedzony przez każdego z uczestniczących w eksperymencie. W następnym etapie jednak biali chłopcy chowali drugi lizak do kieszeni, natomiast chłopcy indiańscy dawali go w prezencie pierwszemu napotkanemu chłopcu, który nie miał lizaka. Eksperyment doprowadził do wniosku, że w wyniku różnic kulturowych przeciwieństwem konsumpcji w gospodarce nie zawsze będą oszczędności, lecz... hojność (eksperyment opisany m.in. w: R. Patel, Wartość niczego..., s. 38).

15 Zob. np. J. C. Cox et al., Trust in Private and Common Property Experiments, „Southern Economic Journal” 2009, vol. 75 (4), s. 957-975.

16 J. E. Stiglitz, A. Sen, J.-P. Fitoussi, Report by the Commission on the Measurement of Economic Performance and Social Progress, http://www.stiglitz-sen-fitoussi.fr/ documents/rapport_anglais.pdf (dostęp: 19.07.2014).

17 Nie ulega wątpliwości, że ,istotną zaletą PKB jest jego niezależność od arbitralnych wycen. Wielkości fizyczne są zawarte w statystyce, a ceny są ustalane przez rynek. Nie daje to możliwości arbitralnego manipulowania przez badaczy. W prze- 
sposobów mierzenia procesów gospodarczych, z których wiele posiada wymiar instytucjonalny. Podając 12 kluczowych rekomendacji w zakresie udoskonalenia procesów pomiaru zjawisk ekonomicznych, podkreślili konieczność większego zainteresowania się sytuacją gospodarstw domowych, zagadnieniami zdrowia, dystrybucji dochodu i bogactwa w różnych skalach geograficznych oraz przekrojach społecznych, problemem wyceny zasobów środowiska naturalnego czy też włączania $\mathrm{w}$ rachunki ekonomicznie zagadnień z zakresu zrównoważonego rozwoju ${ }^{18}$. Za ważny obszar badań uznali też kwestię pomiaru jakości życia, traktując ją jednak bardzo szeroko, tj. uwzględniając zarówno problematykę zdrowia, edukacji, aktywności życiowych, poczucia bezpieczeństwa pojedynczych osób (składających się na tzw. „dobrostan”), jak i istotną rolę możliwości uczestniczenia w życiu publicznym, współdecydowania w zbiorowościach (governance), a także relacji społecznych i zaufania społecznego, przekładających się na efektywność ekonomiczną ${ }^{19}$.

Można przytoczyć wiele przykładów tego, w jaki sposób uwarunkowania instytucjonalne pozytywnie kształtują lub zniekształcają rynki, prowadząc do zwiększenia poziomu ich nieefektywności. Rynki finansowe są niedoskonałe m.in. dlatego, że - jak pisze M. Castells - „ruchy na rynkach finansowych są efektem złożonej kombinacji zasad rynkowych, strategii biznesowych, politycznie motywowanych programów gospodarczych, machinacji banków centralnych, ideologii technokratów, psychologii tłumu, spekulacyjnych manipulacji i zaburzeń informacyjnych o różnych źródłach" ${ }^{20}$.

Powyższe uwarunkowania spowodowały, że we współczesnej literaturze można zaobserwować dynamiczny rozwój analiz teoretycznych i empirycznych, wpisujących się w nurty dające się zaklasyfikować pod wspólnym mianownikiem „ekonomia instytucjonalna”21. Ten obszar eks-

ciwieństwie do tego, wiele innych wskaźników dobrobytu ma charakter arbitralny, nawet jeśli niektórzy badacze są tego nieświadomi” (J. Kronenberg, T. Bergier, Wyzwania zrównoważonego rozwoju w Polsce, Fundacja Sendzimira, Kraków 2010, s. 76). Problem polega jednak na tym, że rozwój metodyki szacowania PKB nie zawsze odpowiada rosnącemu zainteresowaniu zagadnieniami instytucjonalnymi w ekonomii.

18 J. E. Stiglitz, A. Sen, J.-P. Fitoussi, Report by the Commission..., s. 12-18.

19 Szerzej: ibidem, s. 156-215.

20 M. Castells, Społeczeństwo sieci, PWN, Warszawa 2010, s. 135.

21 Koreański ekonomista Ha-Joon Chang, podejmując próbę nieco publicystycznego przybliżenia odbiorcy złożoności dziedziny wiedzy, jaką jest ekonomia, uznał ekonomię instytucjonalną za jedną z dziewięciu kluczowych szkół (obok ekonomii klasycznej, ekonomii neoklasycznej, marksizmu, keynesizmu, szkoły austriackiej, ekonomii rozwoju, szkoły szchumpeteriańskiej oraz ekonomii behawioralnej) (H.-J. Chang, Economics: The User's Guide, Bloomsbury Press, New York 2014, s. 29-122). 
ploracji naukowej pozostaje złożonym konglomeratem różnorodnych podejść oraz metod analitycznych. Pozwala coraz precyzyjniej wyjaśniać takie zjawiska, jak wpływ uwarunkowań historycznych i kulturowych na decyzje gospodarcze, sposoby współpracy podmiotów gospodarczych na rynku oraz $\mathrm{w}$ ramach struktur organizacyjnych $\mathrm{z}$ punktu widzenia ich wpływu na minimalizację kosztów transakcji czy sposób kształtowania relacji społecznych ułatwiających lub utrudniających podejmowanie decyzji zbiorowych.

Ekonomia instytucjonalna nie jest jednak ugruntowaną gałęzią nauk ekonomicznych, pozostając wciąż raczej konglomeratem różnych szkół i podejść. W pierwszej kolejności należy zatem dokonać rozróżnienia między tzw. „starym” i ,nowym” instytucjonalizmem. „Stary” nurt interpretuje instytucje w kategoriach ich budowania poprzez relacje społeczne ${ }^{22}$. Co istotne, nie fetyszyzuje on wartości płynących z indywidualizmu w ekono$\mathrm{mii}^{23}$. Przedstawiciele „starej” ekonomii instytucjonalnej (m.in. Thorstein Veblen, Herbert A. Simon, a współcześnie także Geoffrey M. Hodgson) odrzucają model racjonalnego homo oeconomicus, uważając nawyki, przyzwyczajenia i rutyny (traktowane w kategoriach nieformalnych instytucji) za czynniki ograniczające wolny wybór, jednocześnie jednak przyczyniające się do budowania trwałych ram społecznych ${ }^{24}$.

Natomiast „nowe” nurty instytucjonalne, w tym przede wszystkim tzw. nowa ekonomia instytucjonalna (NEI), czerpią z fundamentalnych założeń ekonomii neoklasycznej, analizując instytucje przede wszystkim jako czynnik ograniczający zachowania pojedynczych jednostek, uznawanych za podmioty kierujące się przede wszystkim indywidualnym dążeniem do maksymalizacji własnej użyteczności. Tacy przedstawiciele NEI, jak Douglas C. North, Olivier Williamson czy Kenneth J. Arrow podkreślają niezależność wyborów oraz wolność działania jednostki gospodarującej i wskazują, że tę niezależność ograniczają jedynie instytucje $e^{25}$.

22 G. M. Hodgson, Economics and Evolution: Bringing Life Back into Economics, University of Michigan Press, Ann Arbor 1997, s. 253.

23 A. Cumbers, D. MacKinnon, R. McMaster, Institutions, Power and Space. Assessing the Limits to Institutionalism in Economic Geography, „European Urban and Regional Studies" 2003, vol. 10, s. 327.

24 B. Klimczak, Uwagi o powiq̨zaniach między standardową ekonomiq i nowq ekonomiq instytucjonalnq, [w:] S. Rudolf (red.), Nowa ekonomia instytucjonalna. Aspekty teoretyczne i praktyczne, Wyższa Szkoła Ekonomii i Administracji im. prof. Edwarda Lipińskiego w Kielcach, Kielce 2005, s. 15-17.

25 Orędownicy tzw. indywidualizmu metodologicznego w naukach ekonomicznych i społecznych odwołują się do twierdzenia K. Arrowa o niemożności. K. Arrow przeprowadził matematyczny wywód prowadzący do wniosku, że nie jest możliwa konstrukcja społecznej funkcji dobrobytu, co w jego opinii oznacza, iż nie istnieje de facto tzw. optimum społeczne w sensie Pareto (K. Arrow, Social Choice and 
Wśród rozwijających się współcześnie nurtów należy także dostrzegać różnice między tzw. nowym instytucjonalizmem lub neoinstytucjonalizmem (a w jego ramach niektórymi pracami nurtu ekonomii ewolucyjnej, francuskiej szkoły regulacji oraz wielu pochodnymi „starego” instytucjonalizmu w wydaniu amerykańskim) a nową ekonomią instytucjonalną ${ }^{26}$. Po pierwsze, nowy instytucjonalizm wydaje się znacznie bardziej zróżnicowany wewnętrznie pod względem prezentowanych poglądów. Uwzględnia on podejścia teoretyczne wypracowane przez tzw. szkołę austriacką (Fryderyk von Hayek) oraz instytucjonalizm amerykański reprezentowany przez prace Johna Commonsa i Thorsteina Veblena (z których ten ostatni jest postrzegany jako prekursor podejścia ewolucyjnego w naukach ekonomicznych, budowanego na bazie odwołań do psychologii czy biologii). W przeciwieństwie do nowej ekonomii instytucjonalnej, nowy instytucjonalizm mocno nawiązuje do niemieckiej szkoły historycznej oraz kontekstowego definiowania pojęcia instytucji (J. Commons) ${ }^{27}$. Ponadto pozostaje silnie powiązany z socjologią ekonomiczną ${ }^{28}$ i odwołuje się do istotnego znaczenia endogenicznych źródeł innowacji ${ }^{29}$. Innymi słowy, neoinstytucjonalizm nie tylko silniej niż nowa ekonomia instytucjonalna czerpie z tradycji „starego instytucjonalizmu" ${ }^{30}$, lecz także jest silniej wewnętrznie zróżnicowany.

Natomiast nowa ekonomia instytucjonalna wprost odwołuje się do podstawowych założeń charakterystycznych dla ekonomii głównego nurtu. Zakłada istnienie jednostek, które w swych decyzjach kierują się dążeniem do maksymalizacji użyteczności w warunkach ograniczonego

Individual Values, Yale University Press, New Haven 1963; wyd. pierwsze 1951). Używając bardziej obrazowego języka - nie istnieją społeczeństwa, którego członkowie kierują się bliżej nieokreślonym dobrem ogółu. Osiąganie społecznego porozumienia (np. w drodze głosowania) nie jest tym samym procesem dyskursu toczącego się wokół idei społeczeństwa, lecz swoistym targowaniem się, w trakcie którego uczestnicy procesu wypracowują konsensus będący wypadkową ich osobistych dążeń. Podział na zwolenników i przeciwników tego twierdzenia jest zatem podstawowym źródłem różnic między tradycyjnym instytucjonalizmem a nową ekonomią instytucjonalną.

26 F. Moulaert, Institutional Economics and Planning Theory: A Partnership Between Ostriches?, „Planning Theory” 2005, vol. 4, no. 21, s. 21.

27 Zob. także: ibidem, s. 28-30.

28 R. Swedberg, Current Sociology, Sage, London 1987.

29 G. M. Hodgson, Economics and Institutions, Polity Press, Cambridge 1988; F. Moulaert, J. Lambooy, The Economic Organisation of Cities: An Institutional Perspective, „International Journal of Urban and Regional Research" 1966, vol. 20 (2), s. 217-237.

30 Niektórzy autorzy sugerują nawet, że neoinstytucjonalizm jest na tyle bezpośrednią kontynuacją tradycji wywodzącej się z pierwotnego instytucjonalizmu, iż trudno mówić o istotnych różnicach między nimi w tym względzie. 
dostępu do informacji oraz dążenia do redukcji kosztów transakcyjnych. Zatem NEI bada wpływ relacji między jednostkami na kształtowanie instytucji (podejście indywidualistyczne), nie skupiając się na zagadnieniach funkcjonowania instytucji w ujęciu kolektywistycznym ${ }^{31}$ (tab. 5). Wspomniany indywidualizm metodologiczny pozostaje zresztą podstawowym przedmiotem krytyki ze strony przedstawicieli neoinstytucjonalizmu, według których działanie zbiorowe to nie agregat wypranych z kontekstu, racjonalnych działań cząstkowych, lecz zbiór obowiązujących $\mathrm{w}$ danej zbiorowości przekonań ${ }^{32}$.

Tabela 5. „Stara” a nowa ekonomia instytucjonalna

\begin{tabular}{|l|l|}
\hline \multicolumn{1}{|c|}{ „Stara” ekonomia instytucjonalna } & \multicolumn{1}{c|}{ Nowa ekonomia instytucjonalna } \\
\hline $\begin{array}{l}\text { 1. Instytucje powodują, że człowiek nie } \\
\text { może być w pełni homo oeconomicus. } \\
\text { 2. Koncepcja wyrasta z krytyki fundamental- } \\
\begin{array}{l}\text { nych założeń ekonomii neoklasycznej. } \\
\text { 3. Silne powiązania z tzw. neoinstytucjona- } \\
\text { lizmem/nowym instytucjonalizmem }\end{array}\end{array}$ & $\begin{array}{l}\text { 1. Człowiek dąży do racjonalnych zachowań, } \\
\text { ale napotyka na ograniczenia instytucjo- } \\
\text { nalne. }\end{array}$ \\
$\begin{array}{l}\text { 2. Koncepcja ta nie podważa fundamental- } \\
\text { nych założeń ekonomii głównego nurtu, } \\
\text { podkreślając jedynie silną złożoność rze- } \\
\text { czywistych systemów gospodarczych. }\end{array}$ \\
3. Kontynuacja sporu metodologicznego \\
z tzw. neoinstytucjonalizmem/nowym in- \\
stytucjonalizmem.
\end{tabular}

Źródło: opracowanie własne na podstawie: B. Klimczak, Uwagi o powiq̨zaniach między standardowq ekonomiq i nowq ekonomiq instytucjonalna, [w:] S. Rudolf (red.), Nowa Ekonomia Instytucjonalna. Aspekty teoretyczne i praktyczne, Wyższa Szkoła Ekonomii i Administracji im. prof. Edwarda Lipińskiego w Kielcach, Kielce 2005, s. 11-26.

Generalnie ekonomia instytucjonalna zaczyna być coraz częściej traktowana jako gałąź teorii ekonomicznych odrębna od tzw. ekonomii głównego nurtu. Należy jednak zauważyć, że wątki instytucjonalne zaczynają gościć również w tej ostatniej, np. ekonomia eksperymentalna i teoria gier. Jednocześnie, jak wskazuje G. M. Hodgson, mimo wszystko po ekonomii głównego nurtu nie należy spodziewać się radykalnego odwrotu w kierunku instytucji. W tym nurcie, zdaniem Hodgsona, „formalizm przyćmił istotę i nastąpiła fragmentacja ekonomii na osobne techniczne specjalizacje, gdzie nie ma miejsca na głębsze rozważa-

31 Zob. także: F. Moulaert, Institutional Economics..., s. 23.

32 S. Barczyk, Przedsiębiorczy samorzq̨d lokalny i jego instytucje, Wyd. Akademii Ekonomicznej im. Karola Adamieckiego, Katowice 2010, s. 118. 
nia i eksperymenty metodologiczne"33. Stwarza to zagrożenie, że obecne programy studiów ekonomicznych mogą doprowadzić do ukształtowania pokolenia idiot savants - biegłych w kwestiach technicznych, ale niekompetentnych w zakresie realnych kwestii gospodarczych. Choć wyrafinowane modele i techniki są ważne dla pomiaru i oceny procesów gospodarczych, to biorąc pod uwagę złożoność gospodarki światowej, tym, co jest naprawdę potrzebne, jest szersza gama modeli i technik bardziej wyczulonych na zagadnienia historyczne, instytucjonalne, psychologiczne i inne istotne czynniki ${ }^{34}$.

Pomimo zróżnicowania instytucjonalizmu można wskazać istotne cechy wspólne różnych jego nurtów:

1. Założenie, że sfera ekonomii jest uzależniona od sfery instytucji. Każde podejście instytucjonalne odrzuca lub przynajmniej dystansuje się od założenia o doskonałej racjonalności podmiotów gospodarczych, jak również z ostrożnością traktuje postulat o konieczności opisywania każdego zjawiska ekonomicznego jedynie $\mathrm{w}$ ramach formalnych modeli matematycznych.

2. Podejścia instytucjonalne koncentrują się nie tyle na zagadnieniu równowagi, ile na procesie zmiany. W tym kontekście instytucje postrzegane są jako czynnik zapewniający określony poziom stabilności w warunkach zmiennego otoczenia.

3. Same instytucje są także przedmiotem zmiany - każde z podejść instytucjonalnych podejmuje próbę badania uwarunkowań oraz przyczyn ewolucyjnej lub rewolucyjnej transformacji instytucji, stanowiących ramy procesów gospodarczych.

4. Każda ze szkół w ramach ekonomii instytucjonalnej odwołuje się do zagadnienia wyłaniania się nowego porządku instytucjonalnego ${ }^{35}$.

Ekonomia instytucjonalna uwzględnia zatem w istotnym stopniu społeczny kontekst procesów gospodarczych, podkreślając ewolucyjny charakter rozwoju gospodarczego. Tym samym, z jednej strony dystansuje się od nadmiernego upraszczania zjawisk gospodarczych w formule typowej dla ekonomii neoklasycznej, zaś z drugiej - także od marksistowskiego determinizmu i redukcjonizmu ${ }^{36}$.

33 G. M. Hodgson, The Revival of Veblenian Institutional Economics, „Journal of Economic Issues" 2007, vol. XLI, no. 2 (June), s. 328-329.

34 The GFC and University Economics Education, An Open Letter to the Queen, 2009; http://media.wix.com/ugd/b629ee_fdfa30c31db1110443977ca5697b5b47.pdf (dostęp: 13.11.2013).

35 B. Chavance, L'économie..., s. 100-101.

36 A. Cumbers, D. MacKinnon, R. McMaster, Institutions, Power and Space..., s. 325. Z drugiej strony, rozważania podejmowane w dalszej części wskażą jednak, że ekonomii instytucjonalnej nie powinno się traktować jako nurtu przeciwstawnego 
Bez względu na różnorodność poszczególnych nurtów instytucjonalnych, każdy z nich podziela tezę o wpływie instytucji na zachowania aktorów ekonomicznych. Każdy wybór podejmowany przez jednostki jest bowiem ograniczony przez takie czynniki, jak ${ }^{37}$ :

1) wielkość, struktura i jakość posiadanych zasobów (naturalnych, pracy, materialnych, itp.),

2) wiedza (ograniczenia w percepcji wynikające z czynników zewnętrznych, np. ograniczonego dostępu do informacji, a także z cech osobowościowych poszczególnych osób),

3) uwarunkowania instytucjonalne, zarówno będące pochodną, jak i warunkujące ludzkie zachowania.

Wspomniany wcześniej - i wspólny dla różnych szkół w ramach ekonomii instytucjonalnej - dystans do koncepcji racjonalnego człowieka ekonomicznego (homo oeconomicus) ma swoje źródła w upowszechnieniu się w latach 60. XX w. koncepcji ograniczonej racjonalności Herberta A. Simona ${ }^{38}$. Podejście to odrzuca tezę o absolutnej racjonalności działania, jako że wiele podmiotów podejmuje decyzje ekonomicznie nieracjonalne, np. wyciągając wnioski z niekompletnych przesłanek lub też decyzje irracjonalne, płynące z niepoprawnego wnioskowania. Wynika to $\mathrm{z}$ faktu, iż jednostki zwykle silniej oceniają potencjalne straty niż potencjalne zyski ${ }^{39}$, a podejmowane przez nie wybory są często intuicyjne, a nie precyzyjnie skalkulowane. Innymi słowy, racjonalność osądów jest punktem, do którego każda jednostka dąży, jednak pozostaje ograniczona i bazuje na swej intuicji oraz doświadczeniu.

Krytykę nadmiernie upraszczającego rzeczywistość modelu „człowieka ekonomicznego" prezentował już zresztą A. Marshall, uznając go za zbyt abstrakcyjny i odbiegający od rzeczywistości. W to miejsce zaproponował postrzeganie ludzi takimi, jakimi są: człowiekowi ekonomicznemu przeciwstawił obraz człowieka, który w życiu gospodarczym pozostaje

do ekonomii klasycznej i neoklasycznej. Szczególnie analizy podejmowane przez Oliviera Williamsona, identyfikowanego jako czołowego przedstawiciela nowej ekonomii instytucjonalnej dowodzą, że analiza instytucjonalna nie jest koncepcją przeciwną, lecz uzupełniającą w stosunku do analiz podejmowanych w ramach ekonomii głównego nurtu.

37 J. Wilkin, Teoria wyboru publicznego - homo oeconomicus w sferze polityki, [w:] idem (red.), Teoria wyboru publicznego. Wstęp do ekonomicznej analizy funkcjonowania sfery publicznej, Scholar, Warszawa 2005, s. 9.

38 H. A. Simon, A Behavioral Model of Rational Choice, "Quarterly Journal of Economics" 1955, no. 6, s. 99-118.

39 R. Hardin, Collective Action, John Hopkins University Press, Baltimore 1982; D. Kahneman, A. Tversky, Prospect Theory: An Analysis of Decision Under Risk, „Econometrica" 1979 , vol. 47, no. 2, s. 263-291. 
pod wpływem pożądania bogactwa, lecz „nie są mu również obce, z jednej strony, próżność i lekkomyślność, a z drugiej - zadowolenie z dobrze wykonanej pracy oraz zdolność do poświęcania się dla dobra rodziny, bliźnich czy kraju" ${ }^{40}$.

Wychodząc z podobnego co Marshall założenia, H. A. Simon wyróżnił dwa typy racjonalności ${ }^{41}$ :

1. Racjonalność substancjalną (rzeczywistą), która odnosi się do wyniku podjętej decyzji. Decyzja jest racjonalna wówczas, gdy prowadzi do najlepszego możliwego wyniku.

2. Racjonalność proceduralną (kalkulacyjną, intencjonalną), odnoszącą się do sposobu podejmowania decyzji gospodarczej. Za racjonalną uznaje się taką decyzję, która $\mathrm{w}$ danych warunkach i w danym momencie przybliża do najlepszego możliwego wyniku ${ }^{42}$.

W ekonomii klasycznej, opartej na modelu standardowego wyboru, „działanie jest działaniem tylko wtedy, gdy jest celowe (interes własny), gdy jest omniscjentne (kompletna wiedza i informacja) i gdy jest świadome (rozsądne, przemyślane)"*3. Tymczasem w świetle założeń ekonomii instytucjonalnej decyzje ekonomiczne nigdy nie będą w pełni racjonalne, ponieważ każda jednostka ludzka:

1) posługuje się uproszczonym obrazem rzeczywistości,

2) nie jest w stanie dokonać analizy wszystkich dostępnych rozwiązań (funkcjonując w warunkach niepełnego dostępu do informacji),

3) $\mathrm{w}$ procesie podejmowania decyzji stosuje proste heurystyki w miejsce pogłębionych analiz stanu istniejącego.

W konsekwencji decyzje ekonomiczne nie opierają się zazwyczaj na najlepszym możliwym rozwiązaniu, lecz na rozwiązaniu uznanym za najbardziej satysfakcjonujące przez konkretną osobę w konkretnym miejscu i czasie ${ }^{44}$. W związku z tym funkcjonowanie systemów społecznych, po-

40 A. Marshall, Principles of Economics, Macmillan, London 1920, s. 27, [cyt. za:] J. Dzionek-Kozłowska, System ekonomiczno-społeczny Alfreda Marshalla, Wyd. Naukowe PWN, Warszawa 2007, s. 86.

41 H. A. Simon, From Substantive to Procedural Rationality, [w:] C. Latsis (ed.), Method and Appraisal in Economics, Cambridge University Press, Cambridge 1976, s. $129-148$.

42 Warto nadmienić, że z czasem Charles Sabel wyróżnił dodatkowo tzw. racjonalność refleksyjną, uwzględniającą długofalowe skutki podejmowanych decyzji (C. Sabel, Flexible Specialization and the Re-emergence of Regional Economies, [w:] A. Amin (ed.), Post-Fordism: A Reader, Blackwell, Oxford 1994, s. 101-156).

43 S. Rudolf (red.), Nowa ekonomia instytucjonalna. Aspekty..., s. 13.

44 A. Kacprzyk, Wkład psychologii w neoinstytucjonalna modyfikację zasady racjonalności, [w:] S. Rudolf (red.), Nowa ekonomia instytucjonalna. Aspekty..., s. 123125. Historię rozwoju koncepcji ograniczonej racjonalności znaleźć można m.in. 
litycznych, a także gospodarczych nie może być rozpatrywane ani w ujęciu statycznym, ani przy założeniu funkcjonowania homo oeconomicus ${ }^{45}$. Dość powszechnie bowiem w konstruowaniu obrazu rzeczywistości funkcjonują określone typy tendencyjności:

1. Uczestnicy wydarzeń mają skłonność do zawyżania niskiego i zaniżania wysokiego prawdopodobieństwa.

2. Uczestnicy wydarzeń mają skłonność do przypisywania pożądanym wyborom wyższego prawdopodobieństwa niż pozostałym.

3. Uczestnicy wydarzeń postrzegają historię w sposób, który potwierdza ich wcześniejsze przekonania lub przedstawia ich w dobrym świetle.

4. Uczestnicy wydarzeń przypisują korzystne rezultaty rozumności swych działań, a niekorzystne - działaniom innych.

5. Uczestnicy wydarzeń mają skłonność do wyolbrzymiania własnego udziału we wspólnych wynikach.

6. Uczestnicy wydarzeń mają skłonność do preferowania rzeczy osiągalnych.

James G. March oraz Johan P. Olsen dowodzą, iż funkcjonowanie rzeczywistości zależy od dotychczasowych ludzkich przekonań, dostępności do wiedzy, zaufania do poszczególnych osób, z którymi ma się kontakt itd. Obraz rzeczywistości jest zatem zawsze postrzegany przez pryzmat określonego kontekstu instytucjonalnego ${ }^{46}$.

Reasumując, w ramach zachodzących interakcji ekonomicznych zawarcie "doskonałego" kontraktu (precyzyjnie alokującego wzajemne zobowiązania, przewidującego wszelkie odstępstwa i zawartego przy zerowych kosztach transakcyjnych) w rzeczywistości nie może mieć miejsca i taki kontrakt pozostaje przede wszystkim daleko idącym uproszczeniem. W praktyce niemal zawsze występować będą różnego rodzaju niedoskonałości rynkowe, wynikające z zaburzeń w indywidualnej racjonalności oraz występowanie kosztów transakcyjnych ${ }^{47}$. Uwarunkowania te zawsze będą prowadzić do uzależnienia decyzji gospodarczych od czynników instytucjonalnych.

w: B. D. Jones, Bounded Rationality, „Annual Review of Political Science” 1997, vol. 2, s. 297-321.

45 Obrazowo ujął to Raj Patel, który przypisując autorstwo pojęcia homo oeconomicus Johnowi Stuartowi Millowi, stwierdzit, że „wymyślit człowieka, którego nikt dotąd nie widział" (R. Patel, Wartość niczego..., s. 33).

46 J. G. March, J. P. Olsen, Instytucje. Organizacyjne podstawy polityki, Scholar, Warszawa 2005, s. 53-54.

47 R. Cooter, Th. Ulen, Ekonomiczna analiza prawa, C.H. Beck, Warszawa 2009, s. 269-279. 


\section{Pojęcie i typy instytucji}

Pojęcie instytucji definiowanie jest w naukach społecznych i ekonomicznych od niemal dwóch stuleci. Z biegiem czasu obserwuje się przy tym różnorodność wyjaśniania tego pojęcia, co związane jest przede wszystkim z rosnącym zainteresowaniem zagadnieniem instytucji przez coraz większą liczbę różnych nurtów i podejśćc ${ }^{48}$.

W naukach społecznych pojęcie instytucji funkcjonuje od drugiej połowy XIX w., kiedy zostało upowszechnione przez Herberta Spencera na gruncie socjologii. Spencer zdefiniował je jako silnie utrwalone elementy ładu społecznego, stanowiące ogólnie akceptowalne normy zachowań. Instytucjami w szerokim rozumieniu są zatem grupy lub konteksty społeczne, do których należą m.in. rodzina, grupy rówieśnicze, szkoła, media, miejsca pracy ${ }^{49}$, a także zestawy wartości, norm, zasad, związane z charakterystycznym dla ludzkiej działalności obszarem ${ }^{50}$.

Pojęcie instytucji, choć najbardziej upowszechnione na gruncie socjologii, stosowane jest też w naukach prawnych i ekonomii w podobnym, choć nie identycznym znaczeniu. Przykładowo, socjologiczne ujęcie instytucji uznawane jest za szersze w stosunku do wypracowanego na gruncie nauk prawnych. Zakłada ono, iż normy kształtujące zachowania regulują nie tylko prawo (instytucje formalne), lecz także tradycje czy religie (instytucje nieformalne). Jednak zarówno prawoznawstwo, jak i socjologia w pojęciu instytucji akcentują:

- funkcjonowanie grup i zbiorowości społecznych (rodziny, zbiorowości nabywców i sprzedawców, społeczeństw),

- znaczenie norm, reguł i wzorców określających, co należy i czego nie należy czynić w danej grupie,

- regulowanie działań i zachowań ludzkich w celu osiągnięcia ich zbieżności z treścią danej instytucji ${ }^{51}$.

Odwołując się do dorobku nauk socjologicznych, w podobnym duchu instytucje zaczęli definiować przedstawiciele wielu nurtów nauk ekonomicznych. Goeffrey Hodgson przyjmuje, że instytucja to tradycja, zwyczaj i norma (w postaci obyczajów lub prawa), które kształtują i zarazem ograniczają zachowania jednostek. Jego zdaniem, elementy te tworzą pewne wzory, według których winna postępować jednostka należąca do danej instytucji

48 Por. m.in. J. Godłów-Legiędź, Instytucje i koszty transakcji jako podstawowe pojęcie nowej ekonomii instytucjonalnej, [w:] eadem (red.), Instytucje i transformacja, Wyd. Adam Marszałek, Toruń 2009, s. 13-15.

49 A. Giddens, Socjologia, PWN, Warszawa 2007, s. 722.

50 N. Goldman, Wstęp do socjologii, Zysk i S-ka, Poznań 1997, s. 55.

51 B. Klimczak, Uwagi o powiqzaniach..., s. 15-16. 
$(\text { kultury })^{52}$. Szerokie definiowane instytucji jako ustanowionych i dominujących zasad, kształtujących ludzkie zachowania, skłania do uznawania za nie takich systemów i pojęć, jak język (uznawany przez G. M. Hodgsona za jedną z najbardziej podstawowych instytucji społecznych), pieniądz, prawo, system miar i wag, ale także np. sposób zachowania się przy stole czy savoir vivre ${ }^{53}$.

Olivier Williamson, odwołując się do rozważań Johna R. Commonsa, stwierdził natomiast, iż ,instytucje możemy zdefiniować jako społeczne ramy kontroli, wyzwalania oraz ukierunkowania działań indywidualnych"54. Z ekonomicznego punktu widzenia składają się one na tzw. środowisko instytucjonalne, traktowane jako „zbiór fundamentalnych praw politycznych, społecznych oraz zasad prawnych, stanowiących podstawę dla procesów produkcji, wymiany oraz dystrybucji”" ${ }^{55}$.

Według C. Edquista i B. Johnsona instytucje definiowane są jako układ stałych zwyczajów, rutynowych zachowań, wykształconych i powszechnie obowiązujących praktyk oraz praw, które kształtują wzajemne relacje pomiędzy jednostkami, grupami i organizacjami ${ }^{56}$. Tym samym wśród instytucji wymienić można nie tylko te formalne (organizowane przez państwo, stanowiące powszechnie obowiązujące kodeksy postępowania), lecz także wyłonione „spontanicznie”, oparte na normach kulturowych i konwencjach, często uzgadnianych $\mathrm{w}$ drodze interakcji, finalizowanych pisanymi lub niepisanymi umowami gospodarczymi ${ }^{57}$.

Douglas North stwierdził, iż instytucjami są wszelkie formy ograniczeń, jakie stworzył człowiek w celu kształtowania zachowań, mające charakter formalny (reguły i zasady wymyślone przez człowieka, np. normy prawne, których nieprzestrzeganie pociąga sankcje) oraz nieformalny (zwyczajowe wzory zachowań) ${ }^{58}$. Innymi słowy, w ujęciu ekonomicznym instytucje należy postrzegać jako „reguły gry” w gospodarce ${ }^{59}$.

52 G. M. Hodgson, What Are Institutions?, „Journal of Economics Issues” 2006, vol. 40 (1), s. 5.

53 Ibidem, s. 2.

54 O. E. Williamson, Transaction Cost Economics and Organization Theory, [w:] O. E. Williamson (ed.), Organization Theory: From Chester Barnard to the Present and Beyond, Oxford University Press, Oxford 1995, s. 209.

55 O. E. Williamson, Comparative Economic Organization: The Analysis of Discrete Structural Alternatives, „Administrative Science Quarterly” 1991, vol. 36 (2), s. 287.

56 C. Edquist, B. Johnson, Institutions and Organizations in Systems of Innovation, [w:] C. Edquist (ed.), Systems of Innovation: Technologies, Institutions and Organizations, Pinter/Cassell Academic, London-Washington 1997, s. 46.

57 Zob. np.: C. J. Webster, L. W. C. Lai, Property Rights, Planning and Markets. Managing Spontaneous Cities, Edward Elgar, Cheltenham-Northampton 2003, s. 60.

58 D. C. North, The New Institutional Economics, „Journal of Institutional and Theoretical Economics" 1986, no. 142, s. 234.

59 D. C. North, Institutions, Institutional Change and Economic Performance, Cambridge University Press, Cambridge 1997, s. 5. 
Definicja D. C. Northa uznawana jest zresztą za istotny przełom w definiowaniu instytucji. Do czasu jej zaproponowania większość podejść (zwłaszcza na gruncie nauk społecznych) włączała do tego zbioru pojęciowego organizacje jako jeden z typów instytucji. Natomiast North zaproponował odróżnienie organizacji od instytucji w myśl zasady konieczności „odróżnienia reguł gry od graczy”. Teza, że instytucje to „reguły gry” w gospodarce, istotnie odróżnia nową ekonomię instytucjonalną od wcześniejszych podejść instytucjonalnych ${ }^{60}$.

W ostatniej kwestii panuje spór na temat zależności między pojęciami „instytucja” a „organizacja”. Jedno z podejść wskazuje, że organizacje powstają po to, by „realizować instytucje i egzekwować je” ${ }^{61}$, same jednak nie będąc instytucjami. Na poparcie tej tezy wykorzystuje się często interpretację D. Northa, zgodnie z którą

ewolucję instytucjonalną w gospodarce kształtują interakcje zachodzące między instytucjami i organizacjami. Jeśli zatem instytucje są regułami gry, to organizacje, rozumiane jako grupy pojedynczych osób połączonych w celu realizacji wspólnych interesów, pozostają graczami ${ }^{62}$.

Z drugiej strony znajdują się zwolennicy poglądu, że organizacje nie są przeciwieństwem, lecz specjalną odmianą instytucji. Przykładowo, G. M. Hodgson za instytucje uznaje także przedsiębiorstwa i inne typy organizacji. Jego zdaniem,

jeśli instytucje definiowane są jako społecznie zakorzenione systemy zasad, wydaje się oczywiste, że organizacje stanowią ich specyficzny rodzaj, posiadając jednak dodatkowe cechy, tj:

- funkcjonują w oparciu o dodatkowe kryteria umożliwiające ustanowienie granic i rozróżnienie między członkami i nie-członkami organizacji,

- posiadają ustanowione zasady zarządzania pozwalające zidentyfikować stosunki nadrzędności i podrzędności między członkami,

- posiadają łańcuchy decyzyjne, jasno identyfikujące prawa i obowiązki poszczególnych członków ${ }^{63}$.

Nie rozstrzygając opisanego sporu, należy podkreślić, że między organizacjami i instytucjami zachodzą ścisłe związki oraz że pierwsze z tych

60 J. Godłów-Legiędź, Instytucje i koszty transakcji..., s. 15.

61 M. Gancarczyk, Instytucja a organizacja w nowej ekonomii instytucjonalnej, „Gospodarka Narodowa” 2002, nr 5-6, s. 78-94.

62 D. C. North, Economic Performance through Time, „American Economic Review” 1994, vol. 84, no. 3 (June), s. 361.

63 G. M. Hodgson, What Are Institutions..., s. 8. 
pojęć pozostaje niewątpliwie szersze. Pomimo dyskusji na temat dokonywania rozróżnienia na instytucje formalne i nieformalne, trzeba też zauważyć, iż podział ten pozostaje użyteczny z punktu widzenia szerokiego nurtu teoretycznego, jakim jest ekonomia instytucjonalna. Podążając tym tropem rozumowania, w każdym systemie społeczno-ekonomicznym, obok instytucji formalnych, można wskazać takie społecznie akceptowalne struktury i pojęcia, jak własność, pieniądz, wymiana rynkowa czy przedsiębiorstwo (por. tab. 6).

Tabela 6. Pojęcia nawiązujące do koncepcji instytucji

\begin{tabular}{|c|c|}
\hline Pojęcie & Definicja \\
\hline Struktury społeczne & $\begin{array}{l}\text { Wszystkie rodzaje stosunków społecznych, zarówno epizodycz- } \\
\text { nych, jak i opartych na trwałych zasadach (te drugie należy zaliczyć } \\
\text { do grona instytucji społecznych) }\end{array}$ \\
\hline Instytucje & $\begin{array}{l}\text { Ustanowione i silnie zakorzenione reguły określające w sposób } \\
\text { trwały interakcje społeczne }\end{array}$ \\
\hline Reguły & $\begin{array}{l}\text { Utrwalone (zarówno formalnie, jak i zwyczajowo) nakazy lub imma- } \\
\text { nentnie dyspozycje normatywne prowadzące do ogólnie przyjętego } \\
\text { przekonania, że w okolicznościach X należy zrobić Y }\end{array}$ \\
\hline Konwencje & Szczególne przypadki reguł instytucjonalnych \\
\hline Organizacje & $\begin{array}{l}\text { Specyficzne typy instytucji posiadające granice oraz kryteria po- } \\
\text { zwalające na rozróżnienie między członkami i nie-członkami orga- } \\
\text { nizacji, ustanowione wewnętrzne zasady zarządzania oraz cuchy } \\
\text { decyzyjne, jasno identyfikujące prawa i obowiązki członków }\end{array}$ \\
\hline Przyzwyczajenia & $\begin{array}{l}\text { Mechanizm psychologiczny, według którego jednostki nabywają } \\
\text { skłonności do zachowań zgodnych z przyjętymi wcześniej zasa- } \\
\text { dami. }\end{array}$ \\
\hline
\end{tabular}

Źródło: opracowanie własne na podstawie: G. M. Hodgson, What Are Institutions?, „Journal of Economic Issues" 2006, vol. XL, no. 1, s. 17-18.

W ekonomii głównego nurtu mechanizm rynkowej konkurencji rozpatrywany jest jako „dana”, natomiast $\mathrm{z}$ instytucjonalnego punktu widzenia konkurencja czy rynek nie są aksjomatami, lecz właśnie swoistymi instytucjami, rozumianymi jako konsekwencje historycznie ukształtowanych reguł społecznych odwołujących się do wartości, jak np. wolność i odpowiedzialność. Przykładowo, konkurencja doskonała jako forma organizacji rynku (podobnie jak wszelkie inne struktury rynku) stanowi formę relacji społecznych charakterystycznych dla kręgu kultury śród- 
ziemnomorskiej i cywilizacji zachodniej, lecz niewątpliwie nie jest ona jedyną formą tego rodzaju relacji ${ }^{64}$.

Instytucjonalne uwarunkowania procesów gospodarczych powinny być rozważane na różnych poziomach złożoności systemów społecznych. Wyróżnić więc można instytucje rozwijane spontanicznie na skutek interakcji między ludźmi i rodzących się w oparciu o nie relacji społecznych, instytucje kształtowane na drodze formalnych kontraktów zawieranych między indywidualnymi podmiotami prywatnymi i wreszcie instytucje najbardziej sformalizowane, organizowane przez państwo w formie powszechnych regulacji prawnych. Sankcje, z jakimi mogą się spotkać jednostki postępujące niezgodnie z zasadami wynikającymi z uwarunkowań instytucjonalnych będą się różniły w zależności od typu instytucji. W odniesieniu do instytucji o charakterze nieformalnym mogą się one wiązać z brakiem akceptacji ze strony określonej grupy społecznej bądź z utratą nadanych w jej ramach przywilejów, natomiast instytucje posiadające zakorzenienie w systemach prawnych wywierać będą sankcje w postaci jasno sformułowanych kar i grzywien (por. tab. 7).

Tabela 7. Typologia instytucji według poziomu ich sformalizowania

\begin{tabular}{|c|c|c|}
\hline & Typ instytucji & $\begin{array}{c}\text { Sankcje za nieprzestrzeganie } \\
\text { zasad przyjętych w ramach } \\
\text { instytucji }\end{array}$ \\
\hline Spontaniczne & $\begin{array}{l}\text { konwencje; } \\
\text { zasady postępowania; } \\
\text { zwyczaje }\end{array}$ & $\begin{array}{l}\text { ograniczenie interesów } \\
\text { jednostki; } \\
\text { wyrzuty sumienia; } \\
\text { brak akceptacji ze strony grupy }\end{array}$ \\
\hline $\begin{array}{l}\text { Tworzone przez } \\
\text { kontrakty prywatne }\end{array}$ & $\begin{array}{l}\text { porozumienia nieformalne } \\
\text { dotyczące podziału kompetencji } \\
\text { w związku z wykonywaniem } \\
\text { postanowień zawieranych umów; } \\
\text { sformalizowane kodeksy } \\
\text { postępowania }\end{array}$ & $\begin{array}{l}\text { utrata przywilejów w ramach } \\
\text { grupy; } \\
\text { formalne pozbawienie } \\
\text { przywilejów przez grupę }\end{array}$ \\
\hline $\begin{array}{l}\text { Organizowane } \\
\text { przez państwo }\end{array}$ & $\begin{array}{l}\text { publiczne (powszechnie } \\
\text { i prawnie obowiązujące) kodeksy } \\
\text { postępowania }\end{array}$ & $\begin{array}{l}\text { utrata określonych praw (system } \\
\text { kar i grzywien) }\end{array}$ \\
\hline
\end{tabular}

Źródło: C. J. Webster, L. W. C. Lai, Property Rights, Planning and Markets. Managing Spontaneous Cities, Edward Elgar, Cheltenham-Northampton 2003, s. 60.

64 B. Klimczak, Uwagi o powiqzzaniach..., s. 22. 
Klasyfikowanie instytucji z punktu widzenia poziomu ich sformalizowania stwarza przy tym możliwość analizy wzajemnych powiązań między różnymi ich typami ${ }^{65}$. Najbardziej powszechna klasyfikacja została zaproponowana przez O. Williamsona, wyodrębniającego trzy zasadnicze poziomy instytucji (rys. 5). Poziom pierwszy odwołuje się do instytucji nieformalnych (norm, kodów zachowań, kultury, tradycji, obyczajów itp.), powstałych zazwyczaj w drodze spontanicznego rozwoju. Instytucje nieformalne nakładają ograniczenia na instytucje poziomu drugiego, czyli na tzw. otoczenie (środowisko) instytucjonalne, stanowione przez formalne reguły gry (ustrój państwa, akty prawne, wymiar sprawiedliwości, prawo umów, prawo własności). Rzeczywista "gra ekonomiczna" toczy się natomiast na poziomie trzecim, który Williamson nazywa strukturami zarządzania lub instytucjami kierującymi (kontrakty, zarządzanie transakcjami, wykorzystywanie rynków, hybryd, przedsiębiorstw i urzędów). Przedmiotem analizy w ramach ekonomii neoklasycznej są natomiast instytucje poziomu czwartego, które determinują wybory (alokację zasobów w gospodarce). Instytucje wyższych poziomów są obiektem rozważań w ramach innych szkół instytucjonalnych, stąd de facto nie ma sprzeczności w sposobach analizowania instytucji ${ }^{66}$. Innymi słowy, klasyfikację O. E. Williamsona należy traktować jako próbę wykazania, że poszczególne nurty instytucjonalizmu nie wykluczają się, lecz pozostają w stosunku do siebie komplementarne.

W rozważaniach na temat roli i funkcji instytucji w gospodarce nie sposób pominąć wyrażanego przez wielu badaczy przekonania, że instytucje w pewnych warunkach mogą stanowić bariery dla zmian oraz rozwoju gospodarczego. W tym kontekście $\mathrm{w}$ ramach analizy instytucjonalnej prowadzone są studia nad zjawiskiem uzależnienia decyzji gospodarczych od przeszłych doświadczeń, tzw. path-dependency ${ }^{67}$. Zjawisko to może zostać ujęte w świetle tezy, iż ewolucja działalności gospodarczych, technologii czy terytoriów stanowi wypadkową wcześniejszych decyzji ${ }^{68}$.

65 Warto podkreślić, że różne typy instytucji pozostają przedmiotem zainteresowania odmiennych nurtów ekonomii instytucjonalnej.

66 Zob. także: K. Kowalska, Kontraktowanie i koszty transakcyjne w nowej ekonomii instytucjonalnej, „Gospodarka Narodowa” 2005, nr 7-8, s. 50.

67 A. Cumbers, D. MacKinnon, R. McMaster, Institutions, Power and Space..., s. 328.

68 W. B. Arthur, Increasing Returns and Path Dependence in the Economy, Michigan University Press, Michigan 1994. 


\begin{tabular}{|c|c|c|c|}
\hline Teorie & Poziom & $\begin{array}{c}\text { Trwałość } \\
\text { porządku } \\
\text { instytucjonal- }\end{array}$ & Cel istnienia \\
\hline 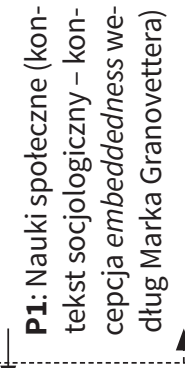 & $\begin{array}{l}\text { Zakorzenienie w relacjach spo- } \\
\text { łecznych; instytucje o charakterze } \\
\text { nieformalnym, zwyczaje, tradycje, } \\
\text { przyjęte normy, poglądy religijne }\end{array}$ & $20-30$ & $\begin{array}{l}\text { Często nieartykułowa- } \\
\text { ny, spontaniczny }\end{array}$ \\
\hline 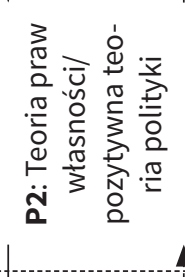 & $\begin{array}{l}\text { Otoczenie instytucjonalne; for- } \\
\text { malne „reguły gry”, w szczególno- } \\
\text { ści te dotyczące ochrony własno- } \\
\text { ści (ustanawiane prze władzę po- } \\
\text { lityczną, sądownictwo, struktury } \\
\text { biurokratyczne w administracji) }\end{array}$ & $10-20$ & $\begin{array}{l}\text { Stworzenie odpowied- } \\
\text { niego porządku instytu- } \\
\text { cjonalnego } \\
\text { Ekonomizacja pierwsze- } \\
\text { go stopnia (first order } \\
\text { economizing) }\end{array}$ \\
\hline 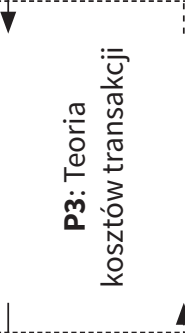 & $\begin{array}{l}\text { Wybór najbardziej efektywnych } \\
\text { struktur zarządzania (govern- } \\
\text { ance); włączenie się do gry we- } \\
\text { dług reguł ustalonych na pozio- } \\
\text { mie 2, w szczególności poprzez } \\
\text { wybór stosownej formy kontraktu } \\
\text { ekonomicznego między graczami }\end{array}$ & $1-10$ & $\begin{array}{l}\text { Ustanowienie najbar- } \\
\text { dziej efektywnych/ } \\
\text { optymalnych struktur } \\
\text { zarządzania } \\
\text { Ekonomizacja drugiego } \\
\text { stopnia (second order } \\
\text { economizing) }\end{array}$ \\
\hline 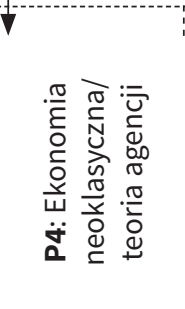 & $\begin{array}{l}\text { Alokacja i wykorzystanie zaso- } \\
\text { bów. Analiza w kategoriach ilości } \\
\text { i ceny czynników produkcji }\end{array}$ & Ciągłość zmian & $\begin{array}{l}\text { Maksymalizacja/ } \\
\text { optymalizacja relacji } \\
\text { krańcowych kosztów do } \\
\text { krańcowych korzyści } \\
\text { Ekonomizacja trzeciego } \\
\text { stopnia (third order eco- } \\
\text { nomizing) }\end{array}$ \\
\hline
\end{tabular}

\section{Charakter zależności:}

Poziom wyższy w sposób znaczący kształtuje ramy dla poziomu niższego

Poziom niższy w sposób zwrotny oddziałuje na poziom wyższy, jednak w mniejszym zakresie. Charakter oddziaływania pośredni i długookresowy

Rys. 5. Poziomy instytucji i ich wzajemne relacje w świetle teorii instytucjonalnych w ujęciu Oliviera E. Williamsona

Źródto: O. E. Williamson, The New Institutional Economics: Taking Stock, Looking Ahead, „Journal of Economic Literature” 2000, vol. XXXVIII (September), s. 597. 
Zagadnienie path-dependency odwołuje się do konieczności analizy wpływu specyficznych grup aktorów, struktur organizacyjnych, systemów technicznych oraz systemów wiedzy, jak również specyficznych uwarunkowań instytucjonalnych czy kulturowych na procesy gospodar$\mathrm{cze}^{69}$. W związku z powyższym, w rozważaniach na temat roli i funkcji instytucji w gospodarce nie sposób pominąć faktu, że w pewnych uwarunkowaniach instytucje mogą również stanowić bariery, np. ograniczając skłonność do ryzyka w procesie wprowadzania innowacji. Zmiany instytucjonalne bywają powolne i pojawiają się zwykle w opóźnieniu w stosunku do zmian technologicznych. Należy zatem mieć świadomość ograniczeń w przyspieszaniu zmian instytucjonalnych oraz istnienia wzorców zachowań odpowiedzialnych za ten stan rzeczy. Instytucje mogą bowiem działać w dwóch kierunkach: zarówno przyspieszać, jak i opóźniać efekty zmian ${ }^{70}$.

\section{Początki orientacji instytucjonalnej w naukach ekonomicznych - „stara” ekonomia instytucjonalna}

Nauki ekonomiczne uwzględniające istnienie instytucji oraz fakt ich wpływu na procesy ekonomiczne nie stanowią jednorodnego nurtu. Różnorodne pod względem podstawowych założeń i metodyki analiz koncepcje zaczęły wyłaniać się $\mathrm{w}$ ekonomii $\mathrm{w}$ drugiej połowie XIX w. w Niemczech (historyzm), jednak szybko nastąpił ich rozwój (choć w nieco innym ujęciu) także w Austrii (tzw. szkoła austriacka). Początek XX w. przyniósł ze sobą dynamiczny rozwój rozważań dotyczących instytucji, podejmowanych przez ekonomistów amerykańskich i to na tym gruncie ekonomiści zaczęli używać powszechnie terminu „instytucjonalizm”.

Do pierwszych dociekań instytucjonalnych w naukach ekonomicznych należy zatem zaliczyć prace Gustava Schmöllera, który zapoczątkował twórczość tzw. niemieckiej szkoły historycznej. W Stanach Zjed-

69 G. Schienstock, Path Dependency and Path Creation in Finland, [w:] P. Jakubowska, A. Kukliński, P. Żuber (eds.), The Future of European Regions, Polish Ministry of Regional Development, Warsaw 2007, s. 170.

70 E. Okoń-Horodyńska, Narodowy system innowacji w Polsce, Wyd. Akademii Ekonomicznej w Katowicach, Katowice 1998, s. 46. 
noczonych do pionierów instytucjonalizmu należeli John R. Commons (m.in. rozpoczął dyskusję nt. rozróżniania pojęć „instytucje” i „organizacje") oraz amerykański ekonomista pochodzenia norweskiego Thorstein Veblen (zaproponował wykorzystanie ewolucjonizmu w analizie instytucjonalnej). Ekonomistą, który w roku 1918 wprowadził pojęcie „ekonomia instytucjonalna” do powszechnego „obiegu” był Walton Hamilton ${ }^{71}$. Pierwsze koncepcje instytucjonalne silnie podkreślały antropologiczne i ewolucyjne korzenie swoich rozważań, a w warstwie metodologicznej odwoływały się do historyzmu ekonomicznego jako sposobu uzasadniania stawianych tez. Swoistym podsumowaniem tego ujęcia była kompleksowa historyczna analiza ewolucji systemu kapitalistycznego od czasów Kongresu Wiedeńskiego do wybuchu I wojny światowej, dokonana we wcześniej wspomnianej, wydanej w 1944 r. Wielkiej transformacji Karla Polanyi. Współczesnym wybitnym kontynuatorem tej myśli pozostaje brytyjski ekonomista Geoffrey M. Hodgson.

Wśród wczesnych nurtów nauk ekonomicznych silnie akcentujących rolę instytucji w procesach ekonomicznych ${ }^{72}$ - poza podejściem historycznym i ewolucyjnym - wymienia się zaliczane do doktryny liberalnej: szkołę austriacką i niemiecki ordoliberalizm, reprezentowane przede wszystkim przez Karla Mengera, Friedricha von Hayeka oraz Waltera Euckena.

Wspomniane nurty mają wiele podobieństw, które odróżniają je od nurtów ekonomii instytucjonalnej upowszechnionych w latach późniejszych. Wśród najważniejszych zbieżności należy wskazać:

- traktowanie instytucji jako spuścizny przeszłości,

- wyróżnianie zarówno formalnego, jak i pozaformalnego wymiaru instytucji,

- założenie, że procesy gospodarcze są zakorzenione w instytucjach ekonomicznych i pozaekonomicznych,

- niejednokrotne przeciwstawianie instytucji rynkowi,

- skupienie się na społecznym wymiarze tworzenia instytucji i przemian instytucjonalnych ${ }^{73}$.

71 Por. B. Chavance, L'économie..., s. 23; W. Stankiewicz, Ekonomika instytucjonalna. Zarys wykładu, Warszawa 2012, s. 14; http://pwsbia.edu.pl/pdf_files/Waclaw_ Stankiewicz_Ekonomika_Instytucjonalna_III.pdf (dostęp: 28.12.2014).

72 W powszechnym obiegu funkcjonuje pojęcie tzw. „starej” ekonomii instytucjonalnej.

73 Ta cecha różnych nurtów tzw. „starego” instytucjonalizmu uważana jest za podstawową różnicę względem nowej ekonomii instytucjonalnej, która w swych analizach kieruje się tzw. indywidualizmem ekonomicznym. Zakłada tym samym, że instytucje powstają jako „agregaty”, będące efektem wyborów indywidualnych, a nie działań zbiorowych, które następnie dla tych wyborów jawią się jako ograniczenia indywidualnych działań (szerzej w podrozdziale 1 rozdziału III). 
Traktowanie instytucji jako spuścizny przeszłości wynika niewątpliwie z genezy instytucjonalizmu, który czerpie swoje początki od niemieckich przedstawicieli tzw. historyzmu w ekonomii. Historyzm niemiecki analizował zagadnienie gospodarowania z punktu widzenia uniwersalistycznego i społecznego. Przede wszystkim przeciwstawiał się pod tym względem indywidualizmowi poznawczemu angielskiej i francuskiej szkoły klasycznej. Oderwanie rozważań ekonomicznych od konkretnego miejsca i czasu było - zgodnie z historyzmem - niewskazane. Pod tym względem kierunek ten wypełniał zresztą pewną lukę metodologiczną, postulując i przeprowadzając historyczne badania życia gospodarczego. Zasługą ekonomii historycznej było zatem to, że pozwalała zrozumieć, iż znajomość rozwoju dziejowego gospodarki przyczyni się do właściwej oceny teraźniejszości ${ }^{74}$ (tab. 8).

Tabela 8. Założenia niemieckiego historyzmu na tle sporu pomiędzy przedstawicielami niemieckiej szkoły historycznej z austriackimi przedstawicielami ekonomii klasycznej

\begin{tabular}{|l|l|l|}
\hline \multicolumn{1}{|c|}{ Kryteria } & \multicolumn{1}{|c|}{ Historycyzm } & \multicolumn{1}{c|}{ Marginalizm } \\
\hline $\begin{array}{l}\text { 1. Natura praw } \\
\text { ekonomicznych }\end{array}$ & $\begin{array}{l}\text { są relatywne, zależą od } \\
\text { kontekstu czasu i przestrzeni }\end{array}$ & są uniwersalne \\
\hline 2. Metody analizy & $\begin{array}{l}\text { oparte na faktach; } \\
\text { nieunikające kontekstu; } \\
\text { idiograficzne; } \\
\text { rozumowanie indukcyjne }\end{array}$ & $\begin{array}{l}\text { oparte na modelach; } \\
\text { uniwersalne } \\
\text { nomotetyczne; } \\
\text { rozumowanie dedukcyjne }\end{array}$ \\
\hline 3. Postrzeganie człowieka & człowiek „społeczny” & homo oeconomicus \\
\hline
\end{tabular}

Źródło: opracowanie własne na podstawie: J. Dzionek-Kozłowska, System ekonomiczno-spoteczny Alfreda Marshalla, Wyd. Naukowe PWN, Warszawa 2007, s. 58-60.

Tym samym niemiecka szkoła historyczna wniosła istotny wkład w instytucjonalizm. Jej kluczowi reprezentanci (m.in. Gustav Schmöller, Adam H. Müller, Adolf H. Wagner, a także Max Weber) jako pierwsi podkreślili, iż ważną cechą instytucji jest ich relatywna inercja w stosunku do ewoluujących struktur społecznych, co z kolei warunkuje efektywność systemów ekonomicznych.

Jako swoista reakcja przeciw przesadnemu rozwojowi ekonomii neoklasycznej, w początkach XX w. wyłoniła się amerykańska odmiana historyzmu. Instytucjonalizm amerykański hołdował przy tym subtelnym

74 G. B. Spychalski, Zarys historii myśli ekonomicznej, PWN, Warszawa-Łódź 2002, s. $177-178$. 
rozważaniom psychologicznym o motywach działania człowieka-jednostki oraz występował przeciw zaniedbaniu przez myśl neoklasyczną zagadnień społecznych warunków gospodarowania, szczególnie intensywnie i szybko zmieniających się w owym czasie w Ameryce ${ }^{75}$.

Cechą charakterystyczną amerykańskiego instytucjonalizmu pozostaje podejście ewolucyjne, rozpropagowane szczególnie szeroko przez Th. Veblena, gdzie podstawą funkcjonowania instytucji są konkretne cechy ludzkie, rozpatrywane na dwóch poziomach. Pierwszy poziom reprezentują instynkty, które można podzielić na instynkty przynoszące korzyść grupie (idea dobrej roboty, instynkt rodzicielski, duch grupy, poczucie bycia członkiem wspólnoty, bezinteresowność itd.) oraz instynkty zagrażające grupie (instynkt przetrwania, dążenie do współzawodnictwa, egoizm). Poziom drugi to ukształtowane historycznie zwyczaje, mające swój kontekst społeczny i kulturowy ${ }^{76}$. Instytucje obydwu poziomów grają rolę ambiwalentną $-\mathrm{z}$ jednej strony stymulują, a $\mathrm{z}$ drugiej ograniczają rozwój społeczno-gospodarczy ${ }^{77}$.

Co istotne, Veblen wierzył, iż darwinowskie mechanizmy różnorodności, dziedziczenia i selekcji ${ }^{78}$ dotyczą nie tylko świata natury, lecz także procesów społecznych, a sam darwinizm to koncepcja zarówno ewolucji organizmów, jak i struktur społecznych - i jako taki może być wykorzystywany do analizy instytucjonalnej. Różnorodność Veblen interpretował przy tym przez pryzmat zróżnicowania jednostek ludzkich i struktur społecznych jako istotny warunek rozwoju gospodarczego, a istnienia mechanizmu selekcji w społeczeństwie dowodził poprzez fakt, że największą trwałość zapewniają siebie instytucje najsilniejsze i najbardziej powszechnie akceptowalne ${ }^{79}$. W odniesieniu do mechanizmu dziedziczenia, w powszechnych zwyczajach i instytucjach widział natomiast źródło względnej stabilności i ciągłości w czasie struktur oraz procesów społeczno-ekonomicznych ${ }^{80}$. W Teorii klasy próżniaczej autor ten podkreślał, że

75 Ibidem, s. 187.

76 B. Chavance, L'économie..., s. 17.

77 Według Th. Veblena człowiek nie powinien być nazywany istotą rozumną, ale istotą kierującą się zwyczajami. To założenie stało się zresztą podstawą krytyki uproszczonej analizy ludzkiej motywacji, prezentowanej zarówno na gruncie ekonomii neoklasycznej, jak i marksizmu (G. M. Hodgson, Toward an Evolutionary and Moral Science. Remarks upon Receipt of the Veblen-Commons Award, „Journal of Economic Issues" 2012, vol. 46, no. 2, s. 267.

78 Głównie założenia ekonomii ewolucyjnej są przedmiotem opisu w podrozdziale 2.2 rozdziału III.

79 G. M. Hodgson, How Veblen Generalized Darwinism, „Journal of Economic Issues” 2008, vol. XLII, no. 2 (June), s. 401-402.

80 Th. B. Veblen, Why is Economics Not an Evolutionary Science?, „Quarterly Journal of Economics" 1898, vol. 12, no. 3 (July), s. 390-393. 
w pewnym sensie instytucje stanowią produkty minionych czasów, które silnie oddziałują na teraźniejszość, ale też nigdy w nie będą w pełni zgodne $\mathrm{z}$ wymogami współczesności ${ }^{81}$. Stanowią one jednak gwarancję trwałości wobec zmienności innych procesów gospodarczych.

Kluczowa wartość veblenowskiego ujęcia instytucjonalizmu wynika z akcentowania mechanizmu przemiany (ewolucyjna przyczynowość) nie tylko jednostek, lecz także grup społecznych ${ }^{82}$. Tym samym wkład podejścia ewolucyjnego do ekonomii dotyczy przede wszystkim wykorzystania darwinowskiego aparatu poznawczego do badania genezy, wzrostu, trwałości oraz zmian instytucji jako trwałych ram procesów społeczno-gospodarczych ${ }^{83}$.

Według G. M. Hodgsona udział Th. Veblena w rozwoju ekonomii instytucjonalnej - choć często niedoceniany - z perspektywy czasu należy uznać za bardzo istotny. Uzupełnia on bowiem lukę pomiędzy klasycznym podejściem do analizy ekonomicznej, abstrahującym od złożoności środowiska instytucjonalnego w procesie podejmowania decyzji, a podejściami, na gruncie których podejmowane są próby rygorystycznych metodologicznie analiz złożonych procesów decyzyjnych (por. rys. 6).

\begin{tabular}{|c|c|c|c|}
\hline \multirow[b]{2}{*}{$\begin{array}{r}\text { duży/duża } \\
\text { zakres wiedzy na temat } \\
\text { złożoności procesów } \\
\text { decyzyjnych/zdolność } \\
\text { do deliberatywnego } \\
\text { podejmowania decyzji }\end{array}$} & \multirow[b]{2}{*}{ 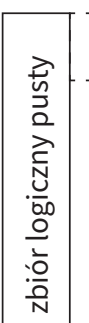 } & domena teorii gier & $\begin{array}{r}\text { modele racjonalnych } \\
\text { oczekiwań }\end{array}$ \\
\hline & & \multicolumn{2}{|c|}{$\begin{array}{l}\text { veblenowska domena ograniczonej } \\
\text { racjonalności, zwyczajów, zasad, } \\
\text { algorytmów behawioralnych }\end{array}$} \\
\hline \multirow[t]{2}{*}{ brak wiedzy/ zdolności } & monopol & $\begin{array}{l}\text { konkurencja niedoskonała } \\
\text { bez interakcji strategicznych }\end{array}$ & $\begin{array}{r}\text { konkurencja } \\
\text { doskonała }\end{array}$ \\
\hline & jedna & & wiele \\
\hline
\end{tabular}

Rys. 6. Miejsce veblenowskiej ekonomii instytucjonalnej na mapie innych koncepcji ekonomicznych

Źródto: G. M. Hodgson, The Revival of Veblenian Institutional Economics, „Journal of Economic Issues" 2007, vol. XLI, no. 2 (June), s. 334.

81 Th. B. Veblen, The Theory of the Leisure Class: An Economic Study in the Evolution of Institutions, Macmillan, New York 1899, s. 191, [cyt. za:] G. M. Hodgson, How Veblen..., s. 402.

82 G. M. Hodgson, Darwinism and Institutional Economics, „Journal of Economic Issues" 2003, vol. 37, no. 1, s. 86-90.

83 Th. B. Veblen, Gustav Schmoller's Economics, "Quarterly Journal of Economics” 1901, vol. 16 (1), s. 81. 
Nawyki, przyzwyczajenia i rutyny, spowodowane przez oddziaływanie instytucji ograniczają wolne wybory jednostek, a samo funkcjonowanie instytucji to wzajemne przenikanie się ich wymiaru tzw. formalnego i nieformalnego. Przyznanie prymatu któremukolwiek z nich zaburza równowagę, prowadząc albo do chaosu, albo do nieefektywności wynikającej z nadmiernych regulacji. Dlatego w ujęciu „starej” ekonomii instytucjonalnej instytucje bywają niejednokrotnie przeciwstawiane rynkowi, gdzie rynek pozwala na maksymalizowanie użyteczności pojedynczych jednostek, podczas gdy sprawne instytucje są podstawowym warunkiem osiągania tzw. równowagi społecznej (optimum społecznego).

Kolejny, obok Th. Veblena, ważny przedstawiciel amerykańskiego instytucjonalizmu to John Rogers Commons. Kontestując tradycje ekonomii klasycznej, dość dobitnie akcentował znaczenie otoczenia instytucjonalnego dla gospodarki, twierdząc, że nie tyle rynek, ile sprawne instytucje są podstawowym warunkiem osiągania równowagi ${ }^{84}$.

J. R. Commons wskazywał ponadto, że dla rozwoju kapitalizmu istotne są organizacje, czyli jako jeden z pierwszych ekonomistów zwrócił uwagę na rozbieżności pojęciowe między terminem „instytucje” a „organizacje”. Te ostatnie uznał za byty, które w społeczeństwie rozwiniętym są bardzo liczne (bowiem jeden człowiek może należeć do wielu organizacji) i długowieczne (trwają dłużej niż czas życia pojedynczego człowieka). Za najważniejszą organizację nowoczesnej gospodarki Commons uznał przy tym państwo, jako podmiot najbardziej odpowiedzialny za kształtowanie ładu instytucjonalnego. Zwrócił też uwagę na fakt, iż instytucje gospodarcze kształtowane są na tle różnorodnych transakcji zachodzących między członkami społeczeństwa. Wprowadził podział na transakcje rynkowe, zarządcze (odbywające się $\mathrm{w}$ ramach przedsiębiorstwa) oraz redystrybucyjne, organizowane przez państwo ${ }^{85}$. Każdy z tych typów transakcji charakteryzuje inny cel, wzajemna pozycja jednostek biorących udział w transakcji oraz sposób monitorowania ich skuteczności.

Wydaje się więc, że najbardziej istotnym wkładem Commonsa w ekonomię instytucjonalną było przede wszystkim uzasadnienie funkcjonowania różnych typów instytucji (prostych i złożonych, prywatnych i publicznych) jako warunku istnienia gospodarki rynkowej oraz interpretowanie złożonych relacji społecznych i gospodarczych w kategoriach transakcji (co zostało potem rozwinięte w ramach tzw. ekonomiki kosztów transakcyjnych i innych nurtów nowej ekonomii instytucjonalnej). Ponadto uznaje się, że Commons wyposażył instytucjonalizm w podbudowę teoretyczną dającą się operacjonalizować na tyle, aby móc wyko-

84 B. Chavance, L'économie..., s. 28-30.

85 Ibidem, s. 34. 
rzystać ją w polityce gospodarczej i związanej z nią legislacją ${ }^{86}$. Wkład ten wydaje się szczególnie cenny w obliczu często podnoszonego wobec ekonomii instytucjonalnej zarzutu o trudności jej operacjonalizacji na potrzeby praktyki gospodarczej.

$\mathrm{W}$ podejściu Commonsa uwydatnia się szczególnie wiara $\mathrm{w}$ to, że instytucje mają swą własną logikę (nie pozostają jedynie sumą intencji jednostek) i że w kształtowaniu otoczenia instytucjonalnego kluczowe są instytucje formalne, w tym prawo. Innymi słowy, John R. Commons nie uznawał prawa za epifenomen relacji społecznych, lecz twierdził, iż regulacje prawne jako element otoczenia instytucjonalnego mają zdolność i obowiązek zmieniania rzeczywistości w kierunku bardziej pożądanych struktur $^{87}$ (tab. 9).

Tabela 9. Typy transakcji w ujęciu J. R. Commonsa i ich charakter

\begin{tabular}{|c|c|c|c|}
\hline Transakcje & Rynkowe & $\begin{array}{c}\text { W ramach } \\
\text { przedsiębiorstwa }\end{array}$ & Redystrybucyjne \\
\hline Pozycja jednostek & $\begin{array}{l}\text { równość z prawnego } \\
\text { punktu widzenia }\end{array}$ & $\begin{array}{l}\text { relacje nadrzędności } \\
\text { i podrzędności }\end{array}$ & $\begin{array}{l}\text { relacje nadrzędności } \\
\text { i podrzędności }\end{array}$ \\
\hline $\begin{array}{l}\text { Charakter negocjacji } \\
\text { i dyskursu }\end{array}$ & $\begin{array}{l}\text { negocjowanie na } \\
\text { równych zasadach } \\
\text { lub w warunkach } \\
\text { nierównej sity prze- } \\
\text { targowej kontrahen- } \\
\text { tów }\end{array}$ & $\begin{array}{l}\text { polecenia i posłu- } \\
\text { szeństwo wobec } \\
\text { podmiotu nadrzęd- } \\
\text { nego }\end{array}$ & $\begin{array}{l}\text { dyskurs prowadzony } \\
\text { w oparciu o ścisłe } \\
\text { procedury (postępo- } \\
\text { wanie administra- } \\
\text { cyjne, cywilne, karne } \\
\text { itd.) }\end{array}$ \\
\hline Podstawowa zasada & rzadkość & efektywność & bezstronność \\
\hline $\begin{array}{l}\text { Charakter pryncy- } \\
\text { pała }\end{array}$ & $\begin{array}{l}\text { brak podziału na } \\
\text { agenta i pryncypała }\end{array}$ & $\begin{array}{l}\text { konkretna osoba } \\
\text { lub struktura hierar- } \\
\text { chiczna }\end{array}$ & władza zbiorowa \\
\hline Cel transakcji & $\begin{array}{l}\text { transfer praw wła- } \\
\text { sności (zobowiąza- } \\
\text { nia i płatności) }\end{array}$ & tworzenie bogactwa & $\begin{array}{l}\text { redystrybucja korzy- } \\
\text { ści i kosztów przed- } \\
\text { sięwzięć publicznych }\end{array}$ \\
\hline $\begin{array}{l}\text { Sposób pomiaru } \\
\text { przyszłych korzyści } \\
\text { z zaangażowania się } \\
\text { w dany typ transakcji }\end{array}$ & cena, ilość towaru & nakłady vs. wyniki & $\begin{array}{l}\text { budżet, podatki, } \\
\text { usztywnienie cen, } \\
\text { usztywnienie płac }\end{array}$ \\
\hline
\end{tabular}

Źródto: J. R. Commons, K. H. Parsons, S. Perlman, The Economics of Collective Action, University of Wisconsin Press, Madison 1950, s. 107.

86 G. M. Hodgson, John R. Commons and the Foundations of Institutional Economics, „Journal of Economic Issues” 2003, vol. 37, no. 3, s. 546.

87 Ibidem, s. 570. 
Wątek historycznego kształtowania instytucji oraz ich znaczenia dla rozwoju gospodarczego podniósł również K. Polanyi. Choć był on historykiem i antropologiem, zasadnicze tezy jego pracy Wielka transformacja są zbieżne z instytucjonalizmem. Na podstawie analizy przemian gospodarki kapitalistycznej w Europie od roku 1815 do 1914 autor ten potwierdził, że gospodarka jest zakorzeniona w instytucjach ekonomicznych i pozaekonomicznych oraz że utopijna wizja, według której rynek jest najlepszym regulatorem rzeczywistości, jest niebezpieczna ${ }^{88}$. We wspomnianym okresie do rozwoju gospodarki kapitalistycznej doprowadziły przede wszystkim nie tyle zachowania pojedynczych ludzi dążących do maksymalizacji swej użyteczności, ile takie obiektywne czynniki, jak: równowaga polityczna mocarstw i sił ukształtowana po Kongresie Wiedeńskim, ustanowienie w handlu międzynarodowym systemu waluty złotej oraz rozwój koncepcji liberalnego państwa-minimum w polityce ekonomicznej. Czwarty z kluczowych czynników - upowszechnienie się mechanizmu wolnorynkowego - był według K. Polanyi czynnikiem ważnym, ale nie jedynym ${ }^{89}$.

Kontekst historyczny rozwoju gospodarczego ma zatem istotne znaczenie, a rynek nie jest wyłącznym sposobem regulowania procesów gospodarczych. Co więcej, kapitalistyczna gospodarka wolnorynkowa nie rozwinęłaby się w XIX w. w Europie, gdyby nie została wyposażona w odpowiednio funkcjonujące instytucje ekonomiczne, polityczne i społeczne. Karl Polanyi wyróżnił też trzy formy wymiany dóbr: wymianę odwzajemnioną (zwykle niepieniężną), wymianę redystrybucyjną (organizowaną przez instytucje publiczne) oraz wymianę rynkową. Zdaniem Polanyi każda $\mathrm{z}$ nich towarzyszy następującym po sobie etapom rozwoju społeczno-gospodarczego, a fakt, że w fazie kapitalizmu dominuje trzecia, zależy od szeregu historycznie ukształtowanych czynników instytucjonalnych.

Przywykliśmy sądzić, że podstawową formą wymiany jest wymiana rynkowa regulowana prawem popytu i podaży, oparta na pieniądzu, której celem jest maksymalizacja zysku przy użyciu dostępnych (legalnych) środków. A jednak wymiana w naszym własnym społeczeństwie i w innych społeczeństwach służy nie tylko maksymalizacji zysku, ale wielu innym ważnym celom: prowadzi do integracji społecznej, pozwala zdobywać władzę i prestiż społeczny, kontrolować poczynania innych. Tak naprawdę industrializacja i rozwój kapitalizmu przyczyniły się w pewnym sensie do ograniczenia i ujednolicenia systemów wymiany dóbr ${ }^{90}$.

88 K. Polanyi, L'économie comme procesus institutionnalisé, [w:] K. Polanyi, C. Arensberg, K. Pearson, Les systèmes économiques dans l'histoire et la théorie (oryg.: Trade and Market in the Early Empires), Larousse, Paris 1957, s. 249.

89 K. Polanyi, The Great Transformation..., s. 3.

90 Ibidem, s. 33. 
Za bliskie, a często wprost przypisywane nurtowi „starego" instytucjonalizmu, uznaje się koncepcje wypracowane na gruncie tzw. szkoły austriackiej oraz niemieckiego ordoliberalizmu. Nurty te jednak, w przeciwieństwie do instytucjonalizmu mającego swe korzenie w historyzmie, nie tylko nie podchodzą krytycznie do idei wolnego rynku, lecz uważają wolny rynek za najdoskonalszą formę regulowania procesów gospodarczych. Natomiast podobnie jak ujęcie historyczne nadają istotne znaczenie uwarunkowaniom instytucjonalnym. Ponadto, szkołę austriacką i ordoliberalizm zbliża do historycyzmu podejście metodologiczne, również oparte na dystansie wobec koncepcji homo oeconomicus oraz doskonałej racjonalności. Według przedstawicieli tych szkół formalizm metodologiczny prowadzi do nadmiernego uproszczenia rzeczywistości i przez to nie potrafi jej dobrze wyjaśnić. Ambicja współczesnej ekonomii, żeby tworzyć matematyczne modele pozwalające na ilościowe prognozy (w tym np. współczesne instrumenty finansowe, które doprowadziły do kryzysu), jest przejawem postawy, którą F. A. von Hayek jako czołowy przedstawiciel szkoły austriackiej określał mianem niebezpiecznej inżynierii społecznej ${ }^{91}$.

Za twórcę szkoły austriackiej uznawany jest austriacki ekonomista Carl Menger, którego wkład w myśl ekonomiczną ceni się przede wszystkim za rozwój koncepcji użyteczności krańcowej oraz rozwój prakseologii jako metody sprawnego działania. $Z$ punktu widzenia instytucjonalizmu należy natomiast wyróżnić wprowadzony przez niego podział (który przez samego autora nie był jednak nigdy traktowany jako dychotomiczny) na tworzone oddolnie instytucje pragmatyczne oraz instytucje organiczne, takie jak pieniądz, język, pismo, rynki, państwo $)^{92}$.

Kontynuatorami myśli C. Mengera byli dwaj wiedeńczycy - Eugen von Böhm-Bawerk i Friedrich von Wieser. Ich myśl, oparta na założeniu liberalizmu gospodarczego oraz indywidualizmie poznawczym, była później kontynuowana przez Fryderyka Augusta von Hayeka - najbardziej uznanego przedstawiciela tzw. nowej szkoły austriackiej. Odwołując się $\mathrm{z}$ jednej strony do liberalizmu A. Smitha ${ }^{93}$, $\mathrm{z}$ drugiej zaś do tez C. Mengera, von Hayek wprowadził podział na tzw. porządki i reguły, dzielone odpowiednio na spontaniczne i zorganizowane ${ }^{94}$. Pierwszy typ porządku

91 J. Godłów-Legiędź, Spory metodologiczne w ekonomii z perspektywy kryzysu finansowego, [w:] S. Rudolf (red.), Nowa ekonomia instytucjonalna wobec kryzysu gospodarczego, Wyższa Szkoła Ekonomii i Administracji im. prof. Edwarda Lipińskiego w Kielcach, Kielce 2012, s. 52.

92 B. Chavance, L'économie..., s. 43-46.

93 Prace F. A. Von Hayeka były inspiracją dla późniejszego rozwoju myśli neoliberalnej drugiej połowy XX w.

94 F. A. von Hayek, Law, Legislation and Liberty, vol. 1: Rules and Order, University of Chicago Press, Chicago 1973. 
jest prosty, ma konkretny cel i reguły funkcjonowania. Porządek spontaniczny natomiast jest złożony, abstrakcyjny i nie posiada wprost określonych reguł działania ${ }^{95}$ (tab. 10).

Tabela 10. Dwa typy porządku i reguł według Friedricha A. von Hayeka

\begin{tabular}{|c|c|}
\hline $\begin{array}{l}\text { Porządek zorganizowany } \\
\text { (taxis) }\end{array}$ & $\begin{array}{l}\text { Porządek spontaniczny } \\
\text { (kosmos) }\end{array}$ \\
\hline $\begin{array}{l}\text { stworzony, egzogeniczny, uporządkowany, } \\
\text { zorganizowany; } \\
\text { prosty; } \\
\text { ukierunkowany, posiadający organizatora; } \\
\text { posiada cel istnienia; } \\
\text { posiada podmioty koordynujące } \\
\text { i kontrolujące; } \\
\text { zarządzany przez dyrektywy i jasno } \\
\text { określone reguły; } \\
\text { konkretny }\end{array}$ & $\begin{array}{l}\text { powstający w sposób ewolucyjny, } \\
\text { endogeniczny, dojrzewający w czasie; } \\
\text { złożony; } \\
\text { pozbawiony ukierunkowania i organizatora; } \\
\text { pozbawiony konkretnego celu istnienia; } \\
\text { koordynacja nieplanowana, } \\
\text { nieuświadomiona; } \\
\text { funkcjonujący w oparciu o reguły } \\
\text { spontaniczne; } \\
\text { abstrakcyjny }\end{array}$ \\
\hline $\begin{array}{l}\text { Reguty w organizacji } \\
\text { (thesis) }\end{array}$ & $\begin{array}{l}\text { Reguły rządzące porządkiem spontanicznym } \\
\qquad \text { (nomos) }\end{array}$ \\
\hline $\begin{array}{l}\text { jasno i ostatecznie zapisane lub } \\
\text { zwerbalizowane; } \\
\text { konkretne; } \\
\text { tworzone w oparciu o negocjacje i dyskurs; } \\
\text { różne dla różnych członków organizacji; } \\
\text { o charakterze nakazowym }\end{array}$ & $\begin{array}{l}\text { niezapisane i niezwerbalizowane; } \\
\text { abstrakcyjne; } \\
\text { tworzone spontanicznie, często } \\
\text { podświadomie; } \\
\text { identyczne dla wszystkich; } \\
\text { o charakterze zakazowym }\end{array}$ \\
\hline
\end{tabular}

Źródło: B. Chavance, L'économie institutionelle, Editions La Découverte, Paris 2007, s. 50, na podstawie: F. A. von Hayek, Droit, législation et liberté, vol. 1: Règles et ordres, Presses Universitaires de France, Paris 1973.

Porządek zorganizowany ma jasno określony cel, opiera się na jasno zdefiniowanych i zapisanych regułach oraz posiada podmioty kontrolujące jego postrzeganie. Oparty jest zatem na zapisanych lub zwerbalizowanych zasadach, mających charakter nakazowy. Jego przeciwieństwem jest porządek spontaniczny, zbudowany na regułach tworzonych często nieświadomie, w wyniku przekształceń ludzkich przekonań i przyzwyczajeń. Ten typ porządku powstaje w sposób ewolucyjny i zmienia się w czasie. Pozbawiony jest ukierunkowania i organizatora, a jego koordynacja pozostaje niezaplanowana i niewyrażona explicite.

95 B. Chavance, L'économie..., s. 48. 
F. A. von Hayek stawia przy tym tezę, że z obu typów porządków (instytucji), które mają wpływ na gospodarkę, właśnie porządek spontaniczny w większym stopniu przyczynia się do jej efektywnego funkcjonowania. $\mathrm{W}$ tym kontekście uznał on m.in. wyższość angloamerykańskiego systemu common law nad europejskim systemem kontynentalnym (skodyfikowanym, biurokratycznym) i jednocześnie pozostał zagorzałym przeciwnikiem socjalizmu, który w jego opinii dążył do wprowadzenia jedynie pierwszego rodzaju porządku. Zdaniem von Hayeka w realnej gospodarce rozproszenie informacji jest na tyle duże, iż systemem społeczno-gospodarczym nie da się sterować odgórnie. Ponieważ kapitalizm w wydaniu liberalnym odwołuje się przede wszystkim do porządku drugiego rodzaju, opartego na bardziej elastycznych i ewoluujących regułach, spontanicznie kształtowany system instytucjonalny jest systemem doskonalszym ${ }^{96}$.

Według von Hayeka państwo nie jest w stanie zastąpić rynku jako mechanizmu alokacji, ponieważ nie może dysponować niezbędnym zasobem informacji. Zawsze bowiem informacje są rozproszone pośród olbrzymiej liczby jednostek. Tym samym to rynek stanowi najbardziej skuteczny mechanizm porządkowania informacji oraz podejmowania na ich podstawie działań przez poszczególne jednostki gospodarcze. Natomiast główne zadanie rządu (instytucji formalnych, odpowiedzialnych za porządek zorganizowany) stanowi obowiązek odpowiedniego doskonalenia przepisów prawnych w celu stworzenia właściwych ram i warunków sprawnego funkcjonowania systemu konkurencji97.

Ważnym wkładem szkoły austriackiej w myśl ekonomiczną, przypisywanym Ludwigowi von Misesowi, był rozwój jej heterodoksyjnej metodologii badawczej. Von Mises wskazywał w tym zakresie przede wszystkim na konieczność stosowania prakseologii jako metody nauki ekonomii ${ }^{98}$, która powinna być wykorzystywana $\mathrm{w}$ analizie ludzkiego

96 W tym ujęciu F. A. von Hayek pozostawał również krytykiem nurtów nienegujących gospodarki rynkowej, takich jak keynesizm czy monetaryzm. Nurty te zakładają bowiem możliwość oddziaływania przez państwo (politykę ekonomiczną) na wybrane procesy ekonomiczne (w przypadku keynesizmu - na poziom inwestycji, w przypadku monetaryzmu - na ilość pieniądza w obrocie). Hayek natomiast twierdzit, ze żadna forma interwencjonizmu, a także żadna forma matematycznego modelowania kierunków rozwoju procesów gospodarczych (w szczególności w skali makro) nie jest w stanie przewidzieć rzeczywistych ludzkich zachowań.

97 G. B. Spychalski, Zarys historii..., s. 337.

98 W ogólnym ujęciu prakseologia (práxis - działanie, lógos - słowo, nauka) definiowana jest jako teoria sprawnego działania. Terminu tego po raz pierwszy użyt w 1890 r. Alfred Espinas, Les origines de la technologie, „Revue Philosophique”, vol. XV, nr XXX, s. 114-115. Uznawana jest za dziedzinę badań naukowych dotyczących wszelkiego celowego działania ludzkiego, zwłaszcza racjonalności, skuteczności i efektywności jego metod (Encyklopedia PWN; http://encyklopedia.pwn.pl/ 
działania (interpretowanego przez takie podstawowe kategorie, jak cele, środki, hierarchia wartości, czas oraz niepewność), propagując przy tym indywidualizm metodologiczny ${ }^{99}$. „Właściwe podejście do problemów ekonomicznych musi rozpoczynać się od badania aktów wyboru; ekonomia staje się częścią - jak dotąd najbardziej rozwiniętą - uniwersalnej nauki, jaką jest prakseologia" ${ }^{100}$.

Należy podkreślić, że dorobek szkoły austriackiej jest w znacznym stopniu rozwijany w ramach nowej ekonomii instytucjonalnej. Podobieństw należy doszukiwać się przede wszystkim w podobnym podziale „porządków” instytucjonalnych ${ }^{101}$, podzielanej świadomości wpływu kosztów funkcjonowania mechanizmu rynkowego oraz kosztów funkcjonowania organizacji gospodarczych na efektywność ekonomiczną (por. koszty transakcyjne), akceptacji istotnego znaczenia wpływu bodźców na zachowania aktorów ekonomicznych (por. teoria agencji), jak również wpływu struktury praw własności na efektywność alokacyjną (por. teoria praw własności) ${ }^{102}$. Podobieństwo dostrzegalne jest też m.in. w dyskusji Austriaków z ekonomistami socjalizmu. Ekonomia socjalistyczna była przez reprezentantów szkoły austriackiej krytykowana przede wszystkim za to, iż analizowała układy statyczne (austriaccy ekonomiści preferowali analizę dynamiczną) oraz za to, że nie uwzględniała kosztów funkcjonowania systemu socjalistycznego planowania (tu można dostrzec podobieństwo z ekonomiką kosztów transakcyjnych). Zdaniem ekonomistów austriackich koszty transakcyjne są w znacznej mierze ograniczane przez sprawnie funkcjonujący system cen (podobnie jak przedstawiciele ekonomiki kosztów transakcyjnych uznają pieniądz za instrument minimalizowania „tarcia” w gospodarce), podczas gdy ekonomia socjalistyczna w ogóle nie była przywiązana do systemu cen ${ }^{103}$.

haslo/4009631/prakseologia.html, dostęp: 30.01.2014), co stanowi podstawę dla propagowania stosowania jej teoretycznego dorobku, zwłaszcza na gruncie nauk ekonomicznych i nauk o zarządzaniu.

99 L. von Mises, Human Action: A Treatise on Economics, Yale University Press, New Haven 1949.

100 L. von Mises, Ludzkie działanie. Traktat o ekonomii, s. 4; http://mises.pl/pliki/ upload/HumanAction_rozdz1-3.pdf (dostęp: 30.12.2012).

101 Hayekowski podział na porządek spontaniczny i zorganizowany pozostaje bardzo podobny do podziału na rynki i hierarchie lub też podziału na systemy zarządzania spontaniczne i intencjonalne, upowszechnionego przez O. Williamsona (O. E. Williamson, Economic Institutions: Spontaneous and Intentional Governance, „Journal of Law, Economics, and Organizations" 1991, no. 7 (special issue), s. 159-187).

102 N. J. Foss, P. G. Klein, Austrian Economics and the Theory of the Firm, [w:] P. G. Klein, M. Sykuta (eds.), The Elgar Companion to Transaction Cost Economics, Edward Elgar Publishing, Cheltenham-Northampton 2010, s. 282-286.

103 Ibidem, s. 284. 
Równolegle do rozwoju myśli ekonomicznej szkoły austriackiej, w latach 30. XX w. zaczęła rozwijać się niemiecka forma liberalizmu, która w swych założeniach podejmowała zagadnienie konieczności poszanowania podmiotowości człowieka oraz była budowana na tezie, że brak uwarunkowań instytucjonalnych (przede wszystkim w postaci rządów prawa) uniemożliwia sprawne funkcjonowanie gospodarki wolnorynkowej. Nurt ten został nazwany ordoliberalizmem ${ }^{104}$.

Ordoliberałowie analizowali procesy ekonomiczne przez pryzmat podziału na dwa podstawowe modele gospodarcze: gospodarki centralne sterowanej i gospodarki dobrowolnej wymiany. Co istotne, linia tego podziału nie przebiegała przede wszystkim w odniesieniu do charakterystycznego dla marksizmu kryterium własności środków produkcji, lecz do kryterium koordynacji (gospodarka centralna a gospodarka zindywidualizowana). Z punktu widzenia założeń tego nurtu, podobieństw do głównych założeń szkoły austriackiej należy doszukiwać się przede wszystkim w przyznaniu prymatu wolnemu rynkowi jako mechanizmowi w największym stopniu zapewniającemu efektywność ekonomiczną. Jednak, w przeciwieństwie do F. A. von Hayeka, ordoliberałowie twierdzili, iż wolny rynek ma szansę funkcjonować jedynie w sytuacji istnienia sprawnego państwa jako gwaranta własności i gospodarki opartej na zasadach konkurencji. Jeden z kluczowych przedstawicieli ordo liberalizmu, Walter Eucken, wprowadził w tym kontekście podział na zasady konstytutywne i regulujące, stanowiące instytucjonalną podstawę procesów ekonomicznych. Te pierwsze wyłaniają się w drodze formowania się porządku społecznego, drugie zaś mają charakter instytucji formalnych. Do zasad konstytutywnych zaliczono: prymat gospodarki pieniężnej, otwarte rynki, dominację własności prywatnej, swobodę zawierania umów, odpowiedzialność przedsiębiorców i menadżerów oraz stabilność polityki ekonomicznej. Na zasady regulujące składają się natomiast: istnienie systemu antymonopolowego, progresywny system podatkowy jako element społecznie pożądanej polityki redystrybucyjnej, regulacje prawne odpowiedzialne za zarządzanie efektami zewnętrznymi oraz zarządzanie rynkami pracy ${ }^{105}$. Innymi słowy, zdrowa gospodarka wolnorynkowa nie powstaje spontanicznie, lecz potrzebuje stabilnych instytucji (niem. Ordnungpolitik).

104 Nazwa nurtu pochodzi od tytułu czasopisma „Ordo”, założonego w 1948 r. przez jego czołowych przedstawicieli - Franza Böhma i Waltera Euckena.

105 Cyt. za: B. Chavance, L'économie..., s. 58. Zob. też: W. Eucken, Polityka porzqdku konkurencji - zasady konstytuujace, [w:] E. Mączyńska, P. Pysz (red.), Społeczna gospodarka rynkowa. Idee i możliwości praktycznego wykorzystania w Polsce, Wyd. Polskiego Towarzystwa Ekonomicznego, Warszawa 2003, s. 74. 
Za współczesną kontynuację zaprezentowanych nurtów „starego" instytucjonalizmu (w tym przede wszystkim historycyzmu) uznaje się tzw. neoinstytucjonalizm ${ }^{106}$. Kontynuacja ta uwidacznia się przede wszystkim w przekonaniu o złożoności problemu wyłaniania się i ewolucji instytucji, a tym samym w dystansie do rygoru metodologicznego analizy instytucjonalnej, jaki cechuje tzw. nową ekonomię instytucjonalną. Neoinstytucjonalizm jednak nie neguje, ale postuluje rozwinięcie koncepcji „człowieka ekonomicznego". Uznaje, że w toku podejmowania decyzji i prowadzenia działalności jednostka ludzka nie podlega tylko wpływom racjonalizmu. Innymi ważnymi dla jednostki bodźcami są moralność oraz psychika.

Za wyraz istoty nurtu neoinstytucjonalnego można uznać prace przywoływanego już Geoffreya Hodgsona, którego wkład do ekonomii instytucjonalnej cechuje z jednej strony ogromna erudycja, $z$ drugiej jednak - brak zdecydowania w określeniu własnego miejsca w konkretnym nurcie lub szkole oraz próby połączenia „starego" $i$ „nowego" instytucjonalizmu w jednolitym obszarze ekonomiki ewolucyjnej ${ }^{107}$. Cechy te wyróżniają nie tylko Hodgsona, lecz z powodzeniem mogą zostać odniesione do neoinstytucjonalizmu jako całości. Wspólną charakterystyką tego nurtu pozostaje wspomniana krytyka formalizmu ekonomii głównego nurtu (co stanowi wyraz kontynuacji „starej” ekonomii instytucjonalnej) oraz nacisk na różnorodność metodologiczną jako jedną z głównych wartości ekonomii instytucjonalnej.

Holizm poznawczy i metodologiczny neoinstytucjonalizmu uwidacznia się ponadto w jego otwarciu na próbę godzenia podejść reprezentowanych przez nową ekonomię instytucjonalną oraz „stary” instytucjonalizm. Podczas gdy NEI uznaje instynkty, zwyczaje, przekonania (instytucje) za następstwa serii podejmowanych wyborów, drugie wymienione podejście zakłada zależność odwrotną (ewolucyjnie kształtowane zwyczaje warunkują podejmowane wybory). Natomiast neoinstytucjonalizm stara się raczej akcentować wzajemną i obukierunkową zależność między tymi czynnikami ${ }^{108}$ (rys. 7).

106 Należy jednak podkreślić, że neoinstytucjonalizm jest przez jednych autorów klasyfikowany jako bliski nowemu instytucjonalizmowi i przeciwstawiany nowej ekonomii instytucjonalnej (NEI) - por. S. Barczyk, Przedsiębiorczy samorząd lokalny..., s. 118), podczas gdy inni autorzy traktują zarówno nowy instytucjonalizm, jak i neoinstytucjonalizm jako elementy NEI (por. Z. Staniek, Zróżnicowanie ekonomii instytucjonalnej; http://www.e-sgh.pl/niezbednik/plik. php?id=27233173\&pid=1081, dostęp 12.12.2013; S. Rudolf, Nowa ekonomia instytucjonalna lekarstwem na kryzys, [w:] idem (red.), Nowa ekonomia instytucjonalna wobec kryzysu..., s. 13-27). W niniejszym opracowaniu zdecydowano się na przyjęcie pierwszej perspektywy.

107 W. Stankiewicz, Ekonomika instytucjonalna..., s. 38.

108 G. M. Hodgson, Choice, Habit and Evolution, „Journal of Evolutionary Economics” 2010, vol. 20, s. 1. 


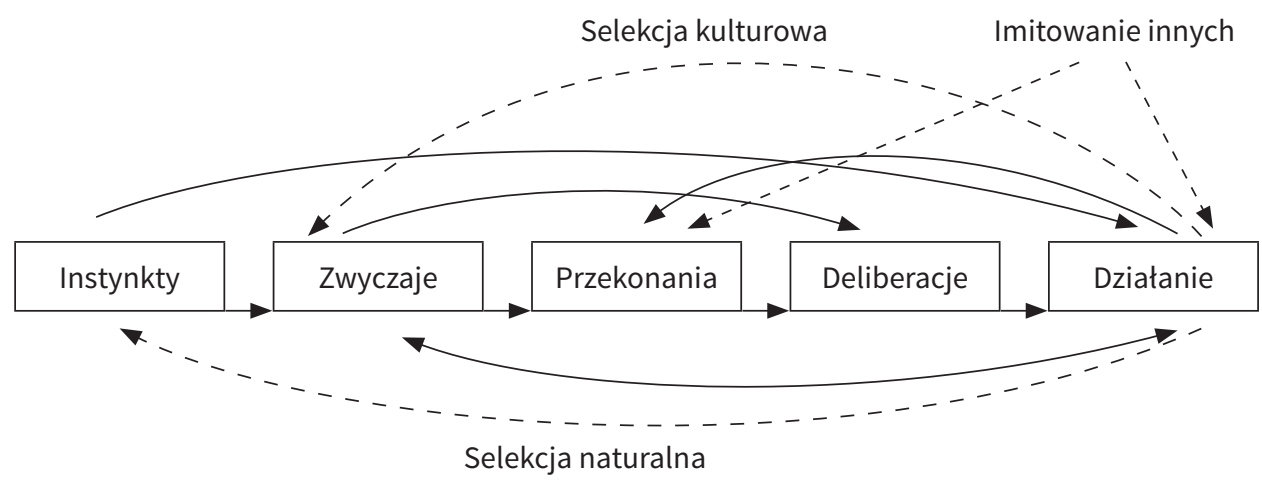

Rys. 7. Złożoność relacji między instytucjami a wyborami ekonomicznymi

Źródło: G. M. Hodgson, Choice, Habit and Evolution, „Journal of Evolutionary Economics” 2010, vol. 20, s. 15.

Pomimo wewnętrznej różnorodności pierwotnych nurtów instytucjonalnych (kontynuowanych współcześnie przez tzw. neoinstytucjonalizm), za ich istotną cechę wspólną (poza poglądami przedstawicieli szkoły austriackiej) należy uznać przekonanie, że instytucje pełnią w społeczeństwie ważną rolę integracyjną. Tym zresztą najbardziej różni się współczesny neoinstytucjonalizm od fundamentalnych założeń tzw. nowej ekonomii instytucjonalnej. Pierwszy z wymienionych nurtów podkreśla bowiem, że instytucje należy interpretować przede wszystkim w kategoriach dóbr wspólnych, podczas gdy NEI traktuje je jako wypadkową ścierania się indywidualnych interesów jednostek.

Tak rozumiane pojęcie nowego instytucjonalizmu wprowadzili do literatury naukowej James G. March i Johann P. Olsen ${ }^{109}$. Z czasem ich rozważania teoretyczne doprowadziły do rozróżnienia dwóch podejść do analizy instytucji, tj. agregacyjnego i integracyjnego. W pierwszym przypadku instytucje są pochodną woli ludów, którą poznaje się za pośrednictwem kampanii politycznych oraz przetargów między racjonalnymi obywatelami. W przypadku drugim wolę ludów poznaje się poprzez obradowanie rozsądnych obywateli i władców, dążących do osiągnięcia powszechnego dobrobytu w kontekście wspólnych wartości społecznych. W agregacyjnym podejściu do instytucji akcentowana jest zatem tradycja ekonomii neoklasycznej, podczas gdy w podejściu integracyjnym można identyfikować odwołanie do tradycji weberowskiej w teorii polityki ${ }^{110}$.

109 J. G. March, J. P. Olsen, The New Institutionalism: Organizational Factors in Political Life, „The American Political Science Review” 1984, vol. 78, no. 3, s. 734-749.

110 J. G. March, J. P. Olsen, Instytucje..., s. 148. 
W ujęciu Marcha i Olsena ważną kwestią jest przy tym nie tylko źródło instytucji, lecz także sposób podejścia do tzw. problemu agencji, tj. sposobu regulowania relacji między pryncypałem i agentem $w$ ramach dwóch odmiennych form instytucji ${ }^{111}$. W przypadku instytucji agregacyjnych zakłada się, że aktorzy instytucjonalni, jako homo oeconomici, mają własne preferencje i dążą do maksymalizacji swych indywidualnych użyteczności. Przy takim założeniu rozwiązanie problemu agencji leży w takim zaprojektowaniu bodźców i ograniczeń, które zapewnią zgodność działań racjonalnego agenta $\mathrm{z}$ wolą interesariuszy (problem zgodności bodźców - incentive compatibility). $\mathrm{W}$ drugim przypadku problem agencji to kwestia uczciwości urzędniczej lub zawodowej. Funkcja urzędnika traktowana jest jako sprawowanie służby społecznej, a nie maksymalizowanie własnej użyteczności ${ }^{112}$.

Należy podkreślić, że najistotniejszym problemem współczesnych instytucji integrujących jest jednak ich niezdolność do zagwarantowania uczciwości, kompetencji i racjonalnej debaty w życiu społecznym i politycznym, bowiem bezstronna uczciwość i oparcie funkcjonowania różnorodnych instytucji jedynie na etosie pracy na rzecz ogółu jawi się jako utopia. Z drugiej strony trudno też się zgodzić z faktem, że jedynym motywem zachowania współczesnych ludzi jest tylko korzyść własna, bowiem znaczna część uczestników życia nie tylko społeczno-politycznego, ale i gospodarczego, kieruje się celami, która można nazwać społecznymi lub publicznymi. Tym, co może powodować działanie na rzecz „dobra wspólnego”, może być przy tym rozwijająca się edukacja obywatelska, której w określonych warunkach sprzyja decentralizacja władzy, a zatem proces, który obserwuje się współcześnie w znacznej liczbie państw ${ }^{113}$. Według Marcha i Olsena historię demokracji zachodnich można przedstawić z punktu widzenia ciągłych zmian, gdzie - chociaż w ciągu ostatnich kilkudziesięciu lat dominowały instytucje w formie agregacyjnej - można zakładać, iż w ciągu następnych kilku lub kilkunastu lat osłabnie ich dominacja ${ }^{114}$. Przywołani autorzy dostrzegają przy tym, że o ile rozwojowi instytucji agregacyjnych sprzyjają okresy ekonomicznej prosperity, o tyle czas recesji czy kryzysu zwykle zwiastuje rozwój struktur integracyjnych ${ }^{115}$.

111 Szczegółowy opis teorii agencji znajduje się w podrozdziale 1.2 rozdziału III.

112 S. A. Ross, The Economic Theory of Agency: The Principal's Problem, „American Economic Review” 1977, vol. 63, s. 134-139; D. Levinthal, A Survey of Agency Models of Organizations, „Journal of Economic Behavior and Organization” 1988, vol. 9, s. 153-185.

113 J. G. March, J. P. Olsen, Instytucje..., s. 164-165.

114 Ibidem, s. 167-170.

115 Autorzy w książce wydanej po raz pierwszy w 1989 r. przewidywali zwrot w kierunku integracji już w latach 90 . XX w. Wydaje się jednak, że zwrot ten został 
Reasumując, neoinstytucjonalizm budowany na fundamentalnych założeniach „starej” ekonomii instytucjonalnej zakłada, że formułowanie polityki jest czymś więcej, niż wyrazem indywidualnych interesów i powinno czerpać zarówno z kompetencji (technicznych oraz moralnych), jak i uczciwości. Interes społeczny jest przy tym nie tyle wynikiem przetargów odbywających się między egoistycznie działającymi jednostkami, ile pozostaje kryterium etycznym. Procesami integracyjnymi kieruje zatem logika jedności, a nie logika wymiany, zaś transakcje, koalicje i zakulisowe układy określa się jako niesprzyjające zdrowemu rozsądkowi, sprawiedliwości i efektywności. Prawa uznawane za „podstawowe” (takie jak: wolność słowa, wolność pracy, godność itd.) nie są narzędziami usprawniającymi efektywną wymianę, lecz elementami systemu wartości. Innymi słowy, są one instytucjonalnymi fundamentami, a nie narzędziami systemu społeczno-gospodarczego ${ }^{116}$.

W odniesieniu do "starego” instytucjonalizmu należy wspomnieć, że dystansuje się on od założeń ekonomii klasycznej i neoklasycznej również w warstwie metodologicznej. Dążenie do uściślenia analizy ekonomicznej prowadzi bowiem ekonomię do zbliżenia teoretyczno-metodologicznego do nauk przyrodniczych kosztem oddalenia od nauk społecznych. Ekonomiści skupiający się na kalkulacji i optymalizacji przekształcają ekonomię w matematykę stosowaną, czyniąc przedmiotem badań abstrakcyjne ludzkie zachowanie, podczas gdy ludzie zachowania nie są abstrakcyjne i zawsze pozostają uwarunkowane instytucjonalnie $^{117}$.

W świecie, w którym występują takie problemy, jak niedoskonałość i asymetria informacji, efekty zewnętrzne oraz nierównomierność rozwoju, nie można liczyć na to, że strukturę instytucjonalną charakteryzującą się

opóźniony przez upadek ZSRR i systemu realnego socjalizmu w krajach Europy Środkowo-Wschodniej czy niektórych krajach Azji, Afryki i Ameryki Południowej. Podążające w ślad za nim otwieranie nowych gospodarek na idee kapitalizmu, potęgowane niechęcią do socjalizmu, stworzyło podatny grunt na przyspieszenie procesów globalizacji gospodarki w formie neoliberalnej. Dopiero potężny kryzys gospodarczy końca pierwszej dekady XXI w. uwydatnił negatywne przejawy funkcjonowania tej przeciwnej skrajności. W takich wydarzeniach, jak protest „ruchu oburzonych" w krajach latynoskich czy też powrót do wielu koncepcji ,interwencjonistycznych", a nawet marksistowskich we współczesnym dyskursie intelektualnym i publicystyce widać silne przejawy eksponowania koncepcji instytucji integracyjnych.

116 J. G. March, J. P. Olsen, Instytucje..., s. 155-161.

117 J. Godłów-Legiędź, Spory metodologiczne..., s. 46. 
efektywnością adaptacyjną ${ }^{118}$ może wyłonić spontaniczny mechanizm prób i błędów ${ }^{119}$.

Z drugiej strony, założenia nowego instytucjonalizmu stanowią podstawę krytyki. Ponieważ w stosunku do ekonomii głównego nurtu oraz nowej ekonomii instytucyjnej cechuje go większa złożoność, wielu uznaje za nieuprawnione postrzeganie tego nurtu jako spójnej orientacji badawczej $^{120}$. Prowadzi to do wielu ograniczeń, np. braku wyrazistości metodologicznej, problemu z precyzyjnym definiowaniem instytucji, uproszczonego obrazu motywacji działania jednostek w ramach systemów instytucjonalnych. Potwierdzają to J. G. March i J. P. Olsen, wskazując, że nowy instytucjonalizm jest raczej podejściem teoretycznym niż koncepcją opartą na jednolitych założeniach ${ }^{121}$.

Warto zauważyć, że poszczególne elementy „starej” ekonomii instytucjonalnej mogą być wykorzystane w podejmowaniu decyzji w zakresie polityki ekonomicznej, przy czym każdy z nurtów prezentuje odmienny wkład w postrzeganie roli sektora publicznego w tym zakresie. Ujęcie historyczne, które uwypukla inercję instytucji w stosunku do dynamiki procesów gospodarczych, wydaje się silnie podkreślać konieczność uwzględniania tego faktu jako warunku skuteczności wszelkich reform. Z kolei instytucjonalizm amerykański, eksponujący różnorodność i ewolucyjny charakter instytucji - szczególnie w zakresie odmienności

118 Koncepcja efektywności alokacyjnej jest koncepcją statyczną. Dlatego Douglas North wprowadził pojęcie efektywności adaptacyjnej (dynamicznej), interpretowanej jako „zdolność struktury społeczno-gospodarczej do dostosowania się do zmian” (D. C. North, Institutions..., s. 80; zob. także: J. Godłów-Legiędź, Instytucjonalna analiza transformacji ustrojowej, [w:] S. Rudolf (red.), Nowa ekonomia instytucjonalna. Aspekty..., s. 31). Za J. Greenem i E. Sheshinskim można przytoczyć podobny podział na tzw. efektywność technologiczną (wyrażoną w najlepszej dostępnej alokacji zasobów w danym momencie dla konkretnych podmiotów) oraz efektywność instytucjonalną (wyrażoną w najlepszej alokacji zasobów przy „najlepszym” - w ujęciu absolutnym - układzie instytucjonalnym (J. Green, E. Sheshinski, Competitive Inefficiencies in the Presence of Constrained Transactions, „Journal of Economic Theory” 1975, vol. 10 (3), s. 343-357). W sytuacji, gdy koszty rozpoznania jakości środowiska instytucjonalnego dla dowolnej decyzji ekonomicznej są niezerowe, wówczas efektywność technologiczna jest różna niż efektywność instytucjonalna ( $Ł$. Hardt, Ekonomia kosztów transakcyjnych - geneza i kierunki rozwoju, Wydawnictwa Uniwersytetu Warszawskiego, Warszawa 2009, s. 89).

119 J. Godłów-Legiędź, Spory metodologiczne..., s. 56.

120 S. Mazur, Władza dyskrecjonalna wysokich urzędników publicznych. Perspektywa nowego instytucjonalizmu, Wyd. Uniwersytetu Ekonomicznego, Kraków 2011, s. 51.

121 Ibidem, s. 21. 
procesów rynkowych, mechanizmów zachodzących w sektorze przedsiębiorstw oraz $\mathrm{w}$ organizacjach publicznych - wydaje się inspirować do świadomego stosowania różnych typów interwencji w odniesieniu do każdego z nich.

Szkoła austriacka uczula przede wszystkim na ograniczoną efektywność zaplanowanego porządku, czyli podaje w wątpliwość możliwość precyzyjnego organizowania interwencji publicznych w odniesieniu do rzeczywistych procesów gospodarczych i społecznych. Wreszcie neoinstytucjonalizm dąży do godzenia postrzegania polityk publicznych jako służebnych w stosunku do procesów wolnorynkowych z upatrywaniem ich logiki w kryteriach etycznych czy społecznych. W tym kontekście można jednak zaryzykować twierdzenie, że „stara” ekonomia instytucjonalna „uczy” unikania ekstremów w polityce ekonomicznej. Fakt, że „struktury ekonomiczne mogą krystalizować się wokół małych losowych zdarzeń i ich sprzężeń, jest argumentem na rzecz polityki o umiarkowanej ingerencji państwa w sferę gospodarki". Rządy powinny unikać obu ekstremów, bowiem ani silna ręka rządu, ani niewidzialna ręka rynku, lecz "delikatne pchnięcia w kierunku pożądanych struktur” są warunkiem skuteczności interwencji publicznej ${ }^{122}$.

122 R. Domański, Ewolucyjna gospodarka przestrzenna, Wyd. Uniwersytetu Ekonomicznego w Poznaniu, Poznań 2012, s. 16. 


\section{Rozdział III \\ Współczesne nurty \\ ekonomii instytucjonalnej}

\section{Nowa ekonomia instytucjonalna jako próba operacjonalizacji instytucji w ekonomii}

Nowa ekonomia instytucjonalna (NEI) definiowana jest jako interdyscyplinarne podejście, będące kombinacją ekonomii, prawa, teorii organizacji, politologii, socjologii i antropologii, mające na celu zrozumienie instytucji rządzących życiem społecznym, politycznym i ekonomicznym. Wykorzystuje przy tym dorobek różnorodnych dyscyplin z obszaru nauk społecznych, przy czym jego dominującą dyscypliną jest ekonomia. Celem NEI jest wyjaśnienie, czym są instytucje, jak powstają, jakim celom służą, jak się zmieniają oraz jak - jeśli w ogóle - mogą być reformowane ${ }^{1}$.

W literaturze przedmiotu można spotkać się z poglądem, że NEI stanowi pewną kontynuację tradycyjnej ekonomii instytucjonalnej, bowiem podobnie jak w ujęciu tradycyjnym cechuje ją:

1) koncentracja raczej na zachowaniach kolektywnych, a nie indywidualnych (pomimo założenia o tzw. indywidualizmie metodologicznym),

2) proponowanie podejścia ewolucyjnego do procesów ekonomicznych w miejsce statycznego,

3) nacisk na obserwację empiryczną i przedkładanie jej nad rozumowanie dedukcyjne.

W opinii przedstawicieli NEI „stary” instytucjonalizm jako dziedzina naukowa ma jednak pewną słabość. Choć posługuje się bogatym materiałem empirycznym, to jednak analizuje go w oderwaniu od przejrzystych ram teoretycznych. Natomiast na gruncie NEI zdołano wypracować bardziej trwałe ramy analityczne, zbudowane na indywidualizmie

1 P. G. Klein, New Institutional Economics, [w:] B. Bouckaert, G. DeGeest (eds.), Encyclopedia of Law and Economics, Edward Elgar, Cheltenham 2000, s. 456. 
metodologicznym. W ramach NEI takie zmienne, jak kultura organizacji, pamięć organizacyjna itp. stanowią przy tym explananda, natomiast rolę explanans pełnią cele, plany i działania pojedynczych jednostek ${ }^{2}$. W konsekwencji nową ekonomię instytucjonalną należy uznać za dziedzinę, którą do wcześniejszych nurtów instytucjonalnych zbliża przypisywanie istotnego znaczenia instytucjonalnym uwarunkowaniom procesów ekonomicznych, natomiast odróżnia ją rygor metodologiczny w doborze aparatu badawczego oraz powrót do koncepcji człowieka ekonomicznego (homo oeconomicus).

W ostatnim z wymienionych założeń NEI znacząco zbliża się do ekonomii głównego nurtu, jednak od ekonomii neoklasycznej różni się przede wszystkim tym, że odrzuca model doskonałej racjonalności na rzecz koncepcji racjonalności ograniczonej. Instytucje interpretowane są przy tym - w przeciwieństwie do tradycyjnego podejścia instytucjonalnego - jako czynnik nie tyle wspomagający, ile ograniczający wolne wybory jednostek. Warto jednak zaakcentować, iż obecnie toczy się dyskusja, czy NEI jest częścią szkoły neoklasycznej (jak twierdzi wielu przedstawicieli „starego" instytucjonalizmu), czy też się od niego oddala poprzez swoją wewnętrzną złożoność, oparcie na zasadzie ograniczonej racjonalności i skłonność do rozpatrywania procesów gospodarczych w kategoriach zmian ewolucyjnych (w miejsce poszukiwania stanów równowagi) ${ }^{3}$.

Wśród głównych założeń nowej ekonomii instytucjonalnej należy wymienić następujące tezy"

1. Człowiek jako homo oeconomicus funkcjonuje w środowisku o rzadkich zasobach i dąży do maksymalizacji swojej użyteczności.

2. Człowiek ma ograniczone możliwości zbierania i przetwarzania informacji, zatem nie może podjąć decyzji w pełni racjonalnej (koncepcja ograniczonej racjonalności).

3. Decyzje ekonomiczne podejmowane są w warunkach niedoskonałej informacji, którą cechuje niekompletność i asymetria.

4. Informacja bywa często fałszowana w wyniku działań oportunistycznych, wynikających z tzw. pokusy nadużycia jednostek (moral hazard).

2 P. G. Klein, Transaction Cost Economics and the New Institutional Economics, [w:] P. G. Klein, M. Sykuta (eds.), The Elgar Companion to Transaction Cost Economics, Edward Elgar Publishing, Cheltenham-Northampton 2010, s. 28.

3 P. G. Klein, Transaction Cost Economics..., s. 31-32.

4 A. Kacprzyk, Wkład psychologii w neoinstytucjonalna modyfikację zasady racjonalności, [w:] S. Rudolf (red.), Nowa ekonomia instytucjonalna. Aspekty teoretyczne i praktyczne, Wyższa Szkoła Ekonomii i Administracji im. prof. Edwarda Lipińskiego w Kielcach, Kielce 2005, s. 116-117. 
5. W społeczeństwie i gospodarce istnieją instytucje jako „reguły gry", które jedne typy działań hamują, a do innych typów działań stymulują.

6. Procesy wymiany gospodarczej odbywają się w warunkach niezerowych kosztów transakcji.

Nowa ekonomia instytucjonalna stanowi złożony konglomerat szczegółowych programów badawczych. Do najważniejszych z nich należy zaliczyćs:

1. Ekonomiczną teorię kontraktu (ETK) i teorię agencji (TA), które zajmują się problematyką asymetrii informacji oraz formułowania kontraktów tak, aby zawarta w nich struktura bodźców, metody wymuszania praw i obowiązków kontraktowych sprzyjały realizacji celów partnerów kontraktowych.

2. Ekonomikę kosztów transakcyjnych (EKT), która koncentruje się na kategorii kosztów transakcyjnych i problematyce realizacji kontraktu.

3. Teorię praw własności (TPW), w ramach której analizuje się wpływ struktury praw własności (uprawnień własnościowych) na funkcjonowanie gospodarki.

4. Ekonomię wyboru publicznego (EWP), która stosuje metody badawcze ekonomii neoklasycznej do analizy funkcjonowania instytucji publicznych, takich jak rządy, parlamenty, organizacje publiczne, grupy nacisku itp.

5. Ekonomię konstytucyjną (EK), wyjaśniającą wybory dokonywane pomiędzy różnymi regułami prawnoinstytucjonalnymi (konstytucjami), które w konsekwencji stanowią ograniczenie dla działalności podmiotów ekonomicznych i politycznych.

6. Ekonomię polityczną (EP), której przedmiot badawczy obejmuje zagadnienia funkcjonowania państwa, instytucji rządowych, administracji publicznej, organizacji międzynarodowych i kształtowania się (lub zmiany) instytucji politycznych.

5 K. Kowalska, Kontraktowanie i koszty transakcyjne w nowej ekonomii instytucjonalnej, „Gospodarka Narodowa” 2005, nr 7-8, s. 47, na podstawie: O. E. Williamson, Ekonomiczne instytucje kapitalizmu, PWN, Warszawa 1998; E. G. Furubotn, R. Richter, Institutions and Economic Theory. The Contribution of the New Institutional Economics, The University of Michigan Press, Ann Arbor 1997; M. Iwanek, J. Wilkin, Instytucje i instytucjonalizm w ekonomii, Uniwersytet Warszawski, Wydział Nauk Ekonomicznych, Warszawa 1997; P. G. Klein, New Institutional Economics...; O. E. Williamson, The New Institutional Economics: Taking Stock, Looking Ahead, „Journal of Economic Literature” 2000, vol. 38, s. 595-613; Z. Hockuba, Nowa Ekonomia Instytucjonalna - czy zdominuje nasze myślenie w rozpoczynajacym się stuleciu?, [w:] A. Wojtyna (red.), Czy ekonomia nadąża za wyjaśnianiem rzeczywistości?, PTE-Bellona, Warszawa 2001, s. 39-56. 
7. Instytucjonalną analizę historii gospodarczej, w której stosowanie metodologii historycznej i porównawczej analizy instytucjonalnej pozwala poszukiwać odpowiedzi na fundamentalne dla rozwoju gospodarczego i dobrobytu jednostek pytania: o przyczyny rozwoju społeczeństw według różnych trajektorii instytucjonalnych, o odmienne skutki stosowania tych samych rozwiązań instytucjonalnych w różnych społeczeństwach, o powiązania między instytucjami formalnymi i nieformalnymi6 ${ }^{6}$ Tej szkole bliskie są m.in. pojęcia zmiany instytucjonalnej i zależności od ścieżek rozwoju (path-dependency $)^{7}$, które ukazują dynamikę zmiany czy ewolucji instytucjonalnej i jej zależność od zdarzeń oraz instytucji występujących obecnie i w przeszłości. Ta ostatnia kategoria znajduje poważne zastosowanie w analizie gospodarek (czy ich poszczególnych sektorów) tzw. krajów transformujących się $e^{8}$.

Z uwagi na dużą różnorodność i wzajemne zależności pomiędzy wymienionymi obszarami zainteresowań teorii wyboru publicznego, w celach porządkujących warto wyróżnić trzy podstawowe nurty ${ }^{9}$ :

6 A. Greif, Historical an Comparative Institutional Analysis, "American Economic Review" 1998, vol. 88 (2), s. 80-84.

7 D. C. North, Institutions, Institutional Change and Economic Performance, Cambridge University Press, Cambridge 1997.

8 J. Kornai, K. Eggleston, Welfare, Choice and Solidarity in Transition. Reforming the Health Sector in Eastern Europe, Cambridge University Press, Cambridge 2001.

9 B. Fiedor, Nowa Ekonomia Instytucjonalna jako podstawa teoretycznej refleksji nad procesem transformacji od gospodarki centralnie sterowanej do rynkowej, http:// www.wiedzainfo.pl/wyklady/138/nowa_ekonomia_instytucjonalna_jako_podstawa_teoretycznej_refleksji_nad_procesem_transformacji_od_gospodarki_centralnie_sterowanej_do_rynkowej.html (dostęp: 21.03.2012). Należy podkreślić, że w literaturze funkcjonują również inne klasyfikacje. Jeden z bardziej popularnych podziałów zaproponował O. E. Williamson, The New Institutional Economics... Dokonat on rozróżnienia między nurtem NEI poświęconym instytucjom zarządzania (institutions of governance) oraz instytucjom w otoczeniu transakcji (institutions of environment). Pierwsza grupa odnosi się do teorii kosztów transakcyjnych i teorii agencji, natomiast na drugą grupę składają się teoria praw własności i teoria wyboru publicznego. W podziale B. Fiedora teoria agencji została włączona do teorii kosztów transakcyjnych. Z punktu widzenia dążenia do uproszczenia klasyfikacji nurtów ekonomii instytucjonalnej jest to zabieg uprawomocniony (i zastosowany także w niniejszej pracy). Należy podkreślić, że teoria agencji ma wiele wspólnego z ekonomią kosztów transakcyjnych (założenie indywidualizmu metodologicznego, ograniczonej racjonalności, podobne zmienne zależne). Dla porządku należy jednak wspomnieć, iż obydwie teorie wyrastają z odmiennych tradycji i dowołują się do innych zmiennych niezależnych. W przypadku TKT zmiennymi są bowiem czynniki dotyczące transakcji rynkowych - m.in. specyficzność aktywów oraz liczba kontraktów (szerzej w dalszej części rozdziału), a w przypadku TA zmiennymi niezależnymi są analizowane postawy członków 
1) teorię praw własności (TPW),

2) teorię kosztów transakcyjnych (TKT), która wyjaśnia procesy poruszane na gruncie teorii agencji, teorii kontraktu oraz ekonomiki kosztów transakcyjnych,

3) nową ekonomię polityczną (NEP), zamiennie nazywaną teorią wyboru publicznego (TWP), uwzględniającą analizę instytucji publicznych w duchu głównych założeń nowej ekonomii instytucjonalnej.

\subsection{Teoria praw własności}

Najwcześniejsze analizy podejmowanie na gruncie nowej ekonomii instytucjonalnej dotyczyły zjawiska wpływu sposobów oraz możliwości w zakresie egzekwowania prawa własności na zachowania właścicieli i dysponentów zasobów ekonomicznych. Główna teza sformułowana na gruncie TPW wskazuje, iż wzmocnienie systemu praw własności, zwłaszcza poprzez upowszechnienie własności prywatnej, będzie prowadzić do internalizacji znacznej części efektów zewnętrznych, a także - co istotne - stymulować posiadaczy zasobów do ich efektywnego wykorzystania, co w długim okresie powinno sprzyjać ich optymalnej alokacji. Pełna eliminacja efektów zewnętrznych nie jest oczywiście możliwa w żadnej realnej gospodarce rynkowej, ze względu na niedoskonałości rynku. W tym kontekście, jak podkreśla B. Fiedor,

nieprecyzyjne zdefiniowanie i/lub osłabienie praw własności, a zwłaszcza niemożliwość internalizacji korzyści związanych z tymi prawami, musi prowadzić do wzrostu tzw. kosztów transakcyjnych w gospodarce, osłabienia systemu bodźców mikroekonomicznych, a w ten sposób do ogólnego spadku poziomu racjonalności czy efektywności ekonomicznej ${ }^{10}$.

Ogólnie rzecz ujmując, prawa własności są efektywne, kiedy tworzą bodźce do maksymalizacji bogactwa. Dobrowolna wymiana przesuwa zwykle zasoby od osób, które przypisują im niższą wartość do osób, które przypisują im wartość wyższą. Prawa własności maksymalizują więc bogactwo, zwiększając rozwój dobrowolnej wymiany ${ }^{11}$. Natomiast „nie-

organizacji, niepewność co do wyników ich działań oraz wewnątrzorganizacyjne systemy informacji (por. K. Eisenhardt, Agency Theory: An Assessment and Review, „Academy of Management Review” 1989, vol. 14 (1), s. 64).

10 B. Fiedor, Nowa Ekonomia Instytucjonalna jako podstawa...

11 R. Cooter, Th. Ulen, Ekonomiczna analiza prawa, C.H. Beck, Warszawa 2009, s. 134. 
pewność co do własności obciąża obrót handlowy i powoduje znaczne dyskontowanie wartości składnika aktywów przez przyszłych nabywców”, czyli istnieje odstępstwo od „typowej” sytuacji, w której nabywca przypisuje danej rzeczy większą wartość niż zbywca ${ }^{12}$.

Własność można zdefiniować jako zbiór efektywnie wykorzystywanych (a nie tylko zadeklarowanych czy zapisanych w kodeksie lub konstytucji) uprawnień. W sensie prawnym rozumiana jest ona zazwyczaj jako określony stosunek między osobą a rzeczą, natomiast w sensie ekonomicznym to przede wszystkim stosunek między ludźmi, który powstaje w związku z faktycznym i nie zawsze odzwierciedlonym w przepisach prawa korzystaniem przez ludzi z wyników działalności gospodarczej oraz dysponowaniem czynnikami produkcji ${ }^{13}$.

W systemie prawnym krajów demokratycznych własność stanowi podstawowe i najsilniejsze prawo rzeczowe. Zgodnie $\mathrm{z}$ wypracowanym jeszcze na gruncie prawa rzymskiego katalogiem uprawnień, właściciel rzeczy może z nich korzystać w niemal dowolny sposób, przetwarzać je, pobierać $\mathrm{z}$ nich pożytki oraz zbywać innym podmiotom ${ }^{14}$. Własność jest ograniczona $\mathrm{w}$ tym zakresie jedynie przez sytuacje jasno zdefiniowane w obowiązujących przepisach. Przykładowo, w polskim prawie należy wymienić zasadę, w myśl której rzeczy powinny być wykorzystywane zgodnie $\mathrm{z}$ ich społeczno-gospodarczym przeznaczeniem oraz $\mathrm{w}$ granicach określonych przez prawo i zasady współżycia społecznego ${ }^{15}$. Po-

12 Ibidem, s. 191.

13 R. Milewski, E. Kwiatkowski, Podstawy ekonomii, PWN, Warszawa 2007, s. 11.

$14 \mathrm{Z}$ tac. ius possidendi (prawo posiadania), ius utendi (prawo używania), ius fruendi (prawo pobierania pożytków), ius abutendi (prawo zużycia rzeczy), ius disponendi (prawo rozporządzania). Należy jednak podkreślić, że katalog uprawnień wynikających z własności w toku rozwoju cywilizacyjnego (a co za tym idzie - instytucjonalnego) został znacznie rozszerzony oraz powiązany z obowiązkami wynikającymi z posiadania rzeczy. Przykładowo, w brytyjskim systemie prawnym wskazuje się aż 11 uprawnień i obowiązków wynikających z własności, tj.: 1) prawo wyłącznej fizycznej kontroli nad rzeczą; 2) prawo używania; 3) prawo zarządzania, tj. decyzji, kto i jak może rzecz wykorzystywać; 4) prawo do dochodu uzyskiwanego z rzeczy; 5) prawo do wartości kapitałowej rzeczy, uzyskanej z jej pozbycia się, konsumpcji, zmiany lub zniszczenia; 6) prawo do bezpieczeństwa, tj. immunitet przed wywłaszczeniem; 7) prawo do przekazania rzeczy w spadku lub w testamencie; 8) bezterminowość prawa; 9) zakaz szkodliwego dla innych użycia rzeczy; 10) odpowiedzialność karna, np. możliwość odebrania rzeczy na opłatę długu; 11) uzasadnione oczekiwanie naturalnego zwrotu przekazanych komuś pełnomocnictw po upływie ustalonego terminu (A. M. Honorè, Ownership, [w:] A. G. Guest (ed.), Oxford Essays in Jurisprudence, Oxford University Press, London 1961, cyt. za: W. Stankiewicz, Ekonomika instytucjonalna. Zarys wykładu, Warszawa 2012, s. 72; http://pwsbia.edu.pl/pdf_files/ Waclaw_Stankiewicz_Ekonomika_Instytucjonalna_III.pdf (dostęp: 28.12.2014).

15 Art. 5 ustawy z dnia 23 kwietnia 1964 r. Kodeks cywilny (Dz. U. 1964, nr 16, poz. 93). 
nadto prawo własności do pewnego stopnia ogranicza tzw. stan wyższej konieczności (wyrażający się np. w możliwości czasowego zajęcia nieruchomości przez osoby trzecie w celu ograniczenia negatywnych skutków klęsk żywiołowych), a także prawo sąsiedztwa (korzystanie z nieruchomości przez jej właściciela nie powinno ograniczać zakresu wykonywania tego samego prawa właścicielom nieruchomości sąsiednich). Wreszcie do ograniczenia prawa własności może dojść w sytuacji np. dopuszczenia do czasowego zajęcia nieruchomości w związku z budową urządzeń infrastruktury technicznej, wydobywaniem i poszukiwaniem kopalin oraz w przypadku wywłaszczenia na cele publiczne ${ }^{16}$.

Należy jednak wyraźnie podkreślić, że opisane powyżej warunki są ściśle regulowane przez przepisy prawa, a sytuacje naruszenia prawa własności są rozstrzygane przez sądy powszechne. Reasumując, właściciel rzeczy może planować swe przedsięwzięcia, nie będąc ograniczonym perspektywą wygaśnięcia prawa własności w czasie. W wielu przypadkach dysponuje on możliwością finansowania swej działalności poprzez zabezpieczanie za pomocą własności ewentualnych wierzytelności.

Koncepcje opisujące znaczenie własności nie wyrażają jednak jednoznacznego stanowiska $\mathrm{w}$ kwestii roli tej formy władania dobrami $\mathrm{w}$ procesach społeczno-ekonomicznych. Warto przy tym podkreślić, że źródłem takich rozważań (z którego zresztą wyraźnie czerpią przedstawiciele teorii praw własności) są filozoficzne koncepcje własności. Do najważniejszych z nich zalicza się ${ }^{17}$ :

1. Podejście utylitarne (J. Bentham), traktujące własność jako narzędzie maksymalizacji użyteczności. Podejście to cechuje jednak pewne ryzyko, bowiem eksponuje ono tymczasowość roszczenia wobec własności (własność może zostać odebrana, jeśli beneficjenci wywłaszczenia uzyskają więcej w kategoriach użyteczności niż utraci jej właściciel).

2. Podejście odwołujące się do idei sprawiedliwości dystrybutywnej (Arystoteles, R. Nozick), w którym własność traktowana jest jako narzędzie uzyskania zakładanej alokacji zasobów. Według założeń tej koncepcji każdy podział bogactwa jest sprawiedliwy pod warunkiem, że rozpoczyna się od sprawiedliwiej pierwotnej dystrybucji zasobów, a ostateczny podział następuje za pomocą dobrowolnej wymiany. Ważne jest przy tym, że każde społeczeństwo

16 J. Szachułowicz, Gospodarka nieruchomościami, Wyd. Prawnicze LexisNexis, Warszawa 2004, s. 93-111, na podstawie ustawy z dnia 23 kwietnia 1964 r. Kodeks cywilny (Dz. U. 1964, nr 16, poz. 93) oraz ustawy z dnia 21 sierpnia 1997 r. o gospodarce nieruchomościami (Dz.U. 1964, nr 16, poz. 93).

17 R. Cooter, Th. Ulen, Ekonomiczna analiza..., s. 136-139. 
może wspierać własną koncepcję sprawiedliwości dystrybutywnej (jedno wybierze równy podział zasobów oparty na strukturze własności, odwołując się do wartości demokratycznych, zaś inne będzie skłaniało się do modelu arystokratycznego).

3. Podejście interpretujące własność jako narzędzie wolności i swobody wypowiedzi (F. A. von Hayek, G. Hegel). Ten nurt jest szczególnie bliski liberalnej myśli ekonomicznej.

4. Podejście traktujące własność w ujęciu konserwatywnym (E. Burke, F. A. von Hayek), w którym własność wynika z jej genezy i jest wynikiem ewolucji oraz naturalnego procesu historycznego, który należy uszanować jako swoiste prawo naturalne.

Teoria praw własności znajduje wśród ekonomistów coraz większe rzesze zwolenników. Jej założenia wykorzystywane są też coraz powszechniej przez przedstawicieli ekonomii rozwoju, którzy identyfikowalność prawa własności interpretują jako ważny warunek „uwolnienia” zasobów kapitału w krajach rozwijających się. Obecnie kapitał nie przynosi wartości dodanej przede wszystkim dlatego, że istnieje trudność lub brak woli politycznej dla jasnego zidentyfikowania jego posiadaczy. Do czołowych przedstawicieli tego nurtu należy m.in. Hernando de Soto ${ }^{18}$, który stawia tezę, że o bogactwie jednych i niepowodzeniu innych krajów decyduje przede wszystkim brak mechanizmów umożliwiających przejście z sektora pozalegalnego ${ }^{19}$ do legalnego. Można zidentyfikować sześć kluczowych efektów jasno zidentyfikowanej własności, mających pozytywny wpływ na rozwój gospodarczy ${ }^{20}$ :

1) możliwość określenia nie tylko rzeczowego, ale i ekonomicznego potencjału zasobów,

2) zintegrowanie rozproszonych informacji o prawach własności $\mathrm{w}$ jeden system,

3) uczynienie obywateli współodpowiedzialnymi za przestrzeganie tytułów własności i przestrzeganie prawa w ogóle,

4) zapewnienie wymienialności zasobów,

5) tworzenie sieci powiązań społecznych, ułatwiających rzetelną identyfikację właścicieli zasobów.

Według $\mathrm{H}$. de Soto gwarancje ochrony prawa własności formalnie obowiązują niemal w każdym kraju oraz w umowach i traktatach międzynarodowych (włączając w to większość konstytucji państw demokratycznych, Powszechną Deklarację Praw Człowieka z roku 1948, Katechizm Kościoła Katolickiego, Konwencję Haską z roku 1849 itp.) $)^{21}$. Jednak pra-

18 H. de Soto, Tajemnica kapitału, Fijorr Publishing, Chicago-Warszawa 2002, s. 24.

19 W oryginale extralegal, w odróżnieniu od illegal (por. ibidem, s. 50).

20 Ibidem, s. 72-85.

21 Ibidem, s. 190. 
wo własności, aby było skutecznie egzekwowane, musi pozostawać silnie zakorzenione w umowie społecznej. Współcześnie własność traktuje się jako jedno z podstawowych praw człowieka (obok prawa do życia i wolności), jednak nie jako prawo „naturalne”, lecz czerpiące swą moc z decyzji zbiorowości co do zakresu treści pojęcia „własność”. Taka umowa społeczna powinna zostać zapisana w konstytucji ${ }^{22}$.

W naukach ekonomicznych własność analizowana jest również przez pryzmat jej podziału na publiczną i prywatną ${ }^{23}$. Rozróżnienie to implikuje odmienny charakter zachowań właścicieli zasobów. Ponadto podział ten rozszerzany jest zwykle o dwie formy pośrednie, tzw. wspólne zasoby oraz dobra klubowe. Takie ujęcie ekonomiczne klasyfikacji dóbr wynika z przyjęcia dwóch kluczowych kryteriów: $\mathrm{z}$ jednej strony możliwości wyłączenia innych podmiotów (poza właścicielem) z konsumpcji danego dobra, z drugiej zaś - z poziomu konkurencyjności w konsumpcji.

Sytuacja występowania czystych dóbr prywatnych ma miejsce wówczas, gdy uwarunkowania techniczne i prawne umożliwiają właścicielom zapewnienie wyłączności $\mathrm{w}$ konsumpcji bez ponoszenia $\mathrm{z}$ tego tytułu istotnych kosztów, jak również wtedy, gdy w procesie korzystania $\mathrm{z}$ tych dóbr nie istnieje konieczność ich współdzielenia z innymi użytkownikami (wysoki poziom konkurencyjności w konsumpcji). W takiej sytuacji ma miejsce czytelna alokacja praw własności, a ich transfer odbywa się zwykle za pomocą mechanizmu rynkowego.

Odwrotna sytuacja ma miejsce w odniesieniu do czystych dóbr publicznych, gdzie występują wysokie koszty wyłączenia z konsumpcji, co implikuje pozostawienie tych dóbr $\mathrm{w}$ charakterze ogólnodostępnych. Ma to jednak swoje konsekwencje $\mathrm{w}$ fakcie, iż dobra te nie podlegają mechanizmowi konkurencyjności w konsumpcji, w związku z czym finansowanie ich utrzymania odbywa się poza mechanizmem rynkowym. Czyste dobra publiczne są zatem wytwarzane przez sektor publiczny oraz finansowane $\mathrm{z}$ publicznych danin. $\mathrm{Z}$ taką formą wiąże się ryzyko, że pewna część użytkowników będzie unikała płacenia za nie, co jawi się jako jeden z problemów efektywności sektora publicznego (mechanizm „pasażera na gape").

22 J. Miklaszewska, Filozofia a ekonomia. W kręgu teorii publicznego wyboru, Wyd. Uniwersytetu Jagiellońskiego, Kraków 2001, s. 103.

23 Ujmując to w sposób bardziej precyzyjny, własność prywatna może mieć dodatkowo charakter indywidualny lub zbiorowy. Własność publiczną dzieli się niejednokrotnie na własność państwową i własność jednostek samorządu terytorialnego, a także wymienia się własność spółdzielczą jako specyficzną, odmienną od publicznej i prywatnej formę własności. Rozważania te pozostają jednak poza głównym nurtem niniejszej pracy. 


\begin{tabular}{|c|c|c|c|}
\hline & \multicolumn{2}{|c|}{ Możliwość wyłączenia z konsumpcji } \\
\hline \multirow{4}{*}{ 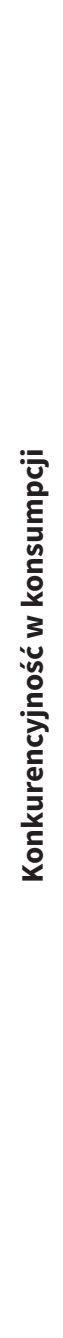 } & \multirow[b]{2}{*}{ TAK } & TAK & NIE \\
\hline & & $\begin{array}{l}\text { Czyste dobra prywatne: } \\
\text { - } \text { koszty wykluczenia niskie, } \\
\text { - produkowane przez firmy pry- } \\
\text { watne, } \\
\text { - dystrybucja przez rynek, } \\
\text { - } \text { finansowanie przychodów ze } \\
\quad \text { sprzedaży }\end{array}$ & $\begin{array}{l}\text { Dobra mieszane (wspólne zasoby): } \\
\text { - } \text { dobra, których korzyści są wspól- } \\
\text { nie konsumowane, ale które są } \\
\text { podatne na przepełnienie lub } \\
\text { zatłoczenie, } \\
\text { - } \text { produkowane przez firmy prywat- } \\
\text { ne lub bezpośrednio przez sektor } \\
\text { publiczny, } \\
\text { - } \text { dostarczane przez rynek lub bez- } \\
\text { pośrednio przez budżet (sektor } \\
\text { publiczny), } \\
\text { - finansowanie z przychodów ze } \\
\text { sprzedaży lub z podatków } \\
\text { Przykłady: towiska ryb, lasy, dzika } \\
\text { przyroda, park publiczny, basen } \\
\text { publiczny, zasoby będące wspólną } \\
\text { własnością (commons) }\end{array}$ \\
\hline & \multirow[t]{2}{*}{ NIE } & $\begin{array}{l}\text { Dobra mieszane (dobra klubowe): } \\
\text { - dobra prywatne z efektami ze- } \\
\text { wnętrznymi, } \\
\text { - } \text { produkowane przez firmy pry- } \\
\text { watne, } \\
\text { - dostarczane przez rynek z dopłatą } \\
\text { lub korektą podatku, } \\
\text { - finansowanie z dochodów ze } \\
\text { sprzedaży }\end{array}$ & $\begin{array}{l}\text { Czyste dobra publiczne: } \\
\text { - wysokie koszty wykluczenia, } \\
\text { - wytwarzanie bezpośrednio przez } \\
\text { rząd lub przez firmy prywatne na } \\
\text { podstawie umowy z rządem, } \\
\text { - finansowanie przez budżety pu- } \\
\text { bliczne }\end{array}$ \\
\hline & & $\begin{array}{l}\text { Przykłady: kina, kluby prywatne, } \\
\text { szkoły, baseny, transport, usługi } \\
\text { ochrony zdrowia itp. }\end{array}$ & $\begin{array}{l}\text { Przykłady: oświetlenie ulic, obrona } \\
\text { narodowa, telewizja publiczna }\end{array}$ \\
\hline
\end{tabular}

Rys. 8. Podział dóbr według konkurencyjności oraz możliwości wykluczenia z konsumpcji

Źródło: opracowanie na podstawie C. V. Brown, P. M. Jackson, Public Sector Economics, Basic Blackwell, Oxford 1990.

Wśród pośrednich form własności wskazuje się wspólne zasoby (w stosunku do których nie występuje możliwość wyłączenia z konsumpcji, jednak ma miejsce istotny poziom konkurencji w korzystaniu z nich przez użytkowników) oraz tzw. dobra klubowe, w odniesieniu do których występuje możliwość wyłączenia z konsumpcji (przy pozostawieniu możliwości korzystania z tego typu zasobów dla wąsko zdefiniowanej 
grupy użytkowników), jednak w ramach „klubu” nie występuje zjawisko przepełnienia lub zatłoczenia ${ }^{24}$ (rys. 8).

Należy podkreślić, że powyżej opisany układ ulega ciągłej ewolucji poprzez zmiany kulturowe, społeczne, prawne i technologiczne. Innymi słowy, dobra, które dotychczas miały charakter publiczny, mogą wykazywać tendencje do stawiania się dobrami klubowymi lub prywatnymi, jak też mogą pojawiać się nowe dobra stanowiące obszar domeny publicznej. Według wielu ekonomistów proces przekształcania dóbr publicznych w prywatne jest wręcz naturalny, a kategorie dóbr mieszanych (wspólnych zasobów oraz dóbr klubowych) pozostają przejściowe ${ }^{25}$. Założenie to odwołuje się do tzw. twierdzenia (teorematu) Coase ${ }^{26}$, zgodnie z którym czytelna alokacja praw własności (a taką teoretycznie zapewnia własność prywatna) jasno identyfikuje strony ewentualnych konfliktów ekonomicznych, które dzięki temu łatwiej mogą rozwiązywać sprzeczność interesów w drodze porozumienia stron lub procesów sądowych ${ }^{27}$. Wątek ten rozwinął w późniejszym okresie Garret Hardin, który w swym opisie „tragedii wspólnego pastwiska” wskazywał, iż nieograniczony dostęp do ograniczonych dóbr publicznych i wspólnych zasobów prowadzi do ich nadmiernej eksploatacji, zaś sposobem na uniknięcie tego zagrożenia może być prywatyzacja tego typu dóbr ${ }^{28}$.

Pogląd o pozytywnym wpływie prywatyzacji zasobów na ich alokację nie jest jednak powszechnie akceptowany. Wskazuje się bowiem, że niekontrolowane uwłaszczenie niezamożnych posiadaczy (przede wszystkim nieruchomości) może prowadzić do działań zmierzających do pozbawienia ich własności ${ }^{29}$. Z kolei Elinor Ostrom ${ }^{30}$ dowodzi, że

24 Analizę dóbr klubowych jako pierwszy przedstawił James Buchanan (J. M. Buchanan, An Economic Theory of Clubs, „Economica” 1965, no. 32, s. 1-14).

25 C. J. Webster, L. W. C. Lai, Property Rights, Planning and Markets. Managing Spontaneous Cities, Edward Elgar, Cheltenham-Northampton 2003, s. 141.

26 Teoremat Coase'a pojawił się po raz pierwszy w głośnym artykule: R. H. Coase, The Problem of Social Costs, „Journal of Law and Economics” 1960, vol. 3 (1), s. 1-44. Autor polemizuje w nim z przeciwną tezą innego ekonomisty, Arthura Pigou, który twierdzi, iż w przypadku pojawienia się efektów zewnętrznych w produkcji dóbr uprawniona jest interwencja państwa w postaci opodatkowania tych efektów (tzw. podatek Pigou).

27 R. H. Coase, The Problem of Social Cost, „The Journal of Law and Economics” 1960, vol. III (October), s. 10.

28 G. Hardin, The Tragedy of the Commons, „Science” 1968, vol. 162, no. 3859, s. 12431248.

29 Por. R. Patel, Wartość niczego. Jak przeksztatcić społeczeństwo rynkowe i na nowo zbudować demokrację, Wyd. Muza, Warszawa 2010, s. 170; D. Harvey, Bunt miast. Prawo do miasta i miejska rewolucja, Fundacja Bęc Zmiana, Warszawa 2012, s. 42-43.

30 Ekonomistka ta w 2009 r. została laureatką Nagrody Banku Szwecji im. Alfreda Nobla w dziedzinie ekonomii (wspólnie z Oliverem Williamsonem) za „analizę 
ustanowienie prywatnej własności (czyli w kategoriach gry Hardina - podzielenie pastwisk i ich ogrodzenie celem precyzyjnego zdefiniowania zasięgu prawa własności) pozostaje jedynie pozornie najlepszym rozwiązaniem. Problem polega bowiem na tym, iż w odniesieniu do wspólnych zasobów nie zawsze istnieją „techniczne” możliwości ogrodzenia (wyłączenia z konsumpcji). W praktyce gospodarczej funkcjonuje cała gama rozwiązań dotyczących sposobów zarządzania wspólnymi zasobami, uwarunkowana czynnikami o charakterze instytucjonalnym. Należą do nich m.in. panujące $\mathrm{w}$ danej społeczności przekonania na temat skali „publiczności” danego dobra, wzajemne zaufanie między członkami społeczeństwa lub jego brak, historia miejsca i tradycje oraz dotychczasowe doświadczenia wynikające z zarządzania wspólnymi zasobami. Innymi słowy, zdaniem Ostrom uproszczenia i idące w ślad za nimi rekomendacje dla polityki są niczym więcej, jak tylko metaforami stosowanymi zarówno przez zwolenników centralizacji, jak i prywatyzacji. Obie strony zbytnio jednak upraszczają rzeczywistość, tworząc wizję „,instytucji niemal wolnych od instytucji”31. Postulat prywatyzacji zasobów nie odnosi się do tego, jak precyzyjnie identyfikować prawa własności i mierzyć ich wartość, kto ma pokrywać koszty wykluczania z konsumpcji, jak rozwiązywać konflikty dotyczące praw itd. Natomiast postulat centralnego sterowania zasobami zazwyczaj nie odnosi się do tego, jaki podmiot publiczny będzie odpowiedzialny za władanie zasobami, kto i w oparciu o jakie kryteria ma wybierać oraz wynagradzać jego pracowników, jak pozyskiwać informacje niezbędne dla podejmowania decyzji, monitorować zachowania itd.

Wydaje się, że wyzwaniem dla nauk społecznych i ekonomicznych jest nie tyle formułowanie ogólnych rekomendacji, ile budowanie teorii bazujących na rzeczywistych zachowaniach ludzkich, bowiem „siła teorii jest wprost proporcjonalna do liczby sytuacji, które potrafi wyjaśniać" ${ }^{32}$. W tym kontekście największym wkładem nowej ekonomii instytucjonalnej, a szczególnie teorii praw własności wydaje się uświadomienie, iż „szczegóły instytucjonalne” organizacji systemu praw własności pozostają niezwykle istotne zarówno dla funkcjonowania krajów, jak i regionów oraz mniejszych jednostek terytorialnych. W myśl zasadniczych założeń TPW należy zatem stwierdzić, że

ekonomicznych aspektów zarządzenia, w szczególności zarządzania wspólnymi zasobami" (http://www.nobelprize.org/nobel_prizes/economics/laureates/2009, dostęp 31.01.2014).

31 E. Ostrom, Governing the Commons. The Evolution of Institutions for Collective Action, Cambridge University Press, New York 1990, s. 12-13.

32 Ibidem, s. 23-24. 
własność prywatna sprawdza się dobrze, kiedy można oddzielić funkcje produkcji i użyteczności lub kiedy efekty zewnętrzne mają wpływ na niewielką liczbę osób (posiadaczy praw), mogących prowadzić ze sobą przetargi. Ponadto, własność jest zazwyczaj najlepszym rozwiązaniem wówczas, kiedy celem jest bogactwo, podczas gdy zarządzanie publiczne - w przypadku bardziej rozproszonych celów ${ }^{33}$. Natomiast czynnikiem, który w istotnym stopniu warunkuje skuteczność ochrony własności (np. poprzez fizyczne rozgraniczenie własności, porozumienia między właścicielami zasobów co do treści przysługujących im praw lub wprowadzanie i egzekwowanie prawnych środków ochrony własności) jest poziom występujących w gospodarce tzw. kosztów transakcyjnych.

Brak precyzji w określeniu praw własności stanowi ważną przeszkodę w osiągnięciu efektywności ekonomicznej, teoretycznie zapewnianej przez konkurencyjną równowagę rynkową. Jednak - jak wskazuje T. Żylicz - błędne byłoby założenie, że każdy inny rodzaj własności poza prywatnym jest gorszy z punktu widzenia efektywności ekonomicznej. $\mathrm{W}$ wielu regionach świata własność komunalna, czyli wspólna, urządzeń infrastruktury technicznej albo zasobów naturalnych z powodzeniem funkcjonuje od wieków. Co więcej, w obrocie gospodarczym wykształciły się specyficzne formy z pogranicza własności prywatnej i wspólnej właśnie w odpowiedzi na wymagania efektywności ekonomicznej. Dotyczy to w szczególności wielu istotnych elementów środowiska ${ }^{34}$. W przypadku zasobów naturalnych i szczególnie cennych zasobów środowiskowych szczególnie ujawnia się bowiem zjawisko efektów zewnętrznych, gdzie korzystanie z dóbr nie może odbywać się bez wpływu na sytuację innych podmiotów. Zgodnie z teorią praw własności efekty zewnętrzne są zjawiskiem normalnym w gospodarce i społeczeństwie. Odbiega to wyraźnie od tradycyjnego, neoklasycznego traktowania mechanizmu rynkowego, dla którego niedoskonałości (w tym efekty zewnętrzne) są zjawiskami incydentalnymi. Teoria praw własności, uznając „normalność” zjawiska efektów zewnętrznych, wyraźnie podkreśla możliwość ich internalizacji, czyli przypisania sprawcom powstających kosztów. Pozwala to ograniczyć zakres występowania niewymiennych (pozarynkowych) stosunków między podmiotami ${ }^{35}$.

33 R. Cooter, Th. Ulen, Ekonomiczna analiza..., s. 172-177.

34 T. Żylicz, Ekonomia środowiska i zasobów naturalnych, PWE, Warszawa 2004, s. 22.

35 S. Czaja, Zanieczyszczenie i ochrona środowiska a prawa własności i koszty transakcyjne, [w:] S. Czaja et al., Podstawy ekonomii środowiska i zasobów naturalnych, Wyd. C.H. Beck, Warszawa 2002, s. 57. 


\subsection{Teoria kosztów transakcyjnych i teoria agencji}

Teoria kosztów transakcyjnych jest komparatywnym, instytucjonalnym podejściem do badań nad strukturami gospodarczymi, w którym podstawową jednostką analityczną jest transakcja. To podejście interdyscyplinarne, obejmujące różne aspekty teorii ekonomii, prawa i organizacji. Ma stosunkowo szeroki zakres i zastosowanie. Absolutnie każdą relację, która przyjmuje formę problemu kontraktowego lub którą można tak określić, da się z pożytkiem oceniać w kategoriach ekonomii kosztów transakcyjnych - dotyczy to większości jawnych i ukrytych relacji kontraktowych ${ }^{36}$.

Dla sprawnego funkcjonowania systemu gospodarczego nie wystarczy samo zdefiniowanie praw własności oraz gwarancja ich ochrony, lecz zapewnienie ich transferu, którego możliwość stanowi podstawę gospodarki rynkowej. Wymianie sprzyja natomiast minimalizacja kosztów ponoszonych w związku z poszukiwaniem stron tej wymiany, uzgadnianiem jej warunków oraz zapewnieniem warunków ograniczających potencjalne zachowania oportunistyczne każdej ze stron. Na zjawisko to zwrócił uwagę jako jeden z pierwszych John R. Commons, który zauważył, że przedmiotem obrotu na rynku są nie tyle dobra, ile prawa do tych dóbr ${ }^{37}$, a transfer tych praw wiąże się z dodatkowymi kosztami.

Ekonomistami, którzy jako pierwsi zajęli się tym zagadnieniem, byli przedstawiciele monetaryzmu, w tym przede wszystkim John R. Hicks, koncentrujący swoje analizy na kosztach transferu aktywów na rynkach kapitałowych. Wprowadził on pojęcie tarcia w ekonomii (friction), rozumianego jako zakłócający wpływ czynników pozaekonomicznych na działanie systemu gospodarczego ${ }^{38}$. Za tarcie w gospodarce są przy tym odpowiedzialne nie tylko zwyczaje, lecz także występki, kaprysy i zwykłe ludzkie błędy. Tarcie może być też rozumiane jako trudności w przepływie kapitału i niezdolność siły roboczej do szybkiego odpowiadania na popyt na pracę ze strony przedsiębiorców, ogólnie zaś - jako wszelkie okoliczności, które uniemożliwiają i utrudniają funkcjonowanie procesów rynkowych ${ }^{39}$. Zgodnie z założeniami J. R. Hicksa kluczowym czynnikiem ograniczającym tarcie w gospodarce jest upowszechnienie w niej

36 O. E. Williamson, Ekonomiczne instytucje..., s. 389-390.

37 Szerzej w: $Ł$. Hardt, Transaction Cost Economics as a Three Dimensional Externally Driven Research Program, „Economic Studies” 2006, no. 1-2, s. 7-31.

38 Ł. Hardt, Ekonomia kosztów transakcyjnych - geneza i kierunki rozwoju, Wydawnictwa Uniwersytetu Warszawskiego, Warszawa 2009, s. 55.

39 M. G. Davidson, Friction in Economics, [w:] I. Palgrave (ed.), Dictionary of Political Economy, Macmillan, London 1894, [cyt. za:] Ł. Hardt, Ekonomia kosztów transakcyjnych..., s. 55. 
gotówki. Odwołując się do analogii z obszaru mechaniki - pieniądz jest jak olej smarujący silnik, którym jest gospodarka.

W swojej kluczowej pracy ${ }^{40}$ Hicks nie używa jednak pojęcia „kosztów transakcyjnych", choć stwierdza, że tego typu koszty z pewnością w gospodarce istnieją i zależą od kształtu systemu instytucjonalnego. Przykładem nakładów, które należy ponieść w celu minimalizacji tarcia, są według niego podatki i opłaty brokerskie, interpretowane jako niezbędne wydatki na rzecz utrzymania systemu instytucjonalnego usprawniającego obrót gospodarczy i jego bezpieczeństwo. Literalnie pojęcie „koszty transakcyjne" zostało użyte w pracy T. Scitovskiego z roku $1940^{41} \mathrm{w}$ odniesieniu do opłat transakcyjnych, prowizji oraz podatków związanych z operacjami rynku pieniężnego, natomiast szerzej, gdyż w kontekście całości wymiany towarowej, upowszechnione zostało przez J. Marschaka $\mathrm{w}$ roku $1950^{42}$. Niezerowe koszty transakcyjne powstają jako rezultat faktu, że poza ceną płaconą za dobra podczas ich nabywania na rynku strony transakcji ponoszą też inne koszty, związane z poszukiwaniem kontrahentów, negocjowaniem warunków umowy, opłatami administracyjnymi, ubezpieczeniem transakcji czy ryzykiem niesolidności partnerów ${ }^{43}$.

Poza samym pojęciem kosztów transakcyjnych, źródeł ekonomiki kosztów transakcyjnych jako dziedziny wiedzy ekonomicznej należy doszukiwać się w pracach R. Coase'a ${ }^{44}$, a jej szerokiego rozwinięcia - w pracach O. Williamsona ${ }^{45}$. Obecnie koncepcja oraz pojęcie kosztów transakcyjnych stanowią trwały element niemal każdej analizy podejmowanej $\mathrm{w}$ duchu nowej ekonomii instytucjonalnej. Pierwszy $\mathrm{z}$ wymienionych autorów interpretował to pojęcie przede wszystkim w kontekście wpływu kosztów transakcji na swobodę zawierania umów. Wspomniany wcześniej teoremat Coase’a głosi, że jeśli koszty transakcyjne są zerowe, to korzyści i koszty zewnętrzne nie powodują zawodności rynku, ponieważ obie strony mogą zawrzeć obopólnie korzystne porozumienie. $\mathrm{W}$ tym kontekście podstawową rolą państwa jest takie stanowienie prawa, by

40 J. R. Hicks, A Suggestion for Simplifying the Theory of Money, „Economica” 1935, vol. 2 (5), s. 18.

41 T. Scitovsky, A Study of Interest and Capital, „Economica” 1940, vol. 7 (27), s. 293317.

42 J. Marschak, The Rationale for the Demand for Money and for 'Money Illusion', „Metroeconomica" 1950, vol. 2, s. 71-100.

43 M. E. Sokołowicz, Region w gospodarce globalnej - bezpośrednie inwestycje zagraniczne a rozwój regionu, [w:] A. Nowakowska, Z. Przygodzki, M. E. Sokołowicz, Region w gospodarce opartej na wiedzy. Kapitat ludzki - innowacje - korporacje transnarodowe, Difin, Warszawa 2011, s. 142.

44 R. Coase, The Nature of the Firm, „Economica” 1937, 4 (16), s. 386-405.

45 O. Williamson, Market and Hierarchies. Analysis and Antitrust Implications, Free Press, New York 1975. 
minimalizować koszty transakcyjne, które stanowią „tarcie” dla porozumień zawieranych $\mathrm{w}$ warunkach gospodarki wolnorynkowej. Warto jednak podkreślić, że w świecie rzeczywistym teoremat ten nigdy nie został zweryfikowany empirycznie ani pozytywnie, ani negatywnie, bowiem $\mathrm{w}$ praktyce koszty transakcyjne są zawsze dodatnie, a rolą systemu prawnego jest ich minimalizowanie ${ }^{46}$. Podejście Coase’a do zagadnienia kosztów transakcyjnych doprowadziło jednak do wniosku, że w warunkach zawodności rynku kontrola efektów zewnętrznych przez podmioty sektora publicznego nie jest rozwiązaniem absolutnym, lecz zależnym od tego, który rodzaj reakcji jest bardziej efektywny (negocjacje odbywające się w warunkach wolnego rynku czy też sankcjonowane przez państwo i prawo instytucje formalne).

W konsekwencji przytoczonych wyżej rozważań ekonomiści zaczęli coraz częściej brać w pod uwagę fakt istotnego wpływu poziomu kosztów transakcyjnych na funkcjonowanie gospodarki. Wysokość tych kosztów uznaje się przy tym za czynnik decydujący o złożoności struktur organizacyjnych oraz o zakresie ingerencji sektora publicznego w procesy ekonomiczne (por. rys. 9).

\begin{tabular}{l|r}
$\begin{array}{l}\text { granica } \\
\text { targowanie się jest pomyślne; } \\
\text { prawa nie mają znaczenia } \\
\text { dla efektywności (rynek) }\end{array}$ & $\begin{array}{r}\text { targowanie się zawodzi; } \\
\text { prawa mają znaczenie dla } \\
\text { efektywności (prawo) }\end{array}$ \\
\hline
\end{tabular}

niskie

koszty transakcyjne

wysokie

Rys. 9. Poziom kosztów transakcyjnych jako granica zastosowania twierdzenia Coase'a

Źródło: R. Cooter, Th. Ulen, Ekonomiczna analiza prawa, C.H. Beck, Warszawa 2009, s. 112.

Sam Coase wyróżnił dwa rodzaje kosztów transakcyjnych: 1) koszty hierarchicznego zarządzania w firmie oraz 2) koszty transakcji rynkowych. Z czasem zaczęto wyróżniać także 3) polityczne koszty transakcyjne, rozumiane jako koszty utrzymania struktury instytucjonalno-prawnej, finansowanej z budżetu (tab. 11) ${ }^{47}$.

46 S. G. Medema, R. O. Zerbe, The Coase Theorem, [w:] B. Bouckaert, G. De Geest (eds.), Encyclopedia of Law and Economics, vol. I: The History and Methodology of Law and Economics, Edward Elgar, Cheltenham 1999, s. 836-892.

47 J. Godłów-Legiędź, Instytucje i koszty transakcji jako podstawowe pojęcie nowej ekonomii instytucjonalnej, [w:] eadem (red.), Instytucje i transformacja, Wyd. Adam Marszatek, Toruń 2009, s. 22. 
Tabela 11. Rodzaje i przykłady kosztów transakcji

\begin{tabular}{|c|c|c|}
\hline Typ kosztów transakcji & $\begin{array}{c}\text { Rodzaje kosztów } \\
\text { składających się na dany typ } \\
\text { kosztów transakcji }\end{array}$ & Przykłady \\
\hline \multirow{3}{*}{$\begin{array}{l}\text { Koszty transakcji ryn- } \\
\text { kowych (koszty sponta- } \\
\text { nicznego mechanizmu } \\
\text { kooperacji opartej na } \\
\text { konkurencji) }\end{array}$} & $\begin{array}{l}\text { Koszty związane ze zdobywa- } \\
\text { niem informacji niezbędnych } \\
\text { do zawierania umów kupna- } \\
\text {-sprzedaży. }\end{array}$ & $\begin{array}{l}\text { Marketing, czas i środki po- } \\
\text { święcone na zdobywanie infor- } \\
\text { macji o potencjalnych kontra- } \\
\text { hentach. }\end{array}$ \\
\hline & $\begin{array}{l}\text { Koszty negocjowania warun- } \\
\text { ków umów. }\end{array}$ & Koszty obsługi prawnej umów. \\
\hline & $\begin{array}{l}\text { Koszty związane z realizacją } \\
\text { wynegocjowanych warunków } \\
\text { umowy. }\end{array}$ & $\begin{array}{l}\text { Straty z tytułu niedotrzyma- } \\
\text { nia umowy przez kontrahenta, } \\
\text { koszty monitorowania procesu } \\
\text { realizacji umów. }\end{array}$ \\
\hline \multirow{2}{*}{$\begin{array}{l}\text { Koszty zarządzania } \\
\text { w przedsiębiorstwie } \\
\text { (koszty organizacji } \\
\text { hierarchicznej) }\end{array}$} & $\begin{array}{l}\text { Koszty stałe* związane z utrzy- } \\
\text { maniem struktury organizacji } \\
\text { przedsiębiorstwa. }\end{array}$ & $\begin{array}{l}\text { Place kierownictwa, nakła- } \\
\text { dy na systemy informacyjne } \\
\text { w przedsiębiorstwie. }\end{array}$ \\
\hline & $\begin{array}{l}\text { Koszty zmienne związane z po- } \\
\text { dejmowaniem decyzji w przed- } \\
\text { siębiorstwie. }\end{array}$ & $\begin{array}{l}\text { Koszty nadzoru nad pracowni- } \\
\text { kami, koszty związane z trans- } \\
\text { ferem produktów i półproduk- } \\
\text { tów w przedsiębiorstwie. }\end{array}$ \\
\hline $\begin{array}{l}\text { Polityczne koszty } \\
\text { transakcji }\end{array}$ & $\begin{array}{l}\text { Koszty tworzenia, utrzymania } \\
\text { i zmian sytemu formalnych in- } \\
\text { stytucji i organizacji politycz- } \\
\text { nych, czyli koszty związane } \\
\text { z tworzeniem i funkcjonowa- } \\
\text { niem ustroju politycznego. }\end{array}$ & $\begin{array}{l}\text { Koszty utrzymania parlamen- } \\
\text { tu, administracji publicznej, } \\
\text { sądownictwa, policji. }\end{array}$ \\
\hline
\end{tabular}

* Podział na stałe i zmienne koszty zarządzania za: E. G. Furubotn, R. Richter, Insititutions and Economic Theory. The Contribution of the New Institutional Economics, The University of Michigan Press, Ann Arbor 2000, s. 46.

Źródło: J. Godłów-Legiędź, Instytucje i koszty transakcji jako podstawowe pojęcie nowej ekonomii instytucjonalnej, [w:] eadem (red.), Instytucje i transformacja, Wyd. Adam Marszałek, Toruń 2009, s. 23.

Poziom kosztów transakcyjnych nie decyduje jedynie o zakresie ingerencji sektora publicznego w procesy gospodarcze, lecz także o skali złożoności struktur organizacyjnych samych przedsiębiorstw oraz o skali sektorów gospodarki, których rolą jest minimalizacja tego rodzaju kosztów. Stąd - poza analizą wpływu kosztów transakcyjnych na wielkość sektora publicznego w gospodarce - można wyróżnić następujące kluczowe obszary zainteresowania teorii kosztów transakcyjnych: 
1. Analiza wpływu kosztów transakcyjnych na powstawanie i rozwój struktur organizacyjnych przedsiębiorstw (dylemat „rynek vs. hierarchia").

2. Analiza wpływu „kosztów transakcyjnych” występujących wewnątrz struktur organizacyjnych na procesy zarządzania („problem agencji").

3. Analiza wpływu kosztów transakcyjnych na poziom rozwoju tzw. sektora transakcyjnego w gospodarce, tj. gałęzi gospodarki, których celem jest minimalizacja kosztów transakcyjnych.

W pierwszym przypadku teoria kosztów transakcyjnych podejmuje próbę odpowiedzi na pytanie, jaki jest wpływ wysokości kosztów transakcyjnych na złożoność struktur organizacyjnych w gospodarce. Dyskusję na ten temat zapoczątkował R. Coase w pracy o znamiennym tytule Natura przedsiębiorstwa ${ }^{48}$, zadając w niej fundamentalne pytanie, dlaczego w warunkach gospodarki rynkowej przedsiębiorstwa w ogóle powstają. Odpowiedzią było uznanie, że koszty funkcjonowania wolnego rynku są niezerowe i tworzenie przedsiębiorstw stanowi sposób na uniknięcie tego typu kosztów. W konsekwencji firmy będą powstawały i ich rozmiar będzie się zwiększał, dopóki koszt zorganizowania dodatkowej transakcji w ramach przedsiębiorstwa zrówna się z kosztem prowadzenia tej samej transakcji $\mathrm{z}$ wykorzystaniem rynkowego mechanizmu wymiany lub kosztem zorganizowania tejże transakcji przez inną firmę ${ }^{49}$.

Innymi słowy, w przypadku braku specyficzności aktywów, prostych dóbr i usług, wytypowaniu niewielkiej liczby partnerów transakcji, wysokiego poziomu zaufania stron transakcji ${ }^{50}$ czy niskich kosztów monitorowania realizacji kontraktów (por. tab. 12) poziom kosztów transakcyjnych pozwala na funkcjonowanie w warunkach wolnego rynku. Natomiast wzrost kosztów transakcyjnych pociąga za sobą konieczność wprowadzania coraz bardziej złożonych rozwiązań instytucjonalnych, mających na celu zabezpieczenie zawieranych transakcji (rys. 10).

48 R. H. Coase, The Nature...

49 Ibidem, s. 395, [cyt. za:] Ł. Hardt, Ekonomia kosztów transakcyjnych..., s. 209-210).

50 W tym miejscu należy zasygnalizować, że w świetle badań empirycznych czynnikiem zwiększającym poziom specyficzności aktywów oraz ograniczania kosztów transakcyjnych w warunkach zaufania pozostaje niejednokrotnie bliskość w wymiarze fizycznym (J. P. H. Fan, Price Uncertainity and Vertical Integration: An Examination of Petrochemical Firms, „Journal of Corporate Finance: Contracting, Governance, and Organizaton" 2000, vol. 6, s. 629-660; P. L. Joskow, Contract Duration and Relationship-specific Investment: Empirical Evidence from Coal Markets, „American Economic Review” 1987, vol. 77 (1), s. 168-185). 
Tabela 12. Czynniki decydujące o wysokości kosztów transakcyjnych

\begin{tabular}{|c|c|c|}
\hline $\begin{array}{l}\text { Etap genero- } \\
\text { wania kosztów } \\
\text { transakcyjnych }\end{array}$ & Niższe koszty transakcyjne & Wyższe koszty transakcyjne \\
\hline $\begin{array}{l}\text { Koszty } \\
\text { poszukiwania } \\
\text { kontrahentów }\end{array}$ & $\begin{array}{l}\text { 1. Wystandaryzowane dobro } \\
\text { lub usługa }\end{array}$ & 1. Skomplikowane prawa \\
\hline \multirow{7}{*}{$\begin{array}{l}\text { Koszty } \\
\text { negocjowania } \\
\text { warunków } \\
\text { transakcji }\end{array}$} & 2. Jasne, proste prawa & 2. Unikatowe dobro lub usługa \\
\hline & 3. Niewielka liczba stron & 3. Duża liczba stron \\
\hline & 4. Zaprzyjaźnione strony & 4. Wrogie strony \\
\hline & 5. Znające się strony & 5. Nieznające się strony \\
\hline & 6. Rozsądne zachowanie & 6. Nierozsądne zachowanie \\
\hline & 7. Natychmiastowa wymiana & 7. Wymiana rozłożona w czasie \\
\hline & 8. Wymiana bezwarunkowa & $\begin{array}{l}\text { 8. Wymiana z zastrzeżeniem licz- } \\
\text { nych warunków lub terminów }\end{array}$ \\
\hline \multirow{2}{*}{$\begin{array}{l}\text { Koszty } \\
\text { monitoringu } \\
\text { realizacji } \\
\text { transakcji }\end{array}$} & 9. Niskie koszty monitoringu & 9. Wysokie koszty monitoringu \\
\hline & 10. Tanie kary & 10. Kosztowne kary \\
\hline
\end{tabular}

Źródło: R. Cooter, Th. Ulen, Ekonomiczna analiza prawa, C.H. Beck, Warszawa 2009, s. 111.

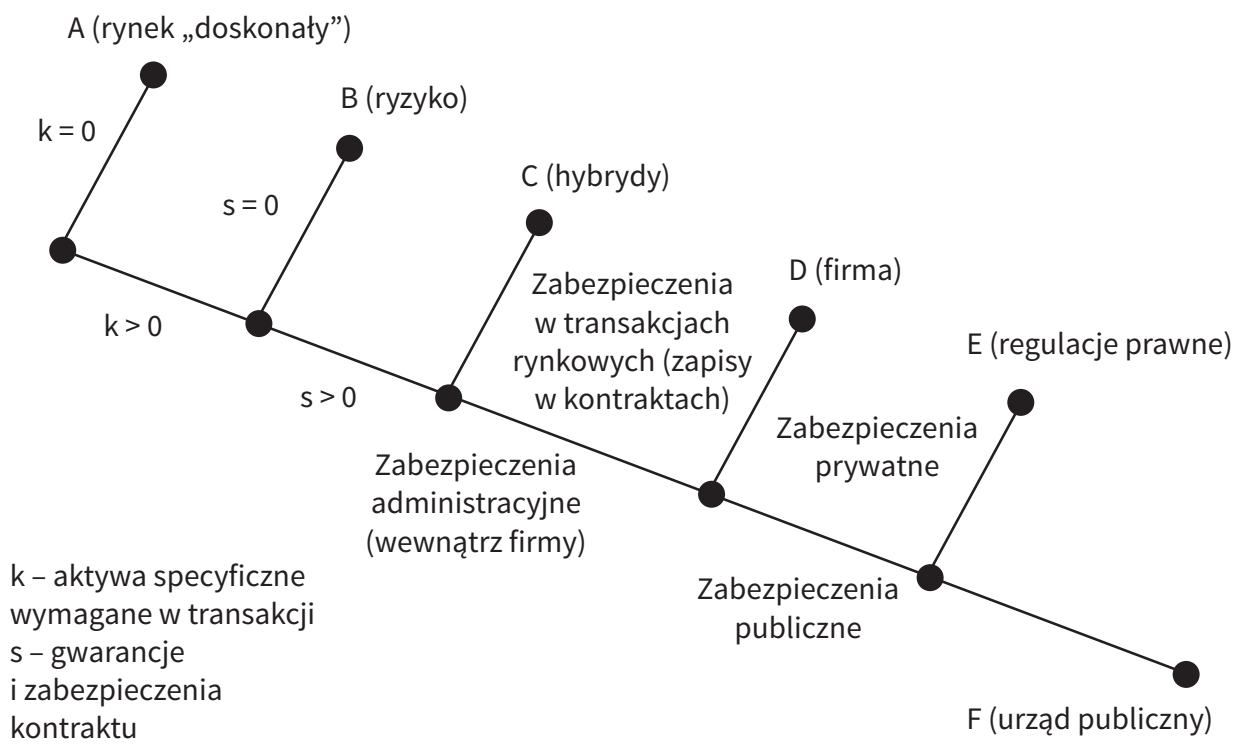

Rys. 10. Struktury zarządzania transakcjami w zależności od poziomu kosztów transakcyjnych Źródło: O. E. Williamson, Transaction Cost Economics: How It Works, Where It is Headed, „The Economist” 1998, no. 146, s. 47. 
Brak skłonności do ponoszenia ryzyka wynikającego z zawierania skomplikowanych kontraktów w warunkach wolnego rynku skłania do tworzenia struktur hierarchicznych, prowadzących do internalizacji części zawieranych transakcji w ramach przedsiębiorstw. Jeśli natomiast włączenie pewnych operacji gospodarczych $\mathrm{w}$ struktury organizacyjne przedsiębiorstwa jest zabiegiem niewystarczającym (np. w warunkach niepewności funkcjonowania otoczenia, pokusy nadużyć ze strony partnerów transakcji itp.), konieczne może okazać się wprowadzenie instytucji stanowiących zabezpieczenia publiczne $\mathrm{w}$ formie stosownych regulacji prawnych lub funkcjonowania podmiotów sektora publicznego (urzędów).

Analiza kosztów dokonywania transakcji na rynku, tj. poza przedsiębiorstwem, nie wyczerpuje jednak w pełni zagadnienia internalizacji działalności. Włączenie w struktury organizacyjne podmiotu gospodarczego nowych typów działalności w celu obniżenia rynkowych kosztów transakcji generuje bowiem koszty innego rodzaju. Należą do nich m.in. koszty szkolenia nowej kadry, stworzenia nowych procedur organizacyjnych, koszty rozpoznania rynku, związane z ryzykiem działalności w nieznanym dotychczas otoczeniu itp.

W związku z tym obok tradycyjnego modelu wyboru między tzw. hierarchiq a rynkiem występować mogą formy pośrednie, stwarzające pole dla partnerskiego współdziałania przedsiębiorstw, zwane hybrydami (por. tab. 13). Do tego typu form należy zaliczyć sieci (w tym lokalne sieci produkcyjne), alianse strategiczne, umowy franczyzowe itp. Do kluczowych przyczyn tworzenia takich pośrednich struktur organizacyjnych zalicza się m.in. ${ }^{51}$ :

1. Akceptowanie konieczności podziału praw pomiędzy partnerami w ramach sieci, w celu sprostania złożoności i zmienności otoczenia.

2. Poszukiwanie wartości dodanej ze współpracy:

a) powiększanie skali dostępu do zasobów partnera,

b) korzystanie z komplementarności zasobów,

c) możliwości uczenia się od partnera,

d) spodziewany pozytywny efekt marketingowy.

3. Trudność w oszacowaniu z góry (ex ante) wartości kontraktów zawieranych w transakcjach rynkowych i związana z tym nadzieja na zawarcie tego tupu kontraktów ex post (po lepszym rozpoznaniu partnerów w sieci).

51 C. Ménard, Hybrid Organizations, [w:] P. G. Klein, M. E. Sykuta, The Elgar Companion..., s. 179-180. 
Tabela 13. Charakterystyki form organizacyjnych z punktu widzenia kosztów transakcyjnych

\begin{tabular}{|c|c|c|c|}
\hline \multirow[b]{2}{*}{ Charakterystyki } & \multicolumn{3}{|c|}{ Sposób zarządzania } \\
\hline & $\begin{array}{l}\text { rynek } \\
\text { (market) }\end{array}$ & $\begin{array}{c}\text { struktura pośrednia } \\
\text { (hybrid) }\end{array}$ & $\begin{array}{l}\text { hierarchia } \\
\text { (hierarchy) }\end{array}$ \\
\hline $\begin{array}{l}\text { Instrumenty: } \\
\text { - siła bodźców } \\
\text { - } \text { kontrola administracyjna }\end{array}$ & $\begin{array}{c}++ \\
0\end{array}$ & $\begin{array}{l}+ \\
+\end{array}$ & $\begin{array}{c}0 \\
++\end{array}$ \\
\hline $\begin{array}{l}\text { Atrybuty działania: } \\
\text { - zdolność dostosowania do } \\
\text { warunków zewnętrznych } \\
\text { - zdolność do wewnętrznej } \\
\text { koordynacji }\end{array}$ & $\begin{array}{l}++ \\
0\end{array}$ & $\begin{array}{l}+ \\
+\end{array}$ & $\begin{array}{l}0 \\
++\end{array}$ \\
\hline Prawo kontraktowe & $\begin{array}{c}++ \\
\text { klasyczne* }\end{array}$ & $\stackrel{+}{\stackrel{+}{\text { neoklasyczne }}}$ & $\begin{array}{c}0 \\
\text { forbearance }{ }^{\star \star \star}\end{array}$ \\
\hline
\end{tabular}

(++) Silne; (+) średnie; (0) słabe.

* 1 . Tożsamość stron transakcji jest traktowana jako nieistotna. 2. Trzecia strona nie jest potrzebna - transakcje odbywają się bez zakłóceń. 3. Warunki kontraktu są starannie określone nie ma miejsca na niepewność.

** Umowy są niekompletne, pojawia się konieczność zaangażowania trzeciej strony.

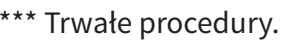

Źródto: Na podstawie O. E. Williamson, Comparative Economic Organization: The Analysis of Discrete Structural Alternatives, „Administrative Science Quarterly” 1991, vol. 36 (2), s. 281, zmodyfikowane przez: $Ł$. Hardt, Ekonomia kosztów transakcyjnych - geneza i kierunki rozwoju, Wyd. Uniwersytetu Warszawskiego, Warszawa 2009, s. 160.

W warunkach upowszechnionego rozwoju złożonych struktur organizacyjnych - pośrednich między hierarchią a rynkiem - dostrzega się rosnącą rolę bliskości fizycznej w procesach gospodarowania. A. Scott wysuwa tezę, że skoro rosnące znaczenie korzyści wynikających z różnorodności zwiększa elastyczność systemu produkcyjnego i zastępuje duże, skoncentrowane przedsiębiorstwa wykorzystujące korzyści skali, to mniej efektywna, przestrzenna, fordowska organizacja tych systemów (zintegrowanych pionowo) ustępowałaby miejsca skupieniom przedsiębiorstw zorganizowanych w sieci i poszukujących minimalnych kosztów transakcji ${ }^{52}$. Warunkiem wysokiej efektywności funkcjonowania takich

52 A. Scott, L'économie métropolitaine: organisation industrielle et croissance urbaine, [w:] G. Benko, A. Lipietz (eds.), Les régions qui gagnent, Presses Universitaires de France, Paris 1992, s. 118-120, [cyt. za:] A. Jewtuchowicz, Terytorium i współczesne dylematy jego rozwoju, Wyd. Uniwersytetu Łódzkiego, Łódź 2005, s. 125. 
systemów pozostaje jednak istnienie dobrze funkcjonującego, zakorzenionego terytorialnie otoczenia instytucjonalnego, ograniczającego te koszty. Wydaje się, że jedynie w takich warunkach spełnione jest założenie, zgodnie z którym hybrydowe formy organizacyjne pozwalają na optymalizację relacji między kosztami zarządzania strukturą organizacji a korzyściami wynikającymi z kontroli i koordynacji posiadanych zasobów (rys. 11).

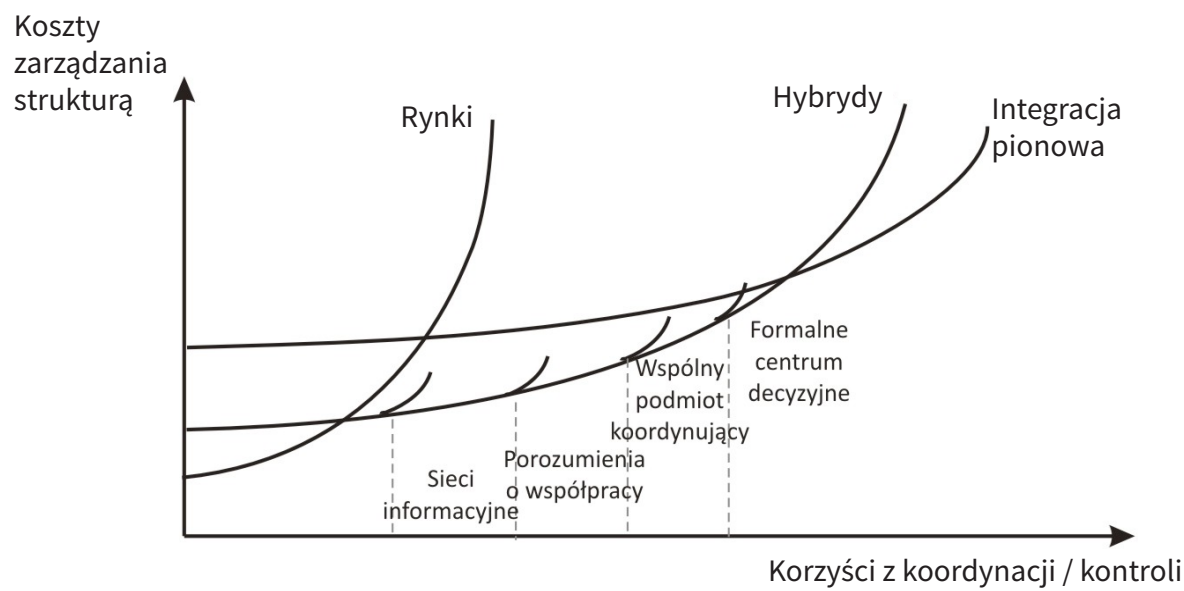

Rys. 11. Formy hybrydowych struktur organizacyjnych a koszty zarządzania

Źródto: C. Ménard, Hybrid Organizations, [w:] P. G. Klein, M. E. Sykuta, The Elgar Companion to Transaction Cost Economics, Edward Elgar Publishing, Cheltenham-Northampton 2010, s. 182.

Wpływ otoczenia instytucjonalnego na wysokość kosztów transakcyjnych pozostaje zagadnieniem ściśle powiązanym $\mathrm{z}$ ich podziałem na koszty ex ante (poniesionymi) oraz ex post (potencjalnymi). Pierwszy z typów pojawia się w fazie poszukiwania i negocjowania warunków kontraktu, jak również na etapie formułowania warunków umów zawieranych na rynku oraz dostosowania struktury organizacji do warunków kontraktu. Koszty transakcyjne ex post mogą natomiast pojawić się wraz z rozpoczęciem fazy realizacji warunków umów i dotyczą bieżącego zarządzania czy pomiaru mającego na celu weryfikację stopnia realizacji kontraktu. Ponadto, w tej fazie należy uwzględnić koszty potencjalne, jakie pojawiłyby się w przypadku zachowań oportunistycznych co najmniej jednej ze stron umowy, prowadzących do niekompletności lub niezrealizowania kontraktu (por. rys. 12). 


\begin{tabular}{|c|c|c|}
\hline $\begin{array}{l}\text { Dostrzeżenie okazji } \\
\text { do realizacji zysku }\end{array}$ & $\begin{array}{l}\text { Zawarcie } \\
\text { kontraktu }\end{array}$ & $\begin{array}{l}\text { Rozpoczęcie realizacji } \\
\text { kontraktu }\end{array}$ \\
\hline$t-2$ & $t-1$ & $t$ \\
\hline $\begin{array}{l}\text { Koszty poszukiwania } \\
\text { Koszty utworzenia/zmiany } \\
\text { organizacji } \\
\text { Koszty negocjowania }\end{array}$ & $\begin{array}{l}\text { Koszty dostosowania } \\
\text { struktury organizacji do } \\
\text { warunków kontraktu } \\
\text { Wydatki związane } \\
\text { z przygotowaniem do } \\
\text { realizacji umowy } \\
\text { Koszty zabezpieczeń } \\
\text { (redukcji ryzyka w przyszłej } \\
\text { realizacji kontraktu) } \\
\text { Koszty mierzenia }\end{array}$ & $\begin{array}{l}\text { Bieżące koszty zarządzania } \\
\text { Wydatki związane } \\
\text { z niekompletnością } \\
\text { kontraktu i możliwością } \\
\text { zachowań } \\
\text { oportunistycznych (koszty } \\
\text { potencjalne) } \\
\text { Koszty mierzenia }\end{array}$ \\
\hline
\end{tabular}

Rys. 12. Koszty transakcyjne w poszczególnych fazach kontraktowania Źródło: Ł. Hardt, Ekonomia kosztów transakcyjnych - geneza i kierunki rozwoju, Wyd. Uniwersytetu Warszawskiego, Warszawa 2009, s. 230.

Podstawowa różnica między kosztami transakcyjnymi ex ante a kosztami ex post polega na tym, iż o ile w przypadku tych pierwszych można podjąć próbę ich kwantyfikacji, o tyle koszty drugiego rodzaju nie są bezpośrednio mierzalne. Ponadto daje się zauważyć, iż istnieje negatywna korelacja między jednym a drugim rodzajem kosztów, tzn. im większe poniesione koszty na etapie sporządzania umowy (związane z uwzględnieniem większej liczby niespodziewanych sytuacji), tym mniejsze ryzyko poniesienia koszów w przyszłości. Innymi słowy, im większe koszty transakcyjne ex ante, tym mniejsze ryzyko ex post $t^{53}$.

$\mathrm{W}$ rozważaniach na gruncie nowej ekonomii instytucjonalnej podkreśla się również, że minimalizacja kosztów transakcyjnych może odbywać się nie tylko poprzez ponoszenie wyższych kosztów ex ante w zamian za minimalizację ryzyka ex post (lub odwrotnie), lecz także poprzez poprawę warunków instytucjonalnych zawierania umów (wykres 6). Przykładem takiej zmiany instytucjonalnej może być np. wprowadzenie przepisów prawa sprzyjających redukcji ryzyka nieuczciwych zachowań (instytucji formalnych). Równie dobrze może to być też wzajemny wysoki poziom

53 Ł. Hardt, Instytucje a koszty transakcyjne w nowej ekonomii instytucjonalnej, „Gospodarka Narodowa” 2005, nr 1-2, s. 15. 
zaufania i zrozumienia między przedsiębiorcami, który sprzyja bardziej efektywnemu podejmowaniu decyzji oraz $\mathrm{w}$ istotnym stopniu ogranicza ryzyko niepowodzenia (instytucje nieformalne). Dobrym przykładem korzystnego środowiska instytucjonalnego dla ograniczania kosztów transakcyjnych w każdej fazie kontraktowania jest funkcjonowanie rozwiniętych lokalnych środowisk przedsiębiorczości, funkcjonujących w warunkach bliskości przestrzennej.

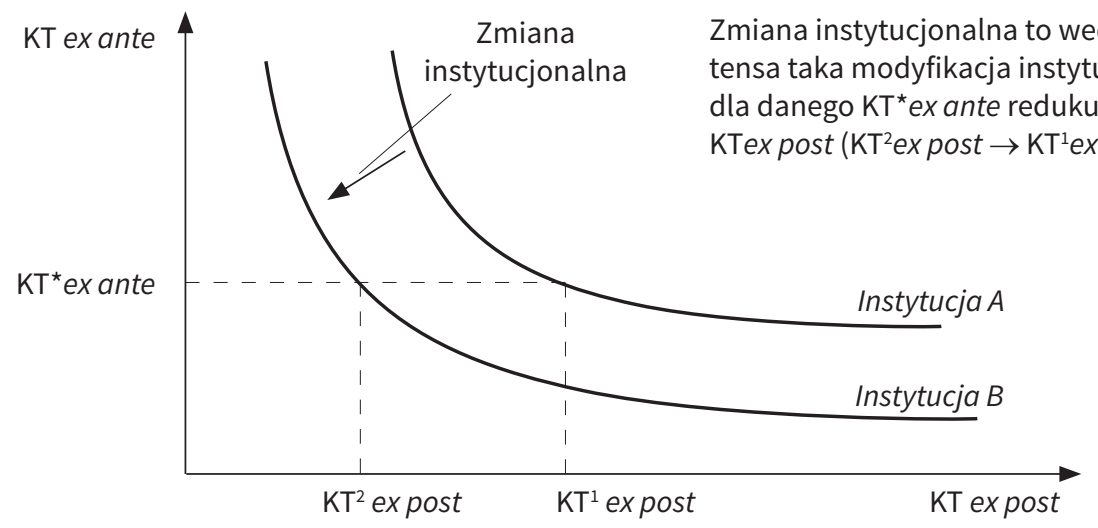

Wykres 6. Wpływ zmiany instytucjonalnej na wysokość kosztów transakcyjnych

Źródło: Ł. Hardt, Instytucje a koszty transakcyjne w nowej ekonomii instytucjonalnej, „Gospodarka Narodowa" 2005, nr 1-2, s. 16, [cyt. za:] B. Martens, The Cognitive Mechanics of Economic Development and Institutional Change, Routledge, London-New York 2004.

Założenie o istotnym wpływie otoczenia instytucjonalnego na wysokość kosztów transakcyjnych nawiązuje do zaproponowanego przez J. Greena i E. Sheshinskiego podziału na tzw. efektywność technologiczną i instytucjonalną $a^{54}$. Pierwszy jej typ oznacza najlepszą dostępną alokację zasobów przy danym środowisku regulacyjno-instytucjonalnym i technologii transakcji, natomiast drugi - najlepszą alokację zasobów przy hipotetycznym „najlepszym” układzie instytucjonalnym. Jeśli koszty transakcyjne są niezerowe, wówczas efektywność technologiczna jest różna niż efektywność instytucjonalna, co skłania m.in. do interwencjonizmu sektora publicznego $\mathrm{w}$ gospodarkę, a także stanowi podstawową przyczynę ekonomiczną powstawania przedsiębiorstw jako sposobu na internalizację części kosztów transakcyjnych.

54 J. Green, E. Sheshinski, Competitive Inefficiencies in the Presence of Constrained Transactions, „Journal of Economic Theory” 1975, vol. 10 (3). 
Należy wszak pamiętać, że w szerokim ujęciu koszty transakcyjne pojawiają się nie tylko w wyniku interakcji gospodarczych zachodzących na rynku, lecz powstają $w$ ramach przedsiębiorstw $i$ innych organizacji, $w$ tym w organizacjach sektora publicznego. Innymi słowy, wyróżnione na wstępie polityczne koszty transakcyjne, podobnie jak rynkowe koszty transakcyjne, nigdy w praktyce gospodarczej nie są zerowe. W przypadku realizowania polityk publicznych pojawiają się one zarówno na etapie ustanawiania zasad przepisów prawa i późniejszego ich przestrzegania, jak i na etapie funkcjonowania organizacji sektora publicznego oraz ich interesariuszy (tab. 14).

Tabela 14. Typologia kosztów transakcyjnych związanych z funkcjonowaniem sektora publicznego

\begin{tabular}{|c|c|c|c|}
\hline \multirow{2}{*}{$\begin{array}{l}\text { Typ kosztów } \\
\text { transakcyjnych }\end{array}$} & \multicolumn{3}{|c|}{ Źródła kosztów transakcyjnych } \\
\hline & $\begin{array}{l}\text { legislatywa/ } \\
\text { sądownictwo }\end{array}$ & $\begin{array}{l}\text { organizacje sektora } \\
\text { publicznego }\end{array}$ & interesariusze \\
\hline Poszukiwania informacji & + & ++ & + \\
\hline $\begin{array}{l}\text { Ustanowienia zasad i ich } \\
\text { przestrzegania }\end{array}$ & ++ & + & ++ \\
\hline $\begin{array}{l}\text { Utworzenia struktur } \\
\text { organizacyjnych }\end{array}$ & & ++ & + \\
\hline $\begin{array}{l}\text { Funkcjonowania struktur } \\
\text { organizacyjnych }\end{array}$ & & ++ & + \\
\hline $\begin{array}{l}\text { Zawierania umów } \\
\text { publicznych }\end{array}$ & & + & ++ \\
\hline Monitorowania & & ++ & + \\
\hline Egzekwowania praw & + & ++ & + \\
\hline
\end{tabular}

() Zerowe koszty transakcyjne; (+) niskie koszty transakcyjne; (++) wysokie koszty transakcyjne.

Źródło: L. McCann et al., Transaction Cost Measurement for Evaluating Environmental Policies, „Ecological Economics” 2005, vol. 52, s. 533.

Specyficznym typem kosztów transakcyjnych pozostają koszty funkcjonowania samych organizacji, w ramach których również dochodzi do zawierania wewnętrznych „transakcji” (np. umowa o pracę może być interpretowana jako kontrakt między pracodawcą a pracownikiem). Odmianą teorii kosztów transakcyjnych zajmującą się tym rodzajem kosztów jest tzw. teoria agencji, której nazwa wynika z podziału członków organizacji na tzw. agentów i pryncypałów. Zadaniem agenta w ramach organizacji jest wykonywanie zadań w imieniu oraz na rzecz pryncypała, którym jest podmiot sprawujący kontrolę nad organizacją (jako właściciel, udziałowiec itp.) (tab. 15). 
Tabela 15. Przegląd założeń teorii agencji

\begin{tabular}{|c|c|}
\hline Główna idea & $\begin{array}{l}\text { Relacje między agentem i pryncypałem powinny zapewniać } \\
\text { efektywne funkcjonowanie organizacji, przepływ informacji } \\
\text { i podział ryzyka. }\end{array}$ \\
\hline Jednostka analizy & Umowa (kontrakt) między pryncypałem i agentem. \\
\hline $\begin{array}{l}\text { Założenia co do } \\
\text { ludzkich cech }\end{array}$ & $\begin{array}{l}\text { 1. Obie strony dążą do maksymalizacji własnej użyteczności } \\
\text { (self-interest). } \\
\text { 2. Działanie w warunkach ograniczonej racjonalności (bounded } \\
\text { rationality). } \\
\text { 3. Występowanie odmiennego poziomu awersji do ryzyka obu } \\
\text { stron kontraktu. }\end{array}$ \\
\hline $\begin{array}{l}\text { Założenia w stosunku } \\
\text { do organizacji }\end{array}$ & $\begin{array}{l}\text { Między członkami organizacji występują konflikty celów. } \\
\text { Podstawowym kryterium analizy jest efektywność. } \\
\text { Między pryncypałem i agentem występuje asymetria informacji. }\end{array}$ \\
\hline $\begin{array}{l}\text { Założenia w stosunku } \\
\text { do informacji }\end{array}$ & Informacja jest traktowana jako towar dający się wycenić. \\
\hline $\begin{array}{l}\text { Problemy związane } \\
\text { ze sformutowaniem } \\
\text { umowy }\end{array}$ & $\begin{array}{l}\text { Problem agencji wynika ze zjawisk: } \\
\text { 1. Ryzyka nadużycia ze strony agenta (moral hazard). } \\
\text { 2. Negatywnej selekcji (adverse selection). } \\
\text { 3. Dążenia do sformułowania kontraktu jasno precyzującego } \\
\text { podział ryzyka. }\end{array}$ \\
\hline Obszar problemowy & $\begin{array}{l}\text { Relacje między agentem i pryncypałem są zawsze obarczone } \\
\text { różnicami w celach, do których dążą oraz w preferencjach co do } \\
\text { ponoszenia ryzyka (agenta cechuje większa awersja do ryzyka } \\
\text { niż pryncypała). } \\
\text { Występują zatem różnorodne narzędzia zarządzania tymi rela- } \\
\text { cjami, takie jak: systemy regulacji w ramach organizacji, przy- } \\
\text { wództwo w organizacji, zarządzanie emocjami pracowników, } \\
\text { ujawnianie nieprawidłowości w organizacji (whistle-blowing), } \\
\text { rekompensaty za wysiłek, integracja pionowa w organizacji, sto- } \\
\text { sowanie cen transferowych itp. }\end{array}$ \\
\hline
\end{tabular}

Źródło: K. Eisenhardt, Agency Theory: An Assessment and Review, „Academy of Management Review" 1989, vol. 14 (1), s. 59.

Podstawowy problem $\mathrm{w}$ teorii agencji wynika przy tym $\mathrm{z}$ asymetrii informacji, tj. agent ma znaczny zakres wiedzy na temat mechanizmów funkcjonowania organizacji, podczas gdy pryncypał ma trudności w jego 
kontrolowaniu ${ }^{55}$. W efekcie, na gruncie teorii agencji analizuje się przede wszystkim dwa kluczowe zagadnienia ${ }^{56}$ :

1) problem rozbieżności celów pryncypała i agenta,

2) wysokie koszty „transakcyjne” kontroli agenta przez pryncypała, spowodowane $\mathrm{z}$ jednej strony występowaniem zjawiska asymetrii informacji, z drugiej zaś - różnicą w preferencjach dotyczących skłonności do ryzyka (agenta cechuje zwykle większa awersja do ryzyka niż pryncypała).

W konsekwencji ponieważ agent może nie podzielać (i przeważnie nie podziela) tych samych wartości, co osoba delegująca uprawnienia, sprawowanie nadzoru nad zachowaniem agenta jest kosztowne i trudne ${ }^{57}$. Celem teorii agencji jest $\mathrm{w}$ tych warunkach dążenie do stworzenia takiego kontraktu w ramach organizacji, który zbędzie zapewniał minimalizację kosztów transakcyjnych tego procesu.

W ramach teorii agencji wyróżnia się zazwyczaj dwa jej nurty: pozytywistyczny i ogólny ${ }^{58}$. Pierwszy nurt, rozpoczęty artykułem M. Jensena i W. Mecklinga z $1976 \mathrm{r}^{59}$, pozostaje mniej rygorystyczny metodologicznie i zajmuje się przede wszystkim analizą struktur korporacyjnych. $\mathrm{Na}$ jego gruncie, $w$ wyniku podejmowanych badań wyodrębniono dwa zasadnicze czynniki prowadzące do sytuacji, w której agent wykazuje większą skłonność do zachowań zgodnych z interesem pryncypała. Pierwszy $\mathrm{z}$ nich wiąże się z takim sformułowaniem warunków kontraktu, aby umowa między agentem i pryncypałem była oparta na osiąganych wynikach, natomiast drugi czynnik dotyczy sytuacji, w której pryncypał posiada informacje umożliwiające mu skuteczną weryfikację zachowań agenta.

Nurt pozytywistyczny uznawany jest za silnie oddający istotę teorii agencji i ceniony za prostotę poznawczą. Krytykowany jest natomiast głównie za minimalizm oraz za podejście nieco tautologiczne i pozba-

55 Klasyczny model agencji opisują m.in.: S. A. Ross, The Economic Theory of Agency: The Principal's Problem, „American Economic Review” 1977, vol. 63, s. 134-139;

B. Holmstrom, Moral Hazard in Teams, „Bell Journal of Economics” 1982, vol. 13 (2), s. 324-340; K. Arrow, Agency and the Market, [w:] K. Arrow, M. D. Intrilligator (eds.), Handbook of Mathematical Economics, vol. 3, Elsevier, Amsterdam 1986, s. 1183-1195; D. Levinthal, A Survey of Agency Models of Organizations, „Journal of Economic Behavior and Organization" 1988, vol. 9; K. Eisenhardt, Agency Theory..., s. 67-74; S. P. Shapiro, Agency Theory, „Annual Review of Sociology” 2005, vol. 31, s. 263-284

56 K. Eisenhardt, Agency Theory..., s. 58.

57 J. G. March, J. P. Olsen, Instytucje. Organizacyjne podstawy polityki, Scholar, Warszawa 2005, s. 38.

58 K. Eisenhardt, Agency Theory..., s. 59.

59 M. Jensen, W. Meckling, Theory of the Firm: Managerial Behavior, Agency Costs, and Ownership Structure, „Journal of Financial Economics” 1976, vol. 3, s. 305-360. 
wione rygoru metodologicznego. Na skutek tego z czasem dynamicznie zaczął rozwijać się drugi nurt, który poszukuje daleko idących uogólnień (generalizacji), co jednak determinuje większy rygor metodologiczny (ze staranną specyfikacją założeń i dedukcją logiczną) oraz formalizację matematyczną testowanych modeli empirycznych.

Warto podkreślić, że choć teoria agencji rozwija się najbardziej dynamicznie na gruncie nauk ekonomicznych, rośnie też zainteresowanie tym nurtem wśród przedstawicieli innych nauk, $\mathrm{w}$ tym przede wszystkim socjologów i politologów ${ }^{60}$. Nieekonomiści zajmujący się problemem agencji odrzucają wiele upraszczających założeń - dopuszczają wielość agentów i pryncypałów w ramach jednej organizacji; dostrzegają, że obok zachowań związanych z maksymalizacją własnej użyteczności pojawiają się zachowania altruistyczne; uświadamiają niestabilność i nieczytelność preferencji, jak również problemy w zidentyfikowaniu skutecznych bodźców dla agentów. Wreszcie, w mniej rygorystycznych metodologicznie analizach silny nacisk kładzie się na uwzględnianie kontekstu historycznego, kulturowego oraz zmienności w czasie relacji między pryncypałem i agentem. Warto zauważyć, że w takim ujęciu teoria agencji może okazać się użyteczna w interpretacji mechanizmów działających nie tylko w przedsiębiorstwach, lecz także $\mathrm{w}$ ramach bardziej złożonych struktur rządzenia. System polityczny można bowiem rozumieć jako złożoną sieć relacji miedzy pryncypałami i agentami, składającą się z obywateli, państw, urzędników, prawodawców, członków władzy wykonawczej, organów administracyjnych, sądów, organizacji międzynarodowych, ambasadorów, urzędników, żołnierzy, policjantów itd. W zależności od kontekstu i struktury politycznej wymienione podmioty mogą przy tym odgrywać równocześnie role pryncypałów i agentów ${ }^{61}$.

Należy w tym miejscu zauważyć, że nawet identyfikowane na gruncie nowego instytucjonalizmu krytyczne podejście do teorii agencji, w pewnym sensie mimo wszystko zainspirowało do operacjonalizacji analiz relacji zachodzących wewnątrz struktur organizacyjnych. Przykładem tego jest tzw. model kosza na śmieci (garbage can model), zaproponowany przez Marcha i Olsena ${ }^{62}$. Autorzy zgadzają się, podobnie jak zwolennicy teorii agencji, że procesom w ramach organizacji towarzyszy wewnętrzna - choć

60 Teoria agencji rozwinęła się w tym samym niemal czasie na gruncie nauk ekonomicznych (S. A. Ross, The Economic Theory...) i politologicznych (B. M. Mitnick, Fiduciary Responsibility and Public Policy: The Theory of Agency and Some Consequences, presented at $69^{\text {th }}$ Annual Meeting of American Political Science Association, New Orleans 1973). Ponieważ jednak sprawniej rozwinęła się w ekonomii, to dziś z niej zapożyczają politolodzy, a nie odwrotnie (szerzej: S. P. Shapiro, Agency Theory..., s. 271).

61 S. P. Shapiro, Agency Theory..., s. 271.

62 J. G. March, J. P. Olsen, Instytucje..., s. 21-25. 
złożona - logika działania, wynikająca z różnorodności potrzeb, aspiracji i celów poszczególnych członków organizacji. Krytyczne podejście do upraszczających założeń teorii agencji wyraża się przez obserwację, że wiele współcześnie funkcjonujących struktur organizacyjnych pozostaje strukturami niezwykle złożonymi, a ich elementy („aktorów”) cechuje odmienność postaw i funkcji celów. Determinuje to brak jasnych reguł oraz częstą przypadkowość lub wręcz chaotyczność decyzyjną, wzmacnianą dotykowo faktem, iż współcześnie coraz większa liczba decyzji podejmowana jest w sytuacji dużej presji czasu i złożoności sytuacji ${ }^{3}$.

W czystej postaci model kosza na śmieci zakłada, że problemy, rozwiązania, decydenci i możliwości wyboru są niezależnymi, egzogenicznymi strumieniami przepływającymi przez system. $\mathrm{W}$ ramach takiego systemu

jednostki walczą o prawo do udziału w podejmowaniu decyzji, a następnie niezbyt ochoczo z niego korzystają. Decydenci nie uwzględniają posiadanych informacji, żądają ich więcej, po czym ignorują nowe informacje, gdy są one dostępne. Organizacje oddzielają procesy koncepcyjne od procesów operacyjnych. Dyrektorzy poświęcają dużo czasu na czynności, które wydają się jedynie potwierdzać ważność innych, jak również ich samych. Mało znaczące problemy wywołują kryzysy rządowe i niespodziewane reakcje polityczne, a następnie mijają. Uczestnicy zajadle walczą o przyjęcie pewnej polityki, lecz kiedy to już nastąpi, ci sami walczący w dużym stopniu wydają się podchodzić obojętnie do jej realizacji lub zarzucenia ${ }^{64}$.

Organizacja tego typu posiada następujące cechy ${ }^{65}$ :

1. Rozwiązywanie problemów nie jest najczęstszym stylem podejmowania decyzji (zwykle wybory dokonywane są jedynie wówczas, gdy nie wiążą się z żadnymi problemami).

63 Na potrzeby swych rozważań cytowani autorzy wprowadzają modelową koncepcję organizacji, którą nazywają „tymczasowym uporządkowaniem” lub „zorganizowana anarchią" (organized anarchy). Pod tym pojęciem rozumieją organizację niepoddającą się klasycznym analizom procesów decyzyjnych, w której zachodzące procesy i decyzje są efektem wielu złożonych uwarunkowań. Problemy, ich rozwiązania i uczestnicy zachowują sie w ten sposób, że natura decyzji, rodzaje rozwiązywanych problemów i potrzebny do tego czas są konsekwencją bardzo złożonych uwarunkowań. „Zorganizowaną anarchię” charakteryzują: 1) problemy w jednoznacznym zdefiniowaniu zestawu preferencji; 2) niejasne techniki zarządcze - oparte częściej na logice prób i błędów niż na logice przejrzystych procedur; 3) płynne uczestnictwo członków organizacji, którego intensywność jest zmienna w czasie i trudno przewidywalna (M. D. Cohen, J. G. March, J. B. Olsen, A Garbage Can Model of Organizational Choice, „Administrative Science Quarterly” 1972, vol. 17, no. 1, s. 1).

64 J. G. March, J. P. Olsen, Instytucje..., s. 21-22.

65 Ibidem, s. 23. 
2. Zmiany obciążenia wywierają wpływ na proces, np. decydenci są skłonni do częstszego przerzucania uwagi na inne problemy, wydłuża się czas dokonywania wyborów, maleje prawdopodobieństwo rozwiązania problemów.

3. Decydenci i problemy wykazują tendencję do wpływania na siebie samych za pośrednictwem wyborów.

4. Proces jest wyraźnie interakcyjny. Problemy, rozwiązania, decydenci i wybory na skutek jednoczesnej dostępności wzajemnie na siebie oddziałują.

Trzecim istotnym zagadnieniem analizowanym w nawiązaniu do problematyki kosztów transakcyjnych pozostaje analiza wpływu tych kosztów na poziom rozwoju tzw. sektora transakcyjnego w gospodarce. Zalicza się do niego te gałęzie gospodarki, których funkcjonowanie ma na celu minimalizację kosztów transakcyjnych. Wyróżnianie działalności gospodarczych tego typu zapoczątkowało opracowanie Northa i Wallisa, którzy dokonali podziału działalności gospodarczych na transakcyjne (transaction) i wytwórcze (transformation) ${ }^{66}$ (tab. 16).

Tabela 16. Podział działalności na produkcyjną i transakcyjną w gospodarce

\begin{tabular}{|c|c|c|c|}
\hline \multicolumn{2}{|c|}{ Sektor prywatny } & \multicolumn{2}{|c|}{ Sektor publiczny } \\
\hline wytwórczy & transakcyjny & wytwórczy & transakcyjny \\
\hline $\begin{array}{l}\text { Rolnictwo } \\
\text { Budownictwo } \\
\text { Górnictwo } \\
\text { Przemyst } \\
\text { przetwórczy } \\
\text { Transport/ } \\
\text { magazynowanie } \\
\text { Usługi }\end{array}$ & $\begin{array}{l}\text { Pośrednictwo } \\
\text { finansowe (bez } \\
\text { ubezpieczeń) } \\
\text { Ubezpieczenia } \\
\text { Nieruchomości } \\
\text { Handel hurtowy } \\
\text { Handel detaliczny }\end{array}$ & $\begin{array}{l}\text { Edukacja } \\
\text { Ochrona Zdrowia } \\
\text { Transport kolejowy } \\
\text { i powietrzny } \\
\text { Usługi użyteczności } \\
\text { publicznej } \\
\text { Opieka społeczna } \\
\text { Łączność }\end{array}$ & $\begin{array}{l}\text { Administracja } \\
\text { publiczna } \\
\text { Bezpieczeństwo } \\
\text { publiczne } \\
\text { Obrona narodowa } \\
\text { Usługi pocztowe }\end{array}$ \\
\hline
\end{tabular}

Źródło: B. E. Dollery, W. H. Leong, Measuring the Transaction Sector in the Australian Economy 1911-1991, „Australian Economic History Review” 1998, vol. 38, no. 3, s. 209, cyt. za: A. Sulejewicz, P. Graca-Gelert, Ksztattowanie się poziomu kosztów transakcyjnych w Polsce w latach 19962002, [w:] R. Rapacki (red.), Wzrost gospodarczy w krajach transformacji. Konwergencja czy dywergencja?, PWE, Warszawa 2009, s. 225-262.

66 D. C. North, J. J. Wallis, Measuring the Transaction Sector in the American Economy, 1870-1970, [w:] S. L. Engerman, R. E. Gallman, Long Term Factors in American Economic Growth, University of Chicago Press, Chicago 1986, s. 97. 
Zdaniem Northa i Wallisa w latach $1870-1970 \mathrm{w}$ gospodarce amerykańskiej na skutek wzrostu skali wymiany rynkowej, dynamicznie zwiększającej się konsumpcji, rozmiarów i stopnia złożoności struktur organizacyjnych przedsiębiorstw, rosnącej specjalizacji itp. sukcesywnie wzrastało zapotrzebowanie na takie aktywności gospodarcze, które prowadzą do ograniczania kosztów transakcyjnych. W efekcie zarówno w sektorze publicznym, jak i prywatnym istotnie rozwinęły się przedsiębiorstwa sektora transakcyjnego.

Pomimo trudności metodologicznych pomiaru (często trudno jednoznacznie stwierdzić, jakie gałęzie gospodarki należy zaliczyć do sektora transakcyjnego) oraz uwzględnienia pomiaru obsługi jedynie tych transakcji, które „przechodzą przez rynek”, nie ulega wątpliwości, że rozwojowi gospodarczemu krajów kapitalistycznych towarzyszy dynamiczny rozwój usług przyczyniających się do ograniczania kosztów transakcyjnych. Choć trudno nie zgodzić się z tezą Glaesera i współpracowników, że same instytucje nie powodują wzrostu gospodarczego, a niektóre instytucje są nawet efektem wzrostu ${ }^{67}$, nie ulega wątpliwości, że rozwój sektora transakcyjnego (w szerszym ujęciu rozumianego jako otoczenie instytucjonalne transakcji) jest nieuniknionym „instytucjonalnym skutkiem ubocznym" funkcjonowania rozwiniętej gospodarki rynkowej.

Teoria kosztów transakcyjnych stanowi niewątpliwie najsilniej rozwiniętą gałąź nowej ekonomii instytucjonalnej, zarówno pod względem konceptualnym, jak i poziomu zaawansowania badań empirycznych. Należy jednak zaznaczyć, że to, co stanowi o sile tego nurtu ekonomii (tj. wypracowanie szeregu upraszczających założeń modelowych, pozwalających na daleko idącą operacjonalizację badawczą), z innego punktu widzenia może być traktowane jako ograniczenie. W opinii krytyków TKT w niedostatecznym stopniu umożliwia analizowanie problemu ograniczonej racjonalności i zachowań oportunistycznych oraz kwestii zmienności instytucji w czasie - efektywność w ramach ekonomii kosztów transakcyjnych jest bowiem rozpatrywana w kategoriach ahistorycznych i atemporalnych ${ }^{68}$. Dodatkowo, z punktu widzenia tego nurtu nowej ekonomii instytucjonalnej przedsiębiorstwa $i$ inne organizacje traktowane są w przeważającej mierze jako podmioty homogeniczne, których występowanie zależy jedynie od poziomu kosztów transakcyjnych. W rzeczywistości przedsiębiorstwa różnią się mię-

67 E. L. Glaeser et al., Do Institutions Cause Growth?, „Journal of Economic Growth” 2004, vol. 9, no. 3, s. 271-303.

68 N. J. Foss, P. G. Klein, Critiques of Transaction Cost Economics: An Overview, [w:]

P. G. Klein, M. E. Sykuta (eds.), The Elgar Companion..., s. 266-269. 
dzy sobą posiadanymi zasobami, a zatem ich istnienie nie jest jedynie konsekwencją występowania kosztów transakcyjnych. Firmę opłaca się bowiem utrzymywać nie tylko po to, by minimalizować koszty transakcyjne, lecz także w celu "przechwytywania” specyficznych dla niej wartości (kluczowych kompetencji, zdolności innowacyjnych itp.). Podobnie zresztą współpraca między przedsiębiorstwami (czyli w rozumieniu TKT utrzymywanie hybrydowych form organizacyjnych) może służyć nie tylko ograniczaniu kosztów transakcji rynkowych, ale też zapewnieniu dostępu do specyficznych zasobów partnerów. Teoria kosztów transakcyjnych pomija zatem w znacznym stopniu te aspekty funkcjonowania podmiotów gospodarczych, na których zbudowane są koncepcje kluczowych kompetencji czy np. ekonomia ewolucyjna ${ }^{69}$. Z drugiej strony trzeba wyraźnie podkreślić, iż przedstawiona wyżej krytyka TKT nie wypracowała dla tej gałęzi ekonomii alternatywy - szczególnie $\mathrm{w}$ aspekcie operacjonalizacji konkurencyjnych podejść. Zatem teorię kosztów transakcyjnych należy uznać za jedną z najbardziej wartościowych gałęzi ekonomii instytucjonalnej.

Uwzględnienie w TKT istotnego znaczenia środowiska instytucjonalnego $\mathrm{w}$ procesach gospodarczych jest natomiast bezsprzeczne oraz stanowi wyraz łączenia w tym nurcie nauk ekonomicznych tradycji marginalistycznej i instytucjonalnej. Potwierdza to m.in. O. E. Williamson, wskazując, iż teoria kosztów transakcyjnych nie może zastąpić analizy neoklasycznej prowadzonej w kategoriach kosztów i zysków krańcowych, lecz jest w stosunku do niej podejściem komplementarnym. Nastawienie takie stanowi „powrót do międzywojennej tradycji współistnienia instytucjonalnej i neoklasycznej metody uprawiania ekonomii, a przez to wnosi istotny wkład w proces rosnącego pluralizmu w teorii ekonomii w latach 70. i 80. XX wieku"70. W tym aspekcie analiza instytucji nie może być pozostawiona jedynie ekonomistom, gdyż wtedy trudno będzie znaleźć źródła trwania określonych instytucji. R. Coase postuluje zatem umożliwienie członkostwa w programie badawczym NEI prawnikom, antropologom, socjologom i politologom ${ }^{71}$.

69 Por. G. M. Hodgson, Limits of Transaction Costs Analysis, [w:] P. G. Klein, M. E. Sykuta (red.), The Elgar Companion..., s. 297-306.

70 G. M. Hodgson, Institutional Economics: Surveying the 'Old' and the 'New', „,Metroeconomica” 1993, vol. 44 (1), s. 1-28, [cyt. za:] Ł. Hardt, Ekonomia kosztów transakcyjnych..., s. 209-210.

71 R. Coase, Message from Ronald Coase, „Newsletter of the International Society for New Institutional Economics" 1998, vol. 1 (1), s. 3, [cyt. za:] Ł. Hardt, Ekonomia kosztów transakcyjnych..., s. 221. 


\subsection{Teoria wyboru publicznego}

Teoria wyboru publicznego, zwana także nową ekonomią polityczną, współdzieląc podstawowe tezy nowej ekonomii instytucjonalnej, za przedmiot badań uznaje mechanizmy zachodzące w sferze polityki oraz szeroko rozumianej domenie publicznej. Główne jej założenie opiera się na tym, że koncepcja homo oeconomicus odnosi się nie tylko do wyborów indywidualnych i dokonywanych przez rynek, lecz także do wyborów zbiorowych, realizowanych przez mechanizm polityczny. TWP eksponuje zatem indywidualizm metodologiczny i racjonalizm zachowań, akceptując przy tym - podobnie jak inne nurty instytucjonalizmu - zasadę ograniczonej racjonalności $\mathrm{H}$. Simona. Zasada ta w największym stopniu odzwierciedla nacisk kładziony na istnienie ograniczeń instytucjonalnych, wpływających na zachowania pojedynczych jednostek (obywateli, przedsiębiorców, wyborców) oraz złożonych struktur organizacyjnych (partii politycznych, organizacji społecznych i publicznych), czy wreszcie na taktyki działań reprezentowanych odpowiednio w sferze władzy wykonawczej, prawodawczej (na różnych poziomach terytorialnych sprawowania władzy) i sądowniczej.

W konsekwencji teorię wyboru publicznego uważa się za szczególną postać teorii racjonalnego wyboru ${ }^{72}$, która opiera się na założeniach sformułowanych przez J. S. Colemana ${ }^{73}$ :

- indywidualizm metodologiczny - zarówno w polityce, jak i we wszelkich organizacjach publicznych jednostki w pierwszej kolejności dążą do zaspokojenia własnych potrzeb; nie jest więc możliwa konstrukcja tzw. społecznej funkcji dobrobytu, bowiem głosowanie większościowe nie wytwarza spójnego zestawu decyzji społecznych ${ }^{74}$;

- zasada maksymalizacji lub optymalizacji - podmioty funkcjonujące w sferze polityki i w sferze publicznej dążą do maksymalizacji przede wszystkim własnej użyteczności, nie kierując się nieprecyzyjnym pojęciem interesu społecznego. Akceptacja ograniczeń potocznie kojarzonych $\mathrm{z}$ interesem społecznym jest możliwa, lecz stanowi efekt racjonalnej kalkulacji indywidualnych korzyści i kosztów takiej akceptacji;

72 J. Wilkin, Teoria wyboru publicznego - homo oeconomicus w sferze polityki, [w:] idem (red.), Teoria wyboru publicznego. Wstęp do ekonomicznej analizy funkcjonowania sfery publicznej, Scholar, Warszawa 2005, s. 13.

73 J. S. Coleman, A Rational Choice Perspective on Economic Sociology, [w:] N. J. Smelser, R. Swedberg (eds.), The Handbook of Economic Sociology, Princeton University Press, Princeton 1994; J. S. Coleman, Foundations of Social Theory, Harvard University Press, Cambridge 1990.

74 J. Miklaszewska, Filozofia a ekonomia..., s. 24. 
- koncepcja optimum społecznego (optimum Pareto) - systemy sprawowania władzy i stanowienia prawa (systemy instytucjonalne) powinny być konstruowane w taki sposób, aby indywidualne działania jednostek w polityce i biurokracji nie wpływały na pogorszenie sytuacji innych jednostek;

- koncepcja równowagi systemu (według Johna F. Nasha Jr.) - z uwagi na rozbieżność indywidualnych interesów jednostek z interesami tworzonych przez nie zbiorowości stan równowagi nie musi pokrywać się ze stanem optimum społecznego w sensie V. Pareto ${ }^{75}$. Z tego powodu zachowująca się racjonalnie jednostka wie, że w pewnych sytuacjach bardziej korzystne jest ograniczenie wolności niż nieskrępowane dążenie do maksymalizacji własnej użyteczności ${ }^{76}$. Wyjście z tego typu równowagi w celu poprawy sytuacji wszystkich uczestników działań wymaga na ogół skoordynowanej współpracy;

- możliwość poprawy użyteczności poprzez zrzeczenie się kontroli (na rzecz podmiotu, który ma w danej dziedzinie więcej informacji i/lub kompetencji);

75 Z tego powodu należy zasygnalizować, że współcześnie częściej niż do kryterium V. Pareto (optimum absolutne) następują odwołania do tzw. kryterium wypłat kompensacyjnych Kaldora-Hicksa (optimum względne). W pierwszym przypadku warunkiem działania w sferze publicznej jest dążenie do niepogarszania sytuacji żadnej z jednostek, natomiast w drugim działanie może być rekomendowane, jeśli osoby (grupy), które zyskują na jego realizacji, mogą całkowicie i potencjalnie rekompensować straty osobom, których sytuacja uległa pogorszeniu, pozostając nadal w lepszej sytuacji (R. Cooter, Th. Ulen, Ekonomiczna analiza..., s. 33; A. Drobniak, Ocena projektów publicznych, Wyd. Akademii Ekonomicznej w Katowicach, Katowice 2005, s. 47).

76 Odzwierciedleniem takiej sytuacji jest znany z teorii gier tzw. dylemat więźnia. W oryginalnej wersji opisu tej gry w warunkach, gdy obydwaj gracze nie mogą ze sobą współpracować w procesie podejmowania decyzji, dla każdego z nich racjonalne będzie działanie na niekorzyść drugiego, podczas gdy najbardziej optymalne rozwiązanie występuje jedynie w warunkach współpracy (celowo w opisywanym przypadku uniemożliwionej). Prowadzi to zatem do sytuacji, w której żaden podmiot działający indywidualnie nie jest w stanie poprawić swojego położenia i dlatego wygaszane są wszelkie bodźce do zmiany (system osiąga równowagę, jednak przy braku osiągnięcia optimum Pareto) (por. np. H. Varian, Mikroekonomia, PWN, Warszawa 2001, s. 498-500). Badania eksperymentalne wskazują, że dylemat więźnia rzadko występuje w praktyce, ponieważ ludzie są mimo wszystko skłonni inwestować w dobra publiczne (zob. m.in. T. K. Ahn, R. K. Wilson, Elinor Ostrom's Contributions to the Experimental Study of Social Dilemmas, „Public Choice” 2010, no. 143, s. 327-333). Ponadto, gdy społeczności są małe i istnieje w nich możliwość wzajemnej obserwacji, nakładania kar i wywierania wpływów, mogą one efektywnie zarządzać wspólnymi zasobami (M. Jakubowski, Dobra publiczne i dobra wspólne, [w:] J. Wilkin (red.), Teoria wyboru publicznego. Wstęp do ekonomicznej analizy..., s. 182). 
- koncepcja kapitału społecznego (który według J. Colemana jest szczególnym typem dobra publicznego i dlatego może występować niedostateczna skłonność do inwestowania w tego typu dobro);

- założenie o społecznych źródłach uprawnień (których alokacja może być źródłem konfliktów);

- koncepcja instytucji (działanie człowieka przebiega w ramach ograniczeń oraz możliwości stwarzanych przez instytucje formalne i nieformalne).

Wśród podstawowych dziedzin teorii wyboru publicznego wymienia się?:

1) ekonomiczną teorię demokracji,

2) teorię władzy ustawodawczej, wykonawczej, sądowniczej i biurokracji państwowej,

3) teorię kontraktu (ładu konstytucyjnego, umowy społecznej),

4) teorię grup interesu i koalicji dystrybutywnych,

5) teorię pogoni za rentą.

Za twórcę pierwszego z nurtów, znanego pod nazwą ekonomicznej teorii demokracji, uważa się Anthony’ego Downsa, który zakłada, że rynek polityczny jest podobny do zachowań ludzkich $\mathrm{w}$ sferze ekonomii ${ }^{78}$. W takim ujęciu partie polityczne są odpowiednikami przedsiębiorstw - zarówno wyborcy, jak i partie polityczne działają racjonalnie oraz kierują się zasadą maksymalizacji swych użyteczności. Udział obywateli w wyborach można zatem widzieć jako swoistą transakcję, której kosztami transakcyjnymi są koszty poszukiwania informacji o programach wyborczych oraz bezpośrednie koszty udziału w wyborach. Decyzja o udziale w wyborach warunkowana jest przy tym relacją marginalnych korzyści (powszechnie postrzeganych jako niewielkie, biorąc pod uwagę fakt, że pojedynczy głos nie wpływa na wynik wyborów ${ }^{79}$ ) i krańcowych kosztów ${ }^{80}$.

Istotnym dokonaniem ekonomicznej teorii demokracji są pragmatyczne w swojej istocie obserwacje, prowadzące do identyfikacji ścisłej relacji między rozkładem preferencji politycznych a stabilnością systemów rządzenia. $Z$ uwagi na duży poziom ogólności tych badań znajduje

77 J. Wilkin, Teoria wyboru publicznego..., s. 21-26.

78 A. Downs, An Economic Theory of Democracy, Collier-MacMillan, London 1970.

79 W ramach ekonomicznej teorii demokracji używa się często pojęcia „racjonalnej ignorancji”. W myśl jej założeń ignorancja wyborcy w zdobywaniu nowych informacji jest racjonalna, gdyż nie ma sensu ponosić wysokich kosztów ich poszukiwania w sytuacji, gdy pojedynczy wyborca ma bardzo ograniczony wpływ na ostateczny wynik wyborów (por. T. Michalak, Ekonomiczna teoria demokracji Anthony'ego Downsa, [w:] J. Wilkin (red.), Teoria wyboru publicznego. Wstęp do ekonomicznej analizy...).

80 Szerzej: ibidem, s. 69-86. 
ona zastosowanie zarówno $\mathrm{w}$ odniesieniu do analiz struktur rządzenia na szczeblu krajowym, jak i na poziomie samorządów terytorialnych. Teoria ta głosi, iż głównym czynnikiem determinującym rozwój systemu politycznego jest kształt rozkładu preferencji (wykres 7). Przy rozkładzie jednowierzchołkowym zachodzi zjawisko konwergencji programów wyborczych partii politycznych celem zdobycia maksymalnie dużej liczby głosów reprezentowanych przez tzw. „medianowego wyborcę”. Natomiast przy rozkładzie dwuwierzchołkowym partie istotnie różnią się od siebie i polityka rządowa jest niestabilna ${ }^{81}$.
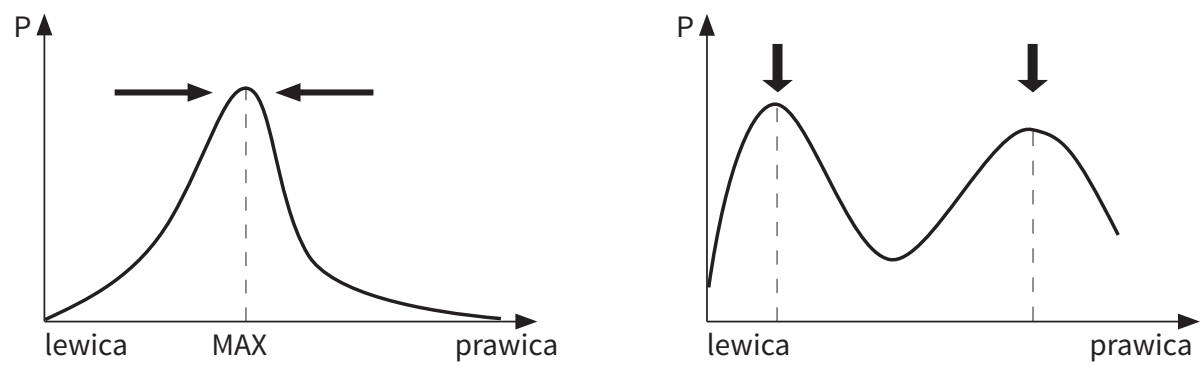

Wykres 7. Przykłady rozkładów preferencji wyborców

$\mathrm{P}$ - poparcie wyborcze, oś pozioma - ewolucja programowa partii.

Źródło: A. Downs, An Economic Theory of Democracy, Collier-MacMillan, London 1970, s. 118-119.

Nie mniej ważnym nurtem badawczym rozwijanym w ramach ekonomicznej teorii demokracji pozostaje też badanie zależności pomiędzy systemami (metodami) głosowania a kształtem i sposobem funkcjonowania sfery politycznej. Problematyka ta zbliża TWP do pokrewnej jej teorii wyboru społecznego, która zajmuje się przede wszystkim takimi zagadnieniami, jak:

- analiza, w jakim stopniu w warunkach demokratycznych form sprawowania rządów różne metody głosowania przynoszą różne wyniki (np. porównywanie wyników głosowań w metodzie zwykłej większości, większości proporcjonalnej, w głosowaniu sekwencyjnym itp.),

- analiza zjawisk polegających na tym, iż w wielu sytuacjach politycznych zwycięża tzw. „medianowy” wyborca oraz że niejednokrotnie o ostatecznych wynikach wyborów decydować mogą takie czyn-

81 Ibidem, s. 82-83. 
niki, jak „manipulowanie” głosami i metodami głosowania oraz fakt „głosowania strategicznego", dokonywanego przez racjonalnie działających wyborców,

- weryfikowanie charakterystycznej dla TWS i TWP tezy, iż nie istnieje funkcja dobrobytu społecznego, spełniająca warunki optymalności z punktu widzenia preferencji indywidualnych ${ }^{82}$.

Punktem wyjścia dla rozważań w ramach kolejnego nurtu, tj. teorii władzy ustawodawczej, wykonawczej, sądowniczej i biurokracji państwowej, jest - podobnie jak w przypadku pozostałych nurtów TWP - założenie, iż politycy oraz biurokraci w swoich działaniach nie dążą przede wszystkim do niemożliwego do osiągnięcia optimum społecznego (maksymalizowania tzw. funkcji dobrobytu społecznego), lecz do maksymalizacji własnej użyteczności (indywidualizm metodologiczny) ${ }^{83}$. Jednak w ramach przyjętych założeń można dążyć do konstruowania systemów, które powodują, że indywidualne działania homo eocenomicus w sferach polityki i biurokracji będą się przyczyniać do poprawy sytuacji lub przynajmniej nie będą wpływać na pogorszenie sytuacji innych jednostek (optimum w sensie Pareto).

Przykładowo, w konstruowaniu optymalnych systemów politycznych należy się posiłkować pojęciem kosztów transakcyjnych, które nawet nie będąc wyrażonymi $\mathrm{w}$ ujęciu pieniężnym, pojawiają się w obszarze podejmowania decyzji zbiorowych. W tym aspekcie należy zgodzić się ze stwierdzeniem, iż „szczególną kompetencją władzy ustawodawczej na tle pozostałych władz w państwie jest obniżanie kosztów transakcyjnych związanych z prowadzeniem politycznych przetargów poprzez stanowienie forum, na którym reprezentowane są różne partie, frakcje i interesy

82 Szerzej na ten temat pisze M. Jakubowski, Teoria wyboru społecznego, [w:] J. Wilkin (red.), Teoria wyboru publicznego. Wstęp do ekonomicznej analizy..., s. 46-68.

$83 \mathrm{~W}$ tym sensie ekonomiczna teoria władzy publicznej, sformułowana w ramach teorii wyboru publicznego, prezentuje ujęcie do pewnego stopnia przeciwne do teorii biurokracji M. Webera. Chociaż Weber wyraźnie podkreśla, że to interes własny kieruje działaniami jednostek, a nie kierują nimi idee, dodaje jednak, iż czynnik racjonalny obecny $w$ działaniu jednostek może być zrozumiany tylko w ramach istniejącego porządku instytucjonalnego (M. Weber, The Social Psychology of the World's Religions, [w:] H. Gerth, C. W. Mills (eds.), Max Weber, Oxford University Press, New York 1946). Jednostka, podejmując decyzje gospodarcze, kieruje się racjonalnością, jednak zarówno ta racjonalność, jak i dokonywane wybory zawsze są zakorzenione społecznie, determinowane przez istniejące, historycznie uformowane instytucje prawne, polityczne czy religijne (B. Radzka, Stary i nowy instytucjonalizm. Spotkanie socjologii i ekonomii, „MBA” 2009, nr 2, s. 65). Na gruncie tak rozumianej motywacji podejście M. Webera utożsamia się z takimi zagadnieniami, jak etos służby publicznej czy pierwszeństwo interesu publicznego nad interesem prywatnym. 
obecne w państwie" ${ }^{84}$. Można więc teoretycznie wyznaczyć optymalną wielkość struktury władzy ustawodawczej na dowolnym poziomie jej sprawowania (krajowym, regionalnym, lokalnym), podejmując próbę szacowania kosztów jej funkcjonowania w konfrontacji z korzyściami, interpretowanymi jako redukcja kosztów transakcyjnych dla obywateli, w imieniu których władza ta jest sprawowana (wykres 8).

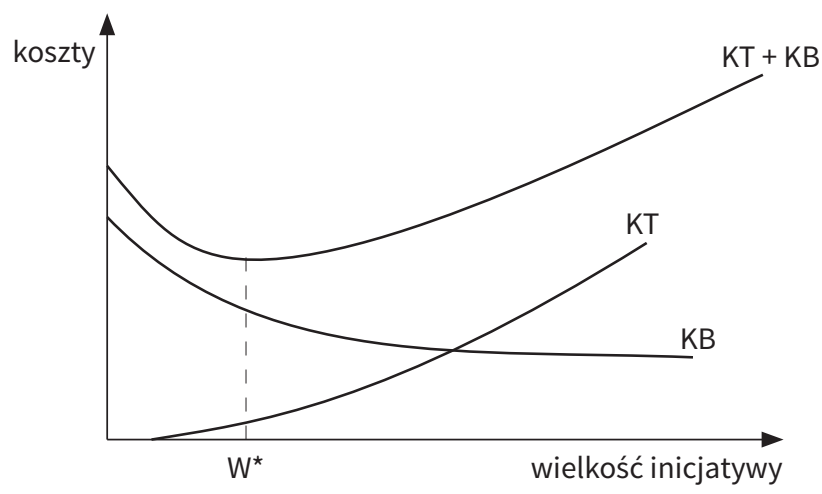

Wykres 8. Optymalna wielkość legislatywy

Objaśnienia: krzywa kosztów transakcyjnych KT rośnie wraz ze wzrostem wielkości grupy ustawodawców, a krzywa kosztów związanych z możliwością popełniania błędów KB jest odpowiednio malejąca. Krzywa kosztów całkowitych KT + KB ma kształt litery „U” - jest początkowo malejąca, a następnie rosnąca. Punkt, w którym osiąga minimum, oznaczony przez $\mathrm{W}^{\star}$, odpowiada optymalnej wielkości legislatywy jako grupy podejmującej decyzję w sprawie wydania aktów prawnych.

Źródło: K. Metelska-Szaniawska, Ekonomia konstytucyjna - ekonomia polityczna ładu gospodarczego, [w:] J. Wilkin (red.), Teoria wyboru publicznego. Wstęp do ekonomicznej analizy funkcjonowania sfery publicznej, Scholar, Warszawa 2005, s. 116.

Ekonomiczne teorie władzy ustawodawczej, wykonawczej, sądowniczej i biurokracji państwowej poszukują sposobów ograniczania niedoskonałości funkcjonowania sfery publicznej (tzw. government failures), przejawiających się przede wszystkim poprzez:

- nieelastyczność oraz zbyt długi czas reakcji na zmieniające się potrzeby;

- tendencje do stałego wzrostu struktur biurokratycznych, nieidących w parze z poprawą efektywności funkcjonowania sektora publicznego;

84 K. Metelska-Szaniawska, Ekonomia konstytucyjna - ekonomia polityczna ładu gospodarczego, [w:] J. Wilkin (red.), Teoria wyboru publicznego. Wstęp do ekonomicznej analizy..., s. 89. 
- pojawianie się efektu wypychania w sytuacji, gdy sektor publiczny dostarcza dobra, które mógłby dostarczać sektor prywatny;

- brak mechanizmu konkurencji lub jego znaczne ograniczenie;

- występowaniu zachowań polegających na maksymalizacji własnej użyteczności kosztem celów, dla których zostały powołane poszczególne organy władzy i administracji;

- wysokie koszty transakcyjne kontroli kadry urzędniczej przez przedstawicieli władzy oraz przez obywateli, na skutek asymetrii informacji.

Wśród rozwiązań problemów funkcjonowania sfery publicznej, pojawiających się $\mathrm{w}$ wyniku analiz podejmowanych na gruncie TWP, wymienia się:

- upodabnianie struktur rządzenia państwem do efektywnych struktur rynkowych, np. badania organizacji rynku wskazują, że gdy jest na nim czterech dostawców, jego funkcjonowanie jest zbliżone do rynku w pełni konkurencyjnego ${ }^{85}$. Postuluje się więc wprowadzanie w życie takich rozwiązań, jak czwórpodział władzy czy decentralizację władzy poprzez rozwój struktur samorządu terytorialnego;

- poszukiwanie możliwości zaangażowania sektora prywatnego w sprawowanie władzy (np. prywatne sądy arbitrażowe w miejsce sadów powszechnych) oraz świadczenie usług publicznych (instytucje przetargów publicznych ${ }^{86}$, programy partnerstwa publiczno-prywatnego, przekazywanie spraw publicznych do sektora organizacji pozarządowych). Warto podkreślić, że obecność na jednym „rynku” podmiotów zaliczanych do wszystkich trzech sektorów sprawia, iż podmioty te stosują strategie rynkowe i albo ze sobą konkurują, albo wchodzą ze sobą w relacje kooperacyjne ${ }^{87}$;

- konstruowanie systemów wyborczych minimalizujących koszty transakcyjne ich funkcjonowania. Przykładowo, większościowy system wyborczy kieruje transakcje polityczne w stronę struktur podobnych do funkcjonowania organizacji hierarchicznych na rynku, konsolidując scenę polityczną, natomiast reprezentacja

85 K. Metelska-Szaniawska, Ekonomiczna teoria władzy ustawodawczej i sqadowniczej, [w:] J. Wilkin (red.), Teoria wyboru publicznego. Wstęp do ekonomicznej analizy..., s. 113.

86 Wśród form marketyzacji usług publicznych można wyróżnić: zlecanie zadań na podstawie umów cywilnoprawnych, koncesjonowanie, subwencjonowanie przedsiębiorstw i organizacji sektora trzeciego, franchising, dzierżawę majątku komunalnego oraz bony na usługi publiczne (szerzej: E. Wojciechowski, Zarzq̨dzanie w samorządzie terytorialnym, Difin, Warszawa 2003).

87 P. Tłaczała, Podstawy ekonomicznej teorii biurokracji, [w:] J. Wilkin (red.), Teoria wyboru publicznego. Wstęp do ekonomicznej analizy..., s. 147-148. 
proporcjonalna preferuje budowanie struktur rządzenia przypominających transakcje rynkowe, co jednak prowadzi do fragmentacji sceny politycznej ${ }^{88}$;

- wprowadzenie przejrzystych procedur związanych z przechowywaniem dokumentacji i jej udostępnianiem na podstawie prawa dostępu do informacji publicznej, jasne reguły podejmowania decyzji, upowszechnienie metod partycypacji społecznej w podejmowaniu decyzji itp.

Warto zaznaczyć, iż TWP znajduje się w opozycji do tych nurtów ekonomii politycznej, które widzą rząd jako uniwersalny sposób na eliminację ułomności rynku. Zakładając, że biurokraci dążą do maksymalizacji własnej użyteczności, teoria wyboru publicznego eksponuje problem odwrotny, tj. zjawisko występowania ułomności biurokracji (government failure). Jednym $\mathrm{z}$ rozwiązań proponowanych $\mathrm{w}$ celu zmniejszenia społecznych kosztów tych niedoskonałości jest zmniejszenie roli biurokratów poprzez zwiększanie udziału podmiotów prywatnych i organizacji trzeciego sektora w alokację społecznych zasobów oraz dostarczanie dóbr publicznych ${ }^{89}$.

Istotny wkład w teorię wyboru publicznego ma ekonomia konstytucyjna (teoria ładu konstytucyjnego). Jej celem jest wyjaśnienie właściwości działania alternatywnych zestawów prawno-instytucjonalno-konstytucyjnych zasad, stawiających ograniczenia dla wyborów i działań aktorów ekonomicznych oraz politycznych, a także określających ramy, w których dokonują się zwykłe wybory aktorów ekonomicznych i politycznych ${ }^{90}$. Podstawowym punktem odniesienia dla wszelkich analiz podejmowanych w tym obszarze pozostaje zatem pojęcie konstytucji, rozumianej jako podstawowa umowa społeczna zawierana dobrowolnie przez obywateli, godzących się z narzuceniem praw oraz powołaniem rządów po to, by prawa te były egzekwowane ${ }^{91}$.

Niezwykle doniosłe znaczenie ma przy tym akcentowanie $\mathrm{w}$ ramach TWP tezy, że konstytucja stanowi pewnego rodzaju umowę zbiorową zawieraną między obywatelami (co odróżnia ten nurt badawczy od np. ekonomii konwencji i wyraźnie włącza teorię konstytucyjnego kontraktu w ramy myślenia charakterystyczne dla nowej ekonomii instytucjonalnej $)^{92}$. Zmiany takiej umowy powinny odbywać się niezwykle rzadko,

88 K. Metelska-Szaniawska, Ekonomiczna teoria..., s. 119.

89 P. Tłaczała, Podstawy ekonomicznej teorii..., s. 157.

90 J. M. Buchanan, Constitutional Economics, [w:] J. Eatwell, M. Milgate, P. Newman (eds.), The New Palgrave: A Dictionary of Economics, Macmillan, London-Basingstoke 1987, s. 585.

91 J. Miklaszewska, Filozofia a ekonomia..., s. 109.

92 Por. D. C. Mueller, Public Choice III, Cambridge University Press, Cambridge 2003, s. 634-639. 
drogą tzw. „rewolucji konstytucyjnej”93. W takim ujęciu termin „konstytucja" może więc oznaczać jedną z czterech kategorii ${ }^{94}$ :

1. Ograniczenia, które jednostka nakłada na siebie samą, aby zrealizować swoje cele (prywatna konstytucja).

2. Ograniczenia nakładane na siebie przez jednostki w różnych sytuacjach społecznych, w których znajdują się z własnej i nieprzymuszonej woli, np. małżeństwa i rodziny, wspólnoty mieszkaniowe, kluby sportowe, związki zawodowe, kościoły, firmy itd.

3. Ograniczenia nałożone na przedstawicieli władzy państwowej.

4. Ograniczenia nakładane przez władzę państwową na obywateli.

Należy pamiętać, że w myśl założeń ekonomii konstytucyjnej zakres regulacji o charakterze sformalizowanym i skodyfikowanym ma być możliwie jak najmniejszy. Elementy, które mają się znaleźć w konstytucji, powinny regulować przede wszystkim zakres ograniczeń dla zachowań ludzkich wobec innych jednostek, nakreślać ogólne ramy systemu gwarantującego ochronę praw własności oraz definiować zasady dotyczące produkcji i finansowania dóbr publicznych. W związku z tym czołowi przedstawiciele tego nurtu teorii wyboru publicznego, J. Buchanan i G. Tullock, zaproponowali trzy podstawowe zasady formułowania kontraktu konstytucyjnego ${ }^{95}$ :

1. Dobra powinny być dostarczane w drodze działań kolektywnych tylko wtedy, gdy zapewnienie ich drogą prywatną byłoby bardziej kosztowne.

2. Działania kolektywne powinny być organizowane przez relatywnie małe grupy, kiedy tylko jest to możliwe.

3. Podejmowane decyzje powinny prowadzić do minimalizacji kosztów wzajemnej zależności (interdependence costs).

Sugestia dotycząca organizowania działań kolektywnych w ramach stosunkowo małych grup może być przy tym interpretowana jako uzasadnienie rozwoju samorządności terytorialnej oraz decentralizacji władzy. Ponadto, zasada dotycząca możliwie wąskiego zakresu regulacji życia społeczno-gospodarczego może być rozumiana jako postulat ograniczania do minimum zakresu regulacji prawnych, szczególnie na poziomie stanowienia prawa miejscowego. A zatem skoro według założeń J. Buchanana konstytucja musi być „minimalna” i zarezerwowana dla ustaleń podjętych jednomyślnie, również samorząd lokalny i regionalny nie powinien być przede wszystkim dodatkowym publicznym organem regula-

93 J. M. Buchanan, Constitutional Economics..., s. 585.

94 K. Metelska-Szaniawska, Ekonomiczna teoria..., s. 114.

95 J. M. Buchanan, G. Tullock, The Calculus of Consent: Logical Foundations of Constitutional Democracy, University of Michigan Press, Ann Arbor 1962. 
cyjnym (stanowiącym kolejne prawa formalne), lecz raczej podejmować działania o charakterze inspiracyjnym, koordynacyjnym, planistycznym czy informacyjnym.

Kolejna grupa zjawisk i procesów analizowanych w ramach teorii wyboru publicznego dotyczy formułowania instytucjonalnych aliansów w ramach tworzonych grup interesu oraz mechanizmów rządzących zjawiskiem tzw. lobbingu. Ten zestaw zagadnień stanowi przedmiot badań teorii grup interesu i koalicji dystrybutywnych. Wśród grup interesu można przy tym wyróżnić ich różnorodne typy. Niektóre z nich tworzone są w celu bezpośredniego zabezpieczenia interesów członków (związki zawodowe, zrzeszenia rolników, samorządy zawodowe, stowarzyszenia handlowe i przemysłowe itp.), podczas gdy inne działają w kierunku ochrony określonych interesów społecznych (organizacje na rzecz pokoju, ochrony środowiska, ochrony prawa lokatorów, niepełnosprawnych itd.).

Wspólnota celów członków grup interesów sprawia, iż cele te mają w ramach grupy charakter dóbr publicznych, co rodzi konsekwencje typowe dla tego rodzaju dóbr (problem jazdy na gape, dylemat więźnia itd.). Warto przy tym zauważyć, że swoiste grupy interesu (koalicje) mogą być z podobnych powodów zawierane również przez organizacje polityczne, w celu realizacji przez nie wspólnych interesów wyborczych. Teoria grup interesu i koalicji dystrybutywnych jest dynamicznie rozwijającą się dziedziną w ramach TWP, opierającą się na założeniu, że im mniejsza grupa interesu oraz im bardziej precyzyjnie sformułowane cele i sposoby ich osiągnięcia, tym większa jej efektywność - zarówno wewnętrzna, jak i w stosunku do instytucji zewnętrznych ${ }^{96}$.

Zakładając, że z ekonomicznego punktu widzenia renta definiowana jest jako dochód i korzyść wynikająca z posiadania rzadkich zasobów (dochód nadzwyczajny ${ }^{97}$ ), obok renty gruntowej czy wynikającej z ulokowanego kapitału finansowego można także wskazać rentę polityczną. Rozumiana jest ona jako forma transferu dochodów od jednych podmiotów do innych przy wykorzystaniu mechanizmu władzy politycznej i jako taka stanowi przedmiot zainteresowania ostatniego z nurtów TWP, tj. koncepcji pogoni za rentą. Opisywane przez nią zjawisko pozostaje przy tym szczególnie dostrzegalne $\mathrm{w}$ krajach rozwiniętych, gdzie podmioty władzy politycznej decydują o podziale prawie $50 \%$ PKB oraz mają istotny wpływ na wyniki podziału pozostałych $50 \%{ }^{98}$.

96 Por. D. C. Mueller, Public Choice III..., s. 473.

97 Renta ekonomiczna to dochody przynoszone przez czynniki produkcji, które stanowią nadwyżkę ponad minimalne dochody niezbędne do tego, by czynnik oferowany był na sprzedaż (H. Varian, Mikroekonomia..., s. 417).

98 J. Wilkin, Pogoń za rentą przy pomocy mechanizmów politycznych, [w:] idem (red.), Teoria wyboru publicznego. Wstęp do ekonomicznej analizy..., s. 206. 
Renta polityczna jest przedmiotem zabiegów racjonalnych jednostek, które uznają, że zaangażowanie posiadanych przez nie zasobów w dodatkową działalność bezpośrednio produkcyjną, której efektem jest jakaś suma użytecznych dóbr i usług, da im mniej korzyści niż zaangażowanie tych zasobów w uzyskanie renty będącej wynikiem decyzji politycznych ${ }^{99}$.

Wysiłki te mogą być realizowane zarówno poprzez legalne metody nacisku politycznego (lobbing, wspieranie kampanii wyborczych itp.), jak i metody nielegalne, których typowym przykładem jest korupcja. Przedmiotem zainteresowań koncepcji pogoni za rentą jest przede wszystkim analiza skutków tego typu zachowań (straty społeczne, koszty alternatywne w postaci mniejszego tempa wzrostu PKB, wypaczanie parametrów ekonomicznych oraz struktur instytucjonalnych) oraz sposobów zapobiegania im. W drugiej grupie wymienia się m.in. ograniczenie do niezbędnego minimum regulacyjnej roli państwa w gospodarce, poprawę obiegu informacji w gospodarce i społeczeństwie, zwiększenie przejrzystości funkcjonowania władzy publicznej, zapewnienie niezależności środków masowego przekazu oraz decentralizację funkcji publicznych, uprawnień decyzyjnych i finansów państwa. Szczególnie proces decentralizacji może sprzyjać efektywności wydatków publicznych oraz zwiększać poziom partycypacji społeczeństwa w podejmowaniu decyzji ${ }^{100}$.

\section{Koncepcje pokrewne i powiązane z ekonomią instytucjonalną}

Poza opisanymi powyżej nurtami bezpośrednio kojarzonymi jako koncepcje rozwinięte $\mathrm{w}$ ramach ekonomii instytucjonalnej, zagadnienia wpływu instytucji na procesy gospodarcze podejmowane są też w wielu innych nurtach badawczych ekonomii. Można do nich zaliczyć francuską ekonomię konwencji, ekonomię ewolucyjną (do której odwołuje się rozwinięta na gruncie nauk o zarządzaniu zasobowa szkoła myślenia strategicznego) oraz bodaj najbardziej ukierunkowaną na uwzględnienie przestrzeni w analizach ekonomicznych tzw. ekonomikę bliskości.

99 Ibidem, s. 212.

100 Więcej na ten temat m.in. w: Building Institutions for Markets: World Development Report 2002, Oxford University Press, Oxford 2002. 
Wspólną cechą wymienionych podejść - oprócz odwołań do pojęcia instytucji - pozostają silne nawiązania do kulturowych i społecznych podstaw procesów gospodarczych. W takim ujęciu koncepcje pokrewne ekonomii instytucjonalnej wyłaniają się niejako na styku ekonomii i socjologii, i jako takie - mniej lub bardziej wprost - czerpią z analiz instytucjonalnych podejmowanych zarówno przez ekonomistów, jak i politologów czy socjologów ${ }^{101}$. Nurty te zasługują na uwagę przede wszystkim ze względu na rosnące zainteresowanie nimi przedstawicieli nauk ekonomicznych.

\subsection{Francuska ekonomia konwencji}

Ekonomia konwencji (économie des conventions) uznawana jest współcześnie za najbardziej wpływową koncepcję ekonomiczną we Francji. Nurt ten rozwinął się szeroko w latach 80 . XX w., w pracach m.in. J.-P. Dupuya, O. Favereau, R. Salaisa czy L. Thévenota ${ }^{102}$. Ponieważ przedstawiciele tej szkoły odwołują się do założeń indywidualizmu metodologicznego, koncepcji ograniczonej racjonalności, a także za jeden z podstawowych przedmiotów analizy uznają transakcje (nazywane jednak przez nich samych konwencjami), można w ich pracach doszukiwać się zbieżności z nową ekonomią instytucjonalną, w szczególności z ekonomiką kosztów transakcyjnych. Jednocześnie jednak, nawołując do heterodoksji w warstwie metodologicznej oraz wskazując na trudność operacjonalizacji pojęcia „instytucje”, w swoich poglądach w tym zakresie

101 Wśród najpowszechniejszych nurtów należy wskazać przede wszystkim orientację ekologiczną, teorię strukturacji, powiązaną z próbą przełożenia koncepcji marksistowskich na analizę społeczności miejskich (Henri Lefebvre, David Harvey), nurt kulturalistyczny (antropologiczny), natomiast w polskiej literaturze - koncepcję społecznego wytwarzania przestrzeni Bohdana Jałowieckiego. Szerzej: A. Giddens, Constitution of Society: Outline of the Theory of Structuration, University of California Press, Berkeley 1986; H. Lefebvre, La révolution urbaine, Paris 1970; D. Harvey, Urbanization of Capital. Studies in the History of Capitalist Urbanization, The John Hopkins University Press, Oxford 1985; B. Jałowiecki, Społeczne wytwarzanie przestrzeni, Wyd. Naukowe Scholar, Warszawa 2010; A. Majer, Socjologia i przestrzeń miejska, PWN, Warszawa 2010.

102 Za datę narodzin ekonomii konwencji uznaje się konferencję poświęconą funkcjonowaniu rynków pracy pt. Les outils de gestion du travail, zorganizowaną w listopadzie 1984 r. (zob. A. Orléan, Vers un modèle général de la coordination économique par les conventions, [w:] A. Orléan (ed.) Analyse économique des conventions, Presse Universitaires de France, Paris 1994, s. 9-40). Jednak szersze upowszechnienie tej szkoły nastąpiło w wyniku publikacji: J.-P. Dupuy et al., Economie des conventions, „Revue Economique” 1989, vol. 40 (2). 
zbliżają się do tradycji neoinstytucjonalizmu ${ }^{103}$. Tym samym w ekonomii konwencji można doszukiwać się zarówno podobieństw z „kontraktowym" podejściem do analizowania instytucji, jak i różnic, wynikających przede wszystkim $\mathrm{z}$ interpretowania otoczenia instytucjonalnego procesów gospodarczych w sposób odmienny od podejścia mechanistycznego, charakterystycznego dla nowej ekonomii instytucjonalnej. Używanie terminu „konwencje” ma przy tym zwrócić uwagę na różnorodność instytucjonalnych form współpracy czy innych rodzajów interakcji gospodarczych - wykraczających poza regulacje rynkowe (tab. 17).

Podstawową misją tej szkoły pozostaje rozwijanie badań nad rolą konwencji w koordynowaniu procesów gospodarczych oraz prowadzenie badań empirycznych nad różnymi typami konwencji i ich dynamiką. Przedmiot tych badań pozostaje zróżnicowany i dotyczy wielu form organizacyjnych funkcjonujących na rynkach towarowych, rynkach pracy i rynkach finansowych ${ }^{104}$.

Program badawczy ekonomiki konwencji zrodził się z kombinacji kilku dyscyplin. Ekonomiści, którzy chcą rozwijać realistyczne podejście do racjonalnego zachowania podmiotów gospodarczych, połączyli siły $\mathrm{w}$ ramach tego podejścia ze specjalistami z innych dyscyplin (socjologia, filozofia, prawo, zarządzanie) w celu badania różnorodnych form koordynacji, obejmujących zasady, przedmioty i interakcje między ludźmi ${ }^{105}$. Podejście konwencjonalistyczne stanowi zatem formę analizy funkcjonowania różnych organizacji funkcjonujących de facto "na przecięciu” wielu typów rynków ${ }^{106}$. Próbuje przy tym czerpać swoją wartość z połączenia głównie perspektywy socjologicznej i ekonomicznej ${ }^{107}$ oraz dwóch punktów widzenia, tj. kolektywnego i indywidualistycznego.

103 Szerzej m.in. w: R. Diaz-Bone, L. Thévenot, La sociologie des conventions. La théorie des conventions, élément central des nouvelles sciences sociales françaises, „Trivium” 2010, nr 5; http://trivium.revues.org/3626 (dostęp: 10.04.2014).

104 S. Jagd, Economics of Convention and New Economic Sociology. Mutual Inspiration and Dialogue, „Current Sociology” 2007, vol. 55 (1) (January), s. 79.

105 F. Eymard-Duvernay, Conventionalist Approaches to Enterprise, [w:] O. Favereau, E. Lazega (eds.), Conventions and Structures in Economic Organization Markets, Networks and Hierarchies, Edward Elgar, Cheltenham-Northampton 2002, s. 60.

106 O. Favereau, E. Lazega (eds.), Conventions and Structures..., s. 12.

107 Ekonomia konwencji w jakimś sensie godzi podejście reprezentowane przez socjologów z podejściem ekonomistów. Ci pierwsi niejednokrotnie odwołują się do homo oeconomicus i uznają ceny, dobra i rynki za naturalne twory, podczas gdy ci drudzy starają się całkowicie zastąpić koordynację rynkową - koordynacją opartą na sieciach społecznych. W ekonomii konwencji natomiast dostrzega się, że w zależności od sytuacji mogą występować różne formy koordynacji i odmienne konwencje. Do pewnego stopnia to właśnie proces wyboru konwencji i uwarunkowań decydujących o tym wyborze jest przedmiotem badań ekonomii konwencji. 
Tabela 17. Kluczowe różnice między „kontraktualizmem” a „konwencjonalizmem”

\begin{tabular}{|c|c|c|}
\hline Zagadnienie & Kontraktualizm & Konwencjonalizm \\
\hline Informacja & $\begin{array}{l}\text { Przepływ informacji między nieza- } \\
\text { leżnymi od siebie jednostkami po- } \\
\text { zostaje autonomiczny. } \\
\text { Informacja służy zabezpieczeniu } \\
\text { indywidualnych interesów jed- } \\
\text { nostek. } \\
\text { Brak interakcji pomiędzy przepły- } \\
\text { wem informacji a systemem. }\end{array}$ & $\begin{array}{l}\text { Informacja jest modyfikowana po- } \\
\text { przez interpretacje analizujących } \\
\text { ją jednostek. }\end{array}$ \\
\hline $\begin{array}{l}\text { Transparent- } \\
\text { ność }\end{array}$ & $\begin{array}{l}\text { Transparentność wynika z dostępu } \\
\text { niezależnych i racjonalnie działają- } \\
\text { cych jednostek do informacji. }\end{array}$ & $\begin{array}{l}\text { Informacja nie jest interpreto- } \\
\text { wana jako „strumień”, lecz jako } \\
\text { „ekran”, w którym odzwiercie- } \\
\text { dlone są subiektywne intencje } \\
\text { i zachowania innych jednostek } \\
\text { - transparentność zależy od stop- } \\
\text { nia, w jakim przestrzegane są kon- } \\
\text { wencje. }\end{array}$ \\
\hline Niepewność & $\begin{array}{l}\text { Decyzje podejmowane są w wa- } \\
\text { runkach niepewności otoczenia. } \\
\text { Niepewność ta sprowadzona jest } \\
\text { jednak do zagadnienia kosztów } \\
\text { transakcyjnych. }\end{array}$ & $\begin{array}{l}\text { Nie chodzi jedynie o podejmowa- } \\
\text { nie decyzji, lecz również o zasady } \\
\text { gry, których przejrzystość ograni- } \\
\text { cza niepewność decyzji. Podejmo- } \\
\text { wanie decyzji jest w silnym stop- } \\
\text { niu uzależnione od zaufania co do } \\
\text { przyszłego stanu rzeczy. }\end{array}$ \\
\hline $\begin{array}{l}\text { Relacje między } \\
\text { jednostką a in- } \\
\text { formacją }\end{array}$ & $\begin{array}{l}\text { Rozdzielenie między jednostką i in- } \\
\text { formacją. }\end{array}$ & $\begin{array}{l}\text { Silne powiązanie między jednost- } \\
\text { ką a przetwarzaną przez nią infor- } \\
\text { macją. } \\
\text { Konwencje to reguły gry, w ramach } \\
\text { których jednostki nie tylko działa- } \\
\text { ją, ale też ewoluują pod ich wpły- } \\
\text { wem. }\end{array}$ \\
\hline Racjonalność & $\begin{array}{l}\text { Racjonalność jest pojęciem obiek- } \\
\text { tywnym. } \\
\text { Istnieje jedna definicja racjonal- } \\
\text { ności. }\end{array}$ & $\begin{array}{l}\text { Racjonalność to pojęcie względne. } \\
\text { Racjonalność warunkowana jest } \\
\text { różnorodnością okoliczności, w ja- } \\
\text { kich jednostki podejmują decyzje. }\end{array}$ \\
\hline Autonomia & $\begin{array}{l}\text { Jednostki działają niezależnie od } \\
\text { siebie. }\end{array}$ & $\begin{array}{l}\text { Racjonalny mimetyzm - upodab- } \\
\text { nianie się do innych (akceptacja } \\
\text { konwencji) jest racjonalną odpo- } \\
\text { wiedzią na niepewność. }\end{array}$ \\
\hline
\end{tabular}

Źródło: opracowanie własne na podstawie: M. Simonson, L'économie des conventions, https://pure.fundp.ac.be/ws/files/4007142/69169.pdf (dostęp: 10.04.2014). 
W tym kontekście ekonomia konwencji skupia się w swych analizach na trzech zasadniczych założeniach:

1. Należy dążyć do modelowania relacji pomiędzy jednostką a jej środowiskiem społecznym (podejście kolektywne, charakterystyczne dla neoinstytucjonalizmu).

2. Poszukiwanie ogólnych modeli opisujących zjawiska regulacji społecznych, dla których punktem wyjścia jest dążenie do zrozumienia relacji między jednostkami a konwencjami, w ramach których funkcjonują (podejście indywidualistyczne, charakterystyczne dla nowej ekonomii instytucjonalnej).

3. Odejście od wyjaśniania relacji gospodarczych jedynie w oparciu o reguły rynkowe, oparte na założeniu, że poza rynkiem istnieje szereg innych konwencji (por. tab. 18) ${ }^{108}$.

Tabela 18. Modele relacji ekonomicznych w zależności od systemów wartości w ujęciu ekonomii konwencji

\begin{tabular}{|l|l|l|l|l|l|l|}
\cline { 2 - 6 } \multicolumn{1}{l|}{} & $\begin{array}{l}\text { Oparty na } \\
\text { inspiracji }\end{array}$ & $\begin{array}{c}\text { Oparty na } \\
\text { wartościach } \\
\text { tradycyjnych }\end{array}$ & $\begin{array}{l}\text { Obywa- } \\
\text { telski }\end{array}$ & $\begin{array}{l}\text { Oparty na } \\
\text { przekazach } \\
\text { opiniotwór- } \\
\text { czych }\end{array}$ & Rynkowy & Produkcyjny \\
\hline $\begin{array}{l}\text { Kryteria i me- } \\
\text { tody oceny } \\
\text { zaistniatych } \\
\text { sytuacji (wy- } \\
\text { ceny dóbr) }\end{array}$ & $\begin{array}{l}\text { honor, } \\
\text { nonkon- } \\
\text { formizm, } \\
\text { kreatyw- } \\
\text { ność }\end{array}$ & $\begin{array}{l}\text { szacunek, } \\
\text { reputacja }\end{array}$ & $\begin{array}{l}\text { wspólny } \\
\text { interes }\end{array}$ & rozgłos & cena & $\begin{array}{l}\text { wydajność, } \\
\text { efektywność }\end{array}$ \\
\hline $\begin{array}{l}\text { Charakter } \\
\text { kluczowych } \\
\text { przekazów } \\
\text { informacyj- } \\
\text { nych }\end{array}$ & $\begin{array}{l}\text { emocjo- } \\
\text { nalny }\end{array}$ & $\begin{array}{l}\text { ustny, } \\
\text { anegdotyczny } \\
\text { odwołujący } \\
\text { się do do- } \\
\text { brych wzor- } \\
\text { ców }\end{array}$ & $\begin{array}{l}\text { zowany } \\
\text { oficjalny }\end{array}$ & semiotyczny & pieniężny & $\begin{array}{l}\text { mierzalne } \\
\text { kryteria, } \\
\text { oparte na } \\
\text { statystyce }\end{array}$ \\
\hline $\begin{array}{l}\text { Elementarne } \\
\text { zależności }\end{array}$ & pasja & zaufanie & $\begin{array}{l}\text { solidar- } \\
\text { ność }\end{array}$ & uznanie & wymiana & $\begin{array}{l}\text { powiązania } \\
\text { funkcjonalne }\end{array}$ \\
\hline $\begin{array}{l}\text { Kryteria oce- } \\
\text { ny jednostek } \\
\text { ludzkich }\end{array}$ & $\begin{array}{l}\text { kreatyw- } \\
\text { ność, } \\
\text { pomy- } \\
\text { stowość, } \\
\text { solidność }\end{array}$ & $\begin{array}{l}\text { władza } \\
\text { wzajem- } \\
\text { ność }\end{array}$ & sława & $\begin{array}{l}\text { chęć po- } \\
\text { siadania, } \\
\text { sita na- } \\
\text { bywcza }\end{array}$ & $\begin{array}{l}\text { profesjona- } \\
\text { lizm, } \\
\text { kompetencje, } \\
\text { wiedza ido- } \\
\text { świadczenie }\end{array}$ \\
\hline
\end{tabular}

Źródło: L. Boltanski, L. Thévenot, The Sociology of Critical Capacity, „European Journal of Social Theory” 1999, vol. 2 (3), s. 368.

108 Na podstawie: P.-Y. Gomez, Information et conventions. Le cadre du modèle général, „Revue Française de Gestion” 2006, nr 160, s. 217-240. 
Ważny dla francuskiej ekonomii konwencji pozostaje silnie akcentowany dystans do koncepcji homo economicus. Szkoła ta zakłada, iż ekonomia neoklasyczna napotkała na poważne problemy metodologiczne dotyczące zagadnienia koordynacji, które trudno analizować, przyjmując za punkt widzenia motywacje niezależnych pojedynczych jednostek ${ }^{109}$. Wskazuje ponadto na trzy główne typy ograniczeń metodologicznych ekonomii neoklasycznej ${ }^{110}$ :

1. Niekompletność wynikająca z niedoskonałości mechanizmu rynkowego. Powoduje ona, że w praktyce może funkcjonować więcej niż jeden mechanizm równowagi. Bez dodatkowych mechanizmów instytucjonalnych trudno zatem zapewnić efektywną koordynację za pomocą mechanizmu rynkowego.

2. Niekompletność racjonalności strategicznej, wynikająca z niestabilności otoczenia społecznego. Odwołując się do teorii gier, analizy neoklasyczne zakładają występowanie przede wszystkim gier niekooperacyjnych (w których równowaga Nasha jest trudna lub niemożliwa do osiągnięcia).

3. Niekompletność kontraktów, wynikająca z niepewności co do przyszłości.

W ekonomii konwencji uznaje się, że wymienione wyżej niekompletności są zjawiskiem powszechnym, w związku z czym ich pomijanie w badaniach procesów gospodarczych skutkuje uzyskiwaniem niewiarygodnych wyników badań ekonomicznych. Działania w społeczeństwie zawsze odbywają się $\mathrm{w}$ warunkach niepewności, a tym samym proces zawierania jakichkolwiek porozumień odbywa się w warunkach ciągłej konieczności rozpoznawania warunków, interpretowania zaistniałych sytuacji i dobierania w tych warunkach sposobów porozumiewania się. W ekonomii konwencji uważa się konwencje za sposoby radzenia sobie z nieprzewidywalnością otoczenia. W przeciwieństwie do badań ekonomicznych głównego nurtu, zamiast skupiać się na czynnikach prowadzących do zapewnienia stabilności i przewidywalności otoczenia działalności gospodarczej, ekonomia konwencji koncentruje się na erystyce, wymuszającej zróżnicowane zachowania $\mathrm{w}$ odmiennych sytuacjach, podejmując na tej podstawie próbę kategoryzacji różnych form konwencji (z pełną świadomością, że konwencje te podlegają nieustannym przemianom $)^{111}$.

Punktem wyjścia dla wszelkich analiz podejmowanych na gruncie ekonomii konwencji jest zatem uznanie, że ludzkich zachowań nie da się uprościć do prostych schematów myślowych. Tym samym w rzeczywistości gospo-

109 S. Jagd, Economics of Convention..., s. 77.

110 Za: A. Orléan, Vers un modèle général...

111 Por. S. Jagd, Economics of Convention..., s. 78-79. 
darczej występują rozmaite sposoby oceny sytuacji, w których podejmowane są decyzje ekonomiczne i którym towarzyszą odmienne działania oraz odmienne formy koordynacji tych działań. Ponieważ dodatkowo decyzje te podejmowane są $\mathrm{w}$ warunkach niepewności otoczenia, aktorzy ekonomiczni skłonni są do działania w ramach wzajemnie wypracowanych konwencji, definiowanych tu stosunkowo szeroko jako gama możliwych do zastosowania, współdzielonych przez różne grupy i jednostki interpretacji i praktyk ${ }^{112}$.

Należy podkreślić, że choć ekonomia konwencji nie zajmuje się wprost zagadnieniem instytucji, to bada metody koordynacji, które przeciwstawiają skrajną opozycję między zasadami mającymi na celu równoważenie partykularnych interesów a zasadami uznanymi za czyste ograniczenia działań jednostek. Jedną z podstawowych hipotez tego programu jest założenie, że interakcje między jednostkami, nawet gdy dotyczą jedynie wymiany towarowej, nie są możliwe bez wspólnych ram, zwanych konwencjami, naturalnie nałożonymi na te jednostki ${ }^{113}$.

Na gruncie ekonomii konwencji, w przeciwieństwie do programu badawczego nowej ekonomii instytucjonalnej, nie zdołano jeszcze wypracować ugruntowanych metod badawczych. Z drugiej strony, ekonomia konwencji zyskuje coraz więcej zwolenników na obszarze anglosaskim, gdzie podejmuje się skuteczne próby jej operacjonalizacji, wykorzystując dorobek intelektualny teorii gier. W tym nurcie ekonomicznym coraz częściej bowiem podejmuje się próby nadania badaniom społecznego charakteru, dotychczas silnie ignorowanego w ramach ekonomi głównego nurtu (do którego zwykle zalicza się teorię gier) ${ }^{114}$. Konwencje znajdują zastosowanie $\mathrm{w}$ przypadku występowania gier posiadających więcej niż jedną równowagę, jako jedno z możliwych rozwiązań. Idąc dalej, należy wskazać, że konwencja to konsekwencja powtarzalności gry w danym społeczeństwie, a jej wpływ na dobrobyt społeczny polega na ograniczaniu kosztów transakcyjnych. Podejmując próbę uchwycenia wymiaru społecznego konwencji, można stwierdzić, że konwencja to stan równowagi w „grze powtarzanej wielokrotnie przez wielu członków społeczeństwa" na tyle często, iż powtarzające się zachowania jej uczestników stały się powszechnie akceptowanym zwyczajem ${ }^{115}$.

112 J. Latsis, G. de Larquier, F. Besis, Are Conventions Solutions to Uncertainty? Contrasting Visions of Social Coordination, „Journal of Post Keynesian Economics” 2010, vol. 32, no. 4, s. 550.

$113 \mathrm{Ch}$. Bessy, Institutional Embeddedness of Economic Exchange: Convergence Between New Institutional Economics and the Economics of Conventions, [w:] O. Favereau, E. Lazega (red.), Conventions and Structures..., s. 81.

114 J. Latsis, G. de Larquier, F. Besis, Are Conventions Solutions..., s. 537.

115 H. P. Young, Social Norms and Economic Welfare, „European Economic Review” 1998, vol. 42 (3-5), s. 823. 
$\mathrm{Z}$ punktu widzenia przestrzennych aspektów procesów gospodarczych, należy zwrócić uwagę także na fakt zróżnicowania konwencji stanowiących podstawę podejmowania decyzji ekonomicznych w zależności od lokalizacji. W ujęciu modelowym można założyć, że w warunkach wysokiego prawdopodobieństwa występowania wzajemnych interakcji w ramach wybranej grupy podmiotów gospodarczych (przedsiębiorstw, gospodarstw domowych) oraz niedoskonałego dostępu do informacji, przy jednocześnie niskim poziomie prawdopodobieństwa występowania sytuacji niespodziewanych, większość członków danej populacji stosować będzie te same konwencje. Sytuację taką można nazwać efektem konformizmu lokalnego (local conformity effect). Jednakże nawet jeśli każda grupa podmiotów gospodarczych początkowo podejmuje decyzje ekonomiczne $\mathrm{w}$ podobnych uwarunkowaniach instytucjonalnych, istnieje wysokie prawdopodobieństwo, że w miarę upływu czasu każda z nich zacznie używać innego zestawu konwencji. Zjawisko to w ekonomii konwencji opisywane jest jako globalny efekt różnorodności (global diversity effect $)^{116}$. Przyczyny tego zjawiska wciąż wydają się niedostatecznie rozpoznane i analiza lokalnych czynników historycznych, kulturowych oraz instytucjonalnych, zarówno powodujących przestrzenne zróżnicowanie konwencji, jak i różnicujących terytorialnie efektywność ekonomiczną, jawi się jako interesujące pole eksploracji naukowej w ramach ekonomii konwencji.

\subsection{Ekonomia ewolucyjna}

Znaczenie instytucji w procesach gospodarczych podkreśla się nie tylko na gruncie nurtów powszechnie klasyfikowanych jako cześć ekonomii instytucjonalnej, lecz także wielu gałęzi uznawanych za elementy tzw. ekonomii głównego nurtu. Wśród nich należy wymienić przede wszystkim ekonomię ewolucyjną (której kluczowymi przedstawicielami są Richard Nelson oraz Sidney Winter ${ }^{117}$ i do pewnego stopnia również Geoffrey M. Hodgson - szczególnie w zakresie jego odwołań do prac Th. Veblena ${ }^{118}$ ) oraz zasobową szkołę myślenia strategicznego (resource-based-view - RBV), za której twórcę uznaje się Jaya

116 H. P. Young, The Economics of Convention, „The Journal of Economic Perspectives" 1996, vol. 10, no. 2, s. 111-112.

117 R. R. Nelson, S. G. Winter, An Evolutionary Theory of Economic Change, Belknap Press, Cambridge 1982.

118 G. M. Hodgson, Economics and Evolution: Bringing Life Back into Economics, University of Michigan Press, Ann Arbor 1997. 
B. Barneya ${ }^{119}$. Podejścia te, w przeciwieństwie do ekonomiki kosztów transakcyjnych, nie są koncepcjami statycznymi, lecz akcentują proces uczenia się (prowadzący do obniżenia wewnętrznych kosztów funkcjonowania organizacji gospodarczych ${ }^{120}$ ), jak też ewolucyjny charakter procesów gospodarczych. Struktura organizacyjna jest $\mathrm{w}$ takim przypadku interpretowana - z jednej strony - jako środowisko pozwalające w bardziej skuteczny sposób „eksperymentować” z nowymi pomysłami oraz chroniące wartościowe zasoby kluczowych kompetencji, z drugiej zaś - jako system zapewniający większą przewidywalność działania w warunkach zmienności uwarunkowań społeczno-gospodarczych ${ }^{121}$.

Zarówno podejście oparte na zasobach, jak i ekonomia rozwijana na gruncie ewolucyjnym odchodzą od założeń ekonomii neoklasycznej, w tym przede wszystkim od koncepcji doskonałej racjonalności podmiotów podejmujących decyzje ekonomiczne. Dlatego w koncepcjach tych rezygnuje się m.in. z supozycji, że popyt na produkty pojedynczego sektora jest jednorodny i z nierealnego $\mathrm{w}$ rzeczywistości założenia o dostępie do pełni informacji przez wszystkich uczestników rynku. Odrzuca się w nich też założenie, iż dążenie do maksymalizacji własnej użyteczności konsumpcji stanowi jedyny motyw podejmowania decyzji ekonomicznych, gdyż w rzeczywistości podmioty gospodarcze kierują się szeregiem innych, czasem niełatwych do zidentyfikowania motywów i systemów wartości.

Renesans myśli ewolucyjnej w głównym nurcie ekonomii poprzedziła krytyka kierunku neoklasycznego, ujawniająca jego ograniczenia ${ }^{122}$. Kierunek neoklasyczny, dominujący w ekonomii przez większą część XX w., badał układy równowagowych zachowań podmiotów tworzących przestrzeń ekonomiczną. I choć odmienne podejście do badań ekonomicznych zaproponował już na początku XX w. J. A. Schumpeter, jego koncepcje długo czekały na zajęcie odpowiedniego miejsca w głównym nurcie ekonomii ${ }^{123}$ (tab. 19).

119 J. B. Barney, Firm Resources and Sustained Competitive Advantage, „Journal of Management" 1991, vol. 12, no. 1, s. 99-120.

120 R. N. Langlois, Transaction Cost Economics in Real Time, „Industrial and Corporate Change" 1992, vol. 1 (1), s. 99-127.

121 N. J. Foss, P. G. Klein, Critiques of Transaction...

122 R. Domański, Ewolucyjna gospodarka przestrzenna, Wyd. Uniwersytetu Ekonomicznego w Poznaniu, Poznań 2012, s. 9.

123 J. A. Schumpeter, Theorie der Wirtschaftlichen Entwicklung, Dunker und Humboldt, Leipzig 1912; J. A. Schumpeter, Teoria rozwoju gospodarczego, PWN, Warszawa 1960. 
Tabela 19. Odejście od założeń ekonomii neoklasycznej na gruncie szkoły zasobowej i ekonomii ewolucyjnej

\begin{tabular}{|c|c|c|}
\hline Założenia & $\begin{array}{l}\text { Teoria oparta na modelu } \\
\text { doskonatej konkurencji }\end{array}$ & $\begin{array}{l}\text { Teorie odrzucające założenia } \\
\text { doskonałej konkurencji }\end{array}$ \\
\hline Popyt & $\begin{array}{l}\text { Zróżnicowany w różnych sektorach. } \\
\text { Niezróżnicowany w pojedynczym } \\
\text { sektorze i stały. }\end{array}$ & $\begin{array}{l}\text { Zróżnicowany i nieelastyczny za- } \\
\text { równo pomiędzy sektorami, jak } \\
\text { i w pojedynczym sektorze. }\end{array}$ \\
\hline $\begin{array}{l}\text { Dostęp konsu- } \\
\text { mentów do infor- } \\
\text { macji na rynku }\end{array}$ & Doskonały i bezpłatny. & Niedoskonały i kosztowny. \\
\hline Motywacje & $\begin{array}{l}\text { Dążenie do maksymalizacji użytecz- } \\
\text { ności. }\end{array}$ & $\begin{array}{l}\text { Ograniczenia społeczne i kulturowe } \\
\text { w dążeniu do maksymalizacji uży- } \\
\text { teczności. }\end{array}$ \\
\hline $\begin{array}{l}\text { Cel } \\
\text { przedsiębiorstwa }\end{array}$ & Maksymalizacja zysku. & $\begin{array}{l}\text { Poprawa wyników finansowych } \\
\text { w możliwie jak największym za- } \\
\text { kresie. }\end{array}$ \\
\hline $\begin{array}{l}\text { Dostęp przedsię- } \\
\text { biorstw do infor- } \\
\text { macji na rynku }\end{array}$ & Doskonały i bezpłatny. & Niedoskonały i kosztowny. \\
\hline $\begin{array}{l}\text { Zasoby } \\
\text { przedsiębiorstw }\end{array}$ & Ziemia, kapitat i praca. & $\begin{array}{l}\text { Finansowe, fizyczne, prawne, ludz- } \\
\text { kie, organizacyjne, informacyjne, } \\
\text { relacyjne. }\end{array}$ \\
\hline $\begin{array}{l}\text { Charakterystyka } \\
\text { zasobów }\end{array}$ & $\begin{array}{l}\text { Homogeniczność i pełna możliwość } \\
\text { imitacji. }\end{array}$ & $\begin{array}{l}\text { Heterogeniczność, brak mobilności } \\
\text { i brak możliwości pełnej imitacji. }\end{array}$ \\
\hline Rola zarządzania & Maksymalizacja funkcji produkcji. & $\begin{array}{l}\text { Rozpoznanie, zrozumienie, two- } \\
\text { rzenie, selekcjonowanie, wdraża- } \\
\text { nie i modyfikowanie strategii roz- } \\
\text { woju. }\end{array}$ \\
\hline $\begin{array}{l}\text { Model } \\
\text { konkurencji }\end{array}$ & $\begin{array}{l}\text { Oparty na analizie równowagi. } \\
\text { Innowacje jako czynnik egzoge- } \\
\text { niczny. }\end{array}$ & $\begin{array}{l}\text { Nierównowaga jako stan naturalny. } \\
\text { Innowacje jako czynnik endoge- } \\
\text { niczny. }\end{array}$ \\
\hline
\end{tabular}

Źródło: S. D. Hunt, Resource-advantage Theory: An Evolutionary Theory of Competitive Firm Behavior?, „Journal of Economic Issues” 1997, vol. 31, no.1, s. 62.

Do dorobku intelektualnego Schumpetera (jak również do dorobku H. Simona w zakresie koncepcji ograniczonej racjonalności) zaczęli odwoływać się w latach 80. XX w. R. N. Nelson i S. G. Winter. Wskazywali 
oni, że Schumpeter $\mathrm{w}$ trafny sposób pozwolił zrozumieć zagadnienie zmiany ekonomicznej (proponując podejście dynamiczne w miejsce równowagowego), natomiast Simon zaproponował obiecujące kierunki badań nad naturą ludzkiego zachowania, która odbiega od uproszczonego modelu homo oeconomicus ${ }^{124}$. Nelson i Winter w swoim opus magnum poświęconym ewolucyjnej analizie procesów gospodarczych zauważyli, że nawet jeśli wszystkie przedsiębiorstwa mają ten sam cel (maksymalizacja zysku), to każde $\mathrm{z}$ nich realizuje go na odmienne sposoby i osiąga $\mathrm{w}$ tym względzie inne rezultaty. $\mathrm{Z}$ czasem podmioty gospodarcze, które czynią to w sposób najmniej efektywny, są eliminowane, podczas gdy podmioty najskuteczniejsze poprawiają swoją pozycję konkurencyjną ${ }^{125}$. Innymi słowy, w gospodarce - podobnie jak w przyrodzie - działają mechanizmy ewolucji. Stąd w swej propozycji programu badawczego ekonomii ewolucyjnej wspomniani autorzy wyróżnili trzy zasadnicze mechanizmy: dziedziczenia rutyn, adaptacji poprzez ciągłe poszukiwanie nowych rozwiązań problemów ekonomicznych oraz selekcji ${ }^{126}$.

Rutyny określają zdolności przedsiębiorstw do produkowania określonych dóbr, tkwiące w wykorzystywanych przez nie procedurach, obejmujących: politykę zatrudnienia, projektowanie nowych produktów i usług, inwestowanie, działalność badawczo-rozwojową, marketing i reklamę, strategie sprzedaży i strategie rozwoju itd. Rutyny porównywane są w kontekście teorii ewolucji do genów, przedsiębiorstwa są organizmami, a poszczególne przemysły - gatunkami.

Rutyny przedsiębiorstw, podobnie jak materiał genetyczny żywych organizmów, są $\mathrm{w}$ procesie ewolucji udoskonalane dzięki mechanizmom dziedziczenia, selekcji i różnorodności. W przypadku podmiotów gospodarczych różnorodność zapewnia istnienie w jednym miejscu wielu przedsiębiorstw funkcjonujących na rynku, które charakteryzują się odmiennymi względem siebie wewnętrznymi mechanizmami funkcjonowania i odpowiadania na pojawiające się potrzeby odbiorców. Proces dziedziczenia polega na tym, że przyszły rozwój podmiotów gospodarczych jest zależny od ich historii. Oznacza to, że sposoby rozwiązywania pojawiających się problemów opierają się na wypracowanych wcześniej kompetencjach organizacyjnych, gdyż te dają $\mathrm{w}$ pewnym sensie poczucie pewności w niepewnym otoczeniu. Dziedziczenie odbywa się jednak również poprzez imitowanie i adaptowanie rozwiązań zaobserwowanych u innych podmiotów, szcze-

124 R. R. Nelson, S. G. Winter, An Evolutionary Theory..., s. IX.

125 Ibidem, s. 399-400.

126 Ibidem. 
gólnie partnerów i konkurentów, czemu z kolei sprzyja wspomniana różnorodnośćc 127 .

Natomiast mechanizm selekcji oddziałuje poprzez fakt, że na rynku utrzymują się i najlepiej rozwijają te podmioty, które poprzez wypracowane rutyny potrafią najlepiej dostosowywać się do zmiennych warunków. O selekcji decydują zatem, $\mathrm{z}$ jednej strony, kompetencje organizacyjne przedsiębiorstw, zaś z drugiej - to, co ma miejsce w ich otoczeniu, a zatem zmiany popytu, sytuacja $\mathrm{w}$ branży, zachowania konsumentów i konkurentów w danym sektorze itd. ${ }^{128}$

Ekonomia ewolucyjna jest więc koncepcją wyjaśniającą wewnętrzną zdolność systemów gospodarczych do zmian polegających na dostosowywaniu posiadanych zasobów do zmieniających się uwarunkowań. Nawiązując do metafory opartej na modelach ewolucji biologicznej zaczerpniętych od K. Darwina i J. B. Lamarcka ${ }^{129}$ oraz do wczesnych koncepcji instytucjonalnych T. Veblena odwołujących się wprost do darwinizmu (por. rozdział II), ekonomia ewolucyjna wskazuje na istotną rolę zmian gospodarczych dla podkreślenia opozycji wobec analizy ekonomicznej skupionej na problemach równowagi i modeli statycznych. Ponadto, modele ewolucyjne mają służyć „wyjściu z pułapki” traktowania mechanizmów cenowych i rynkowych jako jedynych możliwych mechanizmów zapewniających efektywne funkcjonowanie gospodarki ${ }^{130}$.

W ramach ekonomii ewolucyjnej podkreśla się znaczenie, jakie dla rozwoju gospodarczego ma niepewność i zależność od dotychczasowej ścieżki (historii) rozwoju (path-dependency). W tym kontekście uznaje się $\mathrm{w}$ ramach ekonomii ewolucyjnej, że uwarunkowania instytucjonalne w znacznym stopniu decydują o zachowaniach podmiotów ekonomicznych oraz o kierunkach przyszłej ewolucji systemów gospodarczych.

Należy podkreślić, iż ekonomia ewolucyjna ma przynajmniej dwa ograniczenia. Po pierwsze, podejście to koncentruje się jedynie na „wygranych", czyli posiada zdolność wyjaśniania przyczyn przemian w gospodarce, przy jednocześnie ograniczonej zdolności identyfikacji przyczyn problemów gospodarczych. Warto w tym miejscu zauważyć, że podejściu ewolucyjnemu $\mathrm{w}$ ekonomii obce jest w zasadzie charakterystyczne dla nowej ekonomii instytucjonalnej założenie, iż w relacje transakcyjne wschodzą zwykle podmioty, które cechuje względnie równa po-

127 M. E. Sokołowicz, Region wobec procesów globalizacji - terytorializacja przedsiębiorstw międzynarodowych (na przykładzie regionu łódzkiego), Wyd. Uniwersytetu Łódzkiego, Łódź 2008, s. 60.

128 Ibidem, s. 61.

129 W. Kwaśnicki, Ekonomia ewolucyjna - alternatywne spojrzenie na proces rozwoju gospodarczego. Część l, „Gospodarka Narodowa” 1996, nr 10, s. 3.

130 R. R. Nelson, S. G. Winter, An Evolutionary Theory..., s. 403. 
zycja i siła przetargowa. W ekonomii ewolucyjnej bowiem akcentuje się przede wszystkim zjawisko nierównowagi - w tym także nierównowagi w zakresie sił reprezentowanych przez różne strony translacji ekonomicznych. Drugie wskazywane w literaturze ograniczenie ekonomii ewolucyjnej dotyczy faktu, że nie zajmuje się ona relacjami gospodarczymi związanymi z pracą jako czynnikiem produkcji ${ }^{131}$.

Ekonomia ewolucyjna dopiero się kształtuje, jednak

rozwój tego podejścia w ostatnich kilkunastu latach pozwala stwierdzić, że w porównaniu z ujęciem neoklasycznym opis rozwoju gospodarczego proponowany przez ekonomię ewolucyjną na poziomie mikroekonomicznym jest pełniejszy i lepiej oddający rzeczywiste zachowania podmiotów gospodarczych ${ }^{132}$.

\subsection{Zasobowa szkoła myślenia strategicznego}

Jeśli chodzi o zasobową szkołę myślenia strategicznego, to rozwija się ona przede wszystkim na gruncie nauk o przedsiębiorstwie. Jeden z najważniejszych reprezentantów szkoły myślenia strategicznego, J. B. Barney, na wstępie analizy zasobów oraz ich strategicznej wartości stawia dwa podstawowe założenia ${ }^{133}$. Po pierwsze, przedsiębiorstwa w ramach tej samej branży lub grupy strategicznej mogą się od siebie zasadniczo różnić $\mathrm{w}$ kwestii posiadanych zasobów ${ }^{134}$. Po drugie, ze względu na ograniczenia w mobilności i dostępności poszczególnych zasobów odmienności te mogą utrzymywać się w długim okresie i w konsekwencji decydować o przewadze konkurencyjnej. Aby zasoby mogły stać się podstawą dla budowania takiej przewagi, powinny mieć następujące cechy ${ }^{135}$ :

- być strategicznie wartościowe,

- charakteryzować się rzadkością posiadania przez obecnych i potencjalnych konkurentów,

131 Ponieważ powyższymi aspektami zajmuje się do pewnego stopnia francuska szkoła regulacji, można spotkać się z postulatami łączenia ze sobą obydwu nurtów badawczych. Szerzej: F. Moulaert, Institutional Economics and Planning Theory: A Partnership Between Ostriches?, „Planning Theory” 2005, vol. 4, no. 21.

132 W. Kwaśnicki, Ekonomia ewolucyjna..., s. 52.

133 J. B. Barney, Firm Resources..., s. 102.

134 Autor za zasoby uważa przy tym „wszystkie środki trwałe, zdolności, procesy organizacyjne, atrybuty, informację i wiedzę, które pozostają pod kontrolą (przedsiębiorstwa) i są przez nie wykorzystywane w celu poprawy efektywności działania" (ibidem).

135 Ibidem, s. 106-112. 
- być trudne do imitacji i kopiowania przez innych ${ }^{136}$,

- być niezastępowalne przez inne rodzaje zasobów.

Ważnym założeniem szkoły strategicznego myślenia jest postrzeganie pojedynczego podmiotu jako specyficznego z punktu widzenia zasobów strategicznych, które ma i/lub kontroluje. Specyficzność ta stanowi konsekwencję niedoskonałości rynku, ograniczonej mobilności zasobów oraz braku zdolności przedsiębiorstw do modyfikacji zakumulowanego zbioru zasobów w stosunkowo krótkim okresie ${ }^{137}$ (rys. 13).

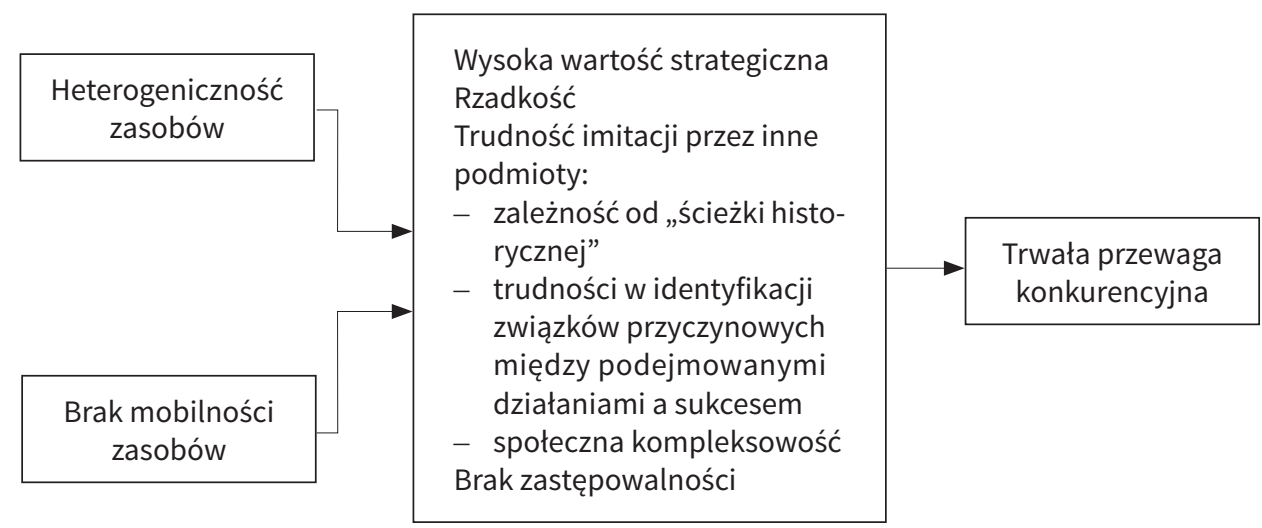

Rys. 13. Zasoby a trwała przewaga konkurencyjna

Źródło: J. B. Barney, Firm Resources and Sustained Competitive Advantage, „Journal of Management" 1991, vol. 17, no. 2, s. 112.

W podejściu zasobowym można dokonać rozróżnienia między pojęciem zasobów a pojęciem zdolności (umiejętności, rutyn). Zasoby mogą być przy tym zarówno materialne (np. kapitał fizyczny), jak i niematerialne (np. kapitał ludzki). Zdolności i umiejętności natomiast są zawsze niematerialne i pojawiają się jako wynik interakcji między różnymi ak-

136 Trudność imitacji stanowi konsekwencję trzech podstawowych czynników. Pierwszy z nich opiera się na założeniu, że każda organizacja posiada własną historię rozwoju, w trakcie której wypracowała własne „ścieżki” rozwiązywania pojawiających się wyzwań. Druga przyczyna trudności w imitacji polega na problemach dotyczących identyfikacji związków przyczynowych między podejmowanymi działaniami a sukcesem podmiotu. Ostatni czynnik odnosi się do faktu, że działania podejmowane wewnątrz organizacji cechuje złożoność i kompleksowość, oparta w znacznej mierze na specyfice powiązań i relacji między jej członkami (ibidem, s. 107-111).

137 G. R. Carroll, A Sociological View on Why Firms Differ, „Strategic Management Journal" 1993, vol. 14, s. 237-249. 
torami ekonomicznymi. Ponadto, o ile zasoby w ujęciu tradycyjnym stanowią zawsze potencjalny przedmiot wymiany handlowej, o tyle rutyny i umiejętności nie podlegają takiemu transferowi. Zasoby, stanowiące kluczowy element podejścia zasobowego do analizy strategicznej, mogą być stosunkowo nietrwale przywiązane do organizacji. Z kolei zdolności odzwierciedlają specyficzne umiejętności do angażowania i koordynowania posiadanych i/lub kontrolowanych zasobów. Można tym samym stwierdzić, że umiejętności również stanowią pewnego rodzaju zasoby, jednak są to zawsze zasoby specyficzne dla przedsiębiorstwa czy np. jednostki terytorialnej ${ }^{138}$.

Dla analizy dorobku szkoły zasobowego myślenia jako podstawy identyfikacji motywów podejmowania decyzji o internalizacji pomocne jest pojęcie mechanizmu izolacji, sformułowane przez R. P. Rumelta, rozumiane jako „zespół zjawisk (procesów) ograniczających ex ante wyrównywanie się nadwyżki pomiędzy konkurującymi przedsiębiorstwami" ${ }^{139}$. Dzięki temu mechanizmowi podmiot będący w posiadaniu zasobów przynoszących mu przewagę konkurencyjną może przewagę tę utrzymywać w długim okresie, a możliwości imitacji przez inne podmioty są utrudnione. Do najważniejszych utrudnień dla imitacji zasobów zaliczyć można $^{140}$ :

- niekorzyści kompresji czasu (np. często jest niemożliwe, aby konkurentom chcącym budować pozycję konkurencyjną na danym zasobie [np. na świadomości marki], w oparciu o taki sam lub podobny zasób, udało się uczynić to w krótszym czasie niż przedsiębiorstwu, które zrobiło to jako pierwsze [first-mover]);

- efektywność masy posiadanych zasobów (pozycja konkurencyjna zależy w tym rozumieniu od masy zasobów zgromadzonej w przeszłości, zatem bieżące nakłady ponoszone przez konkurentów w celu imitacji pewnych zasobów nie zawsze mogą przynieść oczekiwane efekty);

- współzależności między aktualnie posiadanymi zasobami (wartość strategiczna zasobów zależy nie tylko od ich ilości i jakości, lecz także od sposobów, w jakie zasoby te wzajemnie się uzupełniają

138 P. Salmi et al., Industrial Districts and Regional Development. Towards a Knowledge-based View, Telecom Business Research Center, Lappeenranta 2001, s. 66.

139 R. M. Rumelt, Towards a Strategic Theory of the Firm, [w:] R. B. Lamb (ed.), Competitive Strategic Management, Prentice Hall, New Jersey 1984, s. 556, [cyt. za:] B. Godziszewski, Zasobowe uwarunkowania strategii przedsiębiorstwa, Wyd. Uniwersytetu Mikołaja Kopernika w Toruniu, Toruń 2001, s. 78.

140 J. Dierickx, K. Cool, Assets Stock Accumulation and Sustainability of Competitive Advantage, „Management Science” 1989, vol. 35, s. 1504-1513, [cyt. za:] B. Godziszewski, Zasobowe uwarunkowania..., s. 85. 
i specyficznych ich kompozycji, zapewniających ich efektywne wykorzystanie) ${ }^{141}$;

- odmienne tempo erozji wartości różnych zasobów (o trwałości przewagi konkurencyjnej decyduje posiadanie takich zasobów, które swą wartość strategiczną tracą w stosunkowo wolnym tempie);

- niejasność związków przyczynowo-skutkowych między zasobami a wynikającą z ich posiadania przewagą konkurencyjną (niejasność ta wynika zarówno z faktu niewiedzy konkurentów o sposobach wykorzystania zasobów, jak i niewiedzy samej organizacji o tych związkach).

Zasobowa szkoła strategicznego myślenia współcześnie pozostaje dynamicznie rozwijającą się dyscypliną, przede wszystkim w ramach nauk o zarządzaniu. Wykazuje przy tym wiele podobieństw z innymi nurtami, jak np. koncepcja kluczowych kompetencji przedsiębiorstwa, zapoczątkowana przez G. Hamela i C. K. Prahalada ${ }^{142}$. Wspólnym mianownikiem tych koncepcji jest założenie, iż podmioty gospodarcze posiadają specyficzne kompetencje i umiejętności (technologiczne, związane z metodami zarządzania, marketingowe itp.), które stanowią o ich przewadze konkurencyjnej. W przeciwieństwie do głównego teorematu prezentowanego na gruncie ekonomiki kosztów transakcyjnych, rozwój przedsiębiorstwa w oparciu o własne struktury organizacyjne jest motywowany nie tyle dążeniem do ograniczenia kosztów transakcyjnych, ile chęcią zapewnienia pełni kontroli nad specyficznymi przewagami redukcji ryzyka ich imitacji przez konkurentów.

Dorobek omawianej szkoły jest ponadto silnie eksponowany w ramach studiów nad rozwojem lokalnym i regionalnym, przede wszystkim poprzez upowszechnienie podziału zasobów jednostek terytorialnych na podstawowe (generyczne) i specyficzne ${ }^{143}$. O współczesnej przewadze konkurencyjnej regionów decydują przy tym zasoby dru-

141 W tym wypadku ma miejsce tzw. synergia zasobów.

142 G. Hamel, C. K. Prahalad, The Core Competences of the Corporation, „Harvard Business Review" 1990, May/June, s. 79-90; G. Hamel, C. K. Prahalad, Przewaga konkurencyjna jutra, Business Press, Warszawa 1999. Zob. także: J. Kay, Podstawy sukcesu firmy, PWE, Warszawa 1996.

143 Szerzej na temat specyfiki zasobów i terytorialnego charakteru rozwoju gospodarczego piszą przede wszystkim przedstawiciele ekonomiki bliskości (G. Colletis, B. Pecquer, Politiques technologiques locales et création de resources spécifiques, [w:] A. Rallet, A. Torre (eds.), Economie industrielle et spatiale, Economica, Paris 1995), a w literaturze polskiej A. Jewtuchowicz (A. Jewtuchowicz, Terytorium i wspótczesne dylematy...) oraz I. Pietrzyk (I. Pietrzyk, Polityka regionalna Unii Europejskiej i regiony w państwach członkowskich, PWN, Warszawa 2001, s. 26-32). 
giego rodzaju, które tkwią $\mathrm{w}$ jego bazie wiedzy i kompetencji, cechują się wysokim stopniem niekodyfikowalności oraz są podtrzymywane, rozwijane i reprodukowane $\mathrm{w}$ wyniku interakcji zachodzących między aktorami lokalnymi, silnie zakorzenionymi w regionalnym układzie instytucjonalnym ${ }^{144}$.

\subsection{Ekonomika bliskości i koncepcja zakorzenienia (embeddedness)}

Źródła koncepcji zakorzenienia sięgają prac Karla Polanyi ${ }^{145}$ i początkowo były rozwijane przede wszystkim na gruncie socjologii ${ }^{146}$. Główna teza tego ujęcia odwołuje się jednak do podstawowych założeń ekonomii instytucjonalnej i głosi, że relacje gospodarcze są zakorzenione (embedded) w uwarunkowaniach kształtowanych przez instytucje - zarówno ekonomiczne, jak i pozaekonomiczne. Instytucje te definiowane są jako ograniczenia przyjmowane przez jednostki w celu nadania przewidywalnej i możliwie czytelnej struktury w ich wzajemnych relacjach.

W literaturze poświęconej rozwojowi lokalnemu i regionalnemu od lat podkreśla się, iż tzw. wiedza milcząca ${ }^{147}$ rozprzestrzenia się najefektywniej w warunkach kontaktów bezpośrednich, których intensyfikacji sprzyja bliskość geograficzna ${ }^{148}$. Idąc tym tropem tacy badacze, jak

144 R. A. Boschma, Competitiveness of Regions from an Evolutionary Perspective, „Regional Studies" 2004, vol. 38 (9), s. 1012.

145 K. Polanyi, The Great Transformation. The Political and Economic Origins of Time, Rinehart and Company, New York 1944; idem, The Economy as Instituted Process, [w:] K. Polanyi, C. M. Arensberg, H. W. Pearson (eds.), Trade and Market in the Early Empires. Economies in History and Theory, Free Press, New York 1957, s. 243-270.

146 R. Swedberg, Major Traditions of Economic Sociology, „Annual Review of Sociology" 1991, vol. 17, s. 251-276.

147 W ujęciu teoretycznym wyróżnia się zwykle cztery typy wiedzy: skodyfikowaną wiedzę o faktach (know-what), wiedzę naukową lub wiedzę o prawach naturalnych (know-why), wiedzę milczącą (know-how) oraz wiedzę o podmiotach posiadających know-what i know-how (tzw. wiedzę know-who). Na tle innych rodzajów wiedzy, know-how jest wiedzą „milczącą”, tzn. nie może być transferowana poprzez prezentację, naukę, treningi itp. Jest zasobem specyficznym dla danej organizacji (przedsiębiorstwa, instytucji, regionu itp.) i odnosi się do wypracowanych umiejętności wykonywania specyficznych czynności. Jedynym sposobem transferu tego typu wiedzy jest tworzenie sieci powiązań między różnego typu partnerami, współpracującymi ze sobą (szerzej: OECD, Technology and the Economy. The Key Relationships, Paris 1992).

148 P. Maskell et al., Competitiveness, Localised Learning and Regional Development, Routledge, London 1998. 
G. Becattini i E. Rullani ${ }^{149}$, B. Asheim ${ }^{150}$ oraz B. Noteboom ${ }^{151}$ wprowadzili podział na wiedzę kodyfikowaną, transferowaną poprzez sieci ponadlokalne (media, korporacje transnarodowe, instytucje edukacyjne itd.) oraz wiedzę milczącą, zakorzenioną $\mathrm{w}$ relacjach bliskości, stanowiącą konsekwencję „atmosfery przemysłowej” i nabywaną w miejscu pracy oraz $\mathrm{w}$ toku codziennej działalności i interakcji społecznych. W takim podejściu wyraźnie dostrzega się odwołanie do instytucjonalnych aspektów relacji ekonomicznych. W szczególności należy przywołać kontekst teoretyczny budowania kapitału społecznego ${ }^{152}$ oraz tzw. zakorzenienia (embededdness).

Z ekonomicznego punktu widzenia zakorzenienie oznacza, że decyzje gospodarcze zawsze pozostają pod wpływem uwarunkowań instytucjonalnych, które formują określone wzory zachowań i reakcji na zmiany. Istotę tego zjawiska dobrze ilustruje Mark Granovetter, twierdząc, iż wszystkie rodzaje działalności gospodarczej są zakorzenione w sieciach społecznych relacji ${ }^{153}$. W swym artykule - uznawanym współcześnie za początek rozważań na temat zakorzenienia - wskazał, że tradycyjne podejście socjologiczne zbyt silnie uwypukla społeczny kontekst zachowań, natomiast ekonomia klasyczna nie dostrzega ich niemal wcale. Zaproponowane przez niego nowe podejście miało stanowić próbę pogodzenia obydwu stanowisk zgodnie z tezą, iż środowisko społeczno-kulturowe zarówno kształtuje, jak i jest kształtowane przez interakcje ekonomiczne ${ }^{154}$.

Według M. Granovettera każda z form aktywności gospodarczej, znajdującej się pomiędzy rynkiem a hierarchiczną strukturą organizacji, wpleciona jest $\mathrm{w}$ sieci relacji interpersonalnych, zaś nieuwzględnienie tego kontekstu w analizach ekonomicznych z góry skazuje je na niepowo-

149 G. Becattini, E. Rullani, Sistema locale e mercato globale, „Economia e Politica Industriale" 1993, vol. 80, s. 25-40.

150 B. Asheim, 'Learning Regions' in a Globalised World Economy: Towards a New Competitive Advantage of Industrial Districts?, [w:] S. Conti, M. Taylor (eds.), Interdependent and Uneven Development: Global-Local Perspectives, Avebury, London 1997, s. 143-175.

151 B. Nooteboom, Innovation, Learning and Industrial Organization, „Cambridge Journal of Economics" 1999, vol. 23 (2), s. 127-150.

152 Wśród osób wnoszących największy wkład w teorię kapitału społecznego wymienia się Pierre'a Bourdieu, Francisa Fukuyamę oraz Roberta Putnama: P. Bourdieu, Distinction: A Social Critique of the Judgement of Taste, Routledge and Kegan Paul, London 1984; F. Fukuyama, Trust: The Social Virtues and the Creation of Prosperity, Hamish Hamilton, London 1995; R. Putnam, Bowling Alone: The Collapse and Revival of American Community, Simon and Schuster, New York 2000.

153 M. Granovetter, Economic Action and Social Structure. The Problem of Embeddedness, „American Journal of Sociology” 1985, vol. 91 (1), s. 481.

154 Ibidem, s. 483-487. 
dzenie. Tym samym instytucjonalny kontekst działalności gospodarczej nie powinien być wtórnym, lecz podstawowym aspektem prac badawczych w tym obszarze. Odwołując się do tezy, że działalności i decyzje gospodarcze pozostają społecznie zakorzenione, M. Granovetter sugeruje, by odrzucić założenie o doskonałej racjonalności w ekonomii, podobnie jak uczynił to H. A. Simon w ramach koncepcji ograniczonej racjonalności czy Harvey Leibenstein w swojej koncepcji „X-nieefektywności” ${ }^{155}$. Zdaniem M. Granovettera aspekt społeczny nie jest pobocznym, ale centralnym zagadnieniem $\mathrm{w}$ analizach ekonomicznych ${ }^{156}$.

Zagadnienie zakorzenienia $\mathrm{w}$ rozumieniu przedstawionym powyżej bazuje na założeniu, zgodnie z którym tym, co w istotnym stopniu przyczynia się do wzmocnienia otoczenia instytucjonalnego działalności gospodarczej jest bliskość ${ }^{157}$. Dało to podstawę do rozwoju gałęzi ekonomii zwanej ekonomiką bliskości (ang. proximity, fr. proximité). Jej ważna rola $\mathrm{w}$ procesach gospodarczych uwzględniana jest w myśli ekonomicznej od czasów wprowadzenia przez Alfreda Marshalla do teorii ekonomii pojęcia korzyści aglomeracji. W klasycznym ujęciu bliskość, jako źródło takich korzyści, pociąga za sobą minimalizację kosztów związanych z problemem odległości, prowadzi do ograniczeń kosztów transportu oraz daje pożytki związane z koncentracją na danej przestrzeni infrastruktury, instytucji, organizacji i ludzi. Współcześnie najbardziej istotną korzyścią wynikającą z bliskości wydaje się jednak to, iż pociąga ona za sobą współzależności ekonomiczne i kulturowe, prowadzące do budowania relacji, zarówno rynkowych, jak i pozarynkowych, opartych na zaufaniu. Jak twierdzi przy tym wielu badaczy, zależności między lokalnym i globalnym wymiarem gospodarki, bezpośrednie kontakty będące konsekwencją bliskości - w stosunku do kontaktów na odległość (coraz powszechniejszych z uwagi na szybki rozwój technologii komunikacyjnych) - stają się nie tyle substytutem, ile czynnikiem komplementarnym ${ }^{158}$. Innymi

155 Nieefektywnością typu X nazywamy taką sytuację w gospodarce, kiedy producenci nie wybierają najtańszych sposobów produkcji poszczególnych ilości wytwarzanego dobra. Pojawia się ona wtedy, gdy koszt wytworzenia pewnej ilości dobra przez przedsiębiorstwo jest większy od najmniejszego możliwego kosztu wytworzenia tej ilości dobra. Wśród przyczyn tej sytuacji można wyróżnić m.in. zachowania menadżerów nieoparte na ekonomicznej kalkulacji ich decyzji (wygoda, unikanie ryzyka, nepotyzm, brak wiedzy itp.) lub np. wadliwy system kontroli pracowników.

156 M. Granovetter, Economic Action..., s. 505.

157 M. E. Sokołowicz, Terytorializacja korporacji transnarodowych w gospodarce globalnej - przegląd dorobku teoretycznego i badawczego, „Acta Universitatis Lodziensis. Folia Oeconomica" 2012, nr 275, s. 196.

158 Ph. McCann, D. Shefer, Location, Agglomeration, Infrastructure, „Papers in Regional Science" 2004, nr 83, s. 177-196. 
słowy, bliskość jako źródło korzyści aglomeracji nie stanowi przeciwwagi dla procesów gospodarczych zachodzących w skali ponadlokalnej, lecz ich uzupełnienie. Odwołując do trzech zasadniczych źródeł korzyści aglomeracji, wskazywanych pierwotnie przez A. Marshalla (dostępność wykwalifikowanych pracowników, łatwość znalezienia dostawców i odbiorców oraz możliwość uczenia się od znajdujących się w bliskości konkurentów i kooperantów), należy stwierdzić, że paradygmat bliskości eksponuje przede wszystkim ostatnie z nich, tym samym w znacznym stopniu akcentując terytorialny charakter procesów rozwoju społeczno-gospodarczego ${ }^{159}$.

Warto w tym miejscu ponownie odwołać się do analiz podejmowanych przez M. Granovettera, który w podobnym ujęciu interpretował logikę sieci. W swym artykule z 1973 r. autor ten zaproponował wyróżnienie tzw. silnych i słabych więzi społecznych ${ }^{160}$. O ich sile czy słabości decyduje przy tym kombinacja: ilości czasu poświeconego na budowanie relacji, intensywności emocjonalnej, poziomu intymności i wzajemnego zaufania. Czynniki te decydują o liczbie posiadanych więzi silnych (których przeciętni ludzie rzadko mają więcej niż tuzin) oraz więzi słabych.

Kluczowe w propozycji Granovettera było przede wszystkim stwierdzenie, iż najistotniejsze dla rozwoju efektywnych powiązań (tj. takich, które skuteczniej umożliwiają dyfuzję informacji i wiedzy) są paradoksalnie więzi słabe. Stanowią one mosty społeczne, łączące różne kręgi znajomości. Dzięki nim nie tylko łatwiej znaleźć pracę, lecz także to one decydują o rozprzestrzenianiu się mód, innowacji i norm ${ }^{161}$. Podczas gdy więzi silne w istocie ograniczają się zwykle do wąskiego kręgu osób, cechą więzi słabych pozostaje otwartość na różnorodne grona i grupy społeczne. W efekcie, choć intuicja podpowiada, że w znalezieniu pracy bardziej pomagają najbliżsi (silne więzi), badania empiryczne autora wskazały na sytuację odwrotną - to więzi słabe pomagają łączyć z innymi kręgami znajomych (stąd M. Granovetter nazywa je mostami) i to za ich pomocą łatwiej zdobyć nową pracę. W konsekwencji - stwierdza autor - to więzi słabe odgrywają kluczową rolę we wzmacnianiu spójności społecznej ${ }^{162}$.

Okazuje się jednak, że tylko część tzw. słabych więzi społecznych budowana jest w warunkach bliskości fizycznej. Powiązania tego rodzaju powstają bowiem również na większe odległości. O ich efektywności

159 M. E. Sokołowicz, Zagadnienie bliskości w badaniach nad rozwojem terytorialnym. Podejście instytucjonalne, [w:] A. Nowakowska (red.), Zrozumieć terytorium. Idea i praktyka, Wyd. Uniwersytetu Łódzkiego, Łódź 2013, s. 65.

160 M. Granovetter, Strength of Weak Ties, „American Journal of Sociology” 1973, vol. 78, no. 6, s. 1360-1380.

161 E. Bendyk, Świat na sześć osób, „Polityka”, 5.04.2003, nr 14 (2365), s. 74-75.

162 M. Granovetter, Strength of Weak..., s. 1373. 
w zakresie rozprzestrzeniania informacji decyduje nie tyle odległość pojmowana w kategoriach geonomicznych - posługując się terminologią F. Perroux - ile zdolność do budowania relacji o charakterze społecznym i instytucjonalnym ${ }^{163}$.

Koncepcja sieci relacji small world traktowana jest od momentu jej upowszechnienia jako alternatywa zarówno dla regularnego modelu powiązań, w którym każdy z podmiotów ma powiązania jedynie z podmiotem znajdującym się w najbliższym sąsiedztwie, jak i modelu określanego mianem losowego, w którym bliskość w wymiarze fizycznym nie ma żadnego znaczenia dla budowania sieci relacji (por rys. 14).
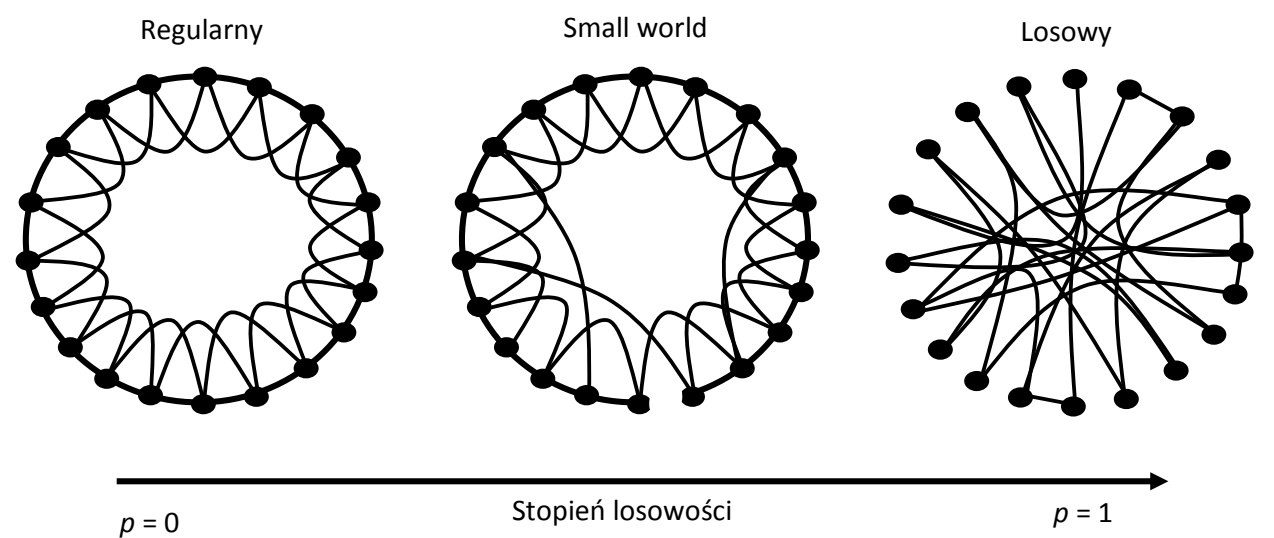

Rys. 14. Model „małego świata” na tle innych modeli relacji sieciowych Źródło: D. J. Watts, S. H. Strogatz, Collective Dynamics of 'Small-world' Networks, „Nature” 1998, vol. 393, s. 441.

163 Potwierdzeniem tej hipotezy jest zresztą przeprowadzony w 1967 r. eksperyment amerykańskiego psychologa społecznego z Yale University, Stanleya Milgrama. Kilkaset osób mieszkających w Bostonie i Omaha w Stanach Zjednoczonych poproszono o przestanie do wskazanej osoby w Bostonie listu w sytuacji nieposiadania adresu tej osoby. Biorący udział w eksperymencie - nie znając bezpośrednio wskazanej osoby - mieli prawo do skorzystania z pośredników w postaci swych przyjaciół. W wyniku eksperymentu obliczono, że średnia długość łańcucha powiązań pozwalających na dostarczenie listu do wybranej osoby liczyła zaledwie sześć osób (S. Milgram, The Small World Problem, „Psychology Today” 1967, no. 2, s. 60-67). Rezultat eksperymentu doprowadzit do sformułowania tzw. hipotezy o małym świecie (small world hypothesis), zwanej niekiedy hipotezą sześciu kroków. Głosi ona, że pomimo posiadania przez większość osób przede wszystkim kontaktów nawiązywanych w skali lokalnej, budowane przez nich sieci relacji posiadają wymiar ponadlokalny. 
Testy empiryczne hipotezy o małym świecie wskazują przy tym, że zbudowany na jej podstawie model w możliwie najbardziej trafny sposób odzwierciedla charakter relacji zachodzących w rzeczywistości. W ramach ekonomiki bliskości podejmuje się natomiast próbę testowania, czy hipoteza ta znajduje swoje odzwierciedlenie także w odniesieniu do relacji o charakterze gospodarczym. W tym celu jej przedstawiciele wyróżniają odmienne typy bliskości, analizując ich wpływ na funkcjonowanie gospodarek w różnych skalach geograficznych.

Od początku lat 90. XX w. paradygmat bliskości dynamicznie rozwijany jest głównie przez francuskich ekonomistów i geografów. Czołowi przedstawiciele tej szkoły to A. Rallet, A. Torre oraz J. B. Zimmermann ${ }^{164}$. Pierwszym istotnym impulsem dla rozwoju ekonomiki bliskości była inicjatywa nieformalnej francuskiej grupy ok. 20 naukowców zajmujących się ekonomiką przemysłu, który postawili sobie za cel uwzględnienie czynnika przestrzeni jako czynnika endogenicznego w analizach ekonomicznych ${ }^{165}$. Francuską szkołę badań nad dynamiką bliskości wskazuje się również jako tą, która podjęła próbę szukania wspólnego mianownika dla wcześniejszych podejść uwzględniających przestrzeń w badaniach ekonomicznych (badania nad dystryktami przemysłowymi, lokalnymi systemami produkcyjnymi, klastrami, środowiskami innowacyjnymi, technopoliami, regionalnymi systemami innowacji itd.). Natomiast w literaturze anglojęzycznej economics of proximity zaczęto upowszechniać od roku $1999^{166}$.

Istota rozważań podejmowanych na gruncie ekonomiki bliskości sprowadza się do dwóch kluczowych tez:

1. Tezy o występowaniu i trwałości powiązań bliskości między ludźmi lub przedsiębiorstwami, przeczącej zarówno tezie o destrukcyjnej roli globalizacji dla relacji budowanych w skali lokalnej, jak i tezie zakładającej nieuniknioność procesów przestrzennej polaryzacji.

2. Tezy o dwuwymiarowości pojęcia bliskości, poprzez wprowadzenie podziału na bliskość organizacyjną i geograficzną (stanowiącą połączenie bliskości o charakterze fizycznym i społecznym).

Paradygmat bliskości podejmuje próbę wyjaśnienia, w jaki sposób i w jakim wymiarze bliskość uczestniczy w kształtowaniu relacji między

164 A. Nowakowska, Regionalny wymiar procesów innowacji, Wyd. Uniwersytetu Łódzkiego, Łódź 2011, s. 45. Ważnymi przedstawicielami tej grupy są również M. Bellet i J.-P. Gilly.

165 A. Torre, J.-P. Gilly, Debates and Surveys: On the Analytical Dimension of Proximity Dynamics, „Regional Studies” 2000, vol. 34, no. 2, s. 173-174.

166 Special Issue on Learning, Proximity and Industrial Performance, „Cambridge Journal of Economics" 1999. 
różnymi aktorami. W tym ujęciu bliskość oznacza zatem znacznie więcej niż tylko bliskość w wymiarze fizycznym. Koncepcja ta wykracza poza sposób rozumienia bliskości eksponowany w ramach klasycznych teorii lokalizacji ${ }^{167}$. Paradygmat ten zakłada, iż bliskość jest miarą łatwości w komunikacji, wymianie i współpracy dokonującej się między zainteresowanymi aktorami określonej przestrzeni ${ }^{168}$.

A. Rallet i A. Torre rozróżniają dwa dodatkowe typy bliskości, tj. bliskość "geograficzną" i organizacyjną ${ }^{169}$. Bliskość pierwszego rodzaju wyraża dystans mierzony np. w kilometrach, dzielący jednostki w przestrzeni fizycznej ${ }^{170}$. Jednostkami tymi mogą być poszczególne osoby, organizacje, miasta itp. Bliskość organizacyjną można natomiast rozumieć jako zdolność organizacji (firmy, jednostki administracyjnej, sieci, społeczności, środowiska itp.) do współdziałania i podejmowania wspólnych przedsięwzięć. Bliskość organizacyjna może być zatem postrzegana przez pryzmat dwóch częściowo wobec siebie komplementarnych, a częściowo substytucyjnych pojęć:

- logiki przynależności - członkowie organizacji są „blisko” w stosunku do siebie, ponieważ zachodzą między nimi częste i powtarzalne interakcje, które są dodatkowo wzmacniane przez reguły i rutynę, będące konsekwencją ciągłego współdziałania;

- logiki podobieństwa - jednostki postrzegane są jako bliskie w stosunku do siebie, ponieważ są w pewnym sensie takie same lub - używając kolokwializmu - są ulepione z tej samej gliny. Logika ta odwołuje się do wspólnego dla konkretnych członków tej samej organizacji systemu wartości, który wzmacnia ich zdolność do współdziałania ${ }^{171}$.

167 A. Nowakowska, Regionalny wymiar..., s. 45.

168 Ph. Cooke, Bliskość, wiedza i powstawanie innowacji, „Studia Regionalne i Lokalne" 2006, nr 2 (24), s. 21-22.

169 A. Rallet, A. Torre, Proximity and Localization, „Regional Studies” 2005, vol. 39, no. 1, s. 49; w języku ojczystym twórców ekonomki bliskości różnym koncepcjom pojęcia proximité poświęcony jest specjalny numer „Revue d'Economie Régionale et Urbaine" 1999, nr 3.

170 Należy jednak podkreślić, iż w opinii przedstawicieli economics of proximity pomiędzy bliskością fizyczną a geograficzną istnieje różnica. Pierwsza z nich dotyczy zorganizowania przestrzeni w sposób minimalizujący jej ograniczenia (infrastruktura transportowa i komunikacyjna, zagospodarowanie architektoniczne, infrastruktura techniczna), natomiast bliskość geograficzna uwzględnia dodatkowo relacje społeczne zachodzące między podmiotami w niej zlokalizowanymi (T. Kirat, Y. Lung, Innovation and Proximity: Territories as Loci of Collective Learning Processes, „European Urban and Regional Studies” 1999, vol. 6 (1), s. 29).

171 A. Rallet, A. Torre, Proximity..., s. 49-50. 


\begin{tabular}{r|l|l|}
\multicolumn{2}{c}{ Bliskość „geograficzna” } & \multicolumn{1}{c}{ Bliskość organizacyjna } \\
\cline { 2 - 3 } $\begin{array}{r}\text { Bliskość } \\
\text { „geograficzna” }\end{array}$ & $\begin{array}{l}\text { Przestrzenna koncentracja } \\
\text { działalności gospodarczej - } \\
\text { aglomeracja bez dyfuzji wiedzy }\end{array}$ & $\begin{array}{l}\text { Lokalne sieci, lokalne systemy } \\
\text { produkcyjne, klastry - rozwój } \\
\text { bazujący na dyfuzji wiedzy na } \\
\text { poziomie lokalnym }\end{array}$ \\
\cline { 2 - 3 } organizacyjná & $\begin{array}{l}\text { Duża mobilność, interakcje oparte } \\
\text { na tzw. tymczasowej bliskości } \\
\text { fizycznej (oryg. temporary } \\
\text { geographical proximity) }\end{array}$ & $\begin{array}{l}\text { Sieci powiązań funkcjonujące } \\
\text { w przestrzeni wirtualnej oparte } \\
\text { na bliskości poznawczej (oryg. } \\
\text { epistemic communities) }\end{array}$ \\
\cline { 2 - 3 }
\end{tabular}

Rys. 15. Przenikanie się dwóch typów bliskości i jego konsekwencje dla rozwoju terytorialnego

Źródło: na podstawie A. Rallet, A. Torre, Proximity and Localization, „Regional Studies” 2005, vol. 39, no. 1, s. 50 oraz A. Torre, On the Role Played by Temporary Geographical Proximity in Knowledge Transmission, „Regional Studies” 2008, vol. 42, no. 6 (July), s. 879.

Wzajemne przenikanie się obydwu typów bliskości stanowi podstawę dla analizy różnorodnych modeli przestrzennych organizacji działalności gospodarczej. Takie modelowe układy przestrzenne, jak dystrykty przemysłowe, środowiska innowacyjne, lokalne systemy produkcyjne, ale również np. tzw. tymczasowe klastry, charakteryzuje przy tym obecność obydwu z wymienionych wyżej typów bliskości (rys. 15). Na przecięciu obu typów bliskości znajduje się tzw. „bliskość terytorialna” - pojęcie odwołujące się do zależności między wzajemnie przenikającymi się relacjami produkcyjnymi i przestrzennymi ${ }^{172}$.

Bardziej szczegółowej klasyfikacji rodzajów bliskości dokonał R. A. Boschma, wyróżniając pięć jej rodzajów: poznawczą (cognitive proximity), organizacyjną (organizational proximity), społeczną (social proximity), instytucjonalną (institutional proximity) oraz "geograficzną" (geographical proximity) $)^{173}$.

U podstaw wyróżnienia bliskości natury poznawczej leży założenie, że podmioty gospodarcze $\mathrm{w}$ rzeczywistości nie działają w warunkach doskonałej racjonalności. Przy ograniczonej racjonalności oraz niepewności działania podmioty gospodarcze starają się funkcjonować w dużej mierze rutynowo. $Z$ tego samego powodu wykazują tendencję do działania w podobnym (np. wspólnym dla określonego zbioru przedsiębiorstw)

172 A. Torre, F. Wallet, The Role of Proximity Relations in Regional and Territorial Development Processes, Proceedings of the 54 ${ }^{\text {th }}$ ERSA Congress, 26-29 September, Saint-Petersburg 2014, s. 13.

173 R. A. Boschma, Proximity and Innovation: A Critical Assessment, „Regional Studies" 2005, vol. 39, no. 1, s. 63. 
otoczeniu. Aby w danym środowisku posiadać zdolność absorpcji wiedzy i innowacji, wymiany wiedzy czy współpracy w celu jej dalszego rozwijania, należy już na samym początku dysponować podobnym jej poziomem i charakterem. W tym kontekście bliskość poznawcza umożliwia bardziej efektywną komunikację, gdyż partnerzy posiadają zdolność „przemawiania tym samym językiem".

Z kolei poprzez bliskość organizacyjną należy rozumieć stopień, w jakim wzajemne relacje są regulowane przez określone struktury organizacyjne, zarówno wewnątrz nich, jak i z innymi podmiotami. Z ekonomicznego punktu widzenia przyczyny powstawania organizacji (rozumianych jako umyślnie stworzone zrzeszenia osób, które w celu realizacji wspólnych celów akceptują funkcjonowanie $\mathrm{w}$ ramach określonych struktur hierarchicznych, dających się wyróżnić z otoczenia) analizowane są na gruncie ekonomiki kosztów transakcyjnych. Istotę bliskości organizacyjnej i jej wpływu na struktury poszczególnych organizacji gospodarczych można zatem wyjaśnić przez kontinuum, w którym na jednym krańcu występuje całkowity brak powiązań lub sporadyczne kontakty między przedsiębiorstwami i instytucjami na rynku (niski stopień bliskości organizacyjnej), natomiast na drugim krańcu - funkcjonowanie firmy zorganizowanej hierarchicznie bądź w sieci (wysoka bliskość organizacyjna). Między tymi dwoma biegunami plasują się natomiast sieci współpracy, mające stosunkowo luźny charakter, długoterminowe umowy o współpracy, porozumienia typu joint-ventures itp., nazwane przez O. Williamsona hybrydami organizacyjnymi.

Bliskość w wymiarze społecznym odwołuje się do założenia, w myśl którego wszelkie relacje ekonomiczne wpisują się w określony (a przy tym przestrzennie zróżnicowany) kontekst społeczny. Jak zauważa R. Putnam, czołowy badacz problematyki kapitału społecznego: „społeczeństwo, które opiera swój rozwój na zaufaniu i wzajemności, funkcjonuje bardziej efektywnie od społeczeństwa, któremu wartości tych brakuje tak samo, jak wymiana pieniężna jest bardziej efektywna niż wymiana barterowa"174.

Pojęcie bliskości społecznej w znacznym stopniu odwołuje się zatem do wspomnianych rozważań $M$. Granovettera. Zakłada bowiem, iż relacje są społecznie zakorzenione wówczas, gdy oparte są na relacjach wzajemności, przyjaźni czy wzajemnym zaufaniu. Należy jednak podkreślić, że zbyt duży poziom bliskości społecznej może też prowadzić do spowolnienia procesów rozwoju. Główną tego przyczyną może być niedocenianie lub niedostrzeganie możliwości pojawiających poza określonym systemem społecznym. W tym wymiarze bliskości R. Boschma postuluje

174 R. Putnam, Bowling Alone..., s. 1356. 
więc koncepcję równoważenia bliskości oraz dystansu o społecznym charakterze. Sieci powiązań między uczestnikami procesów gospodarczych, szczególnie w kontekście procesów kreowania oraz dyfuzji wiedzy i innowacji, powinny być $\mathrm{z}$ jednej strony wewnętrznie spójne, a z drugiej - otwarte na otoczenie zewnętrzne.

Koncepcję polegającą na równoważeniu podejścia opartego na społecznym zakorzenieniu z podejściem neoklasycznym, bazującym na koncepcji wolnorynkowej, zaproponował B. Uzzi. Podejście to stanowi próbę poszukiwania kompromisu między założeniami modelu neoklasycznego a modelem M. Granovettera. Według Uzziego zdolność innowacyjna przedsiębiorstw wzrasta wraz ze stopniem intensyfikacji społecznych relacji tylko do pewnego punktu, po czym, w wyniku zbyt silnego „zamykania się" systemu na zewnętrzne otoczenie, następuje jej spadek (wykres 9).

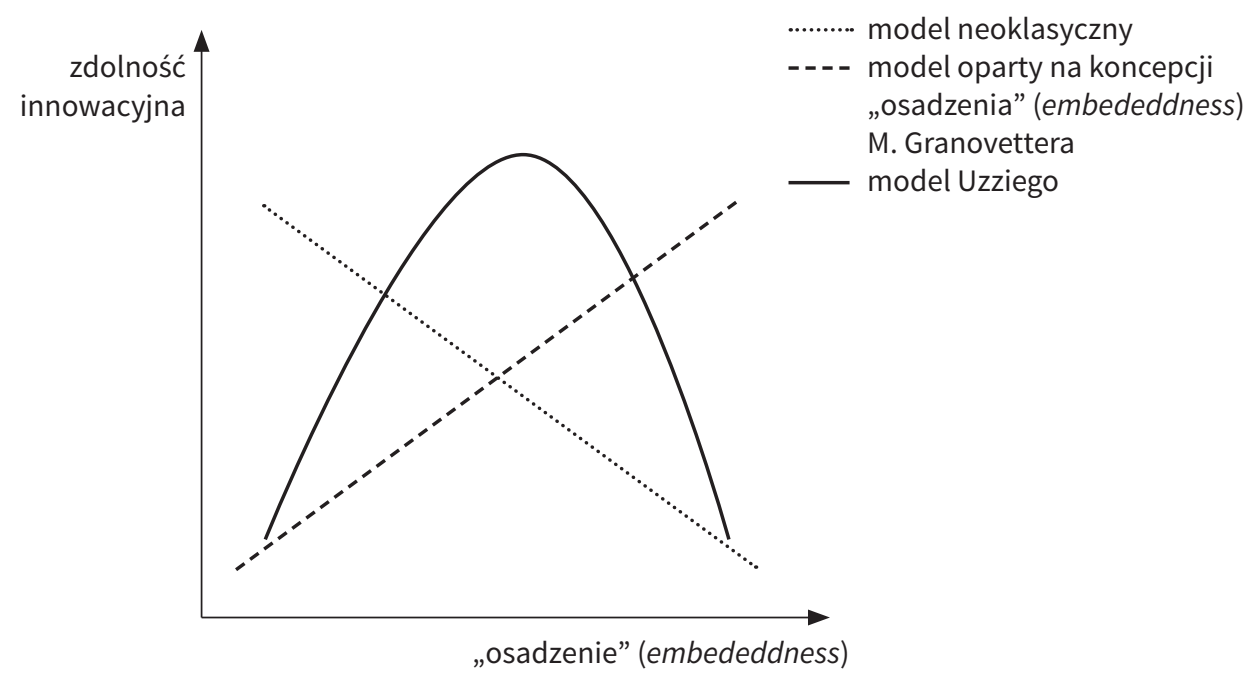

Wykres 9. Relacje między zakorzenieniem społecznym relacji ekonomicznych (embededdness) a zdolnością innowacyjną

Źródło: R. A. Boschma, J. G. Lambooy, V. Schutjens, Embededdness and Innovation, [w:] M. Taylor, S. Leonard (eds.), Embedded Enterprise and Social Capital. International Perspectives, Aldershot, Ashgate 2002, s. 19-35.

Kolejny typ bliskości - bliskość instytucjonalna - wiąże się z przyjęciem założenia, że wspólny język, współdzielone zwyczaje i zasady, a także efektywny system prawny stwarzają wspólną bazę dla koordynacji działań gospodarczych oraz sprzyjają procesom uczenia się przez interakcje. Instytucje wyznaczają i koordynują aktywność podmiotów gospodarczych 
przez zdefiniowanie ram działania. Do podstawowych następstw bliskości instytucjonalnej można zaliczyć:

- redukowanie niepewności poprzez zabezpieczanie i dostarczanie informacji,

- neutralizowanie konfliktów i organizowanie kooperacji między podmiotami życia gospodarczego i społecznego,

- kreowanie motywacji, gdzie kooperacja i kolektywna współpraca okazują się niezwykle istotnym elementem w procesie innowacyjnym ${ }^{175}$.

Ostatni rozważany typ bliskości - bliskość „geograficzna” - może być interpretowana jako dystans przestrzenny między aktorami ekonomicznymi, mierzony zarówno w wartościach względnych, jak i absolutnych ${ }^{176}$. Zalety funkcjonowania podmiotów gospodarczych w niewielkich odległościach fizycznych można wiązać w znacznej mierze z przestrzennymi efektami zewnętrznymi, które wynikają z korzyści, jakie odnosi pojedyncze przedsiębiorstwo przez sam fakt funkcjonowania w miejscu, w którym działa wiele innych podmiotów gospodarczych. Wspólna lokalizacja podobnych działalności (nawet jeśli dotyczy rywali gospodarczych) stanowi przykład klasycznych efektów aglomeracji, gdzie sukces jednego przedsiębiorstwa nie pozostaje niezauważony przez pozostałe 177 (tab. 20).

Bliskość geograficzna pełni funkcję inicjującą wobec pozostałych form bliskości, jednak za sprawą postępu w dziedzinie technologii komunikowania się może tracić na znaczeniu na rzecz pozostałych form. A. Rallet i A. Torre stwierdzili na podstawie badań, że wiedza milcząca może być transmitowana na dalekie odległości, z wykorzystaniem innych form bliskości. Ich studia doprowadziły do wniosku, iż potrzeba działania w bliskości fizycznej jest raczej niewielka w przypadku, kiedy działa się $\mathrm{w}$ warunkach jasno określonego podziału zadań, koordynowanych przez jedną silną jednostkę (bliskość organizacyjna), a partnerzy posiadają podobne kompetencje (bliskość poznawcza). Konieczność działania w bliskości fizycznej jest wówczas realizowana, jednak odbywa się to stosunkowo rzadko i przyjmuje formę niewielu spotkań biznesowych ${ }^{178}$. Bliskość przestrzenna okazuje się bowiem korzystna również z punktu widzenia funkcjonowania sieci tymczasowych, ograniczonych na czas

175 C. Edquist, B. Johnson, Institutions and Organizations in System of Innovation, [w:] C. Edquist (ed.), Systems of Innovation: Technologies, Institutions and Organizations, Pinter Publishers, London 1997, s. 51-55.

176 R. A. Boschma, Proximity and Innovation..., s. 69.

177 P. Maskell, Towards a Knowledge-based Theory of the Geographical Cluster, „Industrial and Corporate Change" 2001, 10 (4), s. 921-943.

178 A. Rallet, A. Torre, Is Geographical Proximity Necessary in the Innovation Networks in the Era of the Global Economy?, „Geo Journal” 1990, 49 (4), s. 373-380. 
trwania projektów ${ }^{179}$. Projekty jako sieci tymczasowe nie zastępują przy tym sieci trwałych, lecz wchodzą z nimi w różne układy współzależności i oddziaływania, a tym samym projekty tymczasowe mogą powiększać efektywność funkcjonowania sieci trwałych ${ }^{180}$.

Tabela 20. Formy bliskości - analiza porównawcza

\begin{tabular}{|c|c|c|c|c|}
\hline Typ bliskości & $\begin{array}{c}\text { Podstawowa } \\
\text { cecha }\end{array}$ & $\begin{array}{c}\text { Problemy } \\
\text { w sytuacji małej } \\
\text { bliskości }\end{array}$ & $\begin{array}{l}\text { Problemy w sytu- } \\
\text { acji nadmiernej } \\
\text { bliskości }\end{array}$ & Rozwiązania \\
\hline $\begin{array}{l}\text { 1. Poznaw- } \\
\text { cza }\end{array}$ & $\begin{array}{l}\text { zmniejszenie } \\
\text { luki wiedzy }\end{array}$ & brak zrozumienia & $\begin{array}{l}\text { brak źródeł nowej } \\
\text { wiedzy }\end{array}$ & $\begin{array}{l}\text { rozwijanie wspólnej } \\
\text { „bazy wiedzy” wraz } \\
\text { ze zróżnicowanymi, } \\
\text { ale komplementarny- } \\
\text { mi względem siebie } \\
\text { zdolnościami part- } \\
\text { nerów }\end{array}$ \\
\hline $\begin{array}{l}\text { 2. Organiza- } \\
\text { cyjna }\end{array}$ & kontrola & oportunizm & biurokracja & $\begin{array}{l}\text { rozwijanie elastycz- } \\
\text { nych struktur organi- } \\
\text { zacyjnych }\end{array}$ \\
\hline 3. Społeczna & $\begin{array}{l}\text { zaufanie } \\
\text { (oparte na } \\
\text { relacjach } \\
\text { społecznych) }\end{array}$ & oportunizm & $\begin{array}{l}\text { brak racjonalności } \\
\text { ekonomicznej }\end{array}$ & $\begin{array}{l}\text { równowaga między } \\
\text { relacjami zakorzenio- } \\
\text { nymi społecznie a re- } \\
\text { lacjami rynkowymi }\end{array}$ \\
\hline $\begin{array}{l}\text { 4. Instytucjo- } \\
\text { nalna }\end{array}$ & $\begin{array}{l}\text { zaufanie } \\
\text { (oparte na } \\
\text { istniejących } \\
\text { normach) }\end{array}$ & oportunizm & $\begin{array}{l}\text { inercja, efekty } \\
\text { lock-in }\end{array}$ & $\begin{array}{l}\text { równowaga między } \\
\text { instytucjami formal- } \\
\text { nymi i nieformalnymi }\end{array}$ \\
\hline $\begin{array}{l}\text { 5. Geogra- } \\
\text { ficzna }\end{array}$ & $\begin{array}{l}\text { pokonywa- } \\
\text { nie oporu } \\
\text { przestrzeni }\end{array}$ & $\begin{array}{l}\text { brak korzyści } \\
\text { aglomeracji }\end{array}$ & $\begin{array}{l}\text { brak otwarcia na } \\
\text { szersze otoczenie } \\
\text { geograficzne }\end{array}$ & $\begin{array}{l}\text { równowaga między } \\
\text { koncentracją na lokal- } \\
\text { nych zasobach a roz- } \\
\text { wijaniem powiązań } \\
\text { ponadlokalnych }\end{array}$ \\
\hline
\end{tabular}

Źródło: R. A. Boschma, Proximity and Innovation: A Critical Assessment, „Regional Studies” 2005, vol. 39 , no. 1 , s. 71 .

179 G. Grabher, Cool Projects, Boring Institutions: Temporary Collaboration in Social Context, „Regional Studies” 2002, no. 3, s. 205-214.

180 R. Domański, Ewolucyjna gospodarka..., s. 126. 
Z drugiej strony, bliskość geograficzna może być także komplementarna w stosunku do innych form bliskości w procesie interaktywnego uczenia się. Dzieje się tak wówczas, gdy bliskie i częste kontakty, stanowiące podstawę bliskości geograficznej, wzmacniają bliskość natury organizacyjnej, instytucjonalnej czy poznawczej ${ }^{181}$. Warunkiem sprawności rozwoju terytorialnego pozostaje zatem poszukiwanie optymalnej kombinacji wyżej wymienionych form bliskości. Sama bliskość geograficzna nie jest bowiem wystarczającym warunkiem wspólnego uczenia się i przyspieszania procesów rozwoju. Pozytywne efekty knowledge spillovers, wzajemnego uczenia się i budowania przewagi konkurencyjnej występują szybciej oraz są wyraźniejsze w warunkach komplementarności, a także dopasowania do siebie bliskości poznawczej, instytucjonalnej, społecznej i geograficznej ${ }^{182}$.

Podsumowując, zagadnienie bliskości na gruncie economics of proximity odwołuje się nie tylko do przestrzeni per se, ale również do zagadnienia interakcji międzyludzkich i różnorodnych form koordynacji zachowań ekonomicznych. W tym kontekście ekonomika bliskości eksponuje społeczny (choć często zlokalizowany) wymiar stosunków gospodarczych. W przeciwieństwie do klasycznych teorii lokalizacji, nie stawia na pierwszym planie zagadnienia kosztów transportu, lecz zagadnienie podziału pracy oraz rozprzestrzeniania się wiedzy i innowacji, sygnalizowane już przez A. Marshalla czy G. Becattiniego, lecz jeszcze dogłębnie przez nich nie analizowane ${ }^{183}$.

W zakresie społecznego wymiaru relacji gospodarczych ekonomika bliskości upowszechniła ważny podział na interakcje intencjonalne i nieintencjonalne. Pierwszy typ odwołuje się do takich form koordynacji, jak wymiana rynkowa lub relacje oparte na kontraktach, współpracy czy partnerstwie. Interakcje (zależności) nieintencjonalne natomiast trzeba rozpatrywać w kategorii efektów zewnętrznych, często poprzez odwołanie do marshallowskiej atmosfery przemysłowej. Istnieje więc granica pomiędzy elementami gry ekonomicznej wynikającymi z zamierzonych działań podmiotów gospodarczych (interakcje intencjonalne) a tymi elementami, które warunkowane są aspektami technicznymi lub zlokalizowanymi efektami zewnętrznymi (interakcje nieintencjonalne). $\mathrm{W}$ odniesieniu do interakcji drugiego typu przedstawiciele ekonomiki bliskości starają się eksponować te, które odwołują się do kooperacji i relacji

181 R. A. Boschma, Proximity and Innovation..., s. 70.

182 W. M. Gaczek, Gospodarka oparta na wiedzy w regionach europejskich, Studia Komitetu Przestrzennego Zagospodarowania Kraju PAN, t. CXVIII, Warszawa 2009, s. 52.

183 A. Torre, J.-P. Gilly, Debates and Surveys..., s. 174-175. 
partnerskich, zakładając, że sprzyjają one transferowi wiedzy milczącej, uczeniu się i innowacyjności ${ }^{184}$.

Wreszcie - poza mechanizmem koordynacji cenowej, za ważne metody współpracy $\mathrm{w}$ ramach procesów gospodarczych przedstawiciele ekonomiki bliskości uznają też inne, oparte na mechanizmie efektów zewnętrznych, zjawisku działań zbiorowych i odwołujące się do istotnej roli instytucji w ekonomii ${ }^{185}$. Zakładają przy tym, że pozarynkowe metody koordynacji mają często zlokalizowany charakter, decydując o terytorialnym charakterze rozwoju społeczno-gospodarczego ${ }^{186}$. Podmioty posiadające zdolności mediacyjne pełnią kluczową rolę w dynamicznych systemach terytorialnych, dzięki umiejętności tworzenia hybrydowych form koordynacji w gospodarce, tj. takich, które łączą korzyści z funkcjonowania jednocześnie w skali globalnej i lokalnej. Między innymi z tego powodu przedstawiciele ekonomiki bliskości sygnalizują, iż największy potencjał badawczy tej gałęzi ekonomii może wyłonić się na styku różnorodnych dyscyplin naukowych ${ }^{187}$.

Współczesne nurty ekonomii instytucjonalnej - zarówno wywodzące się z NEI, jak i nurtów pokrewnych instytucjonalizmowi - mogą być wykorzystywane przy wyjaśnianiu procesów rozwoju terytorialnego z różnych perspektyw (tab. 21). Dorobek teorii praw własności może służyć przede wszystkim do badania zależności między strukturą własności w przestrzeni a efektywnością jej zagospodarowania. Ponadto, pozwala on na analizowanie przestrzeni jako dobra posiadającego cechy tzw. wspólnych zasobów ze wszystkimi tego konsekwencjami, tj. kosztami jej utrzymania, określania wartości przestrzeni publicznych oraz skutków ich prywatyzacji. W tym aspekcie TPW ma również wartość praktyczną, bowiem pozwala na poszukiwania efektywnych form zarządzania dobrami wspólnymi i ogólnodostępnymi (przestrzeniami publicznymi, zasobami naturalnymi, cennymi elementami krajobrazu i przyrody itp.).

Kluczowy wkład w rozwój ekonomii instytucjonalnej wnosi kategoria kosztów transakcyjnych. Trudno wyobrazić sobie współczesne badania nad procesami rozwoju terytorialnego bez uwzględnienia tego pojęcia. Wszelkie analizy dotyczące czynników lokalizacji działalności gospodarczej, wpływu lokalnego i regionalnego otoczenia instytucjonalnego na przedsiębiorczość oraz stymulowania innowacyjności prowadzone

184 Ibidem, s. 175-176.

185 W tych założeniach zwolennicy économie de proximité upodabniają się do francuskiej ekonomiki konwencji.

186 Zob. także: M. E. Sokołowicz, Zagadnienie bliskości..., s. 78-84.

187 A. Torre, J.-P. Gilly, Debates and Surveys..., s. 179. 
Tabela 21. Nurty ekonomii instytucjonalnej

\begin{tabular}{|c|c|c|}
\hline Lp. & Nurt & Główne tezy i kierunki analiz \\
\hline 1. & $\begin{array}{l}\text { Niemiecka szkoła histo- } \\
\text { ryczna } \\
\text { „Stary” instytucjonalizm/ } \\
\text { instytucjonalizm amery- } \\
\text { kański (ewolucyjny) } \\
\text { Neoinstytucjonalizm/ } \\
\text { nowy instytucjonalizm }\end{array}$ & $\begin{aligned}- & \text { skupienie się na kolektywnym i społecznym wymiarze } \\
& \text { tworzenia instytucji i przemian instytucjonalnych, } \\
- & \text { instytucje są spuścizną przeszłości (podejście ewolucyjne), } \\
- & \text { kontekst instytucji formalnych i nieformalnych uwarun- } \\
& \text { kowany jest nie tylko historycznie, ale i geograficznie } \\
& \text { (terytorialnie), } \\
- & \text { instytucje integrują społeczności i społeczeństwo, } \\
- & \text { procesy gospodarcze są zakorzenione w instytucjach, } \\
- & \text { instytucje cechuje inercja }\end{aligned}$ \\
\hline 2. & $\begin{array}{l}\text { Szkoła austriacka i ordo- } \\
\text { liberalizm }\end{array}$ & $\begin{array}{ll}\text { - } & \text { założenie o nadrzędności porządku spontanicznego nad } \\
& \text { instytucjami formalnymi, } \\
\text { - } & \text { główne zadanie instytucji polega na zapewnieniu spraw- } \\
& \text { nego działania wolnego rynku, } \\
\text { - } & \text { dystans wobec koncepcji doskonałej racjonalności oraz } \\
& \text { formalizmu metodologicznego }\end{array}$ \\
\hline 3. & Teoria praw własności &  \\
\hline 4. & $\begin{array}{l}\text { Ekonomika kosztów } \\
\text { transakcyjnych }\end{array}$ & $\begin{array}{l}\text { - wymiana rynkowa (transakcja) pociąga za sobą koszty } \\
\text { związane z poszukiwaniem stron transakcji, negocjowa- } \\
\text { niem warunków umowy oraz monitorowaniem realizacji } \\
\text { transakcji, } \\
\text { - } \\
\text { wraz z rozwojem gospodarczym obserwuje się rozrost } \\
\text { tzw. sektora transakcyjnego w gospodarce }\end{array}$ \\
\hline 5. & Teoria agencji & $\begin{array}{l}\text { - } \quad \text { kluczową relacją w organizacji każdego typu pozostaje } \\
\text { relacja między właścicielem (pryncypałem) i działającym } \\
\text { w jego imieniu menadżerem (agentem), } \\
\text { - } \\
\text { struktury organizacyjne cechują się złożonością, a nawet } \\
\text { sprzecznością celów członków organizacji, } \\
\text { - } \quad \text { cele działania organizacji nie stanowią prostej sumy ce- } \\
\text { lów jej członków, lecz stanowią efekt wewnętrznej kultury } \\
\text { organizacyjnej i polityki wewnątrz organizacji }\end{array}$ \\
\hline 6. & $\begin{array}{l}\text { Teoria wyboru publicz- } \\
\text { nego }\end{array}$ & $\begin{array}{l}\text { - } \text { badanie mechanizmów wyborów zbiorowych i zachowań } \\
\text { biurokratów, } \\
\text { - } \\
\text { mechanizmy zachodzące w sferze polityki oraz w szeroko } \\
\text { rozumianej domenie publicznej mogą być analizowa- } \\
\text { ne przez pryzmat zmiennych ekonomicznych, takich jak } \\
\text { użyteczność czy bilans korzyści i kosztów wyborów zbio- } \\
\text { rowych, } \\
\text { - } \\
\text { instytucje publiczne powinny być zaprojektowane tak, } \\
\text { aby poprawa sytuacji jednych grup i jednostek nie pogar- } \\
\text { szała sytuacji pozostałych }\end{array}$ \\
\hline
\end{tabular}


Tab. 21 (cd.)

\begin{tabular}{|c|c|c|}
\hline 7. & $\begin{array}{l}\text { Francuska ekonomia } \\
\text { konwencji }\end{array}$ & 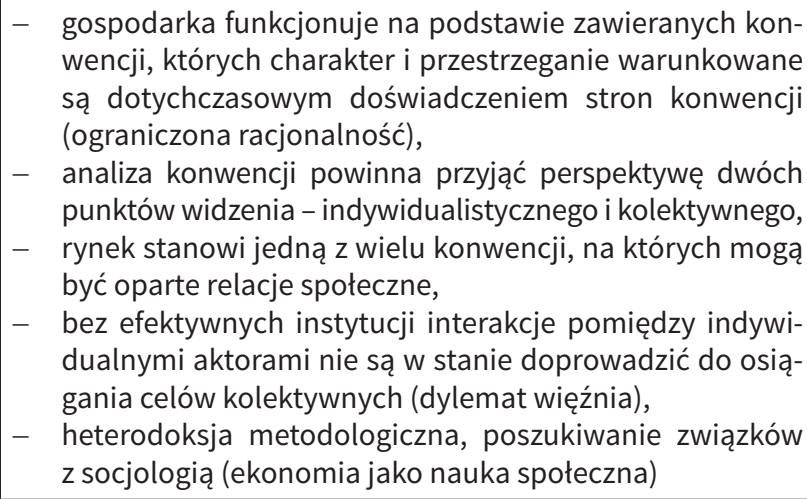 \\
\hline 8. & $\begin{array}{l}\text { Koncepcja zakorzenienia } \\
\text { Ekonomika bliskości }\end{array}$ & 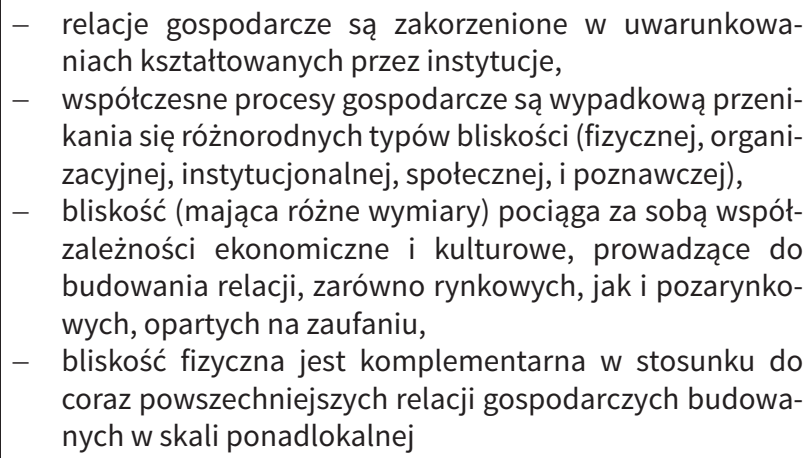 \\
\hline 9. & Ekonomia ewolucyjna & 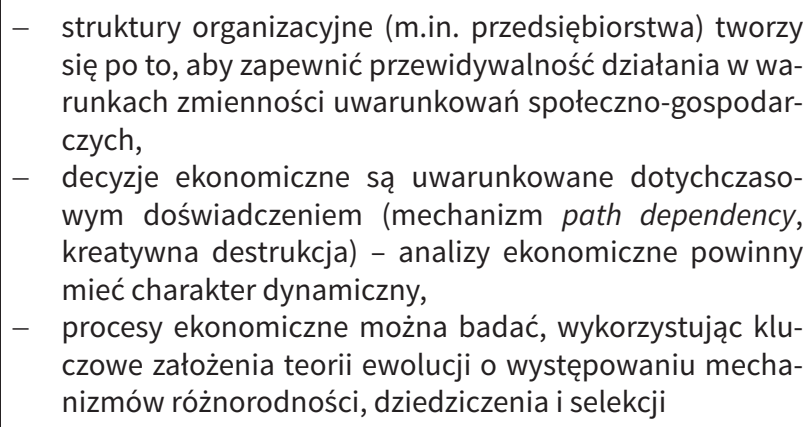 \\
\hline 10. & Szkoła zasobowa (RBV) & $\begin{array}{l}\text { - } \text { podmioty gospodarcze mogą się od siebie istotnie różnić } \\
\text { w kwestii posiadanych zasobów, a różnice te w długim } \\
\text { okresie mogą prowadzić do budowania przewagi konku- } \\
\text { rencyjnej, } \\
\text { - } \\
\text { struktury organizacyjne (m.in. przedsiębiorstwa) tworzy } \\
\text { się po to, aby chronić wartościowe zasoby, } \\
\text { - } \text { budowanie przewagi konkurencyjnej następuje w opar- } \\
\text { ciu o zasoby specyficzne, które powinny być: 1) strate- } \\
\text { gicznie wartościowe, 2) rzadkie, 3) trudne do imitacji, } \\
\text { 4) niezastępowane, } \\
\text { - } \\
\text { przewaga oparta na specyfice zasobów nie jest dana na } \\
\text { zawsze - ma charakter dynamiczny }\end{array}$ \\
\hline
\end{tabular}

Źródło: opracowanie własne. 
są z uwzględnieniem kategorii kosztów transakcyjnych. Zagadnienie to rozwijane jest zresztą zarówno na gruncie samej teorii kosztów transakcyjnych, jak i pozostałych nurtów instytucjonalnych. W ostatnich latach znalazło ono szczególne zastosowanie na gruncie ekonomii konwencji, badającej terytorialne zakorzenienie instytucji o charakterze formalnym i pozaformalnym w kontekście ich wpływu na minimalizowanie kosztów transakcyjnych.

Z kolei takie nurty NEI, jak teoria agencji i teoria wyboru publicznego dostarczają badaczom procesów rozwoju lokalnego oraz regionalnego instrumentarium w zakresie ekonomicznych aspektów funkcjonowania samorządów. Dotyczą one m.in. relacji pracowniczych w agendach samorządowych, strategii politycznych w zdobywaniu i utrzymywaniu władzy w samorządzie terytorialnym, a także analizowania wpływu systemów wyborczych na sposób reprezentacji interesów społeczności lokalnych i regionalnych. Natomiast w warstwie aplikacyjnej teoria wyboru publicznego i teoria agencji pozwalają na poszukiwanie rozwiązań mających na celu zwiększenie efektywności działania sfery publicznej (np. w zakresie i sposobach urynkowienia usług publicznych lub wprowadzania reform strukturalnych w samorządzie) oraz eliminowanie tzw. pokusy nadużyć $\mathrm{w}$ działaniach lobbingowych, przetargach publicznych czy pogoni za rentą polityczną. Nie bez znaczenia w tym ujęciu pozostaje również postulat konieczności pomiaru kosztów funkcjonowania samorządów terytorialnych ${ }^{188}$.

Ekonomia ewolucyjna jako nurt pokrewny ekonomii instytucjonalnej, w odniesieniu do procesów rozwoju terytorialnego daje szanse na poszukiwanie źródeł długookresowej konkurencyjności i czynników innowacyjności jednostek terytorialnych, badanie zależności rozwoju społeczno-gospodarczego od dotychczasowej ścieżki rozwojowej, czy wreszcie identyfikację tzw. inteligentnych specjalizacji regionalnych. Z kolei szkoła zasobowa (RBV) pozwala na poszukiwanie terytorialnie zakorzenionych zasobów specyficznych, składających się na tzw. kapitał terytorialny. Ostatnie z wymienionych zagadnień rozwijane jest na gruncie ekonomiki bliskości, badającej relacje między bliskością fizyczną a pozostałymi jej rodzajami oraz rolę terytorium $\mathrm{w}$ tym układzie.

188 Wśród pierwszych prac zawierających analizy kosztów funkcjonowania samorządu terytorialnego w Polsce warto wymienić: M. Wojciechowski, Koszt władzy w polskim samorządzie terytorialnym, Difin, Warszawa 2014. 



\section{Rozdział IV}

\section{Nurty ekonomii \\ instytucjonalnej w procesach rozwoju terytorialnego \\ - perspektywa badawcza}

\section{Instytucjonalizm w wyjaśnianiu procesów rozwoju terytorialnego - próby konceptualizacji}

Wyjaśnianiem procesów rozwoju lokalnego i regionalnego zajmuje się wiele dyscyplin naukowych. Procesy te stanowią przedmiot badań m.in. ekonomistów (przede wszystkim w zakresie tzw. ekonomiki miast i regionów), socjologów (socjologia przestrzeni, socjologia miasta, socjologia wsi), geografów społeczno-ekonomicznych, politologów oraz przedstawicieli nauk prawniczych. Zagadnienia dotyczące gospodarki przestrzennej od zawsze były interdyscyplinarne i zainteresowanie rolą instytucji w procesach rozwoju lokalnego i regionalnego jest dostrzegalne w każdej z wymienionych dziedzin. Jednak perspektywa instytucjonalna o wyraźnie dostrzegalnych konotacjach przestrzennych zauważalna jest obecnie przede wszystkim na gruncie geografii ekonomicznej. Natomiast badania prowadzone na gruncie ekonomii instytucjonalnej mają wciąż w znacznej mierze aprzestrzenny charakter i dopiero w ostatnich pracach ekonomistów - przede wszystkim ekonomice bliskości oraz rozważaniach na temat tzw. trajektorii rozwojowych i zależności od ścieżki (path-dependency) w ekonomii ewolucyjnej - podjęto próby uwzględnienia czynnika przestrzennego.

Innymi słowy, kiedy we wczesnych latach 80 . XX w. nastąpił renesans myślenia ewolucyjnego $\mathrm{w}$ ekonomii, opierało się ono na co najmniej trzech - wzajemnie się uzupełniających - nurtach badawczych. Pierwszy dotyczył studiów nad zmianą technologiczną, wiedzą i innowacjami; drugi nawiązywał do koncepcji path-dependency, natomiast trzeci dotyczył zapoczątkowanej przez Nelsona i Wintera ekonomii ewolucyj$n e j^{1}$. Badania pierwszego typu określa się niekiedy mianem neo-schum-

1 D. MacKinnon et al., Evolution in Economic Geography: Institutions, Political Economy, and Adaptation, „Economic Geography” 2009, vol. 85 (2), s. 132-133. 
peteriańskich, z uwagi na postrzeganie gospodarki (za Schumpeterem) jako zmiennego systemu napędzanego kolejnymi falami przełomowych innowacji ${ }^{2}$. Drugi nurt podejmuje próbę identyfikacji specyficznych zdarzeń i uwarunkowań historycznych, które w przeszłości inicjowały określone długookresowe trajektorie rozwoju gospodarczego, oparte na dominacji wybranych technologii, a także odkrywa znaczenie rosnących przychodów w generowaniu zjawiska „zależności od ścieżki”. Co istotne, uwarunkowania instytucjonalne i historyczne powodują, iż nie zawsze dominują technologie najbardziej efektywne, ale takie, które na skutek uwarunkowań zdołały lepiej osadzić się w kontekście społeczno-gospodarczym. O tym, że dane technologie zostały powszechnie zaakceptowane, niejednokrotnie zadecydowały w przeszłości nie tylko czynniki ekonomiczne (dążenie do poszukiwania najbardziej efektywnych rozwiązań), lecz także bodźce społeczne czy polityczne, mające nawet przypadkowy charakter ${ }^{3}$. Natomiast trzeci nurt, najsilniej zaakcentowany wspomnianą pracą Nelsona, kładł nacisk na ewoluujące w czasie rutyny, traktowane jako podstawowe źródło różnicowania kompetencji przedsiębiorstw, a przez to budowania przez nie przewagi konkurencyjnej.

Omówione wyżej nurty wciąż jednak w znacznym stopniu cechowało podejście aprzestrzenne $e^{4}$. Lukę tę jako pierwszy wypełnił w roku

2 G. Dosi, The Nature of the Innovative Process, [w:] G. Dosi et al., Technical Change and Economic Theory, Pinter, London 1988; B. J. Loasby, Knowledge, Institutions and Evolution in Economics, Routledge, London 1999; C. Freeman, The Economics of Technical Change, "Cambridge Journal of Economics” 1994, vol. 18, s. 463-514; G. M. Hodgson, Economics and Evolution: Bringing Life Back into Economics, University of Michigan Press, Ann Arbor 1997.

3 Jako przykład dominacji technologicznej, która nie zależy jedynie od efektywności ekonomicznej podaje się często upowszechnienie klawiatury QWERTY pomimo tego, że w jej czasach opracowano szereg innych, często bardziej intuicyjnych i przyjaznych dla użytkowników rozwiązań. Por. P. David, Clio and the Economics of QWERTY, „American Economic Review” 1985, vol. 75, no. 2, s. 332-337; W. B. Arthur, Increasing Returns and Path-Dependence in Economy, University of Michigan Press, Michigan 1994.

4 Za pewien wyjątek należy uznać W. B. Arthura, który w swej kluczowej pracy poświęconej trajektoriom rozwojowym zajął się także zagadnieniem koncentracji działalności gospodarczej w przestrzeni. Podobnie jak A. Marshall zauważył on, że przedsiębiorstwa dążą do lokalizowania się w miejscach, gdzie już istnieją inne przedsiębiorstwa. Zwrócił jednak uwagę, iż trudno wyjaśnić motywy powstawania w określonych miejscach pierwszych osiedli ludzkich. Przyczyn ich lokalizowania się W. B. Arthur upatrywał zarówno w celowych czynnikach ekonomicznych, jak i w czynnikach przypadkowych. Twierdzit, że powodem koncentracji działalności gospodarczej w przestrzeni jest zjawisko korzyści aglomeracji, jednak zarówno historycznych źródeł tych korzyści, jak i rozwoju urbanizacyjnego w przyszłości nie da się wyjaśnić ze stuprocentową pewnością (W. B. Arthur, Urban Systems and the Historical Path Dependence, [w:] idem, Increasing Returns..., s. 100. 
1997 M. Storper, który obok technologii i organizacji jako przedmiotu badań ewolucyjnych podjął próbę analizy terytorialnych trajektorii rozwojowych. Tym samym rozpoczął interpretację roli zasobów relacyjnych i współzależności niebędących przedmiotem klasycznej wymiany ekonomicznej (untraded interdependencies) w budowaniu przewagi konkurencyjnej. Potraktował przy tym te współzależności jako zasoby powstające w wyniku relacji zachodzących w budowanych i wzmacnianych regionalnie sieciach, niemające substytutów w innych lokalizacjach. Zaliczył do nich: wiedzę milczącą, transferowaną tylko w wyniku bezpośrednich kontaktów; rutyny zakorzenione w specyfice codziennych relacji, a także zwyczaje, normy i konwencje budowane w środowisku lokalnym i regionalnym ${ }^{5}$.

Wszystkie trzy nurty otworzyły jednak mimo wszystko drogę dla pogłębienia perspektywy instytucjonalnej $\mathrm{w}$ badaniach nad procesami rozwoju lokalnego i regionalnego ${ }^{6}$. Początkowo przyjęły one formę kontynuacji badań nad terytorialnymi formami organizacji produkcji, która na przełomie XX i XXI w. upowszechniła się pod nazwą regionów „uczących się". Prace w tym kierunku zainicjowali Ph. Cooke i K. Morgan ${ }^{7}$ oraz A. Malmberg ${ }^{8}$, rozumiejąc pod tym pojęciem regiony działające $\mathrm{w}$ oparciu o sieci, w których wzajemne relacje, rozprzestrzenianie się specjalistycznej wiedzy i know-how dzięki relacjom bliskości - również bliskości instytucji - są źródłem uczenia się i umożliwiają regionom dostosowywanie się do zmian zachodzących w otoczeniu. Ich badania odwoływały się do takich regonów, jak Dolina Krzemowa, Badenia-Wirtembergia czy włoskie dystrykty przemysłowe. Wątek ten został następnie spopularyzowany przez amerykańskiego ekonomistę R. Floridę, który postrzegał uczące się regiony jako magazyny wiedzy i pomysłów, zapewniające środowisko oraz infrastrukturę wspomagającą ich przepływy. W rezultacie regiony uczące się coraz częściej zaczęto uznawać za dynamiczne źródła innowacji i motory wzrostu gospodarczego, a tym samym - za istotnych aktorów w globalnej grze gospodarczej ${ }^{9}$. W polskiej literaturze ich znaczenie dla przepływów wiedzy, procesów uczenia się i innowacji opisała

5 M. Storper, The Regional World: Territorial Development in a Global Economy, Guilford Press, London 1997.

6 A. Amin, An Institutionalist Perspective on Regional Economic Development, „International Journal of Urban and Regional Research" 1999, vol. 23 (2), s. 369.

7 Ph. Cooke, K. Morgan, The Associational Economy: Firms, Regions, and Innovation, Oxford University Press, Oxford 1998.

8 A. Malmberg, Industrial Geography: Agglomeration and Local Milieu, „Progress in Human Geography" 1996, vol. 20, no. 3, s. 392-403.

9 R. Florida, Toward the Learning Region, „Futures” 1995, vol. 27, no. 5, s. 532. 
W. M. Gaczek ${ }^{10}$, a w odniesieniu do różnych typów bliskości w poszczególnych nurtach ekonomii instytucjonalnej pierwsze próby analizy podjął M. E. Sokołowicz ${ }^{11}$.

Powyższe rozważania pozwalają stwierdzić, że przede wszystkim za sprawą geografów ekonomicznych oraz ekonomistów skłaniających się ku podejściu ewolucyjnemu i neoschumpeteriańskiemu perspektywa instytucjonalna w wyjaśnianiu procesów rozwoju lokalnego i regionalnego staje się coraz silniej umocowana. Jednak $\mathrm{z}$ uwagi na fragmentaryczny charakter podejmowanych analiz $\mathrm{w}$ dalszym ciągu rozwijane są prace $\mathrm{w}$ kierunku systematyzacji tego podejścia. W tych wysiłkach istotny wkład należy przypisać przedstawicielom ekonomki bliskości, a jako ostatnią próbę systematyzacji wskazuje się podejście oparte na tzw. komplementarnościach instytucjonalnych, proponowane przez Markusa Grillitscha ${ }^{12}$.

W obliczu faktu, że w instytucjonalizmie dostrzega się brak przekonującej konceptualizacji, w jaki sposób określone typy i skale przestrzenne środowisk instytucjonalnych wzajemnie się przenikają, Grillitsch proponuje zwrócenie szczególnej uwagi na współzależności między różnymi typami instytucji. Do tej pory komplementarności instytucjonalne były jednak przedmiotem analizy na poziomie krajów, natomiast to, w jaki sposób przenikają się instytucje w różnych skalach przestrzennych, pozostawało wciąż zagadnieniem mglistym. Co więcej, współzależności między instytucjami o charakterze terytorialnym i innymi (sektorowymi, instytucjami rynku pracy, systemami ochrony własności intelektualnej, instytucjami finansowymi) także wymagają dalszych badań.

Proponowany przez Grillitscha model osadzony jest na założeniu, iż otoczenie instytucjonalne składa się $\mathrm{z}$ wielokrotnych warstw (multiple layers). Autor nazywa go „modelem warstw instytucjonalnych w perspektywie strukturalnej”, odróżniając jednak od znanego już w literaturze pojęcia institutional layering ${ }^{13}$, wykorzystywanego dla opisu procesu

10 W. M. Gaczek, Gospodarka oparta na wiedzy w regionach europejskich, Studia Komitetu Przestrzennego Zagospodarowania Kraju PAN, t. CXVIII, Warszawa 2009, s. 37-52.

11 M. E. Sokołowicz, Zagadnienie bliskości w badaniach nad rozwojem terytorialnym. Podejście instytucjonalne, [w:] A. Nowakowska (red.), Zrozumieć terytorium. Idea i praktyka, Wyd. Uniwersytetu Łódzkiego, Łódź 2013, s. 59-92

12 M. Grillitsch, Institutional Change and Economic Evolution in Regions, Proceedings of the 54 ${ }^{\text {th }}$ ERSA Congress, 26-29 September, Saint-Petersburg 2014.

13 Por. E. Schickler, Disjointed Pluralism: Institutional Innovation and the Development of the US Congress, Princeton University Press, Princeton 2001; W. Streeck, K. Thelen, Introduction: Institutional Change in Advanced Political Economies, [w:] W. Streeck, K. Thelen (eds.), Beyond Continuity: Institutional Change in Advanced Political Economies, Oxford University Press, Oxford 2005, s. 1-39; J. van der Heijden, Institutional Layering: A Review of the Use of the Concept, „Politics” 2001, vol. 31 (1), s. 9-18. 
zmiany instytucjonalnej, polegającego na dodawaniu nowych elementów do już istniejących instytucji. Warstwę instytucjonalną definiuje jako zestaw zasad i ograniczeń, które warunkują interakcje pomiędzy jednostkami przynależącymi do dającej się jednoznacznie wyodrębnić od innych struktury społecznej. Pojedyncza warstwa instytucjonalna może dotyczyć publicznych struktur administracyjnych, takich jak gminy, regiony czy administracja państwowa. Taka warstwa rządzi się kodyfikowanymi zasadami, kształtowanymi przez prawa i regulacje, które są ustanawiane i przestrzegane przez władze publiczne. Jednostki i organizacje przynależące do tego typu warstwy funkcjonują zatem w ściśle określonych granicach terytorialnych.

Istnieje jednak wiele warstw instytucjonalnych, które nie są powiązane ze strukturami terytorialno-administracyjnymi. Należą do nich przedsiębiorstwa, stowarzyszenia, grupy narodowościowe czy związki wyznaniowe. Tego typu warstwy instytucjonalne nie mieszczą się ściśle w konkretnych granicach administracyjnych i często mogą mieć zasięg globalny (np. korporacje transnarodowe). Takie warstwy instytucjonalne są przeważnie niesformalizowane i rządzą się niekodyfikowanymi zasadami, które egzekwują bezpośrednio podmioty należące do danej struktury społecznej, stosując na własny rachunek określony system zachęt i nacisków.

Źródłem wyłaniania się specyficznych nowych warstw instytucjonalnych mogą być relacje budowane w ramach poszczególnych branż gospodarki i klastrów. Struktury tego typu cechują zależności pomiędzy podmiotami, które - jak pisał M. Storper - mogą mieć charakter handlowy (rynkowy) (traded interdependencies), mierzalny np. za pomocą macierzy input-output, lub też pozarynkowy (untraded interdependencies). Drugi $\mathrm{z}$ wymienionych typów relacji dotyczy takich zagadnień, jak relacje na rynkach pracy, konwencje, wspólne kody językowe lub zasady rozwijania, komunikowania i interpretowania wiedzy ${ }^{14}$, w tym wiedzy cichej.

Każda $\mathrm{z}$ warstw instytucjonalnych posiada określone właściwości normatywne, takie jak zawartość, szerokość (tj. jak wielu dziedzin życia dotyczą), głębokość (poziom szczegółowości regulacji zachowań w określonych sytuacjach) i ostrość (w jakim stopniu dopuszczalna jest (re)interpretacja obowiązujących zasad).

Każda jednostka rodzi się, dorasta i przemieszcza między różnorodnymi warstwami instytucjonalnymi, takimi jak rodzina, szkoły, grupy zawodowe czy grupy zainteresowań. Jednostki mają przy tym inną zdolność do rozróżniania (świadomego lub podświadomego) poszczególnych

14 M. Storper, The Resurgence of Regional Economies, Ten Years Later: The Region as a Nexus of Untraded Interdependencies, „European Urban and Regional Studies” 1995, vol. 2 (3), s. 206. 
warstw instytucjonalnych oraz adaptowania obowiązujących w nich zasad do określonych sytuacji życiowych.

Jednostki współdzielą różne warstwy instytucjonalne z innymi jednostkami w zasadzie w nieskończonej liczbie kombinacji. Przykładowo, osoba A pozostaje zakorzeniona głównie w czterech warstwach instytucjonalnych, związanych z jej: 1) zawodem, 2) miejscem pracy, 3) miejscem zamieszkania, 4) grupą zainteresowań. Osoba A współdzieli po dwie warstwy instytucjonalne $\mathrm{z} B$ (związane $\mathrm{z}$ zawodem i miejscem pracy) oraz E (związane $\mathrm{z}$ zawodem i grupą zainteresowań), po jednej z F (grupa zainteresowań) i C (miejsce zamieszkania), a także nie współdzieli żadnej warstwy z G (rys. 16).

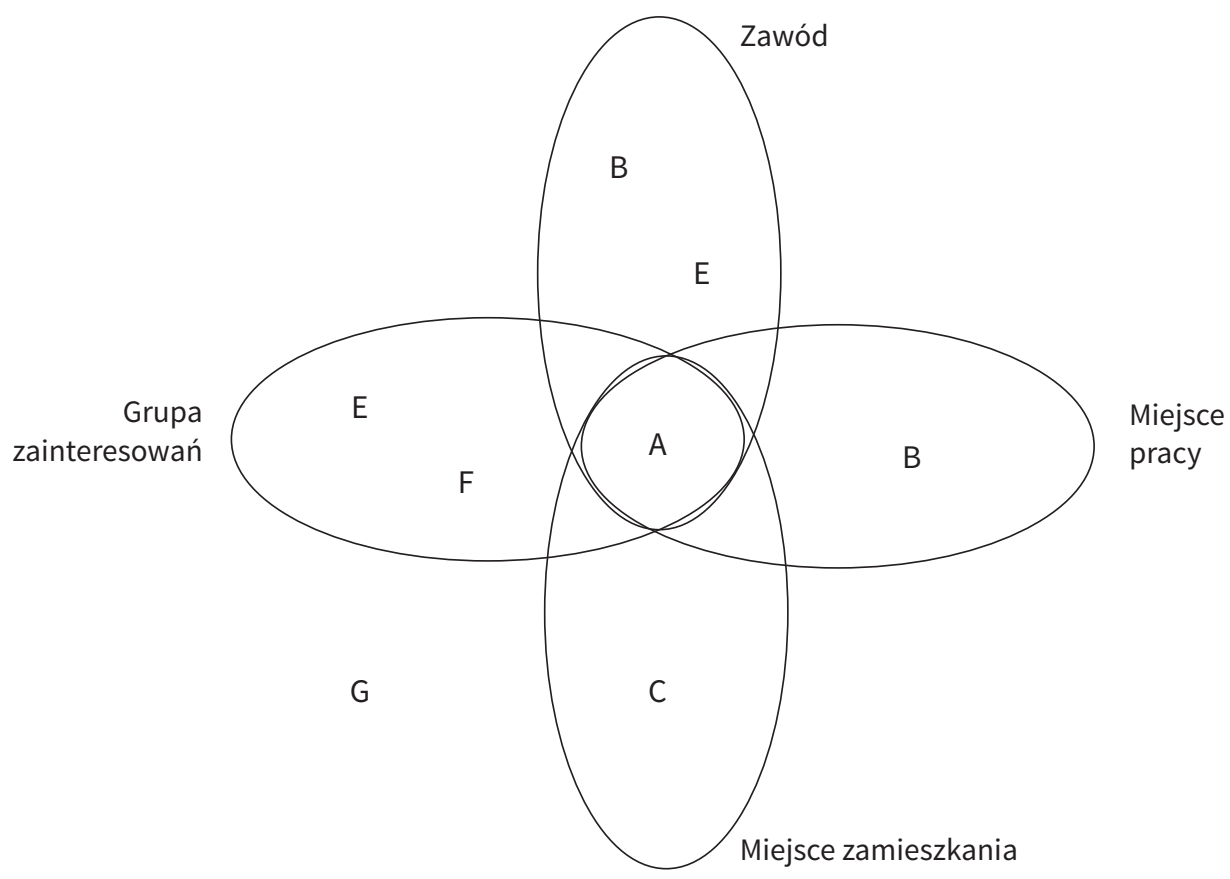

Rys. 16. Przynależność do warstw instytucjonalnych z perspektywy jednostki A

Źródło: M. Grillitsch, Institutional Change and Economic Evolution in Regions, Proceedings of the 54 ${ }^{\text {th }}$ ERSA Congress, 26-29 September, Saint-Petersburg 2014.

Powyższa konceptualizacja warstw instytucjonalnych ma swoje implikacje dla ich analizowania na poziomie lokalnym i regionalnym. W każdym układzie terytorialnym otoczenie instytucjonalne składa się bowiem ze wszystkich obecnych $\mathrm{w}$ nim warstw instytucjonalnych. Wiele $\mathrm{z}$ tych warstw nie jest ograniczonych do jego obszaru, ale często posiada zasięg 
ponadregionalny i międzynarodowy (rys. 17). Kropki na rysunku reprezentują jednostki, linie ciągłe - granice administracyjne, zaś linie przerywane - warstwy instytucjonalne. Jednostki zlokalizowane w danym terytorium należą do różnych, czasem wzajemnie się przenikających warstw instytucjonalnych, a ich lokalizacja determinuje zasięg przestrzenny tych warstw. Podczas gdy jedne z nich są ściśle zdefiniowane przez granice administracyjne (regionalne lub krajowe), inne mogą mieć zasięg globalny (np. wierzenia religijne). Wreszcie warstwy instytucjonalne mogą różnić poziomem penetracji, rozumianym jako odsetek osób dzielących określone warstwy instytucjonalne w regionie, kraju lub w ramach organizacji.


Rys. 17. Przykład delimitacji warstw instytucjonalnych w ujęciu przestrzennym

Źródło: jak do rys. 16.

W ujęciu Grillitscha idea, zgodnie z którą regionalne otoczenie instytucjonalne zbudowane jest $\mathrm{z}$ warstw instytucjonalnych, implikuje tezę, iż „regionalne ramy instytucjonalne obejmują wiele oddzielnych od siebie warstw instytucjonalnych, przynależących do z określonych struktur społecznych" ${ }^{15}$. W konsekwencji koncepcja oparta na delimitacji warstw instytucjonalnych na danych terytorium stoi w opozycji do tendencji redukcjonistycznych, dążących do scalania i - wskutek tego - pomijania wielu typów instytucji. W zamian proponuje ona identyfikowanie specyficznych warstw instytucjonalnych i traktowanie ich jako odrębnych

15 M. Grillitsch, Institutional Change and Economic Evolution..., s. 9. 
bytów. Pozwala to na konceptualizację regionalnej (terytorialnej) różnorodności instytucjonalnej. W zaproponowanym podejściu bliskość przestrzenna pełni rolę pośredniczącą oraz wpływa na zdolności łączenia ze sobą różnych warstw instytucjonalnych (connectedness).

Podsumowując, można powiedzieć, że podstawowym założeniem koncepcji warstw instytucjonalnych jest wyraźne rozróżnienie między jednostkami, strukturami społecznymi oraz warstwami instytucjonalnymi. Warstwy instytucjonalne zdefiniowane są jako zbiór reguł i ograniczeń, które kształtują interakcje między jednostkami związanymi z odrębnymi strukturami społecznymi. Koncepcja warstw instytucjonalnych nie dąży do „scalania” poszczególnych warstw na poziomie regionalnym. Przeciwnie, warstwy instytucjonalne są interpretowane jako odrębne przedmioty analizy, co stanowi wyraz doceniania różnorodności form i skali instytucji. Regionalne otoczenie instytucjonalne składa się z różnych warstw instytucjonalnych, odmiennych pod względem cech normatywnych i strukturalnych oraz zdolności łączenia się ze sobą. W ścisłym sensie ostatnie z wymienionych pojęć dotyczy indywidualnych jednostek przynależących do dwóch lub więcej warstw instytucjonalnych. Natomiast w szerokim znaczeniu pojęcie connectedness materializuje się poprzez takie mechanizmy, jak sieci relacji formalnych i nieformalnych w regionie oraz poza nim, zdolność do organizowania tymczasowych przedsięwzięć o charakterze projektów, mobilność pracowników.

Ponadto koncepcja warstw instytucjonalnych zapewnia ramy analityczne do badania dynamiki instytucjonalnej. Dynamika instytucjonalna może być w tym ujęciu wyjaśniana poprzez zmiany cech strukturalnych i normatywnych poszczególnych warstw instytucjonalnych, jak też poprzez zależności pomiędzy warstwami uwzględniające relacje agencyjne i relacje władzy (rys. 18).

\begin{tabular}{|c|c|c|}
\hline Wysok & Średnie tempo ewolucji gospodarczej & Wysokie tempo ewolucji gospodarczej \\
\hline \multirow{3}{*}{ 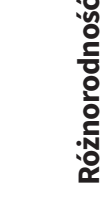 } & Powiększone ryzyko uciążliwych zmian & Ciągła transformacja \\
\hline & Niskie tempo ewolucji gospodarczej & Średnie tempo ewolucji gospodarczej \\
\hline & Wysokie ryzyko uciążliwych zmian & Powiększone ryzyko uciążliwych zmian \\
\hline ska & Niska & Wysoka \\
\hline
\end{tabular}

Rys. 18. Typologia regionów ze względu na różnorodność instytucjonalną i „przenikalność” warstw instytucjonalnych w regionie Źródto: jak do rys. 16. 
Należy przypomnieć, że w ekonomii instytucjonalnej w jej różnych odsłonach uwzględnia się kontekst społeczny procesów ekonomicznych oraz przedkłada podejście dynamiczne nad statyczne, podkreślając ewolucyjny charakter rozwoju gospodarczego. Jednocześnie odchodzi się od upraszczających założeń ekonomii ortodoksyjnej (w tym przede wszystkim koncepcji doskonałej racjonalności i dążenia do budowania statystycznych modeli równowagi gospodarczej). Dystansuje się również od determinizmu i redukcjonizmu, cechującego marksistowskie podejście do myśli ekonomicznej. $\mathrm{W}$ takim ujęciu analiza procesów społecznych i gospodarczych w duchu ekonomii instytucjonalnej może być postrzegana jako „trzecia droga” pomiędzy podejściem neoklasycznym a keynesistowskim ${ }^{16}$.

Podejmując próbę odniesienia dorobku ekonomii instytucjonalnej do procesów rozwoju lokalnego i regionalnego, można zauważyć, że w jej ujęciu przestrzeń staje się „terytorium” - aktywnym uczestnikiem procesów rozwojowych, a nie tylko obszarem koncentracji zasobów ziemi, kapitału i pracy. Ekonomia instytucjonalna wydaje się zatem mieć wiele do zaoferowania naukom regionalnym. Jak zauważyła P. Healey, podejście to może przyczynić się do rozwoju swoistego „dyskursu opartego na miejscu”, ponieważ miejsca są tworzone społecznie, w oparciu o relacje między ich aktorami i własną historię ${ }^{17}$. Tezę tę można z powodzeniem uznać za kwintesencję „mariażu” podejścia instytucjonalnego z nowoczesnymi koncepcjami poświęconymi rozwojowi lokalnemu i regionalnemu, pogłębianego dodatkowo w rozważaniach dotyczących roli bliskości w rozwoju gospodarczym (w ekonomice bliskości).

Powyższe ujęcie stwarza możliwość spojrzenia na procesy rozwoju regionalnego z szerokiej perspektywy, uwzględniającej kontekst instytucjonalny. Wiedza tkwiąca $\mathrm{w}$ regionie może być rozważana jako źródło jego zasobów strategicznych. Dotyczy to zarówno „produkowanej” w danym układzie terytorialnym wiedzy kodyfikowanej, jak i wiedzy milczącej, opartej na kapitale relacyjnym i instytucjach nieformalnych.

Wyrazem konkurencyjności terytorium jest $\mathrm{w}$ tej sytuacji umiejętność rekonfiguracji zasobów w celu wytwarzania dóbr i usług znajdujących nabywców na różnych rynkach (zdolność uczenia się). Stanowi ona wypadkową rutyn, umiejętności i kompetencji, które dzięki

16 A. Cumbers, D. MacKinnon, R. McMaster, Institutions, Power and Space. Assessing the Limits to Institutionalism in Economic Geography, „European Urban and Regional Studies" 2003, vol. 10, s. 325

17 P. Healey, Institutionalist Analysis, Communicative Planning and Shaping Places, „Journal of Planning Education and Research” 1999, no. 19, s. 118. 
mechanizmom wewnętrznej i zewnętrznej selekcji zapewniają (lub w niesprzyjających warunkach - ograniczają) zdolność regionu do poszukiwania nowych rozwiązań, wyłaniających się jako odpowiedź na nowe okazje i wyzwania. W wyniku opisanej dynamiki i ciągłych zmian pojawia się nowa wiedza oraz nowe zasoby, akumulowane w regionie (w języku ekonomii ewolucyjnej następuje ich dziedziczenie) $)^{18}$ (rys. 19).
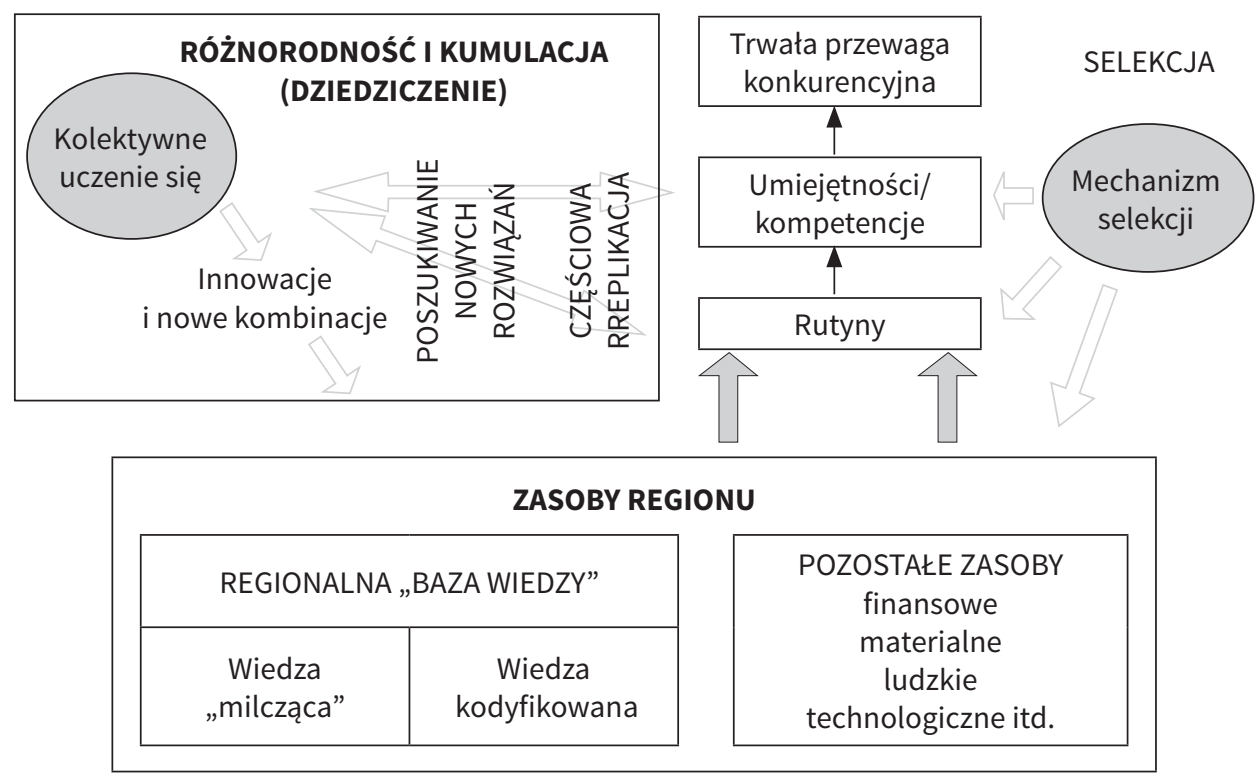

Rys. 19. Podstawowe ramy konkurencyjności regionu w świetle ekonomii ewolucyjnej i teorii zasobów

Źródło: P. Salmi et al., Industrial Districts and Regional Development. Towards a Knowledge-based View, Telecom Business Research Center, Lappeenranta 2001, s. 72.

W takim holistycznym ujęciu pojawia się jednak istotne wyzwanie, aby nie ulec pokusie uznania za instytucje wszelkich elementów i relacji zachodzących w ramach modelu prezentowanego na rys. 19. Instytucje per se są bowiem bardzo niewdzięcznym przedmiotem zarówno badania, jak i oddziaływania ze strony polityki. Dorobek ekonomii instytucjonalnej pozwala bezsprzecznie stwierdzić, że nie tylko na poziomie krajowym czy międzynarodowym, lecz także na poziomie lokalnym i regionalnym instytucje są kluczowe dla rozwoju gospodarczego i dlatego zasługują na szczególną uwagę jako przedmiot polityki rozwoju. Z punktu widzenia

18 P. Salmi et al., Industrial Districts and Regional Development. Towards a Knowledge-based View, Telecom Business Research Center, Lappeenranta 2001, s. 72. 
ekonomiki miejskiej i regionalnej są przy tym jednym z głównych - choć niezwykle trudno mierzalnych - źródeł korzyści aglomeracji.

Pewne jest, że interwencja ze strony polityki w środowisko instytucjonalne musi dostosowywać się do specyficznych uwarunkowań terytorialnych ${ }^{19}$. W takim ujęciu A. Amin wskazuje na następujące uniwersalne konsekwencje stosowania podejścia instytucjonalnego $\mathrm{w}$ polityce regionalnej ${ }^{20}$ :

1) konieczność wspierania funkcjonowania sieci relacji w miejsce pojedynczych organizacji i pomiotów,

2) dążenie do dialogu i negocjacji oraz promowanie otwartości na zmiany i kultury „uczenia się przez całe życie”,

3) mobilizacja różnorodnych aktorów (nie tylko administracji państwowej) jako regulatora procesów gospodarczych (decentralizacja, dzielenie się władzą),

4) promowanie różnorodnych form współrządzenia, opartych na wzajemności (governance),

5) dostosowywanie działań do specyfiki i kontekstu lokalnego.

Ujęcie to jednak wciąż pozostaje ogólne i z naukowego punktu widzenia wymaga dalszych prac $\mathrm{w}$ kierunku konceptualizacji, której zresztą nie sprzyja różnorodność nurtów instytucjonalnych i podejść metodologicznych. Przykładowo, o ile można statystycznie modelować wpływ na rozwój gospodarczy takich czynników, jak kapitał ludzki, innowacja czy infrastruktura fizyczna, o tyle wpływu instytucji w szerokiej interpretacji nie da się łatwo zmierzyć21. Instytucje pojawiają się w wielu analizach jako czynnik wyjaśniający niemal każde zjawisko odpowiedzialne za rozwój terytorialny, który można analizować przede wszystkim przez pryzmat badań jakościowych i studiów przypadku, co z kolei czyni niezwykle trudnymi badania porównawcze oraz utrudnia uogólnianie wyników ${ }^{22}$.

Punktem wyjścia dla sprostania temu wyzwaniu powinna być czytelna klasyfikacja zarówno typów instytucji, jak i - w jej następstwie - podejść instytucjonalnych. W odniesieniu do procesów gospodarczych w ślad za Zbigniewem Stańkiem proponuje się podział systemu instytucjonalnego na trzy wzajemne warunkujące się elementy ${ }^{23}$ :

19 A. Rodríguez-Pose, Do Institutions Matter for Regional Development?, Working Papers Series in Economics and Social Sciences, Sciencias Sociales IMDEA 2010, no. 2, s. 23.

20 A. Amin, An Institutionalist Perspective..., s. 368.

21 J. Tomaney, Region and Place I: Institutions, „Progress in Human Geography” 2014, vol. 38 (1), s. 133.

22 OECD, Promoting Growth in All Regions, Paris 2012.

23 Z. Staniek, Zróżnicowanie ekonomii instytucjonalnej; http://www.e-sgh.pl/niezbednik/plik.php?id=27233173\&pid=1081 (dostęp 12.12.2013). 
1) instytucje - organizacje (np. agencje rządowe i samorządowe, podmioty sektora finansów, fundacje, stowarzyszenia, przedsiębiorstwa),

2) instytucje (regulacje) formalne (prawo regulujące działalność gospodarczą, prawo pracy, prawo energetyczne, prawo wyborcze, prawo finansowe, rozwiązania podatkowe, dopuszczalne formy zawieranych umów czy kontraktów, dopuszczalne formy władania rzeczami ruchomymi i nieruchomościami),

3) instytucje nieformalne (wzorce kulturowe, normy zachowań, poziom zaufania, skłonność do przestrzegania prawa i umów, skłonność do tworzenia sieci kontaktów).

Dwa pierwsze elementy można zaklasyfikować jako instytucje o charakterze formalnym, podczas gdy trzeci pozostaje w sferze relacji i regulacji o charakterze pozaformalnym ${ }^{24}$ (por. rys. 20).

Rozważania na temat pojęcia $\mathrm{i}$ istoty instytucji wiążą się z przemyśleniami poświęconymi rozwojowi lokalnemu i regionalnemu przede wszystkim (choć nie wyłącznie) w kontekście instytucji nieformalnych, które Williamson zalicza do „instytucji poziomu pierwszego” (por. podrozdział 2 rozdziału II). Z drugiej strony, w literaturze dotyczącej terytorialnego aspektu procesów rozwoju społeczno-gospodarczego można znaleźć wiele powiązań z instytucjami „poziomu trzeciego”, przede wszystkim w kontekście wpływu uwarunkowań lokalnych na redukcję kosztów transakcyjnych. Wydaje się też, że na poziomie lokalnym dostrzega się odwrotną - w stosunku do propozycji Williamsona - zależność między poszczególnymi poziomami instytucji. Otóż, specyficzne dla danego terytorium zwyczaje, kody językowe, sposoby rozwiązywania pojawiających się problemów (tzw. rutyny) nie tylko warunkują kolejne poziomy instytucji, lecz także dostosowują się do nich. W konsekwencji uregulowania prawne uniwersalne dla danego kraju mogą być odmiennie interpretowane w różnych kontekstach terytorialnych. Przykładem może być zróżnicowanie w zakresie lokalnej specyfiki rozwiązań architektonicznych i urbanistycznych różnych miast tego samego kraju, pomimo obowiązywania tych samych przepisów w zakresie prawa zagospodarowania przestrzennego oraz prawa budowlanego.

24 Pojęcie „pozaformalny” lub „pozalegalny” zostało zaproponowane przez H. de Soto ze względu na chęć odróżnienia od pojęcia „nieformalny” czy „nielegalny”, kojarzącego się z nieprzestrzeganiem przepisów prawa (w oryginale extralegal, w odróżnieniu od illegal - H. de Soto, Tajemnica kapitatu, Fijorr Publishing, Chicago-Warszawa 2002, s. 50). 


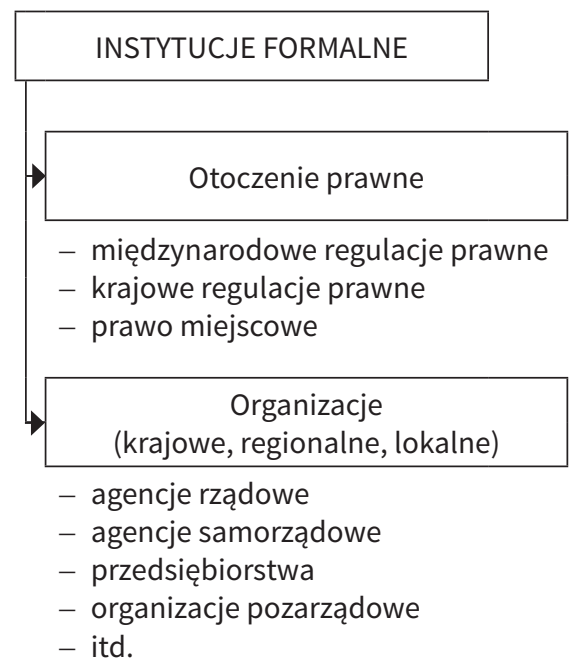

INSTYTUCJE POZAFORMALNE

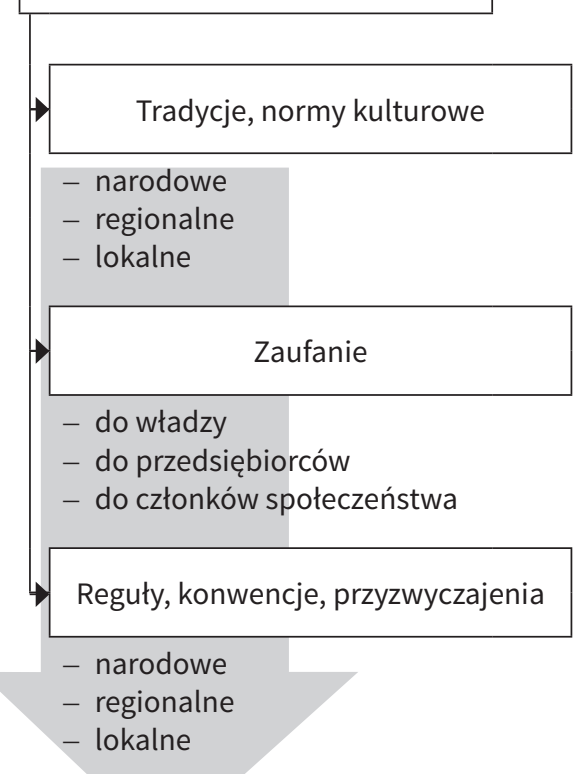

w tym tradycje, normy kulturowe reguły, konwencje i zaufanie, rozwijające się na poziomie lokalnym i regionalnym, tzw. KAPITAŁ TERYTORIALNY, np.

- lokalna/regionalna kultura przedsiębiorczości i skłonność do innowacji

- zakorzeniony terytorialnie kapitał społeczny:

o pomostowy - sprzyjający rozwojowi

o wiążący - ograniczający rozwój

poziom skłonność skłonność do przestrze- skłonność do zrzesza-

zaufania dowspót- gania przepisów prawa nia się i uczestnictwa

pracy idotrzymywania umów wżyciu obywatelskim

Rys. 20. Klasyfikacja instytucji w badaniach procesów rozwoju terytorialnego Źródło: opracowanie własne.

Powyższa klasyfikacja pozostaje przydatna dla lepszego zrozumienia roli instytucji w ekonomii i w naukach regionalnych oraz ma swoje konsekwencje w próbach pomiaru elementów otoczenia instytucjonalnego. Jednak takie podejście badawcze, biorąc pod uwagę charakter społeczny i dynamiczny samych instytucji, nie jest przedsięwzięciem łatwym - zwłaszcza w odniesieniu do badań instytucjonalnych na poziomie lokalnym i regionalnym. Stąd próby zastosowania na tym poziomie ekonomii instytucjonalnej są wciąż w początkowej fazie i różnią 
się w zależności od reprezentowanych szkół i podejść. Należy przy tym podkreślić - za przedstawicielami nauk społecznych - że instytucje formalne, których pomiar wzbudza mniej kontrowersji i wątpliwości terminologicznych, mają mniejszy wpływ na rozwój społeczno-gospodarczy niż trudniej mierzalne instytucje pozaformalne ${ }^{25}$.

\section{Możliwości zastosowań ekonomii instytucjonalnej w badaniach rozwoju terytorialnego}

Każdy z nurtów ekonomii instytucjonalnej odwołuje się do nieco innych założeń, a w swoim programie bazuje na odmiennych zagadnieniach metodologicznych. Z punktu widzenia badań nad procesami rozwoju lokalnego i regionalnego umożliwia to ich wzbogacenie o wiele interesujących „wątków instytucjonalnych" (tab. 22).

Najwcześniejsze koncepcje instytucjonalne zdają się wyrastać z krytyki istotnych założeń ekonomii głównego nurtu, czasem wręcz przeciwstawiając instytucje mechanizmom wolnorynkowym. W tych koncepcjach podkreśla się, że instytucje pełnią w społeczeństwie i w gospodarce ważną rolę integrującą, zapewniając przewidywalność podejmowanych działań. W prowadzonych analizach ujmuje się czynniki kulturowe jako istotne z punktu widzenia przestrzennych zróżnicowań funkcjonowania gospodarek. W warstwie metodologicznej trudno we wspomnianych podejściach doszukiwać się silnie ugruntowanych i rygorystycznie przestrzeganych metod czy procedur badawczych. Badania nad gospodarką prowadzi się w tym ujęciu w oparciu o całościowe spojrzenie na zachodzące procesy, w duchu otwartości na różne nurty i podejścia badawcze. Pozwala to na podejmowanie wyrafinowanych rozważań o charakterze konceptualnym (z których współcześnie najbardziej rozpoznawalne przypisuje się G. M. Hodgsonowi), jednak za cenę stosunkowo ubogich analiz empirycznych.

Z perspektywy badawczej podejmowanej na gruncie rozwoju lokalnego i regionalnego najistotniejsze wydaje się spostrzeżenie, iż kontekst instytucji uwarunkowany jest nie tylko historycznie, ale i geograficznie

25 Ch. Woodruff, Measuring Institutions, [w:] S. Rose-Ackerman (ed.), International Handbook on the Economics of Corruption, Edward Elgar Publishing, Cheltenham 2006, s. 107. 
(terytorialnie). W konsekwencji przestrzenne zróżnicowanie uwarunkowań funkcjonowania społeczeństw i prowadzenia działalności gospodarczej będzie silnie korelować z przestrzennym zróżnicowaniem poziomu rozwoju gospodarczego. Otwiera to pole do prowadzenia badań opartych na tezie o istotnej, integrującej roli instytucji w procesach społeczno-gospodarczych, a także na tezie o silnym wypływie czynników instytucjonalnych na rozwój.

Badania tego typu mogą dotyczyć m.in. terytorialnego zróżnicowania takich czynników, jak poziom zaufania społecznego, stosunek do dóbr publicznych, poziom zaangażowania obywatelskiego (np. przynależność i aktywność w organizacjach pozarządowych, frekwencja wyborcza) czy poziom przedsiębiorczości. Ponadto, studia odwołujące się do klasycznych nurtów instytucjonalizmu mogą nawiązywać do analizy roli samorządu terytorialnego w budowaniu społeczeństwa obywatelskiego i do badań nad jakością rządzenia w samorządzie.

Odwoływanie się do najstarszych nurtów instytucjonalizmu i prowadzenie w ich duchu badań - także badań na procesami rozwoju terytorialnego - determinuje zatem w znacznym stopniu interdyscyplinarny charakter analiz. Zasygnalizowane wyżej kierunki badań skłaniają do sięgania do dorobku takich dyscyplin naukowych, jak ekonomia, socjologia, politologia i nauki prawne. Z punktu widzenia wzbogacenia dorobku nauk ekonomicznych kluczowe wydaje się podejmowanie wysiłków przede wszystkim na rzecz opracowywania złożonych rankingów na podstawie danych pierwotnych, stanowiących efekt kombinacji podejścia ilościowego i jakościowego.

Bardzo ważne pozostaje oparcie analiz na znacznych liczebnie próbach jednostek, których dobór wynika przy tym z metodologii zapewniającej porównywalność danych w skali międzynarodowej. Wyzwaniem pozostaje ponadto umiejętne uwzględnienie $\mathrm{w}$ badaniach zarówno kontekstu instytucji formalnych (których pomiar odwołuje się zwykle do twardych mierników, opartych na dokumentach i liczbach niebudzących wątpliwości), jak i nieformalnych (opartych najczęściej na subiektywnych opiniach ekspertów w danej dziedzinie). Pozostaje to wciąż istotnie utrudnione, szczególnie w przypadku badania instytucji poziomu lokalnego i regionalnego.

Kolejną grupą podejść instytucjonalnych, która znacząco różni się od pierwotnych nurtów ekonomii instytucjonalnej oraz neoinstytucjonalizmu jest nowa ekonomia instytucjonalna. Należy przypomnieć, że instytucje w ramach NEI są postrzegane nie tyle jako czynniki integrujące społeczeństwo, ile jako zestaw ograniczeń funkcjonowania jednostek dążących do maksymalizacji własnej użyteczności. 


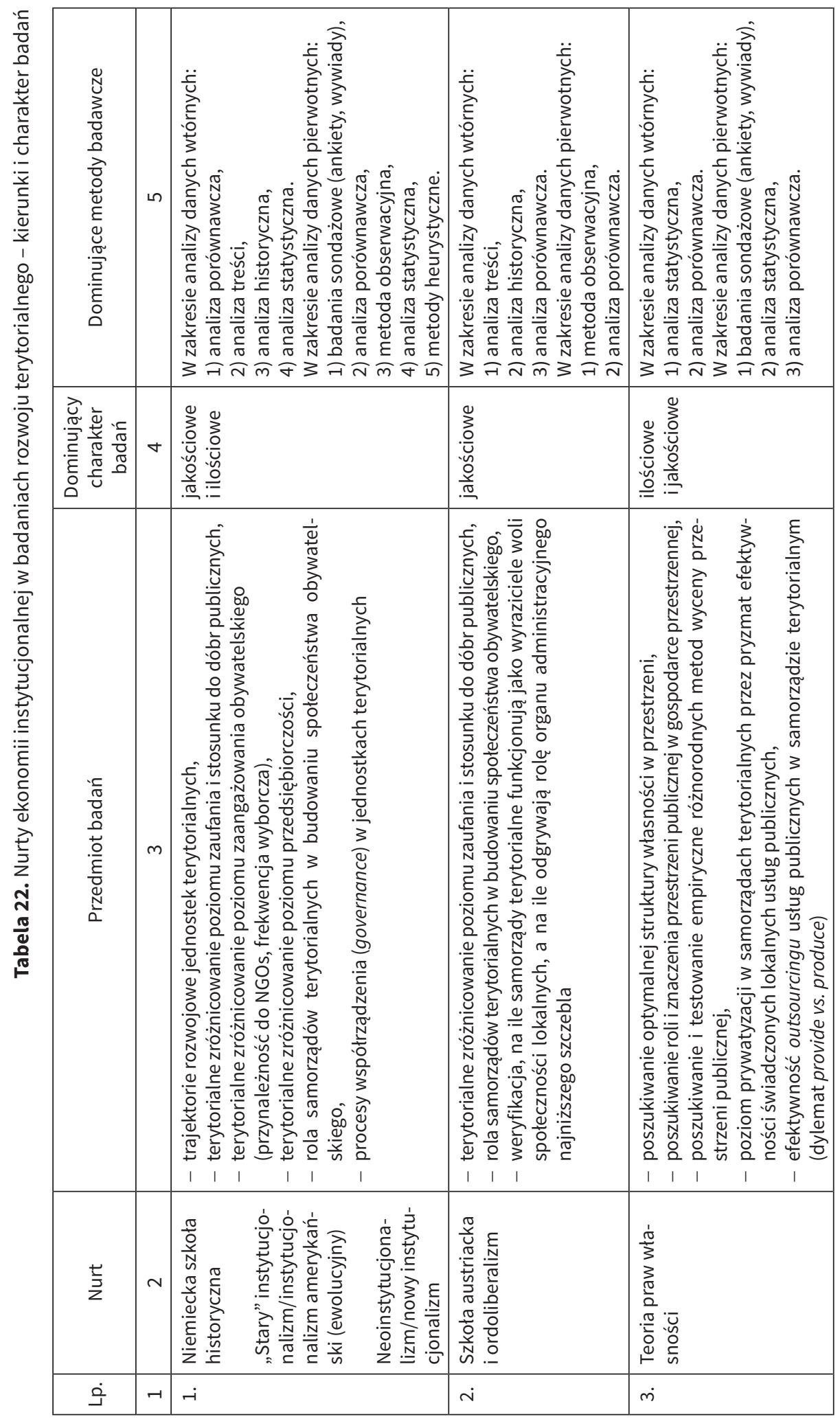




\begin{tabular}{|c|c|c|c|}
\hline 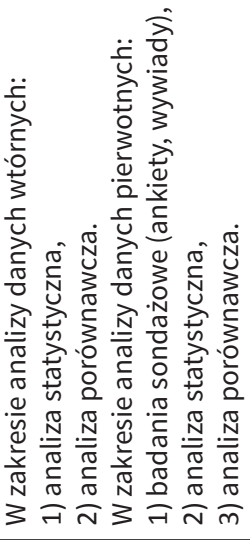 & 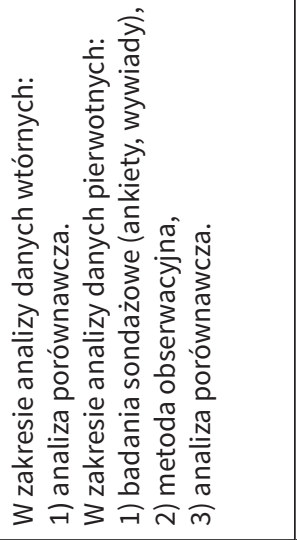 & 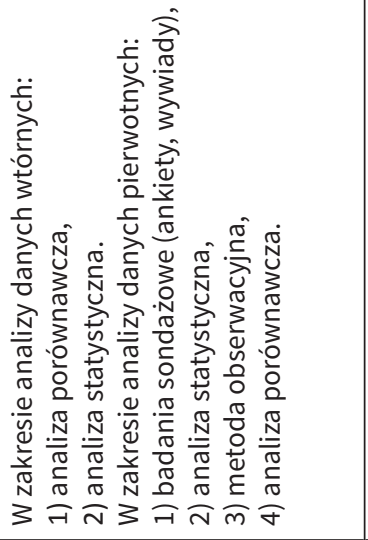 & 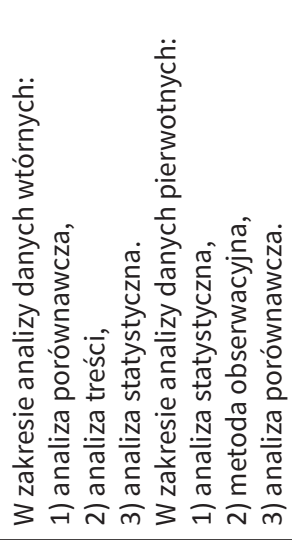 \\
\hline & 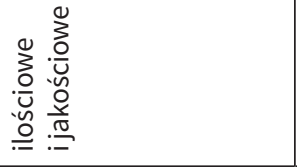 & 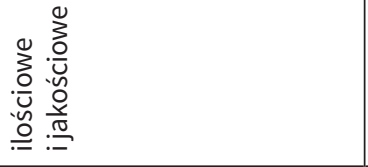 & 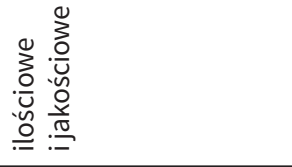 \\
\hline 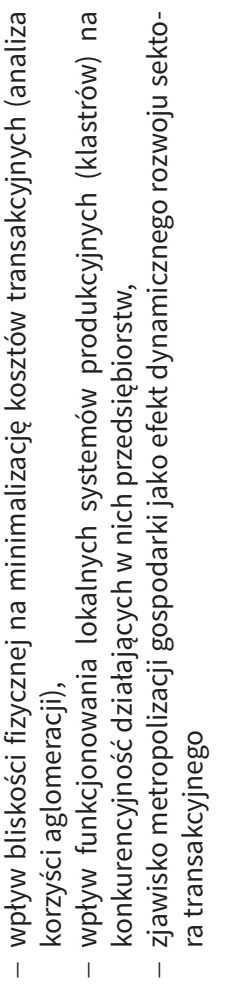 &  & 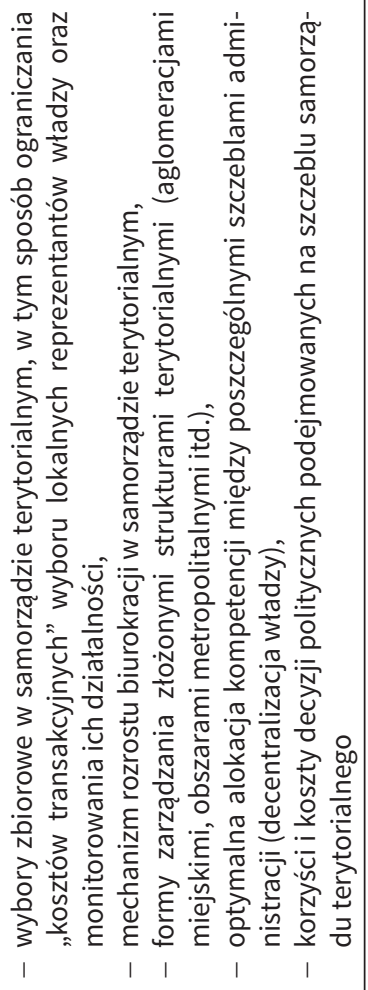 & 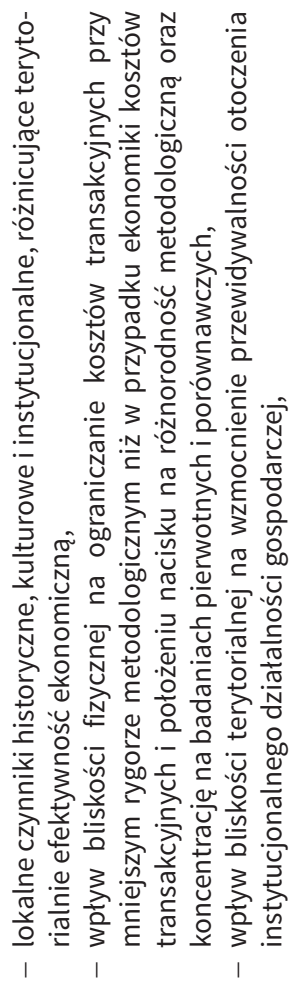 \\
\hline 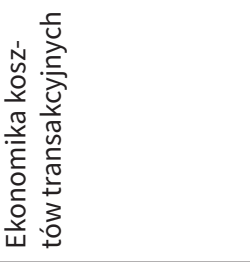 & 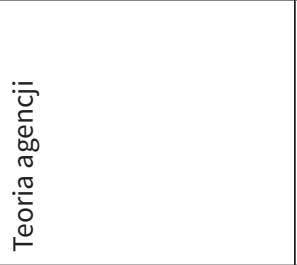 & 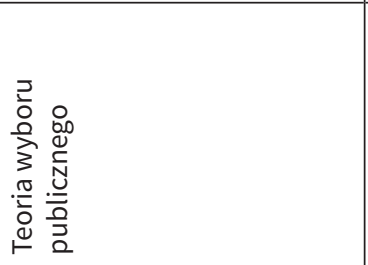 & 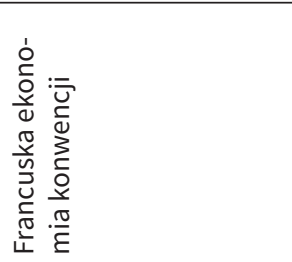 \\
\hline$\dot{+}$ & ம் & 6 & r \\
\hline
\end{tabular}




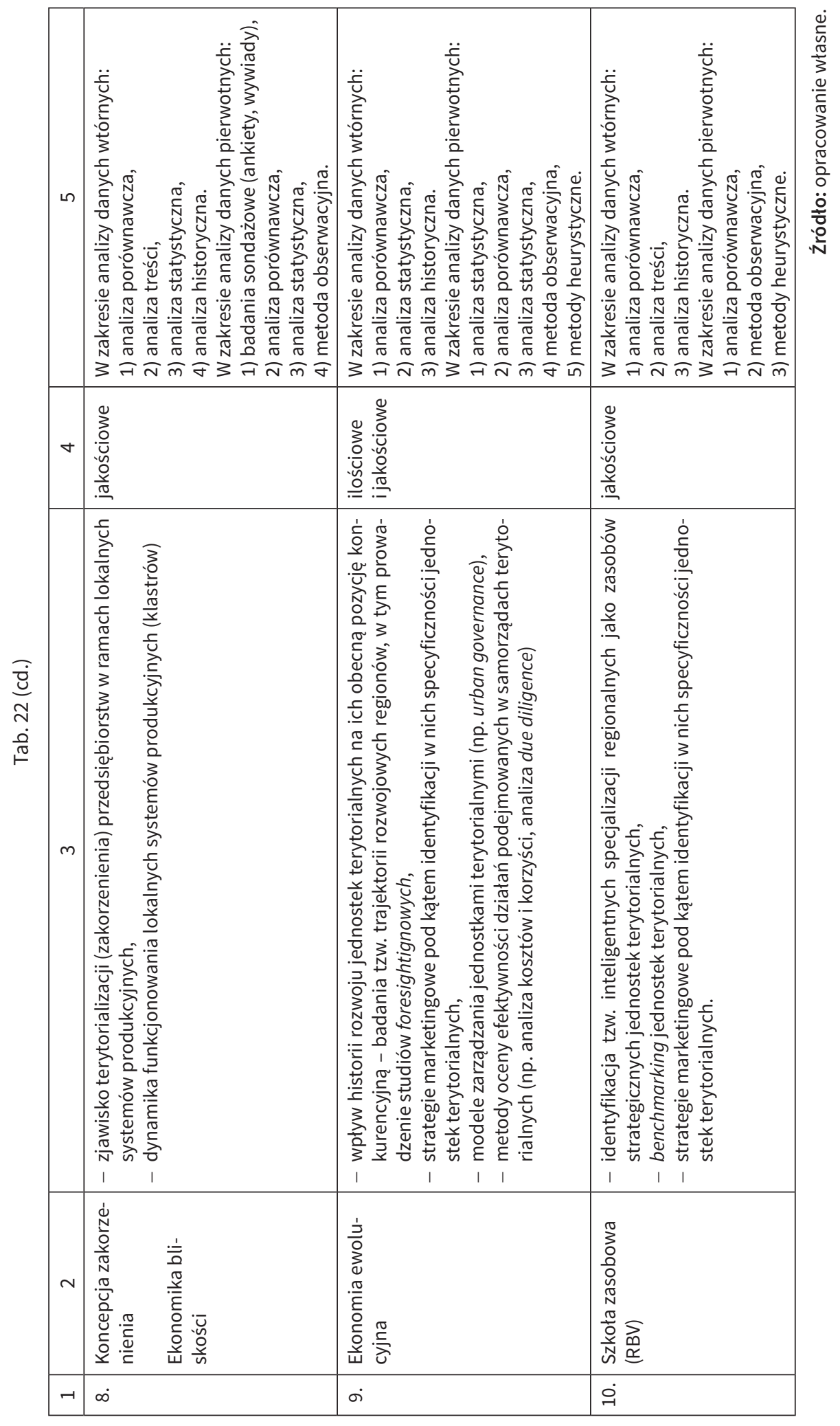


Elementy pierwszego z opisywanych $\mathrm{w}$ ramach NEI nurtów - teorii praw własności -można wykorzystywać w kilku niezależnych od siebie obszarach badań procesów rozwoju lokalnego i regionalnego. Po pierwsze, odwołanie się do fundamentalnych tez teorii praw własności pozwala zakładać, że optymalna, a przede wszystkim czytelna alokacja praw własności w przestrzeni prowadzi do jej efektywniejszego wykorzystania. Natomiast sytuacja przeciwna, w której nie można jednoznacznie zidentyfikować właścicieli zasobów, w tym nieruchomości, utrudnia lub uniemożliwia racjonalną gospodarkę przestrzenną. W tym kontekście teoria praw własności może stanowić teoretyczną podstawę badania wpływu działania otoczenia prawno-administracyjnego (w zakresie ochrony praw własności, prowadzenia rejestrów nieruchomości, digitalizacji systemów informacji o terenie itd.) na decyzje właścicieli i władających zasobami ziemi, zaś w konsekwencji - na racjonalne zagospodarowanie przestrzeni.

Teoria wyboru publicznego odwołuje się pośrednio do relacji między publicznym a prywatnym typem własności, które w gospodarce przestrzennej przekładają się przede wszystkim na zagadnienie roli i znaczenia przestrzeni publicznych. Problematyka ta uznawana jest współcześnie za jedno $\mathrm{z}$ kluczowych zagadnień $\mathrm{w}$ badaniach nad rozwojem terytorialnym. Opisywane przestrzenie, posiadając cechy dóbr publicznych lub wspólnych zasobów, dotyka problematyka efektów zewnętrznych, jazdy na gapę i innych zjawisk, które dotychczas rozważano przede wszystkim na gruncie ekonomii środowiskowej. Tymczasem rosnące znaczenie przestrzeni publicznych jako czynników atrakcyjności miast i regionów (np. w zakresie przyciągania klasy kreatywnej) oraz narastające wyzwania związane z efektywnością gospodarowania nimi (np. w kontekście powszechności zawłaszczania i prywatyzacji przestrzeni publicznych) powodują, że problematyka ta staje się ważnym przedmiotem badań, również za pomocą metod wypracowanych na gruncie TPW (por. rys. 21).

Przestrzenie publiczne za P. Lorensem można zdefiniować jako obszary, których sposób urządzenia i lokalizacja w stosunku do innych obszarów determinuje ich wykorzystanie „na potrzeby realizacji bezpośrednich kontaktów pomiędzy uczestnikami życia społecznego oraz inne potrzeby społeczne korzystających $\mathrm{z}$ niego zbiorowości”, przy czym należy założyć ich „fizyczną dostępność dla wszystkich zainteresowanych osób”26. Współcześnie ważny staje się także „stan przestrzeni publicznej, traktowanej jako składnik produktu miejskiego, istotna

26 P. Lorens, Definiowanie wspótczesnej przestrzeni publicznej, [w:] P. Lorens, J. Martyniuk-Pęczek (red.), Problemy kształtowania przestrzeni publicznych, Wyd. Urbanista, Gdańsk 2011, s. 10. 
atrakcja, wyróżniająca miasto na tle konkurentów, przyciągająca tzw. kapitał ludzki, tzn. wysoko wykwalifikowane kadry, dla których ma ona znaczenie, np. przy wyborze miejsca zamieszkania"27.

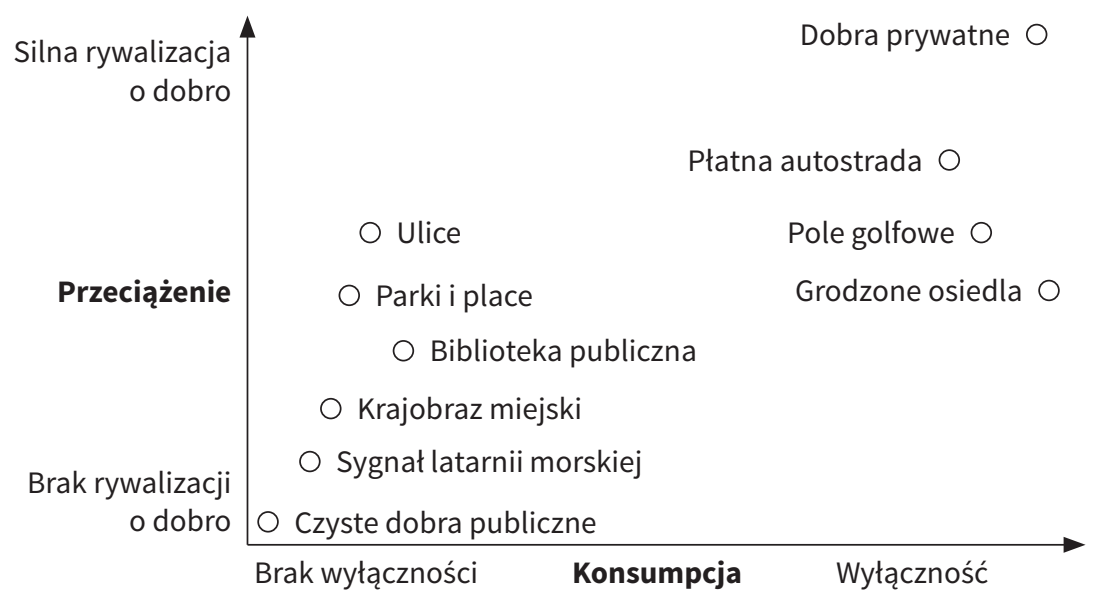

Rys. 21. Przestrzenie publiczne jako przedmiot badań teorii wyboru publicznego

Źródło: A. Polko, Urban Public Spaces - from Economics to Management, [w:] K. Heffner, A. Polko (eds.), Urban Public Space - Economics and Management Perspective, „Studia Regionalia KPZK PAN" 2012, vol. 34, s. 12, na podstawie: J. Choumert, J. Salanie, Provision of Urban Green Spaces: Some Insights from Economics, „Landscape Research” 2008, vol. 33, no. 3, s. 331-345.

$\mathrm{W}$ takim ujęciu przestrzeń publiczna interpretowana jest $\mathrm{z}$ jednej strony jako wspólny zasób lub dobro klubowe (wobec którego pojawia się problem konkurencyjności i wyłączenia z konsumpcji), a z drugiej - w kategoriach efektów zewnętrznych, bowiem jakość przestrzeni publicznej wpływa na wartość i użyteczność innych dóbr ${ }^{28}$. Kluczo-

27 D. Kochanowska, Przestrzeń publiczna - kluczowy element miasta wspótczesnego zintegrowana czy podzielona?, [w:] P. Lorens, J. Martyniuk-Pęczek (red.), Problemy ksztattowania..., s. 32.

28 Wśród podstawowych funkcji przestrzeni publicznej o charakterze efektów zewnętrznych należy przede wszystkim wymienić: organizację systemu transportowego jednostki osadniczej (ułatwienia dla przemieszczania osób i towarów), zapewnienie miejsca spotkań i organizacji wydarzeń zbiorowych sprzyjających interakcjom społecznym, eksponowanie dziedzictwa materialnego, generowanie popytu poprzez potoki ludzi wynikające z pełnionych funkcji komunikacyjnych oraz budowanie wizerunku danego miejsca (por. M. Carmona, C. Magalhaes, L. Hammond, Public Space: The Management Dimension, Routledge, London-New York, 2008; J. Gehl, Życie między budynkami. Użytkowanie przestrzeni publicznych, Wyd. RAM, Kraków 2009; M. Kochanowski (red.), Przestrzeń publiczna miasta postindustrialnego, Wyd. Politechniki Gdańskiej, Gdańsk 2002). 
we w tym kontekście pozostaje traktowanie przestrzeni publicznych jako dóbr „mieszanych”, niedających się zaklasyfikować bezpośrednio jako „czyste" dobra publiczne lub prywatne ${ }^{29}$. Determinuje to uznawanie przestrzeni publicznych za złożony przedmiot badań, zaś wykorzystanie teorii wyboru publicznego jako ram teoretycznych stanowi jedno z możliwych podejść do tego zagadnienia ${ }^{30}$.

Stwarza to z kolei miejsce dla poszukiwania i empirycznego testowania różnorodnych - alternatywnych w stosunku do tradycyjnych - metod wyceny przestrzeni publicznej (tab. 23). Tu należy przywołać przede wszystkim badania poświęcone szacowaniu wartości dóbr o charakterze nierynkowym, w tym głównie elementów środowiska przyrodniczego oraz kulturowego. W ramach tych prac opracowano szereg złożonych metod wyceny, które można podzielić na dwie podstawowe kategorie. Pierwsza $z$ nich - metody oparte na preferencjach ujawnionych - wykorzystują dane z rynków powiązanych z danym dobrem, na których ceny są znane i pozwalają wnioskować na temat jego wartości. Druga grupa metod - opartych na preferencjach deklarowanych - opiera się na stawianiu konsumentów przed hipotetycznymi sytuacjami wyboru. Na podstawie wyborów, jakich konsumenci dokonują w hipotetycznych scenariuszach, można wnioskować na temat ich preferencji, a w rezultacie - na temat wartości dóbr nierynkowych ${ }^{31}$.

29 Warto nadmienić, że badania nad rolą przestrzeni publicznych w rozwoju miast i regionów za podstawowe kryterium „publiczności” uznają przede wszystkim wspomnianą fizyczną dostępność, podczas gdy prawnie determinowana struktura własności pozostaje kwestią wtórną. Innymi słowy, fragment przestrzeni pozostający formalnie własnością podmiotu prywatnego - jeśli jest publicznie udostępniany - uznawany jest za przestrzeń publiczną lub przynajmniej za tzw. przestrzeń „pót-publiczną” lub „quasi-publiczną”. Do współczesnych przykładów tego typu przestrzeni można zaliczyć m.in. otwarte przestrzenie centrów handlowych. Zagadnienie to uświadamia złożoność problemu „publiczności” przestrzeni, pozostając istotnym wyzwaniem dla badaczy.

30 Szczególnie interesującym przedmiotem badań wydaje się w tym kontekście poszukiwanie zróżnicowań kulturowych w zakresie postrzegania roli i zakresu przestrzeni publicznych w rozwoju jednostek terytorialnych. Na różnice te wskazują coraz częściej nie tylko naukowcy, lecz także politycy i publicyści. Dobitnie różnice te akcentował m.in. R. Kapuściński, pisząc, że „dla ludzi Zachodu otoczenie jest przedłużeniem nich samych. Dla ludzi Wschodu jest ono obojętne. Świat brudu i zaniedbania zaczyna się na granicy ich skóry" (R. Kapuściński, Lapidarium, Czytelnik, Warszawa 2006, s. 302).

31 Szerzej: M. Czajkowski, Nierynkowe metody wyceny, [w:] J. Kronenberg, T. Bergier, Wyzwania zrównoważonego rozwoju w Polsce, Fundacja Sendzimira, Kraków 2010, s. 14-16. Badania empiryczne z wykorzystaniem takich metod opisane zostały m.in. w: M. Giergiczny, Rekreacyjna wartość Białowieskiego Parku Narodowego, „Ekonomia i Środowisko” 2009, nr 36, s. 116-128; M. Giergiczny, 
Tabela 23. Przykładowe metody wyceny przestrzeni publicznych

\begin{tabular}{|c|c|c|}
\hline Metody & Wartość & Zastosowanie \\
\hline \multicolumn{3}{|c|}{ Preferencje ujawnione } \\
\hline $\begin{array}{l}\text { Metoda cen } \\
\text { hedonicznych }\end{array}$ & $\begin{array}{l}\text { mierzona bezpośrednio } \\
\text { mierzona pośrednio }\end{array}$ & $\begin{array}{l}\text { wartość nieruchomości (według } \\
\text { domniemania, że wartość } \\
\text { nieruchomość zależy od bliskości } \\
\text { do przestrzeni publicznych) }\end{array}$ \\
\hline $\begin{array}{l}\text { Metoda kosztu } \\
\text { podróży }\end{array}$ & $\begin{array}{l}\text { mierzona bezpośrednio } \\
\text { mierzona pośrednio }\end{array}$ & popyt na miejsca rekreacji \\
\hline \multicolumn{3}{|c|}{ Preferencje wyrażone/deklarowane } \\
\hline $\begin{array}{l}\text { Metoda wyceny } \\
\text { warunkowej }\end{array}$ & $\begin{array}{l}\text { mierzona bezpośrednio } \\
\text { mierzona pośrednio } \\
\text { wartość alternatywna } \\
\text { wartość nieużytkowa }\end{array}$ & $\begin{array}{l}\text { szacowanie wartości pieniężnej } \\
\text { przestrzeni publicznych }\end{array}$ \\
\hline
\end{tabular}

Źródło: A. Polko, Urban Public Spaces..., s. 15; na podstawie: K. J. Boyle, Introduction to Revealed Preference Methods, [w:] P. Champ, K. Boyle, T. Brown (eds.), A Primer on Nonmarket Valuation, Kluwer Academic Publisher, Dortrecht 2003, s. 261; T. C. Brown, Introduction to Stated Preference Methods, [w:] P. Champ, K. Boyle, T. Brown (eds.), A Primer on Nonmarket..., s. 101; J. Choumert, J. Salanie, Provision of Urban Green Spaces: Some Insights from Economics, „Landscape Research” 2008, vol. 33, no. 3, s. 336.

Poza zagadnieniami roli przestrzeni publicznych, optymalnej alokacji praw własności oraz wyceny przestrzeni jako dobra ekonomicznego naturalnym kierunkiem prac badawczych podejmowanych w nawiązaniu do teorii praw własności może być, w przypadku jej aplikacji na poziomie lokalnymi regionalnym, badanie zakresu prywatyzacji majątku będącego w dyspozycji samorządów terytorialnych, jak też prywatyzacji oraz outsourcingu usług publicznych w samorządzie terytorialnym. Teoria wyboru publicznego dostarcza ram teoretycznych dla modelowania efektywności stosowanych rozwiązań - w kontekście rachunku kosztów i korzyści świadczenia usług publicznych bezpośrednio przez sektor publiczny lub w wyniku zapewnienia systemu dostarczania dóbr publicznych przez sektor prywatny, np. koncesjonowania lub kontraktowania (tzw. dylemat provide vs. produce ${ }^{32}$. Ten typ badań w podstawowym

J. Kronenberg, Jak wycenić wartość przyrody w mieście? Wycena drzew przyulicznych w centrum Łodzi, „Zrównoważony Rozwój - Zastosowania” 2012, nr 3, s. 74-89.

32 Badania na ten temat oraz rozważania teoretyczne w warunkach polskich dostępne są pracach E. Wojciechowskiego, Zarządzanie w samorządzie terytorialnym, Difin, Warszawa 2003. 
zakresie jest prowadzony w polskich warunkach od wielu lat, przede wszystkim $\mathrm{w}$ formie monitorowania procesów prywatyzacji majątku jednostek samorządu terytorialnego ${ }^{33}$. Obserwuje się również rozwój badań dotyczących zakresu stosowania różnorodnych form zlecania zadań publicznych podmiotom niepublicznym (w formie konkursów, koncesjonowania, partnerstwa publiczno-prywatnego itp.), jednak na obecnym etapie pozostaje on $\mathrm{w}$ fazie początkowej, a prowadzone analizy i publikacje ich wyników są rozproszone.

Jednym z najbardziej rozwiniętych nurtów w ramach nowej ekonomii instytucjonalnej jest teoria kosztów transakcyjnych, której głównym zadaniem pozostaje poszukiwanie optymalnych struktur gospodarczych, sprzyjających minimalizacji nakładów związanych z zawieraniem transakcji. W kontekście terytorialnym minimalizacji kosztów transakcyjnych może sprzyjać bliskość przestrzenna, stanowiąca źródło instytucji nieformalnych. Ponadto, wraz z rozwojem sektora transakcyjnego obserwuje się zjawisko wzrastającej koncentracji podmiotów tego sektora (zarówno publicznych, jak i prywatnych) w największych ośrodkach miejskich. W konsekwencji rozwój sektora transakcyjnego przyczynia się do zjawiska metropolizacji gospodarki, stanowiącego istotny przedmiot analiz na gruncie nauk regionalnych.

Badanie procesów rozwoju lokalnego i regionalnego w odniesieniu do ekonomiki kosztów transakcyjnych może dotyczyć wpływu bliskości fizycznej na minimalizację kosztów transakcyjnych (analiza korzyści aglomeracji), wpływu funkcjonowania lokalnych systemów produkcyjnych (klastrów) na konkurencyjność funkcjonujących w nich przedsiębiorstw, czy wreszcie zjawiska metropolizacji gospodarki jako efektu dynamicznego rozwoju sektora transakcyjnego.

Należy podkreślić, iż mimo bogatego dorobku teoretycznego dotyczącego przestrzennej koncentracji procesów gospodarczych oraz jej długiej historii, rozwój badań empirycznych nad korzyściami aglomeracji rozpoczął się stosunkowo niedawno, bo w latach 80 . XX w. ${ }^{34}$ Wśród najczęściej przywoływanych przełomowych prac wymienia się badania A. Saxenian nad fenomenem Doliny Krzemowej (1994) $)^{35}$, M. Portera na temat klas-

33 W Polsce zajmuje się tym Ministerstwo Skarbu Państwa oraz do pewnego stopnia Główny Urząd Statystyczny, choć w drugim przypadku dostęp do danych o prywatyzacji na poziomie lokalnym i regionalnym pozostaje dość ograniczony.

34 B. T. McCann, T. B. Folta, Location Matters: Where We Have Been and Where We Might Go in Agglomeration Research, „Journal of Management” 2008, vol. 34, no. 3 (June).

35 A. Saxenian, Regional Advantage: Culture and Competition in Silicon Valley and Route 128, Harvard University Press, Cambridge 1994. 
trów ${ }^{36}$ czy prace G. Beccatiniego i jego współpracowników z Uniwersytetu we Florencji, stanowiące „odświeżenie” koncepcji marshallowskiego dystryktu przemysłowego w odniesieniu do „Trzeciej Italii” ${ }^{37}$. Nieocenione są także prace grupy badawczej GREMI nad środowiskami innowacyjnymi, prowadzone pod kierunkiem $\mathrm{Ph}$. Aydalota. W tym nurcie analizowano przede wszystkim społeczny kontekst procesów gospodarczych na podstawie studiów przypadków Doliny Krzemowej, Cité Scientifique zlokalizowanych na południe od Paryża lub też w regionach „Trzeciej Italii”38. Ponadto powstało wiele opracowań szczegółowych na temat wybranych gałęzi gospodarki, rozwijanych zarówno przez ekonomistów, jak i przedstawicieli nauk o zarządzaniu ${ }^{39}$.

Szczególnie miarodajne wydają się przy tym badania wskazujące na relacje między koncentracją działalności gospodarczej a poziomem cen w danym sektorze gospodarki. Badania B. T. McCanna i G. Grooma

36 M. E. Porter, Clusters and the New Economics of Competition, „Harvard Business Review" 1998, vol. 76 (6), s. 77-90; M. E. Porter, On Competition, Harvard Business School Press, Cambridge 1998.

37 Mianem tym przyjęto określać wybrane regiony włoskie, odróżniając je od „Pierwszej Italii", tj. silnie uprzemysłowionych i wysoko rozwiniętych regionów północnych (w tym przede wszystkim takich obszarów zurbanizowanych, jak Turyn, Mediolan czy Genua) oraz „Drugiej Italii”, czyli słabo rozwiniętych regionów na południu Włoch (Mezzogiorno). Określenie „Trzecia Italia” natomiast dotyczy dynamicznie rozwijających się regionów, których gospodarka nabrała przyspieszenia w latach 70. i 80. XX w. na skutek dynamiki rozwoju małych i średnich przedsiębiorstw, zdolnych konkurować dzięki umiejętności wzajemnej kooperacji opartej na relacjach nieformalnych i zaufaniu, a także zdolności do innowacyjności (Emilia-Romania, Toskania, Umbria, Veneto, Friuli-Wenecja Julijska, Trydent-Górna Adyga).

38 A. Scott, Economic Geography: The Great Half Century, [w:] G. L. Clark, M. P. Feldman, M. S. Gertler (eds.), Oxford Handbook of Economic Geography, Oxford University Press, Oxford 2000, s. 29-30.

39 Można wspomnieć w tym miejscu o badaniach nad koncentracją działalności gospodarczej w branży hotelarskiej (W. Chung, A. Kalnins, Agglomeration Effects and Performance: A Test of the Texas Lodging Industry, „Strategic Management Journal" 2001, vol. 22(10), s. 969-988; B. T. McCann, G. Vroom, Pricing Response to Entry and Agglomeration Economies, „Strategic Management Journal” 2010, vol. 31, s. 284-305), w przetwórstwie przemysłowym (J. M. Shaver, F. Flyer, Agglomeration Economies, Firm Heterogeneity, and Foreign Direct Investment in the United States, „Strategic Management Journal” 2000, vol. 21(12), s. 1175-1193), obuwniczym (O. Sorenson, P. Audia, The Social Structure of Entrepreneurial Activity: Geographic Concentration of Footwear Production in the United States, 1940-1989, „American Journal of Sociology" 2000, vol. 106(2), s. 424-461), półprzewodnikowym (P. Almeida, B. Kogut, The Exploration of Technological Diversity and the Geographic Localization of Innovation, „Small Business Economics” 1997, vol. 9 (1), s. 21-31) czy biotechnologicznym (O. Sorenson, P. Audia, The Social Structure...). 
ujawniły, iż korzyści aglomeracji mogą prowadzić do sytuacji, w której paradoksalnie napływ kolejnych firm do tego samego sektora w tej samej lokalizacji będzie skutkował tym, że dotychczasowe przedsiębiorstwa podniosą ceny, bowiem firmy będą traktować nowe wejścia jako szansę, a nie zagrożenie ${ }^{40}$.

Podobnych dowodów empirycznych dostarczają badania dotyczące korzyści urbanizacji. Przykładowo, S. Rosenthal i W. Strange stwierdzili, że podwojenie populacji na danym obszarze prowadzi do zwiększenia wydajności pracy rzędu 3-8\% ${ }^{41}$. Jednocześnie porównywanie ze sobą $\mathrm{w}$ badaniach empirycznych obydwu typów korzyści aglomeracji nie pozwala na jednoznaczne stwierdzenie przewagi jednego $\mathrm{z}$ nich ${ }^{42}$. Przewaga ta wynika bowiem z występowania dodatkowych czynników, takich jak: typ działalności gospodarczej koncentrującej się w danej przestrzeni, poziom dywersyfikacji struktury gospodarczej jednostki terytorialnej, struktura rynków, na których działają przedsiębiorstwa ${ }^{43}$, cykl życia sektora $^{44}$, liczba przedsiębiorstw w sektorze, wrażliwość na koszty transpor$\mathrm{tu}^{45}$, a także geograficzny poziom analizy ${ }^{46}$.

Przegląd studiów potwierdza generalną tendencję przedsiębiorstw do koncentracji przestrzennej, natomiast nie daje jednoznacznych wyników w zakresie udowodnienia wpływu tej koncentracji na wydajnośćc ${ }^{77}$. Korzyści lokalizacji trudno jest analizować również dlatego, że relatywnie łatwo mierzalny wysoki poziom koncentracji działalności gospodarczej nie zawsze odzwierciedla rzeczywistą dynamikę relacji w danym sektorze

40 B. T. McCann, G. Vroom, Pricing Response..., s. 303.

41 S. Rosenthal, W. Strange, Evidence on the Nature and Sources of Agglomeration Economies, [w:] V. Henderson, J.-F. Thisse (eds.), Handbook of Regional and Urban Economics 4: Cities and Geography, Elsevier, Amsterdam 2004 (rozdział 49), [cyt. za:] A. O’Sullivan, Urban Economics, McGraw Hill-Irwin, New York 2007, s. 49.

42 Zob. m.in. M. E. Edwards, Regional and Urban Economics and Economic Development. Theory and Methods, Auerbach Publications, Taylor and Francis Group, New York 2007, s. 124.

43 Por. G. van der Panne, Agglomeration externalities: Marshall versus Jacobs, „Journal of Evolutionary Economics" 2004, vol. 14.

44 B. T. McCann, G. Vroom, Pricing Response...

45 Por. L. Bertinelli, J. Decrop, Geographical Agglomeration: Ellison and Glaeser Index Applied to the Case of Belgian Manufacturing Industry, „Regional Studies” 2005, vol. 39 (5), s. 567-583.

46 Problem ten definiowany jest w metodologii badań przestrzennych jako tzw. problem MAUP (modifiable area unit problem), który pojawia się wówczas, gdy liczba, wielkości czy nawet kształt poddawanych analizie jednostek przestrzennych wpływa na osiągane wyniki empiryczne, ograniczając lub eliminując efektywność wykorzystywanych wskaźników koncentracji (por. m.in. L. Bertinelli, J. Decrop, Geographical Agglomeration..., s. 568.

47 B. T. McCann, T. B. Folta, Location Matters..., s. 538-540. 
gospodarki. W wielu tradycyjnych gałęziach gospodarki może występować bardzo duża liczba przedsiębiorstw zatrudniających wielu pracowników, jednak wynikające $\mathrm{z}$ tego faktu wskaźniki koncentracji nie będą nic mówiły o poziomie i mechanizmach współpracy między nimi. Innymi słowy, wskaźniki koncentracji mierzą jedynie poziom specjalizacji gospodarczej, a nie dynamiczne korzyści lokalizacji ${ }^{48}$.

Oznacza to konieczność ciągłego poszukiwania odmiennych podejść i metod badawczych. Stąd cenny wkład w rozwój tego rodzaju badań może stanowić wykorzystanie dorobku ekonomii instytucjonalnej dla wyjaśniania zjawisk gospodarczych zachodzących w przestrzeni. Należy jednak podkreślić, iż w obliczu rygoru metodologicznego, jaki cechuje nową ekonomię instytucjonalną, kluczowym wyzwaniem pozostaje precyzyjne zdefiniowanie oraz operacjonalizacja kosztów transakcyjnych.

Płodnym, choć dotychczas słabo eksplorowanym nurtem badań może okazać się analiza zależności między wielkością sektora transakcyjnego w gospodarce a zjawiskiem metropolizacji. Faktem jest, że znakomita większość podmiotów, zarówno z sektora prywatnego, jak i publicznego, działających na rzecz ograniczania kosztów transakcyjnych, lokalizuje swoje siedziby w najbardziej zurbanizowanych ośrodkach miejskich, z których największe stają się globalnymi centrami gospodarki. W Polsce w jednej z pionierskich prac poświęconych szacowaniu wielkości sektora transakcyjnego założono, że na jego elementy składają się następujące typy działalności gospodarczej: pośrednictwo finansowe, obsługa nieruchomości i firm, działalność naukowo-badawcza, handel i naprawy. W pozostałych branżach gospodarki koszty transakcyjne w działalności produkcyjnej szacowano poprzez ustalenie udziału w strukturze zatrudnienia zawodów charakterystycznych dla sektorów transakcyjnych (menadżerowie, właściciele przedsiębiorstw, kadra administracyjna, handlowcy, urzędnicy) ${ }^{49}$. Warto zauważyć, że wskazane branże oraz typy zawodów wykazywały przy tym wyraźną tendencję do koncentracji w najbardziej zaludnionych ośrodkach miejskich Polski. Ujawnia to zbieżność między wielkością sektora transakcyjnego a poziomem metropolizacji przestrzeni w Polsce i może stanowić punkt wyjścia dla kontynuacji tego typu badań.

48 M. Feldman, Location and Innovation: The New Economic Geography of Innovation, Spillover, and Agglomeration, [w:] G. L. Clark, M. P. Feldman, M. S. Gertler (eds.), Oxford Handbook..., s. 283-384.

49 A. Sulejewicz, P. Graca-Gelert, Kształtowanie się poziomu kosztów transakcyjnych w Polsce w latach 1996-2002, [w:] R. Rapacki (red.), Wzrost gospodarczy w krajach transformacji. Konwergencja czy dywergencja?, PWE, Warszawa 2009, s. 225-262. 
Pokrewnym w stosunku do ekonomii kosztów transakcyjnych kierunkiem analiz jest teoria agencji, która opiera się na założeniu, że transakcje zachodzą nie tylko na rynku, lecz także między członkami organizacji, mającymi często odmienne lub wręcz sprzeczne cele. Przydatność tego nurtu NEI jest dostrzegalna na poziomie regionalnym i lokalnym. Oprócz wykorzystywania jej aparatu analitycznego na rzecz usprawniania procesów zarządzania w organizacjach funkcjonujących na danym terytorium może być stosowana również do badania stosunków podrzędności, nadrzędności i kontroli zarówno w pojedynczym samorządzie terytorialnym, jak i pomiędzy różnymi szczeblami władzy - np. w aspekcie relacji między władzą centralną (pryncypał) a władzą gminną (agent) lub między klasą polityczną (pryncypał) a klasą biurokratów (agent).

$\mathrm{W}$ przypadku badania procesów rozwoju terytorialnego podmiot badań stanowi zawsze złożona zbiorowość, w której należy wyróżnić - w zależności od przyjętej klasyfikacji - różnorodne grupy. Na przykład, z punktu widzenia ustroju samorządu terytorialnego teoria agencji za pryncypała uznawałaby wyborców jako członków społeczności lokalnej lub regionalnej, natomiast $\mathrm{w}$ roli agentów sytuowałaby wybieralnych przedstawicieli władzy uchwałodawczej i wykonawczej. $Z$ kolei założenie o wielostopniowości samorządu stawia w roli podmiotów kontrolujących organizacje kontrolne sytuowane na wyższym poziomie podziału terytorialnego kraju, znajdujące się $\mathrm{w}$ relacji nadrzędności w stosunku do agencji na niższych szczeblach samorządu. Wreszcie rozpatrywanie w kategoriach teorii agencji pojedynczych organizacji działających na poziomie lokalnym i regionalnym (np. urzędów gminnych, miejskich, regionalnych, przedsiębiorstw pozarządowych czy nawet złożonych organizacyjnie lokalnych i regionalnych organizacji pozarządowych) pozwala na tradycyjne analizy w podziale na pryncypałów i agentów w ramach jednej organizacji.

Opisana wyżej złożoność powoduje jednak, że analizy w klasycznym, modelowym ujęciu prowadzone są niezwykle rzadko, a ich charakter pozostaje ograniczony do wybranego przedmiotu badań. Spotyka się też prace dostarczające narzędzi związanych z procesami monitoringu i ewaluacji polityk na szczeblu lokalnym i regionalnym (które w kategoriach teorii agencji należałoby traktować jako minimalizujące koszty kontroli agentów przez pryncypałów). Prace te są stosunkowo powszechne, jednak ich związek z opisywaną teorią pozostaje mglisty lub nawet nieuświadomiony. Wynika to przede wszystkim $\mathrm{z}$ faktu, że badania tego typu mają zwykle charakter bardziej narzędziowy (na potrzeby zarządzania) niż ściśle naukowy.

Ostatni ze wskazanych obszarów analiz rozwijany jest na gruncie teorii wyboru publicznego. Przedmiotem jej zainteresowania jest analiza podejmowania wyborów zbiorowych przy wykorzystaniu aparatu ekonomi klasycznej (indywidualizm metodologiczny, założenie racjonalności za- 
chowań). W ramach tego nurtu nowej ekonomii instytucjonalnej można analizować: mechanizm wyborów zbiorowych w samorządzie terytorialnym, poszukiwanie optymalnych form zarządzania złożonymi strukturami terytorialnymi, czy wreszcie poszukiwanie optymalnej alokacji kompetencji pomiędzy poszczególne szczeble administracji. Jak podaje W. Stankiewicz, społeczeństwo uzbrojone przynajmniej w szczątkową wiedzę o wyborze publicznym mogłoby zrozumieć, dlaczego systemy biurokratyczne, raz powołane do życia, dążą do nieograniczonego rozrastania się i to bez związku z pierwotnie nadanymi funkcjami ${ }^{50}$.

W odniesieniu do wyborów zbiorowych godne uwagi są próby znalezienia sposobów ograniczania „kosztów transakcyjnych” wyboru lokalnych reprezentantów władzy oraz monitorowania ich działalności, podejmowane coraz częściej głównie przez organizacje pozarządowe. Przykładem takiego przedsięwzięcia o charakterze aplikacyjnym (które jednak samo w sobie pozostaje interesującym przedmiotem badań jako studium przypadku) jest projekt monitoringowy, prowadzony przez fundację Normalne Miasto - Fenomen w Łodzi od lutego 2012 r. do czerwca 2013 r., finansowany ze środków Fundacji im. Stefana Batorego na rzecz rozwoju społeczeństwa obywatelskiego. Projekt poświęcony był popularyzacji wśród mieszkańców wiedzy o roli i działaniach różnych komisji Rady Miejskiej w Łodzi jako gremiów, w których dyskutowane są i ustalane stanowiska oraz przygotowywane decyzje w najważniejszych kwestiach dotyczących życia miasta ${ }^{51}$. Przedsięwzięcie to - poprzez swój komponent monitoringowy i promocyjno-informacyjny - miało na celu upowszechnienie wiedzy na temat działalności wybranych przez społeczność lokalną przedstawicieli zasiadających $\mathrm{w}$ radzie miejskiej, $\mathrm{w}$ celu zapewnienia przejrzystej prezentacji aktywności każdego z nich i - tym samym - zastąpienia mechanizmu odpowiedzialności zbiorowej odpowiedzialnością osobistą każdego z polityków lokalnych. Zwiększająca się liczba tego typu inicjatyw stwarza na przyszłość szansę dla prowadzenia pogłębionych studiów porównawczych podobnych przedsięwzięć lokalnych, a także udzielenia odpowiedzi na pytanie o ich efektywność w kontekście wpływu na rzeczywisty poziom kosztów monitorowania wiarygodności polityków ${ }^{52}$.

50 W. Stankiewicz, Ekonomika instytucjonalna. Zarys wykładu, Warszawa 2012, s. 196; http://pwsbia.edu.pl/pdf_files/Waclaw_Stankiewicz_Ekonomika_Instytucjonalna_III.pdf (dostęp: 28.12.2014).

51 http://www.radni.dlalodzi.info/o-monitoringu/o-co-chodzi-w-projekcie (dostęp: 6.10.2014).

52 Przedsięwzięcia monitoringowe, takie jak Monitoring Radnych, przyczyniają się do ograniczenia wysiłku weryfikowania realizacji obietnic wyborczych przez reprezentantów władzy, osłabiając mechanizm „racjonalnej ignorancji” wyborców (por. podrozdział $1.3 \mathrm{w}$ rozdziale III). 
Kolejnym obszarem badań i analiz ekonomicznych na poziomie lokalnym i regionalnym w odniesieniu do teorii wyboru publicznego jest poszukiwanie optymalnych form zarządzania złożonymi strukturami terytorialnymi, takimi jak aglomeracje miejskie czy obszary metropolitalne. W obliczu dynamicznych procesów urbanizacyjnych, przy jednoczesnej tendencji do poszukiwania miejsca zamieszkania coraz dalej od centrów tego typu ośrodków (w sąsiednich miastach i gminach), dochodzi do integracji funkcjonalnej przy rosnącym rozproszeniu ośrodków decyzyjnych. O skuteczności zarządzania takimi złożonymi obszarami (regionami) metropolitalnymi decyduje z jednej strony stopień, a $\mathrm{z}$ drugiej - sposób „związania” jednostek terytorialnych odrębnych z punktu widzenia prawno-administracyjnego w spójny system, którego poszczególne elementy pełnią komplementarne w stosunku do siebie funkcje. Efektywność koordynacji działań poszczególnych składowych regionu funkcjonalnego stanowi przy tym czynnik wzmacniający - tudzież osłabiający - jego potencjał metropolitalny ${ }^{53}$.

Należy dodać, że teoria wyboru publicznego pozwala na prowadzenie studiów na styku ekonomii i nauk o zarządzaniu, związanych z poszukiwaniem optymalnej alokacji kompetencji między poszczególnymi

53 Pierwotnie, najbardziej powszechną formą odpowiedzi systemów administracyjnych miast na procesy urbanizacji była inkorporacja terenów znajdujących się w coraz dalszej odległości od centrum miasta. Strategie ta napotykały jednak na szereg problemów związanych z tym, że po pierwsze, procesy aneksji nie nadążały za żywiołowym zjawiskiem rozlewania się miast, a po drugie, spotykały się z oporem ze strony podmiejskich samorządów terytorialnych. Kolejnym rozwiązaniem było zatem tworzenie obszarów metropolitalnych jako jednostek terytorialnych szczebla wyższego od gmin. Formę tę uznaje się za doskonalszą od inkorporacji, jednak również nie wolną od wielu trudności, które dotyczą: podziału zadań i kompetencji, sposobu legitymizacji władz, pochodzenia i redystrybucji środków finansowych czy zasięgu przestrzennego delimitowanego obszaru. Odmienną jakościowo i bardziej elastyczną formą koordynacji zadań publicznych w ramach obszaru metropolitalnego jest kooperacja, która może być realizowana w ścisłych formach prawnych (poprzez związki samorządów terytorialnych lub związki cywilnoprawne, takie jak spółki prawa handlowego) albo nieformalne formy współdziałania metropolitalnego, mające charakter sieci opartych na zasadach partnerstwa i wspólnych interesach (M. E. Sokołowicz, Koordynacja polityki proinwestycyjnej jako wyraz wzmacniania powiqzzań gospodarczych w kształtowaniu spójności Obszaru Metropolitalnego. Studium przypadku ŁOM, [w:] A. Jewtuchowicz, M. Wójcik (red.), Łódzka metropolia. Problemy integracji gospodarczej, Wyd. Biblioteka, Łódź 2010, s. 127, [za:] T. Kaczmarek, Ł. Mikuła, Ustroje terytorialno-administracyjne obszarów metropolitalnych w Europie, Bogucki Wyd. Naukowe, Poznań 2007, s. 29-32). Analiza efektywności poszczególnych złożonych form koordynacyjnych może przy tym wprost nawiązywać do założeń teorii wyboru publicznego (por. M. Lackowska, Zarządzanie obszarami metropolitalnymi w Polsce. Między dobrowolnościq a imperatywem, Wyd. Uniwersytetu Warszawskiego, Warszawa 2009, s. 53-62). 
szczeblami administracji (organizacja systemu terytorialnej administracji publicznej w warunkach decentralizacji władzy), jak również badaniem korzyści i kosztów decyzji politycznych podejmowanych na szczeblu samorządu terytorialnego. W ostatnim $\mathrm{z}$ wymienionych obszarów lokalny kontekst może dotyczyć ekonomicznych skutków wprowadzania i realizowania aktów planistycznych z obszaru zagospodarowania przestrzennego $0^{54}$.

Wśród nurtów bliskich ekonomii instytucjonalnej warto przywołać wspomnianą już koncepcję zakorzenienia społecznych relacji oraz ekonomikę bliskości ( $w$ powiązaniu $\mathrm{z}$ dorobkiem francuskiej ekonomii konwencji). Ponadto, badania procesów rozwoju lokalnego i regionalnego mogą nawiązywać do ekonomii ewolucyjnej oraz strategicznej szkoły zasobowego myślenia.

Pierwsze trzy wymienione nurty pozwalają na analizę lokalnych czynników historycznych, kulturowych i instytucjonalnych, różnicujących terytorialnie efektywność ekonomiczną. Co więcej, umożliwiają one badanie wpływu bliskości fizycznej na ograniczanie kosztów transakcyjnych, jednak przy mniejszym rygorze metodologicznym niż w przypadku ekonomiki kosztów transakcyjnych. Ekonomia bliskości czy ekonomia konwencji eksponują istotne znaczenie różnorodności metodologicznej i kładą większy nacisk na koncentrację na badaniach pierwotnych i porównawczych, które pozwalają silnie uchwycić specyfikę terytorialną przedmiotu badań. W ramach wskazanych nurtów można zatem prowadzić badania porównawcze nad dynamiką lokalnych systemów produkcyjnych oraz badania zjawiska terytorializacji (zakorzenienia) przedsiębiorstw w ramach tych systemów.

$\mathrm{Na}$ gruncie polskim jedną pierwszych inicjatyw badawczych poświęconych zjawisku terytorializacji było badanie zachowań filii korporacji transnarodowych (KTN) we Wrocławiu ${ }^{55}$. Studia przypadków, przeprowadzone w $1997 \mathrm{r}$. na podstawie 12 wywiadów adresowanych do menadżerów korporacyjnych wyższego szczebla, miały na celu znalezienie odpowiedzi na pytanie, czy strategie filii korporacji transnarodowych są

54 Pierwsze prace w tym kierunku w Polsce dostępne są m.in. w opracowaniach: C. Brzeziński, Ekonomiczne aspekty polityki przestrzennej w Polsce, [w:] A. Nowakowska (red.), Zrozumieć terytorium. Idea i praktyka, Wyd. Uniwersytetu Łódzkiego, Łódź 2013, s. 373-384; A. Kowalewski et al., Raport o ekonomicznych stratach i społecznych kosztach niekontrolowanej urbanizacji w Polsce, Fundacja Rozwoju Demokracji Lokalnej - Instytut Geografii i Przestrzennego Zagospodarowania im. S. Leszczyckiego PAN, Warszawa 2013. Badania prowadzone są również w formie prac aplikacyjnych nad szacowaniem ekonomicznych skutków wprowadzania tzw. miejscowych planów zagospodarowania przestrzennego w wielu miastach i gminach w Polsce.

$55 \mathrm{~J}$. Hardy, Cathedrals in the Desert? Transnationals, Corporate Strategy and Locality in Wroclaw, „Regional Studies” 1998, vol. 32 (7), s. 639-652. 
zorientowane na minimalizację kosztów, na rynek czy na wzrost efektywności. Istotne było też sprecyzowanie, czy działalność przedstawicielstw tych korporacji działających we Wrocławiu była w okresie badania oparta na strategii terytorializacji, czy przeciwnie - przedstawicielstwa te były „katedrami na pustyni”, tj. podmiotami gospodarczymi, które nie budują trwałych relacji z lokalnym otoczeniem ${ }^{56}$.

Do kolejnych realizowanych w Polsce badań, dotykających wprost lub pośrednio problemu terytorializacji dużych przedsiębiorstw ponadnarodowych, zalicza się praca B. Domańskiego ${ }^{57}$. Natomiast na terenie województwa łódzkiego i aglomeracji łódzkiej pierwsze badania poświęcone zjawisku terytorializacji KTN zostały zaprezentowane m.in. w publikacji Kuklińskiego i współpracowników ${ }^{58}$, a w późniejszym okresie M. E. Sokołowicza $^{59}$.

Badanie M. E. Sokołowicza z 2005 r. stanowi pogłębioną analizę zjawiska terytorializacji dużych przedsiębiorstw przemysłowych z udziałem kapitału zagranicznego, dokonaną na terenie aglomeracji łódzkiej w oparciu o standaryzowany wywiad swobodny. W badaniu przeprowadzonym w okresie od lipca do grudnia 2005 r. wzięło udział 12 podmiotów, które zostały umieszczone na liście największych inwestorów zagranicznych,

56 Badania ujawnity, że przedsiębiorstwa charakteryzowały się słabymi powiązaniami z lokalnymi dostawcami, jak również nie przyczyniały się w istotnym stopniu do dyfuzji wiedzy i innowacji w regionie. W rezultacie J. Hardy konkluduje, że bez względu na to, czy KTN realizowały swoje inwestycje we Wrocławiu od podstaw (greenfield), czy też przejmowały istniejące podmioty gospodarcze (brownfield), nie integrowały się one istotnie ani nie przyczyniały do wzmacniania lokalnego środowiska przedsiębiorczości. W rezultacie, z powodu braku procesów terytorializacji trudno było mówić o Wrocławiu jako dynamicznie rozwijającym się terytorium, a miejsce to pozostawało jedynie obszarem, na którym zlokalizowało się więcej niż przeciętnie w kraju bezpośrednich inwestycji zagranicznych (J. Hardy, Cathedrals in the Desert..., s. 650).

57 B. Domański, Kapitał zagraniczny w przemyśle Polski. Prawidłowości rozmieszczenia, uwarunkowania i skutki, Instytut Geografii i Gospodarki Przestrzennej Uniwersytetu Jagielońskiego, Kraków 2001; B. Domański (red.), Dziesięć lat doświadczeń pierwszej polskiej specjalnej strefy ekonomicznej. Mielec 1995-2005, Instytut Geografii i Gospodarki Przestrzennej Uniwersytetu Jagiellońskiego, Agencja Rozwoju Przemysłu SA, Kraków 2005; B. Pavlinek, B. Domański, R. Guzik, Industrial Upgrading through Foreign Direct Investment in Central European Automotive Manufacturing, „European Urban and Regional Studies” 2009, vol. 16 (1), s. 43-63.

58 A. Kukliński et al., Globalizacja polskich metropolii, Euroreg, Warszawa 2000.

59 M. E. Sokołowicz, Region wobec procesów globalizacji - terytorializacja przedsiębiorstw międzynarodowych (na przykładzie regionu tódzkiego), Wyd. Uniwersytetu Łódzkiego, Łódź 2008; idem, Strategie lokalne wobec korporacji transnarodowych jako czynnik integracji lub dezintegracji Łódzkiego Obszaru Metropolitalnego, [w:] A. Jewtuchowicz, M. Wójcik (red.), Łódzka metropolia..., s. 109-124. 
opublikowanej w grudniu 2004 r. przez Polską Agencję Informacji i Inwestycji Zagranicznych ${ }^{60}$. Badanie ujawniło, iż większość przedsiębiorstw traktowała aglomerację łódzką przede wszystkim jako miejsce lokalizacji działalności produkcyjnej i nie wykazywała skłonności do realizacji np. proinnowacyjnych przedsięwzięć, co ograniczało transfer technologii do regionu $^{61}$. Wśród dominujących czynników lokalizacji działalności gospodarczej wskazywano przy tym czynniki „nieuwiązane” lokalizacyjnie, tj. takie, które można uzyskać także w innych polskich regionach (niskie koszty siły roboczej, ceny nieruchomości, dostępność komunikacyjna, relatywnie niskie obciążenia podatkowe) ${ }^{62}$.

Do podobnych wniosków doprowadziło kolejne badanie, zrealizowane przez autora w okresie od listopada 2009 r. do stycznia 2010 r. $^{63}$ Obejmowało ono 21 przedsiębiorstw na terenie aglomeracji łódzkiej, z udziałem kapitału zagranicznego, zatrudniających powyżej 50 pracowników. Respondentami byli członkowie zarządów firm (11 przypadków) lub osoby zajmujące inne stanowiska (np. asystent zarządu, główny księgowy, kierownik ds. handlu, rzecznik prasowy) i wskazane przez menadżerów jako kompetentne w zakresie odpowiedzi na zadawane w kwestionariuszu pytania. Warto nadmienić, że wyniki badania zrealizowanego wśród filii KTN działających na terenie aglomeracji łódzkiej zostały porównane $\mathrm{z}$ rezultatami wywiadów prowadzonych równolegle wśród przedstawicieli podmiotów polityki proinwestycyjnej w regionie ${ }^{64}$. Pozwoliło to

60 Na liście tej znalazło się 39 przedsiębiorstw przemysłowych, które do końca 2004 r. zainwestowały w Polsce ponad $1 \mathrm{mln}$ dolarów i były zlokalizowane na terenie aglomeracji tódzkiej (PAIZ, List of Major Foreign Investors in Poland - December 2004, Polska Agencja Informacji i Inwestycji Zagranicznych, Warszawa 2005).

61 M. E. Sokołowicz, Region wobec procesów globalizacji..., s. 118-119.

62 Strategie rozwoju przedsiębiorstw oraz podążające w ślad za nimi sposoby i formy organizacji produkcji silnie warunkowały ich stosunek do zasobów regionu, w tym m.in. relacje z lokalnymi przedsiębiorstwami oraz otoczeniem instytucjonalnym. Wyraża się to chociażby w fakcie, że niewiele badanych przedsiębiorstw deklarowało współpracę z lokalnym sektorem MŚP. Podobnie mały zakres współpracy miał miejsce w przypadku lokalnych jednostek naukowo-badawczych. Obserwacje te doprowadziły do wniosku, że na ówczesnym etapie rozwoju aglomeracji łódzkiej procesy terytorializacji przedsiębiorstw nie miały miejsca.

63 Badanie stanowiło cześć przedsięwzięcia badawczego „Procesy integracji i dezintegracji w Łódzkim Obszarze Metropolitalnym”, finansowanego ze środków Ministerstwa Nauki i Szkolnictwa Wyższego w ramach grantu nr N N114 051335 (pod kierownictwem prof. dr hab. A. Jewtuchowicz), którego autor pozostawał współwykonawcą.

64 Wywiady zrealizowano w oparciu o dobór celowy w gminach realizujących najbardziej aktywną politykę przyciągania inwestorów, tj. w Łodzi, Strykowie, Ozorkowie, Aleksandrowie Łódzkim, Pabianicach, Konstantynowie Łódzkim i Koluszkach. Ponadto, wywiady przeprowadzono z pracownikami średniego lub 
na ocenę zarówno strategii KTN wobec terytorium, jak i polityki wobec inwestorów ${ }^{65}$.

Przegląd dorobku badawczego poświęconego zjawisku terytorializacji można skonkludować spostrzeżeniem, że inicjatywy podejmowane $\mathrm{w}$ tym obszarze nauki pozostają z jednej strony rzadkie, a z drugiej opierają się na zróżnicowanych podejściach metodologicznych ${ }^{66}$. Stąd przegląd poszczególnych badań oraz porównywanie podejść badawczych powinno się traktować jako punkt wyjścia do dyskusji na temat wypracowania sposobów zapewnienia porównywalności ich wyników w przyszłości. Nie ulega jednak wątpliwości, że wykorzystanie koncepcji nawiązujących do instytucjonalizmu - takich jak ekonomia konwencji, a szczególnie ekonomia bliskości - pozwala na postęp w tej dziedzinie badań.

Ostatnie dwa analizowane nurty z gruntu nauk ekonomicznych i nauk o zarządzaniu - szkoła ewolucyjna i zasobowa - mogą być traktowane jako pomocnicze przy formułowaniu koncepcji badawczych wybranych procesów rozwoju terytorialnego. W przypadku podejścia ewolucyjnego największy wkład posiada opisana już koncepcja trajektorii rozwojowych (path dependency). Wkład dorobku ewolucjonistów umożliwia ponadto m.in. analizę strategii marketingowych pod kątem identyfikacji w nich specyficzności jednostek terytorialnych bądź wykorzystywania i testowania w praktyce złożonych metod oceny efektywności działań podejmowanych w samorządach terytorialnych (np. w przypadku inwestycji

wyższego szczebla administracji w Regionalnym Centrum Obsługi Inwestora Województwa Łódzkiego oraz w Łódzkiej Specjalnej Strefie Ekonomicznej.

65 W opinii badanych przedsiębiorstw, podobnie jak pięć lat wcześniej, w stosunku do aglomeracji łódzkiej zdecydowanie dominowały kosztowe czynniki lokalizacji (relatywnie niskie koszty pracy, niskie ceny nieruchomości, lokalizacja regionu w centrum Polski minimalizująca koszty transportu, ulgi podatkowe). Słabo ocenianie były natomiast czynniki efektywnościowe, decydujące o potencjale innowacyjnym gospodarki regionu ( $n$. potencjat instytucji sektora $B+R$, kompetencje lokalnych przedsiębiorców skłaniające do budowania silnych powiązań kooperacyjnych itp.). Inwestorzy pozytywnie oceniali poziom wykształcenia lokalnych pracowników, natomiast oferta badawczo-rozwojowa regionu wciąż nie była przedmiotem istotnego zainteresowania przedstawicielstw korporacji. Oznacza to, iż wśród przewag konkurencyjnych aglomeracji łódzkiej w dalszym ciągu dominowały przewagi kosztowe na niekorzyść regionalnego potencjału badawczo-rozwojowego. Badanie ujawniło ponadto wciąż relatywnie niski poziom terytorializacji przedsiębiorstw (M. E. Sokołowicz, Strategie lokalne...).

66 Przykładowy przegląd badań nad terytorializacją filii i przedstawicielstw korporacji transnarodowych dostępny jest w opracowaniu: M. E. Sokołowicz, Terytorializacja korporacji transnarodowych w gospodarce globalnej - przegląd dorobku teoretycznego i badawczego, „Acta Universitatis Lodziensis. Folia Oeconomica” 2012, nr 275. 
jednostek terytorialnych - analiza kosztów i korzyści, analiza due diligence). Wobec polityki miejskiej interesujący wkład podejścia dynamicznego (ewolucyjnego) może być zastosowany w odniesieniu do analizy porównawczej modeli zarządzania jednostkami terytorialnymi (np. modeli tzw. urban governance). Ostatnie z pojęć, tłumaczone w polskiej literaturze jako „współrządzenie”, nie jest przy tym synonimem „zarządzania", bowiem idea zarządzania wiąże się z oficjalną władzą, wyposażoną w środki przymusu, lecz dotyczy działalności wynikających ze wspólnych celów. Cele te mogą wpisać się - albo nie - w legalne i formalne mechanizmy odpowiedzialności, jednak nie wymagają koniecznie oficjalnych środków przymusu, by przełamać nieufność i stosować przyjęte normy. Tym samym governance cechuje przede wszystkim pośredniość form regulacji („między hierarchią a rynkiem”), struktur własnościowych („między prywatnym a publicznym”) i poziomu formalizacji („między wysokim poziomem formalizacji a prawem niepisanym" ${ }^{67}$. W tym kontekście modele urban governance odwołują się do analizy pośrednich rozwiązań instytucjonalnych (między instytucjami formalnymi i nieformalnymi), zaś dorobek ekonomii ewolucyjnej może te analizy wspomagać poprzez eksponowanie dynamiki (zmienności) instytucji ${ }^{68}$.

Podejście ewolucyjne - w szczególności koncepcja trajektorii rozwojowych - wykorzystywane jest coraz powszechniej w aplikacyjnych opracowaniach naukowych na temat kierunków rozwoju regionów, w postaci

67 A. Jewtuchowicz, Terytorium i jego rozwój w warunkach globalizacji, [w:] E. Molendowski (red.), Globalizacja i regionalizacja we współczesnym świecie. Księga jubileuszowa dedykowana Profesor Irenie Pietrzyk, Wyd. Uniwersytetu Ekonomicznego w Krakowie, Kraków 2012, s. 31.

68 Miejskie współrządzenie (urban governance) może być zdefiniowane jako wypadkowa różnorodnych sposobów, wykorzystywanych przez funkcjonujące w mieście osoby oraz prywatne i publiczne organizacje do planowania i realizowania celów jego rozwoju. Jest to zatem ciągły proces, w wyniku którego różnorodne (często przeciwstawne) aspiracje poszczególnych grup interesariuszy są przeformułowywane w kierunku wyboru wspólnych celów, umożliwiających skoordynowane podejmowanie działań (UN-HABITAT, 2013, Global Campaign on Urban Governance. Global Urban Observatory; http://www.unhabitat.org/governance, dostęp: 07.10.2014). Instytucjonalne modele urban governance zaproponowali m.in. Jon Pierre oraz Alan DiGaetano i Elizabeth Strom (J. Pierre, Models of Urban Governance. The Institutional Dimension of Urban Politics, „Urban Affairs Review” 1999, vol. 34, s. 372-396; A. DiGaetano, E. Strom, Comparative Urban Governance. An Integrated Approach, „Urban Affairs Review” 2003, vol. 38, no. 3, s. 356-395). W polskiej literaturze przegląd tych modeli prezentuje również autor (M. E. Sokołowicz, Instytucjonalne modele urban governance jako próba odpowiedzi na współczesne wyzwania rozwojowe miast, [w:] W. M. Gaczek (red.), Dynamika, cele i polityka zintegrowanego rozwoju regionów. Aspekty teoretyczne i zarządzanie w przestrzeni, Bogucki Wyd. Naukowe, Poznań 2013, s. 147-161. 
tzw. studiów foresightignowych. Stanowią one zestaw różnych narzędzi badawczych służących do przewidywania trendów rozwojowych w długim okresie ${ }^{69}$. Innymi słowy, foresight to systematyczna metoda oceny przyszłych trendów zmian i możliwości techniczno-technologicznych, wynikających z najnowszych odkryć naukowych, które mogą mieć silny wpływ na społeczeństwo i jego przyszły rozwój. Foresight jest również określany mianem dialogu mającego na celu identyfikację technologii, które mogą mieć znaczenie gospodarcze lub/i społeczne ${ }^{70}$. Ze względu na swoją istotę foresight regionalny z natury rzeczy odwołuje się do podejścia ewolucyjnego, uwzględniając analizę wpływu historii rozwoju jednostek terytorialnych na ich obecną pozycję konkurencyjną.

Natomiast w odniesieniu do zasobowej szkoły strategicznego myślenia kluczowe w studiach nad rozwojem lokalnym i regionalnym są badania ukierunkowane na poszukiwanie specyficznych terytorialnie przewag własnościowych. W ujęciu praktycznym przewagi te stanowią przedmiot formułowania strategii marketingowych miast i regionów. Jeśli chodzi o podejścia bardziej zaawansowane z punktu widzenia zastosowania metodologii naukowej, można wskazać m.in. identyfikację tzw. inteligentnych specjalizacji regionalnych oraz benchmarking jednostek terytorialnych.

Pierwsze $\mathrm{z}$ wymienionych wyżej pojęć wyłoniło się $\mathrm{w}$ pierwszej dekadzie XXI w. jako odpowiedź na nieefektywność dotychczasowych instrumentów polityki regionalnej i przemysłowej w zakresie innowacyjności. Stanowi ono połączenie podejścia sektorowego (bazującego na identyfikacji i wspieraniu kluczowych sektorów gospodarki oraz domen technologicznych o silnym potencjale wzrostu) i perspektywy terytorialnej (opartej na poszukiwaniu przewag konkurencyjnych wyróżniających konkretne regiony). Tym samym kładzie nacisk na dostosowanie polityki w zakresie rozwoju innowacyjności do rzeczywistych możliwości jednostek terytorialnych, jak również podkreśla konieczność ciągłego monitorowania trafności podejmowanych w jej ramach decyzji oraz nieustannego poszukiwania nowych domen specjalizacyjnych ${ }^{71}$. W swojej istocie koncepcja ta odwołuje się do modelu elastycznej specjalizacji ${ }^{72}$.

69 Practical Guide to Regional Foresight, FOREN Network (Foresight for Regional Development), European Commission Research Directorate General, STRATA Programme, December 2001.

70 B. Piasecki, Pierwsze kroki w foresight, [w:] idem, Regionalna strategia innowacji - foresight regionalny, Społeczna Wyższa Szkoła Przedsiębiorczości i Zarządzania, Łódź 2004, s. 9.

71 Por. D. Foray, P. A. David, B. Hall, Smart Specialization: The Concept, „Knowledge Economists Policy Brief” 2009, no. 9; http://ec.europa.eu/invest-in-research/pdf/ download_en/kfg_policy_brief_no9.pdf (dostęp: 7.10.2014).

72 M. Piore, C. Sabel, The Second Industrial Divide, Basic Books, New York 1984. 
Drugie pojęcie odnosi się natomiast do procesu ciągłego pomiaru produktów, usług i procedur w odniesieniu do najsilniejszych konkurentów lub tych organizacji, które uważane są za liderów w danej dziedzinie działalności ${ }^{73}$. Innymi słowy, benchmarking obejmuje szereg metod i technik służących do identyfikacji liderów w celu określenia ich pozycji w stosunku do innych organizacji, jak też wypracowania sposobów „dogonienia” tych liderów, poprzez kreatywne zastosowanie podobnych procedur oraz wypracowanie podobnych efektów działalności. Z metodologicznego punktu widzenia każdy benchmarking to heurystyczna metoda badania, w której wykorzystuje się złożone kombinacje podejść ilościowych i jakościowych. Ponadto, każdy benchmarking podkreśla potrzeby analizy zarówno procesów i wyników pojedynczej organizacji (perspektywa wewnętrzna), jak i jej otoczenia (perspektywa zewnętrzna). Od klasycznej analizy porównawczej różni się on tym, że nie poprzestaje na samym określeniu pozycji organizacji $\mathrm{w}$ stosunku do organizacji najlepszych w danej dziedzinie, lecz proponuje też sposób wdrożenia rozwiązań pozwalających poprawić jej pozycję w stosunku do liderów.

Pierwotnie stosowany w odniesieniu do przedsiębiorstw, obecnie benchmarking jest wykorzystywany również do oceny działań niekomercyjnych, takich jak analiza pozycji konkurencyjnej miast i regionów, parków naukowo-technologicznych, a także portów lotniczych i morskich, uczelni wyższych, dostawców energii, organizacji opieki zdrowotnej (np. szpitali) ${ }^{74}$.

73 A. P. Sage, W. B. Rouse (eds.), Handbook of Systems Engineering and Management, John Wiley and Sons, Hoboken 1999, s. 341.

74 Efekty wybranych badań o charakterze benchmarkingu, odnoszących się do badań procesów rozwoju lokalnego i regionalnego, dostępne są m.in. w opracowaniach: P. Rondo-Brovetto, I. Saliterer, Comparing Regions, Cities, and Communities: Local Government Benchmarking as an Instrument for Improving Performance and Competitiveness, „The Innovation Journal: The Public Sector Innovation Journal” 2007, vol. 12, no. 3, artykut 13; J. Hołub-Iwan, A. Olczak, K. Cheba, Benchmarking parków technologicznych w Polsce. Edycja 2012, Polska Agencja Rozwoju Przedsiębiorczości, Warszawa 2012; J. Wożnicki, Benchmarking w systemie szkolnictwa wyższego, Fundacja Rektorów Polskich, Warszawa 2008; http://www.frp.org.pl/publikacje/ FRPBench.pdf (dostęp: 7.10.2014); Energetyka cieplna w liczbach 2009, Polski Urząd Regulacji Energetyki, Warszawa 2010; B. Ziębicki, Benchmarking w doskonaleniu organizacji usług użyteczności publicznej, Wyd. Akademii Ekonomicznej w Krakowie, Kraków 2007 oraz w wybranych publikacjach badań benchmarkingu klastrów z udziałem autora: PARP, Benchmarking klastrów w Polsce - 2010, Polska Agencja Rozwoju Przedsiębiorczości, Warszawa 2010; http://www.pi.gov.pl/PARPFiles/file/ klastry/Benchmarking_klastrow/Benchmarking_klastrow_w_Polsce_2010.pdf (dostęp: 7.10.2014); Th. Lämmer-Gamp, G. Meier zu Köcker, Th. A. Christensen, Clusters Are Individuals. Creating Economic Growth through Cluster Policies for Cluster Management Excellence, Danish Ministry of Science, Technology and Innovation/Competence Networks Germany, Copenhagen-Berlin 2011. 
Przegląd możliwości zastosowań dorobku poszczególnych nurtów ekonomii instytucjonalnej ujawnia bogactwo możliwych kierunków rozwoju badań nad procesami rozwoju terytorialnego w przyszłości. Jednocześnie uwidacznia, że nie tylko różne typy procesów będących przedmiotem badań wymagają odmiennych podejść instytucjonalnych, lecz także poszczególne przedsięwzięcia badawcze mogą czerpać z kilku różnych koncepcji jednocześnie. Skłania to do sformułowania tezy, iż osobne teorie i koncepcje „instytucjonalne” mogą być interpretowane nie jako stojące w stosunku do siebie w sprzeczności, ale jako komplementarne podejścia badawcze.

Analiza dotychczasowego dorobku badań nad procesami rozwoju lokalnego i regionalnego prowadzi do wniosku, że z jednej strony każdy sposób pomiaru pokazuje inne zjawisko o charakterze instytucjonalnym, jednak z drugiej - różne sposoby stosowane do analizy instytucji są między sobą silnie skorelowane ${ }^{75}$. Co więcej, podkreśla się coraz częściej, że większość współcześnie stosowanych sposobów pomiaru określa nie tyle instytucje per se, ile efekty działania instytucji ${ }^{76}$. Zjawisko to dotyka na równi badań nad instytucjami poziomu krajowego, jak i badań nad rolą instytucji w procesach rozwoju lokalnego i regionalnego.

\section{Ujęcie instytucjonalne w dotychczasowych badaniach nad rozwojem terytorialnym}

W ostatnich latach można zaobserwować rosnącą liczbę badań o charakterze ilościowym, w których da się wyróżnić elementy składające się na kontekst instytucjonalny uwarunkowań rozwoju społeczno-gospodarczego. Znajdują się one w początkowej fazie rozwoju, dotyczą przede wszystkim kontekstu instytucji formalnych oraz napotykają na szereg utrudnień ich aplikacji na poziomie niższym niż poziom gospodarki narodowej ${ }^{77}$. Badania poziomu lokalnego i regionalnego mają na-

75 Zob. Ch. Woodruff, Measuring Institutions..., s. 105-124.

76 E. L. Glaeser et al., Do Institutions Cause Growth?, „Journal of Economic Growth” 2004, vol. 9, no. 3.

77 Badania skupiające się na pomiarze instytucji na poziomie krajowym mają przy tym dalece bardziej zaawansowany charakter niż badania nad instytucjami poziomu lokalnego i regionalnego. Do najbardziej rozpoznawalnych badań należą - poza wskaźnikiem rozwoju społecznego - m.in.: Globalny Indeks Konkurencyjności Światowego Forum Gospodarczego (GCl - Global Competitiveness Index), indeks wolności państw, opracowywany przez fundację Freedom House, Wskaź- 
tomiast wciąż charakter fragmentaryczny lub w niskim stopniu dowołują się lokalnego czy regionalnego poziomu analiz. Niemniej jednak, w opracowaniach naukowych coraz częściej można napotkać wyniki badań dotyczących mniejszych niż państwo jednostek terytorialnych.

Za interesujące przedsięwzięcie badawcze tego rodzaju należy uznać próbę dostosowania badań nad wskaźnikiem rozwoju społecznego (Human Development Index - HDI) ${ }^{78}$ do poziomu regionalnego i lokalnego. Tak zwany lokalny wskaźnik rozwoju społecznego (Local Human Development Index - LHDI) nie posiada obecnie charakteru ogólnoświatowego i realizowany jest jedynie w kilku krajach, w tym m.in. w Polsce ${ }^{79}$. Odwołując się do specyfiki konstruowania wskaźnika HDI na poziomie krajowym, można powiedzieć, że wskaźnik LHDI także opiera się na konstrukcji złożonego miernika rozwoju, choć wykorzystuje nieco odmienne dane, tj.:

1) w obszarze zdrowia - przeciętne trwanie życia noworodka oraz zagregowany współczynnik zgonów z powodu nowotworów i chorób układu krążenia,

nik Wolności Gospodarczej (Index of Economic Freedom - IEF), publikowany w corocznym raporcie przygotowywanym wspólnie przez Heritage Foundation we wspótpracy $z$ „The Wall Street Journal”, projekt Polity realizowany przez Centrum na rzecz Pokoju Systemowego (Center for Systemic Peace) czy Światowe Wskaźniki Jakości Rządzenia Banku Światowego (WGI - Worldwide Governance Indicators). Uwzględniają one takie uwarunkowania instytucjonalne, jak: relacje między władzą wykonawczą, ustawodawczą i sądowniczą w państwie, poziom przestrzegania praw i wolności obywatelskich, polityka handlu międzynarodowego, regulacje dla przepływów kapitałowych, zakres interwencji państwa w gospodarkę, stopień ochrony praw własności, zakres szarej strefy. Sposobem na pośredni pomiar uwarunkowań rozwoju gospodarczego jest również określanie poziomu ryzyka inwestycyjnego, którego wielkość zależy w znacznej mierze od stabilności otoczenia instytucjonalnego. Do najważniejszych międzynarodowych badań ryzyka należą International Country Risk Guide (ICRG) oraz Business Environmental Risk Intelligence (BERI). Przegląd tego typu badań w polskiej literaturze przedmiotu dostępny jest m.in. w: J. Wilkin (red.), Jakość rządzenia w Polsce. Jak ja badać, monitorować i poprawiać?, Wyd. Naukowe Scholar, Warszawa 2012; E. Wojciechowski, A. Podgórniak-Krzykacz, Pomiar jakości rzq̨dzenia, „Gospodarka Narodowa" 2008, nr 3, s. 19-38.

78 Wskaźnik ten stosowany jest on od 1993 r. przez agendę ONZ ds. rozwoju (United Nations Development Programme - UNDP) i stanowi bodaj najpopularniejsze uzupełnienie miernika wzrostu gospodarczego, jakim jest produkt krajowy brutto. Stanowi on syntetyczny miernik, którego składowe bazują na takich wskaźnikach, jak: 1) oczekiwana długość życia; 2) średnia liczba lat edukacji otrzymanej przez mieszkańców w wieku 25 lat i starszych; 3) oczekiwana liczba lat edukacji dla dzieci rozpoczynających proces kształcenia; 4) dochód narodowy per capita w dolarach amerykańskich, liczony według parytetu sity nabywczej.

79 Por. UNDP, Krajowy Raport o Rozwoju Społecznym Polska 2012. Rozwój regionalny i lokalny, Biuro Projektowe UNDP w Polsce, Warszawa 2012. 
2) w obszarze jakości edukacji - odsetek dzieci w wieku 3-4 lat uczestniczących w edukacji przedszkolnej oraz wskaźnik wyników części matematyczno-przyrodniczej egzaminu gimnazjalnego ${ }^{80}$,

3) w obszarze zamożności - suma przeciętnych wynagrodzeń z tytułu pracy i innych świadczeń ${ }^{81}$.

Ponadto, w ramach LHDI w Polsce podjęto próbę pomiaru efektów polityki rozwoju poprzez zaproponowanie następujących elementów składowych wskaźnika ${ }^{82}$ :

1) wskaźnik polityki zdrowotnej - uwzględniający liczbę lekarzy i dentystów według podstawowego miejsca pracy na 100000 mieszkańców oraz liczbę pielęgniarek i położnych podstawowej opieki zdrowotnej według podstawowego miejsca pracy na 100000 mieszkańców,

2) wskaźnik polityki edukacyjnej - uwzględniający wydatki na edukację w przeliczeniu na jednego ucznia ogółem (przedszkola, szkoły podstawowe, gimnazjalne i średnie), jak również liczbę uczniów przypadających na jednego nauczyciela w szkołach podstawowych i gimnazjach,

3) wskaźnik wydatków budżetowych - stanowiący sumę wydatków budżetów gmin i powiatów na terenie danego powiatu oraz pozycji budżetowych sfinansowanych ze środków UE, podzieloną przez liczbę mieszkańców.

Powyższa metodyka została zastosowana w odniesieniu do polskich jednostek terytorialnych szczebla lokalnego i regionalnego ${ }^{83}$, ujawniając

80 Wskaźniki te - z uwagi na brak danych na poziomie lokalnym - zastępują „oryginalne" wskaźniki HDI w obszarze edukacji, tj. spodziewaną długość lat kontynuowania edukacji przez rozpoczynające ją dzieci oraz średnią liczbę lat skolaryzacji.

81 Inaczej niż w przypadku HDI, zamożność kalkulowana jest nie poprzez PKB per capita, lecz jako suma przychodów z tytułu: pracy, emerytury, świadczeń pomocy społecznej i rodzinnych. Zastosowanie takiego podejścia stanowiło odpowiedź na brak dostępności danych na temat PKB na poziomie lokalnym, jak również na postulat bardziej precyzyjnego pomiaru dochodów mieszkańców, postulowanych w raporcie J. E. Stiglitza i inwspółpracowników (J. E. Stiglitz, A. Sen, J.-P. Fitoussi, Report by the Commission on the Measurement of Economic Performance and Social Progress, http://www. stiglitz-sen-fitoussi.fr/documents/rapport_anglais.pdf, dostęp: 19.07.2014).

82 United Nations Development Programme, National Human Development Report Poland, 2012. Regional and Local Development, UNDP Project Office in Poland, Warsaw 2012, s. 45-50.

83 Według europejskiej klasyfikacji jednostek terytorialnych do celów statystycznych (NUTS), który w Polsce obejmuje odpowiednio poziomy: NUTS 1 (regiony statystyczne), NUTS 2 (województwa), NUTS 3 (podregiony statystyczne) oraz LAU 1 (powiaty), LAU 2 (gminy), wskaźnik LHDI dla Polski szacowano odpowiednio dla jednostek terytorialnych NUTS 2 oraz LAU 1, odpowiadających polskim samorządom wojewódzkim i powiatowym (UNDP, Krajowy Raport o Rozwoju Społecznym..., s. 33). 
znaczące nierówności terytorialne (rys. 22). Przykładowo, na poziomie polskich województw dostrzega się istotną różnicę w wartości wskaźnika LHDI dla mazowieckiego (wartość 60,21 dla danych z roku 2010) i kolejnych województw. Najniższe wartości (niemal o połowę niższe niż mazowieckie) zaobserwowano w lubelskim, łódzkim i świętokrzyskim (wartości dla 2010 r. odpowiednio 39,55, 39,28 oraz 36,78).

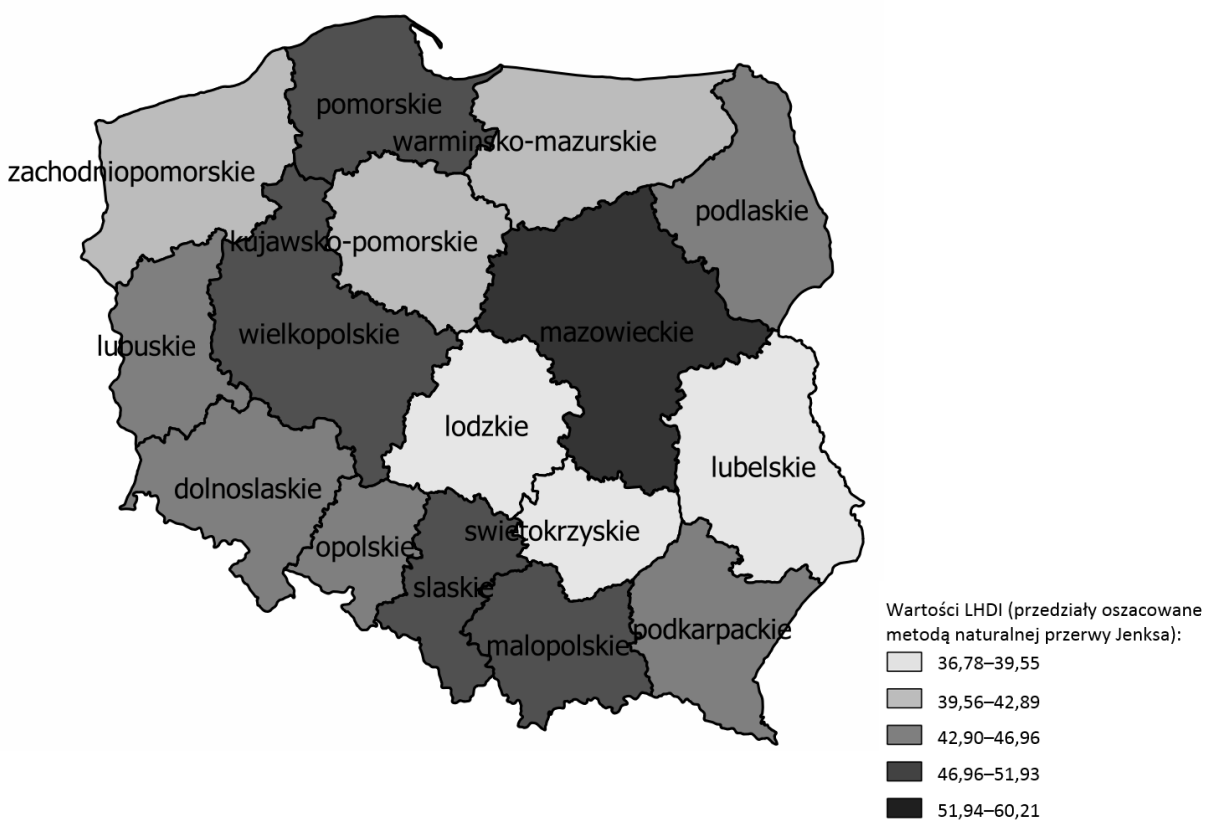

Rys. 22. Wartości lokalnego wskaźnika rozwoju społecznego (LHDI) w Polsce w roku 2010

Źródło: opracowanie własne na podstawie danych z: United Nations Development Programme, National Human Development Report Poland, 2012. Regional and Local Development, UNDP Project Office in Poland, Warsaw 2012, s. 14-15.

Na poziomie powiatów i miast na prawach powiatu różnice w poziomie LHDI okazały się istotnie wyższe (tab. 24). Przykładowo, wskaźnik dla Warszawy osiągnął wartość 87,63 i był 2,3 razy wyższy niż dla Torunia $(37,7)$. Należy nadmienić, że choć o różnicy w poziomie wskaźnika decydują wszystkie jego składowe, to w tym przypadku najsilniej wpłynęły różnice przestrzenne $\mathrm{w}$ wartościach dotyczących osiągnięć edukacyjnych uczniów oraz poziomu zdrowia ${ }^{84}$.

84 Szczegółowe dane dostępne są w opracowaniach: UNDP, Krajowy Raport o Rozwoju Społecznym... oraz United Nations Development Programme, National Human Development Report... 
Tabela 24. Zróżnicowania przestrzenne w rozwoju społeczno-gospodarczym według wskaźnika LHDI (2010 r.)

\begin{tabular}{|c|c|c|c|c|c|c|}
\hline Jednostka terytorialna & Ranking & $\begin{array}{c}\text { Zmiana } \\
\text { w latach } \\
2007-2010\end{array}$ & Ogółem & Zdrowie & Edukacja & $\begin{array}{c}\text { Zamoż- } \\
\text { ność }\end{array}$ \\
\hline \multicolumn{7}{|c|}{ Województwa } \\
\hline Mazowieckie & 1 & 0 & 60,21 & 58,18 & 61,68 & 60,84 \\
\hline Małopolskie & 2 & 0 & 51,93 & 69,10 & 57,65 & 35,15 \\
\hline Pomorskie & 3 & 0 & 51,14 & 71,28 & 47,16 & 39,79 \\
\hline Wielkopolskie & 4 & 0 & 50,22 & 63,32 & 50,19 & 39,86 \\
\hline Śląskie & 5 & 0 & 49,54 & 48,39 & 53,92 & 46,59 \\
\hline Opolskie & 6 & 0 & 46,95 & 59,76 & 55,94 & 30,96 \\
\hline Dolnośląskie & 7 & 0 & 46,34 & 47,61 & 48,79 & 42,84 \\
\hline Podlaskie & 8 & 1 & 44,40 & 66,08 & 51,60 & 25,67 \\
\hline Lubuskie & 9 & 2 & 44,36 & 54,72 & 47,21 & 33,79 \\
\hline Podkarpackie & 10 & 0 & 43,77 & 72,28 & 48,15 & 24,09 \\
\hline Zachodniopomorskie & 11 & -3 & 42,89 & 52,31 & 42,51 & 35,48 \\
\hline Warmińsko-mazurskie & 12 & 0 & 42,33 & 58,61 & 41,85 & 30,93 \\
\hline Kujawsko-pomorskie & 13 & 0 & 41,22 & 49,17 & 42,31 & 33,67 \\
\hline Lubelskie & 14 & 1 & 39,55 & 48,61 & 46,46 & 27,40 \\
\hline Łódzkie & 15 & 1 & 39,28 & 31,48 & 52,25 & 36,85 \\
\hline Świętokrzyskie & 16 & -2 & 36,78 & 45,95 & 39,18 & 27,62 \\
\hline \multicolumn{7}{|c|}{ Miasta } \\
\hline Warszawa & 1 & 0 & 87,63 & 68,97 & 97,75 & 99,83 \\
\hline Kraków & 5 & -1 & 72,05 & 69,00 & 88,47 & 61,27 \\
\hline Wrocław & 14 & -4 & 66,53 & 56,94 & 82,43 & 62,74 \\
\hline Szczecin & 47 & -13 & 56,30 & 55,13 & 69,53 & 46,56 \\
\hline Łódź & 115 & 201 & 44,96 & 25,17 & 70,90 & 50,92 \\
\hline Toruń & 201 & 17 & 37,70 & 61,40 & 29,35 & 29,74 \\
\hline
\end{tabular}

Źródło: United Nations Development Programme, National Human Development Report Poland, 2012. Regional and local development, UNDP Project Office in Poland, Warsaw 2012, s. 14-15.

Wśród najistotniejszych wniosków ogólnych płynących z analiz przestrzennego zróżnicowania wskaźnika LHDI w Polsce można odnotować, że najwyższy poziom rozwoju notowany jest w dużych aglomeracjach miejskich o potencjale metropolitalnym, natomiast najniższy - na 
obszarach wiejskich. Może to stanowić potwierdzenie tezy o istotnym oddziaływaniu wybranych czynników instytucjonalnych na siłę korzyści aglomeracji decydujących o koncentracji przestrzennej procesów społeczno-gospodarczych ${ }^{85}$.

Badanie LHDI wspiera ponadto charakterystyczne dla pierwszych nurtów instytucjonalnych tezy, iż poziom rozwoju gospodarczego nie jest warunkowany jedynie czynnikami mikro- i makroekonomicznymi, lecz także takimi terytorialnie zróżnicowanymi elementami, takimi jak poziom kapitału ludzkiego oraz jakość systemu edukacyjnego i opieki zdrowotnej. W przypadku Polski ujawnia też, że negatywne zmiany demograficzne związane ze starzeniem się społeczeństwa wykazują istotne różnice terytorialne i stanowią wyzwanie dla obszarów wiejskich oraz terenów wschodniej Polski, zaś są mniej istotne w większości wielkich miast.

Najbardziej złożonym przedsięwzięciem badawczym, uwzględniającym głównie kontekst instytucjonalny konkurencyjności regionalnej, jest szacowany na potrzeby Unii Europejskiej tzw. wskaźnik konkurencyjności regionalnej, opracowany jako wspólna inicjatywa Komisji Europejskiej i Europejskiego Centrum Badawczego. Regionalny indeks konkurencyjności w istotnym stopniu bazuje na metodyce pomiaru tzw. Globalnego Indeksu Konkurencyjności, opracowanego przez Światowe Forum Gospodarcze (GCI - Global Competitiveness Index), jednak został on dostosowany do możliwości pomiaru wskaźników na poziomie jednostek terytorialnych, które w europejskiej klasyfikacji dla celów statystycznych stanowią poziom NUTS 2.

Odwołując się do powszechnej definicji konkurencyjności regionów, zakładającej złożoność i różnorodność czynników ją warunkujących, wskaźnik konkurencyjności regionalnej bazuje na danych ilościowych dostępnych w publicznych statystykach państw członkowskich UE (Eurostat), a także na danych pochodzących z badań Światowego Forum Gospodarczego, Banku Światowego, OECD i europejskiego obserwatorium polityki wspierania klastrów (The European Cluster Observatory). Do tej pory zrealizowano dwie edycje badań, których wyniki opublikowano w latach 2010 i 2013.

Istotą konstrukcji wskaźnika jest jego złożoność. W jego skład wchodzą bowiem zmienne agregowane w tzw. grupy: 1) grupa czynników

85 Ponadto, autorzy raportu LHDI podkreślają, że różnice w poziomie wskaźników odzwierciedlają dawny XIX-wieczny podział kraju pomiędzy ościenne mocarstwa. Najlepiej rozwinięte jednostki terytorialne zlokalizowane są w zachodniej części kraju, natomiast najsłabiej - w Polsce wschodniej. Pozwala to odwoływać się do założeń o istotnej roli czynników historycznych w procesach gospodarczych i do koncepcji trajektorii rozwojowych (United Nations Development Programme, National Human Development Report..., s. 12-13). 
podstawowych - tzw. baza konkurencyjności; 2) grupa czynników efektywnościowych oraz 3) grupa czynników związanych z innowacyjnością gospodarki. Każda $\mathrm{z}$ grup podzielona dalej została na tzw. filary konkurencyjności (tab. 25). Dane dla każdego filara były analizowane pod względem dostępności i wiarygodności oraz istotności statystycznej (z wykorzystaniem analizy wieloczynnikowej głównych składowych). Zmienne wchodzące w skład wskaźnika były ponadto ważone - odmiennie w zależności od poziomu rozwoju kraju mierzonego PKB per capita. W przypadku krajów o najwyższym poziomie rozwoju wzrastała waga składowych indeksu służących do pomiaru efektywności i innowacyjności, natomiast malała waga podstawowych czynników konkurencyjnościi ${ }^{86}$.

Tabela 25. Czynniki i filary konkurencyjności regionalnej - istota konstrukcji wskaźnika konkurencyjności regionalnej (2013 r.)

\begin{tabular}{|c|c|c|c|}
\hline Grupy & Filary & Przykłady wykorzystywanych zmiennych & $\begin{array}{l}\text { Liczba } \\
\text { użytych } \\
\text { wskaźni- } \\
\text { ków }\end{array}$ \\
\hline 1 & 2 & 3 & 4 \\
\hline $\begin{array}{l}\text { Grupa } \\
\text { czyn- } \\
\text { ników } \\
\text { podsta- } \\
\text { wowych }\end{array}$ & Instytucje & $\begin{array}{l}\text { - indeks percepcji korupcji na poziomie krajowym } \\
\text { i regionalnym, } \\
\text { - wyniki badań Banku Światowego na temat stabilno- } \\
\text { ści politycznej, } \\
\text { - wyniki badań Banku Światowego na temat jakości } \\
\text { funkcjonowania instytucji rządowych i samorządo- } \\
\text { wych, } \\
\text { - wyniki badań Banku Światowego na temat prze- } \\
\text { strzegania przepisów prawa i ich przejrzystości, } \\
\text { - wyniki badania Doing Business, } \\
\text { - wyniki Globalnego Indeksu Konkurencyjności po- } \\
\text { święcone poziomowi ochrony praw własności, } \\
\text { w tym własności intelektualnej, } \\
\text { - wyniki Globalnego Indeksu Konkurencyjności w za- } \\
\text { kresie poziomu przestępczości, strat ponoszonych } \\
\text { przez przedsiębiorstwa z tytułu przestępczości } \\
\text { i przemocy oraz w zakresie skuteczności dziatań } \\
\text { policji }\end{array}$ & 17 \\
\hline
\end{tabular}

86 P. Annoni, L. Dijkstra, EU Regional Competitiveness Index RCI 2013, Publications Office of the European Union, Luxembourg 2013, s. 14. 
Tab. 25 (cd.)

\begin{tabular}{|c|c|c|c|}
\hline 1 & 2 & 3 & 4 \\
\hline \multirow{4}{*}{$\begin{array}{l}\text { Grupa } \\
\text { czynników } \\
\text { podstawo- } \\
\text { wych }\end{array}$} & $\begin{array}{l}\text { Stabil- } \\
\text { ność } \\
\text { makro- } \\
\text { ekono- } \\
\text { miczna* }\end{array}$ & $\begin{array}{l}\text { - wielkość deficytu lub nadwyżki budżetowej w pozio- } \\
\text { mie PKB, } \\
\text { - relacja poziomu oszczędności do PKB, } \\
\text { - stopa inflacji, } \\
\text { - oprocentowanie obligacji rządowych, } \\
\text { - relacja długu publicznego do PKB }\end{array}$ & 5 \\
\hline & $\begin{array}{l}\text { Infra- } \\
\text { struktura }\end{array}$ & $\begin{array}{l}\text { - dostępność autostrad mierzona liczbą ludności zloka- } \\
\text { lizowanej w ich sąsiedztwie i ważona czasem dojazdu } \\
\text { do autostrady, } \\
\text { - dostępność linii kolejowych mierzona liczbą ludności } \\
\text { zlokalizowanej w ich sąsiedztwie i ważona czasem do- } \\
\text { jazdu do linii kolejowej, } \\
\text { - liczba pasażerów w ruchu lotniczym }\end{array}$ & 3 \\
\hline & Zdrowie & $\begin{array}{l}\text { - liczba łóżek w szpitalach na } 100000 \text { mieszkańców, } \\
\text { - liczba śmiertelnych wypadków drogowych na milion } \\
\text { mieszkańców, } \\
\text { - spodziewana długość życia noworodka, } \\
\text { - śmiertelność niemowląt, } \\
\text { - wskaźnik umieralności na choroby nowotworowe } \\
\text { w grupie osób poniżej 65. roku życia, } \\
\text { - wskaźnik umieralności na choroby układu sercowo- } \\
\text {-naczyniowego w grupie osób poniżej 65. roku życia, } \\
\text { - wskaźnik samobójstw w grupie osób poniżej 65. roku } \\
\text { życia }\end{array}$ & 7 \\
\hline & $\begin{array}{l}\text { Edukacja } \\
\text { na po- } \\
\text { ziomie } \\
\text { podsta- } \\
\text { wowym* }\end{array}$ & $\begin{array}{l}\text { - wskaźniki wyników osiąganych przez uczniów szkół } \\
\text { podstawowych w zakresie pisania, matematyki oraz } \\
\text { nauk ścisłych, opracowywanych w wyniku badań OECD } \\
\text { osiągnięć uczniów (PISA) }\end{array}$ & 3 \\
\hline \multirow{2}{*}{$\begin{array}{l}\text { Grupa } \\
\text { czynni- } \\
\text { ków efek- } \\
\text { tywno- } \\
\text { ściowych }\end{array}$} & $\begin{array}{l}\text { Edukacja } \\
\text { na po- } \\
\text { ziomie } \\
\text { wyższym } \\
\text { i uczenie } \\
\text { się przez } \\
\text { całe życie }\end{array}$ & $\begin{array}{l}\text { - udział ludności z wyższym wykształceniem w grupie } \\
\text { 25-64 lata, } \\
\text { - udział osób dorosłych podejmujących naukę w sto- } \\
\text { sunku do ogółu ludności w wieku 25-64 lata, } \\
\text { - liczba osób w wieku 18-24 lata przedwcześnie kończą- } \\
\text { cych edukację, } \\
\text { - udział osób z zapewnionym dostępem do szkoły wyż- } \\
\text { szej w czasie } 60 \text { minut i krótszym w stosunku do ogółu } \\
\text { ludności, } \\
\text { - udział kobiet z wyższym wykształceniem }\end{array}$ & 4 \\
\hline & $\begin{array}{l}\text { Efek- } \\
\text { tywność } \\
\text { rynków } \\
\text { pracy }\end{array}$ & $\begin{array}{l}\text { - wskaźnik zatrudnienia, } \\
\text { - stopa bezrobocia, } \\
\text { - stopa bezrobocia długotrwałego, } \\
\text { - wydajność pracy w przemyśle i usługach, } \\
\text { - udział kobiet w stosunku do ogółu zatrudnionych } \\
\text { i ogółu bezrobotnych, } \\
\text { - udział osób nieuczących się i niepracujących w grupie } \\
\text { 15-24 lata }\end{array}$ & 8 \\
\hline
\end{tabular}




\begin{tabular}{|c|c|c|c|}
\hline 1 & 2 & 3 & 4 \\
\hline $\begin{array}{l}\text { Grupa } \\
\text { czynni- } \\
\text { ków efek- } \\
\text { tywno- } \\
\text { ściowych }\end{array}$ & $\begin{array}{l}\text { Wielkość } \\
\text { rynku }\end{array}$ & $\begin{array}{l}\text { - dochód rozporządzalny na osobę, } \\
\text { - poziom PKB mierzony według parytetu siły nabywczej, } \\
\text { - liczba ludności }\end{array}$ & 3 \\
\hline \multirow{3}{*}{$\begin{array}{l}\text { Grupa } \\
\text { czynni- } \\
\text { ków zwią- } \\
\text { zanych } \\
\text { z innowa- } \\
\text { cyjnością }\end{array}$} & $\begin{array}{l}\text { Społe- } \\
\text { czeństwo } \\
\text { infor- } \\
\text { macyjne } \\
\text { i wraż- } \\
\text { liwość } \\
\text { przedsię- } \\
\text { biorstw } \\
\text { na nowe } \\
\text { technolo- } \\
\text { gie }\end{array}$ & $\begin{array}{l}\text { - udział gospodarstw domowych posiadających dostęp } \\
\text { do Internetu oraz Internetu szerokopasmowego w sto- } \\
\text { sunku do ogółu ludności, } \\
\text { - udział osób, które dokonały zakupu przez Internet } \\
\text { w stosunku do ogółu ludności, } \\
\text { - przedsiębiorstwa posiadające dostęp do Internetu } \\
\text { oraz Internetu szerokopasmowego w stosunku do } \\
\text { ogółu przedsiębiorstw, } \\
\text { - przedsiębiorstwa prowadzące sprzedaż przez Internet } \\
\text { w stosunku do ogółu przedsiębiorstw, } \\
\text { - wyniki Globalnego Indeksu Konkurencyjności w zakre- } \\
\text { sie zakupu przez przedsiębiorstwa nowych technologii } \\
\text { oraz absorpcji istniejących rozwiązań technologicz- } \\
\text { nych }\end{array}$ & $10^{\star *}$ \\
\hline & $\begin{array}{l}\text { Skala } \\
\text { nowocze- } \\
\text { snej dzia- } \\
\text { talności } \\
\text { gospo- } \\
\text { darczej }\end{array}$ & $\begin{array}{l}\text { - liczba przedsiębiorstw działających w sektorach: fi- } \\
\text { nansowym, ubezpieczeniowym, badań i rozwoju oraz } \\
\text { obsługi przedsiębiorstw w stosunku do ogółu przed- } \\
\text { siębiorstw, } \\
\text { - poziom wartości dodanej wypracowanej w przedsię- } \\
\text { biorstwach działających w sektorach: finansowym, } \\
\text { ubezpieczeniowym, badań i rozwoju oraz obsługi } \\
\text { przedsiębiorstw w stosunku do ogółu przedsiębiorstw, } \\
\text { - liczba zatrudnionych w przedsiębiorstwach z udzia- } \\
\text { tem kapitału zagranicznego w stosunku do ogółu za- } \\
\text { trudnionych }\end{array}$ & 3 \\
\hline & $\begin{array}{l}\text { Innowa- } \\
\text { cyjność }\end{array}$ & $\begin{array}{l}\text { - liczba patentów, } \\
\text { - liczba zatrudnionych w tzw. „zawodach kreatywnych” } \\
\text { w stosunku do ogółu zatrudnionych w wieku 15-64 } \\
\text { lata, } \\
\text { - liczba pracowników wiedzy w stosunku do ogółu za- } \\
\text { trudnionych, } \\
\text { - liczba publikacji naukowych, } \\
\text { - udział wydatków na badania i rozwój w stosunku do } \\
\text { PKB, } \\
\text { - liczba zatrudnionych w sektorze B + R w stosunku do } \\
\text { ogółu zatrudnionych }\end{array}$ & 10 \\
\hline
\end{tabular}

* Dane szacowane jedynie na poziomie państw.

** 7 z 10 wskaźników oparto na danych szacowanych jedynie na poziomie państw.

Źródło: P. Annoni, L. Dijkstra, EU Regional Competitiveness Index RCI 2013, Publications Office of the European Union, Luxembourg 2013, s. V i 26-117. 
Należy podkreślić, że elementy instytucjonalne uznane są w przypadku konstrukcji wskaźnika konkurencyjności regionalnej - obok stabilności makroekonomicznej, infrastruktury transportowej, stanu zdrowia i edukacji na poziomie podstawowym - za jeden z podstawowych czynników konkurencyjności. Za kluczowe elementy otoczenia instytucjonalnego autorzy wskaźnika uznali takie czynniki instytucjonalne, jak: poziom korupcji, stabilność systemów politycznych, jakość funkcjonowania instytucji rządowych i samorządowych, poziom przestrzegania przepisów prawa i przejrzystość prawa, skuteczność ochrony praw własności, skuteczność walki z przestępczością. Istotnym elementem filaru „Instytucje” w ramach wskaźnika konkurencyjności regionalnej pozostaje ponadto jakość otoczenia instytucjonalnego dla prowadzenia działalności gospodarczej Doing Business (charakteryzowanego w dalszej części).

Badanie wskaźnika konkurencyjności regionalnej pozwoliło na zidentyfikowanie istotnych zróżnicowań przestrzennych w zakresie czynników decydujących o rozwoju regionów Unii Europejskiej (tab. 26). W roku 2013 do regionów UE uznanych za charakteryzujące się najwyższym poziomem konkurencyjności zaliczono jednostki terytorialne zlokalizowane w krajach najbardziej rozwiniętych (Holandia, Wielka Brytania, Szwecja, Dania, Francja), natomiast najniższe poziomy wskaźnika konkurencyjności zanotowały regiony Grecji, Rumunii i Bułgarii. Należy przy tym zaważyć, iż najwyższy poziom wskaźnika konkurencyjności dotyczy regionów stanowiących aglomeracje o charakterze metropolitalnym, natomiast regiony o najniższym poziomie wskaźnika cechuje przede wszystkim rolniczy charakter i/lub peryferyjne położenie w przestrzeni europejskiej.

Wskaźnik konkurencyjności regionalnej Unii Europejskiej pozwala też na określenie pozycji polskich województw względem pozostałych europejskich jednostek terytorialnych NUTS 2 (tab. 27). Należy podkreślić, że w 2013 r. polskie regiony plasowały się blisko najniższych pozycji w rankingu. Najwyższe miejsce zajęło przy tym województwo mazowieckie (147.), natomiast najniższe - województwo warmińsko-mazurskie (230.). Ujemne wartości wskaźników w przypadku każdego z polskich województw wskazują przy tym, że ich poziomy były niższe niż średnia wartości wskaźnika konkurencyjności regionalnej dla wszystkich jednostek NUTS 2 w Unii Europejskiej. Ponadto, w odniesieniu do Polski można zaobserwować stosunkowo wysoki poziom zróżnicowania wartości wskaźnika, która dla województwa mazowieckiego $(-0,181)$ była niemal pięciokrotnie wyższa niż dla najniżej sytuowanego w rankingu województwa warmińsko-mazurskiego $(-0,871)$. 
Tabela 26. Regiony Unii Europejskiej o najwyższym i najniższym poziomie wskaźnika konkurencyjności regionalnej (2013 r.)

\begin{tabular}{|c|c|c|c|}
\hline Pozycja & Region & Kraj & $\begin{array}{l}\text { Wartość } \\
\text { wskaźnika }\end{array}$ \\
\hline 1. & Utrecht & Holandia & 1,358 \\
\hline 2. & $\begin{array}{l}\text { Bedfordshire and Hertfordshire + Essex + Inner London + } \\
\text { Outer London }\end{array}$ & $\begin{array}{l}\text { Wielka } \\
\text { Brytania }\end{array}$ & 1,192 \\
\hline 3. & Berkshire, Buckinghamshire and Oxfordshire & $\begin{array}{l}\text { Wielka } \\
\text { Brytania }\end{array}$ & 1,174 \\
\hline 4. & Stockholm & Szwecja & 1,149 \\
\hline 5. & Surrey, East and West Sussex & $\begin{array}{l}\text { Wielka } \\
\text { Brytania }\end{array}$ & 1,093 \\
\hline 6. & Flevoland + Noord-Holland & Holandia & 1,078 \\
\hline 7. & Darmstadt & Dania & 1,050 \\
\hline 8. & île de France & Francja & 1,050 \\
\hline 9. & Hovedstaden & Dania & 1,040 \\
\hline 10. & Zuid-Holland & Holandia & 1,006 \\
\hline \multicolumn{4}{|c|}{$\cdots$} \\
\hline 253. & PGRoponnisos & Grecja & $-1,337$ \\
\hline 254. & Sud-Vest Oltenia & Rumunia & $-1,360$ \\
\hline 255. & Centru & Rumunia & $-1,362$ \\
\hline 256. & Anatoliki Makedonia, Thraki & Grecja & $-1,371$ \\
\hline 257. & Notio Aigaio & Grecja & $-1,376$ \\
\hline 258. & Dytiki Makedonia & Bułgaria & $-1,403$ \\
\hline 259. & Yugoiztochen & Butgaria & $-1,403$ \\
\hline 260. & Sterea Grlada & Grecja & $-1,417$ \\
\hline 261. & Sud-Est & Rumunia & $-1,479$ \\
\hline 262. & Severozapaden & Butgaria & $-1,481$ \\
\hline
\end{tabular}

Objaśnienia: dodatnie wartości wskaźników oznaczają, że badana jednostka terytorialna osiągnęła jego wartość wyższą niż średnia dla wszystkich NUTS 2 w Unii Europejskiej, natomiast ujemna wartość wskaźnika oznacza odpowiednio miejsce w rankingu poniżej wartości średniej. 
Tabela 27. Pozycja polskich województw w badaniu wskaźnika konkurencyjności regionalnej (2013 r.)

\begin{tabular}{|c|c|l|c|}
\hline Lp. & Pozycja w rankingu & \multicolumn{1}{|c|}{ Województwo } & Wartość wskaźnika \\
\hline 1. & 147 & Mazowieckie & $-0,180$ \\
\hline 2. & 175 & Śląskie & $-0,406$ \\
\hline 3. & 184 & Małopolskie & $-0,471$ \\
\hline 4. & 190 & Dolnośląskie & $-0,544$ \\
\hline 5. & 194 & Pomorskie & $-0,582$ \\
\hline 6. & 196 & Opolskie & $-0,584$ \\
\hline 7. & 197 & tódzkie & $-0,584$ \\
\hline 8. & 204 & Lubelskie & $-0,666$ \\
\hline 9. & 206 & Lubuskie & $-0,704$ \\
\hline 10. & 207 & Zachodniopomorskie & $-0,712$ \\
\hline 11. & 209 & Wielkopolskie & $-0,728$ \\
\hline 12. & 211 & Podlaskie & $-0,729$ \\
\hline 13. & 212 & Świętokrzyskie & $-0,733$ \\
\hline 14. & 214 & Podkarpackie & $-0,743$ \\
\hline 15. & Kujawsko-pomorskie & $-0,744$ \\
\hline 16. & Warmińsko-mazurskie & $-0,871$ \\
\hline
\end{tabular}

Źródło: jak do tab. 25, s. 130-131.

Zróżnicowanie terytorialne konkurencyjności regionalnej dotyczy nie tylko ogólnego poziomu wskaźnika, ale też jego elementów składowych (filarów), w tym filaru opisującego jakość otoczenia instytucjonalnego w europejskich regionach. Analiza wartości tego elementu wskaźnika konkurencyjności regionalnej w 2013 r. pozwala zauważyć, że najlepszą jakość instytucji obserwuje się w centralnie zlokalizowanych, najlepiej rozwiniętych regionach UE oraz w Skandynawii, natomiast najniższa jakość instytucji obserwowana jest w regionach Europy Środkowo-Wschodniej i Południowej (por. rys. 23). W przypadku Polski można przy tym zaobserwować, iż województwa wielkopolskie, dolnośląskie i śląskie zanotowały niższą pozycję w rankingu instytucjonalnych uwarunkowań konkurencyjności, niż pozostałe polskie jednostki terytorialne poziomu NUTS 2. 




Rys. 23. Ranking instytucjonalnych uwarunkowań konkurencyjności regionów według wskaźnika konkurencyjności regionalnej (2013 r.)

Objaśnienia: kolory na mapie stanowią wynik podziału wszystkich regionów NUTS 2 w Unii Europejskiej na grupy, według wartości osiągniętego wskaźnika. Regiony zaznaczone kolorem zielonym osiągnęły wartość wyższą niż 80\% średniej wartości wskaźnika dla wszystkich regionów. Stanowią one grupę cechującą się najlepszą jakością otoczenia instytucjonalnego w całej UE. Regiony zaznaczone kolorem ciemnoczerwonym osiągnęły wartość niższą lub równą $20 \%$ średniej wartości wskaźnika dla wszystkich regionów i cechują się najgorszą jakością otoczenia instytucjonalnego w całej UE.

Źródło: P. Annoni, L. Dijkstra, EU Regional Competitiveness Index RCI 2013, Publications Office of the European Union, Luxembourg 2013, s. 34.

Powyższe rozważania prowadzą do wniosku, że uwarunkowania instytucjonalne - podobnie jak poziom stabilności ekonomicznej, rozwoju infrastruktury czy kapitału ludzkiego - w istotnym stopniu decydują o nierównościach przestrzennych w Europie. Innymi słowy, polaryzacja przestrzenna warunkowana jest nie tylko koncentracją podstawowych czynników produkcji, lecz także zależy od otoczenia instytucjonalnego. Badanie wskaźnika konkurencyjności regionalnej należy zatem uznać za 
niezwykle obiecujące z perspektywy programu badawczego dotyczącego instytucjonalnych uwarunkowań rozwoju regionalnego. Charakteryzuje go przy tym możliwość prowadzenia badań porównawczych w skali europejskiej, zaś w sytuacji kontynuacji badania stwarza nadzieję na jego ciągłość w kolejnych latach. Daje też sposobność do badania dynamiki czynników konkurencyjności, w tym związanych z instytucjami.

Badanie zróżnicowania jakości otoczenia instytucjonalnego w wymiarze regionalnym stanowi przedmiot tzw. europejskiego wskaźnika jakości rządzenia EQI (European QoG Index). Zrealizowano dotychczas dwie edycje tego badania - w roku 2010 oraz 2013, adaptując na jego potrzeby metodykę wypracowaną we wcześniejszych badaniach tzw. jakości rządzenia (QoG - Quality of Governance), prowadzonych na poziomie państw. Oparte są one na założeniu, że o sprawności funkcjonowania rządu (lub szerzej - sektora publicznego) decydują przede wszystkim bezstronność w działaniu, skuteczność oraz brak zjawiska korupcji ${ }^{87}$. Wyniki badań zdążyły posłużyć do analizowania zależności między wartościami QoG a takimi zjawiskami, jak osiągane wyniki gospodarcze, zrównoważenie środowiskowe, poziom ubóstwa i nierówności społecznych, subiektywne poczucie szczęścia, prawdopodobieństwo zajścia konfliktów zbrojnych. Jednak większość tego typu badań koncentrowała się na poziomie gospodarek narodowych i odnosiło się przede wszystkim do krajów rozwijających się ${ }^{88}$.

Potrzeba badania jakości rządzenia na poziomie niższym od narodowego stała się zatem punktem wyjścia dla opracowania i obliczenia podobnego wskaźnika na szczeblu regionalnym. European QoG Index odwołuje się w swojej strukturze do czterech kluczowych kategorii:

1) percepcja korupcji,

2) poziom praworządności,

3) efektywność instytucji publicznych,

4) odpowiedzialność władz przed obywatelami i jakość instytucji związanych z przebiegiem procesu wyborczego.

Wartości wskaźnika dla powyższych składowych szacowane są na podstawie wyników badań kwestionariuszowych, w których odpowiedzi odwołują się do subiektywnego postrzegania przez respondentów takich aspektów funkcjonowania instytucji, jak:

- w zakresie percepcji korupcji - przekonanie o występowaniu lub braku korupcji w procesie rekrutacji do szkół oraz w systemie

87 Por. B. Rothstein, J. Teorell, What is Quality of Government? A Theory of Impartial Government Institutions, Governance, „International Journal of Policy, Administration and Institutions" 2008, vol. 21, s. 166.

88 N. Charron, L. Dijkstra, V. Lapuente, Regional Governance Matters: Quality of Government within European Union Member States, „Regional Studies” 2013, vol. 48 (1), s. 69. 
opieki zdrowotnej, jak również pytanie o to, czy respondenci byli kiedykolwiek zmuszeni w wymienionych sferach do dawania łapówek,

- w zakresie praworządności - jakość funkcjonowania policji, jej skuteczność $\mathrm{w}$ podejmowanych interwencjach oraz podatność służb policyjnych na korupcję,

- w zakresie efektywności instytucji publicznych - pytania dotyczyły oceny jakości systemu szkolnictwa i systemu opieki zdrowotnej oraz przekonania o występowaniu lub braku zjawiska równego traktowania beneficjentów obydwu systemów,

- w zakresie systemu demokratycznego - respondentów pytano o przekonania co do poziomu uczciwości lokalnych reprezentantów władzy oraz poczucie przejrzystości procesów wyborczych ${ }^{89}$.

Badanie wskaźnika EQI koncentruje się zatem na wybranych instytucjach formalnych, funkcjonujących jedynie w sektorze publicznym. Badane aspekty niemal w ogóle nie dotykają natomiast jakości rządzenia w ujęciu gospodarczym, bowiem struktura pytań zawartych w opracowanym kwestionariuszu dotyczy funkcjonowania policji, szkolnictwa i służby zdrowia. Trudno jednak ocenić jednoznacznie, czy fakt ten uznać za wadę czy zaletę. Uwzględnienie w kwestionariuszu stosunkowo małej liczby zagadnień może świadczyć o tym, iż jest ubogi. Jednak z drugiej strony wydaje się, że autorzy badania celowo skoncentrowali się na tych instytucjach, których funkcjonowanie dotyczy każdego respondenta i których logika pozostaje zrozumiała w podobny sposób, bez względu takie czynniki, jak wiek, dochody czy poziom wykształcenia osób biorących udział w badaniu (rys. 24).

Kolejnym interesującym przykładem - szczególnie w kontekście wpływu uwarunkowań instytucjonalnych na poziom pewnych typów kosztów transakcyjnych - może okazać się prowadzone na międzynarodową skalę badanie Doing Business. Polega ono na analizie regulacji uwarunkowań instytucjonalnych dla prowadzenia działalności gospodarczej, ze szczególnym uwzględnieniem potrzeb małych i średnich przedsiębiorstw. Prowadzone jest od 2002 r. pod auspicjami International Finance Corporation, stanowiącej część grupy Banku Światowego. W pierwszej edycji badanie dotyczyło pięciu grup tematycznych i prowadzone było w 133 krajach. Obecnie dotyczy ono 11 grup tematycznych i 189 światowych gospodarek (tab. 28).

89 Measuring the Quality of Government and Subnational Variation, Raport Dyrekcji Generalnej ds. Polityki Regionalnej Komisji Europejskiej, Uniwersytet Goeteborski, Goeteborg 2010, s. 26; http://ec.europa.eu/regional_policy/sources/docgener/studies/pdf/2010_government_1.pdf (dostęp: 11.06.2015). 


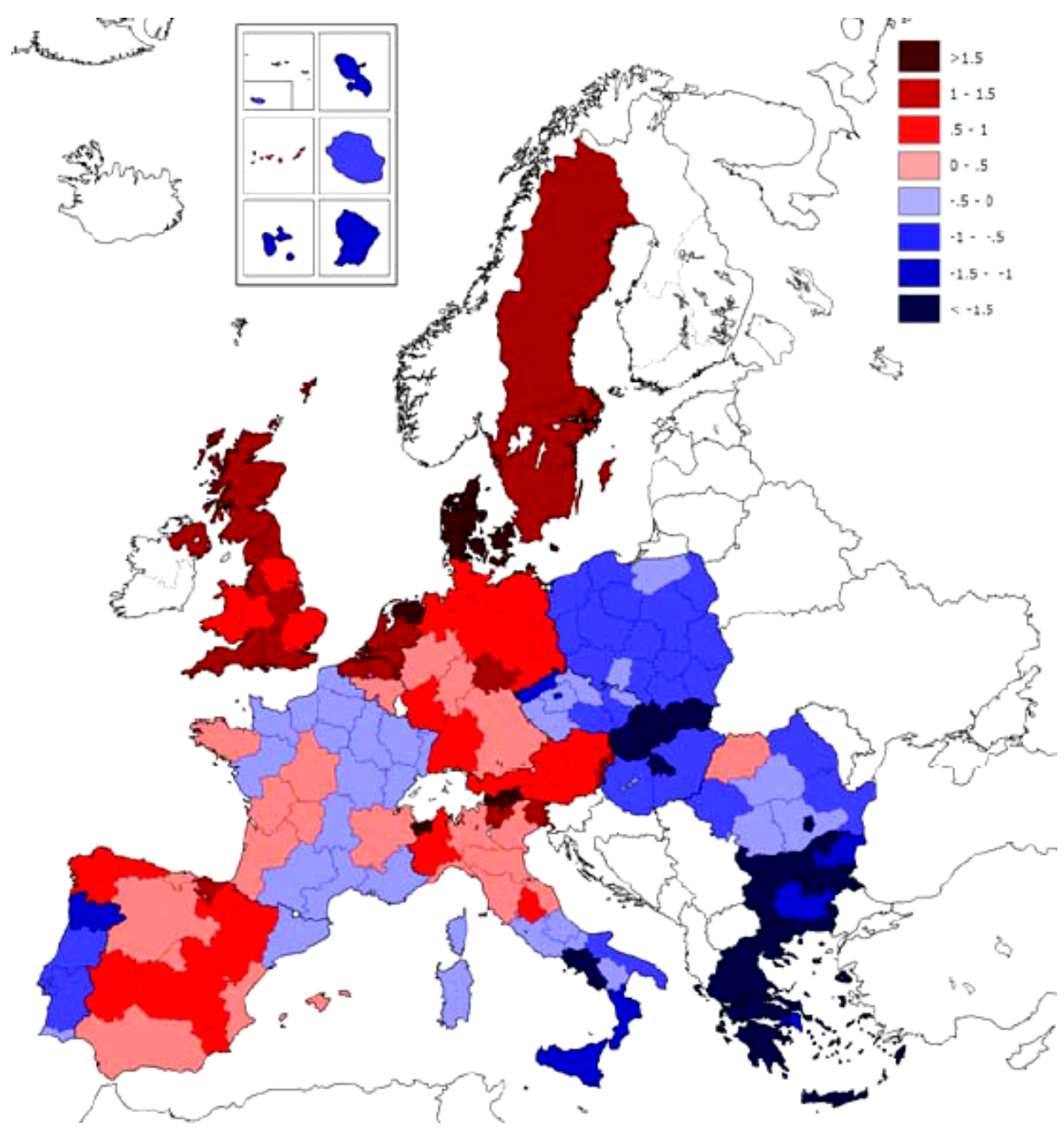

Rys. 24. Regionalne zróżnicowanie jakości rządzenia według EQI - European QoG Index (2011 r.) Źródto: Measuring the Quality of Government and Subnational Variation, Raport Dyrekcji Generalnej ds. Polityki Regionalnej Komisji Europejskiej, Uniwersytet Goeteborski, Goeteborg 2010, s. 26; http://ec.europa.eu/regional_policy/sources/docgener/studies/pdf/2010_government_1.pdf (dostęp: 11.06.2015). 
Tabela 28. Grupy tematyczne i liczba krajów biorących udział w badaniu Doing Business

\begin{tabular}{|c|c|c|c|c|c|c|c|c|c|c|c|c|}
\hline Grupa tematyczna & 2004 & 2005 & 2006 & 2007 & 2008 & 2009 & 2010 & 2011 & 2012 & 2013 & 2014 & 2015 \\
\hline $\begin{array}{l}\text { Rozpoczęcie } \\
\text { działalności } \\
\text { gospodarczej* }^{*}\end{array}$ & + & + & + & + & + & + & + & + & + & + & + & + \\
\hline $\begin{array}{l}\text { Zatrudnianie } \\
\text { pracowników }\end{array}$ & + & + & + & + & + & + & + & + & + & + & + & + \\
\hline $\begin{array}{l}\text { Przestrzeganie } \\
\text { warunków umów* }\end{array}$ & + & + & + & + & + & + & + & + & + & + & + & + \\
\hline $\begin{array}{l}\text { Ogłaszanie } \\
\text { upadtości }\end{array}$ & + & + & + & + & + & + & + & + & + & + & + & + \\
\hline $\begin{array}{l}\text { Otrzymywanie } \\
\text { kredytu }\end{array}$ & + & + & + & + & + & + & + & + & + & + & + & + \\
\hline $\begin{array}{l}\text { Rejestrowanie } \\
\text { praw własności do } \\
\text { nieruchomości* }\end{array}$ & - & + & + & + & + & + & + & + & + & + & + & + \\
\hline $\begin{array}{l}\text { Ochrona } \\
\text { inwestorów }\end{array}$ & - & - & + & + & + & + & + & + & + & + & + & + \\
\hline Płacenie podatków & - & - & + & + & + & + & + & + & + & + & + & + \\
\hline $\begin{array}{l}\text { Procedury } \\
\text { importowe } \\
\text { i eksportowe }\end{array}$ & - & - & + & + & + & + & + & + & + & + & + & + \\
\hline $\begin{array}{l}\text { Uzyskiwanie } \\
\text { pozwoleń na } \\
\text { budowę }\end{array}$ & - & - & + & + & + & + & + & + & + & + & + & + \\
\hline $\begin{array}{l}\text { Uzyskiwanie } \\
\text { przyłącza } \\
\text { energetycznego }\end{array}$ & - & - & - & - & - & - & - & + & + & + & + & + \\
\hline Liczba gospodarek & 133 & 145 & 155 & 175 & 178 & 181 & 183 & 183 & 183 & 185 & 189 & 189 \\
\hline
\end{tabular}

* Grupa uwzględniona w badaniach na poziomie subnarodowym.

Źródło: http://www.doingbusiness.org/methodology/methodology-note (dostęp: 1.10.2015). 
Metodyka badania Doing Business opiera się przede wszystkim na analizie regulacji prawnych (instytucji formalnych) związanych z czynnościami typowymi dla prowadzenia działalności gospodarczej. Dane te są weryfikowane przez ekspertów z każdego kraju, uczestniczących w tego typu procedurach (prawników, konsultantów biznesowych, księgowych, spedytorów, przedstawicieli instytucji rządowych i samorządowych itp.). W procedurze kalkulowania danych dla roku 2015 zaangażowanych było ok. 10600 tego typu osób ${ }^{90}$. Doing Business w swej istocie opiera się zatem na dwóch typach danych: 1) pochodzących z analizy oficjalnych dokumentów i przepisów, 2) odnoszących się do poziomów złożoności i kosztów realizacji poszczególnych procedur. Innymi słowy, sposobem na pomiar kosztów transakcyjnych prowadzenia działalności gospodarczej jest ich kwantyfikacja w postaci liczby procedur, czasu spędzonego na ich realizację czy też bezpośrednich kosztów ich przeprowadzenia (np. w postaci opłat administracyjnych).

Do podstawowych zalet metodyki Doing Business można przy tym zaliczyć jej przejrzystość, odwoływanie się do pierwotnych źródeł informacji, stosunkowo niski koszt i możliwość prowadzenia porównań międzynarodowych na bazie uzyskiwanych wyników. Z punktu widzenia założeń ekonomii instytucjonalnej za zaletę badania należy uznać również to, że dostarcza ono złożonego miernika, uwzględniającego kluczowe elementy formalnego otoczenia instytucjonalnego dla prowadzenia działalności gospodarczej. Natomiast wśród słabości badania można wymienić jego wciąż ograniczony zakres (z perspektywy ekonomii instytucjonalnej wskaźniki nie są z pewnością wyczerpujące i dotyczą jedynie instytucji formalnych $)^{91}$, niedostateczną wrażliwość na specyfikę terytorialną oraz założenie o nieomylności respondentów (zakłada się na przykład, że każdy przedsiębiorca realizuje każdą czynność w najkrótszym możliwym czasie, nie popełniając przy tym błędów) ${ }^{92}$. Pomimo to, Doing Business stanowi niewątpliwie najbardziej rozwinięte przedsięwzięcie badawcze

90 http://www.doingbusiness.org/methodology/methodology-note (dostęp: 1.10.2015).

91 Słabości tego typu rankingów w tym aspekcie akcentuje m.in. koreański ekonomista Ha-Joon Chang. Podając przykład sukcesu gospodarczego swego kraju, który w latach 90 . XX w. rozwijał się w tempie $6 \%$ rocznie, a w którym uruchomienie nowej działalności gospodarczej wymagało w tym czasie 399 pozwoleń od 199 agencji, podkreślit, że rozwój gospodarczy w długim okresie jest pochodną nie tyle liczby regulacji, lecz ich treści oraz celu ich wprowadzenia (H.-J. Chang, 23 rzeczy, których nie mówiq ci o kapitalizmie, Wyd. Krytyki Politycznej, Warszawa 2013, s. 128).

92 http://www.doingbusiness.org/ /media/FPDKM/Doing\%20Business/Documents/Annual-Reports/English/DB12-Chapters/About-Doing-Business.pdf (dostęp 2.10.2014). 
tego typu. Staje się ono użyteczne w aspekcie procesów rozwoju terytorialnego, ponieważ w coraz większej liczbie krajów podejmuje się próby kalkulacji wybranych wskaźników Doing Business również na poziomie miast i regionów. Dotychczas badania na poziomie subnarodowym podjęto w Brazylii (2006), Indiach (2009), Kolumbii (2008, 2010, 2013), Indonezji (2010, 2012), Meksyku (2007, 2009, 2014), Filipinach (2008, 2011), Rosji (2009, 2012), Włoszech (2013) oraz w Egipcie (2014) ${ }^{93}$.

Największym terytorialnie państwem, w którym badania Doing Business prowadzone są na poziome regionalnym jest Rosja. Zrealizowano tam dotąd jego dwie edycje. Ten największy pod względem powierzchni i dziesiąty co do liczby ludności kraj świata (142 470272 mieszkańców $\mathrm{w}$ roku 2014 $)^{94}$ charakteryzuje także jeden $\mathrm{z}$ najwyższych poziomów zróżnicowania przestrzennego rozwoju społeczno-gospodarczego ${ }^{95}$. Opisane cechy, w połączeniu z federalnym charakterem kraju i wynikającym z niego wysokim poziomem zróżnicowań w regulacjach prawnych funkcjonowania samorządów terytorialnych ${ }^{96}$, implikują istotne różnice w uwarunkowaniach instytucjonalnych funkcjonowania przedsiębiorstw.

93 Zob.: http://www.doingbusiness.org/Reports/Subnational\%20Reports (dostęp: 2.10.2014). Należy jednak zauważyć, że badania na poziomie subnarodowym prowadzone są przede wszystkim w państwach dużych terytorialnie. Stosowanie metodyki Doing Business w mniejszych krajach uniemożliwia bowiem brak stosownych danych dla jednostek terytorialnych niższego szczebla lub fakt, że zróżnicowania przestrzenne wskaźników nie są w takich krajach istotne. W przypadku małych krajów prowadzi się badania porównawcze dla grup państw, np. Doing Business in South East Europe 2011, Doing Business in OHADA 2012, Doing Business in the Arab World 2012, Doing Business in the East African Community 2013 itd. (por. http://www.doingbusiness.org/Reports/Regional\%20Reports, dostęp: 2.10.2014).

94 https://www.cia.gov/library/publications/the-world-factbook/geos/rs.html (dostęp: 03.10.2014).

95 Dla porównania, w Unii Europejskiej relacja wartości górnego kwartyla PKB per capita w stosunku do wartości kwartyla dolnego wynosi 2,8, podczas gdy w przypadku Rosji to 4,8 (E. von Breska, Investing in Europe's Future. Fifth Report on Economic, Social and Territorial Cohesion, European Commission, Directorate-General for Regional Policy, Publications Office of the European Union, Luxembourg 2010, s. 5).

96 Kluczowe zmiany w systemie organizacji terytorialno-administracyjnej w Rosji nastąpiły w wyniku przyjęcia nowej konstytucji w 1993 r. oraz w wyniku zmian w ustawach samorządowych w latach 1995 i 2003 (M. Kalisiak-Mędelska, Self-Government in Poland and Russian Federation - Introductory Remarks, [w:] M. E. Sokołowicz (red.), Functioning of the Local Production Systems in Central and Eastern European Countries and Siberia - Case Studies and Comparative Studies, Wyd. Uniwersytetu Łódzkiego, Łódź 2015, s. 119-138). 


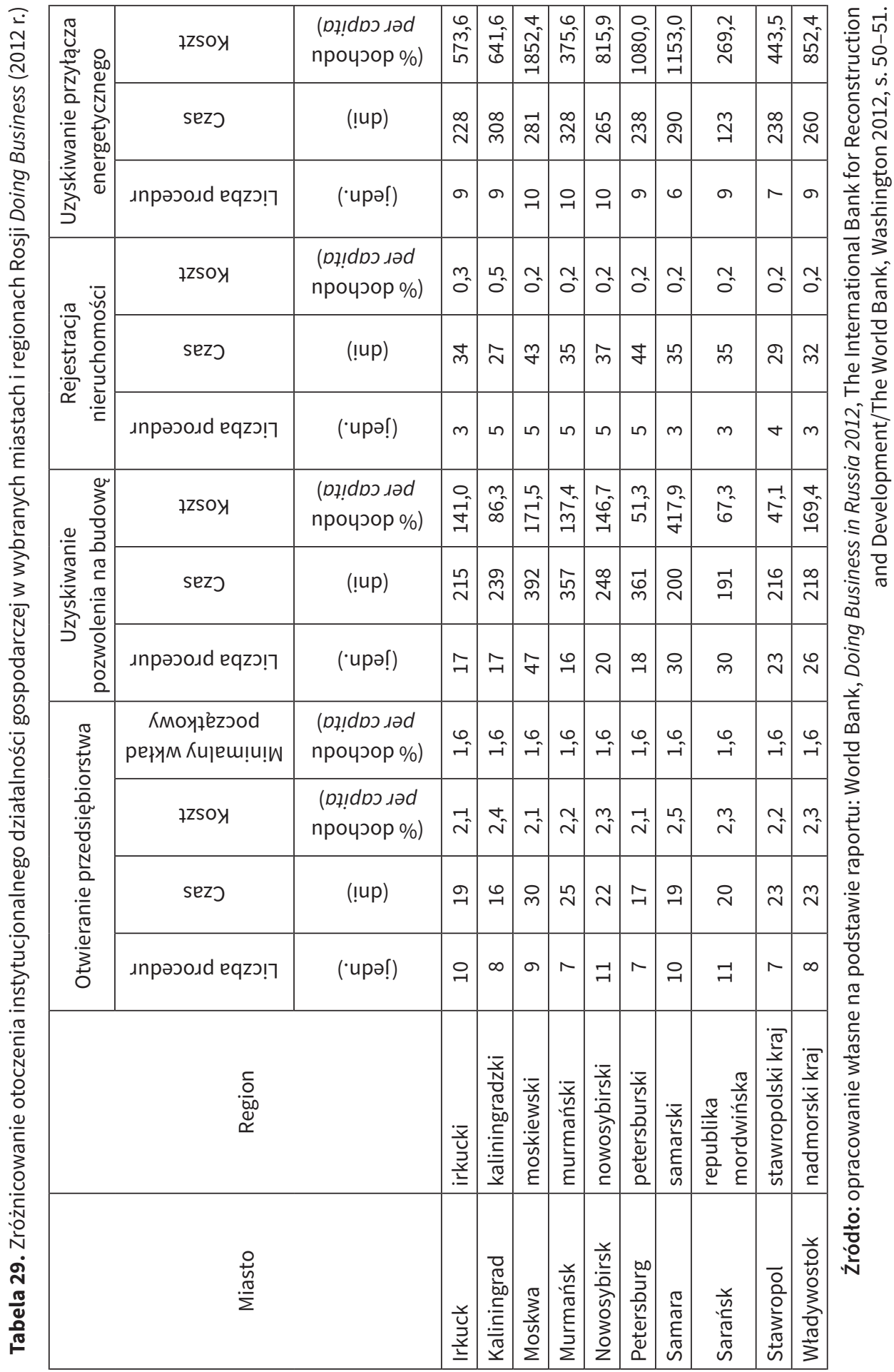


Tezę tę potwierdza analiza wartości wskaźników w badaniu Doing Business w Rosji w roku 2012, wskazując na istotne różnice w kosztach i długości trwania procedur związanych $\mathrm{z}$ otwieraniem nowego przedsiębiorstwa, uzyskiwaniem pozwoleń na budowę, rejestrowaniem nieruchomości oraz uzyskiwaniem przyłącza energetycznego. Przykładowo, otwieranie nowej działalności gospodarczej w Petersburgu wymaga 7 procedur zajmujących średnio 17 dni oraz poniesienia kosztów stanowiących 2,1\% przychodów per capita. Tymczasem w przypadku otwierania przedsiębiorstwa w regionie nowosybirskim (Новосибирская область) wymagane jest przejście 11 procedur realizowanych w ciągu 22 dni przy koszcie stanowiącym 2,3\% przychodów per capita (tab. 29). Brak różnic występuje jedynie pod względem takiego samego w całej Rosji wymaganego wkładu początkowego dla założenia przedsiębiorstwa stanowiącego odpowiednik polskiej spółki z ograniczoną odpowiedzialnością. Istotne różnice pojawiają się $\mathrm{w}$ odniesieniu do uzyskiwania pozwoleń na budowę. W Irkucku lub Kaliningradzie wymagają one 17 czynności, podczas gdy w Moskwie ich liczba wzrasta do 47. Koszt uzyskiwania pozwolenia na budowę wahał się natomiast od $47,1 \%$ rocznych dochodów w kraju stawropolskim (Ставропольский край) do 417,9\% rocznych dochodów w obwodzie samarskim (Самарская область).

Powyższy, bardzo ogólny przegląd wartości wskaźników Doing Business dla wybranych miast i regionów Rosji uwiarygodnia założenie o istotnym wpływie przestrzennych różnic uwarunkowań instytucjonalnych na poziom wybranych kosztów transakcyjnych ponoszonych przez przedsiębiorstwa. Choć badanie to koncentruje się na pomiarze jedynie wybranych elementów tych uwarunkowań i dotyczy instytucji formalnych, może stanowić punkt wyjścia dla badań procesów rozwoju lokalnego i regionalnego w duchu instytucjonalizmu. Do ograniczeń badania Doing Business na poziome regionalnym należy jednak zaliczyć:

1) redukcję obszarów analizy podejmowanych w przypadku Doing Business na poziomie subnarodowym do $4 \mathrm{w}$ stosunku do $11 \mathrm{ob}-$ szarów badanych na poziomie krajów (wynika to przede wszystkim z faktu, że pozostałe 7 obszarów analizy nie wykazuje istotnych zróżnicowań przestrzennych),

2) pomijanie czynników o charakterze jakościowym wpływających na instytucjonalne uwarunkowania przedsiębiorczości, takich jak korupcja, wielkość i chłonność rynków, stabilność makroekonomiczna, kompetencje pracowników itp. ${ }^{97}$,

97 World Bank, Doing Business In Italy. Smarter Regulations for Small and Medium-Size Enterprises, International Bank for Reconstruction and Development/The World Bank, Washington 2013, s. 9-10. 
3) pomijanie czynników instytucjonalnych o charakterze nieformalnym, istotnych szczególnie w odniesieniu do ich terytorialnego zakorzenienia.

Opisane wyżej trudności sprawiają problemy również w sytuacji porównywania danych $\mathrm{w}$ skali międzynarodowej. Jednak wspomniane ograniczenia nie wydają się istotnie osłabiać wartości tego rodzaju badań, a przedsięwzięcie Doing Business może w znaczący sposób przyczynić się do rozpowszechniania podejścia instytucjonalnego $\mathrm{w}$ badaniach miejskich i regionalnych.

Kolejnym godnym odnotowania badaniem, kładącym do pewnego stopnia nacisk na czynniki instytucjonalne w rozwoju społeczno-gospodarczym, jest Diagnoza warunków i jakości życia Polaków. Jest ona realizowana nieprzerwanie od $2000 \mathrm{r}$. w formie panelowej ${ }^{98} \mathrm{i}$ obejmuje szereg wskaźników uzyskiwanych w drodze badań o charakterze pierwotnym (kwestionariusze badań w gospodarstwach domowych). Ostatni cykl diagnozy społecznej został zrealizowany w $2013 \mathrm{r} .{ }^{99}$

Wiele spośród kompleksowych obszarów analizy odwołuje się do uwarunkowań instytucjonalnych bądź determinujących określone zachowania społeczne i sytuację społeczną, bądź też będących wynikiem określonych zachowań, postaw i poglądów obywateli (np. pomoc społeczna, z jakiej korzysta gospodarstwo domowe, postawy wobec kształcenia dzieci, uczestnictwo w kulturze i wypoczynku, poziom tzw. wykluczenia społecznego, dobrostan psychiczny, stres, postawy i zachowania społeczne i obywatelskie itp.). Z punktu widzenia analiz regionalnych badanie jest o tyle wartościowe, o ile podejmuje próbę identyfikacji powyższych aspektów także na poziomie polskich województw i miast (tab. 30).

W diagnozie społecznej nie artykułuje się wprost instytucjonalnego wymiaru procesów gospodarowania, jednak wiele badanych w niej elementów mówi o jakości instytucji, zarówno formalnych, jak i nieformalnych. Elementy te są dostrzegalne w szczególności w obszarze kapitału społecznego, dobrostanu społecznego oraz poziomu cywilizacyjnego.

98 Badania panelowe polegają na poddawaniu pomiarom tej samej próby badawczej tym samym narzędziem w określonych, powtarzalnych odstępach czasu (szerzej: E. Babbie, Badania społeczne w praktyce, PWN, Warszawa 2004, s. 123124). W przypadku diagnozy społecznej badanie powtarzane jest w odstępach dwuletnich, w marcu.

99 J. Czapiński, T. Panek (red.), Diagnoza społeczna 2013. Warunki i jakość życia Polaków, „Contemporary Economics. Quarterly of University of Finance and Management in Warsaw” 2013, vol. 7, special issue (September). 
Tabela 30. Syntetyczne wymiary jakości życia w Diagnozie warunków i jakości życia Polaków (2013 r.)

\begin{tabular}{|c|c|}
\hline Wymiar & Wykorzystane wskaźniki subiektywne i obiektywne \\
\hline Kapitał społeczny & $\begin{array}{l}\text { - } \text { aktywność na rzecz środowiska lokalnego, } \\
\text { - } \text { udział w wyborach parlamentarnych w } 2011 \text { r. (w } 2011 \text { r. udziat } \\
\text { w wyborach samorządowych w } 2010 \text { r., w } 2009 \text { r. udział w wyborach } \\
\text { parlamentarnych w } 2007 \text { r., w } 2007 \text { r.udział w wyborach samorządowych, } \\
\text { a w } 2005 \text { r. udział w referendum unijnym), } \\
\text { - } \text { udział w nieobowiązkowych zebraniach, } \\
\text { - } \text { pozytywny stosunek do demokracji, } \\
\text { - } \text { przynależność do organizacji i pełnienie w nich funkcji, } \\
\text { - } \text { przekonanie, że większości ludzi można ufać }\end{array}$ \\
\hline $\begin{array}{l}\text { Dobrostan psy- } \\
\text { chiczny }\end{array}$ & $\begin{array}{l}\text { - poczucie szczęścia, } \\
\text { - ocena całego dotychczasowego życia, } \\
\text { - nasilenie objawów depresji psychicznej, } \\
\text { - ocena minionego roku }\end{array}$ \\
\hline $\begin{array}{l}\text { Dobrostan } \\
\text { fizyczny }\end{array}$ & $\begin{array}{l}\text { - natężenie symptomów somatycznych, } \\
\text { - poważna choroba w minionym roku, } \\
\text { - stopień niepełnosprawności, } \\
\text { - natężenie stresu związanego ze zdrowiem }\end{array}$ \\
\hline $\begin{array}{l}\text { Dobrostan } \\
\text { społeczny }\end{array}$ & $\begin{array}{l}\text { - brak poczucia osamotnienia, } \\
\text { - poczucie, że jest się kochanym i szanowanym, } \\
\text { - liczba przyjaciót }\end{array}$ \\
\hline $\begin{array}{l}\text { Poziom cywiliza- } \\
\text { cyjny }\end{array}$ & $\begin{array}{l}\text { - } \text { poziom wykształcenia, } \\
\text { - } \text { posiadanie nowoczesnych urządzeń komunikacyjnych i obycie z nimi } \\
\text { (telewizja satelitarna lub kablowa, laptop, komputer stacjonarny, } \\
\text { telefon komórkowy, podłączenie do Internetu, posługiwanie się } \\
\text { komputerem, korzystanie z Internetu), } \\
\text { - } \text { czynna znajomość języków obcych, } \\
\text { - } \text { posiadanie prawa jazdy }\end{array}$ \\
\hline $\begin{array}{l}\text { Dobrobyt mate- } \\
\text { rialny }\end{array}$ & $\begin{array}{l}\text { - } \text { dochód gospodarstwa domowego na jednostkę ekwiwalentną, } \\
\text { - liczba posiadanych przez gospodarstwo dóbr i urządzeń od pralki } \\
\text { automatycznej po łódź motorową i dom letniskowy (z wyłączeniem } \\
\text { urządzeń wchodzących w skład wskaźnika poziomu cywilizacyjnego) }\end{array}$ \\
\hline Stres życiowy & $\begin{array}{l}\text { - suma } 6 \text { kategorii stresu mierzonego doświadczeniami w zakresie: } \\
\text { finansów, pracy, kontaktów z urzędami, wychowania dzieci, relacji } \\
\text { w małżeństwie, ekologii (mieszkanie, okolica) }\end{array}$ \\
\hline Patologie & $\begin{array}{l}\text { - nadużywanie alkoholu i używanie narkotyków, } \\
\text { - palenie papierosów, wizyty u psychiatry lub psychologa, } \\
\text { - } \text { bycie sprawcą lub ofiarą łamania prawa (włamania, napady, kradzieże) }\end{array}$ \\
\hline
\end{tabular}

Źródło: J. Czapiński, T. Panek (red.), Diagnoza społeczna 2013. Warunki i jakość życia Polaków, "Contemporary Economics. Quarterly of University of Finance and Management in Warsaw" 2013, vol. 7, special issue (September), s. 379. 
Obserwacja poziomów wskaźników syntetycznych 3 z 8 wymiarów jakości życia, poddanych analizie w diagnozie społecznej, pozwala domniemywać o różnicach w zakresie szeroko rozumianych uwarunkowań instytucjonalnych, zarówno pomiędzy polskimi regionami, jak i miastami. Przykładowo, w obszarze kapitału społecznego województwem o najwyższym jego poziomie jest podkarpackie, zaś w dalszej kolejności pomorskie i opolskie, natomiast najniższy poziom obserwuje się w województwie warmińsko-mazurskim, a następnie w łódzkim i świętokrzyskim (por. tab. 31). Znacznie większe różnice pod tym względem obserwowane są natomiast w przypadku analizy wartości wskaźników dla wybranych miast.

W diagnozie społecznej można zatem dostrzec coraz większą liczbę zmiennych, których zróżnicowanie badane jest w przekroju województw i miast. Obecnie ich liczba jest wciąż niewielka, lecz w odniesieniu do syntetycznych miar jakości życia lub wrażliwości na dobro publiczne w ostatniej diagnozie dostępne są dane na poziomie lokalnym i regionalnym.

Zaprezentowane wyniki badań nie wyczerpują listy podobnych przedsięwzięć uwzględniających kontekst instytucjonalny rozwoju terytorialnego. Są to jednak najbardziej powszechne i miarodajne opracowania, które $\mathrm{z}$ jednej strony stanowią próbę kompleksowego spojrzenia na instytucjonalne uwarunkowania rozwoju społeczno-gospodarczego, a $z$ drugiej - są próbą ich pomiaru na poziomie lokalnym i/lub regionalnym. Choć badania te nie pretendują do całościowego ujęcia badanego zagadnienia i z uwagi na swą naturę (podejście ilościowe, konieczność zapewnienia wiarygodności, dostępności i porównywalności danych) koncentrują się na instytucjach formalnych, dają stosunkowo rzetelny obraz regionalnego kontekstu instytucjonalnego, a ich wyniki mogą być z powodzeniem wykorzystywane jako punkt wyjścia lub element bardziej pogłębionych badań.

Jak podkreślił Ch. Woodruff, w ostatnich latach znacznie wzbogacił się dorobek badań dowodzących, że jakość instytucji ma istotny wpływ na wyniki ekonomiczne. Wyzwaniem pozostaje jednak odpowiedź na pytanie, które to instytucje - szczególnie, że najsilniejsze dowody empiryczne wskazują na instytucje nieformalne, na które najtrudniej oddziaływać. Trudno tymczasem oczekiwać, że kraje, regiony i miasta zmienią swoją lokalizację, historię oraz inne silnie zakorzenione kulturowe i społeczne uwarunkowania procesów gospodarczych ${ }^{100}$. Otwiera to istotne pole dla wykorzystania ekonomii instytucjonalnej dla badania procesów rozwoju terytorialnego w przyszłości. 
Tabela 31. Zróżnicowania przestrzenne jakości życia w Diagnozie warunków i jakości życia Polaków (2013 r.)

\begin{tabular}{|c|c|c|c|c|}
\hline Jednostka terytorialna & $\begin{array}{c}\text { Kapitał } \\
\text { społeczny }\end{array}$ & $\begin{array}{c}\text { Poziom } \\
\text { cywilizacyjny }\end{array}$ & $\begin{array}{l}\text { Dobrostan } \\
\text { społeczny }\end{array}$ & $\begin{array}{c}\text { Skala wrażliwości na } \\
\text { dobro publiczne* }\end{array}$ \\
\hline \multicolumn{5}{|c|}{ Województwa } \\
\hline Dolnośląskie & 0,01 & 0,12 & 0,05 & 2,76 \\
\hline Kujawsko-pomorskie & $-0,06$ & $-0,02$ & $-0,09$ & 2,64 \\
\hline Lubelskie & 0,05 & $-0,07$ & 0,1 & 2,72 \\
\hline Lubuskie & 0,00 & 0,04 & $-0,13$ & 2,73 \\
\hline Łódzkie & $-0,09$ & $-0,01$ & $-0,02$ & 2,62 \\
\hline Małopolskie & 0,05 & 0,12 & 0,13 & 2,75 \\
\hline Mazowieckie & 0,05 & 0,17 & 0,05 & 2,82 \\
\hline Opolskie & 0,07 & 0,1 & 0,18 & 2,7 \\
\hline Podkarpackie & 0,13 & $-0,04$ & 0,07 & 2,69 \\
\hline Podlaskie & $-0,03$ & 0,07 & $-0,03$ & 2,77 \\
\hline Pomorskie & 0,08 & 0,23 & 0,07 & 2,71 \\
\hline Śląskie & $-0,02$ & 0,15 & $-0,03$ & 2,78 \\
\hline Świętokrzyskie & $-0,08$ & $-0,14$ & $-0,12$ & 2,61 \\
\hline Warmińsko-mazurskie & $-0,19$ & $-0,12$ & $-0,25$ & 2,43 \\
\hline Wielkopolskie & $-0,05$ & 0,08 & 0 & 2,52 \\
\hline Zachodniopomorskie & $-0,06$ & 0,11 & $-0,08$ & 2,67 \\
\hline \multicolumn{5}{|c|}{ Przykładowe miasta } \\
\hline Warszawa & 0,32 & 0,83 & 0,03 & \multirow{6}{*}{ b. d. } \\
\hline Kraków & 0,33 & 0,51 & 0,1 & \\
\hline Wroctaw & 0,15 & 0,46 & 0,17 & \\
\hline Szczecin & 0,01 & 0,56 & 0,05 & \\
\hline Łódź & $-0,08$ & 0,26 & $-0,04$ & \\
\hline Toruń & 0,49 & 0,49 & $-0,07$ & \\
\hline
\end{tabular}

* Stanowi wypadkową odpowiedzi na pytania o stosunek do: płacenia zbyt niskich podatków, unikania płacenia za transport publiczny, niesłusznego pobierania zasitku dla bezrobotnych, niesłusznego pobierania renty inwalidzkiej oraz wyłudzania odszkodowań. Możliwe odpowiedzi: w ogóle mnie nie obchodzi - mało mnie obchodzi - trochę mnie obchodzi - bardzo mnie obchodzi - trudno powiedzieć.

Źródło: jak do tab. 30, opracowanie własne na podstawie zamieszczonych danych. 
Należy dodać, iż mariaż badań nad rozwojem lokalnym i regionalnym z instytucjonalizmem wciąż pozostaje na dużym poziomie ogólności i z naukowego punktu widzenia wymaga dalszych prac w kierunku konceptualizacji, której zresztą nie sprzyja różnorodność szkół i podejść instytucjonalnych. W przypadku ekonomii instytucjonalnej i szkół pokrewnych nie występują bowiem jednorodne i rygorystycznie przestrzegane metody badawcze.

Ponadto, prowadzenie badań odwołujących się w swej metodyce do nurtów instytucjonalnych napotyka na wiele trudności i ograniczeń. Opinia o słabości statystyk dotyczących zmiennych instytucjonalnych, posługiwanie się zmiennymi, które uwikłane są w problemy wiarygodności, trudności konceptualne i metodologiczne związane z doborem zmiennych czy wreszcie nadużywanie niejednoznacznie definiowalnych pojęć ${ }^{101}$ - należą do najbardziej powszechnych argumentów na rzecz krytyki tego rodzaju podejścia oraz najważniejszych wyzwań w przyszłości ${ }^{102}$.

Wyzwania te jawią się jako szczególnie ważne w odniesieniu do analiz na poziomie lokalnym i regionalnym. Zagadnieniem kluczowym pozostaje przy tym zarówno daleko idący deficyt danych, jak i charakter analiz instytucjonalnych na tym szczeblu. Ponadto, na tym poziomie dominują instytucje o charakterze nieformalnym, oparte na zaufaniu i specyficznych, terytorialnie zakorzenionych powiązaniach społecznych. W obliczu wyzwania polegającego na niedostępności danych i trudnościach w uchwyceniu specyfiki terytorium należy podkreślić konieczność realizacji dużej liczby badań o charakterze pierwotnym. W wielu sytuacjach mogą one czerpać z dotychczasowego dorobku empirycznego, jednak wymagają jego modyfikacji i dostosowania do konkretnych „sytuacji lokalnych”. Prowadzi to siłą rzeczy do wzrostu kosztów badań oraz problemów organizacyjnych związanych $\mathrm{z}$ ich koordynacją, która jest niezbędna $\mathrm{z}$ uwagi na konieczność zapewnienia porównywalności danych między różnymi jednostkami terytorialnymi.

Warto zauważyć, że wykorzystywanie instytucjonalizmu i prowadzenie w jego duchu badań nad procesami rozwoju terytorialnego skłania do sięgania do dorobku wielu dyscyplin naukowych, takich jak ekonomia, socjologia, politologia czy nauki prawne, a zatem niejako wymusza ich interdyscyplinarność. Badania takie charakteryzuje - i z pewnością będzie tak w przyszłości - dominacja badań jakościowych nad ilościowymi lub umiejętna kombinacja obydwu podejść.

Przykładowo, badania bazujące na mierzalnych wskaźnikach, wykorzystujące dane o charakterze wtórnym, pozostają z pewnością wartościowe, jednak próba ich aplikowania na poziomie subnarodowym sprowadza się zwykle do poszukiwania stosownych danych na niższym poziomie ich agregacji. To daje pewien obraz sy-

101 Por. G. M. Hodgson, What Are Institutions?, „Journal of Economics Issues” 2006, vol. 40 (1), s. 1-26.

102 Por. A. Sulejewicz, Czynniki instytucjonalne w badaniach wzrostu gospodarczego krajów transformacji, [w:] R. Rapacki (red.), Wzrost gospodarczy w krajach transformacji. Konwergencja czy dywergencja?, PWE, Warszawa 2009, s. 287-289. 
tuacji, lecz uniemożliwia skuteczną identyfikację instytucji nieformalnych, które powstały w konkretnych miejscach i „zależą od terytorium”, tj. od jego historii, kultury współpracy (lub braku współpracy), systemu kodów porozumiewania się specyficznego dla danego środowiska lokalnego itp. W takiej sytuacji wciąż nieocenione pozostają studia przypadków realizowane „na styku dyscyplin”.

W przypadku badań ilościowych ich zaletą pozostaje możliwość całościowego uchwycenia badanych zagadnień i uogólniania uzyskiwanych wyników, co z kolei pozwala na prowadzenie studiów porównawczych. Jednak badania oparte na modelowaniu matematycznym siłą rzeczy wymuszają uproszczenia stosowanych modeli ${ }^{103}$. Ponadto, $\mathrm{w}$ przypadku badań ilościowych pojawia się wyzwanie związane z zapewnieniem wiarygodności danych na subnarodowym poziomie analizy. Dotyczy ono tzw. problemu MAUP (modifiable area unit problem), zgodnie z którym liczba, wielkość i kształt jednostek terytorialnych wpływają na wyniki analizy. Wynika to $z$ faktu, że istnieje wiele sposobów agregowania i dezagregowania tych jednostek i de facto żadne kryteria wyboru nie pozostają w pełni obiektywne $\mathrm{e}^{104}$. Wreszcie, w sytuacji prowadzenia badań ilościowych pojawia się problem dostępności danych per se. Na przykład w odniesieniu do kalkulowania kosztów transakcyjnych różne ich typy mogą wymagać odmiennych metodyk pozyskiwania danych, nie zawsze ze sobą porównywalnych.

Nawiązując do powyższych rozważań, należy stwierdzić, że duży wkład w prowadzenie badań regionalnych $\mathrm{w}$ duchu instytucjonalizmu ma podejście jakościowe, które w przeciwieństwie do podejścia ilościowego nie odpowiada na pytania ,ile?”, lecz na pytania: ,jak?” i „dlaczego?”. W podejściu jakościowym stosuje się mniej rygorystyczne metody pozyskiwania danych (częste korzystanie z pytań otwartych, wywiadów

103 W badaniach mających na celu identyfikację klastrów, w przypadku stosowania jedynie metod ilościowych (np. metody input-output lub współczynnika lokalizacji) możliwa jest tylko analiza koncentracji działalności gospodarczej w przestrzeni fizycznej. Metody te uniemożliwiają natomiast zidentyfikowanie wewnętrznej struktury przepływów informacji czy wiedzy „milczącej” w ramach pojedynczego klastra (A. Nowakowska, Z. Przygodzki, M. Sokołowicz, Mapping Clusters in Poland. A Comprehensive Methodological Approach, [w:] T. Markowski, M. Turała (eds.), Theoretical and Practical Aspects of Urban and Regional Development, Polish Academy of Sciences - Committee for Spatial Economy and Regional Planning, Warsaw 2009, s. 267-269). Warto również przypomnieć, że ilościowa gałąź badań nad zjawiskiem koncentracji działalności gospodarczej - Nowa Geografia Ekonomiczna - analizuje wprost tylko jedno z trzech marshallowskich źródeł korzyści aglomeracji (tj. powiązania wstecz i wprzód, nie zajmując się bujnymi rynkami pracy oraz zjawiskiem spill-over informacji) (por. rozdział I).

104 L. Bertinelli, J. Decrop, Geographical Agglomeration..., s. 569. 
zogniskowanych, obserwacji itp.) oraz opiera się je na nieprobabilistycznych doborach prób badawczych i mniejszej liczebności tych prób. $\mathrm{Z}$ drugiej strony, badania jakościowe wymagają większego zaangażowania ekspertów, którzy w przypadku badań nad procesami rozwoju lokalnego i regionalnego powinni być szczególnie wrażliwi na terytorialnie zakorzeniony kontekst instytucjonalny. Ich słabością pozostaje przy tym, że mimo bardziej pogłębionych analiz, bazują na znacznie mniejszej liczbie przypadków mogących być przedmiotem badań porównawczych w czasie i przestrzeni, co z kolei zwiększa prawdopodobieństwo falsyfikowalności stawianych hipotez.

W konsekwencji należy podsumować, że badania nad dynamiką rozwoju lokalnego i regionalnego $\mathrm{w}$ duchu instytucjonalizmu powinny być prowadzone $\mathrm{w}$ duchu kombinacji podejść jakościowych $\mathrm{z}$ ilościowymi. Innymi słowy, wykorzystywanie dorobku ekonomii instytucjonalnej w odniesieniu do opisywanego przedmiotu badań powinno odwoływać się do wprowadzonego przez N. K Denzina pojęcia triangulacji odpowiednio: źródeł i typów wykorzystywanych danych, podmiotów prowadzących badanie, podstawy teoretycznej każdego badania oraz stosowanych metod $^{105}$.

105 N. K. Denzin, The Research Act: A Theoretical Introduction to Sociological Methods, Aldine Transaction, Chicago 2009, s. 301. 


\section{Podsumowanie}

\section{Dylematy wokół instytucjonalnych analiz rozwoju terytorialnego}

W toku rozwoju badań ekonomicznych ewoluowało podejście do definiowania i poszukiwania typu oraz charakteru czynników decydujących o nierównościach przestrzennych i ich dynamice. Co istotne, $\mathrm{z}$ upływem czasu relatywnie mniej uwagi poświęcano roli bezpośrednio mierzalnych (twardych) składowych korzyści aglomeracji na rzecz uwarunkowań miękkich, trudniej uchwytnych z punktu widzenia badań naukowych. Z uwagi na swoją złożoność i mało „namacalny” charakter, komponent ten pozostaje jednak wyzwaniem dla badaczy. W obecnych rozważaniach podejmowanych $w$ ramach ekonomiki miejskiej i regionalnej zaczyna dominować pogląd, że współcześnie wiodącymi źródłami korzyści aglomeracji pozostają czynniki instytucjonalne. W związku z tym coraz popularniejsza dziedzina wiedzy ekonomicznej, zwana ekonomią instytucjonalną, może stanowić użyteczne ramy analityczne i metodologiczne dla badań procesów rozwoju terytorialnego.

Dokonany w pracy szeroki przegląd, klasyfikacja i uporządkowanie dorobku ekonomii instytucjonalnej pod kątem jego przydatności dla badań procesów rozwoju terytorialnego miały za zadanie wyeksponować ten coraz silniej dostrzegany czynnik rozwoju gospodarczego. W pracy podjęto przy tym próbę dynamicznego (ewolucyjnego) podejścia do tego zagadnienia. Przeprowadzony wywód pozwala na postawienie pięciu tez, odnoszących się do zastosowania dorobku ekonomii instytucjonalnej w badaniach nad rozwojem terytorialnym.

Po pierwsze, przegląd różnorodnych i bogatych nurtów ekonomii instytucjonalnej pozwala stwierdzić ich wysoką użyteczność do badania 
procesów rozwoju lokalnego i regionalnego. Dokonany przegląd i klasyfikacja „szkół instytucjonalnych”, jak również zestawienie kierunków badań w tym obszarze pozwalają zauważyć, że poszczególne gałęzie tego nurtu ekonomii znajdują zastosowanie w eksploracji naukowej procesów zachodzących nie tylko na poziomie gospodarek narodowych i na poziomie mikroekonomicznym, lecz także mogą być wykorzystywane (i w praktyce coraz częściej bywają) na poziomie lokalnym i regionalnym. Przedmiot badań prowadzonych z wykorzystaniem dorobku ekonomii instytucjonalnej może być przy tym bardzo szeroki oraz dotyczyć m.in. funkcjonowania społeczności lokalnych i regionalnych, działania samorządów terytorialnych, wpływu struktury własności przestrzeni na efektywność gospodarowania nią, jak również zachowań przedsiębiorstw w odniesieniu do poszukiwanych przez nie czynników lokalizacji.

Bogactwo i różnorodność nurtów ekonomii instytucjonalnej rodzą jednak pytanie o możliwość pogodzenia ich ze sobą. Próba odpowiedzi na nie doprowadziła do sformułowania tezy drugiej, zgodnie z którą poszczególne teorie i koncepcje ,instytucjonalne” mogą być interpretowane nie jako stojące $\mathrm{w}$ stosunku do siebie $\mathrm{w}$ sprzeczności, lecz jako komplementarne podejścia badawcze. Złożoność instytucjonalizmu pozostaje bowiem zarówno wyzwaniem, jak i istotną korzyścią z punktu widzenia procesów rozwoju terytorialnego. Wymaga to w konsekwencji dużej wrażliwości na wewnętrzną różnorodność ekonomii instytucjonalnej jako dziedziny wiedzy, warunkującej umiejętność jej zastosowania dla badania różnorodnych w swej istocie procesów rozwoju terytorialnego. Posiadanie tej zdolności otwiera szerokie możliwości dla poruszania się w triadzie wzajemnych zależności: przestrzeń - bliskość - instytucje, a tym samym podejmowania studiów nad szeregiem zagadnień związanych z procesami rozwoju terytorialnego. Wśród nich wymienić można m.in. badania dotyczące:

- wpływu bliskości fizycznej na minimalizację kosztów transakcyjnych, poprzez działanie mechanizmu korzyści aglomeracji (teoria kosztów transakcyjnych, ekonomika bliskości),

- efektywności różnorodnych form dostarczania dóbr publicznych przez samorządy terytorialne i roli samorządów w gospodarowaniu przestrzeniami publicznymi (teoria praw własności), jak również korzyści i kosztów decentralizacji władzy oraz modeli tej decentralizacji (teoria wyboru publicznego, teoria kosztów transakcyjnych),

- roli samorządów terytorialnych w budowaniu społeczeństwa obywatelskiego oraz terytorialnego zróżnicowania poziomu zaufania społecznego („stara” ekonomia instytucjonalna),

- korzyści i kosztów oraz przesłanek i barier współpracy między jednostkami samorządu terytorialnego („stara” ekonomia instytucjonalna, teoria kosztów transakcyjnych), 
- wpływu lokalnych czynników historycznych, kulturowych i instytucjonalnych na konkurencyjność regionów („stara” ekonomia instytucjonalna, ekonomika bliskości, ekonomia ewolucyjna, podejście zasobowe),

- funkcjonowania lokalnych systemów produkcyjnych, klastrów oraz innych terytorialnych form organizacji produkcji, czy wreszcie zjawiska terytorializacji (zakorzenienia) przedsiębiorstw.

Rozważania metodologiczne podjęte $\mathrm{w}$ niniejszej pracy skłaniają natomiast do sformułowania tezy trzeciej, zgodnie z którą warunkiem wykorzystania dorobku ekonomii instytucjonalnej w badaniach nad procesami rozwoju terytorialnego jest kombinacja wykorzystywanych danych, podstaw teoretycznych, stosowanych metod badawczych i podmiotów prowadzących badania. Program badawczy w duchu instytucjonalizmu oraz gospodarka przestrzenna jako dziedzina wiedzy z definicji powinny pozostawać otwarte na interdyscyplinarność. Nie oznacza to bynajmniej pełnej swobody metodologicznej i przyzwolenia na formułowanie dowolnych wniosków, ale konieczność zapewnienia wrażliwości na różnorodność metod, a także obiektów i przedmiotów badań nad rozwojem terytorialnym.

Ostatni cel pracy dotyczył znalezienia odpowiedzi na pytanie, w jaki sposób dorobek instytucjonalizmu może przyczynić się do zwiększenia sprawności oraz efektywności realizacji polityk i strategii rozwojowych. Przegląd i ocena dorobku ekonomii instytucjonalnej pod tym kątem pozwoliły na zaproponowanie czwartej tezy, zakładającej, że warunkiem skuteczności polityki rozwoju lokalnego i regionalnego pozostaje świadomość złożoności procesu przekształcania instytucji (tzw. zmiany instytucjonalnej). Dlatego też „zewnętrzna” i pozbawiona refleksji ingerencja w lokalny i regionalny układ instytucjonalny, bez znajomości złożonych rządzących nim zasad, skazana jest na niepowodzenie. Ponadto, wniosek ten należy uzupełnić o tezę piątą, zgodnie z którą na poziomie lokalnym i regionalnym instytucje nieformalne generują niższe koszty „transakcyjne” niż instytucje formalne, choć są one mniej uchwytne i przewidywalne. W konsekwencji współczesny rozwój terytorialny to efekt hybrydyzacji instytucji formalnych i nieformalnych, będący wynikiem poszukiwania ich optymalnej kombinacji na różnych poziomach warstw instytucjonalnych w ujęciu przestrzennym. Powyższe tezy, poparte rozwijającym się dorobkiem publikacyjnym, wydają się potwierdzać założenie o istotnym oddziaływaniu czynników instytucjonalnych na siłę korzyści aglomeracji decydujących o koncentracji przestrzennej procesów społeczno-gospodarczych.

$\mathrm{Z}$ uwagi na fakt, że kluczowe dla zastosowania ekonomii instytucjonalnej jest wykorzystanie jej dorobku w badaniach, ważnym zadaniem pozostaje pogłębienie postulatów metodologicznych $\mathrm{w}$ tym zakresie. 
Należy przy tym zauważyć, że większość sugestii powinna być wypadkową godzenia ze sobą dwóch sprzeczności. Dotyczą one, z jednej strony, dążenia do uniwersalizacji procedur badawczych (w celu zapewnienia porównywalności wyników), a z drugiej - konieczności uwzględniania specyfiki terytorialnej w odniesieniu do przedmiotu badań. Wśród najważniejszych propozycji w tym względzie można wymienić:

1. W odniesieniu do osób i podmiotów odpowiedzialnych za planowanie i prowadzenie tego rodzaju badań wskazane jest zapewnienie różnorodności ich ujmowania z punktu widzenia wielu dyscyplin naukowych. W konsekwencji, opisywane podejście badawcze powinno pozostawać otwarte na inne niż ekonomia i geografia ekonomiczna dyscypliny oraz podejścia, w tym przede wszystkim socjologię, politologię, prawo, a także nauki o zarządzaniu.

2. Z natury badań procesów rozwoju terytorialnego wynika postulat kombinacji podejścia ilościowego i jakościowego. Choć to mieszane podejście do prowadzenia badań (mixed methods approach, mixed model of studies) skutkuje wieloma trudnościami i wyzwaniami zarówno na etapie projektowania, jak i realizacji badań, wydaje się jednak nieodzownym kierunkiem w przypadku studiów prowadzonych nad procesami rozwoju terytorialnego.

3. Upowszechnienie wyników prowadzonych badań oraz uwiarygodnianie formułowanych w ich ramach hipotez wymaga wprowadzenia programu badawczego, opartego w mniejszym stopniu na bardzo popularnych (w odniesieniu do badań miejskich i regionalnych) studiach przypadków, a w większym stopniu - na badaniach komparatywnych, w miarę możliwości bazujących na danych pierwotnych.

4. Należy postulować rozwój nowej statystyki na potrzeby badań terytorialnych w ramach ekonomii instytucjonalnej. Potrzeba ta wynika ze słabości dotychczasowych badań statystycznych, pozbawionych dostępu do rzetelnych i powszechnych danych na poziomie lokalnym. W krajach Unii Europejskiej można wprawdzie zaobserwować znaczącą poprawę w tym względzie, jednak w odniesieniu do wielu przekrojów analiz pozostają one wciąż mało dostępne lub znacznie okrojone. Dane prezentujące wyniki na poziomie lokalnym dla takich złożonych czynników instytucjonalnych, jak np. publiczne koszty transakcyjne prowadzenia działalności gospodarczej (indeks Doing Business), zaufanie społeczne i zaufanie do organizacji publicznych (Diagnoza społeczna, wskaźnik konkurencyjności regionalnej), jakość rządzenia (European QoG Index) czy postawy i wyznawane wartości (World Values Survey), stały się bardziej osiągalne, jednak stan ten wciąż wydaje się dalece niezadowalający. 
Tymczasem dostępność danych dla zmiennych instytucjonalnych na poziomie lokalnym i regionalnym stanowi warunek niezbędny dla realizacji polityki rozwoju, w której wykorzystywane strategie i narzędzia uzasadniane są oraz uwiarygodniane wynikami badań i "dowodem naukowym" (evidence-based policy) ${ }^{1}$.

5. Badania instytucjonalne powinno cechować podejście dynamiczne, tj. więcej uwagi powinno poświęcać się zagadnieniom zmiany instytucjonalnej, wynikającej z charakteru instytucji oraz źródeł zmiany instytucjonalnej (które tkwią zarówno w uwarunkowaniach zewnętrznych, jak i samych instytucjach). Implikuje to postulat dążenia do zapewnienia systematyczności (sekwencyjności), a w miarę możliwości panelowości tego rodzaju badań2.

Zaprezentowany dorobek ekonomii instytucjonalnej można wykorzystywać we wcześniej wskazanych obszarach badań nad procesami rozwoju terytorialnego, a także poszukiwać nowych dziedzin eksploracji naukowej. Poza badaniami nad terytorialnym zróżnicowaniem poziomu zaangażowania obywatelskiego, poziomu zaufania i stosunku do dóbr publicznych oraz badaniami nad trajektoriami rozwojowymi jednostek terytorialnych, ekonomia instytucjonalna znajdzie z pewnością zastosowanie w odniesieniu do nowych zagadnień. Już dziś można zaobserwować jej wykorzystanie $\mathrm{w}$ analizie procesów współrządzenia (governance) w jednostkach terytorialnych, czy też w kolejnych próbach operacjonalizacji kosztów transakcyjnych współpracy w zakorzenionych terytorialnie relacjach między przedsiębiorstwami, albo w relacjach współpracy między jednostkami samorządu terytorialnego w ramach tzw. obszarów funkcjonalnych.

Ponadto, dorobek intelektualny ekonomii instytucjonalnej może służyć poszukiwaniu i empirycznemu testowaniu różnych metod wyceny przestrzeni publicznej oraz identyfikacji tzw. inteligentnych specjalizacji regionalnych jako zasobów strategicznych jednostek terytorialnych. Istotną użyteczność może też wykazać w odniesieniu do badania wzajemnego przenikania się różnych form bliskości (fizycznej, społecznej, poznawczej, instytucjonalnej itp.) oraz „warstw instytucjonalnych” (formalnych,

1 Zob. m.in.: Cabinet Office, Modernising Government White Paper, The Stationery Office, London 1999; P. Davies, Is evidence区based government possible?, Jerry Lee Lecture, presented at the $4^{\text {th }}$ annual Campbell Collaboration Colloquium, Washington D.C. 2004; J. Górniak, S. Mazur (red.), W kierunku polityki rynku pracy opartej na dowodach, Obserwatorium Regionalnych Rynków Pracy Pracodawców Rzeczypospolitej Polskiej, Warszawa 2011.

2 Por. T. J. Barnes et al., Methods Matter: Transformations in Economic Geography, [w:] A. Tickell et al. (eds.), Politics and Practice in Economic Geography, Sage, London 2007, s. 1-24; M. S. Gertler, Rules of the Game: The Place of Institutions in Regional Economic Change, „Regional Studies” 2010, vol. 44, no. 1, s. 7. 
nieformalnych, lokalnych, ponadlokalnych itd.), jak również do ewaluacji skuteczności efektywności polityk publicznych oraz analiz kosztów i korzyści decyzji politycznych podejmowanych w samorządzie terytorialnym, tym samym zbliżając go do upowszechnienia wspomnianej praktyki działań „opartych na dowodach naukowych” (evidence-based policy).

$\mathrm{W}$ odniesieniu do wymiaru normatywnego analiz procesów rozwoju terytorialnego ekonomia instytucjonalna nie dostarcza bezpośrednich i prostych rozwiązań, jednak z pewnością znajomość tej dziedziny nauk ekonomicznych pozwala na prowadzenie polityki rozwoju lokalnego i regionalnego w sposób bardziej wyczulony na specyfikę terytorialną i różnorodność instytucjonalną. Można przy tym zaryzykować wniosek, iż współczesna polityka rozwoju powinna poszukiwać wartości w różnorodności - czyli dla różnych układów terytorialnych odmiennych dróg do tego samego celu, którym jest długookresowa konkurencyjność jednostek terytorialnych. Innymi słowy, współczesna polityka rozwoju lokalnego i regionalnego powinna pozostawać bardziej zorientowana na specyficzne zasoby terytorialne, których źródło tkwi w specyficznych uwarunkowaniach instytucjonalnych. W tym kontekście stosowanie prostych rozwiązań w obszarze polityki ukierunkowanej na rozwój terytorialny (np. przeciwstawiających w sztuczny sposób podejście promujące interwencjonizm $\mathrm{w}$ gospodarce podejściu promującemu rozwiązania wolnorynkowe) świadczy o braku świadomości złożonych uwarunkowań instytucjonalnych procesów gospodarczych, i mimo swej atrakcyjności wynikającej z prostoty, skazane jest z góry na niepowodzenie.

Powyższe propozycje wynikają przede wszystkim z konieczności usystematyzowania i ujednolicenia podstawowych założeń proponowanych ram konceptualnych dla badań nad procesami rozwoju terytorialnego w duchu instytucjonalizmu. Postulaty te powinny jednak uwzględniać konieczność „wyczulenia” badań na specyfikę terytorialną. Należy zatem pamiętać, że z jednej strony nie wszystko może być przedmiotem dokładnego i obiektywnego pomiaru (szczególnie instytucje nieformalne) i jako takie pozostanie w sferze analiz o charakterze jakościowym, a z drugiej - więcej uwagi powinno się poświęcać analizie instytucji w konkretnych skalach geograficznych. Oznacza to, że w większości przypadków metodyka badań nad instytucjami lokalnymi nie powinna być przenoszona do prowadzenia badań na innych przestrzennych poziomach analizy. Innymi słowy, każdy poziom analizy w ujęciu geograficznym wymaga odmiennego podejścia, dostosowanego do skali i specyfiki badanego układu terytorialnego. Ponadto w prowadzonych badaniach i formułowanych na ich podstawie rekomendacjach dla polityki rozwoju należy unikać teoretycznych, konceptualnych i metodologicznych uproszczeń. Wydaje się, że postulat ten jest niezbędny dla ich dalszego rozwoju, lecz najtrudniejszy w praktycznej realizacji. 


\section{Bibliografia}

Ahn T. K., Wilson R. K., Elinor Ostrom's Contributions to the Experimental Study of Social Dilemmas, „Public Choice” 2010, no. 143, s. 327-333.

Almeida P., Kogut B., The Exploration of Technological Diversity and the Geographic Localization of Innovation, „Small Business Economics" 1997, vol. 9 (1), s. 21-31.

Amable B., The Diversity of Modern Capitalism, Oxford University Press, Oxford 2003.

Amin A. (ed.), Post-Fordism: A Reader, Blackwell, Oxford 1994, s. 101-156.

Amin A., An Institutionalist Perspective on Regional Economic Development, „International Journal of Urban and Regional Research" 1999, vol. 23 (2), s. 365-378.

Amin A., Thrift N. (eds.), Globalization, Institutions and Regional Development in Europe, Oxford University Press, Oxford 1994.

Amin A., Thrift N., Neo-Marshallian Nodes in Global Networks, „International Journal of Urban and Regional Research" 1992, vol. 16 (4), s. 571-587.

Anioł W., Paradoksy globalizacji, Instytut Polityki Społecznej Uniwersytetu Warszawskiego, Warszawa 2002.

Annoni P., Dijkstra L., EU Regional Competitiveness Index RCI 2013, Publications Office of the European Union, Luxembourg 2013.
Aoki M., Toward a Comparative Institutional Analysis, MIT Press, Cambridge 2000.

Arrow K., Agency and the Market, [w:] K. Arrow, M. D. Intrilligator (eds.), Handbook of Mathematical Economics, vol. 3, Elsevier, Amsterdam 1986, s. 1183-1195.

Arrow K., Social Choice and Individual Values, Yale University Press, New Haven 1963; wyd. pierwsze 1951.

Arthur W. B., Urban Systems and the Historical Path Dependence, [w:] W. B. Arthur, Increasing Returns and Path-Dependence in Economy, University of Michigan Press, Michigan 1994, s. 99-110.

Asheim B., 'Learning Regions' in a Globalised World Economy: Towards a New Competitive Advantage of Industrial Districts?, [w:] S. Conti, M. Taylor (eds.), Interdependent and Uneven Development: Global-Local Perspectives, Avebury, London 1997, s. 143-175.

Asheim B., Industrial Districts as Learning Regions. A Condition for Prosperity?, „Studies in Technology, Innovation and Economic Policy", University of Oslo, Oslo 1995.

Asheim B., Industrial Districts, Inter-Firm Cooperation and Endogenous Technological Development. The Experience of Developed Countries, [w:] UNCTAD, Technological Dynamism in Industrial Districts: An Alternative Ap- 
proach to Industrialization in Developing Countries?, New York-Geneva 1994, s. 91-142.

Aydalot Ph., Trajectoires technologiques et milieux l'innovation, [w:] idem (ed.), Milieux innovateurs en Europe, GREMI, Paris 1986.

Babbie E., Badania społeczne w praktyce, PWN, Warszawa 2004.

Bailly A., Territoires et territorialités, [w:] J.-P. Auray, A. Bailly, P. H. Derycke, J.-M. Huriot, Encyclopédie d'economie spatiale: concepts, comportements, organisations, Economica, Paris 1994, s. 274-279.

Barca F., An Agenda for a Reformed Cohesion Policy. A Place-based Approach to Meeting European Union Challenges and Expectations (Barca Report), April 2009.

Barczyk S., Przedsiębiorczy samorząd lokalny i jego instytucje, Wyd. Akademii Ekonomicznej im. Karola Adamieckiego, Katowice 2010.

Barnes T. J. Peck J., Sheppard E. S., Tickell A., Methods Matter: Transformations in Economic Geography, [w:] A. Tickell, E. S. Sheppard, J. Peck, T. J. Barnes (eds.), Politics and Practice in Economic Geography, Sage, London 2007, s. 1-24.

Barney J. B., Firm Resources and Sustained Competitive Advantage, „Journal of Management" 1991, vol. 12, no. 1, s. 99-120.

Becattini G., Rullani E., Sistema locale e mercato globale, „Economia e Politica Industriale" 1993, vol. 80, s. 25-40.

Becattini G., The Marshallian Industrial District as a Socio-economic Notion, [w:] G. Becattini, W. Sengenberger (eds.), Industrial Districts and Inter-firm Co-operation in Italy, International Institute of Labour Studies, Geneva 1990, s. 37-51.

Bendyk E., Świat na sześć osób, „Polityka”, 5.04.2003, nr 14 (2365), s. 74-75.

Benko G., Lipietz A., Les regions qui gagnent, Presses Universitaires de France, Paris 1992.
Bertinelli L., Decrop J., Geographical Agglomeration: Ellison and Glaeser Index Applied to the Case of Belgian Manufacturing Industry, „Regional Studies" 2005, vol. 39 (5), s. 567-583.

Bessy Ch., Institutional Embeddedness of Economic Exchange: Convergence Between New Institutional Economics and the Economics of Conventions, [w:] O. Favereau, E. Lazega (eds.), Conventions and Structures in Economic Organization Markets, Networks and Hierarchies, Edward Elgar, Cheltenham-Northampton 2002, s. 79-92.

Boltanski L., Thévenot L., The Sociology of Critical Capacity, „European Journal of Social Theory" 1999, vol. 2 (3), s. 359-378.

Boschma R. A., Competitiveness of Regions from an Evolutionary Perspective, „Regional Studies" 2004, vol. 38 (9), s. 1001-1014.

Boschma R. A., Lambooy J. G., Schutjens V., Embededdness and Innovation, [w:] M. Taylor, S. Leonard (red.), Embedded Enterprise and Social Capital. International Perspectives, Aldershot, Ashgate 2002, s. 19-35.

Boschma R. A., Proximity and Innovation: A Critical Assessment, „Regional Studies” 2005, vol. 39, no. 1, s. 61-74.

Boudeville J. R., Aménagement du territoire et polarisation, Th. Génin, Librairies techniques, Paris 1972.

Boudeville, J. R., Les espaces économiques, Presses Universitaires de France, Paris 1961.

Bourdieu P., Distinction: A Social Critique of the Judgement of Taste, Routledge and Kegan Paul, London 1984.

Boyce, D., A Short History of the Field of Regional Science, „Papers in Regional Science” 2004, vol. 83, s. 31-57.

Boyle K. J., Introduction to Revealed Preference Methods, [w:] P. Champ, K. Boyle, T. Brown (eds.), A Primer on Nonmarket Valuation, Kluwer Academic Publisher, Dordrecht 2003, s. 259-267. 
Braczyk H.-J., Cooke Ph., Heidenreich M., Regional Innovation Systems. The Role of Governance in a Globalized World, UCL Press, London 1998.

Bradley J., The Impact of Community Support Frameworks on Objective 1 Countries: Greece Ireland, Portugal and Spain 19892006, Economic and Social Research Institute, Dublin 2000.

Brdulak J., Lokalne uwarunkowania kulturowe lokalizacji przedsiębiorstw, [w:] K. Kuciński (red.), Glokalizacja, Difin, Warszawa 2011, s. 44-89.

Brenner N., Globalization as Reterritorialisation: The Re-scaling of Urban Governance in the European Union, „Urban Studies” 1999, vol. 36, no. 3, s. 431-451.

Breska von E., Investing in Europe's Future. Fifth Report on Economic, Social and Territorial Cohesion, European Commission, Directorate-General for Regional Policy, Publications Office of the European Union, Luxembourg 2010.

Brown C. V., Jackson P. M., Public Sector Economics, Basic Blackwell, Oxford 1990.

Brown T. C., Introduction to Stated Preference Methods, [w:] P. Champ, K. Boyle, T. Brown (eds.), A Primer on Nonmarket Valuation, Kluwer Academic Publisher, Dordrecht 2003, s. 99-110.

Brzeziński C., Ekonomiczne aspekty polityki przestrzennej w Polsce, [w:] A. Nowakowska (red.), Zrozumieć terytorium. Idea i praktyka, Wyd. Uniwersytetu Łódzkiego, Łódź 2013, s. 373-384.

Buchanan J. M., An Economic Theory of Clubs, „Economica” 1965, no. 32, s. 1-14.

Buchanan J. M., Constitutional Economics, [w:] J. Eatwell, M. Milgate, P. Newman (eds.), The New Palgrave: A Dictionary of Economics, Macmillan, London-Basingstoke 1987 , s. 585-588.
Buchanan J. M., Tullock G., The Calculus of Consent: Logical Foundations of Constitutional Democracy, University of Michigan Press, Ann Arbor 1962.

Budner W., Lokalizacja przedsiębiorstw. Aspekty ekonomiczno-przestrzenne i środowiskowe, Wyd. Akademii Ekonomicznej w Poznaniu, Poznań 2003.

Building Institutions for Markets: World Development Report 2002, Oxford University Press, Oxford 2002.

Bunnell T. G., Coe N. M., Spaces and Scales of Innovation, „Progress in Human Geography" 2001, 25 (4), s. 569-589.

Cabinet Office, Modernising Government White Paper, The Stationery Office, London 1999.

Camagni R., Conclusion et regard sur l'avenir, [w:] R. Camagni, D. Maillat, Milieux inovateurs. Théorie et politiques, Economica, $\mathrm{Pa}$ ris 2006.

Camagni R., Maillat D., Milieux innovateurs. Theorie et politiques, Economica, Paris 2006.

Cappelen A., Fagerberg J., Verspagen B., Lack of Regional Convergence, [w:] J. Fagerberg, P. Guerrieri, B. Verspagen (eds.), The Economic Challenge for Europe: Adapting to Innovation-based Growth, Edward Elgar, Aldershot 1999.

Carmona M., Magalhaes C., Hammond L., Public Space: the Management Dimension, Routledge, London-New York 2008.

Carroll G. R., A Sociological View on Why Firms Differ, „Strategic Management Journal” 1993, vol. 14, s. 237-249.

Castells M., Społeczeństwo sieci, PWN, Warszawa 2010.

Chakravorty S., Urban Development in the Global Periphery: The Consequences of Economic and Ideological Globalization, "The Annals of Regional Science” 2003, no. 37 , s. 357-367. 
Chang H.-J., 23 rzeczy, których nie mówiq ci o kapitalizmie, Wyd. Krytyki Politycznej, Warszawa 2013.

Chang H.-J., Economics: The User's Guide, Bloomsbury Press, New York 2014.

Charron N., Dijkstra L., Lapuente V., Regional GovernanceMatters:QualityofGovernment within European Union Member States, „Regional Studies” 2013, vol. 48 (1), s. $68-90$.

Chavance B., L'économie institutionelle, Editions La Découverte, Paris 2007.

Choumert J., Salanie J., Provision of Urban Green Spaces: Some Insights from Economics, "Landscape Research" 2008, vol. 33, no. 3, s. 331-345.

Christaller W., Die Zentralen Orte in Süddeutschland. Eine ökonomisch-geographische Untersuchung über die Gesetzmässigkeit der Vorbereitung und Entwicklung der Siedlungen mit städtischen Funktionen, Fischer, Jena 1933.

Christaller W., Ośrodki centralne w Południowych Niemczech, „Przegląd Zagranicznej Literatury Geograficznej” 1963, z. 1.

Chung W., Kalnins A., Agglomeration Effects and Performance: A Test of the Texas Lodging Industry, „Strategic Management Journal" 2001, 22 (10), s. 969-988.

Cieślik A., Geografia inwestycji zagranicznych, Wyd. Uniwersytetu Warszawskiego, Warszawa 2005.

Cities and Regions in the New Learning Economy, OECD 2001.

Clark G. L., Feldman M. P., Gertler M. S. (eds.), Oxford Handbook of Economic Geography, Oxford University Press, Oxford 2000.

Coase R., Message from Ronald Coase, „Newsletter of the International Society for New Institutional Economics" 1998, vol. 1 (1), s. 3.

Coase R., The Nature of the Firm, „Economica” 1937, vol. 4 (16), s. 386-405.
Coase R., The Problem of Social Cost, „The Journal of Law and Economics" 1960, vol. III, s. $1-44$.

Coase R.H., The Problem of Social Costs, „Journal of Law and Economics” 1960, vol. 3 (1), s. 1-44.

Cohen M. D., March J. G., Olsen J. B., A Garbage Can Model of Organizational Choice, „Administrative Science Quarterly" 1972, vol. 17, no. 1, s. 1-25.

Coleman J. S., A Rational Choice Perspective on Economic Sociology, [w:] N. J. Smelser, R. Swedberg (eds.), The Handbook of Economic Sociology, Princeton University Press, Princeton 1994.

Coleman J. S., Foundations of Social Theory, Harvard University Press, Cambridge 1990.

Colletis G., Gilly J.-P., Leroux I., Pecqueur B., Perrat J., Rychen F., Zimmermann J.-B., Construction territoriale et dynamiques économiques, „Sciences de la Société” 1999, $\mathrm{nr} 48$.

Colletis G., Pecquer B., Politiques technologiques locales et création de resources spécifiques, [w:] A. Rallet, A. Torre (eds.), Economie industrielle et spatiale, Economica, Paris 1995.

Commons J. R., Parsons K. H., Perlman S., The Economics of Collective Action, University of Wisconsin Press, Madison 1950.

Cooke Ph., Bliskość, wiedza i powstawanie innowacji, „Studia Regionalne i Lokalne” 2006, vol. 2 (24), s. 21-22.

Cooke Ph., Morgan K., The Associational Economy: Firms, Regions, and Innovation, Oxford University Press, Oxford 1998.

Cooter R., Ulen Th., Ekonomiczna analiza prawa, C.H. Beck, Warszawa 2009.

Corolleur F., Boulianne L., Crevoisier O., Decoutere S., Villes et innovation: le cas de trots villes de Suisse occidentale, Neuchatel: IRER, Working Paper 1996, no. 9601. 
Courlet C., Les systèmes productifs locaux: de la définition au modèle, [w:] Réseaux d'entreprises et territoires. Regards sur les systèmes productifs locaux, DATAR, La documentation Française, Paris 2001.

Couzon I., "Les espaces économiques » de Francois Perroux (1950). Organisation de l'espace et aménagement du territoire dans l'économie et la géographie françaises au milieu du XXème siècle, „Revue d'Histoire des Sciences Humaines" 2003, nr 9, s. 81-102.

Cox J. C., Ostrom E., Walker J. M., Castillo A. J., Coleman E., Holahan R., Schoon M., Trust in Private and Common Property Experiments, „Southern Economic Journal” 2009, vol. 75 (4), s. 957-975.

Cruz S., Teixeira A., A New Look into the Evolution of Clusters Literature. A Bibliometric Exercise, Working Papers 2007, issue 164 (December); http://wps.fep.up.pt/wps/ wp257.pdf (dostęp: 20.07.2012).

Cumbers A., MacKinnon D., McMaster R., Institutions, Power and Space. Assessing the Limits to Institutionalism in Economic Geography, „European Urban and Regional Studies" 2003, no. 10, s. 325-342.

Czaja S., Fiedor B., Graczyk A., Jakubczyk Z., Podstawy ekonomii środowiska i zasobów naturalnych, Wyd. C.H. Beck, Warszawa 2002.

Czapiński J., Panek T. (red.), Diagnoza społeczna 2013. Warunki i jakość życia Polaków, „Contemporary Economics. Quarterly of University of Finance and Management in Warsaw" 2013, vol. 7, special issue (September).

David P., Clio and the Economics of QWERTY, „American Economic Review” 1985, vol. 75, no. 2, s. 332-337.

Davidson M. G., Friction in Economics, [w:] I. Palgrave (ed.), Dictionary of Political Economy, Macmillan, London 1894.
Davies P., Is Evidence囚based Government Possible?, Jerry Lee Lecture, presented at the $4^{\text {th }}$ annual Campbell Collaboration Colloquium, Washington D.C. 2004.

Denzin N. K., The Research Act: A Theoretical Introduction to Sociological Methods, Aldine Transaction, Chicago 2009.

Diaz-Bone R., Thévenot L., La sociologie des conventions. La théorie des conventions, élément central des nouvelles sciences sociales françaises, „Trivium” 2010, nr 5; http://trivium.revues.org/3626 (dostęp: 10.04.2014).

Dierickx J., Cool K., Assets Stock Accumulation and Sustainability of Competitive Advantage, „Management Science” 1989, vol. 35, s. 1504-1513.

DiGaetano A., Strom E., Comparative Urban Governance. An Integrated Approach, „Urban Affairs Review" 2003, vol. 38, no. 3, s. 356-395.

Dixit A. K., Stiglitz J. E., Monopolistic Competition and Optimum Product Diversity, „American Economic Review” 1997, vol. 3, s. 297-308.

Dollery B. E., Leong W. H., Measuring the Transaction sector in the Australian Economy 1911-1991, „Australian Economic History Review” 1998, vol. 38, no. 3, s. 207-231.

Domański B. (red.), Dziesięć lat doświadczeń pierwszej polskiej specjalnej strefy ekonomicznej. Mielec 1995-2005, Instytut Geografii i Gospodarki Przestrzennej Uniwersytetu Jagielońskiego, Agencja Rozwoju Przemysłu SA, Kraków 2005.

Domański B., Kapitat zagraniczny w przemyśle Polski. Prawidłowości rozmieszczenia, uwarunkowania i skutki, Instytut Geografii i Gospodarki Przestrzennej Uniwersytetu Jagielońskiego, Kraków 2001.

Domański R., Ewolucyjna gospodarka przestrzenna, Wyd. Uniwersytetu Ekonomicznego w Poznaniu, Poznań 2012. 
Domański R., Geografia ekonomiczna. Ujęcie dynamiczne, PWN, Warszawa 2004

Domański R., Gospodarka przestrzenna, PWN, Warszawa 2002.

Domański R., Gospodarka przestrzenna. Podstawy teoretyczne, PWN, Warszawa 2006.

Domański R., Nowa geografia ekonomiczna według Paula Krugmana, [w:] W. M. Gaczek, Prace z gospodarki przestrzennej, „Zeszyty Naukowe Uniwersytetu Ekonomicznego w Poznaniu" 2010, nr 161, s. 9-29.

Dosi G., The Nature of the Innovative Process, [w:] G. Dosi, C. Freeman, R. Nelson, G. Silverberg, L. Soerte, Technical Change and Economic Theory, Pinter, London 1988.

Downs A., An Economic Theory of Democracy, Collier-MacMillan, London 1970.

Drobniak A., Ocena projektów publicznych, Wyd. Akademii Ekonomicznej w Katowicach, Katowice 2005.

Drucker P.F., Management Challenges for the $21^{\text {st }}$ Century, Butterworth-Heineman, Oxford-New York-Tokyo 2002.

Dupuy J.-P., Eymard-Duvernay F., Favereau O., Salais R., Thévenot L., Economie des conventions, „Revue Economique” 1989, vol. 40 (2).

Dzionek-Kozłowska J., System ekonomiczno-społeczny Alfreda Marshalla, Wyd. Naukowe PWN, Warszawa 2007.

Edquist C. (ed.), Systems of Innovation: Technologies, Institutions and Organizations, Pinter/Cassell Academic, London-Washington 1997.

Edquist C., Johnson B., Institutions and Organizations in System of Innovation, [w:] C. Edquist (ed.), Systems of Innovation: Technologies, Institutions and Organizations, Pinter/Cassell Academic, London-Washington 1997, s. 51-55.

Edwards M. E., Regional and Urban Economics and Economic Development. Theory and
Methods, Auerbach Publications, Taylor and Francis Group, New York 2007.

Eisenhardt K., Agency Theory: An Assessment and Review, „Academy of Management Review" 1989, vol. 14 (1), s. 57-74.

Elden S., Land, Terrain, Territory, „Progress in Human Geography" 2010, vol. 34 (6), s. 1-19.

Encyklopedia PWN; http://encyklopedia.pwn. pl/haslo/4009631/prakseologia.html (dostęp: 30.01.2014).

Energetyka cieplna w liczbach 2009, Polski Urząd Regulacji Energetyki, Warszawa 2010.

Espinas A., Les origines de la technologie, „Revue Philosophique", vol. XV, nr XXX, s. 113135.

Eucken W., Polityka porządku konkurencji-zasady konstytuujące, [w:] E. Mączyńska, P. Pysz (red.), Społeczna gospodarka rynkowa. Idee i możliwości praktycznego wykorzystania w Polsce, Wyd. Polskiego Towarzystwa Ekonomicznego, Warszawa 2003.

Eymard-Duvernay F., Conventionalist Approaches to Enterprise, [w:] O. Favereau, E. Lazega (eds.), Conventions and Structures in Economic Organization Markets, Networks and Hierarchies, Edward Elgar, Cheltenham-Northampton 2002, s. 60-78.

Fajferek A., Region ekonomiczny i metody analizy regionalnej, PWE, Warszawa 1996.

Fan J. P. H., Price Uncertainity and Vertical Integration: An Examination of Petrochemical Firms, „Journal of Corporate Finance: Contracting, Governance, and Organizaton" 2000, vol. 6, s. 629-660.

Feldman M., Location and Innovation: The New Economic Geography of Innovation, Spillover, and Agglomeration, [w:] G. L. Clark, M. P. Feldman, M. S. Gertler (eds.), Oxford Handbook of Economic Geography, Oxford University Press, Oxford 2000, s. 373-394. 
Feser E. J., Old and New Theories of Industry Clusters, [w:] M. Steiner (ed.), Clusters and Regional Specialisation, Pion Ltd., Londyn 1998.

Fiedor B., Nowa Ekonomia Instytucjonalna jako podstawa teoretycznej refleksji nad procesem transformacji od gospodarki centralnie sterowanej do rynkowej, http:// www.wiedzainfo.pl/wyklady/138/nowa_ ekonomia_instytucjonalna_jako_podstawa_teoretycznej_refleksji_nad_procesem_transformacji_od_gospodarki_centralnie_sterowanej_do_rynkowej.html (dostęp: 21.03.2012).

Fierla I., Lokalizacja przemysłu, PWE, Warszawa 1987.

Fischer J. H., Harrington Jr. J. E., Product Variety and Firm Agglomeration, „RAND Journal of Economics” 1996, vol. 27 (2), s. 281-309.

Florida R., Toward the Learning Region, „Futures” 1995, vol. 27, no. 5, s. 527-536.

Foray D., David P. A., Hall B., Smart Specialization: The Concept, „Knowledge Economists Policy Brief" 2009, no. 9; http:// ec.europa.eu/invest-in-research/pdf/ download_en/kfg_policy_brief_no9.pdf (dostęp: 7.10.2014).

Foss N. J., Klein P. G., Austrian Economics and the Theory of the Firm, [w:] P. G. Klein, M. Sykuta (eds.), The Elgar Companion to Transaction Cost Economics, Edward Elgar Publishing, Cheltenham-Northampton 2010, s. 281-296.

Foss N. J., Klein P. G., Critiques of Transaction Cost Economics: an Overview, [w:] P. G. Klein, M. Sykuta (eds.), The Elgar Companion to Transaction Cost Economics, Edward Elgar Publishing, Cheltenham-Northampton 2010, s. 263-272.

Freeman C., The Economics of Technical Change, "Cambridge Journal of Economics" 1994, vol. 18, s. 463-514.
Friedman J. R., A General Theory of Polarized Development, University of California, School of Architecture and Urban Planning, Los Angeles 1969.

Friedman J. R., Regional Development Policy: A Case Study of Venezuela, MIT Press, Cambridge 1966.

Fujita M., Krugman P., Venables T., The Spatial Economy, MIT Press, Cambridge 1999.

Fujita M., Thisse J. F., Economics of Agglomeration. Cities, Industrial Location, and Regional Growth, Cambridge University Press, Cambridge 2002.

Fukuyama F., Trust: The Social Virtues and the Creation of Prosperity, Hamish Hamilton, London 1995.

Furubotn E. G., Richter R., Institutions and Economic Theory. The Contribution of the New Institutional Economics, The University of Michigan Press, Ann Arbor 2000.

Gaczek W. M., Gospodarka oparta na wiedzy w regionach europejskich, Studia Komitetu Przestrzennego Zagospodarowania Kraju PAN, t. CXVIII, Warszawa 2009, s. 37-52.

Gaczek W. M., Zarządzanie w gospodarce przestrzennej, Branta, Bydgoszcz-Poznań 2003.

Gajewski P., Ekonomiczne aspekty polityki regionalnej, „Gospodarka Narodowa” 2007, nr 1-2, s. 29-81.

Gancarczyk M., Instytucja a organizacja w nowej ekonomii instytucjonalnej, „Gospodarka Narodowa" 2002, nr 5-6, s. 78-94.

Garofoli G., Economic Development. Organisation of Production and Territory, "Revue d'Économie Industrielle" 1993, nr 64, s. 22-37.

Gawlikowska-Hueckel K., Innowacje a rozwój regionów w Unii Europejskiej. Europa dwóch prędkości?, [w:] A. Jewtuchowicz (red.), Region w gospodarce opartej na wiedzy, Wyd. Uniwersytetu Łódzkiego, Łódź 2007, s. $125-137$. 
Gawlikowska-Hueckel K., Konwergencja regionalna w Unii Europejskiej, „Gospodarka Narodowa" 2002, nr 10, s. 91-113.

Gawlikowska-Hueckel K., Procesy rozwoju regionalnego w Unii Europejskiej. Konwergencja czy polaryzacja?, Wyd. Uniwersytetu Gdańskiego, Gdańsk 2003.

Gehl J., Życie między budynkami. Użytkowanie przestrzeni publicznych, Wyd. RAM, Kraków 2009.

Gertler M. S., Rules of the Game: The Place of Institutions in Regional Economic Change, „Regional Studies" 2010, vol. 44, no. 1, s. 1-15.

Gesteland R., Różnice kulturowe a zachowania w biznesie, PWN, Warszawa 2000.

Giddens A., Constitution of Society: Outline of the Theory of Structuration, University of California Press, Berkeley 1986.

Giddens, A., Socjologia, PWN, Warszawa 2007.

Giergiczny M., Kronenberg J., Jak wycenic wartość przyrody w mieście? Wycena drzew przyulicznych w centrum Łodzi, „Zrównoważony Rozwój - Zastosowania” 2012, nr 3, s. 74-89.

Giergiczny M., Rekreacyjna wartość Białowieskiego Parku Narodowego, „Ekonomia i Środowisko" 2009, no. 36, s. 116-128.

Glaeser E. L., La Porta R., Lopez-de-Silanes F., Shleifer A., Do Institutions Cause Growth?, „Journal of Economic Growth” 2004, vol. 9, no. 3, s. 271-303.

Glaeser E., Kallal H. D., Scheinkman J. D., Schleifer A., Growth in Cities, „Journal of Political Economy" 1992, no. 100, s. 1126-1152.

Godlewska H., Lokalizacja działalności gospodarczej, Wyższa Szkoła Handlu i Finansów Międzynarodowych, Warszawa 2001.

Godłów-Legiędź J., Instytucje i koszty transakcji jako podstawowe pojęcie nowej ekonomii instytucjonalnej, [w:] eadem (red.), Instytucje i transformacja, Wyd. Adam Marszałek, Toruń 2009, s. 11-32.
Godłów-Legiędź J., Instytucjonalna analiza transformacji ustrojowej, [w:] S. Rudolf (red.), Nowa ekonomia instytucjonalna. Aspekty teoretyczne i praktyczne, Wyższa Szkoła Ekonomii i Administracji im. prof. Edwarda Lipińskiego w Kielcach, Kielce 2005, s. 27-45.

Godłów-Legiędź J., Spory metodologiczne w ekonomii z perspektywy kryzysu finansowego, [w:] S. Rudolf (red.), Nowa ekonomia instytucjonalna wobec kryzysu gospodarczego, Wyższa Szkoła Ekonomii i Administracji im. prof. Edwarda Lipińskiego w Kielcach, Kielce 2012, s. 45-59.

Godziszewski B., Zasobowe uwarunkowania strategii przedsiębiorstwa, Wyd. Uniwersytetu Mikołaja Kopernika w Toruniu, Toruń 2001.

Goldman N., Wstęp do socjologii, Zysk i S-ka, Poznań 1997.

Gomez P.-Y., Information et conventions. Le cadre du modèle général, „Revue Française de Gestion" 2006, nr 160, s. 217-240.

Górniak J., Mazur S. (red.), W kierunku polityki rynku pracy opartej na dowodach, Obserwatorium Regionalnych Rynków Pracy Pracodawców Rzeczypospolitej Polskiej, Warszawa 2011.

Grabher G., Cool Projects, Boring Institutions: Temporary Collaboration in Social Context, „Regional Studies” 2002, no. 3, s. 205-214.

Granovetter M., Economic Action and Social Structure. The Problem of Embeddedness, „American Journal of Sociology” 1985, vol. 91 (1), s. 481-510.

Granovetter M., Strength of Weak Ties, „American Journal of Sociology” 1973, vol. 78, issue 6, s. 1360-1380.

Green J., Sheshinski E., Competitive Inefficiencies in the Presence of Constrained Transactions, „Journal of Economic Theory” 1975, vol. 10 (3), s. 343-357. 
Greif A., Historical an Comparative Institutional Analysis, „American Economic Review” 1998, vol. 88 (2), s. 80-84.

Grillitsch M., Institutional Change and Economic Evolution in Regions, Proceedings of the 54 ${ }^{\text {th }}$ ERSA Congress, 26-29 September, Saint-Petersburg 2014.

Grosse T. G., Przegląd koncepcji teoretycznych rozwoju regionalnego, „Studia Regionalne i Lokalne" 2002, nr 1 (8), s. 25-48.

Gruchman B., Czynniki aglomeracji i deglomeracji przemysłu w gospodarce socjalistycznej (na przykładzie Polski), PWN, Warszawa 1967.

Gruchman B., Od aglomeracji do klastrów przemysłowych i środowisk innowacyjnych, [w:] M. Klamut (red.), Polityka ekonomiczna. Współczesne wyzwania, Wyd. Naukowe PWN, Warszawa 2007, s. 203-209.

Grzeszczak J., Bieguny wzrostu a formy przestrzeni spolaryzowanej, Instytut Geografii i Przestrzennego Zagospodarowania PAN, Wyd. Continuo, Wrocław 1999.

Hamdouch A., Innovation Networks and Clusters: A Critical Review of the Recent Literature, Proceedings of the $19^{\text {th }}$ EAEPE Conference: „Economic Growth, Development and Institutions", Porto 2007; http://www. fep.up.pt/conferencias/eaepe2007/Papers\%20and\%20abstracts_CD/Hamdouch. pdf (dostęp: 20.07.2012).

Hamel G., Prahalad C. K., The Core Competences of the Corporation, „Harvard Business Review" 1990, May/June, s. 79-90.

Hamel, G., Prahalad, C.K., Przewaga konkurencyjna jutra, Business Press, Warszawa 1999. Hampden-Turner Ch., Trompenaars A., Siedem kultur kapitalizmu: USA, Japonia, Niemcy, Francja, Wielka Brytania, Szwecja, Holandia, Oficyna Ekonomiczna, Warszawa 2006.

Hardin G., The Tragedy of the Commons, "Science" 1968, vol. 162, no. 3859, s. $1243-1248$.
Hardin R., Collective Action, John Hopkins University Press, Baltimore 1982.

Hardt Ł., Ekonomia kosztów transakcyjnych - geneza i kierunki rozwoju, Wydawnictwa Uniwersytetu Warszawskiego, Warszawa 2009.

Hardt Ł., Instytucje a koszty transakcyjne w nowej ekonomii instytucjonalnej, „Gospodarka Narodowa" 2005, no. 1-2, s. 1-19.

Hardt Ł., Transaction Cost Economics as a Three Dimensional Externally Driven Research Program, „Economic Studies” 2006, no $1-2$, s. 7-31.

Hardy J., Cathedrals in the Desert? Transnationals, Corporate Strategy and Locality in Wroclaw, „Regional Studies” 1998, vol. 32 (7), s. 639-652.

Harrison B., The Italian Industrial Districts and the Crisis of the Cooperative Form: Part I-II, „European Planning Studies” 1994, no. 2 (1-2), s. 3-22; 159-174.

Harrison L., Huntington S. (red.), Kultura ma znaczenie, Zysk i S-ka, Warszawa 2003.

Harvey D., Urbanization of Capital. Studies in the History of Capitalist Urbanization, The John Hopkins University Press, Oxford 1985.

Hayek von F. A., Droit, législation et liberté, vol. 1: Règles et ordres, Presses Universitaires de France, Paris 1973.

Hayek von F. A., Law, Legislation and Liberty, vol. 1: Rules and Order, University of Chicago Press, Chicago 1973.

Healey P., Institutionalist Analysis, Communicative Planning and Shaping Places, „Journal of Planning Education and Research" 1999, no. 19 , s. 111-121.

Heijden van der J., Institutional Layering: A Review of the Use of the Concept, "Politics” 2001, vol. 31 (1), s. 9-18.

Hicks J. R., A Suggestion for Simplifying the Theory of Money, „Economica” 1935, vol. 2 (5), s. 1-19. 
Hirschman A. O., Investment Policies and Dualism in Underdeveloped Countries, „American Economic Review” 1957, vol. 47, no. 5, s. 550-570.

Hockuba Z., Nowa Ekonomia Instytucjonalna - czy zdominuje nasze myślenie w rozpoczynającym się stuleciu?, [w:] A. Wojtyna (red.), Czy ekonomia nadąża za wyjaśnianiem rzeczywistości?, PTE-Bellona, Warszawa 2001, s. 39-56.

Hodgson G. M., Choice, Habit and Evolution, "Journal of Evolutionary Economics" 2010, vol. 20, s. 1-18.

Hodgson G. M., Darwinism and Institutional Economics, „Journal of Economic Issues” 2003 , vol. 37 , no. 1 , s. 85-97.

Hodgson G. M., Economics and Evolution: Bringing Life Back Into Economics, University of Michigan Press, Ann Arbor 1997.

Hodgson G. M., Economics and Institutions, Polity Press, Cambridge 1988.

Hodgson G. M., How Veblen Generalized Darwinism, „Journal Of Economic Issues” 2008, vol. XLII, no. 2 (June), s. 399-405.

Hodgson G. M., Institutional Economics: Surveying the "Old" and the "New", „Metroeconomica" 1993, vol. 44 (1), s. 1-28.

Hodgson G. M., John R. Commons and the Foundations of Institutional Economics, „Journal of Economic Issues" 2003, vol. 37, no. 3, s. 547-576.

Hodgson G. M., Limits of Transaction Costs Analysis, [w:] P. G. Klein, M. E. Sykuta (eds.), The Elgar Companion to Transaction Cost Economics, Edward Elgar Publishing, Cheltenham-Northampton 2010, s. 297-306.

Hodgson G. M., The Revival of Veblenian Institutional Economics, „Journal of Economic Issues" 2007, vol. XLI, no. 2 (June), s. 325-340.

Hodgson G. M., Toward an Evolutionary and Moral Science. Remarks upon Receipt of the
Veblen-Commons Award, "'Journal of Economic Issues" 2012, vol. 46, no. 2, s. 265275.

Hodgson G. M., What are Institutions?, „Journal of Economics Issues" 2006, vol. 40 (1), s. 1-26.

Hofstede G., Kultury i organizacje. Zaprogramowanie umysłu, PWE, Warszawa 2000.

Holmstrom B., Moral Hazard in Teams, „Bell Journal of Economics” 1982, vol. 13 (2), s. 324-340.

Hołub-Iwan J., Olczak A., Cheba K., Benchmarking parków technologicznych w Polsce. Edycja 2012, Polska Agencja Rozwoju Przedsiębiorczości, Warszawa 2012.

Honorè A. M., Ownership, [w:] A. G. Guest (ed.), Oxford Essays in Jurisprudence, Oxford University Press, London 1961.

Hoover E. M., Location Theory and the Shoe and Leather Industries, Harvard University Press, Cambridge 1937.

Hoover E. M., Lokalizacja działalności gospodarczej, PWN, Warszawa 1962.

Hotelling H., Stability in Competition, „Economic Journal" 1929, vol. 39 (153), s. 41-57.

http://www.doingbusiness.org/ /media/ FPDKM/Doing\%20Business/Documents/ Annual-Reports/English/DB12-Chapters/About-Doing-Business.pdf (dostęp: 2.10.2014).

http://www.doingbusiness.org/methodology/ methodology-note (dostęp: 1.10.2015).

http://www.doingbusiness.org/Reports/Regional\%20Reports (dostęp: 2.10.2014).

http://www.doingbusiness.org/Reports/Subnational\%20Reports (dostęp: 2.10.2014).

http://www.nobelprize.org/nobel_prizes/ economics/laureates/2009 (dostęp: 31.01.2014).

http://www.radni.dlalodzi.info/o-monitoringu/o-co-chodzi-w-projekcie (dostęp: 06.10.2014). 
https://www.cia.gov/library/publications/ the-world-factbook/geos/rs.html (dostęp: 03.10.2014).

Hunt S. D., Resource-advantage Theory: An Evolutionary Theory of Competitive Firm Behavior?, „Journal of Economic Issues” 1997, vol. 31, no. 1, s. 59-71.

International Council of Shopping Centers, Certified Shopping Center Manager (CSM) Handbook, New York 2001.

Isard W., Metody analizy regionalnej. Wprowadzenie do nauki o regionach, PWN, Warszawa 1965.

Iwanek M., Wilkin J., Instytucje i instytucjonalizm w ekonomii, Uniwersytet Warszawski, Wydział Nauk Ekonomicznych, Warszawa 1997.

Jacobs J., The Economy of Cities, Random House, New York 1969.

Jagd S., Economics of Convention and New Economic Sociology. Mutual Inspiration and Dialogue, „Current Sociology” 2007, vol. 55 (1) (January), s. 75-91.

Jakubowski M., Dobra publiczne $i$ dobra wspólne, J. Wilkin (red.), Teoria wyboru publicznego. Wstęp do ekonomicznej analizy funkcjonowania sfery publicznej, Scholar, Warszawa 2005, s. 159-183.

Jakubowski M., Teoria wyboru społecznego, [w:] J. Wilkin (red.), Teoria wyboru publicznego. Wstęp do ekonomicznej analizy funkcjonowania sfery publicznej, Scholar, Warszawa 2005, s. 46-68.

Jałowiecki B., Społeczne wytwarzanie przestrzeni, Wyd. Naukowe Scholar, Warszawa 2010.

Jażdżewska I., Sieć i system osadniczy miast, [w:] S. Liszewski (red.), Geografia urbanistyczna, Wyd. Uniwersytetu Łódzkiego, Łódź 2008, s. 321-354.

Jensen M., Meckling W., Theory of the Firm: Managerial Behavior, Agency Costs, and Ownership Structure, „Journal of Financial Economics" 1976, no. 3, s. 305-360.
Jewtuchowicz A., Bieguny wzrostu, [w:] K. B. Matusiak (red.), Innowacje i transfer technologii. Słownik pojęć, Polska Agencja Rozwoju Przedsiębiorczości, Warszawa 2008, s. 31.

Jewtuchowicz A., Budowa konkurencyjności regionów. Rozważania na temat dynamiki rozwoju terytorialnego, [w:] R. Brol (red.), Gospodarka lokalna i regionalna $w$ teorii i praktyce, „Prace Naukowe Akademii Ekonomicznej we Wrocławiu" nr 1023, Wrocław 2004.

Jewtuchowicz A., Efekty zewnętrzne w procesach urbanizacji i uprzemysłowienia, Wyd. Uniwersytetu Łódzkiego, Łódź 1987.

Jewtuchowicz A., Terytorium i jego rozwój w warunkach globalizacji, [w:] E. Molendowski (red.), Globalizacja i regionalizacja we współczesnym świecie. Księga jubileuszowa dedykowana Profesor Irenie Pietrzyk, Wyd. Uniwersytetu Ekonomicznego w Krakowie, Kraków 2012, s. 23-33.

Jewtuchowicz A., Terytorium i współczesne dylematy jego rozwoju, Wyd. Uniwersytetu Łódzkiego, Łódź 2005.

Jones B. D., Bounded Rationality, „Annual Review of Political Science” 1997, vol. 2, s. 297-321.

Joskow P. L., Contract Duration and Relationship-specific Investment: Empirical Evidence from Coal Markets, „American Economic Review" 1987, vol. 77 (1), s. 168-185.

Kacprzyk A., Wkład psychologii w neoinstytucjonalna modyfikację zasady racjonalności, [w:] S. Rudolf (red.), Nowa ekonomia instytucjonalna. Aspekty teoretyczne i praktyczne, Wyższa Szkoła Ekonomii i Administracji im. prof. Edwarda Lipińskiego w Kielcach, Kielce 2005, s. 123-125.

Kaczmarek T., Mikuła Ł., Ustroje terytorialno-administracyjne obszarów metropolitalnych w Europie, Bogucki Wyd. Naukowe, Poznań 2007. 
Kahneman D., Tversky A., Prospect Theory: An Analysis of Decision Under Risk, „Econometrica” 1979, vol. 47, no. 2, s. 263-291.

Kalisiak-Mędelska M., Self-Government in Poland and Russian Federation - Introductory Remarks, [w:] M. E. Sokołowicz (red.), Functioning of the Local Production Systems in Central and Eastern European Countries and Siberia - Case Studies and Comparative Studies, Wyd. Uniwersytetu Łódzkiego, Łódź 2015, s. 119-138.

Kapuściński R., Lapidarium, Czytelnik, Warszawa 2006.

Kay J., Podstawy sukcesu firmy, PWE, Warszawa 1996.

Keynes J. M., Ogólna teoria zatrudnienia, procentu i pieniądza, PWN, Warszawa 2003.

Kirat T., Lung Y., Innovation and Proximity: Territories as Loci of Collective Learning Processes, „European Urban and Regional Studies" 1999, vol. 6 (1), s. 27-39.

Klasik A., Optymalna struktura przestrzenna a rozwój regionalny, PWE, Warszawa 1974.

Klein P. G., New Institutional Economics, [w:] B. Bouckaert, G. DeGeest (eds.), Encyclopedia of Law and Economics, Edward Elgar, Cheltenham 2000, s. 456-489.

Klein P. G., Transaction Cost Economics and the New Institutional Economics, [w:] P. G. Klein, M. E. Sykuta, The Elgar Companion to Transaction Cost Economics, Edward Elgar Publishing, Cheltenham-Northampton 2010, s. 27-35.

Klimczak B., Uwagi o powiq̨zaniach między standardowq ekonomiq i nowq ekonomiq instytucjonalnq, [w:] S. Rudolf (red.), Nowa ekonomia instytucjonalna. Aspekty teoretyczne i praktyczne, Wyższa Szkoła Ekonomii i Administracji im. prof. Edwarda Lipińskiego w Kielcach, Kielce 2005, s. 11-26.

Knödler H., Alberthauser U., Glocalisation, Foreign Direct Investment and Regional Develop- ment Perspectives: Empirical Results for West German Regions, HWWA Discusion Paper no. 117, Hamburg 2001, s. 14; http://econstor. eu/bitstream/10419/19434/1/117.pdf (dostęp: 28.08.2013).

Kochanowska D., Przestrzeń publiczna - kluczowy element miasta współczesnego - zintegrowana czy podzielona? [w:] P. Lorens, J. Martyniuk-Pęczek (red.), Problemy ksztattowania przestrzeni publicznych, Wyd. Urbanista, Gdańsk 2011, s. 21-35.

Kochanowski M. (red.), Przestrzeń publiczna miasta postindustrialnego, Wyd. Politechniki Gdańskiej, Gdańsk 2002.

Kornai J., Eggleston K., Welfare, Choice and Solidarity in Transition. Reforming the Health Sector in Eastern Europe, Cambridge University Press, Cambridge 2001.

Kostro K., Zagadnienia kulturowe w ekonomii, „Gospodarka Narodowa” 2009, nr 3, s. 27-59. Kowalewski A., Mordasewicz J., Osiatyński J., Regulski J., Stępień J., Śleszyński P., Raport o ekonomicznych stratach $i$ spotecznych kosztach niekontrolowanej urbanizacji w Polsce, Fundacja Rozwoju Demokracji Lokalnej - Instytut Geografii i Przestrzennego Zagospodarowania im. S. Leszczyckiego PAN, Warszawa 2013.

Kowalska K., Kontraktowanie i koszty transakcyjne w nowej ekonomii instytucjonalnej, „Gospodarka Narodowa” 2005, nr 7-8, s. 45-64.

Kronenberg J., Bergier T., Wyzwania zrównoważonego rozwoju w Polsce, Fundacja Sendzimira, Kraków 2010.

Krugman P., Development, Geography and Economic Theory, MIT Press, Cambridge 1998.

Krugman P., Geography and Trade, MIT Press, Cambridge 1991.

Krugman P., Increasing Returns and Economic Geography, „Journal of Political Economy” 1991, vol. 99 (3), s. 483-499. 
Krugman P., Where in the World is the 'New Economic Geography'?, [w:] G. L. Clark, M. P. Feldman, M. S. Gertler (eds.), Oxford Handbook of Economic Geography, Oxford University Press, Oxford 2000, s. 49-60.

Kuciński K., Podstawy teorii rozwoju ekonomicznego, PWN, Warszawa 1990.

Kukliński A., Kołodziejski J., Markowski T., Dziemianowicz G., Globalizacja polskich metropoliii, Euroreg, Warszawa 2000.

Kwaśnicki W., Ekonomia ewolucyjna - alternatywne spojrzenie na proces rozwoju gospodarczego. Część l, „Gospodarka Narodowa” 1996, nr 10, s. 1-13.

Lackowska M., Zarzadzanie obszarami metropolitalnymi w Polsce. Między dobrowolnościq a imperatywem, Wyd. Uniwersytetu Warszawskiego, Warszawa 2009.

Lacour C., La tectonique des territoires: d'une métaphore à une théoretisation, [w:] B. Pecqueur (red.), Dynamiques territoriales et mutations économiques, L'Harmattan, Paris 1996, s. 36-38.

Lambooy J. G., Globalization, Regional Context and Governance: A Relational Perspective, [w:] H. Bünz, A. Kukliński, Globalization, Experiences and Prospects, Wyd. Rewasz, Warszawa 2001, s. 301-302.

Lämmer-Gamp Th., Meier zu Köcker G., Christensen Th. A., Clusters Are Individuals. Creating Economic Growth through Cluster Policies for Cluster Management Excellence, Danish Ministry of Science, Technology and Innovation/Competence Networks Germany, Copenhagen-Berlin 2011.

Langlois R. N., Transaction Cost Economics in Real Time, "Industrial and Corporate Change" 1992, vol. 1 (1), s. 99-127.

Latsis J., de Larquier G., Besis F., Are Conventions Solutions to Uncertainty? Contrasting Visions of Social Coordination, „Journal of
Post Keynesian Economics” 2010, Vol. 32, no. 4, s. 535-558.

Launhardt W., Die Bestimmung des Zweckmäßigsten Standortes einer gewerblichen Anlage, „Zeitschrift des Vereins Deutschen Ingenieure" 1882, vol. XXVI.

Le Berre M., Territoires, [w:] A. Bailly, R. Ferras, D. Pumain (eds.), Encyclopedie de géographie, Economica, Paris 1992.

Lefebvre H., La révolution urbaine, Gallimard, Paris 1970.

Levinthal D., A Survey of Agency Models of Organizations, „Journal of Economic Behavior and Organization" 1988, no. 9, s. 153-185.

Loasby B. J., Knowledge, Institutions and Evolution in Economics, Routledge, London 1999.

Lorens P., Definiowanie współczesnej przestrzeni publicznej, [w:] P. Lorens, J. Martyniuk-Pęczek (red.), Problemy ksztattowania przestrzeni publicznych, Wyd. Urbanista, Gdańsk 2011, s. 6-20.

Lösch A., Die räumliche Ordnung der Wirtscha$f t$. Eine Untersuchung über Standort, Wirtschaftsgebiete und internationalem Handel, Fischer, Jena 1940.

Lösch A., Gospodarka przestrzenna - teoria lokalizacji, PWE, Warszawa 1961.

Lösch A., The Economics of Location, Yale University Press, New Haven 1954.

Lucas R., Making a Miracle, „Econometrica” 1993, no. 61, s. 251-272.

MacKinnon D., Cumbers A., Pike A., Birch K., McMaster R., Evolution in Economic Geography: Institutions, Political Economy, and Adaptation, „Economic Geography” 2009, vol. 85 (2), s. 129-150.

Maillat D., Interactions between Urban Systems and Localized Productive Systems: An Approach to Endogenous Regional Development in Terms of Innovative Milieu, „European Planning Studies” 1998, vol. 6 (2), s. $117-130$. 
Majer A., Socjologia i przestrzeń miejska, PWN, Warszawa 2010.

Malawski M., Wieczorek A., Sosnowska H., Konkurencja i kooperacja. Teoria gier w ekonomii i naukach społecznych, PWN, Warszawa 2006.

Malisz B., Zarys teorii kształtowania układów osadniczych, Arkady, Warszawa 1966.

Malizia E. E., Feser E. J., Understanding Local Economic Development, Center for Urban Policy Research, Rutgers, New York 1999, s. 109-117.

Malmberg A., Industrial Geography: Agglomeration and Local Milieu, „Progress in Human Geography” 1996, vol. 20, no. 3, s. 392-403.

March J. G., Olsen J. P., Instytucje. Organizacyjne podstawy polityki, Scholar, Warszawa 2005.

March J. G., Olsen J. P., The New Institutionalism: Organizational Factors in Political Life, „The American Political Science Review” 1984, vol. 78, no. 3, s. 734-749.

Marschak J., The Rationale for the Demand for Money and for "Money Illusion”, „Metroeconomica" 1950, vol. 2, s. 71-100.

Marshall A., Principles of Economics, Macmillan, London 1920.

Marshall A., Zasady ekonomiki, Wyd. M. Arota, Warszawa 1925.

Martens B., The Cognitive Mechanics of Economic Development and Institutional Change, Routledge, London-New York 2004.

Martin R., Sunley P., Deconstructing Clusters: Chaotic Concept or Political Panacea?, „Journal of Economic Geography” 2003, vol. 3 (1), s. 5-35.

Martin R., The New „Geographical Turn” in Economics: Some Critical Reflections, "Cambridge Journal of Economics” 1999, nr 23, s. 65-91.

Maskell P., Eskelinen H., Hannibalsson I., Malmberg A., Vatne E., Competitiveness,
Localised Learning and Regional Development, Routledge, London 1998.

Maskell P., Towards a Knowledge-based Theory of the Geographical Cluster, „Industrial and Corporate Change" 2001, vol. 10 (4), s. 921-943.

Mazur S., Władza dyskrecjonalna wysokich urzędników publicznych. Perspektywa nowego instytucjonalizmu, Wyd. Uniwersytetu Ekonomicznego, Kraków 2011.

McCann B. T., Vroom G., Pricing Response to Entry and Agglomeration Economies, „Strategic Management Journal" 2010, vol. 31, s. 284-305.

McCann L., Colby B., Easter K. W., Kasterine A., Kuperan K. V., Transaction Cost Measurement for Evaluating Environmental Policies, „Ecological Economics” 2005, vol. 52, s. 527-542.

McCann Ph., Shefer D., Location, Agglomeration, Infrastructure, „Papers in Regional Science" 2004, nr 83, s. 177-196.

McCann Ph., Urban And Regional Economics, Oxford University Press, Oxford 2001.

McCann, B.T., Folta, T.B., Location Matters: Where We Have Been and Where We Might Go in Agglomeration Research," Journal of Management", Vol. 34 No. 3, June 2008, ss. 532-565

Measuring the Quality of Government and Subnational Variation, Raport Dyrekcji Generalnej ds. Polityki Regionalnej Komisji Europejskiej, Uniwersytet Goeteborski, Goeteborg 2010; http://ec.europa.eu/regional_policy/sources/docgener/studies/pdf/2010_ government_1.pdf (dostęp: 11.06.2015).

Medema S. G., Zerbe R. O., The Coase Theorem, [w:] B. Bouckaert, G. De Geest (eds.), Encyclopedia of Law and Economics, vol. I: The History and Methodology of Law and Economics, Edward Elgar, Cheltenham 1999, s. $836-892$. 
Ménard C., Hybrid organizations, [w:] P. G. Klein, M. Sykuta (eds.), The Elgar Companion to Transaction Cost Economics, Edward Elgar Publishing, Cheltenham-Northampton 2010, s. 176-184.

Metelska-Szaniawska K., Ekonomia konstytucyjna - ekonomia polityczna ładu gospodarczego, [w:] J. Wilkin (red.), Teoria wyboru publicznego. Wstęp do ekonomicznej analizy funkcjonowania sfery publicznej, Scholar, Warszawa 2005, s. 87-110.

Metelska-Szaniawska, Ekonomiczna teoria władzy ustawodawczej i sqdowniczej, [w:] J. Wilkin (red.), Teoria wyboru publicznego. Wstęp do ekonomicznej analizy funkcjonowania sfery publicznej, Scholar, Warszawa 2005, s. 111-142.

Michalak T., Ekonomiczna teoria demokracji Anthony'ego Downsa, [w:] J. Wilkin (red.), Teoria wyboru publicznego. Wstęp do ekonomicznej analizy funkcjonowania sfery publicznej, Scholar, Warszawa 2005, s. 69-86.

Miklaszewska J., Filozofia a ekonomia. W kręgu teorii publicznego wyboru, Wyd. Uniwersytetu Jagiellońskiego, Kraków 2001.

Milewski R., Kwiatkowski E., Podstawy ekonomii, PWN, Warszawa 2007.

Milgram S., The Small World Problem, „Psychology Today" 1967 , no. 2, s. 60-67.

Mises von L., Human Action: A Treatise on Economics, Yale University Press, New Haven 1949.

Mises von L., Ludzkie działanie. Traktat o ekonomii, s. 4; http://mises.pl/pliki/upload/HumanAction_rozdz1-3.pdf (dostęp: 30.12.2012).

Mitnick B. M., Fiduciary Responsibility and Public Policy: The Theory of Agency and Some Consequences, presented at $69^{\text {th }}$ Annual Meeting of American Political Science Association, New Orleans 1973.

Moulaert F., Institutional Economics and Planning Theory: A Partnership Between
Ostriches?, „Planning Theory” 2005, vol. 4, no. 21, s. 21-32.

Moulaert F., Lambooy L., The Economic Organisation of Cities: An Institutional Perspective, „International Journal of Urban and Regional Research" 1966, vol. 20 (2), s. 217-237.

Moulaert F., Sekia F., Territorial Innovation Models: A Critical Survey, „Regional Studies” 2003, vol. 37, no. 3, s. 289-302.

Mueller D. C., Public Choice III, Cambridge University Press, Cambridge 2003, s. 634-639.

Myrdal G., Economic Theory and Underdeveloped Regions, Gerald Duckworth, London 1957.

Neffke F., Henning M., Boschma R., Lundquist K.-J., Olander L.-O., The Dynamics of Agglomeration Externalities Along the Life Cycle of Industries, „Regional Studies” 2011, vol. 45, no. 1 , s. 49-65.

Nelson R. R., Winter S. G., An Evolutionary Theory of Economic Change, Belknap Press, Cambridge 1982.

Nooteboom B., Innovation, Learning and Industrial Organization, „Cambridge Journal of Economics” 1999, vol. 23 (2), s. 127-150.

North D. C., Economic Performance through Time, „American Economic Review” 1994, vol. 84, no. 3 (June), s. 359-367.

North D. C., Institutions, Institutional Change and Economic Performance, Cambridge University Press, Cambridge 1997.

North D. C., The New Institutional Economics, "Journal of Institutional and Theoretical Economics" 1986, no. 142, s. 230-237.

North D. C., Wallis J. J., Measuring the Transaction Sector in the American Economy, 18701970, [w:] S. L. Engerman, R. E. Gallman, Long Term Factors in American Economic Growth, University of Chicago Press, Chicago 1986, s. 95-148.

Nowakowska A., Przygodzki Z., Sokołowicz M., Mapping Clusters in Poland. A Com- 
prehensive Methodological Approach, [w:] T. Markowski, M. Turała (eds.), Theoretical and Practical Aspects of Urban and Regional Development, Polish Academy of Sciences - Committee for Spatial Economy and Regional Planning, Warsaw 2009, s. 265-280.

Nowakowska A., Regionalny wymiar procesów innowacji, Wyd. Uniwersytetu Łódzkiego, Łódź 2011.

Nowińska-Łaźniewska E., Relacje przestrzenne w Polsce w okresie transformacji w świetle teorii rozwoju regionalnego, „Prace Habilitacyjne Akademii Ekonomicznej w Poznaniu" nr 13, Poznań 2004.

O'Brien R., Global Financial Integration: The End of Geography, Pinter, London 1992.

O'Sullivan A., Urban Economics, McGraw Hill-Irwin, New York 2007.

OECD, Promoting Growth in All Regions, Paris 2012.

OECD, Technology and the Economy. The Key Relationships, Paris 1992.

Okoń-Horodyńska E., Narodowy system innowacji w Polsce, Wyd. Akademii Ekonomicznej w Katowicach, Katowice 1998.

Orléan A., Vers un modèle général de la coordination économique par les conventions, [w:] idem (ed.), Analyse économique des conventions, Presse Universitaires de France, Paris 1994, s. 9-40.

Ostrom E., Governing the Commons. The Evolution of Institutions for Collective Action, Cambridge University Press, New York 1990.

PAIZ, List of Major Foreign Investors in Poland December 2004, Polska Agencja Informacji i Inwestycji Zagranicznych, Warszawa 2005.

Palander T., Beitrdge zur Standortstheorie, Almqvist and Wiksells, Uppsala 1935.

Panne van der G., Agglomeration Externalities: Marshall versus Jacobs, „Journal of Evolutionary Economics" 2004, no. 14, s. 593604.
PARP, Benchmarking klastrów w Polsce - 2010, Warszawa 2010; http://www.pi.gov.pl/ PARPFiles/file/klastry/Benchmarking_klastrow/Benchmarking_klastrow_w_Polsce_2010.pdf (dostęp: 7.10.2014).

Parysek J. J., Podstawy gospodarki lokalnej, Wyd. Uniwersytetu A. Mickiewicza w Poznaniu, Poznań 2001.

Patel R., Wartość niczego. Jak przekształcić spoteczeństwo rynkowe i na nowo zbudować demokrację, Wyd. Muza, Warszawa 2010.

Pavlinek B., Domański B., Guzik R., Industrial Upgrading through Foreign Direct Investment in Central European Automotive Manufacturing, „European Urban and Regional Studies" 2009, vol. 16 (1), s. 43-63.

Pecqueur B., Le développement local; pour une économie des territories, deuxième edition revue et augmentée, Syros, Paris 2000.

Perroux F., Economic Space: Theory and Applications, "Quarterly Journal of Economics” 1950, vol. 64 (1), s. 89-104.

Perroux F., La notion de pôle de croissance, „Économie Appliquée" 1955, vol. 8, s. 307-314.

Perroux F., Les espaces économiques, „Économie Appliquée" 1950, vol. 3, s. 225-244

Piasecki P., Pierwsze kroki w foresight, [w:] Regionalna strategia innowacji - foresight regionalny, Społeczna Wyższa Szkoła Przedsiębiorczości i Zarządzania, Łódź 2004.

Pierre J., Models of Urban Governance. The Institutional Dimension of Urban Politics, „Urban Affairs Review” 1999, vol. 34, s. 372-396.

Pietrzyk I., Globalizacja, integracja europejska a rozwój regionalny, [w:] A. Jewtuchowicz (red.), Wiedza, innowacyjność, przedsiębiorczość a rozwój regionów, Wyd. Uniwersytetu Łódzkiego, Łódź 2004, s. 9-22.

Pietrzyk I., Polityka regionalna Unii Europejskiej i regiony w państwach członkowskich, PWN, Warszawa 2001. 
Pigou A. C., The Economics of Welfare, Macmillan and Co., London 1920.

Pike A., Rodríguez-Pose A., Tomaney J., Local and Regional Development, Routledge, London-New York 2006.

Piore M., Sabel C., The Second Industrial Divide, Basic Books, New York 1984.

Płatkowski T., Wstęp do teorii gier, Uniwersytet Warszawski, Warszawa 2012; http://mst. mimuw.edu.pl/wyklady/wtg/wyklad.pdf (dostęp: 17.04.2014).

Polanyi K., L'économie comme procesus institutionnalisé, [w:] K. Polanyi, C. Arensberg, $\mathrm{K}$. Pearson, Les systèmes économiques dans l'histoire et la théorie (oryg.: Trade and Market in the Early Empires), Larousse, Paris 1957.

Polanyi K., The Economy as Instituted Process, [w:] K. Polanyi, C. M. Arensberg, H. W. Pearson (red.), Trade and Market in the Early Empires. Economies in History and Theory, Free Press, New York 1957, s. 243-270.

Polanyi K., The Great Transformation: The Political and Economic Origins of Our Time, Rinehart, New York 1944.

Polanyi K., Wielka transformacja, PWN, Warszawa 2010.

Polko A., Urban Public Spaces - from Economics to Management, [w:] K. Heffner, A. PoIko (eds.), Urban Public Space - Economics and Management Perspective, Polish Academy of Sciences - Committee for Spatial Economy and Regional Planning, Warsaw 2012, s. 9-21.

Ponsard G., Économie et éspace, Sedes, Paris 1955.

Porter M. E., Clusters and the New Economics of Competition, „Harvard Business Review” 1998, vol. 76 (6), s. 77-90.

Porter M. E., On Competition, Harvard Business School Press, Cambridge 1998.

Porter M. E., The Competitive Advantage of Nations, The Free Press, New York 1990.
Practical Guide to Regional Foresight, FOREN Network (Foresight for Regional Development), European Commission Research Directorate General, STRATA Programme, December 2001.

Predöhl A., Das Standortsproblem in der Wirtschaftstheorie, „Weltwirtschaftliches Archiv" 1925, vol. 21, s. 294-321.

Przygodzki Z., Nowakowska A., Chądzyński J., Region i jego rozwój w warunkach globalizacji, Wyd. CeDeWu, Warszawa 2007.

Putnam R., Bowling Alone: The Collapse and Revival of American Community, Simon and Schuster, New York 2000.

Radzka B., Stary i nowy instytucjonalizm. Spotkanie socjologii i ekonomii, „MBA” 2009, nr 2, s. 62-74.

Rallet A., Torre A., Is Geographical Proximity Necessary in the Innovation Networks in the Era of the Global Economy?, "GeoJournal” 1990, vol. 49 (4), s. 373-380.

Rallet A., Torre A., Proximity and Localization, „Regional Studies” 2005, vol. 39, no. 1 , s. 47-59.

Regulski, J., Ekonomika miasta, PWE, Warszawa 1982.

Reilly J., The Law of Retail Gravitation, W. Reilly Editions, New York 1931.

Rodríguez-Pose A., Do Institutions Matter for Regional Development?, Working Papers Series in Economics and Social Sciences, Sciencias Sociales IMDEA 2010, no. 02.

Rondo-Brovetto P., Saliterer I., Comparing Regions, Cities, and Communities: Local Government Benchmarking as an Instrument for Improving Performance and Competitiveness, „The Innovation Journal: The Public Sector Innovation Journal" 2007, vol. 12, no. 3, article 13.

Rosenthal S., Strange W., Evidence on the Nature and Sources of Agglomeration Economies, [w:] V. Henderson, J.-F. Thisse (eds.), 
Handbook of Regional and Urban Economics 4: Cities and Geography, Elsevier, Amsterdam 2004.

Ross S. A., The Economic Theory of Agency: The Principal's Problem, „American Economic Review" 1977, no. 63, s. 134-139.

Rothstein B., Teorell J., What is Quality of Government? A Theory of Impartial Government Institutions, Governance, „International Journal of Policy, Administration and Institutions" 2008, vol. 21, s. 165-190.

Rudolf S., Nowa ekonomia instytucjonalna lekarstwem na kryzys, [w:] S. Rudolf (red.), Nowa ekonomia instytucjonalna wobec kryzysu gospodarczego, Wyższa Szkoła Ekonomii i Administracji im. prof. Edwarda Lipińskiego w Kielcach, Kielce 2012, s. $13-27$.

Rumelt R. M., Towards a Strategic Theory of the Firm, [w:] R. B. Lamb (ed.), Competitive Strategic Management, Prentice Hall, New Jersey 1984, s. 556-570.

Sage A. P., Rouse W. B. (eds.), Handbook of Systems Engineering and Management, John Wiley and Sons, Hoboken 1999.

Salmi P., Blomqvist K., Ahola J., Kyläheiko K., Industrial Districts and Regional Development. Towards a Knowledge-based View, Telecom Business Research Center, Lappeenranta 2001.

Sassen S., Cities in a World Economy, Columbia University Press, New York 2003.

Sassen S., Globalizacja. Eseje o nowej mobilności ludzi o pieniędzy, Wyd. Uniwersytetu Jagiellońskiego, Kraków 2007.

Saxenian A., Regional Advantage: Culture and Competition in Silicon Valley and Route 128, Harvard University Press, Cambridge 1994.

Schickler E., Disjointed Pluralism: Institutional Innovation and the Development of the US Congress, Princeton University Press, Princeton 2001.
Schienstock G., Path Dependency and Path Creation in Finland, [w:] A. Jakubowska, A. Kukliński, P. Żuber (eds.), The Future of European Regions, Polish Ministry of Regional Development, Warsaw 2007.

Schumpeter J. A., Teoria rozwoju gospodarczego, PWN, Warszawa 1960.

Schumpeter J. A., Theorie der Wirtschaftlichen Entwicklung, Dunker und Humboldt, Leipzig 1912.

Scitovsky T., A Study of Interest and Capital, „Economica” 1940, vol. 7 (27), s. 293-317.

Scitovsky T., Two concepts of external economies, „Journal of Political Economy” 1954, no. 2, s. 443-451.

Scott A., Economic Geography: The Great Half Century, [w:] G. L. Clark, M. P. Feldman, M. S. Gertler (eds.), Oxford Handbook of Economic Geography, Oxford University Press, Oxford 2000, s. 18-44.

Scott A., L'économie métropolitaine: organisation industrielle et croissance urbaine, [w:] G. Benko, A. Lipietz (eds.), Les régions qui gagnent, Presses Universitaires de France, Paris 1992, s. 118-120, [cyt. za:] A. Jewtuchowicz, Terytorium i wspótczesne dylematy jego rozwoju, Wyd. Uniwersytetu Łódzkiego, Łódź 2005, s. 125.

Scott A., New Industrial Spaces: Flexible Production Organization and Regional Development in North America and Western Europe, Pion, London 1998.

Scott A., Storper M., Regions, Globalization, Development, „Regional Studies” 2003, vol. 37 (6-7), s. 579-593.

Secomski K., Teoria rozwoju regionalnego i planowania, PWE, Warszawa 1987.

Shapiro S. P., Agency Theory, „Annual Review of Sociology" 2005, vol. 31, s. 263-284.

Shaver J. M., Flyer F., Agglomeration Economies, Firm Heterogeneity, and Foreign Direct Investment in the United States, 
„Strategic Management Journal” 2000, vol. 21 (12), s. 1175-1193.

Simon H. A., A Behavioral Model of Rational Choice, „Quarterly Journal of Economics” 1955, no. 6, s. 99-118.

Simon H. A., From Substantive to Procedural Rationality, [w:] C. Latsis (ed.), Method and Appraisal in Economics, Cambridge University Press, Cambridge 1976, s. 129-148.

Simonson M., L'économie des conventions; https://pure.fundp.ac.be/ws/files/4007142/69169.pdf (dostęp: 10.04.2014).

Słodczyk J., Przestrzeń miasta i jej przeobrażenia, „Studia i Monografie Uniwersytetu Opolskiego" nr 298, Opole 2003.

Soja E. E., The Political Organization of Space, Association of American Geographers, Commission on College Geography Resource Paper 8, Washington D.C. 1971.

Sokołowicz M. E., Instytucjonalne modele urban governance jako próba odpowiedzi na współczesne wyzwania rozwojowe miast, [w:] W. M. Gaczek (red.), Dynamika, cele i polityka zintegrowanego rozwoju regionów. Aspekty teoretyczne i zarządzanie w przestrzeni, Bogucki Wyd. Naukowe, Poznań 2013, s. 147-161.

Sokołowicz M. E., Koordynacja polityki proinwestycyjnej jako wyraz wzmacniania powiq̨zań gospodarczych w kształtowaniu spójności Obszaru Metropolitalnego. Studium przypadku ŁOM, [w:] A. Jewtuchowicz, M. Wójcik (red.), Łódzka metropolia. Problemy integracji gospodarczej, Wyd. Biblioteka, Łódź 2010, s.125-150.

Sokołowicz M. E., Region w gospodarce globalnej - bezpośrednie inwestycje zagraniczne a rozwój regionu, [w:] A. Nowakowska, Z. Przygodzki, M. E. Sokołowicz, Region w gospodarce opartej na wiedzy. Kapitat ludzki - innowacje - korporacje transnarodowe, Difin, Warszawa 2011, s. 131-213.
Sokołowicz M. E., Region wobec procesów globalizacji - terytorializacja przedsiębiorstw międzynarodowych (na przykładzie regionu łódzkiego), Wyd. Uniwersytetu Łódzkiego, Łódź 2008.

Sokołowicz M. E., Strategie lokalne wobec korporacji transnarodowych jako czynnik integracji lub dezintegracji Łódzkiego Obszaru Metropolitalnego, [w:] A. Jewtuchowicz, M. Wójcik (red.), Łódzka metropolia. Problemy integracji gospodarczej, Wyd. Biblioteka, Łódź 2010, s. 109-124.

Sokołowicz M. E., Terytorializacja korporacji transnarodowych w gospodarce globalnej - przegląd dorobku teoretycznego i badawczego, „Acta Universitatis Lodziensis. Folia Oeconomica” 2012, nr 275, s. 189220.

Sokołowicz M. E., Zagadnienie bliskości w badaniach nad rozwojem terytorialnym. Podejście instytucjonalne, [w:] A. Nowakowska (red.), Zrozumieć terytorium. Idea i praktyka, Wyd. Uniwersytetu Łódzkiego, Łódź 2013, s. 59-92.

Sokołowicz M. E., Territorial Context in the Research on the EU Cohesion. One-Speed or Multi-Speed Europe?, [w:] T. Markowski, M. Turała (red.), Territorial Cohesion Policy in Poland - Issues in Impact Assessment, „Studia Regionalia” 2012, vol. 33, s. 9-28.

Sokołowicz M. E., W kierunku nowej polityki regionalnej? Rozważania nad przyszłym kształtem polityki regionalnej w Polsce, [w:] Polityka spójności. Ocena i wyzwania, Ministerstwo Rozwoju Regionalnego, Warszawa 2008, s. 7-22.

Sokołowicz M. E., Zintegrowane podejście do rozwoju. Polityka spójności a polityki wspierania konkurencyjności i innowacyjności Unii Europejskiej, [w:] T. G. Grosse, A. Galek, Zintegrowane podejście do rozwoju - rola polityki spójności, Ministerstwo 
Rozwoju Regionalnego, Warszawa 2008, s. 47-72.

Sorenson O., Audia P., The Social Structure of Entrepreneurial Activity: Geographic Concentration of Footwear Production in the United States, 1940-1989, „American Journal of Sociology" 2000, vol. 106 (2), s. 424461.

Soto de H., Tajemnica kapitału, Fijorr Publishing, Chicago-Warszawa 2002.

Special issue on Learning, Proximity and Industrial Performance, „Cambridge Journal of Economics" 1999, vol. 23 (2).

Spychalski G. B., Zarys historii myśli ekonomicznej, PWN, Warszawa-Łódź 2002.

Stackelberg von K., Hahne U., Teorie rozwoju regionalnego, [w:] S. Golinowska (red.), Rozwój ekonomiczny regionów. Rynek pracy. Procesy migracyjne. Polska, Czechy, Niemcy, Raport IPiSS, z. 16, Warszawa 1998.

Stahl K., Differentiated Products, Consumer Search, and Locational Oligopoly, „Journal of Industrial Economics” 1982, vol. 31 (1/2), s. 97-113.

Staniek Z., Zróżnicowanie ekonomii instytucjonalnej; http://www.e-sgh.pl/niezbednik/ plik.php?id=27233173\&pid=1081 (dostęp 12.12.2013).

Stankiewicz W., Ekonomika instytucjonalna. Zarys wykładu, Warszawa 2012; http:// pwsbia.edu.pl/pdf_files/Waclaw_Stankiewicz_Ekonomika_Instytucjonalna_III.pdf (dostęp: 28.12.2014).

Stiglitz J. E., Sen A., Fitoussi J.-P., Report by the Commission on the Measurement of Economic Performance and Social Progress; http://www.stiglitz-sen-fitoussi.fr/ documents/rapport_anglais.pdf (dostęp: 19.07.2014).

Storper M., The Regional World: Territorial Development in a Global Economy, Guilford Press, London 1997.
Storper M., The Resurgence of Regional Economies, Ten Years Later: The Region as a Nexus of Untraded Interdependencies, „European Urban and Regional Studies" 1995, vol. 2 (3), s. 191-221.

Straffin Ph. D., Teoria gier, Scholar, Warszawa 2004.

Streeck W., Thelen K., Introduction: Institutional Change in Advanced Political Economies, [w:] W. Streeck, K. Thelen (eds.), Beyond Continuity: Institutional Change in Advanced Political Economies, Oxford University Press, Oxford 2005, s. 1-39.

Sulejewicz A., Czynniki instytucjonalne w badaniach wzrostu gospodarczego krajów transformacji, [w:] R. Rapack (red.), Wzrost gospodarczy w krajach transformacji. Konwergencja czy dywergencja?, PWE, Warszawa 2009, s. 287-289.

Sulejewicz A., Graca-Gelert P., Ksztattowanie się poziomu kosztów transakcyjnych w Polsce w latach 1996-2002, [w:] R. Rapacki (red.), Wzrost gospodarczy w krajach transformacji. Konwergencja czy dywergencja?, PWE, Warszawa 2009, s. 225-262.

Sutton J., Sunk Costs and Market Structure, MIT Press, Cambridge 1991.

Swedberg R., Current Sociology, Sage, London 1987.

Swedberg R., Major Traditions of Economic Sociology, „Annual Review of Sociology” 1991, vol. 17, s. 251-276.

Szachułowicz J., Gospodarka nieruchomościami, Wyd. Prawnicze LexisNexis, Warszawa 2004.

Szymla Z., Determinanty rozwoju regionalnego, Zakład Narodowy im. Ossolińskich, Wrocław 2000.

The GFC and University Economics Education, An Open Letter to the Queen, 2009; http:// media.wix.com/ugd/b629ee_fdfa30c31db1110443977ca5697b5b47.pdf (dostęp: 13.11.2013). 
The World Bank, World Development Indicators 2001, Washington D.C. 2001.

Thünen von J., Der isolierte Staat in Beziehung auf Landwirtschaft und Nationalekonomie, Perthes, Hamburg 1826.

Tłaczała P., Podstawy ekonomicznej teorii biurokracji, [w:] J. Wilkin (red.), Teoria wyboru publicznego. Wstęp do ekonomicznej analizy funkcjonowania sfery publicznej, Scholar, Warszawa 2005, s. 143-158.

Tomaney J., Region and Place I: Institutions, „Progress in Human Geography” 2014, vol. 38 (1), s. 131-140.

Torre A., Gilly J.-P., Debates and Surveys: On the Analytical Dimension of Proximity Dynamics, „Regional Studies” 2000, vol. 34, no. 2, s. $169-180$.

Torre A., On the Role Played by Temporary Geographical Proximity in Knowledge Transmission, „Regional Studies” 2008, vol. 42, no. 6 (July), s. 869-889.

Torre A., Wallet F., The Role of Proximity Relations in Regional and Territorial Development Processes, Proceedings of the $54^{\text {th }}$ ERSA Congress, 26-29 September, Saint-Petersburg 2014.

Tuan Y.-F., Przestrzeń i miejsce, Państwowy Instytut Wydawniczy, Warszawa 1987.

UNDP, Krajowy Raport o Rozwoju Społecznym Polska 2012. Rozwój regionalny i lokalny, Biuro Projektowe UNDP w Polsce, Warszawa 2012.

UN-HABITAT, 2013, Global Campaign on Urban Governance. Global Urban Observatory; http://www.unhabitat.org/governance (dostęp: 7.10.2014).

United Nations Development Programme, National Human Development Report Poland, 2012. Regional and Local Development, UNDP Project Office in Poland, Warsaw 2012.

Ustawa z dnia 21 sierpnia 1997 r. o gospodarce nieruchomościami, Dz.U. 1964, nr 16, poz. 93.
Ustawa z dnia 23 kwietnia 1964 r. Kodeks cywilny, Dz. U. 1964, nr 16, poz. 93.

Varian H., Mikroekonomia, PWN, Warszawa 2001.

Veblen T. B., Gustav Schmoller's Economics, "Quarterly Journal of Economics" 1901, vol. 16, no. 1 (November), s. 69-93.

Veblen T. B., The Theory of the Leisure Class: An Economic Study in the Evolution of Institutions, Macmillan, New York 1899.

Veblen T. B., Why Is Economics Not an Evolutionary Science?, „Quarterly Journal of Economics" 1898, vol. 12, no. 3 (July), s. 373-397.

Veltz P., Mondialisation, villes et territoires: une économie d'archipel, Presses Universitaires de France, Paris 1996.

Viner J., Cost Curves and Supply Curves, [w:] K. E. Boulding, G. J. Stigler (eds.), Readings in Price Theory, Bradford and Dickens, London 1960, s. 198-232.

Watts D. J., Strogatz S. H., Collective Dynamics of 'Small-world' Networks, „Nature” 1998, vol. 393, s. 440-442.

Weber A., Über den Standort der Industrie. Reine Theorie des Standorts, J. C. B. Mohr, Tübingen 1909.

Weber M., The Social Psychology of the World's Religions, [w:] H. Gerth, C. W. Mills (eds.), Max Weber, Oxford University Press, New York 1946.

Webster C. J., Lai L. W. C., Property Rights, Planning and Markets. Managing Spontaneous Cities, Edward Elgar, CheltenhamNorthampton 2003.

White House, Developing effective place-based policies for the FY 2012 Budget, 2010; http:// www.whitehouse.gov/sites/default/files/ omb/assets/memoranda_2010/m10-21. pdf (dostęp: 16.09.2014).

Wilkin J. (red.), Jakość rządzenia w Polsce. Jak ją badać, monitorować i poprawiać?, Wyd. Naukowe Scholar, Warszawa 2012. 
Wilkin J., Pogoń za renta przy pomocy mechanizmów politycznych, [w:] J. Wilkin (red.), Teoria wyboru publicznego. Wstęp do ekonomicznej analizy funkcjonowania sfery publicznej, Scholar, Warszawa 2005, s. 204-219.

Williamson J. G., Regional Inequality and the Process of International Development: A Description of Patterns, „Economic Development and Cultural Change" 1965, z. 13, $\mathrm{nr}$ 4, s. 3-84.

Williamson O. E. (ed.), Organization Theory: From Chester Barnard to the Present and Beyond, Oxford University Press, Oxford 1995.

Williamson O. E., Comparative Economic Organization: The Analysis of Discrete Structural Alternatives, "Administrative Science Quarterly" 1991, vol. 36 (2), s. 269-296.

Williamson O. E., Economic Institutions: Spontaneous and Intentional Governance, „, Journal of Law, Economics, and Organizations" 1991, no. 7 (special issue), s. 159-187

Williamson O. E., Ekonomiczne instytucje kapitalizmu, PWN, Warszawa 1998.

Williamson O. E., Market and Hierarchies. Analysis and Antitrust Implications, Free Press, New York 1975.

Williamson O. E., The New Institutional Economics: Taking Stock, Looking Ahead, „Journal of Economic Literature" 2000, vol. 38, s. 595-613.

Williamson O. E., Transaction Cost Economics: How it Works, Where it is Headed, „The Economist" 1998 , no. 146, s. 23-58.

Wojciechowski E., Gospodarka samorządu terytorialnego, Difin, Warszawa 2012.

Wojciechowski E., Podgórniak-Krzykacz A., Pomiar jakości rządzenia, „Gospodarka Narodowa" 2008, nr 3, s. 19-38.

Wojciechowski E., Zarządzanie w samorządzie terytorialnym, Difin, Warszawa 2003.
Wojciechowski M., Koszt władzy w polskim samorzq̨dzie terytorialnym, Difin, Warszawa 2014

Woodruff Ch., Measuring Institutions, [w:] S. Rose-Ackerman (ed.), International Handbook on the Economics of Corruption, Edward Elgar Publishing, Cheltenham 2006, s. 105-124.

World Bank, Doing Business In Italy. Smarter Regulations for Small and Medium-Size Enterprises, International Bank for Reconstruction and Development / The World Bank 2013

World Bank, Doing Business in Russia 2012, International Bank for Reconstruction and Development/The World Bank, Washington 2013.

Wożnicki J., Benchmarking w systemie szkolnictwa wyższego, Fundacja Rektorów Polskich, Warszawa 2008; http://www.frp. org.pl/publikacje/FRPBench.pdf (dostęp: 7.10.2014).

Young H. P., Social Norms and Economic Welfare, „European Economic Review” 1998, vol. 42 (3-5), s. 821-830.

Young H. P., The Economics of Convention, „The Journal of Economic Perspectives" 1996, vol. 10, no. 2, s. 105-122.

Ziębicki B., Benchmarking w doskonaleniu organizacji usług użyteczności publicznej, Wyd. Akademii Ekonomicznej w Krakowie, Kraków 2007.

Zipf G.K ., The Psychobiology of Language, Routledge, London 1936.

Zipf G.K., Human Behavior and the Principle of Last Effort, Addison-Wesley, Cambridge 1949.

Zorska A., Ku globalizacji?, PWN, Warszawa 1998.

Żylicz T., Ekonomia środowiska i zasobów naturalnych, PWE, Warszawa 2004. 


\section{Territorial development and institutional economics Space - proximity - institutions}

(Summary)

Contemporary analyses of territorial development processes expose more and more often the impact of institutional environment on the economies, as well as on local and regional communities. This perspective takes into consideration both formal and informal institutions. It claims that such factors, as: transparency and efficiency of laws and regulations, efficient functioning of enterprises and public sector organizations, but also culture and the level of trust in the society, affect essentially the level of development, not only in national but also local and regional economies. What is more, in the conditions of growing mobility of capital, people, goods and information, certain institutional factors responsible for economic development are still localized, although their nature is sometimes elusive.

This book aims at identification of the possible applications of institutional economics, in the analysis of territorial development processes, especially in the context of the relations between institutions, proximity, and the contemporary current understanding of the concept of "space". The review and classification of various strands of institutional economics in terms of their helpfulness for the study of territorial development processes, highlights the role of institutions as more and more important factor of economic development.

The reasoning of this monograph allowed to conclude high usefulness of various fields of institutional economics in the study of local and regional development processes, as well as the possibility of treating them as complementary research approaches. However, one of the important conditions for use of the achievements of institutional economics in the study of the processes of territorial development is a combination of data, theoretical base, as well as research methods and researchers. As far as the local and regional development policy is concerned, this work makes it possible to form a thesis that the effectiveness of this policy depends on the awareness of the complexity of the process of institutional 
transformation. Furthermore, the modern territorial development is the result of the hybridization of formal and informal institutions, resulting from the search for their optimal combination of different institutional layers in various spaces.

Among the addressees of the book, we can mention the representatives of economic science, geography, management, and social scientists engaged in the exploration of institutional factors responsible for the socio-economic development at local and regional level. It can be also interesting for the specialists of land-use planning, urban and regional economics, local government managers and employees, as well as workers of central government agencies responsible for regional planning, urban policy and spatial policy. 


\section{Spis tabel, rysunków i wykresów}

\section{Tabele}

1. Korzyści i niekorzyści płynące z polaryzacji przestrzennej............ 37

2. Różnice między Nową Geografią Ekonomiczną a Nową Geografią Przemy-

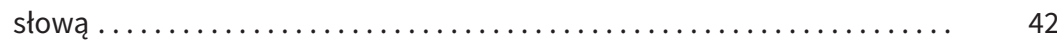

3. Typy korzyści aglomeracji a dynamika cyklu życia produktów i sektorów 51

4. Zestawienie typów przestrzeni w ujęciu François Perroux. ............. 61

5. „Stara” a nowa ekonomia instytucjonalna .................... 76

6. Pojęcia nawiązujące do koncepcji instytucji.................. 84

7. Typologia instytucji według poziomu ich sformalizowania........... 85

8. Założenia niemieckiego historyzmu na tle sporu pomiędzy przedstawicielami niemieckiej szkoły historycznej z austriackimi przedstawicielami ekonomii klasycznej.............................. 90

9. Typy transakcji w ujęciu J. R. Commonsa i ich charakter.............. 94

10. Dwa typy porządku i regut według Friedricha A. von Hayeka. . . . . . . . . . . 97

11. Rodzaje i przykłady kosztów transakcji.................... 123

12. Czynniki decydujące o wysokości kosztów transakcyjnych ........... 125

13. Charakterystyki form organizacyjnych z punktu widzenia kosztów trans-

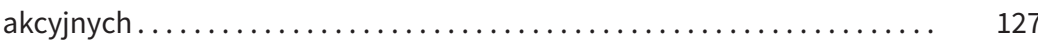

14. Typologia kosztów transakcyjnych związanych z funkcjonowaniem sektora publicznego...................................... 131

15. Przegląd założeń teorii agencji ......................... 132

16. Podział działalności na produkcyjną i transakcyjną w gospodarce ...... 136

17. Kluczowe różnice między „kontraktualizmem” a „konwencjonalizmem” 152

18. Modele relacji ekonomicznych w zależności od systemów wartości w ujęciu ekonomii konwencji ................................. 153

19. Odejście od założeń ekonomii neoklasycznej na gruncie szkoły zasobowej i ekonomii ewolucyjnej .................................. 158

20. Formy bliskości - analiza porównawcza ................... 176

21. Nurty ekonomii instytucjonalnej .......................... 179 
22. Nurty ekonomii instytucjonalnej w badaniach rozwoju terytorialnego - kierunki i charakter badań ................................ 198

23. Przykładowe metody wyceny przestrzeni publicznych ............. 204

24. Zróżnicowania przestrzenne $w$ rozwoju społeczno-gospodarczym według wskaźnika LHDI (2010 r.) .......................... 223

25. Czynniki i filary konkurencyjności regionalnej - istota konstrukcji wskaźnika konkurencyjności regionalnej (2013 r.)..................

26. Regiony Unii Europejskiej o najwyższym i najniższym poziomie wskaźnika konkurencyjności regionalnej (2013 r.) . . . . . . . . . . . . . . .

27. Pozycja polskich województw w badaniu wskaźnika konkurencyjności regionalnej $(2013$ r.) . . . . . . . . . . . . . . . . . . . . . . . . . . . . .

28. Grupy tematyczne i liczba krajów biorących udział w badaniu Doing Business

29. Zróżnicowanie otoczenia instytucjonalnego działalności gospodarczej w wybranych miastach i regionach Rosji Doing Business (2012 r.) ......

30. Syntetyczne wymiary jakości życia w Diagnozie warunków i jakości życia

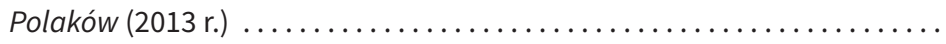

31. Zróżnicowania przestrzenne jakości życia według w Diagnozie warunków i jakości życia Polaków (2013 r.) ...........................

\section{Rysunki}

1. Gradienty renty dla czterech typów działalności rolniczej wokół miasta będącego rynkiem zbytu . .............................

2. Kształt systemu osadniczego w systemie ośrodków centralnych W. Christallera.

3. Klasyfikacja przyczyn koncentracji działalności gospodarczej - korzyści aglomeracji.

4. Etapy rozwoju terytorialnego ewolucja koncepcji korzyści aglomeracji ..

5. Poziomy instytucji i ich wzajemne relacje w świetle teorii instytucjonalnych w ujęciu Oliviera E. Williamsona .......................

6. Miejsce veblenowskiej ekonomii instytucjonalnej na mapie innych kon-



7. Złożoność relacji między instytucjami a wyborami ekonomicznymi .....

8. Podział dóbr według konkurencyjności oraz możliwości wykluczenia

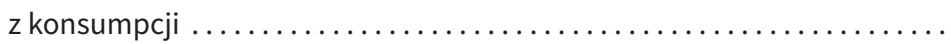

9. Poziom kosztów transakcyjnych jako granica zastosowania twierdzenia Coase'a ............................................

10. Struktury zarządzania transakcjami w zależności od poziomu kosztów

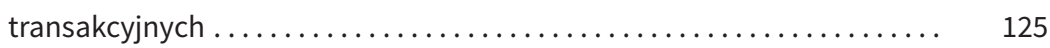

11. Formy hybrydowych struktur organizacyjnych a koszty zarządzania ... 128 
12. Koszty transakcyjne w poszczególnych fazach kontraktowania ........ 129

13. Zasoby a trwała przewaga konkurencyjna.................. 162

14. Model „małego świata” na tle innych modeli relacji sieciowych....... 169

15. Przenikanie się dwóch typów bliskości i jego konsekwencje dla rozwoju

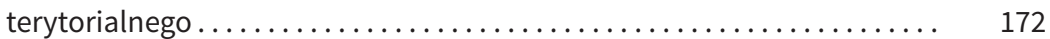

16. Przynależność do warstw instytucjonalnych z perspektywy jednostki A... 188

17. Przykład delimitacji warstw instytucjonalnych w ujęciu przestrzennym ... 189

18. Typologia regionów ze względu na różnorodność instytucjonalną i „przenikalność" warstw instytucjonalnych w regionie .............. 190

19. Podstawowe ramy konkurencyjności regionu w świetle ekonomii ewolucyjnej i teorii zasobów............................. 192

20. Klasyfikacja instytucji w badaniach procesów rozwoju terytorialnego ... 195

21. Przestrzenie publiczne jako przedmiot badań teorii wyboru publicznego 202

22. Wartości lokalnego wskaźnika rozwoju społecznego (LHDI) w Polsce

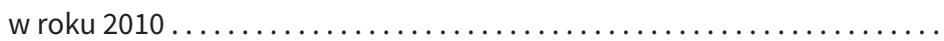

23. Ranking instytucjonalnych uwarunkowań konkurencyjności regionów według wskaźnika konkurencyjności regionalnej (2013 r.). .........

24. Regionalne zróżnicowanie jakości rządzenia według EQI - European QoG

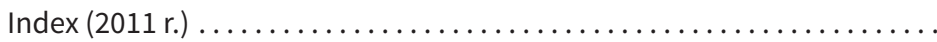

\section{Wykresy}

1. Alokacja funkcji w przestrzeni miejskiej według sektorów ............ 17

2. Alokacja funkcji mieszkaniowych w mieście według dochodów ......... 18

3. Kształtowanie się hierarchii osadniczej na skutek działania siła ......... odśrodkowych i dośrodkowych w modelu Paula Krugmana ...........

4. Optymalna wielkość produkcji w warunkach występowania korzyści zewnętrznych.

5. Relacje pomiędzy poziomem użyteczności a wielkością hipotetycznej aglomeracji miejskiej

6. Wpływ zmiany instytucjonalnej na wysokość kosztów transakcyjnych ....

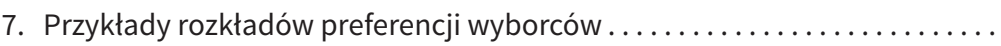

8. Optymalna wielkość legislatywy

9. Relacje między zakorzenieniem społecznym relacji ekonomicznych (embededdness) a zdolnością innowacyjną . . 



\section{Od Redakcji}

Dr Mariusz E. Sokołowicz jest absolwentem kierunku gospodarka przestrzenna na Wydziale Ekonomiczno-Socjologicznym Uniwersytetu Łódzkiego i pracownikiem naukowym Instytutu Gospodarki Przestrzennej UŁ. Jest członkiem Towarzystwa Urbanistów Polskich oraz zarządu polskiej sekcji European Regional Science Association. Zajmuje się zagadnieniami ekonomii instytucjonalnej i możliwościami jej integracji z obszarem badawczym gospodarki przestrzennej, a także znaczeniem bliskości w procesach gospodarczych. Specjalizuje się też w zakresie marketingu terytorialnego oraz zarządzania w sektorze publicznym. Ma w swoim dorobku ponad 70 opracowań naukowych w języku polskim i angielskim oraz kilkanaście ekspertyz poświęconych polityce gospodarczej, zarządzaniu strategicznemu i marketingowi w jednostkach terytorialnych.

W latach 2009-2013 zdobywał doświadczenie jako pracownik samorządowy w Łodzi, odpowiedzialny za działania na rzecz rewitalizacji centrum miasta. Swoją wiedzę i doświadczenie pogłębia podczas licznych staży zagranicznych i wyjazdów, m.in. do Francji, Niemiec, Szkocji, Portugalii, Rosji, Ukrainy, Słowacji, Bułgarii.

W wolnych chwilach dużo czyta, szczególnie literaturę współczesną, jeździ motocyklem oraz angażuje się na rzecz rozwoju jego rodzinnego miasta - Łodzi. 
